\title{
FJELLFISKE I FORTIDEN
}

\author{
ÅRTUSENER MED SVØMMENDE RIKDOM
}

Kulturhistorisk museum i samarbeid med Norsk Maritimt Museum og Oppland fylkeskommune 



\section{FJELLFISKE I FORTIDEN}

ÅRTUSENER MED SVØMMENDE RIKDOM

Kulturhistorisk museum i samarbeid med

Norsk Maritimt Museum og Oppland fylkeskommune

Axel Mjærum og Elling Utvik Wammer (red.)

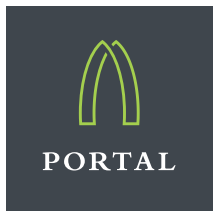


(C) 2016 Portal forlag og Kulturhistorisk museum

Utgitt i samarbeid med Norsk Maritimt Museum og Oppland fylkeskommune.

ISBN: 978-82-8314-078-1

Forsidebilde: Notfiske i Sølensjøen i Hedmark. Foto: Tore Fossum, Norsk Skogmuseum.

Baksidebilde: Trinseformet søkke fra innsjøen Tesse i Oppland, datert til tidlig middelalder.

Foto: Vegard Vike, Kulturhistorisk museum

Grafisk design: Rune Eilertsen

Omslag: Gisle Lyng-Vagstein, deTuria Design.

Trykk: Dardedze holografija, Latvia

Font: Adobe Caslon Pro 11/14

Papir: MultiArt Silk $130 \mathrm{gr} / \mathrm{m}^{2}$

Papir fra bærekraftige kilder

Alle henvendelser om denne boken kan rettes til:

Portal forlag AS

Agder Allé

4631 Kristiansand

www.portalforlag.no

post@portalforlag.no

Kulturhistorisk museum

Arkeologisk seksjon

Postboks 6762 St. Olavs plass

N-0130 Oslo

Norway

Tlf.: (+47) 22851900

Fax: (+47) 22851938

E-mail: postmottak@khm.uio.no

Det må ikke kopieres fra denne boken i strid med åndsverkloven eller fotografiloven eller i strid med avtaler inngått av KOPINOR, interesseorgan for rettighetshavere til åndsverk. 


\section{INNHOLD}

$\begin{array}{ll}\text { Forord } & 9\end{array}$

Fjellfiske i dag og i fortiden 11

PROLOG:

Tesse - et arkeologisk eldorado og en innfallsport til fjellfisket 15

AV BIRGITTE BJØRKLI, ELLEN KATHRINE FRIIS, AXEL MJÆRUM, KULTURHISTORISK MUSEUM, UNIVERSITET I OSLO OG ELLING UTVIK WAMMER, NORSK MARITIMT MUSEUM

Auren i Jotunheimen - når vart han innført, og kor kom han frå?

TRYGVE HESTHAGEN, NORSK INSTITUTT FOR NATURFORSKNING, TRONDHEIM OG EINAR KLEIVEN, NORSK INSTITUTT FOR VANNFORSKNING, GRIMSTAD

De første fiskerne i fjellet

AXEL MJÆRUM, KULTURHISTORISK MUSEUM, UNIVERSITETET I OSLO

Fisken i fjellet i fortid og nåtid. Hva kan DNA-analyser fortelle?

JAN HEGGENES, HØGSKOLEN I SøRøST-NORGE

Fiskemåtar i fjellet i eldre tid

TRYGVE HESTHAGEN, NORSK INSTITUTT FOR NATURFORSKNING, TRONDHEIM OG EINAR KLEIVEN, NORSK INSTITUTT FOR VANNFORSKNING, GRIMSTAD 
Fjellfunn og fiskebein - Om fiske og bruken av fjellet i fortiden

ANNE KARIN HUFTHAMMER, UNIVERSITETSMUSEET, UNIVERSITETET I BERGEN OG AXEL MJÆRUM, KULTURHISTORISK MUSEUM, UNIVERSITETET I OSLO

Tesse-dokumentet og fjellfisket i mellomalderen

JO RUNE UGULEN, RIKSARKIVET

Om landskyldvara «bergefisk» i Gudbrandsdalen

ARNFINN KJELLAND, HØGSKULEN I VOLDA

Sørsamenes fjellfiske. Ørret, sik og røye - et svømmende matforråd ANNE SEVERINSEN

Fjellfiske i grenselandet mellom fangstmark og jordbruksbygd i yngre jernalder og middelalder

AV ELLING UTVIK WAMMER, NORSK MARITIMT MUSEUM

Båtrelaterte kulturminner i fjellet som kilder til kunnskap om fiske i fortiden 207 CHARLOTTE MELSOM OG ELLING UTVIK WAMMER, NORSK MARITIMT MUSEUM

EPILOG:

Noen pessimistiske tanker om tilstanden til kulturminnene ved våre fjellvann 229 AXEL MJÆRUM OG ELLEN KATHRINE FRIIS, KULTURHISTORISK MUSEUM, UNIVERSITETET I OSLO 
Noter og appendiks

Litteraturliste

Forfatterpresentasjoner

Stedsnavnregister 


\section{FORORD}

Det var knyttet spenning til seminaret om fortidens fjellfiske som ble holdt ved Fjellmuseet i Lom 3.-4. juni 2015. Aldri før hadde et bredt utvalg av kultur- og naturhistorikere møttes for å diskutere dette temaet. Hva ville det komme ut av et slikt møte mellom fagfolk med helt ulike tilnærminger og utgangspunkt?

Tanken om et seminar hadde dukket opp to år tidligere i forbindelse med arkeologiske undersøkelser i fjellvannet Tesse i Jotunheimen. Denne innsjøen er rik på arkeologiske funn, men også velstudert av biologer. I tillegg er det sjeldne historiske kilder knyttet til vannet. Samlet var det altså mye kunnskap om fortidens fiske i vannet, men kunnskapen var spredt på ulike fag og flere fagmiljøer. Gjennom seminaret og denne boken har målet vært å samle kunnskap og stimulere til ny forskning. Det har også vært et mål å skape økt oppmerksomhet om fjellfiske og tilgjengeliggjøre kunnskapen for forskere og et bredere publikum.

Seminaret og bokutgivelsen hadde ikke vært mulig uten velvilje fra Riksantikvaren, samarbeid med og økonomisk støtte fra Oppland fylkeskommune og midler fra Norsk arkeologisk selskap. Prosjektet hadde heller ikke latt seg gjennomføre uten bidrag fra Norsk Maritimt Museum og Kulturhistorisk museum. Det må også rettes en spesiell takk til Norsk Fjellmuseum i Lom, som var vertskap for seminaret, og som har vært en betydningsfull administrativ støttespiller.

Til slutt må også foredragsholdere og artikkelforfattere takkes. Uten deres innsats ville det ha eksistert mindre kunnskap om fjellfiske i fortiden.

Oslo, 1. juni 2016

Axel Mjærum og Elling Utvik Wammer 


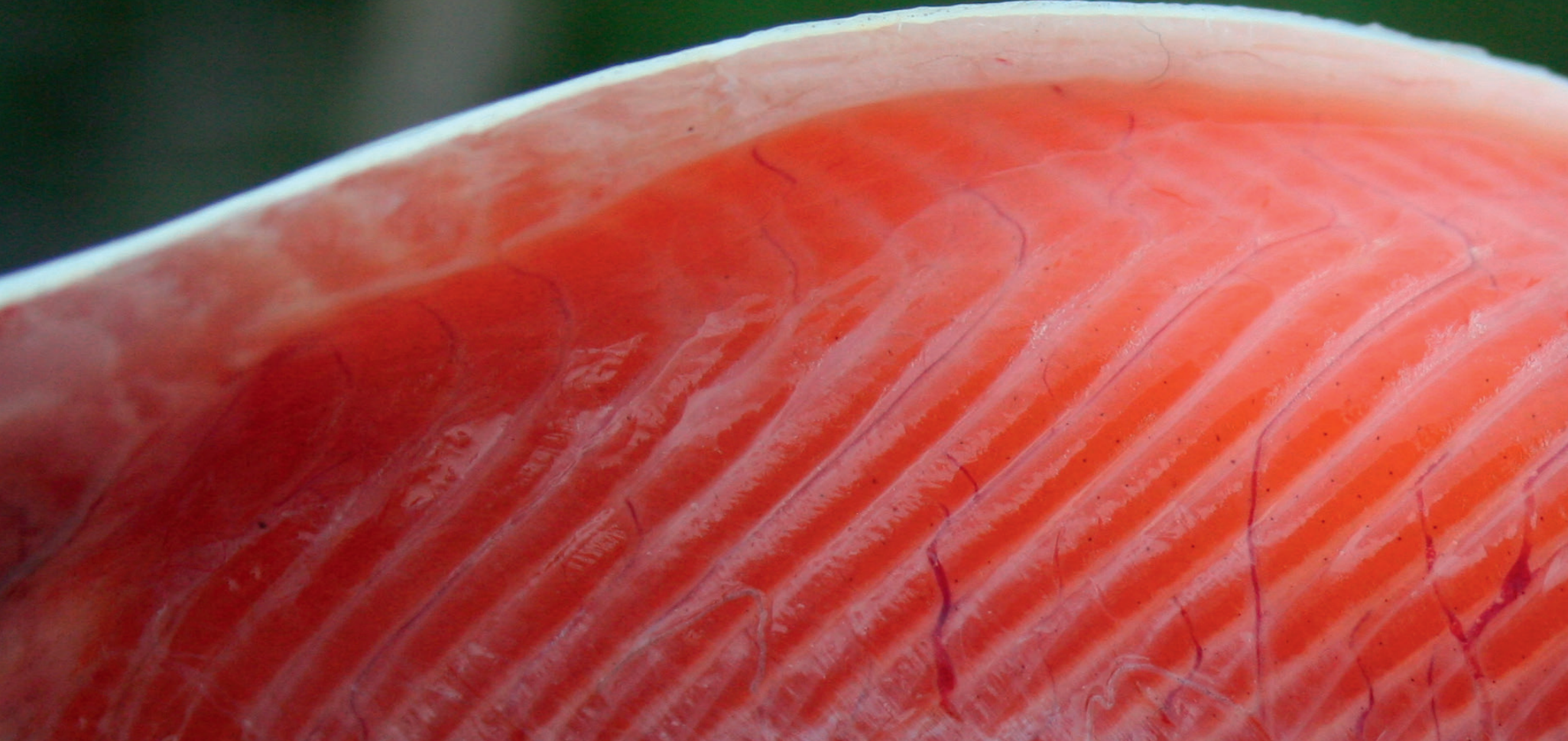

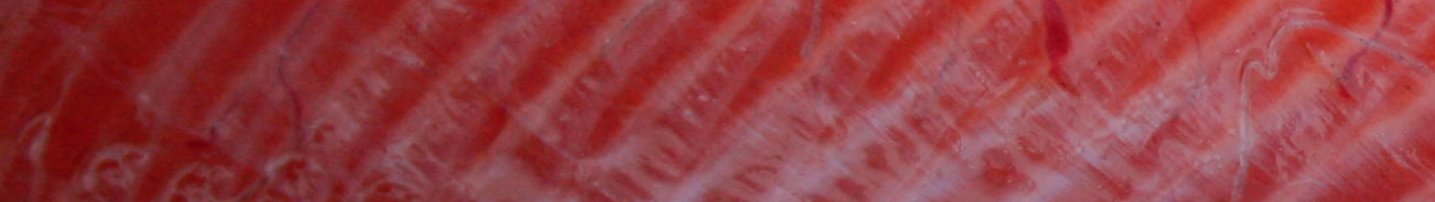

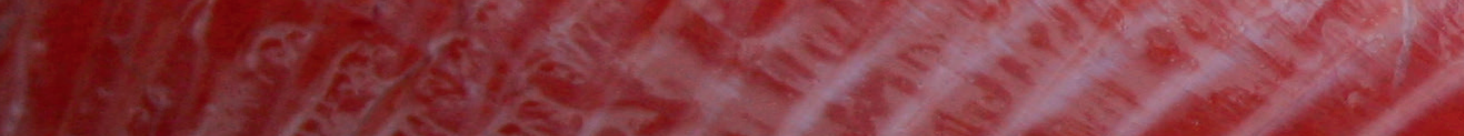

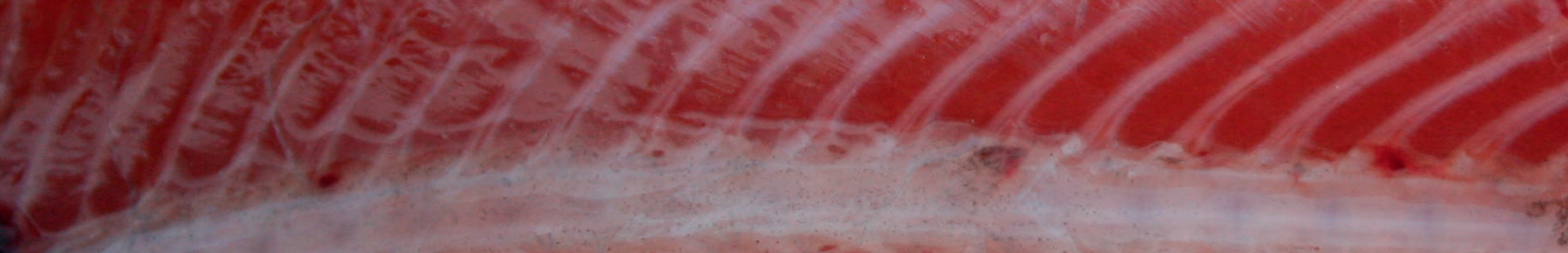

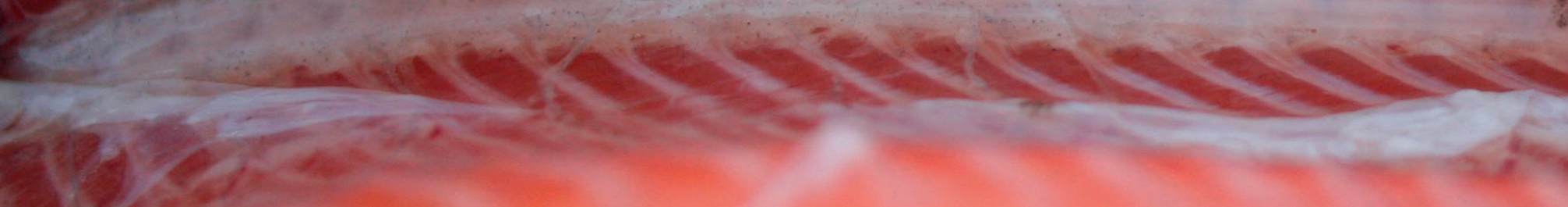
1 


\title{
FJELLFISKE I DAG OG I FORTIDEN
}

\author{
Voluspå, strofe 59:

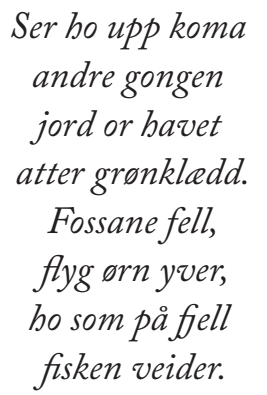

Over halve den norske befolkningen fisker årlig. ${ }^{1}$ Fisking foregår både ved kysten og $\mathrm{i}$ innlandet, men for mange av oss representerer ørret- og røyefisket en ultimat fjellopplevelse. $\AA$ dra i land en sterk, blank fisk på en midtsommerskveld og deretter steke det røde kjøttet på bål eller stormkjøkken skaper den gode villmarksfølelsen. Fjellfisking er også noe vi gjerne forbinder med matauk på høsten, og mange norske familier holder for eksempel rakfisktradisjonene i hevd. Antallet aktive yrkesfiskere er imidlertid svært lavt $\mathrm{i}$ innlandet $\mathrm{i}$ våre dager. ${ }^{2}$

Det norske sportsfisket slik vi kjenner det i dag, har mye av sitt opphav i utenlandsk turisme på 1800-tallet. Fisket i norske fjell startet imidlertid på ingen måte med tweedkledde engelskmenn og flueutstyr. Spesielt ørreten har spilt en rolle for folk mye lenger tilbake enn dette. Hvor lenge? Og hvilken rolle? Dette er noen av spørsmålene vi forsøker å besvare i denne boken. Målet vårt er å vise at mange vitenskapsgrener, slik som arkeologi, beinvitenskap, etnologi, fiskebiologi, genetikk og historie, i fellesskap kan føre oss langt nærmere svarene.

Denne boken synliggjør også at fortidens fiske har vært mer mangfoldig enn vi ofte tenker oss. De tidvis kreative fangstmetodene viser hvor viktig fisken har vært som ressurs. En annen side av denne mangfoldigheten er at fjellene i Sør-Norge har vært utnyttet av mennesker med ulikt levesett og variert 


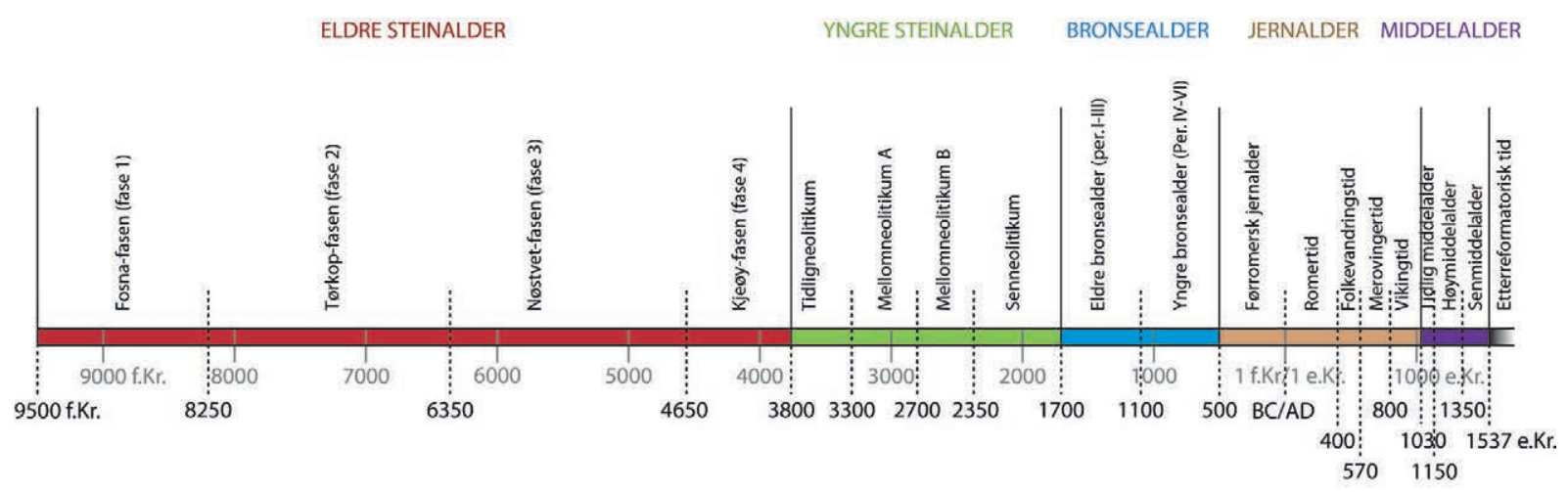

Figur 1: Det har oppholdt seg mennesker i Norge i minst 11000 år. Arkeologer og historikere deler inn dette lange tidsrommet i en rekke perioder på bakgrunn av samfunnsmessige og teknologiske endringer. Tidlig begynte folk å utnytte fjellområdene. Fulgte fisken også med til fjells? Illustrasjon, Tone Wikstrøm, KHM.

kulturell og geografisk bakgrunn. Både fangstfolk og bønder har levd i og brukt fjellene. At fjellfisket har vært fritt for konflikter, kan vi slett ikke regne med. I mange bygder har uenigheter om fiskeretter endt i slagsmål, og slike konflikter har sågar endt i drap.

Ette 1800-tale begjynte såg de ut te, at grensestri'n lågå upp-att verre hell någun gong forr, og dee va mest likt te, at Valdersan radt gjor' mannamord på Frøningom ner dom såg se tak te di, de va någå dom ha drivi med frå gåmålt, de; i 1468 skaut Valdersan ibel ein ong gut frà Uleberg på Sør-Fron, og kasta like oppå butake på Tåkåsta-fiskjebu'n ve Raggen. ${ }^{3}$

Samtidig er det mange aspekter som sjelden kan trekkes ut av selv de beste av fortidens kilder: Hvordan opplevde folk fjellfisket og det å ha sitt virke i fjellet i eldre tid? Hadde menneskene den gang den samme følelsen av storhet i fjellnaturens nærhet som vi? Kjente de også på gleden over å få napp eller over en god fangst? Søkte de til fjellet for å finne urørt villmark også i fortiden?

Det siste spørsmålet kan vi kanskje gi et bedre svar på i dag enn tidligere ut fra et arkeologisk perspektiv. Tallrike spor etter fortidens folk i fjellet har blitt og blir stadig avdekket, særlig rundt vassdragene. Samlet vitner de om stor aktivitet i mange fjellstrøk. Her har det foregått jakt og fangst, setring og jernproduksjon, for å nevne noen aktiviteter. Ofte ser denne virksomheten ut til å ha vært kombinert med fiske. Vi kan altså anta at for fortidens mennesker var fjellene naturlige bruksområder, i større grad enn hva vi opplever i dag.

Trolig har folk oppigjennom tidene båret ørret til fisketomme vann for å ha et selvproduserende matforråd til kommende fjellturer. Utsetting av fisk er en inngripen fra mennesker som vitner om en utviklet naturforståelse og planleggingsevne. Menneskene har på denne måten satt sitt preg på fjellene, og av denne grunn kan vi si at fisken er en del av fjellets kulturlandskap. Den har kommet dit ved hjelp av folk og har vært utnyttet av mennesker 
siden steinalderen. I fjellvannene svømmer altså sprell levende kulturminner!

Undersøkelsene i innsjøen Tesse i Jotunheimen viser at det kan ligge et rikt kildemateriale på bunnen av et fjellvann. Å passe på fjellfiskets kulturlandskap handler imidlertid ikke bare om å sikre de fysiske sporene som dukker opp langs innsjøenes bredder. Det handler også i stor grad om å holde fiskebestandene sunne og tradisjonene rundt fiskingen levende. I dette samles vår oppfordring til leserne av denne boken: Dra til fjells og bruk de flotte ressursene vi har der! Du er imidlertid ikke den første fiskeren i villmarka, så stell godt med våre forfedres spor. 



\title{
PROLOG: \\ TESSE - ET ARKEOLOGISK ELDORADO OG EN INNFALLSPORT TIL FJELLFISKET
}

\author{
Av Birgitte Bjørkli, Ellen Kathrine Friis, Axel Mjarum, Kulturhistorisk museum, Universitet $i$ \\ Oslo og Elling Utvik Wammer, Norsk Maritimt Museum
}

Innsjøen Tesse ligger i Lom og Vågå kommuner, nord i Jotunheimen og på sørsiden av Ottadalen i Oppland. Vannet befinner seg ca. 850 moh. og har et flatemål på om lag $12 \mathrm{~km} 2$. Tesse er kjent som et meget godt ørretvann i moderne tid, men man vet også at fisket lenge har stått sentralt i bruken av området. Blant annet har det foregått en omfattende bruk av fiskefeller (sløer) i tilførselselvene til Tesse, i alle fall siden 1600 -tallet. ${ }^{1}$ Fiskerettigheter knyttet til vannet er videre omtalt i middelalderkilder. ${ }^{2}$ Etter at vannet ble regulert på 1940-tallet, er det gjort funn av et unikt materiale av fiskesøkker i never, tre og stein fra den tidligere sjøbunnen, ${ }^{3}$ søkker som har vært i bruk siden vikingtiden. ${ }^{4}$ Etter reguleringen er det også blitt vasket frem 20 boplasser fra steinalderen, lokaliteter som belyser den eldste utnyttelsen av Tesse.

Med denne kunnskapen som bakteppe ble det i 2013 og 2014 utført arkeologiske undersøkelser i forbindelse med konsesjonsfornyelsen for reguleringen av Tesse. Samarbeidsprosjektet mellom Oppland fylkeskommune, Kulturhistorisk museum og Norsk Maritimt Museum ble kalt «Tesse - svømmende rikdom». Vi vil her presentere hvordan vi gikk til verks for å få ny kunnskap om fiske ut fra sporene etter fortidens mennesker i og rundt vannet, samt noe av informasjonen som fremkom ved de arkeologiske utgravningene.

Arbeidet ved Tesse har ikke bare gitt kunnskap om fortiden, men også vist i hvilken grad vannkraftproduksjonen har skadet både kulturminnene og muligheten til å få ny kunnskap om fortiden. Mange av kulturminnene ved fjellvannene er i ferd med å forsvinne for godt, og det vil ikke være mulig å grave frem ny kunnskap om fortiden i fjellet for alltid. ${ }^{5}$

\section{DE ARKEOLOGISKE UNDERSØKELSENE}

RUNDT TESSE I 2013 OG 2014

- OM METODER OG TILNERMINGER

Utgravninger i regulerte vassdrag på fjellet dreier seg mye om timing, også de i Tesse. Reguleringen innebærer at vannet kan tappes 11,6 meter ned og 0,8 meter opp i forhold til strandlinjen før reguleringen. ${ }^{6}$ Tesse blir i likhet med mange andre kraftmagasiner tappet ned vinterstid og fylt med vann fra snøsmeltingen i fjellet om våren. Bunnen og strendene rundt vannet er tilgjengelige kun i kort tid, og det 


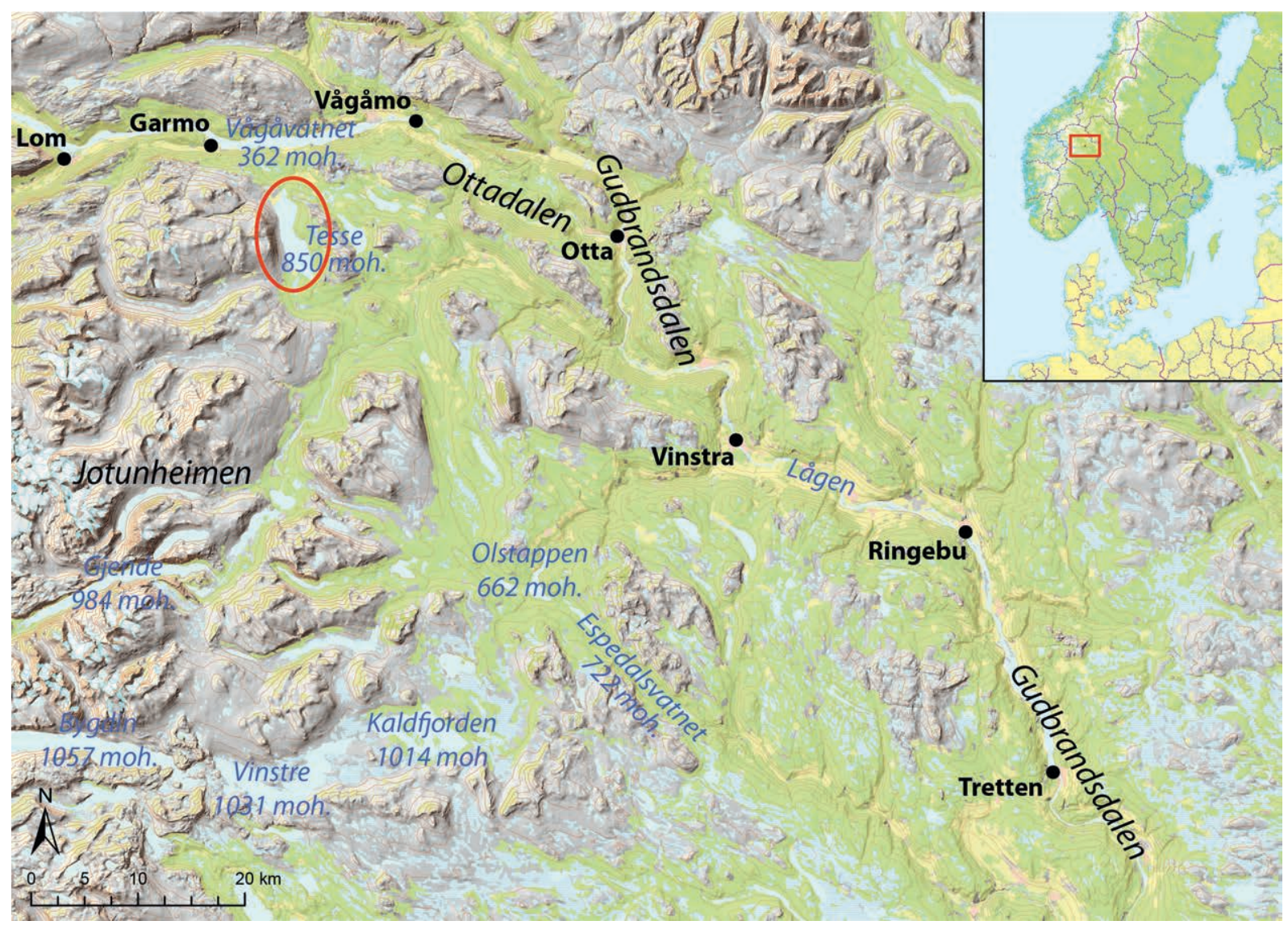

Figur 1: Plasseringen av Tesse. Kart: Ellen Kathrine Friis, KHM.

er i tidsvinduet mellom issmelting i fjellet og før magasinene er fylt opp, vi har mulighet til å arbeide. Mange år skjer smeltingen hurtig i fjellet, og tidvis utarter den til flom. Det er også en stor utfordring at isen i reguleringssonen ofte ikke rekker å smelte før vannet stiger. Erfaringene fra de siste års undersøkelser i fjellheimen er at det gjelder å komme i gang tidlig for å kunne utnytte den korte perioden med lav vannstand før vårflommen setter inn. ${ }^{7}$

Deler av bunnen i Tesse er tørrlagt og isfri kun noen få dager eller uker i året. Her var det alt funnet flere fiskefeller (sløer), og en tidlig start ville gi oss størst mulige arealer for funn av både sløer og garnsøkker. Områdene rundt vannet blir imidlertid ikke oversvømt like raskt, noe som gav god anledning til å finne spor fra aktiviteter som har foregått ned mot vannet. I løpet av noen hektiske våruker i disse to årene ble det foretatt utgravninger av allerede kjente boplasser og nye registreringer i hele den neddemte reguleringssonen.

\section{UNDERSØKELSER TIL VANNS}

Arkeologer fra Norsk Maritimt Museum undersøker vanligvis sjøbunnen $i$ hav og vassdrag ved hjelp av 


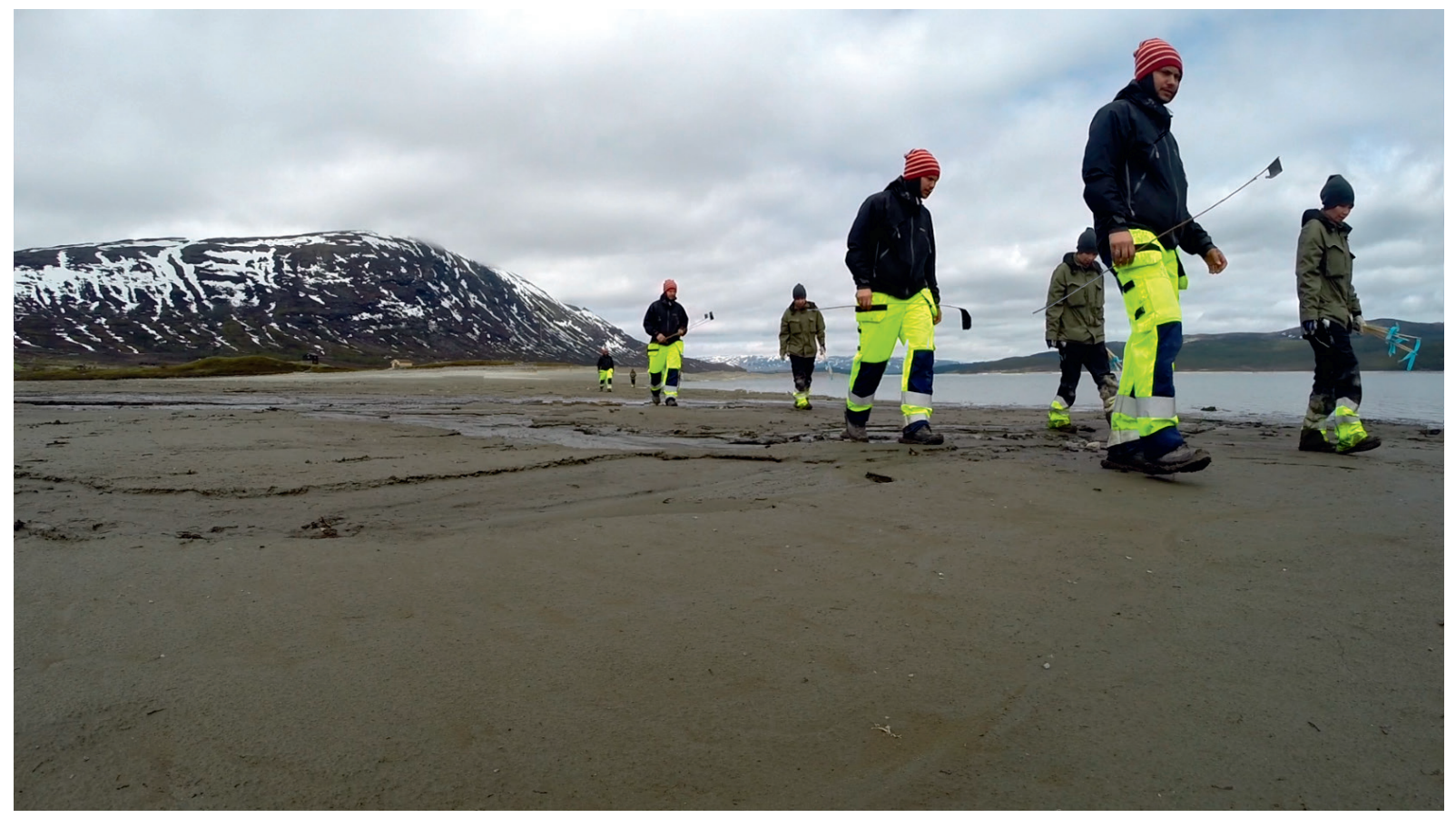

Figur 2: Illustrasjon av metode brukt under søk etter søkker og sløedeler i reguleringssonen. Foto: Elling Utvik Wammer, Norsk Maritimt Museum.

dykkerutstyr. Dykking har mange fordeler, men arbeidet blir ofte hemmet av dårlig sikt i vannet og vanskelige værforhold for bruk av båt. Under feltarbeidene i Tesse konsentrerte vi oss om fiskeredskaper i vannet, i tillegg til båter, båtstøer, naust og lignende. For en gangs skyld var det mulig å lete over store områder uten hverken dykkemaske eller båt. Vi startet med systematiske registreringer av fiskesøkker og sløer ved vannkanten (bunnen av magasinet) $\mathrm{i}$ begynnelsen av feltperioden og forflyttet oss oppover etter som vannet steg. Søkene foregikk ved at to arkeologer gikk linjer med ca. 3 meters mellomrom parallelt med vannkanten (figur 2).

Fiskesøkkene ble innmålt med GPS med noen centimeters nøyaktighet. Det var viktig med nøyaktig posisjonering av disse funnene ettersom de kunne ligge ganske nøyaktig der de ble mistet. Den innbyrdes plasseringen deres kunne være viktig i forbindelse med tolkningene, og flere søkker kunne være del av et sammenhengende funn. De fleste av funnene lå fullt eksponert på overflaten, og noen var delvis dekket av sand eller silt. Søkkene av tre og never er svært skjøre og krever stor forsiktighet. Gjenstandene er nå konservert, og de oppbevares på Kulturhistorisk museum i Oslo.

Registreringene på sjøbunnen i Tesse hadde som mål å utfylle allerede kjent kunnskap om bruken av fiskevannet, først og fremst ved at områder uten tidligere kjente lokaliteter skulle undersøkes. Underveis måtte vi imidlertid legge om strategien og prioritere områdene med kjente funn siden funnmengden her var mye større enn noen kunne ane på forhånd (figur 3). 

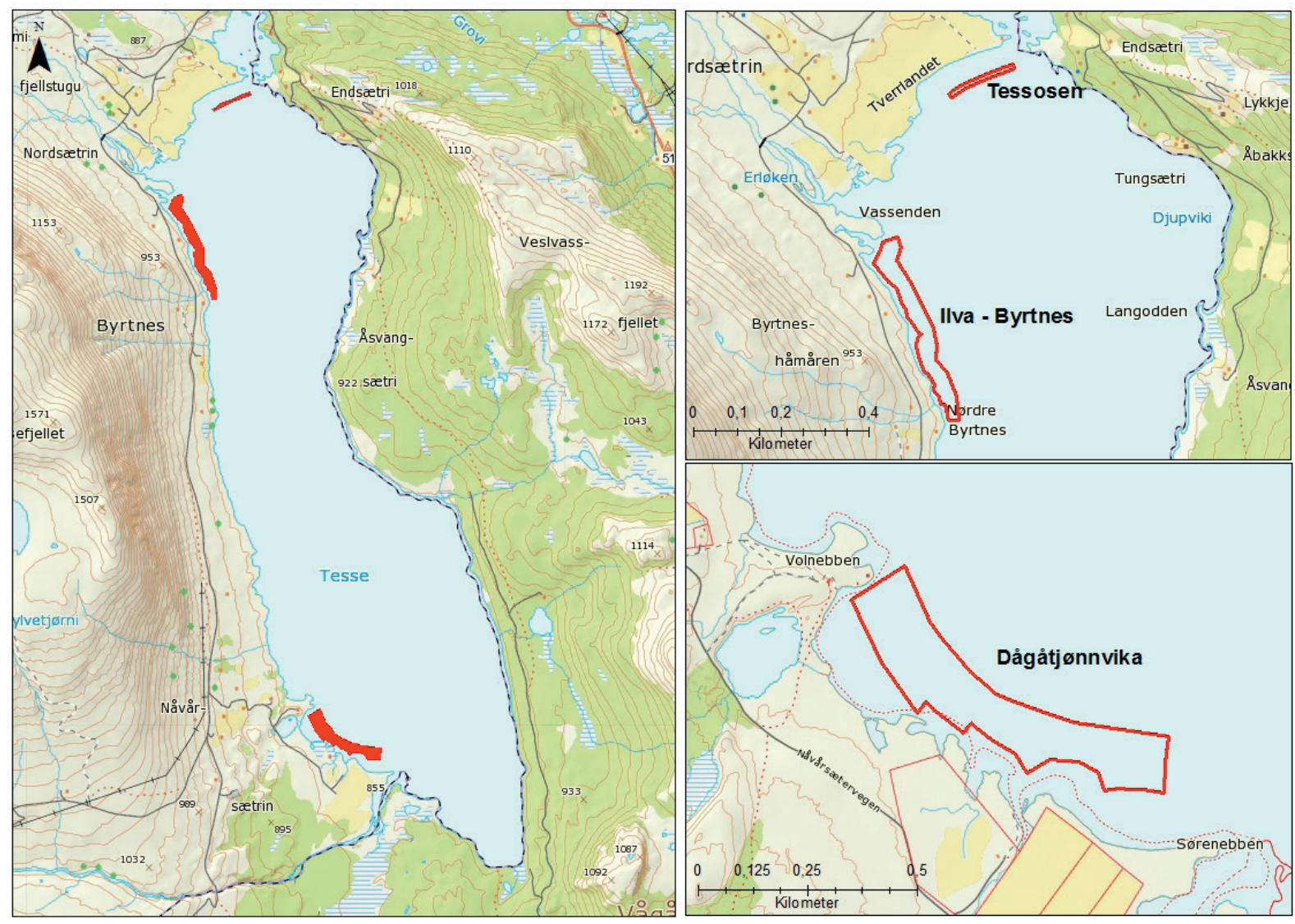

Figur 3: Kart som viser feltene hvor den tidligere sjøbunnen ble systematisk undersøkt i 2014. Fra alle disse områdene er det oppigjennom årene blitt innlevert søkker og andre funn til museene og fylkeskommunen, men det var aldri foretatt systematiske kartlegginger. Kart: Elling Utvik Wammer, Norsk Maritimt Museum.

\section{UNDERSØKELSER PÅ LAND}

Ved undersøkelsene av den gamle strandsonen ved Tesse konsentrerte man seg om å sjekke tilstanden til kulturminner man alt kjente til, undersøke om det fantes uoppdagete steinalderboplasser, samt lete etter spor fra andre tidsperioder. Søk etter gjenstander som var synlige på overflaten, og testgravning på utvalgte steder (prøvestikking) viste at de tidligere befaringene var av uvanlig pålitelig karakter. Mye var blitt vasket frem etter reguleringen på 1940-tallet, og folk har vært flinke til å informere om funnene til den daværende Oldsaksamlingen i Oslo. Dette førte videre til at arkeologer har vært ved Tesse og registrert kulturminner ved flere anledninger. ${ }^{8}$

Mye av kanten av erosjonssonen er dekket av jord og torv, og håndkraft er ikke bestandig tilstrekkelig for å påvise sporene som skjuler seg i grunnen. Vi benyttet derfor gravemaskin til å fjerne torv for å få et større overblikk over kulturminnene som kunne ligge langs vannet. Dette er til nå en nær 


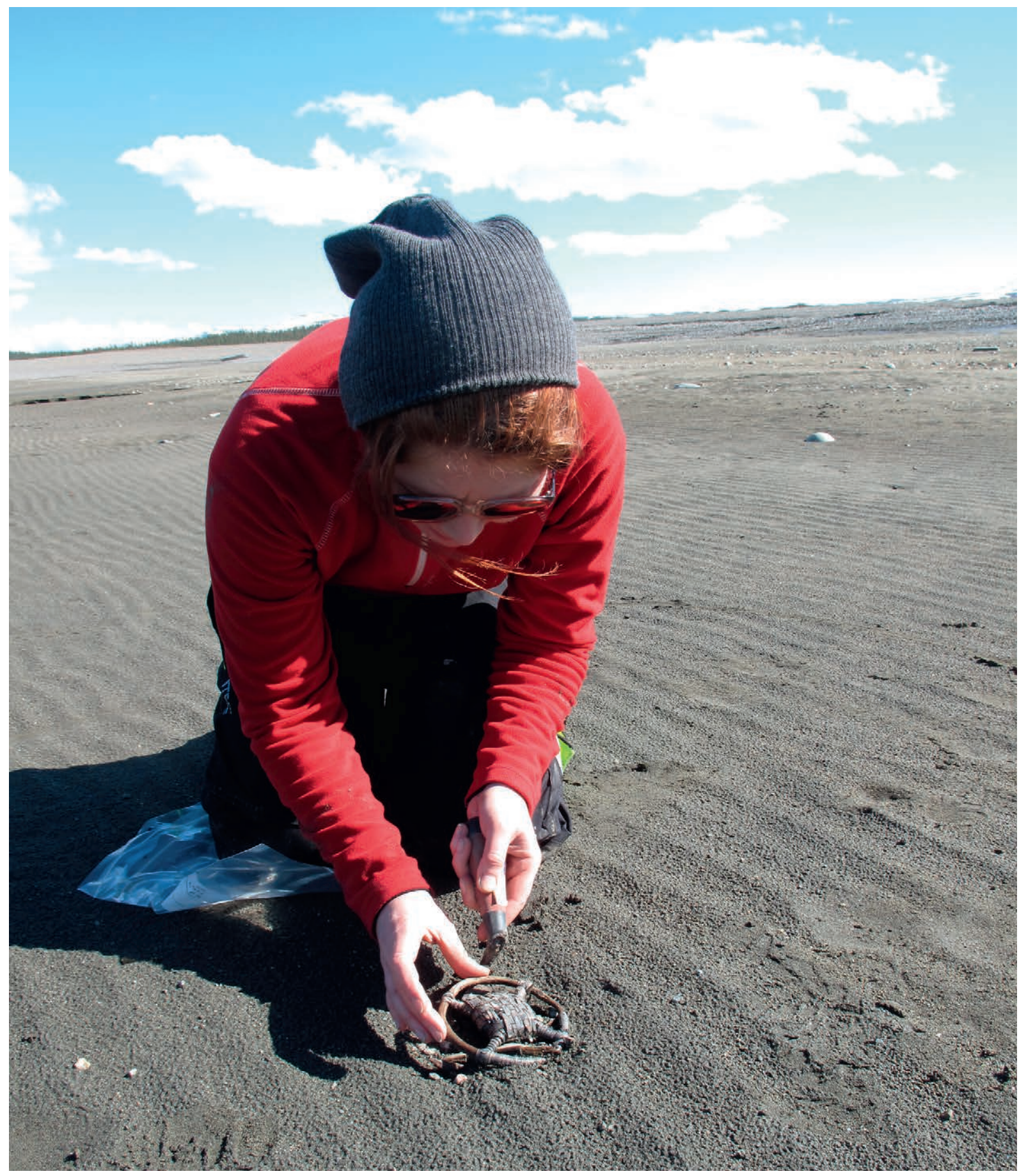

Figur 4: Innsamling av trinseformet søkke på en tørrlagt sjøbunn. Noen av funnene lå fullt eksponert, mens andre måtte graves fram. Foto: Elling Utvik Wammer, Norsk Maritimt Museum. 


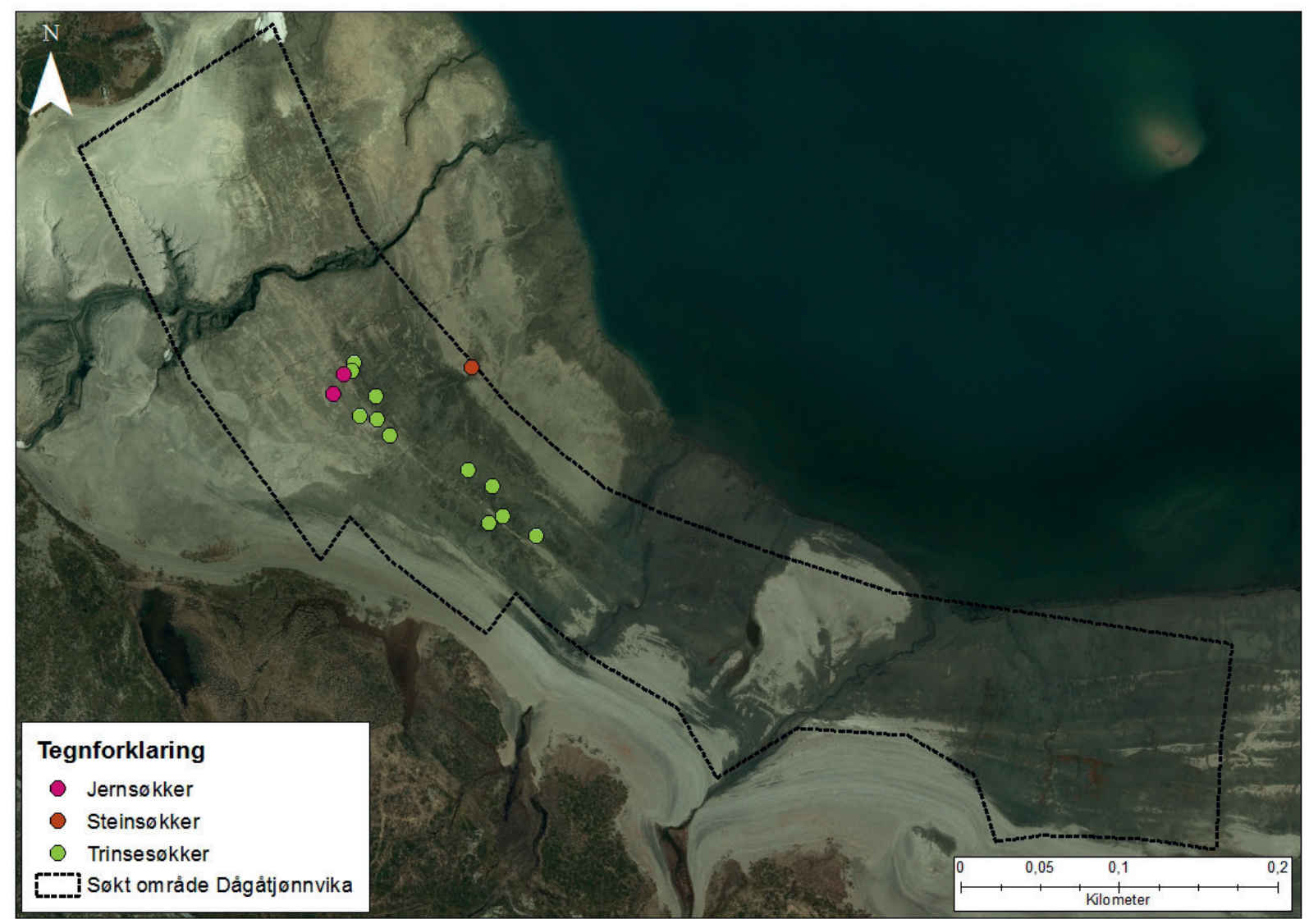

Figur 5: Oversikt over funnstedene for søkker i Dågåtjønnvika. Kart: Elling Utvik Wammer, Norsk Maritimt Museum.

uprøvd metode langs fjellvannene og vi valgte den i utgangspunktet for å forsøke å påvise rester etter bygninger, kokegroper og ildsteder fra andre tidsperioder enn steinalderen. Om lag $300 \mathrm{~m} 2 \mathrm{med}$ torv ble fjernet, og det gav gode resultater. Det ble funnet syv ildsteder som fremdeles var dekket av jord og torv, i tillegg til dem som var vasket frem av erosjonen. Konklusjonen vår er at man i økende grad bør ta i bruk gravemaskin ved utgravninger langs fjellvannene for å få frem ny viten.

I tillegg til å foreta registreringer ble det også utgravd åtte boplasser fra steinalderen. Utvalget ble gjort ut fra et ønske om å studere boplasser med ulik beliggenhet og å se nærmere på enkelte av dem som ligger ved det som må ha vært de beste fiskeplassene også i forhistorien. I tillegg ble det tatt hensyn til bevaringsforholdene. Det var ikke alle steder det var mulig å frembringe kunnskap etter 70 år med regulering og erosjon. ${ }^{9}$

Utgravningene vektla spesielt å finne spor etter fortidens fiske, slik som redskaper og fiskebein, men på tross av målrettet leting gjorde vi ikke funn av verken fiskeredskaper eller bevarte fiskebein på land. Dette kan skyldes at bevaringsforholdene for bein 
ved Tesse ikke er spesielt gode, ${ }^{10}$ og at fiskeredskaper fra steinalderboplasser tilhører sjeldenhetene. ${ }^{11}$

\section{FISKESØKKER}

Søkker, eller tyngder, av ulike slag brukt ved fiske blir tidvis gravd frem på steder med levninger fra jern- og middelalder på land. ${ }^{12}$ Også fiskekroker i jern og bein er relativt utbredte funntyper både ved kysten og i innlandet. ${ }^{13}$ På grunn av nedbryting av organisk materiale over tid finner man svært sjelden rester av ytterligere deler av fiskeutstyret, slik som garn, not, snøre eller lignende. Ved større arkeologiske bygravinger, blant annet i middelalderbyen Oslo, er det gjort funn av et hundretalls tyngder. De fleste av disse er antakelig fiskesøkker. ${ }^{14}$ For mange av innlandets vann og vassdrag dreier det seg imidlertid som regel om enkeltstående funn av søkker.

Totalt ble det funnet 40 søkker i løpet av undersøkelsen i Tesse i 2014 (jf. figur 4). Dette er i seg selv et vesentlig høyere antall funn enn hva som er vanlig $i$ norske innsjøer. Samtlige funn ble gjort innenfor de områdene som vi kartla systematisk i Dågåtjønnvika og ved Ilva-Byrtnes. De aller fleste søkkene ble samlet inn. Søkketypene varierte i utforming og materialvalg og fordeles i gruppene trinseformete søkker, neverhylster, steinsøkker, søkker av jern og flottører. Den siste gruppen ble for enkelhets skyld samlet inn som søkke, men har egentlig vært brukt for å løfte øvre kant av garnet og holde garnet utspent i vannet. Gruppen inneholder få funn, og funnene ble tatt inn som eksempel siden de var vanskelige å skille fra annet treverk i reguleringssonen.

I et fjellvann som Tesse er det naturlig å tolke søkkene som spor etter garn- eller notfiske. En sammenligning av de antatt eldre søkkenes tyngde viser at gjennomsnittsvekten på alle tre hovedtyper er relativt lik. Målingene ble gjort mens søkkene av never fortsatt var fuktige under konserveringen, noe som vil virke inn på tyngden. I vann vil treverket og neveren kun ha svakt negativ oppdrift. Dette kan få vesentlige utslag for objektenes funksjon som tyngder på garn, særlig for trinsesøkkene, hvor en relativt stor andel av massen består av treverk. Steinsøkkene ser ut til å kunne grupperes etter både størrelse og tyngde. Tyngden varierer mellom 55,7 og 321 gram, men alle søkkene er av former som på kysten anses som garnsøkker. ${ }^{15}$

Samtlige søkker ble funnet på sand- eller siltbunn uten større steiner i nærheten. Kanskje kan en av grunnene til dette være at man har villet unngå å sette fast garnene i bunnen? Mange av søkkene lå også i nærheten av mindre bekkefar eller vannstrømmer som hadde erodert bort de omkringliggende sedimentene. Funnene Dågåtjønnvika hadde en jevn fordeling i vannets lengderetning og så ut til å ligge i en sone ca. 100-200 meter fra land på omtrent samme dybde (figur 5). En årsak til dette kan være at fisket har vært mest effektivt på en bestemt dybde. Vanndybden ved søkkene er i dag omtrent seks meter, med utgangspunkt i opprinnelig vannstand. I denne beregningen er det imidlertid ikke tatt høyde for erosjonens endringer av bunntopografien. Ifølge den lokale fiskeren og kjentmannen Torstein Bjørgen skal dybden i Dågåtjønnvika ha økt betraktelig etter reguleringen, og flere meter med sedimenter kan ha forsvunnet. ${ }^{16}$

Mellom Ilva og Byrtnes var også søkkene spredt i vannets lengderetning på lignende måte. Både steinsøkker og søkker med never er funnet spredt over hele undersøkelsesområdet. Det er en tendens til at funnmengden avtar nærmere land, og også dette kan tolkes som at fisket kan ha foregått på bestemte dybder.

\section{Trinseformete søkker}

De trinseformete søkkene består av en stein surret eller bundet fast med bjørkeneverbånd i midten av en vidjering (figur 6). Festet mellom stein og ring 


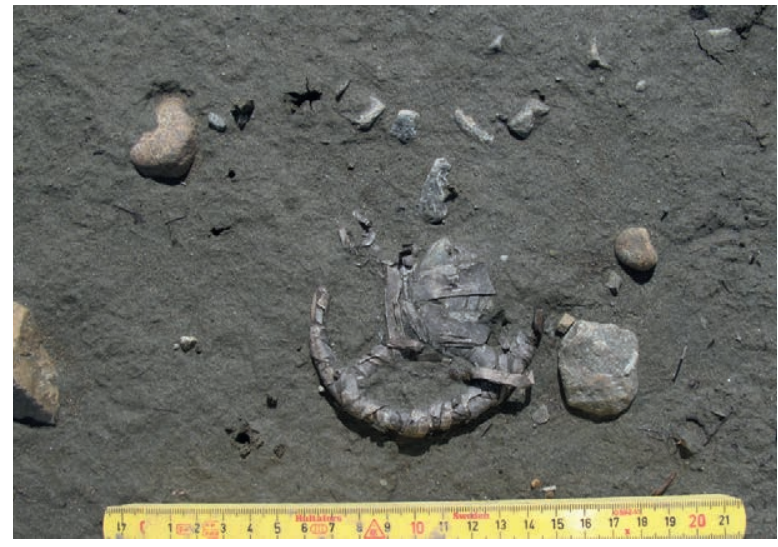

Figur 6a: Trinseformet søkke (C59636-109) slik det ble funnet. Foto: Elling Utvik Wammer, Norsk Maritimt Museum.

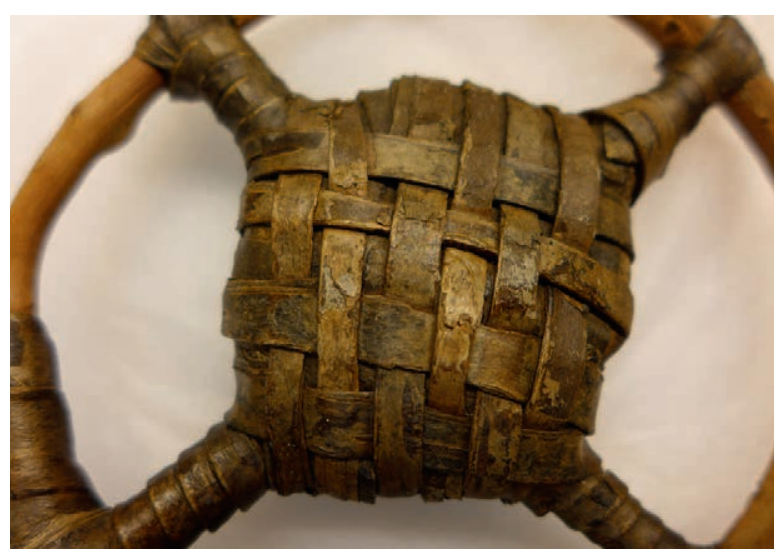

Figur 7a: Stein på søkke med fint flettverk (C59636-105).

består av fire armer, eller eiker, av spiralsurret never. Årsaken til at de ofte benevnes som trinseformede, er formlikheten med trinser på skistaver. Det ble tatt fire prøver til C14-dateringer, og søkkene kan på bakgrunn av disse plasseres innenfor tidsrommet merovingertid-høymiddelalder (se tabell 1).

Det ble totalt funnet 14 trinseformete søkker under feltarbeidet, og de ble funnet i begge hovedområdene. Elleve ble funnet i Dågåtjønnvika og tre

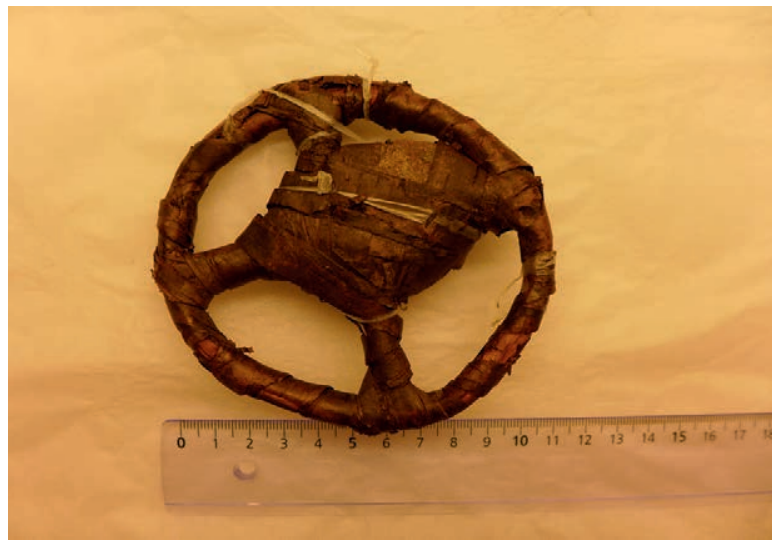

Figur 6b: Det samme søkket under konservering. Foto: Elling Utvik Wammer, Norsk Maritimt Museum.

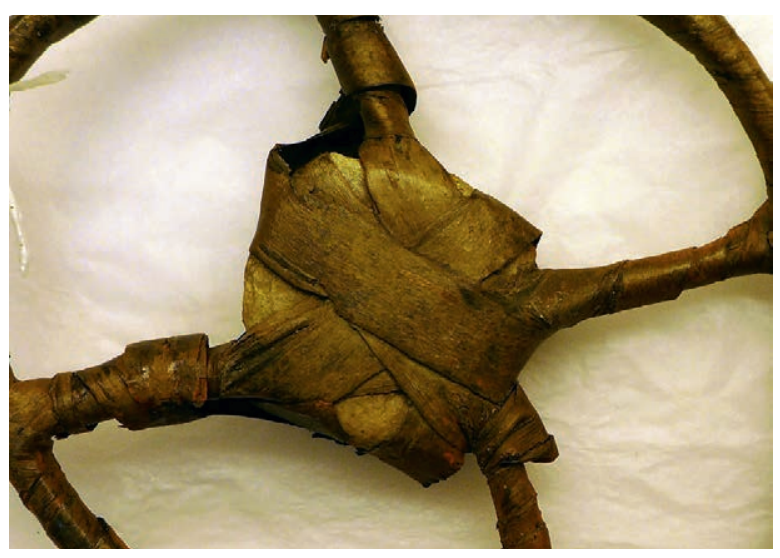

Figur 7b: Stein surret i bredere neverremser (C59636-104).

i området Ilva-Byrtnes. Selv om mange likhetstrekk kan observeres i tilvirkningsteknikk, varierer søkkene også mye i både utforming og størrelse. Midtsteinen kan være bundet fast med en enkelt kryssformet binding, surret i diagonalt lagte neverbånd, eller den kan være festet med et finmasket flettverk (figur 7). Det er surret neverbånd hele veien rundt vidjeringen på de fleste, trolig både så koblingspunktet mellom vidjekvistens to ender skal bindes sammen, 


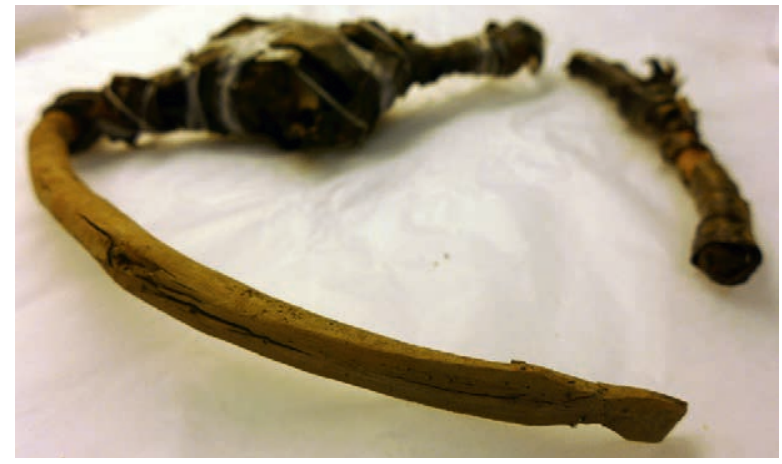

Figur 8: Fordi neversurringen er falt av, ses den tilvirkete enden av vidjeringen på flere av trinsesøkkene (C59636107). Foto: Elling Utvik Wammer, Norsk Maritimt Museum.

og så kvisten skal beskytte. På et mindre antall av søkkene ble det observert at neversurringen kun dekket koblingspunktet mellom kvistens ender. På noen av søkkene var ringen brutt (ødelagt), og koblingspunktet var synlig (figur 8). Det ser ut til å ha vært brukt ulike former for låsmekanismer, slik at kvistendene ikke glir fra hverandre.

\section{Hylsterformete søkker}

Søkker i gruppen hylstersøkker, også kalt neverhylster, består av én eller flere avlange steiner med et flak av bjørkenever viklet rundt som et hylster (figur 9). Hylsteret er ikke sydd sammen, men på de fleste søkkene er det ett hull i hver kortende. Hullene har sannsynligvis fungert som fester til fiskegarnet. Det ble funnet totalt seks slike søkker under feltarbeidet, kun i området Ilva-Byrtnes. Det skal også ha vært observert slike søkker på andre sandflater på vestsiden av vannet, på strekningen mellom de to kartlagte områdene. ${ }^{17}$ Neverhylstrene har store formog tilvirkningsmessige likhetstrekk, men varierer i størrelse. To av søkkene ble datert, og de faller innenfor boymiddelalder-senmiddelalder (se tabell 1).

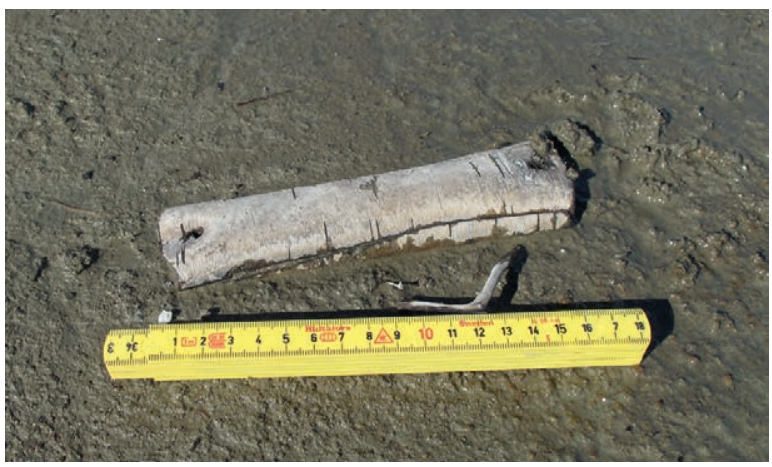

Figur 9: Hylstersøkke in situ (C59636-116). Et hull i hver ende av neverhylsteret, der hvor innfesting til bunntelna har vært. Foto: Elling Utvik Wammer, Norsk Maritimt Museum.

\section{Steinsøkker}

Steinsøkker er den største gruppen, med totalt 18 funn (figur 10). De aller fleste ble funnet i området Ilva-Byrtnes. Gruppen er variert, både når det gjelder valg av steintyper, og når det gjelder utforming. Både kleber og andre bergarter ser ut til å være brukt. De fleste søkkene har avlang/oval fasong, men også tre- og firkantete søkker opptrer. Samtlige av steinsøkkene har ett eller to gjennomgående hull. Det har vært brukt ulike teknikker for boring av hull; blant annet er det flere som ser ut til å være boret med maskin eller lignende fra én side. Disse er følgelig ikke veldig gamle. Flere har derimot bikoniske hull, uregelmessige i ytre del, det vil si at hullene er boret eller hugget fra hver side for å møtes i midten. Dette kan være et eldre trekk, men kan også ha vært brukt opp i nyere tid.

Steinsøkkene fra Tesse mangler organisk materiale og er følgelig ikke mulig å C14-datere, men denne typen søkker har vært i bruk over et langt tidsspenn. Det er funnet lignende søkker blant annet i vikingtids- og middelalderkontekst ved kysten andre steder i landet. ${ }^{18}$ Når det gjelder steinsøkkene, kan det være 

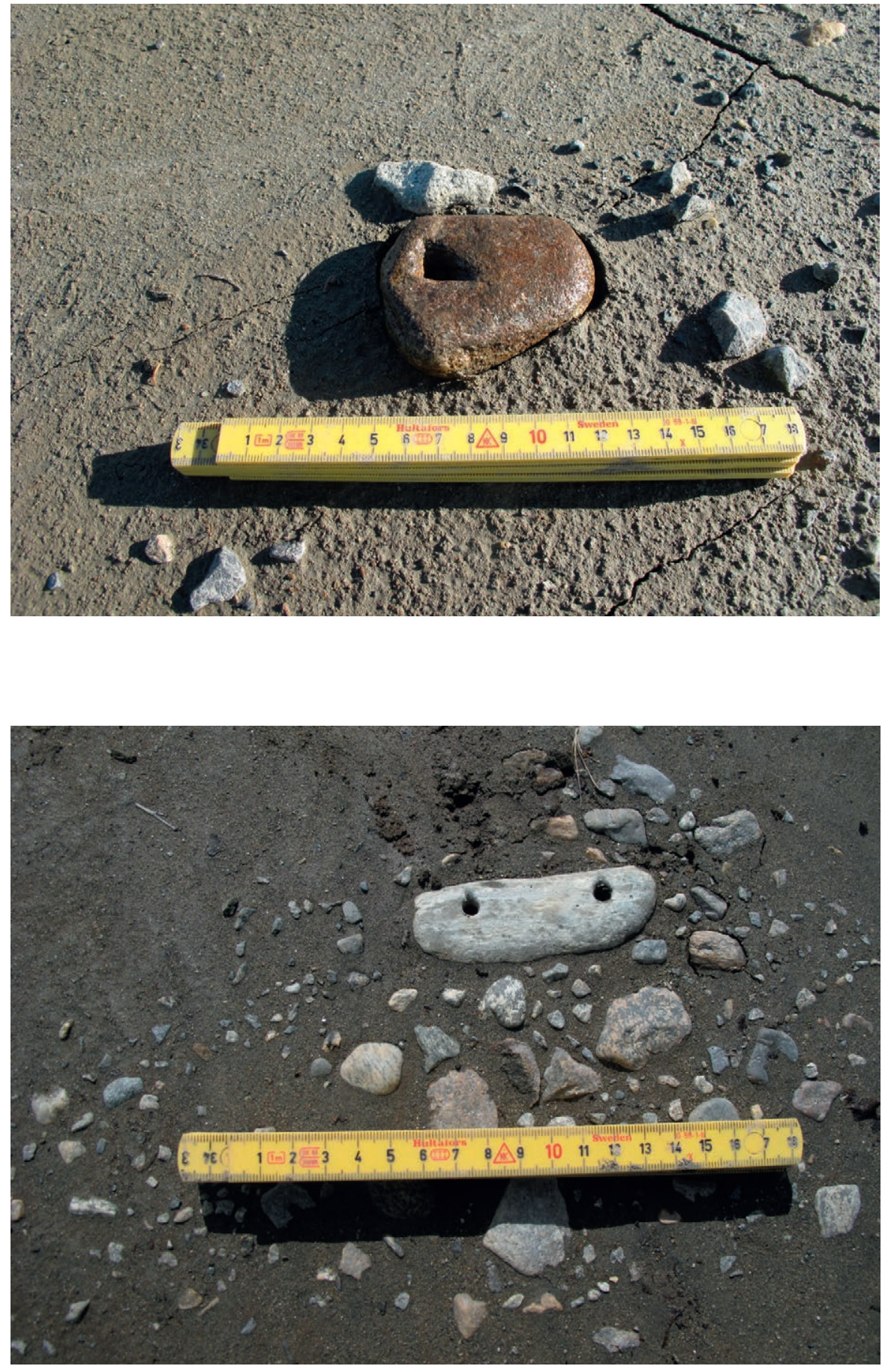

Figur 10a: Steinsøkke med ett hull. Hullet ser ut til å være hugget ut med meisel eller lignende redskap (C59636-133). Foto: Elling Utvik Wammer, Norsk Maritimt Museum.
Figur 10b: Steinsøkke med to hull i øvre kant og slitemerker etter festet til garnet eller nota (C59636135). Foto: Elling Utvik Wammer, Norsk Maritimt Museum. 


\begin{tabular}{|c|c|c|}
\hline Lokalitetsnavn & $\begin{array}{l}\text { Museumsnr./ } \\
\text { gjenstandstype }\end{array}$ & $\begin{array}{l}\text { Dateringer omregnet til kalenderår f.Kr./e.Kr. } \\
\text { og C14-år for nåtid (BP) }\end{array}$ \\
\hline Tesseosen I & C59128 & $\begin{array}{l}\text { 4722-4547 f.Kr. (5794 } \pm 35 \text { BP, Ua-47998) } \\
\text { 2888-2666 f.Kr. (4182 } \pm 31 \text { BP, Ua-47999) }\end{array}$ \\
\hline Tesseosen II & C59130 & 3784-3646 f.Kr. (4930 \pm 39 BP, Ua-49905) \\
\hline Nåvårseter I S & C60088 & $\begin{array}{l}\text { 3100-2900 f.Kr. (4377 } \pm 37 \text { BP, Ua-49906) } \\
\text { 3312-2908 f.Kr. (4398 } \pm 38 \text { BP, Ua-49907) }\end{array}$ \\
\hline Nåvårseter II & C60089 & \\
\hline Nåvårseter IV & C60090 & $\begin{array}{l}2620-2450 \text { f.Kr. (3991 } \pm 34 \text { BP, Ua-49908) } \\
1750-1560 \text { f.Kr. (3376 } \pm 34 \text { BP, Ua-49909) }\end{array}$ \\
\hline Nåvårseter VII & - & \\
\hline Dågåtjønnvikje & C60091 & \\
\hline Kojenebba I & C50129 & 3360-3102 f.Kr. (4527 \pm 32 BP, Ua-47996) \\
\hline Kojenebba II & C50129 & \\
\hline Tessekalven & C59131 & \begin{tabular}{|l|l}
$130-340$ e.Kr. $(1780 \pm 30$ BP, Ua-49910) \\
430-640 e.Kr. $(1505 \pm 30$ BP, Ua-49911) \\
\end{tabular} \\
\hline Ilva-Byrtnes & C59636/13, garnsøkke med trinseform & 721-946 e.Kr. (1190 \pm 31 BP, Ua-49913) \\
\hline Dågåtjønnvika & C59636/4, garnsøkke med trinseform & 777-987 e.Kr. (1134 £ 32 BP, Ua-49195) \\
\hline Dågåtjønnvika & C59636/8, garnsøkke med trinseform & 971-1152 e.Kr. (1009 \pm 33 BP, Ua-49198), \\
\hline Dågåtjønnvika & C59636/5, garnsøkke med trinseform & 1041-1221 e.Kr. (882 \pm 31 BP, Ua-49196) \\
\hline Ilva-Byrtnes & C59636-16, garnsøkke med hylsterform & 1190-1279 e.Kr. (789 \pm 30 BP, Ua-49913) \\
\hline Ilva-Byrtnes & C59636/17, garnsøkke med hylsterform & 1279-1395e.Kr. (652 \pm 32 BP, Ua-49197) \\
\hline Dågåtjønnvika & Fiskefelle (sløe 3) & 1513-moderne (266 $\pm 32 \mathrm{BP}, \mathrm{Ua}-49904)$ \\
\hline Dågåtjønnvika & Fiskefelle (sløe 8) & 1451-1635 e.Kr. (358 \pm 31 BP, Ua-49200) \\
\hline Dågåtjønnvika & Fiskefelle (sløe 18) & 1490-1659 e.Kr. (296 \pm 31 BP, Ua-49201) \\
\hline Dågåtjønnvika & Fiskefelle (sløe 20a) & 1218-1285 e.Kr. (760 \pm 32 BP, Ua-49202) \\
\hline Dågåtjønnvika & Fiskefelle (sløe 20b) & 1294-1405 e.Kr. (610 \pm 34 BP, Ua-49903) \\
\hline
\end{tabular}

Tabell 1: C14-dateringer fra undersøkelsene i Tesse i 2013 og 2014.

fruktbart å giøre typologiske sammenligninger, men med kildekritiske momenter i bakhodet. ${ }^{19}$

\section{SLØER}

Sløer er faste fiskeinnretninger som ble plassert i elver og bekker i tilknytning til vann og innsjøer. Teknikken gikk ut på at man fanget ørret i en kasse eller på en rist dannet av trestokker når fisken var på vei nedstrøms etter gytingen på høsten. Fiskemetoden er spesielt godt dokumentert i Oppland gjennom Trygve Hesthagens arbeid. ${ }^{20}$ Metoden har imidlertid også vært kjent både på Vestlandet, i Trøndelag og i Hedmark. ${ }^{21}$ Sløefiske er godt belagt i skriftlig materiale, og de første kildene som omtaler sløer i Valdres og Gudbrandsdalen, går tilbake til 13-1400-tallet. Før våre undersøkelser 


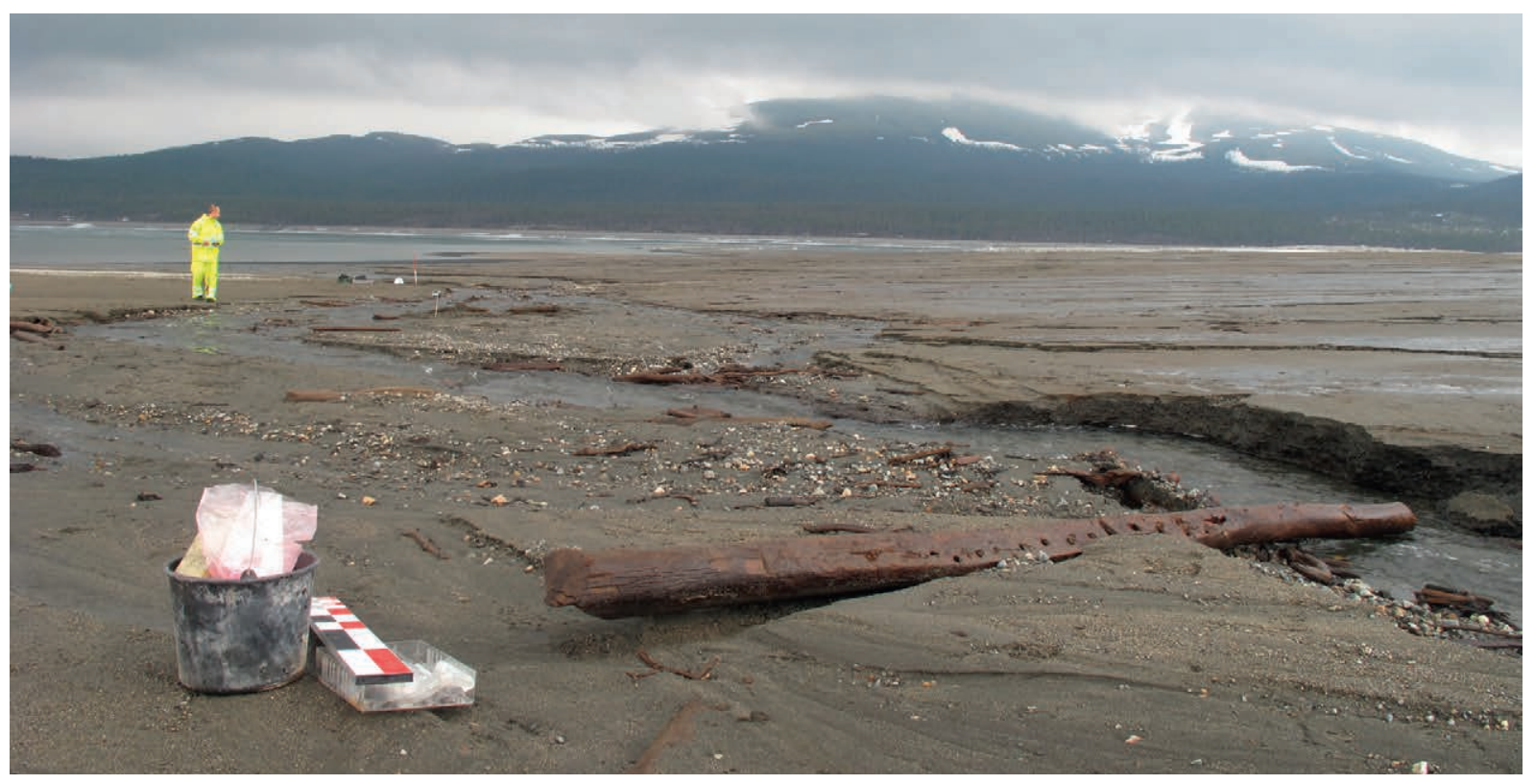

Figur 11: Ansamling av sløedeler og annet trevirke i Dågåtjønnvika. I forgrunnen ses tverrstokk (sløe 8). Legg merke til elveleiet som er dannet ved erosjon på den gamle sjøbunnen. Foto: Charlotte Melsom, Norsk Maritimt Museum.

gravde Åsmund Eknæs fra Norsk skogmuseum frem en sløe i Tesse i 1977. Denne var fra tidlig 1600-tall. ${ }^{22}$

De få arkeologiske funnene av sløer som så langt er kjent i Norge, består i sin enkleste form av en stokk på tvers av vannløpet (tverrstokk) og en rist dannet av et større antall smalere stokker (slindre, eller slindrestokker) ${ }^{23} \mathrm{I}$ reguleringssonen på Tesse var det store mengder velbevart treverk. Mye av dette treverket var bearbeidet, men kunne ikke sikkert anses som deler av sløer (figur 11).

Totalt ble det registrert 40 sløer i løpet av feltundersøkelsen. Samtlige funn, med ett unntak, ble gjort i Dågåtjønnvika. Det har vært stor variasjon i både utforming av og størrelse på så vel slindrestokker som tverrstokker. Dette tolkes som lokale tilpasninger til det stedet hvor de har vært plassert, størrelse og form på elva eller bekken. Det er også dokumentert forskjeller i tilvirkningsgrad og konstruksjonsmåter, som kanskje forteller om ulike tradisjoner, personlige/ håndverksmessige uttrykk og eventuelt alder.

De fleste sløene er i gruppen løse sløedeler, som i hovedsak er tolket som slindrestokker. Dette er ikke et uventet mengdeforhold når man regner med at det har vært et større antall slindrer i hver sløe. Alle sløene ble funnet på sandholdig eller siltig sjøbunn, men særlige konsentrasjoner ble observert ved bekkefar som var blitt skapt av erosjonen. Treverket i de fleste sløedelene var svært godt bevart, og det var på de fleste mulig å observere konstruksjonsdetaljer som treplugger og huggspor. Mange av stokkene var kløvd på langs.

Sløene lå fordelt utover det meste av Dågåtjønnvika, men var konsentrert til utløpet av de to bekkene Nørdre Elve og Meløken. Dette stemmer godt overens med lokal tradisjon, som forteller at Meløken 


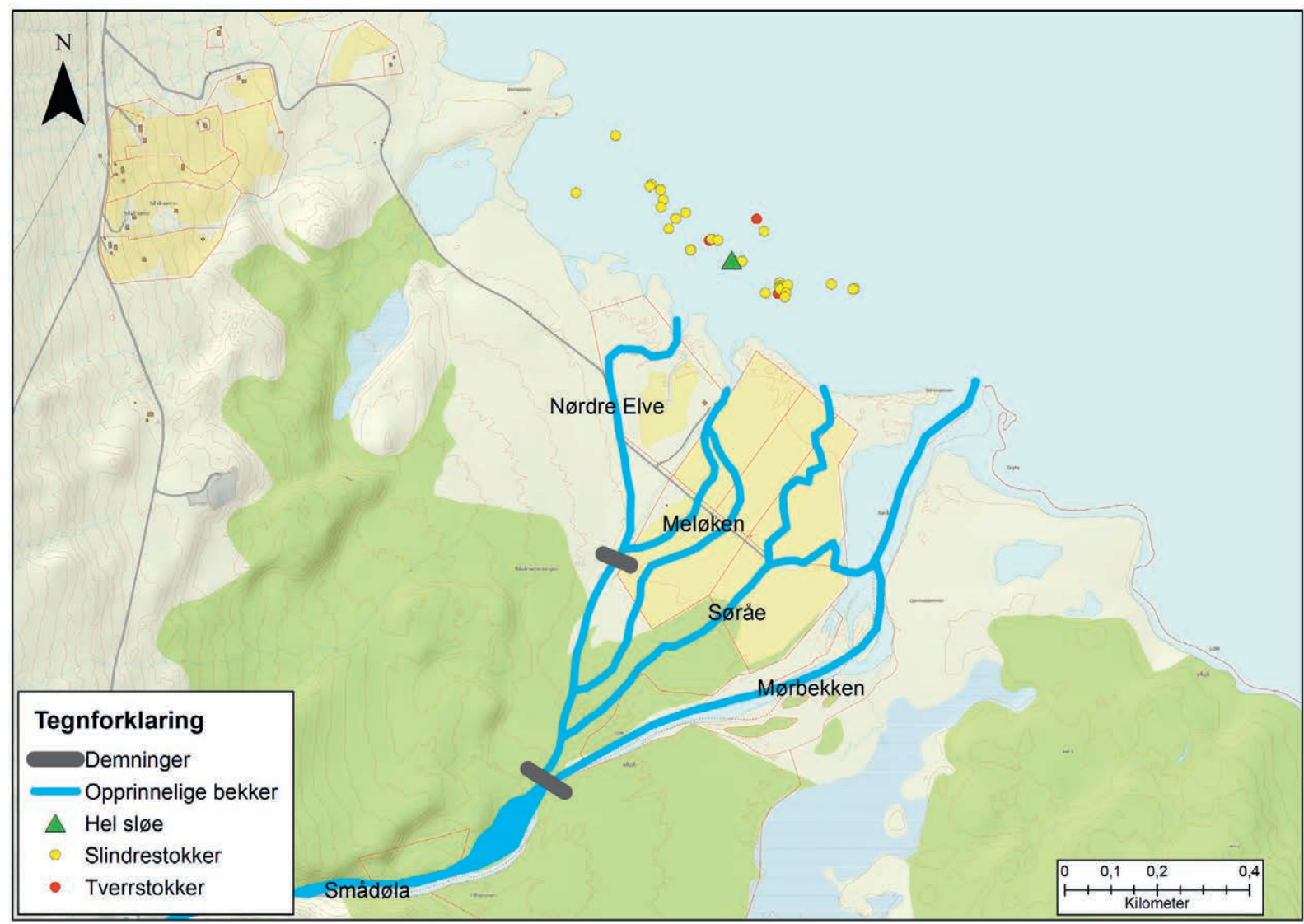

Figur 12: Oversiktskart over Dågåtjønnvika og utløpet av Smådøla, med registrerte funnsteder for sløer. Trygve Hesthagens (2011: 106) skisse av de historiske bekkeløpene hvor sløefisket tradisjonelt har vært omfattende, er brukt som grunnlag. Kart: Elling Utvik Wammer, Norsk Maritimt Museum.

var den beste gytebekken for Tessørreten i nyere tid. ${ }^{24}$ Kartet nedenfor gjengir hvordan man tenker seg de opprinnelige bekkeløpene i nedre del av Smådøla. Disse er helt eller delvis tørrlagt i dag. I forbindelse med sløene bygget man også demninger av både stein og tre for å sikre stabil vanntilstrømning til gytebekkene. Den sørligste demningen kalles Flådammen, eller Nåldammen, navn som skal vise til den gammelnorske betegnelsen «flomme over» eller «utvidelse av elv». ${ }^{25} \mathrm{I}$ dette området ble det funnet en hel sløe fra 12-1300-tallet. Kanskje indikerer dette at Flådammens alder går helt tilbake til middelalder?

Sløedelene ble funnet i ulik avstand fra land og er ikke knyttet til noen bestemt dybde. Dette reflekterer trolig en tilfeldig deponeringssituasjon i forbindelse med flom i bekkene hvor de opprinnelig ble plassert. Fra Valdres er det kjent at sløene jevnlig ble tatt av flom: «Det vart fiska på den sløe om hausten. I vårflaume so veit du åne reiste med garde, sløegarde. $\mathrm{O}$ so va det o gjerde uppatt.». ${ }^{26}$ 

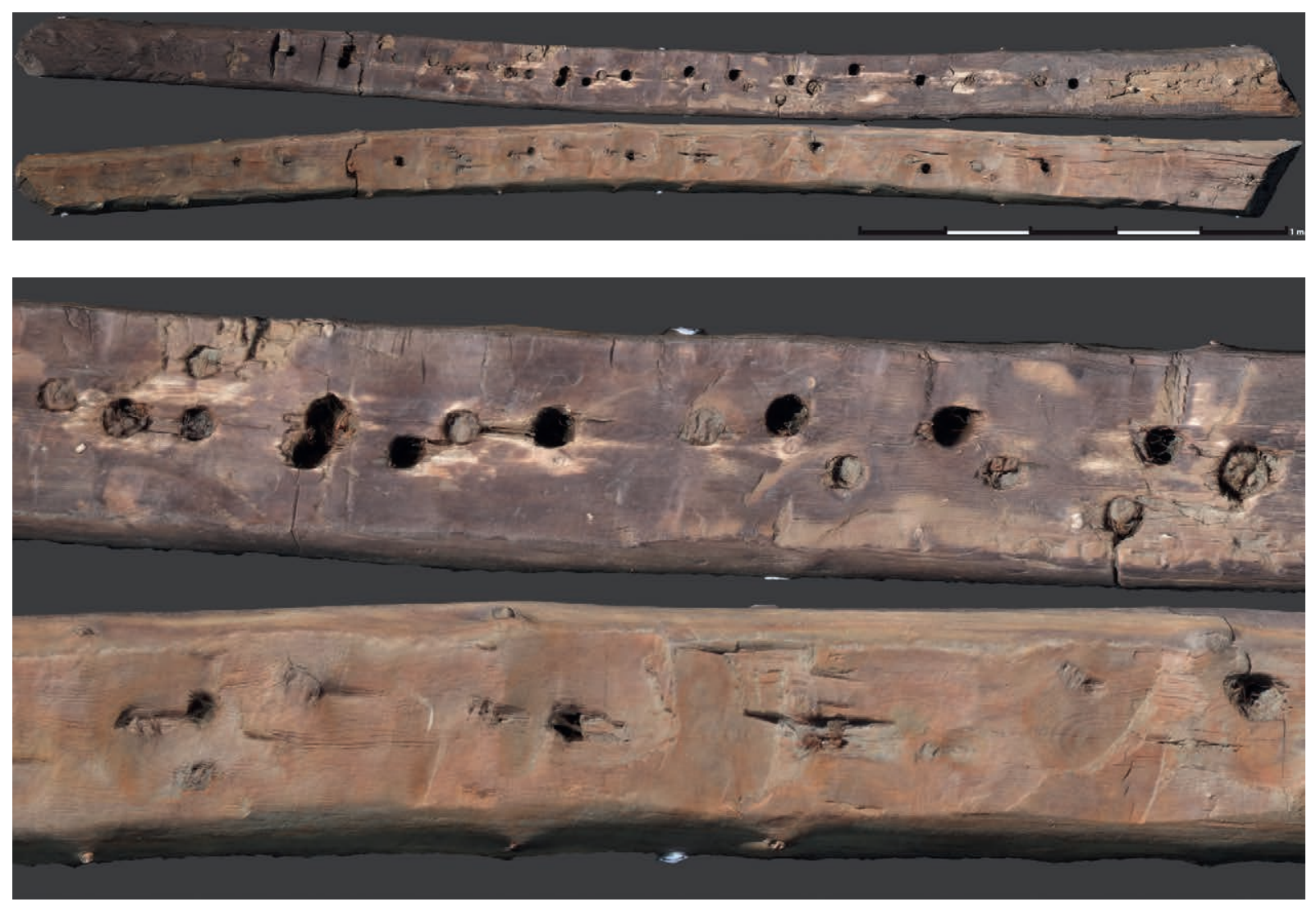

Figur 13: Fotogrammetri av sløe nummer 3. Det var i alt 20 plugghull, noen tett ved hverandre og med ulike dimensjoner, som kan tyde på reparasjoner eller gjentatt bruk. Begge stokkens ender var intakt med tydelige huggmerker. Fotogrammetri: Kristina Steen, Norsk Maritimt Museum.

Sånn gikk det nok også for seg når sløedeler fra sideelvene til slutt havnet i Tesse.

Tverrstokkene utgjorde en vesentlig del av sløen da den var i bruk, og blir antatt å si mye om sløens konstruksjon og størrelse. De skiller seg fra slindrene ved at de er betydelig tykkere (ca. 15-20 centimeter), og de har som regel et større antall hull på siden hvor slindrestokkene var festet. En av de utgravde tverrstokkene hadde en diameter på 13-15 centimeter og var 2,22 meter lang. Dette sier noe om størrelsen på bekken sløa har stått i. En prøve ble C14-datert til 266. Sløa er altså fra etter reformasjonen.

Kun én tilnærmet intakt sløe ble funnet (figur 14). Den ble funnet i Dågåtjønnvika, blant de løse sløedelene. Funnet ble gjort ikke langt fra funnstedet for den hele sløen som ble gravd ut og dokumentert i 1977. Sløen var så vidt synlig over bakken. Ved utgravning kom det frem 13 slindrestokker i vifteform og 1 tverrstokk under den bredeste enden av disse. Slindrestokkene var bevart i det meste av 


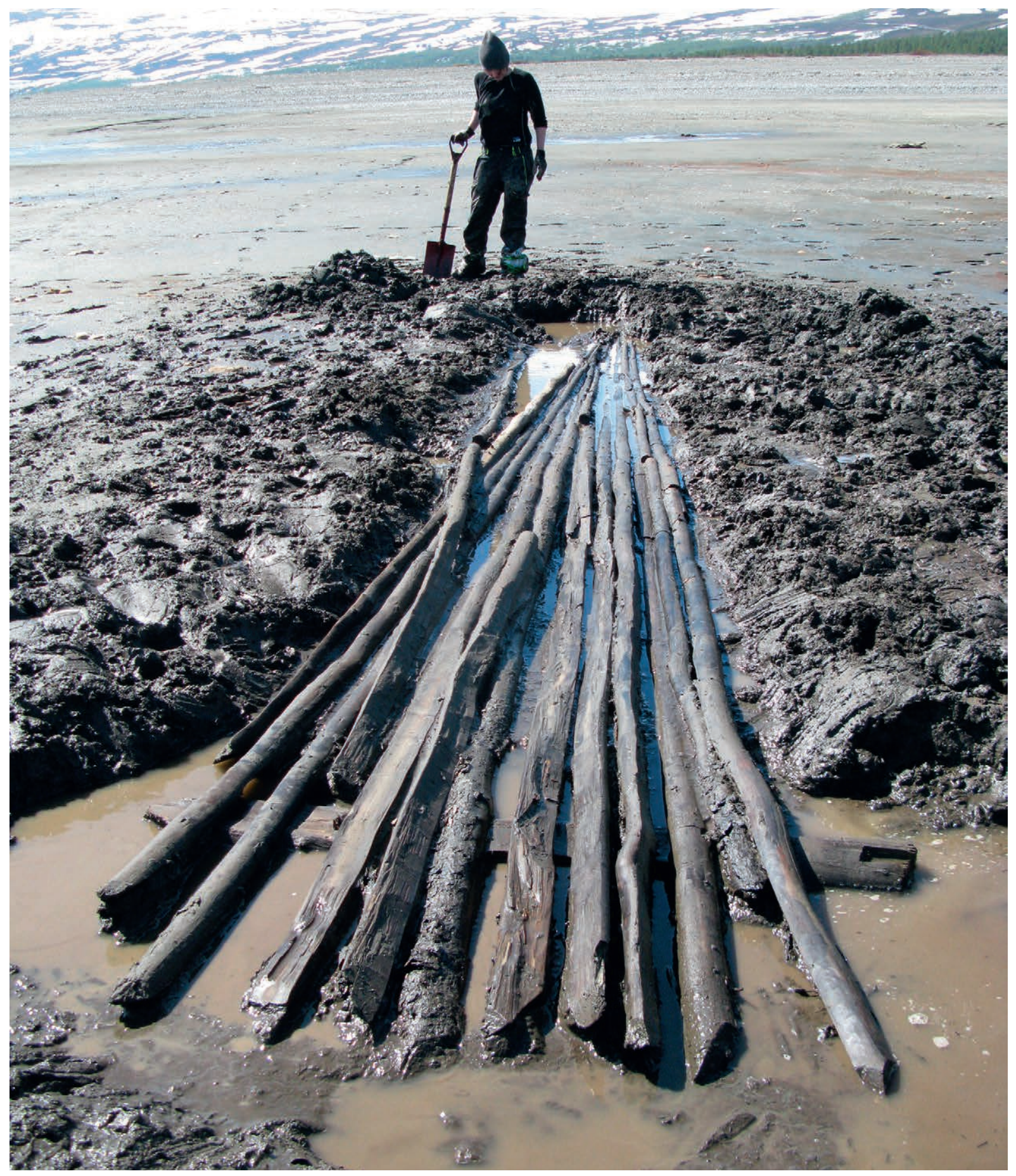

Figur 14: Den hele sløa fra middelalderen etter utgravning. Foto: Elling Utvik Wammer, Norsk Maritimt Museum. 


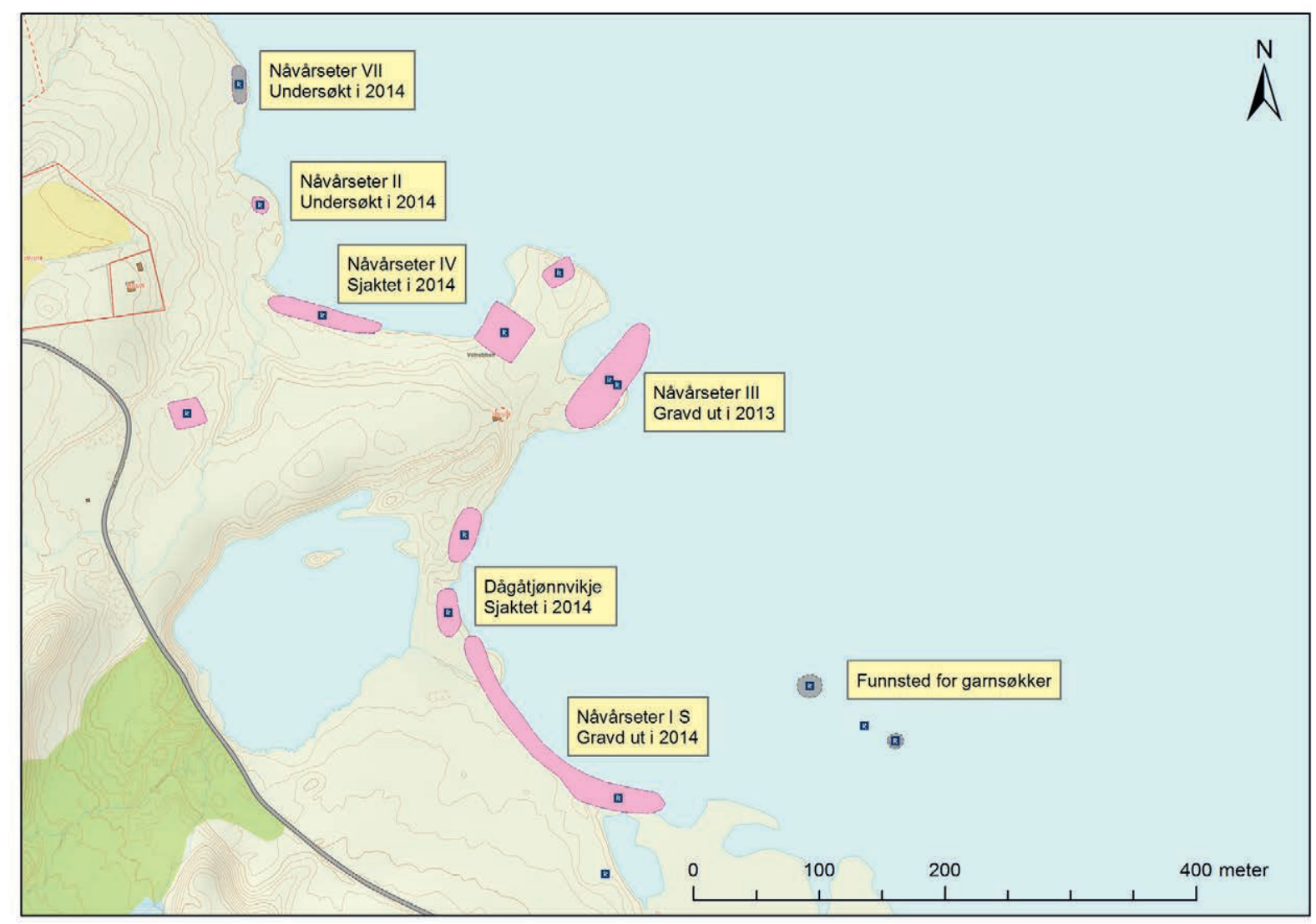

Figur 15: Oversikt over steinalderboplassene ved Nåvårseter. Kart: Ellen Kathrine Friis, KHM.

sin fulle lengde, men de fleste var noe knekt i den smaleste enden.

Slindrene var mellom 5,7 og 6,4 meter lange. I den tykkeste delen av stokkene var de kløvd på langs, og flere hadde bark bevart. Slindrene var ikke festet til tverrstokken med treplugger, men lå løst og hvilte på denne. I tverrstokken var det festet to treplugger med firkantet tverrsnitt, som stakk opp mellom slindrene. Tre C14-prøver ble tatt fra ulike deler av sløen, og to av disse ble sendt til datering. Begge prøvene plasseres godt før reformasjonen (1537), og sløen er derfor med rimelig sikkerhet fra middelalderen. Den ene er datert til 1200-tallet og den andre til 1300-tallet (se tabell 1). Årsaken til denne forskjellen i alder kan være at man har gjenbrukt materiale fra gamle sløer eller har brukt gammelt trevirke til byggingen.

\section{FUNN OG RESULTATER - STEINALDEREN}

Det er få fjellvann i Norge hvor kulturminnene er blitt like grundig kartlagt som i Tesse. Det helhetlige bildet som et slikt prosjekt gir, skaper et godt inntrykk av hvor det var mest aktivitet i steinalderen, for eksempel om det var de gode jakt- og/eller fiskeplassene 

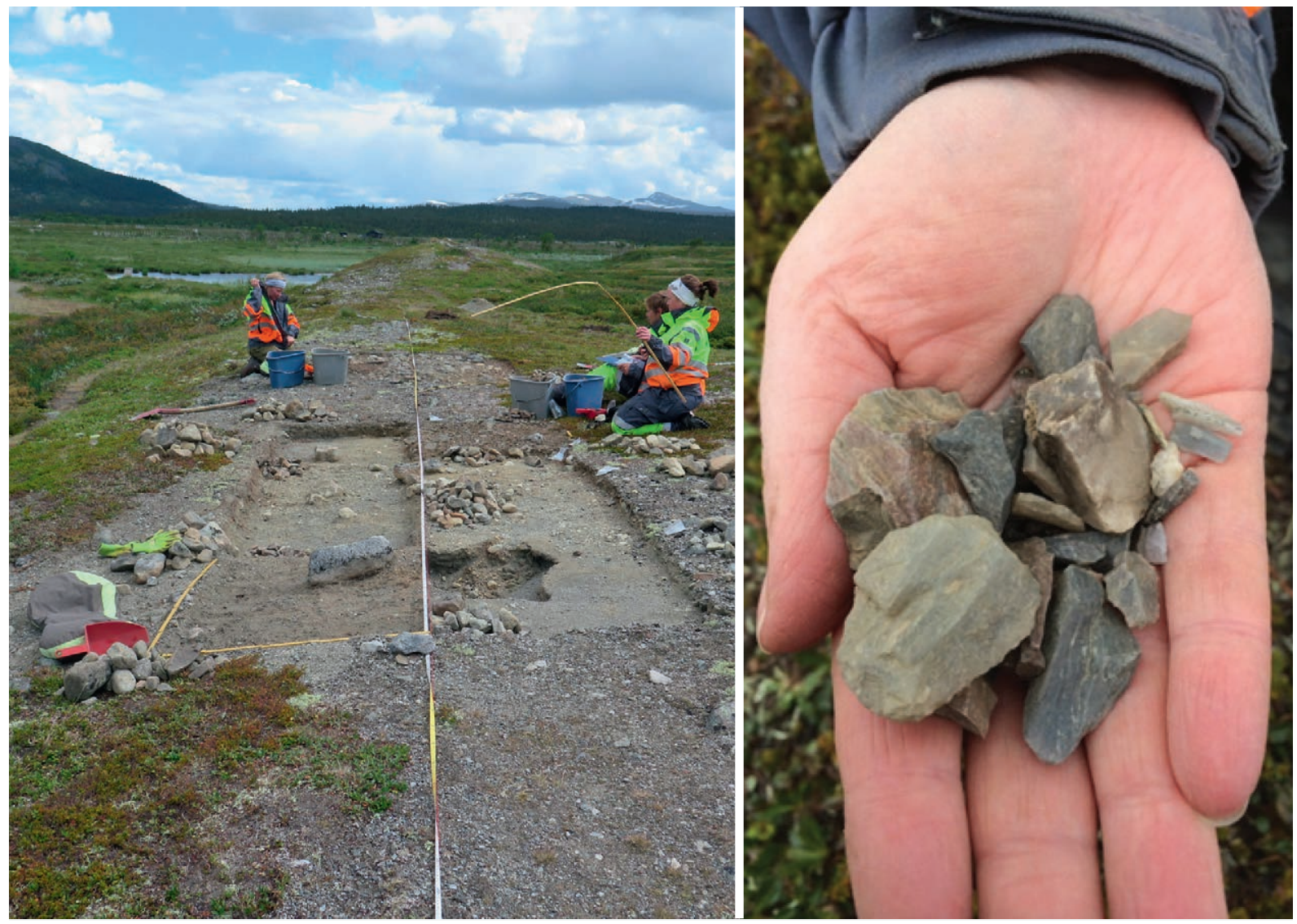

Figur 16: T.v. utgravning av Nåvårseter I S. T.h. funn fra Nåvårseter I S, avslag av ulike typer kvartsitt. Foto: Birgitte Bjørkli, KHM.

som trakk folk til vannet. ${ }^{27}$ Uoppdagete boplasser har med stor sannsynlighet gått tapt som følge av erosjon de siste tiårene, og det ble ikke påvist nye funnplasser fra steinalderen ved våre undersøkelser. ${ }^{28}$

Sporene etter folk strekker seg mye lenger tilbake i tid enn de omtale fiskeredskapene vitner om. Nedenfor følger en kortfattet presentasjon av resultatene fra utgravningene av steinalderboplassene langs Tesse. Gjennomgangen forteller noe om hvilke spor som er bevart rundt fjellvannene, men også hva som er i ferd med å gå tapt. Samtidig danner resultatene et fundament for betraktninger omkring fjellfiske og utdypende diskusjoner av temaet $\mathrm{i}$ andre artikler i denne boken. ${ }^{29}$

\section{Nåvårseter}

Lokalitetene ved Volnebben sørvest i Tesse, kalt Nåvårseter I-VII, ble først beskrevet i 1967,30 og tilstanden ble kontrollert i 2006 (figur 15). ${ }^{31}$ Lokalitetene som ble vurdert som å være mest utsatt for videre erosjon og å stå i fare for å forsvinne helt, ble gravd ut i 2014. Det ble samlet inn 1009 gjenstander 


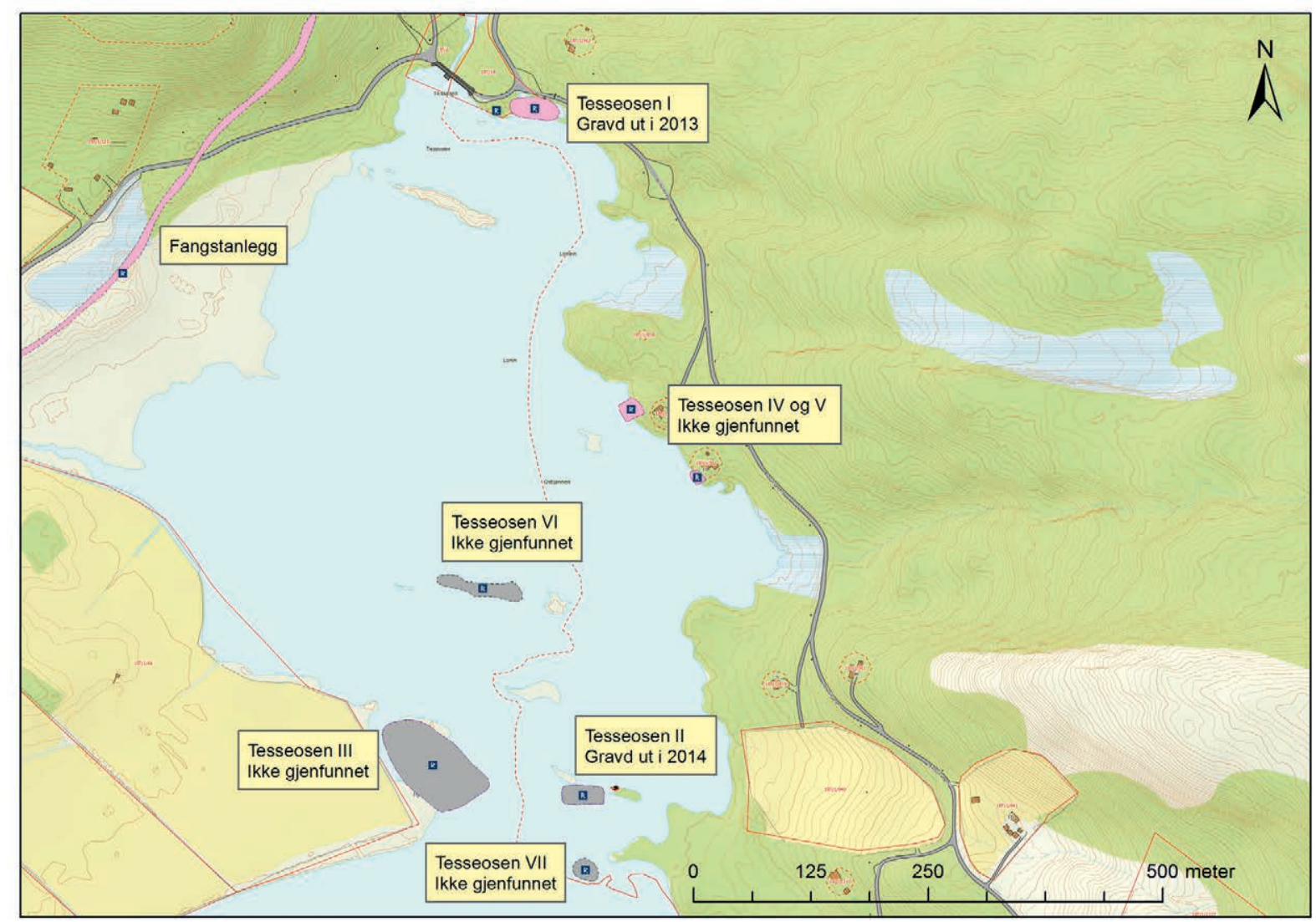

Figur 17: Oversikt over steinalderboplassene ved Tesseosen. Kart: Ellen Kathrine Friis, KHM.

i stein i dette området i 2014. I tillegg lyktes det oss å finne $36,3 \mathrm{~g}$ med bein. Beinstykkene var av pattedyr (ingen fiskebein), men det har ikke latt seg gjøre å foreta en presis artsbestemmelse av dem. ${ }^{32}$

Den største av disse lokalitetene er Nåvårseter I S. Boplassen var allerede delvis vasket vekk, men var fortsatt stor i utstrekning og strekker seg langs en lang rygg på sørsiden av Volnebben og øst for Dågåtjønn. Den ligger fint til på et opprinnelig platå, rett vest for noen av de beste fiskebankene i Tesse. Det er her flesteparten av fiskesøkkene er blitt oppsamlet, og her er det også funnet en type steinsøkker som er blitt anvendt siden steinalderen. ${ }^{33}$ Funnmaterialet på Nåvårseter I S består i alt vesentlig av stein. Det er også en del varmepåvirket stein spredt på flaten, noe som kan tyde på at det har vært ildsteder i området. Steinfunnene er i hovedsak dannet av ulike kvartsitter, trolig med lokalt opphav. Gjenstandsmaterialet består for det meste av rester etter produksjon av steinredskaper, men også av to pilspisser. Det ble også funnet seks skrapere, høvellignende redskaper som blant annet ble anvendt til bearbeiding av skinn, bein og tre. Stedet må ha blitt besøkt flere ganger, trolig i ulike deler av forhistorien. 

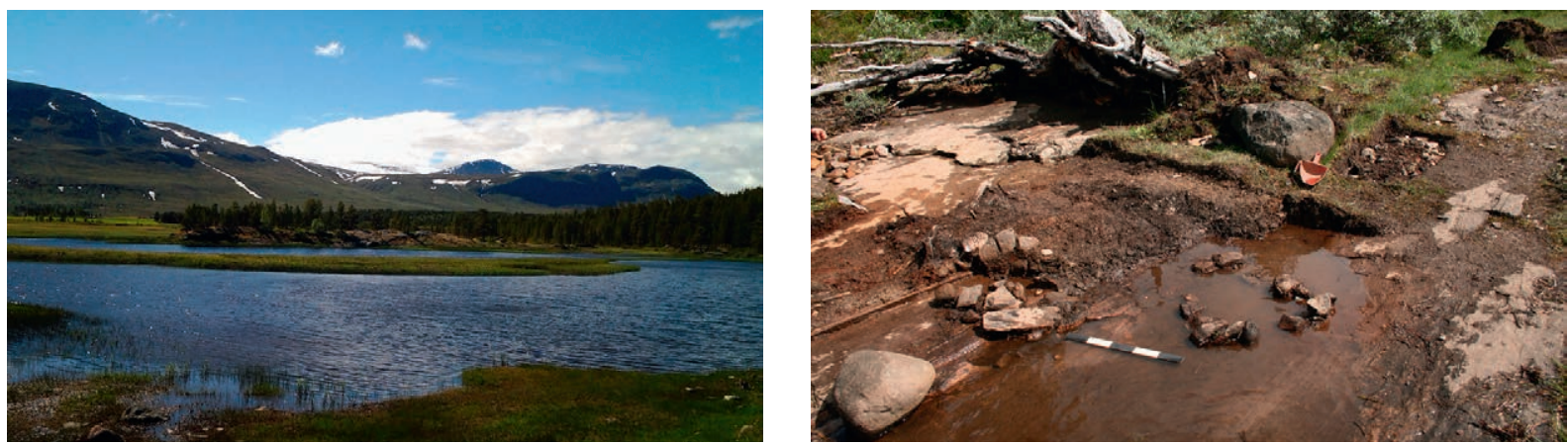

Figur 18: T.v. steinalderboplassen Tesseosen I. T.h. utgravde ildsteder på Tesseosen I, datert til eldre og yngre steinalder. På bildet t.v. kan man se hvordan ildstedene er i ferd med å bli oversvømt av det stigende vannet i Tesse. Foto: Birgitte Bjørkli, KHM.

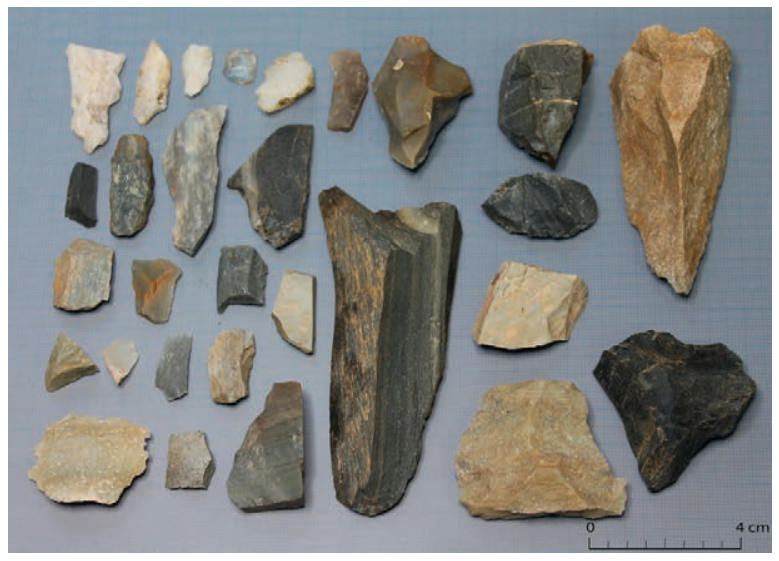

Nåvårseter II og VII viste seg å være mer eller mindre fullstendig erodert vekk, og funnmaterialet var følgelig svært sparsomt. Ved Nåvårseter VII ble det ikke gjort noen funn i det hele tatt og ved Nåvårseter II kun ti gjenstander av stein.

Lokalitetene Nåvårseter IV og Dågåtjønnvikja ble undersøkt ved hjelp av gravemaskin. Trekull fra fire av de syv ildstedene som fremkom, er blitt tidfestet med C14-metoden, og de viste seg å være overraskende gamle. Tre av dem ble anvendt i yngre steinalder (3312-2458 f.Kr., se tabell 1), mens ett var fra den tidligste delen av bronsealderen (1752-1561 f.Kr.).

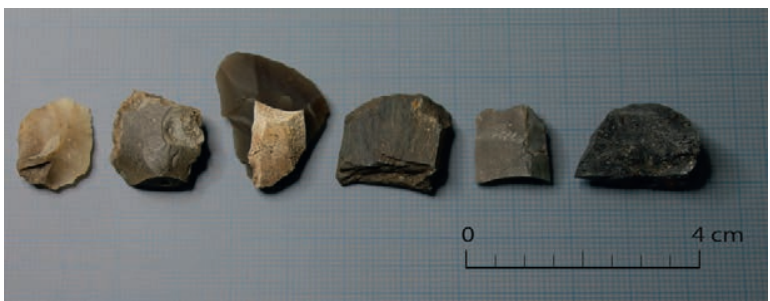

Figur 19: T.v. funn fra

Tesseosen I som viser den store variasjonen av kvartsitt. T.h. et utvalg skrapere fra Tesseosen I. Foto: Birgitte Bjørkli, KHM.

\section{Tesseosen}

I 1964 ble det beskrevet syv steinalderlokaliteter rundt Lonin (Tesseosen I-VII), det som tidligere var en liten elvestrekning med småvann nord i det nåværende Tessemagasinet (figur 17). ${ }^{34}$ Kun to av lokalitetene, Tesseosen I og II, lot seg gjenfinne i 2013. Ytterligere to andre hadde nok latt seg gjenfinne ved hjelp av prøvestikking, men dette ble ikke prioritert, da disse ikke sto i umiddelbar fare for å forsvinne. De øvrige har trolig forsvunnet som en følge av vannkraftproduksjonen. Tesseosen I ble gravd ut i 2013 og Tesseosen II i 2014. 
Det er tidligere blitt gjort funn i et belte på ca. 180 meter langs østbredden av elva, men bare ca. 10 meter var bevart i 2013. Det ble gjort rundt 900 funn fra steinalder på lokaliteten, i hovedsak ulike typer kvartsitt (minst 15 typer). Det ble også funnet redskaper av flint, kvarts og skifer, blant annet flere skrapere og en skiferspiss. Det ble påvist to ildsteder (figur 18), og radiologiske dateringer fra disse viser bruk både i slutten av eldre og $\mathrm{i}$ begynnelsen av yngre steinalder (4722-4547 f.Kr. og 2888-2666 f.Kr., se tabell 1). Tidfestingen passer godt med funnmaterialet.

Det ble også foretatt en mindre utgravning av det som må være restene av Tesseosen II, en lokalitet som har ligget rett ved innløpsosen mellom Lonin og Tesse. Her ble det gjort til sammen 20 funn av kvartsitt, flint og kvarts i et lite, avgrenset område. Datering av kull (3784-3646 f.Kr.) kan fortelle at det trolig har ligget et ildsted her i yngre steinalder.

\section{Kojenebba}

Rester av en liten boplass ved utløpet av Smådøla skiller seg noe fra de andre lokalitetene ved Tesse blant annet fordi funnmaterialet her domineres av flint. Grunnen i området består av finkornet sand, og den gamle strandlinjen er nærmest helt ødelagt av erosjon. Totalt ble det utgravd 268 funn, derav 48 hele og fragmenterte mikroflekker, det vil si avlange, små flintstykker som blant annet er blitt anvendt til å lage skarpe egger på pil- og spydspisser i bein i eldre steinalder. ${ }^{35}$ Funn av et utvasket ildsted med 1 gram bein, datert til begynnelsen av yngre steinalder (3360-3102 f.Kr.), viser at stedet også har vært besøkt senere.

\section{HVA FORTELLER FUNNENE I TESSE?}

Undersøkelsene som er gjennomført i Tesse, viser et arkeologisk materiale med et stort tidsspenn som strekker seg gjennom de fleste tidsepoker, fra eldre steinalder helt opp til etterreformatorisk tid. Blant de viktigste indikatorene på gjentagende bruk og tilknytning til landskapet er utnyttelsen av lokale råstoff. Flere studier over spredningen og utnyttelsen av lokale råstoff er blitt brukt som indikatorer på territorielle grenser og gruppeidentitet i forhistorien. ${ }^{36}$ Bruken av lokal kvartsitt over et lengre tidsspenn kan tyde på at det i hovedsak er lokale grupper som har brukt og kjent til Tesse.

Det totale bildet fra undersøkelsene viser at det var aktivitet rundt Tesse fra ca. 4500 f.Kr. eller tidligere. Flest spor finner vi fra yngre steinalder, perioden ca. 3800-2500 f.Kr. Det er dessverre ikke blitt funnet bevarte fiskebein på noen av boplassene, ei heller redskaper som kan knyttes direkte til fiske. Det at boplassene stort sett er lokalisert innenfor fiskebankene og ved gode fiskeplasser ved inn- og utløpsoset til Tesse, antyder at fisket kan ha spilt en rolle så tidlig som i yngre steinalder. ${ }^{37}$

Undersøkelsene i de dype delene av reguleringssonen resulterte $\mathrm{i}$ et omfattende og unikt kildemateriale fra innsjøen. Når det gjelder mengden og graden av bevaring av fiskeredskaper, er Tesse så langt unik i nasjonal sammenheng og har ikke mange skandinaviske paralleller. Funnene fra sjøbunnen bidrar til både å flytte tidsgrensene for når de ulike fiskeredskapstypene har vært i bruk, og å gi oss sikrere kunnskap om funntyper som man tidligere hadde få holdepunkter for å si noe om. Den første førreformatoriske dateringen i Norge av en sløe gir for eksempel spennende ny innsikt i norsk middelalderhistorie.

Nye funn og dateringer vil også gi gode muligheter til å diskutere forholdet mellom ulike fiskemetoder. De trinseformete søkkene har eksempelvis en tidsmessig utstrekning som går tilbake til yngre jernalder, og deretter ser det ut til at de hylsterformete garnsøkkene tar over. På samme tid ser det ut til at man tar i bruk sløer i Smådøla. Hvordan henger disse endringene sammen? 
Etter undersøkelsene våre satt vi igjen med mange nye spørsmål. Litteratur om innlands- og fjellfiske viser at dette er et lite utforsket tema innenfor arkeologien generelt. Flere av spørsmålene våre gjelder ikke bare for fisket i Tesse i Norge, men for hele Sør-Skandinavia. Finnes det andre og konkrete eksempel på at fiske var viktig i steinalderen, og i hvilket omfang? Når startet man å fiske i fjellet i Norge generelt? Hvordan ble dette fjellfisket organisert, og hvordan forholdt fisket seg til andre aktiviteter i fjellet?

Funnene fra Tesse gir flere spennende innfallsvinkler til videre diskusjoner av hvem det var som drev fiske i sørnorske fjell i fortiden, ved hjelp av ulike teknikker, identitetsmarkører og lignende. De arkeologiske undersøkelsene ved Tesse er med andre ord en innfallsport til fjellfiske som et tverrvitenskapelig tema.

\section{SUMMARY:}

\section{TESSE - AN}

\section{ARCHAEOLOGICAL ELDORADO AND A GATEWAY TO MOUNTAIN FISHING AS AN INTERDISCIPLINARY RESEARCH TOPIC}

The inland lake named Tesse is situated in Lom and Vaga counties, on the north-eastern side of the Jotunheimen alpine area. The lake lies 850 m.a.s.l. and covers an area of approximately 12 square kilometers. Tesse is well known in the region as a great trout-fishing lake in modern times. However, written sources and archaeological finds confirm that fishing has also been important in the area both in historic and probably prehistoric periods.

On the basis of this, a collaborative archaeological field project was conducted by Oppland County, the Museum of Cultural History, and the Norwegian Maritime Museum in 2013 and 2014. In this article, we present how we worked to gain new insight and knowledge about mountain fishing in the past based on securing and documenting archaeological evidence from the bottom of the lake and on the lake's shores.

The recent surveys and excavations in Tesse generated an archaeological material from a large span of time, stretching through most periods, from the early Stone Age up to the early post-medieval period. The total picture created is that the human activity in Tesse starts as early as $4500 \mathrm{BC}$, perhaps even earlier. Surveys deep in the water reservoir, made possible on dry land thanks to the power dam regulation, resulted in a rich source material from the lake. The amount of finds and the condition of organic objects are so far unique on a national level and have few, if any, parallels in Scandinavia.

The finds from Tesse give us a number of exciting gateways to further discussions of who was fishing in the lake, and how fishing was combined with other activities in the mountains in all periods. 


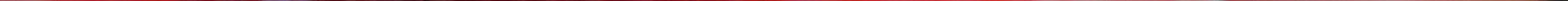




\title{
AUREN I JOTUNHEIMEN - NÅR VART HAN INNFØRT, OG KOR KOM HAN FRÅ?
}

\author{
Trygre Hesthagen, Norsk institutt for naturforskning, Trondheim og \\ Einar Kleiven, Norsk institutt for vannforskning, Grimstad
}

\section{INNLEIING}

I dag er det fisk i så og seia alle vatn og elver over heile landet, frå lågland til høgfjell. Men slik har det ikkje alltid vore. $\mathrm{Da}$ isen trekte seg attende og forsvann frå innlandet for kring 10000 år sidan, byrja ulike fiskartar å vandre inn i vassdraga våre. På den tida stod havet mykje høgare enn i dag, og fisken kom seg relativt langt inn i landet. Men etter kvart sette fossar og stryk ein effektiv stoppar for ei vidare spreiing. Mange vassdrag i høgareliggjande strøk vart difor liggjande fisketome. Det kan også gjelde Jotunheimen og andre fjellstrøk i Sør-Noreg. Når ein finn fisk ovanfor slike spreiingsbarrierar, er det fordi menneske ein gong har bore han opp. Det er lite kunnskap om når dette skjedde i førhistorisk tid. Det einaste skriftlege og handfaste provet er ein liten bautastein med runeskrift som stod på garden Li i Austre Gausdal i Oppland. Historikar Gerhard Schøning såg denne steinen da han reiste gjennom Gudbrandsdalen i $1775 .^{1}$ På steinen stod det: «Eiliv Elg bar fisk i Raudsjø» (figur 1). Runesteinen vart truleg sett opp ein gong etter vikingtida, ikring år 1050-1100. ${ }^{2}$ Raudsjøen ligg på vestsida av Gudbrandsdalslågen, om lag 25 kilometer nord for innløpet av Mjøsa (figur 2). I

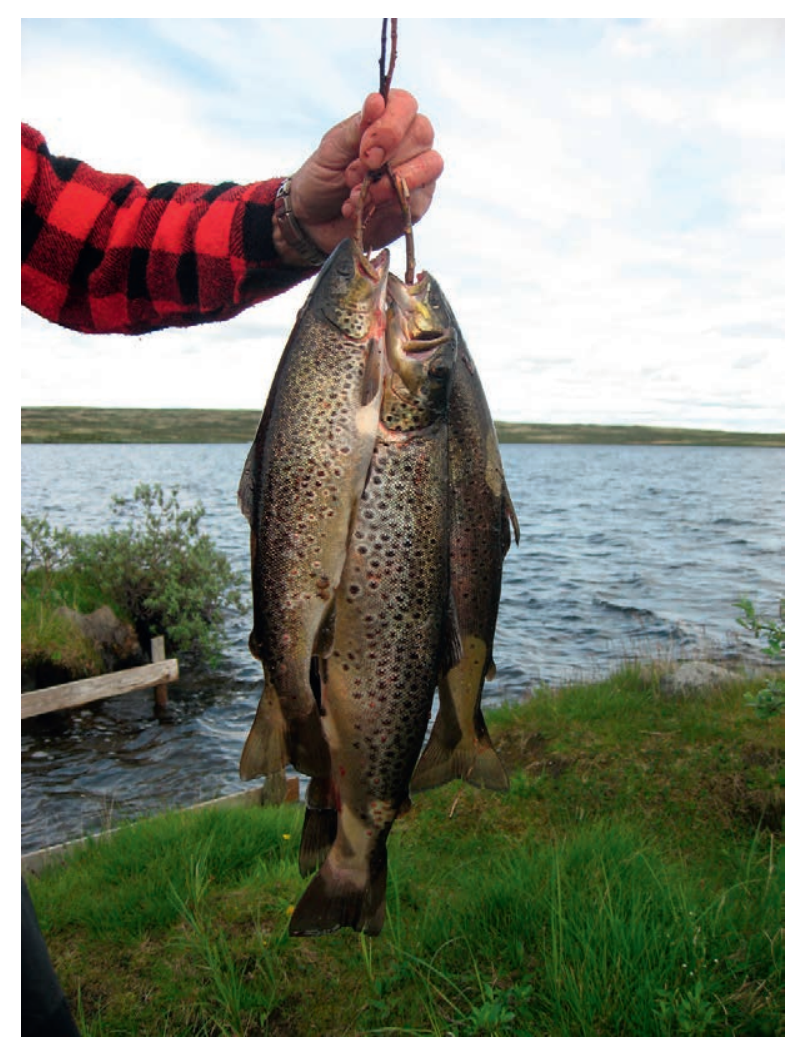

Aure var den fiskearten som steinalderfolket sette ut i vatna i Jotunheimen. 


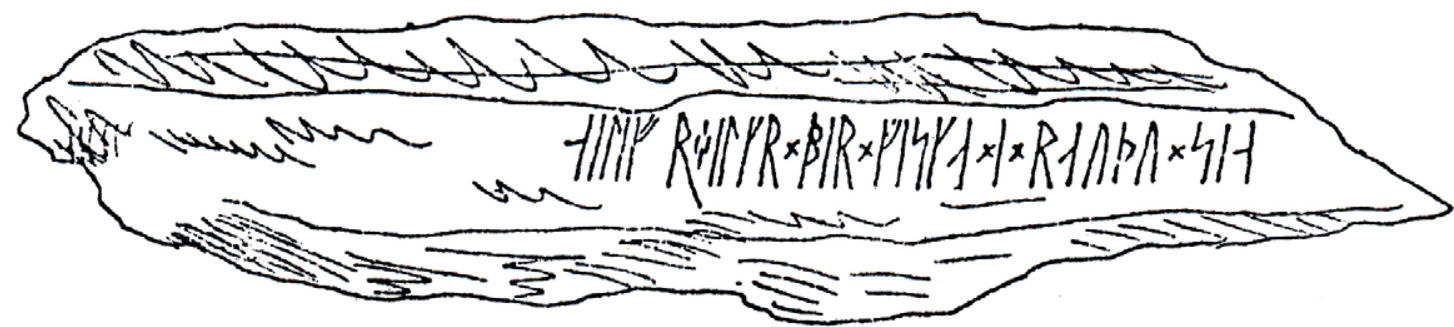

Figur 1: Innskrifta på runesteinen frå Li i Austre Gausdal frå tida ikring 1050-1100 e.Kr. (Schøning 1926; Olsen 1941). Det var Martin Friedrich Arendt (1783-1823), tysk oldforskar, som i 1805 teikna av innskrifta på steinen. Frå 1833 vart det også laga ei penneteikning av steinen, utført av Chr. C.A. Lange, seinare riksarkivar (Olsen 1941). I 1839 vart steinen borte, da han «er bleven anvendt som Bygningssteen i et muret Fæhus» (Kraft 1840). Det er gjort fleire freistnadar på å finne att denne særeigne runesteinen, men utan hell (Olsen 1941; Einstad 1952).

middelalderen gjev ymse diplom, Diplomatarium Norvegicum, nokre opplysningar om fisk i enkelte fjellvatn. ${ }^{3}$ Heller ikkje denne kjelda nemner kva tid fisken vart innført.

For å finne ut meir om når fisk vart innført til høgfjellet i Sør-Noreg i førhistorisk tid, lyt vi ty til indirekte prov gjennom arkeologiske studiar. Den norske steinalderen omfattar ei tidsepoke på over 7500 år, frå ikring 9200 til 1700 f.Kr. Den yngre steinalderen strekkjer seg frå ikring 3800 til 2350 f.Kr. ${ }^{4} \mathrm{I}$ løpet av dei siste åra har arkeologiske undersøkingar kasta nytt ljos over fisket i Jotunheimen i steinalderen. Dette er basert på kartlagde buplassar, funn av fiskereiskap og C14-dateringar av fiskebein og fiskereiskap. ${ }^{5}$ Også i andre fjellstrøk i Sør-Noreg finn ein liknande spor etter fisk i steinalderen. ${ }^{6}$

I denne artikkelen skal vi sjå nærare på desse arkeologiske funna for å danne oss eit bilete av kor det var fisk i Jotunheimen attende i steinalderen. Moglege «spreiingsvegar» vil også bli diskutert. I tillegg vil vi dokumentere ymse utsettingar og utbreiinga av fisk i historisk tid, frå 1600-talet og framover. Fisk i denne samanheng er synonymt med aure (Salmo trutta), som var einaste fiskeslaget i Jotunheimen til langt inn på 1900-talet. Dette fjellområdet omfattar i grove trekk høgfjellspartiet mellom Sogn i vest, Valdres i sør, Gudbrandsdalen i aust og Ottadalen i nord (figur 3).

\section{STORE DØLASJØ: VAR DENNE BREDEMDE} INNSJØEN EI VANDRINGSRUTE FOR FISK?

For over 100 år sidan vart det lansert ei hypotese om at auren hadde kome seg opp i Olstappen. ${ }^{7}$ Vatnet ligg i nedre delar av Vinstravassdraget, på 668 moh. (figur 2). Det kan i så fall ha skjedd anten via Lågen eller gjennom vassdrag i Gausdal, opp til Espedalsvatnet og Breidsjøen. Ny kunnskap om kvartærgeologiske prosessar og bredemde sjøar har kasta nytt ljos over dette temaet. Det viser seg at restane av innlandsisen i Vågå og Sel var tjukkast ved isskiljet som låg i aust-vest-retning om lag ved Vinstra. ${ }^{8}$ Herfrå strekte dalbrear seg oppover både til øvst i Gudbrandsdalen og til Ottadalen. Mellom desse isrestane og dalsidene danna det seg fleire sjøar. Den største av dei strekte seg frå det nemnde isskiljet ved Vinstra og opp til Lesja, med 


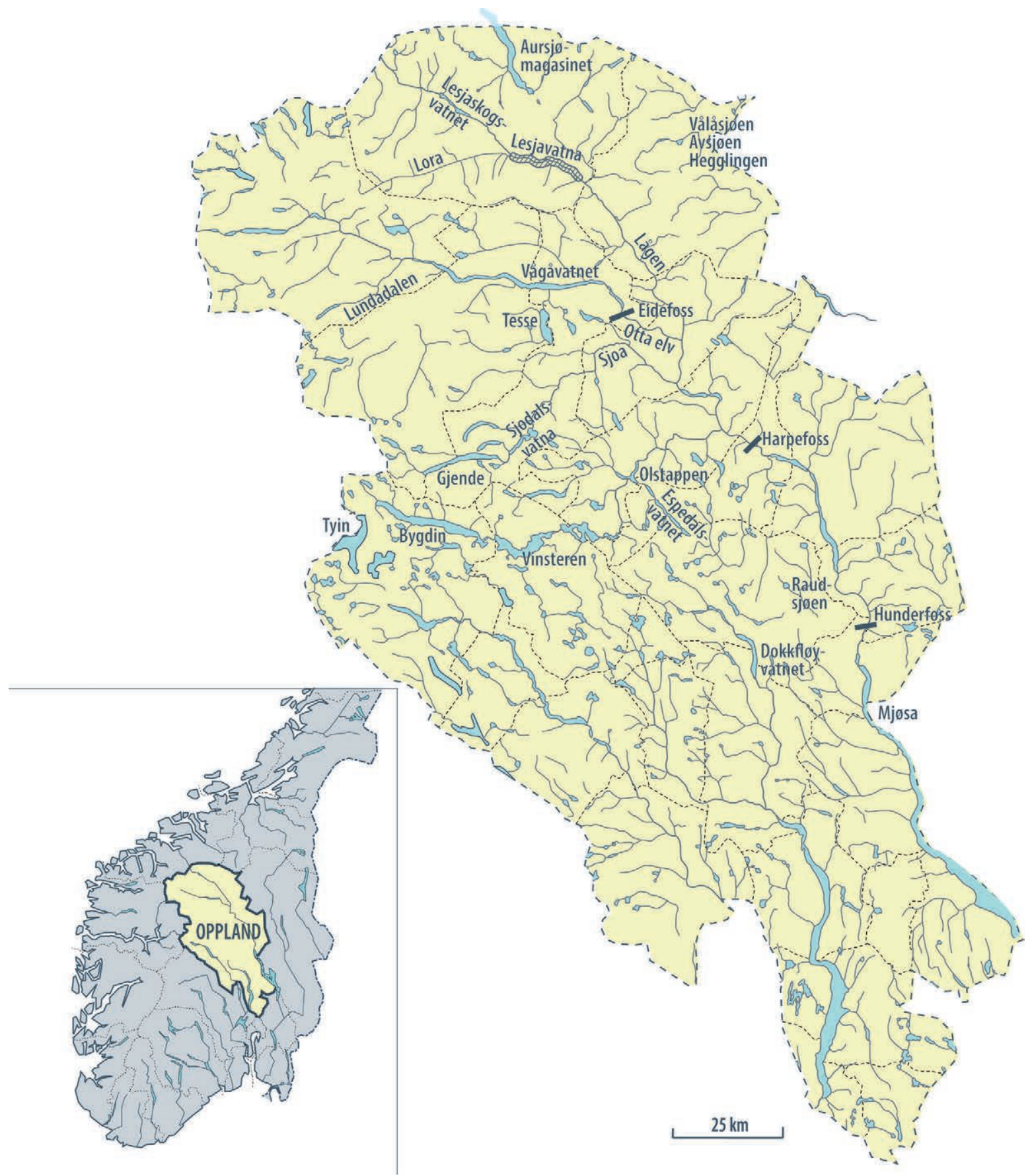

Figur 2: Kart over kommunane i Oppland med ymse vassdrag og innsjøar som er nemnde i teksten. Lesjavatna vart tappa ut og turrlagde på 1860-talet (skraverte på figuren). Hunderfoss, Harpefoss og Eidefoss er avmerka med tjukk strek. 


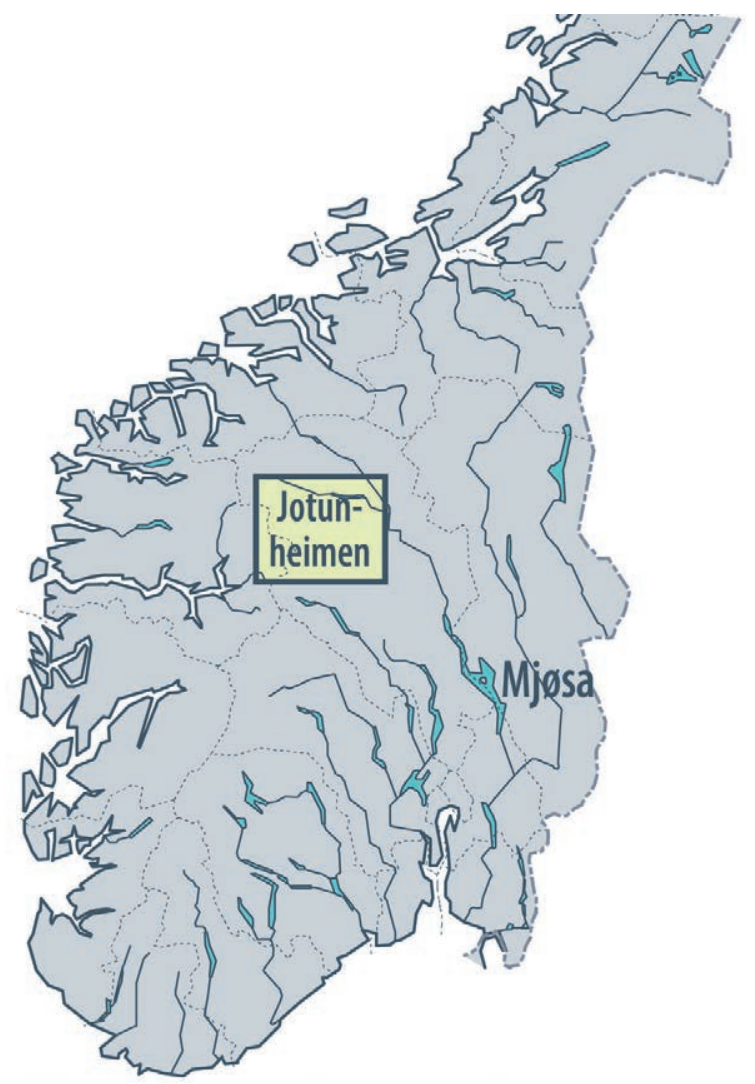

ein sidearm til Skjåk i Ottadalen. Denne bresjøen blir kalla Store Dølasjø og hadde utløp ved Lesja, der vatnet rann ned i Romsdalen. Ut frå danninga av strandline ved bølgjevasking $i$ dalsidene, setar, låg Store Dølasjø ikring 650-669 moh. Ein har ingen konkrete dateringar av når sjøen vart drenert. Truleg skjedde det over nokre hundre år, etter kvart som isen smelta ned i Gudbrandsdalen. Det kan ha skjedd på same tid som Nedre Glåmsjø vart drenert. ${ }^{9}$ Denne bresjøen rann ut gjennom Jutulhogget i Alvdal og Rendal for ikring $9000-10000$ år sidan. ${ }^{10}$

Høgste nivået på Store Dølasjø var altså omtrent det same som for Olstappen. Men Store Dølasjø trekte seg altså gradvis attende og var truleg mykje
Figur 3: Jotunheimen ligg i kommunane Skjåk, Lom, Vang, Øystre Slidre, Vågå, Sel og Nord-Fron i Oppland og Luster og Årdal i Sogn og Fjordane. Det er ikkje fastlagt skarpe grenser for dette fjellområdet. Og etter opprettinga av alle verneområda i dei seinare åra ser det også ut til å ha endra seg noko i folk sitt medvett (Odd Repp, Lom fjellstyre, pers. med.). Blant eldre folk i Lom er den gjengse meininga at Jotunheimen er avgrensa av Lomseggen og vidare Hestbrepiggane i dei nordvestlege delane. No blir dette fjellområdet gjerne rekna som ein del av Breheimen, med Bøverdalen og fylkesveg 55 som grensa mot Jotunheimen. Heilt i nordvest gjekk altså «den gamle grensa» ved Hestbrepiggane. Vi ser det som naturleg å rekne Lundadalen med Skjøli i Skjåk som grensa mellom Jotunheimen og Breheimen. I vest går grensa ved Medalen, Nørstedalsseter og Fortunsdalen. I sør blir Rasletindane på Valdresflya ofte rekna som grensa for Jotunheimen (Reidar Gran, Øystre Slidre fjellstyre, pers. med.). Men i sørvest vil grensa når det gjeld vassdrag, omfatte Tyin i Årdalsvasssdraget, med Bygdin til Olstappen i Vinstravassdraget vidare austover. Frå Olstappen går grensa rett nord, til aust for Lemonsjøen. I nord dannar Ottavassdraget grensa. Sjoavassdraget ligg i sentrale delar av Jotunheimen, og omfatter mellom anna Gjende og Sjodalsvatna. Totalt dekkjer Jotunheimen eit areal på ikring $3500 \mathrm{~km}^{2}$. Jotunheimen nasjonalpark, som vart oppretta i 1980, utgjer sentrale delar av dette fjellområdet.

lågare da fisk mykje seinare vandra inn i Mjøsa og vidare oppover Lågen. I tillegg var truleg isskiljet som låg i aust-vest-retning ved Vinstra, ei barriere som hindra fisken å vandre oppover vassdraget. Basert på dette trur vi at innvandringa av fisk til nedre delar av Lågen har skjedd langs dei vassvegane som i dag finst, etter at Store Dølasjø var borte. Og dersom fisk har spreidd seg naturleg til Olstappen og Vinstravassdraget, skulle ein vente at fleire fiskeartar også hadde kome seg opp. Så er ikkje tilfellet, for inntil nyleg var altså aure einaste fiskeslag i dette vassdraget. Vi trur difor at auren i øvre delar av Lågen, og i Jotunheimen, vart boren opp av menneske langt attende i tida (jf. figur 3). 


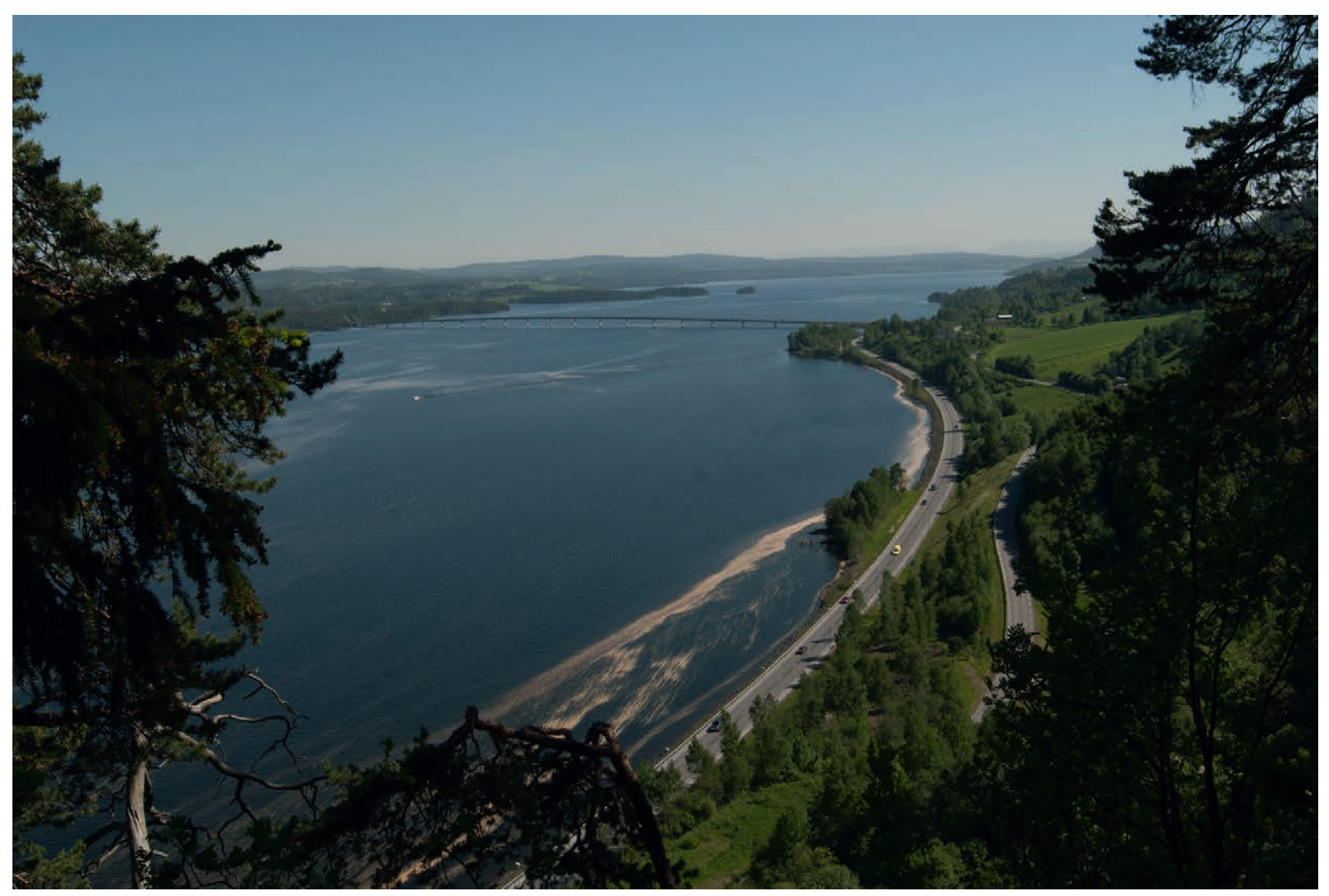

Mjøsa var innfallsporten for fisk som tok seg opp i Gudbrandsdalslågen. Foto: Børre Kind Dervo.

\section{NATURLEG INNVANDRING AV AURE TIL MJØSA OG NEDRE DELAR AV GUDBRANDSDALSLÅGEN}

Under siste istid var heile den nordlege delen av Europa isdekt. Det er identifisert tre refugar som hovudkjelde for postglasial innvandring av ferskvassfisk til Fennoskandia basert på data for aure og abbor: (1) det atlantiske feltet til Den iberiske halvøy og det sørlege Frankrike, (2) det kaspiske bassenget og (3) eit område aust for isdekket. ${ }^{11}$ For om lag 10000 år sidan vart den baltiske israndsjøen danna (Ancylussjøen). Det var eit ferskvasshav som fløymde utover lågareliggjande strøk av Skandinavia. Mange av fiskeartane som fanst i denne sjøen, spreidde seg vidare, blant anna til Sør-Noreg (figur 4). Huitfeldt-Kaas har gjeve ei utgreiing om innvandringsmønsteret til dei enkelte fiskeartane våre ${ }^{12}$. Kor langt dei klarte å spreie seg, var avhengig av ei rekkje faktorar, som symjeevne, toleranse for vasstemperatur og saltinnhald. Det var da heller ikkje alle fiskeartar som nådde Ancylussjøen til same tid, og dei fysiske tilhøva endra seg. Desse faktorane gjorde at dei ymse fiskeartane våre har eit til dels svært ulikt utbreiings- og innvandringsmønster. Dei anadrome fiskeartane, som laks (Salmo salar) og sjøaure, hadde tilgang til vassdraga langs kysten. ${ }^{13}$

Ei gruppe på 20 artar, deriblant aure, nådde heilt opp til Mjøsa, og dei kalla Huitfeldt-Kaas 


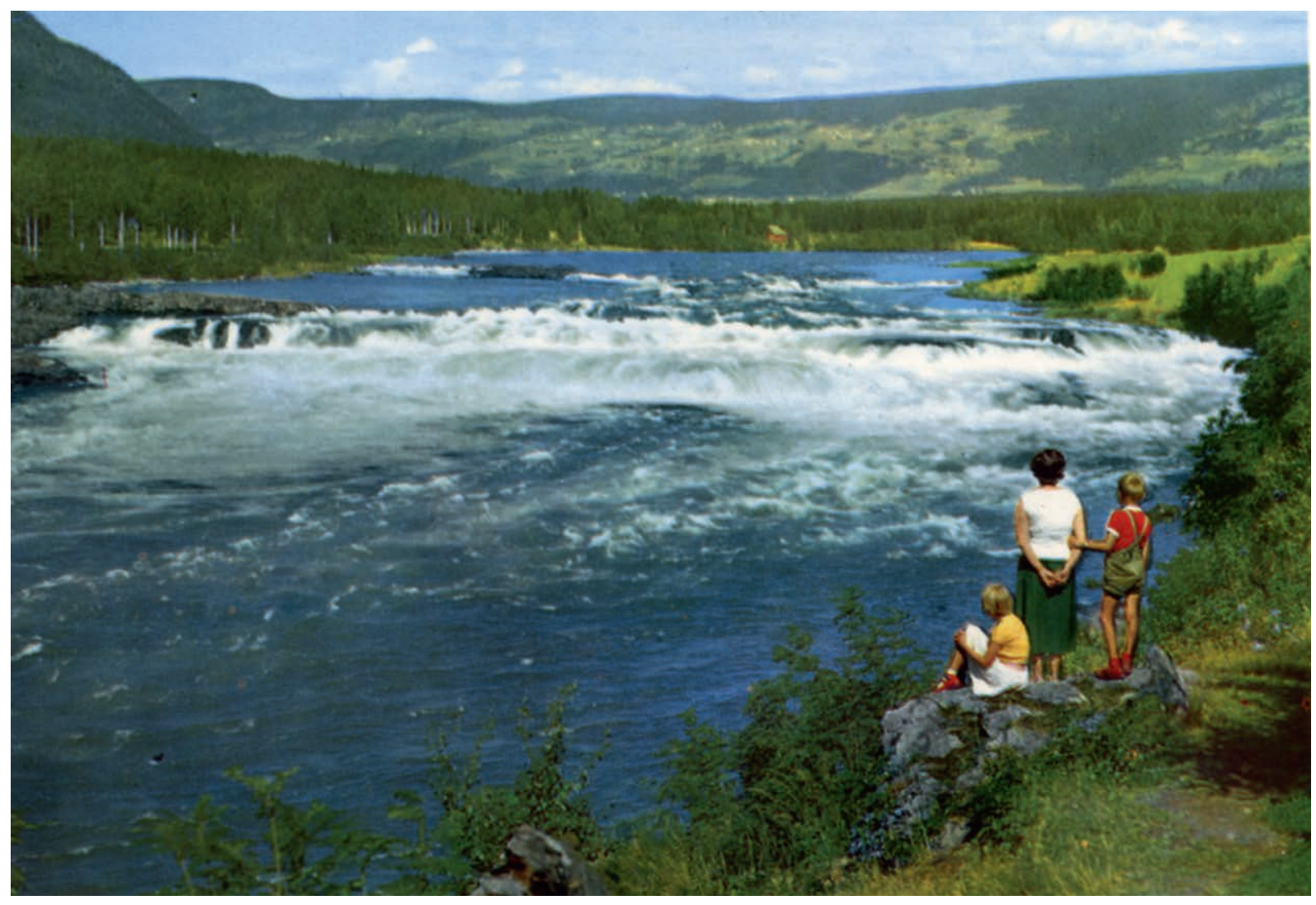

Hunderfoss før han vart regulert på 1960-talet. Foto: Normann.

Mjøsen-(Odals) Storsjø-fiskane. ${ }^{14}$ Dette var mogleg fordi havet stod nærare 60 meter høgare enn i dag. Genetiske analyser har no kartlagt postglasiale innvandringsruter frå Europa til Fennoskandia for både aure, harr (Thymallus thymallus) og abbor (Perca fluvatilis). ${ }^{15}$ Aure vandra til Nord-Europa frå tre område: nordvest (Polen, Nord-Tyskland og SørEngland), sørvest (Spania og Portugal) og søraust (Svartehavet og Det kaspiske hav). ${ }^{16}$ Genstrukturen hjå auren i Mjøsa kan tyde på at det har eksisert fleire innvandringsvegar. ${ }^{17}$

\section{YMSE ARTAR TOK SEG OPP TIL} HARPEFOSS I GUDBRANDSDALSLÅGEN

Gudbrandsdalslågen strekkjer seg frå Lesjaskogsvatnet i nord og ned til Mjøsa (figur 2). Ovanfor Mjøsa gjorde dei topografiske tilhøva med fossar og stryk at mange fiskeartar ikkje nådde særleg langt. Hunderfoss var det fyrste hinderet på vegen. Dei som forserte den fossen kunne vandre opp i Losnavatnet og til Harpefoss på 200 moh. (figur 5). Denne fossen er 34 meter høg og hindra fisk i å spreie seg vidare oppover vassdraget. ${ }^{18}$ I alt 10 fiskeartar tok seg forbi Hunderfoss og opp til Harpefoss. ${ }^{19}$ Vidare oppover vassdraget var Rostenfalla i Lågen 


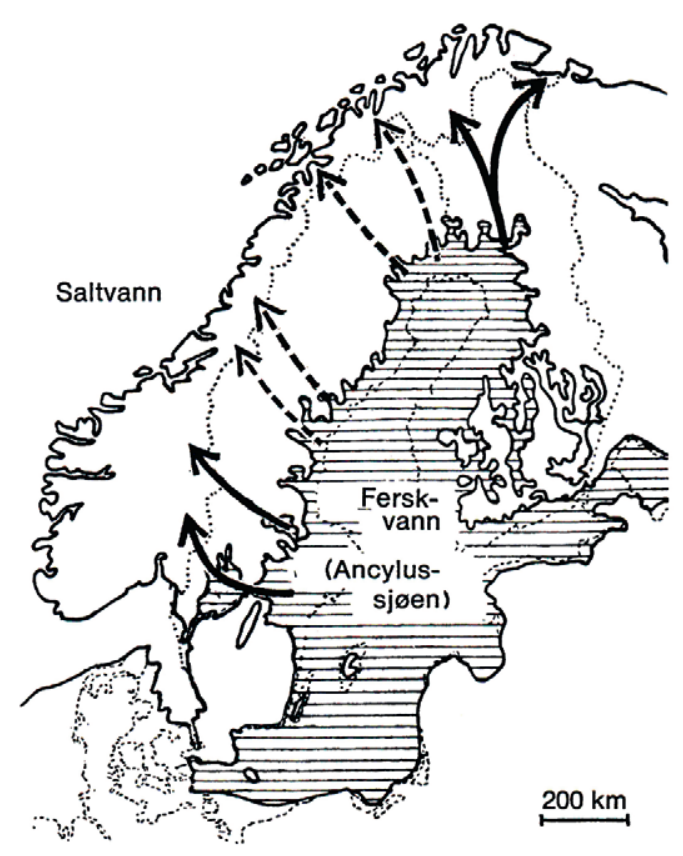

Figur 4: For ikring 10000 år sidan dekte innlandshavet Ancylussjøen blant anna delar av Sverige og Finland (skravert areal). Pilane viser område der ymse ferskvassdyr inkludert fisk har spreidd seg til Noreg. Teikning etter Økland og Økland (1999).

og Eidefoss i Ottagreina nye spreiingsbarrierar. ${ }^{20} \mathrm{Og}$ enda stod dei verste hindringane att før fisk kunne ta seg opp i Jotunheimen. Vatn og elver ovanfor Harpefoss vart såleis liggjande fisketome.

\section{OPPLYSNINGAR OM FISK I \\ GUDBRANDSDALEN FR ̊̊ 1700-TALET}

Ein del opplysningar om utbreiinga av ymse fiskeslag i Gudbrandsdalen vart nedskrive i 1743. Det året sende Danske Kanselli ut lister med 43 spørsmål om ulike samfunnstilhøve i Noreg. ${ }^{21}$ Sorenskrivar Nils Hauritz i Nordre Gudbrandsdalen sorenskriveri skriv følgjande:
Her falder ingen anden slags fisk end øret, uden needenfor Eidefoss faaes siig [sik] og haar [harr], som kommer fra sielve hovedelven Lougen [Lågen] og iche kand komme længer op formedelst fossen / faa carusser [karuss] og aabor [abbor] findes her. ${ }^{22}$

På slutten av 1700-talet kom eit par andre kjelder med opplysningar om fisk. ${ }^{23}$ Schøning ${ }^{24}$ skriv dette: «Paa Vaage [Vågå], fanges ei uden Ørreder [aure].» Desse skriftene frå 1700-talet stadfestar den fattige fiskefaunaen i øvre delar av Lågen på den tida.

\section{KOR FANST DET FISK I JOTUNHEIMEN MOT SLUTTEN AV STEINALDEREN?}

Arkeologiske funn vitnar om at Vinstravassdraget hadde fisk i yngre steinalder (figur 6). ${ }^{25} \mathrm{Ved}$ Olstappen er det registrert steinalderbuplassar med ein aktivitet som strekkjer seg heilt attende til ikring 8000 f.Kr. ${ }^{26} \mathrm{Her}$ er det funne fiskebein som er C14datert til 2862-2538 f.Kr. ${ }^{27}$ Det er også gjort funn av to skifersteinar som ein trur har vore garnsøkke, saman med ymse gjenstandar som er velkjende frå midten av yngre steinalder.

Ved Vinsteren noko lengre oppe i vassdraget budde det også folk i steinalderen. ${ }^{28} \mathrm{På}$ to buplassar ved Mørstastølen i austenden av vatnet er det nyleg funne brente fiskebein, skjørbrent stein og ymse gjenstandar som viser busetnad frå tida 6000-1000 f.Kr. ${ }^{29}$ Aurebeina låg opptil ein meter nedi jorda, og dei kan truleg tidfestast til ulike deler av det 5000 år lange tidsrommet med spor etter aktivitet ved vatnet. Det er også funne fiskebein på eit par andre stadar ved Mørstastølen. Det same gjeld ved Øvre Bjørnhølen nedanfor Vinsteren, ein buplass tidfesta til kring 4700 f.Kr.

Frå Vinsteren kunne fisk fritt vandre opp i Bygdin. Her er det gjort få arkeologiske studiar, men spor etter steinalderfolk er dokumentert. ${ }^{30}$ Nabovatnet 


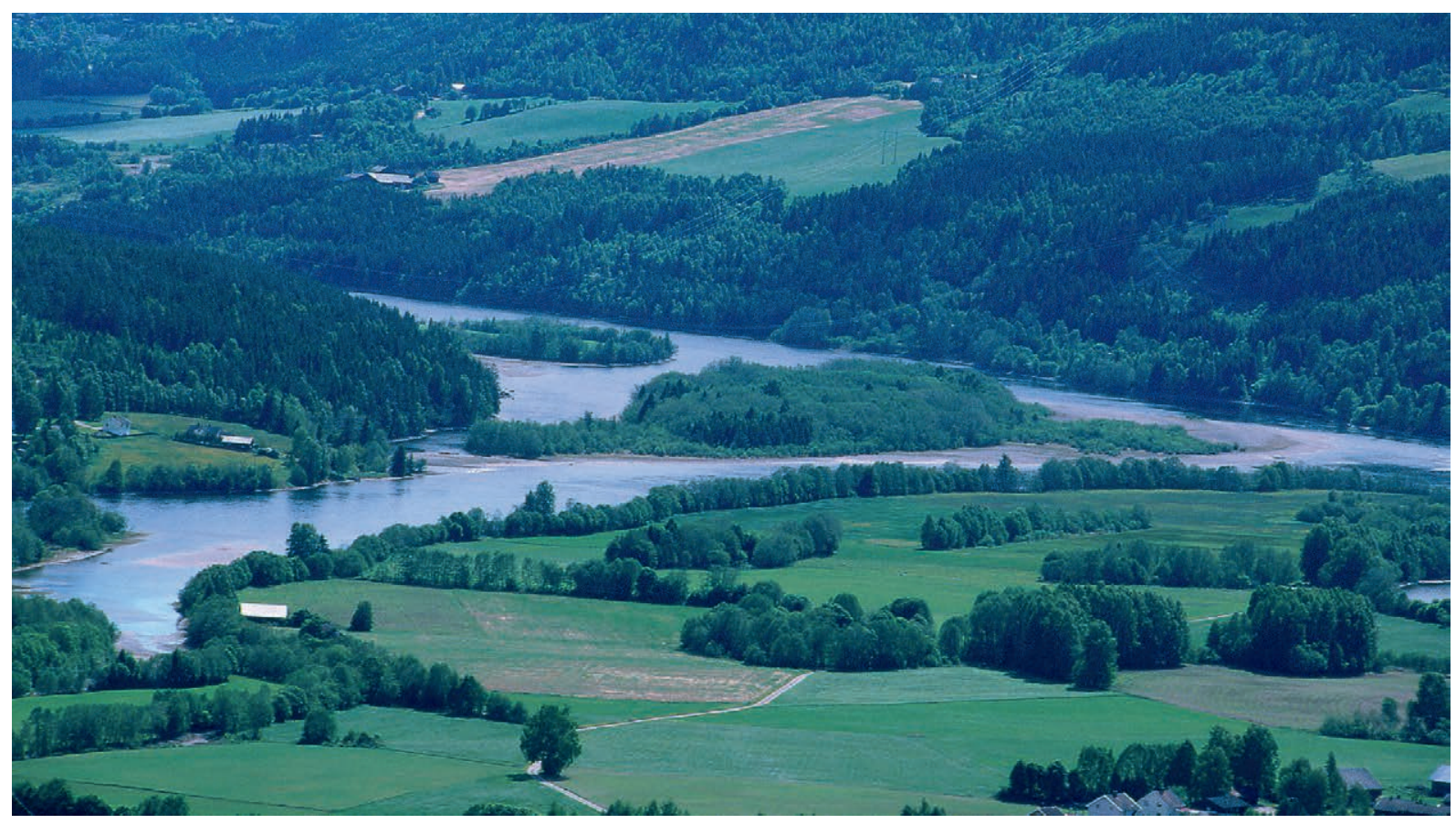

Nedre delar av Gudbrandsdalslågen har lite fall, og fisk kunne difor fritt spreie seg oppover elva. Foto: Børre Kind Dervo.

til Bygdin i vest, Tyin, må ein også tru hadde fisk i steinalderen. Det er i alle fall registrert mange steinalderbuplassar ved denne store innsjøen. ${ }^{31}$ Frå Tyin/Bygdin og ned til Olstappen er det totalt elleve vatn, medrekna Vinstravatna (Sandvatnet, Kaldfjorden og Øyvatnet) og Hersjøane.

I Nedre Heimdalsvatnet, som ligg om lag ei mil nord for Vinsteren, kan det også ha vore fisk svært lenge. Ved vatnet er det hittil påvist seks steinalderbuplassar. ${ }^{32}$ I ein gravhaug er det funne ymse gjenstandar, som piler, bryner og eit spjot. ${ }^{33}$ Eit diplom viser at Ivar Gjæsling frå Vågå fekk Nedre Heimdalsvatnet av kong Sverre (1177-1202) i 1336. ${ }^{34}$ I eit anna diplom frå 1483 er det uttrykkeleg skrive «Heimdals fiskewatn». ${ }^{35}$ Desse handlingane frå kongen tyder på at Nedre Heimdalsvatnet var særs verdifult. Inn i vår tid har det også vore rekna blant dei beste fiskevatna i Jotunheimen. ${ }^{36}$ Utløpselva frå Nedre Heimdalsvatnet (Hinøgla) har også vore fiskerik. Her har det mellom anna vore eit vidstrakt sløefiske gjennom fleire hundre år. ${ }^{37}$ Sløer er fastståande og sjølvfiskande reiskap som vart sette opp i elver og bekkar. Fisken i Nedre Heimdalsvatnet og Hinøgla har såleis vore ein verdfull og høgt skatta ressurs langt attende i tid. Både steinalderbuplassane og nærleiken til andre vatn som truleg hadde fisk på den tida, tyder på at det òg gjeld Nedre Heimdalsvatnet.

Frå Nedre Heimdalsvatnet kunne fisken spreia seg både oppover til Øvre Heimdalsvatnet og nedover til Slangen, nabovatnet til Olstappen. I Øyangen, som ligg litt nord for Vinstravatna, er det òg funne 


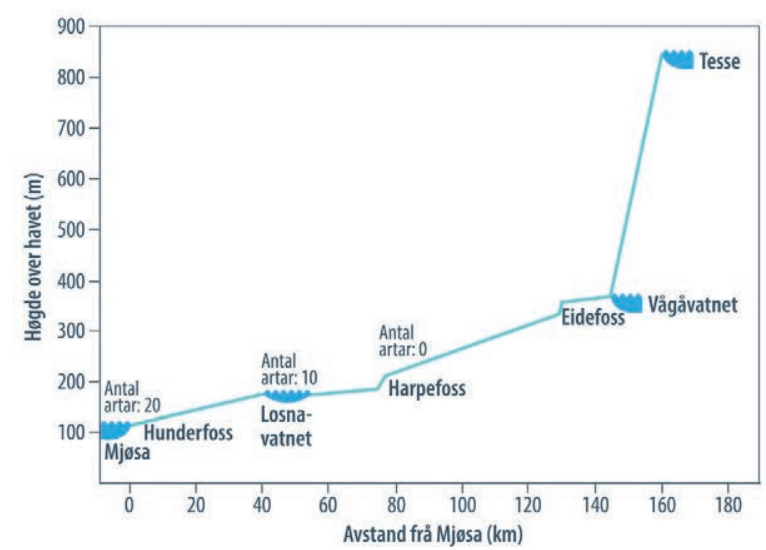

Figur 5: Skisse av vasstrengen frå Mjøsa og opp til Tesse i Jotunheimen. Antal fiskeartar ved ymse stadar etter vassdraget er gjeve.

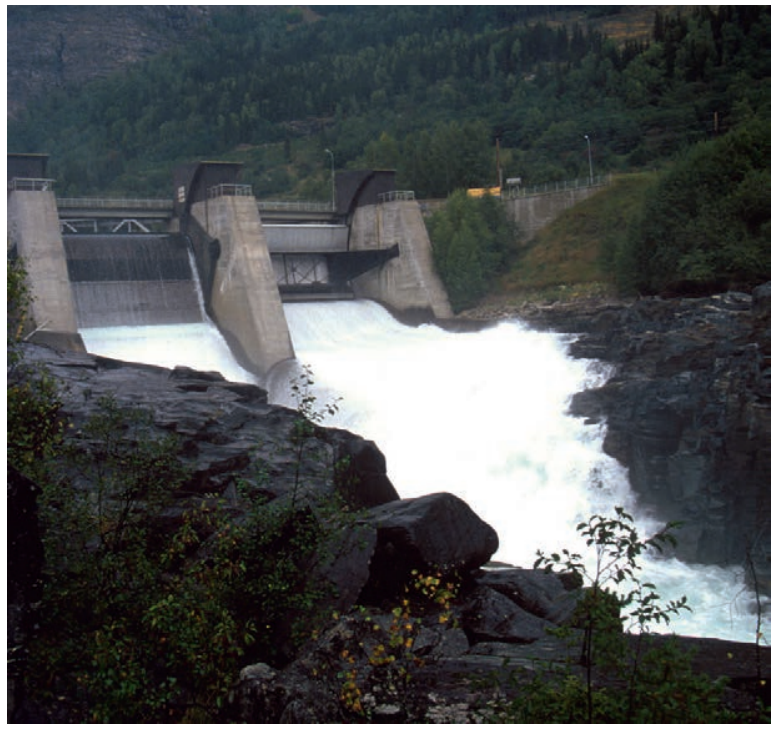

Harpefoss danna ei barriere for at fisk kunne spreie seg vidare oppetter Gudbrandsdalslågen. Eit kraftverk vart sett i drift her i 1965. Foto: Ola Hegge.

fiskebein på ein steinalderbuplass. ${ }^{38}$ Dette gjev grunnlag for å meine at også dette vatnet hadde fisk for fleire tusen år sidan.
Basert på den kunnskapen vi har frå Vinstravassdraget, er det nærliggjande å tru at Sjoavassdraget også hadde fisk mot slutten av steinalderen. Det er nemleg funne steinalderbuplassar ved alle dei fire store vatna øvst i vassdraget, Nedre Leirungen, Gjende og Øvre og Nedre Sjodalsvatnet. ${ }^{39}$ Det fyrste skriftlege provet på fisk i dette vassdraget er eit diplom frà $1466 .{ }^{40}$ Det handlar i tillegg til Sjodalsvatn [Sjodalsvatna] også om Lemonsjøen. Bakgrunnen for diplomet var ein strid mellom vagværer og lomværer om fiskeretten i desse vatna. Det er to variantar av dette diplomet, DN III - 183 og DN X - 235. Det fyrste er datert 22. mars 1466 og skal vera frå Vågå. ${ }^{41}$ Den andre er avskrift med same hand og er datert 5. juli 1466 og frå Lom. ${ }^{42}$

Tesse kan på basis av ymse arkeologiske funn også ha hatt fisk svært lenge. Det er mellom anna registrert over 20 buplassar med spor etter folk attende til 4000 f.Kr. eller tidlegare, med størst aktivitet i yngre steinalder. ${ }^{43}$ Det er flest buplassar i nærleiken av innløpselva (Smådøla). Dette er kjent som ei fiskerik elv. ${ }^{44}$ I strandsona er det funne tre steinsøkke med to hakk langs sidene, som er ein kjent type frå steinalderen. ${ }^{45}$ Likevel er det fyrst frå vikingtida, ikring år 700-800 e.Kr., at det er finne faste haldepunkt om fiske i form av garnsøkke. ${ }^{46}$

Da fisken var etablert i Tesse, må han òg ha breidd seg til Vågåvatnet/Ottavatnet, medrekna Skim i vest og Lalmsvatnet i aust. Det kan likevel ha vore fisk i hovudvassdraget før han kom til Tesse. Også i Smådalsvatna sørvest for Tesse kan det ha vore fisk i yngre steinalder. Om fisken vart boren forbi fossen i Smådøla ved Nåvårseter, som ligg berre to kilometer frå Tesse, kunne han fritt vandre opp i dei to Smådalsvatna. Ymse dokument viser at det i alle fall var fisk i desse vatna i middelalderen, der fiskeretten høyrde til Blakar i Lom. ${ }^{47}$ Smådalen er etter tilhøva ein grøderik dal, der det voks stor furuskog for fleire tusen år sidan..$^{48}$ Det har også vore 
store fangstanlegg for rein i området. ${ }^{49} \mathrm{I}$ isfonner på Kvitingskjølen rett nord for Smådalen er det funne piler frå både yngre steinalder, bronsealder, jernalder og middelalder. ${ }^{50}$ Det er difor grunn til å tru at steinalderfolket ved Tesse jakta og fangsta innover fjellet, mellom anna til Smådalen.

Lemonsjøen kan òg ha hatt fisk attende i steinalderen. Diplomatarium Norvegicum frå $1466 \mathrm{er}$ alt nemnt. ${ }^{51}$ At Lemonsjøen er nabovatnet til Tesse, styrkar påstanden. Lemonsjøen må reknast som eit produktivt vatn, der fiskeressursane lett kunne haustast med ymse reiskapar, som sløe og oppdemming av osen slik at utløpselva vart turrlagd. ${ }^{52}$ Frå Lemonsjøen kan fisken ha breia seg nedover vassdraget, til mellom anna Veslvatnet. Det er elles mange mindre vatn i dette området, der det òg kan ha vore fisk på same tid.

Bjølstadvatnet, som ligg ikring sju kilometer nordaust for Lemonsjøen, hadde også fisk tidleg. ${ }^{53}$ Eit diplom frå 1432 viser at det var strid om fisket i dette vatnet på den tida. ${ }^{54} \mathrm{Da}$ må det også ha vore fisk i minst to andre vatn lengre oppe i vassdraget, Flatningen og Melingen. I tillegg kjem Surtningen og Kvitingen, som ligg berre nokre steinkast vest for Flatningen. Gjæsingvatnet, som ligg to kilometer nordvest for Tesse, kan også ha hatt fisk langt attende i tida. Jordebøker for Akershus len frå slutten av 1500-talet viser at det var fisk her på den tida. ${ }^{55}$ Fiskeretten i vatnet har høyrt til dei tre Storvikgardane på Tessand gjennom fleire hundre år.

\section{DISKUSJON}

Det kan ha vore fisk i minst 30 vatn i Jotunheimen mot slutten av steinalderen (figur 6). Dette er basert på arkeologiske undersøkingar av buplassar, funn av fiskereiskap og C14-dateringar av fiskebein og fiskereiskapar. ${ }^{56}$ Det er truleg ein nær samanheng mellom buplassar i yngre steinalder i dette fjellområdet $\mathrm{og}$ førekomsten av fisk i nærliggjande vatn.

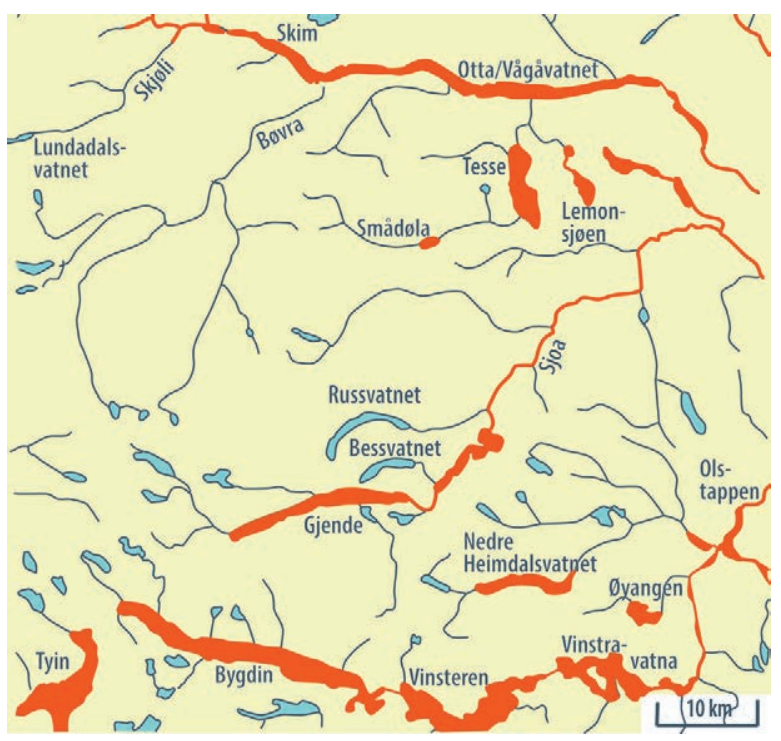

Figur 6: Mogleg utbreiing av aure i ymse vatn i Jotunheimen i steinalderen, vist som raud skravering.

Fisken i Jotunheimen må ha vore boren dit av menneske med fleire spreiingspunkt. Det er i alle fall lite sannsynleg at fisken har kome seg dit via bresjøen Store Dølasjø eller eksisterande vassvegar. Runesteinen på garden Li i Austre Gausdal er altså einaste skriftlege provet på utsetting av fisk i eit vatn inn mot Jotunheimen i førhistorisk tid. ${ }^{57} \AA$ sette opp ein slik runestein var nok ei viktig handling. Det skulle vise kven som hadde fiskeretten i Raudsjøen. ${ }^{58}$ Det å «bera fiska» er eit kjent uttrykk heilt attende til den norrøne litteraturen. ${ }^{59} \mathrm{Og}$ det finst fleire døme på at fisk er boren opp i fisketome vatn i fjellstrøk i Sør-Noreg. I eit vitneutsegn frå Efteløt i Sandsvær frå 1538 står det følgjande: «Der er ingen fisk uten du selv vil bære den (op) deri» (jf. figur 7). ${ }^{60}$ Eit anna døme på utsettingar finst på Vestvidda i Ullensvang statsallmenning. ${ }^{61}$ Heller ikkje her kjenner ein til når det skjedde. I motsetnad til i Jotunheimen er dei topografiske tilhøva i 
desse fjellstråka slike at fisk ikkje trong å bli boren så langt til fjells før han kunne spreie seg eit godt stykkje på eiga hand.

\section{Kor kom auren i Jotunheimen frà?}

Vi kjenner altså ikkje til kor fisken i Jotunheimen kom frå. Genetiske studiar kan kanskje etter kvart vise om han har slektskap med bestandar i Lågen og Mjøsa eller med fisk frå andre vassdrag. Så langt er det ikkje gjort samanliknande genetiske studiar av fisk frå Jotunheimen og tilgrensande strøk. Derimot er den genetiske strukturen hjå mjøsauren kartlagt. ${ }^{62}$ Genetiske analyser av aure frå innsjøar på Hardangervidda viser slektskap med bestandar lengre nedi vassdraga. ${ }^{63}$ Det skulle vise at i desse fjellvatna har auren opphav i bestandar i lågareliggjande strøk. Den har difor vorte boren dit av menneske ein gong attende i tida.

\section{Olstappen: eit aktuelt spreiingspunkt?}

Olstappen i Vinstravassdraget kan ha vore ein sentral lokalitet med omsyn til spreiinga av aure til andre vatn $\mathrm{i}$ Jotunheimen. Det er det næraste vatnet til Harpefoss dit auren har si naturlege utbreiing i Lågen. Utløpselva frå Olstappen (Vinstra) renn ut i Lågen 5-6 kilometer ovanfor Harpefoss. Frå Lågen kan fisken vandre opp til Lofossen i Vinstra, ikring 18 kilometer frå Olstappen. ${ }^{64} \mathrm{I}$ tillegg til sjølve lokaliseringa er dei eldste spora etter folk i strøka kring Jotunheimen altså å finne nettopp ved dette vatnet. ${ }^{65}$

Auren i Olstappen kan også ha vore boren opp frå ymse vatn i Gausdal. Da han var komen til Espedalsvatnet, kunne han fritt spreie seg til Breidsjøen og Olstappen. Gausdal har mange fiskerike vatn og lange tradisjonar med omsyn til fiske. ${ }^{66}$ Det har også vore fisk i fleire vatn langt attende i tida. Ved Dokkfløyvatnet i Gausdal Vestfjell har det vore folk i over 8000 år. ${ }^{67}$ Folket med tilhald her var nok i hovudsak jegerar, men fiske kunne òg ha vore ein næringsveg. Ved Dokkfløyvatnet er det mellom anna funne det ein trur er eit garnsøkke frå steinalderen. ${ }^{68}$ Området ikring dette vatnet kan ha vore bustad for steinalderfolket vår og haust, medan menneska hadde tilhald innover Jotunheimen om sommaren. Om vinteren kunne dei ha halde til i lågare strøk, som ved Mjøsa eller Randsfjorden.

Auren i Vinstravassdraget kan også ha opphavet sitt frå Vestlandet. Her kan fisk frå Tya, utløpselva frå Tyin som renn ut i Årdalsfjorden, ha vore boren opp i Tyin. Derfrå er det ikkje langt til Bygdin og Vinstravassdraget, med påfølgjande spreiing til Olstappen. Steinalderfolket ved Tyin slo seg truleg ned seinare her enn ved Olstappen. ${ }^{69}$ På steinalderbuplassar nær kysten, som Valdresdalen og Vikadalen aust for Årdalsfjorden, er det heller ikkje funne bein av innlandsfisk, berre av torsk. ${ }^{70}$ Kan henda var steinalderfolket i fjellstrøka nær kysten mindre avhengige av innlandsfisk enn dei som heldt til i fjellet mykje av året.

Auren i Tesse kan ha opphavet sitt frå fleire vassdrag. Etter at han kom til Vinstravassdraget, kan han ha vore flytta vidare til Sjoavassdraget, som ligg berre 7-8 kilometer frå Tesse. Det kan også ha vore ei trinnvis flytting av fisk via Ottavassdraget. Da fisken var komen forbi Eidefoss, kunne han spreie seg til Vågåvatnet og derfrå eit lite stykkje opp i Tessa. Da stod det att ei strekning på berre tre kilometer til Tesse.

Auren i Vinstra- og Ottavassdraget kan også ha slektskap med bestandar lengre nord med opphav frå Vestlandet. Det gjeld fisken i Lesjaskogsvatnet og dei turrlagde Lesjavatna (figur 2). Lesjeskogsvatnet hadde opphavleg avløp til Raumavassdraget i vest. ${ }^{71}$ Denne innsjøen var da kortare og låg i vest mot Rauma. Den austlege delen var mest myrar og små tjern med avløp til Lågen. I 1660-åra vart vasstanden heva med ikring tre meter for å gje 


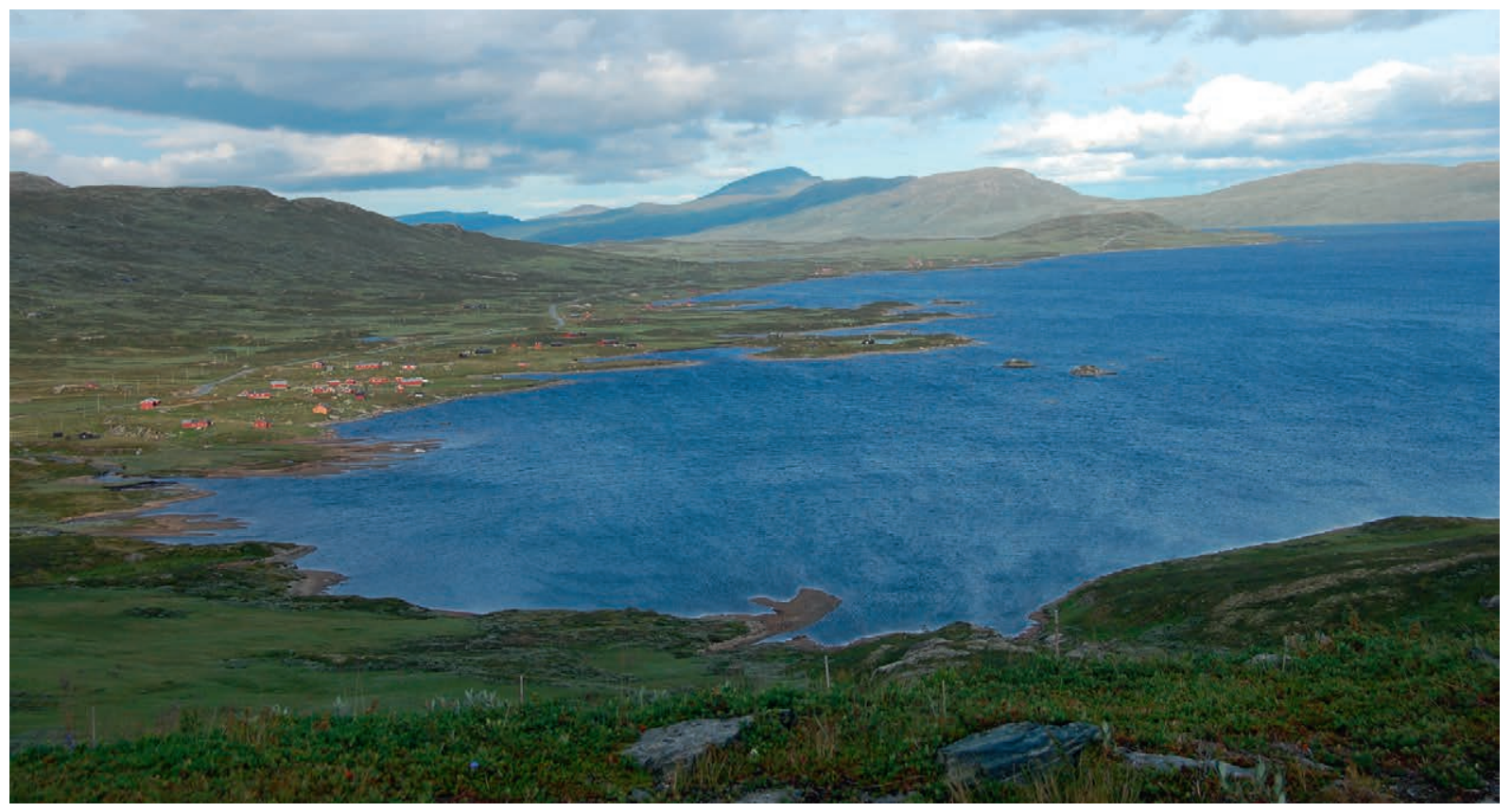

Vinsteren hadde fisk alt i steinalderen og er framleis et godt fiskevatn. Foto: Trygve Hesthagen.

vassforsyning til Lesja jarnverk i aust. ${ }^{72}$ Auren i desse vatna kan i alle høve ha opphav frå nedre delar av Raumavassdraget. Frå det opphavlege Lesjaskogsvatnet kunne fisk lett bli flytta austover til dei mindre tjerna og til Lesjavatna. Så ville han spreie seg nedover Lågen. Litt lengre nord ligg Gautsjøen, Grynningen og Aursjøen, som no utgjer Aursjømagasinet. Desse vatna høyrer til Auravassdraget og drenerer vestover, og fisken her kan ha opphav frå nedre delar av vassdraget. Frå toppen av Auravassdraget (Gautsjøen) er det berre eit steinkast over til det øvste vatnet i Joravassdraget (Trælen). Dette vassdraget drenerer til Lågen. $\mathrm{Om}$ ikkje fisken i desse vatna i Lesja har kome frå vest, må den ha vore boren opp frå Lågen.

At det også har vore folk ved desse vatna i fleire tusen år, er sikkert nok. Ved Lesjavatna er det òg spor etter folk frå eldre tid. Det er mellom anna funne ei 4000 år gamal flintøks. ${ }^{73}$ Det er registrert steinalderbuplassar ved vatna som no utgjer Aursjømagasinet. Ved Grynningen er det funne fiskesøkke som truleg er av eldre dato. ${ }^{74}$ Det er elles funne materiale som kan vera frå to ulike kronologiske fasar, frå eldste til mellomste eldste steinalder og frå bronsealder.

\section{Har auren spreidd seg naturleg til vatn på Dovrefjell?}

Auren i øvre delar av Gudbrandsdalslågen og Ottavassdraget kan også ha opphav i fisk med ei naturleg innvandring til vatn på Dovrefjell. Her høyrer Hegglingen, Avsjøen og Vålåsjøen til Follavassdraget, ei sidegrein til Glomma. I desse innsjøane finst det i dag aure, steinsmett (Cottus poecilpus) og harr. Aure og steinsmett er naturleg utbreidd i store delar av Glommavassdraget, inkludert Atna-greina. ${ }^{75}$ Harr finst også i nedre delar 


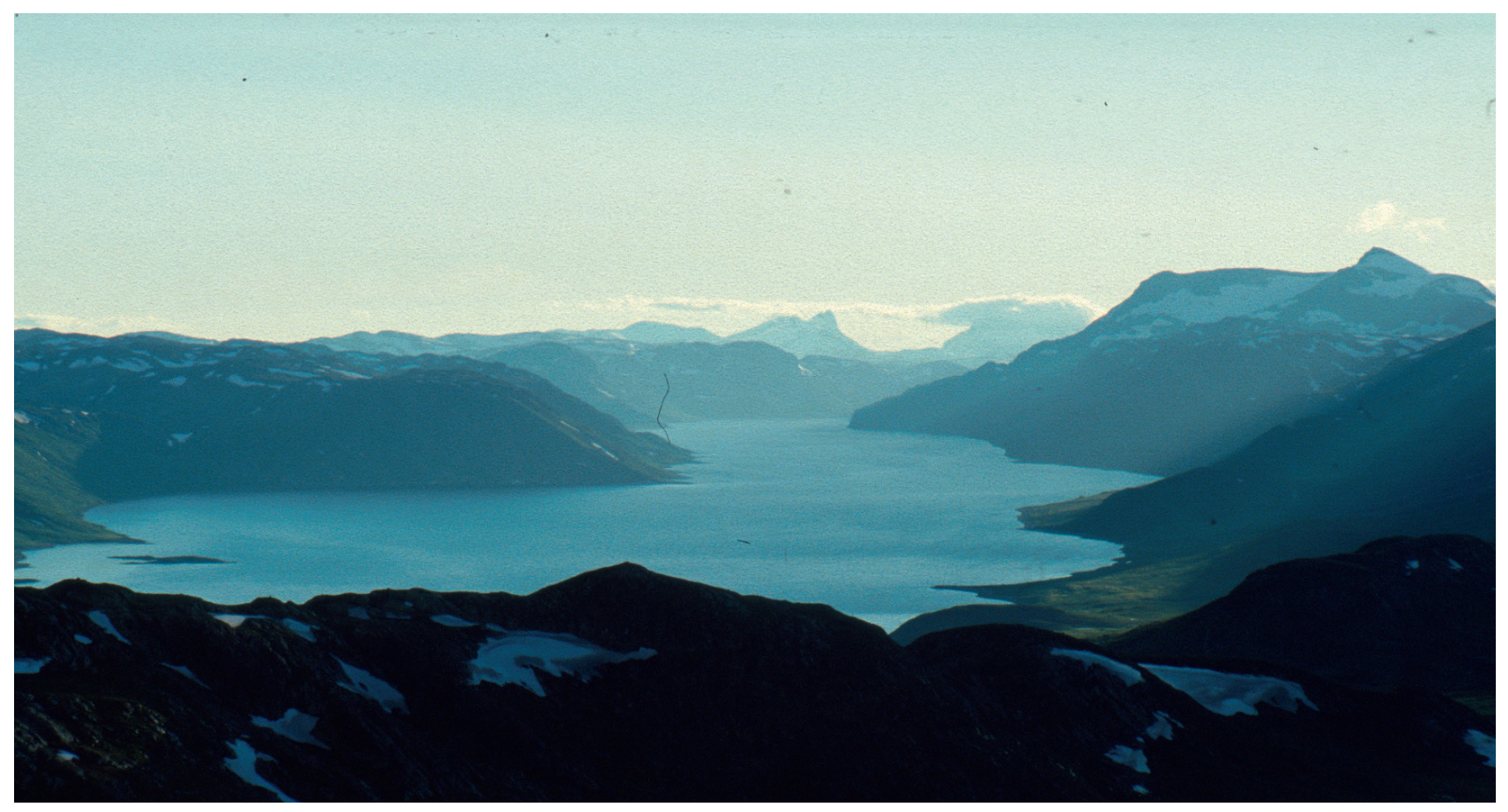

Bygdin var truleg det øvste vatnet i Vinstravassdraget som hadde fisk i steinalderen. Foto: Ola Hegge.

av Atna, men nådde ikkje Atnsjøen, da fossen på utløpet var ei vandringsbarriere.

Frå Glomma via Folla kan fisk ha vandra heilt opp i dei nemnde vatna på Dovrefjell. Denne delen av Folla har størst fall frå Gautåsetrene nedanfor Hegglingen og ikring tre kilometer nedover til Strypbekken. Ei synfaring på denne strekninga viste ingen spesielle hindre med omsyn til oppvandring av fisk, berre ein mindre foss og eit par små strykparti. Både steinsmett, aure og harr kan difor ha ei naturleg utbreiing i desse innsjøane på Dovrefjell. Steinsmetten er ein liten fisk som lever eit anonymt liv på botnen av elver og innsjøar. Det er liten grunn til å tru at steinalderfolk såg seg mon i å sette ut ein slik fisk i fjellvatna sine. Frå Vålåsjøen kunne aure enkelt ha vorte boren over til Lågen litt lengre vest, med vidare spreiing til Otta elv.
Arkeologiske undersøkingar på Dovrefjell støttar opp under at det har vore fisk her i førhistorisk tid. På buplassar ved Vesle Hjerkinn er det nemleg funne store mengder aurebein samt ein del harrbein, som er C14-daterte til vikingtid og middelalder. ${ }^{76}$ Det tyder på at desse vatna på Dovre hadde både aure og harr for 1000 år sidan. Det er elles funne buplassar frå eldre steinalder ved både Avsjøen og Vålåsjøen. ${ }^{77}$ Ved utgravingane på Vesle Hjerkinn og i Grimsdalen er det funne fiskekrokar av jarn og garnsøkke frå vikingtid og middelalder. ${ }^{78}$ Dette vitnar om at Dovrefjell har vore brukt av menneske gjennom fleire tusen år, og at fisk har vore ein del av næringsgrunnlaget deira.

\section{Berre aure vart sett ut}

Steinalderfolket flytta seg over store område og hadde breie kontaktnett. ${ }^{79}$ Både nettverka og mobiliteten 


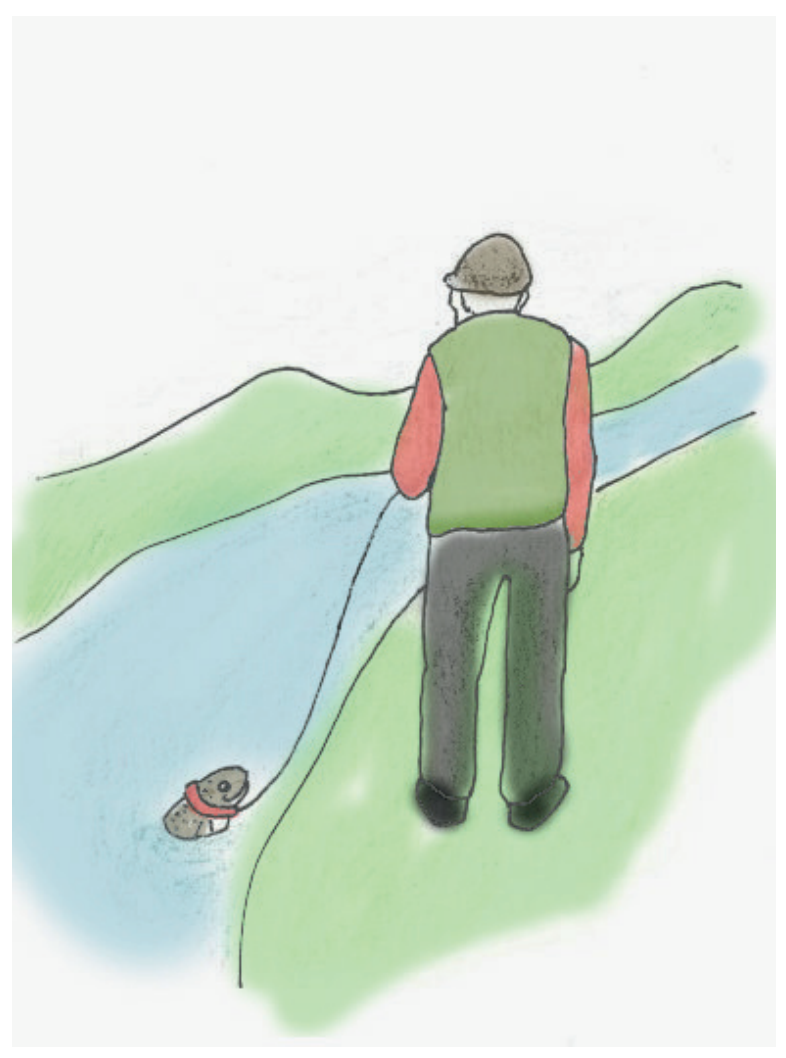

Figur 7: Aure har vore bore opp i fjellvatna av menneske langt attende i tid. Huitfeldt-Kaas (1918) uttrykker det slik: «Indflytterne eftersom bebyggelsen skred frem, enten ved gaardsbruk eller ved sætre, trak stadig ørreten med sig, jeg hadde nært sagt som et andet husdyr.» Teikning: Sigrid Skoglund, Norsk institutt for naturforskning (NINA).

deira kan ha vorte ytterlegare styrka da jordbruket og husdyrhaldet vart meir vanleg mot slutten av steinalderen..$^{80}$ Dei må difor også ha vore kjende med kor det fanst fisk, og kunne ta han med til nye vatn. Steinalderfolket i Gudbrandsdalen sette altså berre ut aure i fjellvatna. Og fordi det fanst ei storvaksen aurestamme i Lågen - hunderauren - var dei spesielt godt kjende med vekstpotensialet til denne arten. Vanleg storleik hjå hunderauren er 3-5 kilo. ${ }^{81}$ Det er heller ikkje uvanleg med langt større individ. ${ }^{82}$ Ikkje merkeleg at steinalderfolket såg på auren som den mest verdfulle fiskearten dei kunne sette ut i fjellvatna sine.

\section{Korleis fekk dei tak i settefisk?}

Huitfeldt-Kaas meinte at når dei i eldre tider valde å sette ut aure framfor andre verdfulle fiskeartar, var det fordi den var så mykje lettare å fange enn andre artar. ${ }^{83}$ Kjønnsmoden fisk kunne dei lett fange med hendene i bekkar om hausten. Ein annan enkel fangstmåte var å demme utløpsos i innsjøar for å turrlegge bekken eller elva nedstrøms. Da var det lett å plukke fisk med hendene i kulpane som stod att. ${ }^{84}$ På same måte kunne dei stengje av eller leide vekk vatn frå ein bekk eller ei mindre elv. I Lågen har det vore fanga småfisk når han samla seg i små vasspyttar etter kvart som elva trekte seg attende utpå sommaren. ${ }^{85} \mathrm{I}$ tilknyting til Lågen har det også vore laga kunstige dammar, til dømes Grafferdammane på Fron som er kjent frå 1785. ${ }^{86}$ Dette var lokalitetar som ein utbetra for å ta vare på fisk som gjekk inn frå elva. I Vågå var det alt på slutten av 1600-talet ein eller fleire fiskedammar. Da bonden på Kleppe ville sette ut fisk i Russvatnet på den tida, fekk han høyre at Kaftin Bruun paa Ner-Øy hadde ein dam med Fiske-Oukje [fiskeyngel]. ${ }^{87}$ Det er også vitneutsegn om at ein overførte fisk ved å sette ut rogn. Det får vi ei kort opplysing om hjå Hammer i Sogne-Beskrivelse over Hadeland, der han skriv dette: «Fiskjegiött [rogn] kan flyttes fra et stæd til andet til Fiskenes formeerelse. ${ }^{88}$ Dette skreiv Hammer i 1780-åra, men det kunne ha vore ein eldgamal tradisjon alt den gongen. Å frakte fisk var nok det minste problemet, og truleg brukte dei skinnposar til dette. Spesielt gytemoden fisk er hardfør, og han kunne difor bli frakta over lengre distansar.

\section{Få nye fiskevatn frå steinalder til middelalder}

I Jotunheimen og elles i Gudbrandsdalen var det truleg ingen særleg stor auke i talet på fiskevatn frå 
steinalderen og fram til middelalderen. Det var nok ikkje før på 1600- og 1700-talet at det vart særleg fleire fiskevatn i distriktet. Dette hadde samanheng med at kongen no selde og bygsla vatn til enkeltpersonar og grupper av bønder med bruksrett i allmenningen. ${ }^{89}$ I Vågåfjellet vart det såleis fisk i fleire vatn i denne tidsbolken. Tolstad på Lalm fekk i 1668 ein eksklusiv fiskerett i Ingulssjøen. ${ }^{90}$ Russvatnet var fisketomt før det vart bygsla på slutten av 1600-talet. ${ }^{91} \mathrm{I}$ åra $1736-1761$ sørgde amtmannen Christen Pram for at fleire vatn i allmenningen i Vågå - Tjønnosen, Sjugurdsjøen, Grjothovdtjønne og Dravtjønne - kom på private hender. ${ }^{92}$ Denne auken i talet på fiskevatn kan ha samanheng med at presset på naturressursane etter kvart vart større, mellom anna fordi seterbruken breidde meir om seg. ${ }^{93}$

I andre bygder i og ikring Jotunheimen var det berre eit fåtal vatn med fisk for 100-200 år sidan. I Lom var det truleg berre Tesse, Smådalsvatna og hovudvassdraget som hadde fisk i førhistorisk tid. I Dalsvatnet i Bøvravassdraget vart auren til dømes innført ein gong etter $1743 .{ }^{94}$ I Skjåk var det tidleg på 1800-talet truleg fisk berre på Skim (hovudvassdraget), i Bråtåvatnet, Liavatnet, Aursjoen og Lortjønnin. ${ }^{95}$ Ved Liavatnet er det spor etter gamal busetnad, ${ }^{96}$ og ved Aursjoen er det funne steinalderbuplassar. ${ }^{97}$

Stor auke i talet på fiskevatn frå siste del av 1800-talet Frå slutten av 1800-talet og fram til tidleg 1900-tal var det ein stor auke i talet på fiskevatn i fjellet. Det hadde samanheng med to ting: (1) Den kunstige produksjonen av fisk vart kjent, og (2) privatpersonar kunne for ein periode bygsle eller leige vatn på staten sin grunn som inntil da var fisketome. Med den kunstige produksjonen av fisk vart det mykje enklare å få tak i settefisk. På slutten av 1700-talet hadde nemleg tyskaren Stephan Ludwig Jacoby gjort vellykka forsøk med kunstig befruktning og klekking av lakse- og aurerogn. ${ }^{98}$ På 1850-talet nådde denne landevinninga innan fiskekultivering også vårt land. Det var professor Halvor Heyerdahl Rasch som fyrst omtala Jacoby si oppdaging, som straks vakte stor interesse. I 1853 løyvde staten pengar for å kome i gang med å bygge klekkeri. Rasch utførde dette arbeidet saman med tollbetjent Magnus Gabriel Hetting. ${ }^{99}$ To år seinare stod det fyrste klekkeriet i offentleg regi ferdig.

Bygslinga av fisketome vatn til enkeltpersonar vart gjort mogleg med ei ny lov i 1870 . Føresetnaden var at bygseltakaren sette ut fisk, og om mogleg fekk til ei fast stamme. Framleis var det mange fisketome vatn i fjellet, og dette representerte sjølvsagt ein uutnytta ressurs. Det offentlege ynskte difor at det vart sett ut fisk i flest mogleg av dei. I Vågå kommune var til dømes Bessvatnet fisketomt heilt fram til 1890-åra, da det vart bygsla. ${ }^{100}$ I Lom kommune vart det ikkje sett ut fisk i Høydalsvatnet og andre vatna på Sognefjellet før i åra 1920-1940. ${ }^{101}$ Dei fleste vatna i sentrale delar av Jotunheimen var med få unntak fisketome fram til 1940/-50-talet. I Skjåk kommune var eit så stort vatn som Breiddalsvatnet ved Grotli fisketomt fram til 1870-åra. ${ }^{102}$ Det same gjaldt fram til 1920-talet for Lundadalsvatnet i den nordvestlege delen av Jotunheimen (jf. figur 2). Også fleire større vatn i andre bygder i NordGudbrandsdalen var fisketome fram til slutten av 1800-talet. Det gjaldt til dømes Rondvatnet i Sel kommune, der dei fyrste utsettingane skjedde på 1860-talet. ${ }^{103}$ I Jotunheimen og i Oppland elles er det no fisk i så å seia alle vatn og tjern over ein viss storleik (figur 8).

\section{Fisken - ein viktig matkjelde}

Motivasjonen for at steinalderfolket sette ut fisk, var naturleg nok at han representerte ei livsviktig matkjelde. Dette er eit sterkt argument for at fleire 
FJELLFISKE I FORTIDEN | TRYGVE HESTHAGEN - EINAR KLEIVEN

av vatna i Jotunheimen hadde fisk i steinalderen. Arkeolog Johannes Bøe meiner at for steinaldermannen var flytting av fisk viktig, for han «visste så inderlig vel hva fisken kunde bety $\mathrm{i}$ kostholdet». ${ }^{104}$ Innskrifta på runesteinen frå Gausdal er særleg interessant fordi ho fortel kva fisken hadde å seie som ressurs. ${ }^{105} \mathrm{Vi}$ veit likevel lite om kva slags rolle fisken spela som matkjelde for fjellfolket i Sør-Noreg i førhistorisk tid. Funn av fiskebein er naturleg nok avgrensa til relativt få stadar, da dei er små og skjøre. ${ }^{106}$ I det heile er det å finne spor etter fiske i eldre tid vanskeleg fordi det meste av reiskapen var laga av organisk materiale, i motsetnad til pilspissar brukt til jakt, som var laga av stein. ${ }^{107}$ Steinalderfolket ser ut til å ha vore særs selektive med omsyn til kor dei slo seg ned, da buplassane deira ofte låg ved eller $\mathrm{i}$ nærleiken av innsjøar. ${ }^{108}$ Elles er spor etter fiske er nesten alltid frå buplassar med funn av pilspissar og bein av pattedyr, som oftast nær elg- eller reinstrekk. ${ }^{109}$ Steinalderfolket har såleis drive eit vekselbruk mellom jakt og fiske. Men jakt med primitive fangstmåtar bydde nok på vanskar, og utfallet kunne vera usikkert. I tillegg var viltet ein sesongprega ressurs. På bakgrunn av dette trur vi at fisken betydde mykje for at steinalderfolket i det heile kunne ha tilhald i fjellstroka i Sør-Noreg. Fisk hadde dei tilgang på i fleire månadar i året, og han var òg ei relativt sikker matkjelde. Fisk kunne lett bli konservert i form av turking. ${ }^{110} \mathrm{Og}$ alt i førhistorisk tid fanst det gode og spesialiserte fiskereiskapar og fangstmåtar. ${ }^{111}$ Tilgangen på fisk ved dei enkelte vatna kunne òg vera god. I den tidlegare omtalte Smådøla, innløpselva til Tesse, var utbytet av sløefiske ein haust på over to tonn. ${ }^{12}$ Med små grupper av folk ved kvart vatn skulle det gje eit godt mattilskot til den enkelte.

\section{KONKLUSJON}

Dei eldste spora etter fisk og fiske ved fleire vatn $\mathrm{i}$ Jotunheimen kan daterast attende til steinalderen. ${ }^{113}$

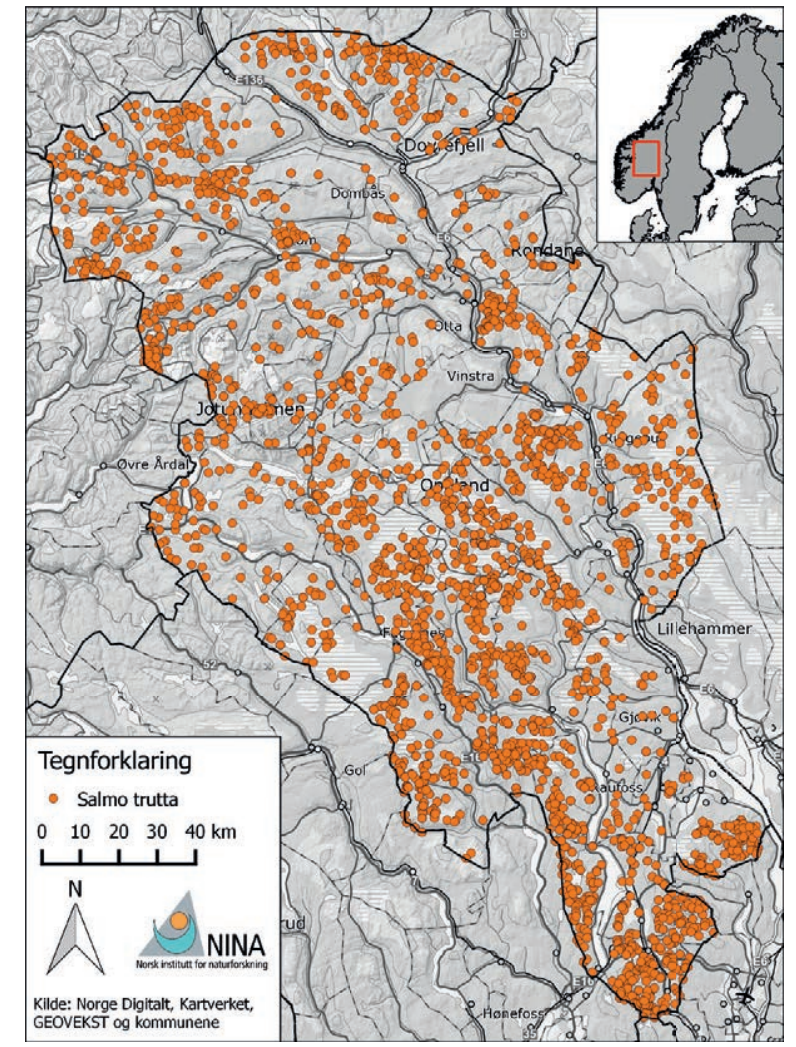

Figur 8: Utbreiing av aure i Oppland per 2015. Kjelde: NINA.

Og det var truleg fisk i fleire nærliggjande strøk på den tida. At steinalderfolket hadde samkvem med eller var blant dei som nytta fisken og viltet $i$ Jotunheimen, er svært sannsynleg. Ut frå dette må det ha vore fisk i dei to store vassdraga i Jotunheimen $\mathrm{i}$ steinalderen, Vinstra- og Sjoavassdraget. Det same gjeld Tesse. Herfrå har fisken spreidd seg til Øvre Ottavassdraget, om den ikkje kom dit tidlegare. Det kan såleis ha vore fisk i minst 30 vatn $i$ Jotunheimen i yngre steinalder. Aure må ha vore ein livsviktig matressurs for steinalderfolket, og dei sørgde difor for utsetting av fisk i vatna ved buplassane sine. 
SUMMARY:

\section{POSSIBLE DISTRIBUTION OF BROWN TROUT (SALMO TRUTTA) IN THE JOTUNHEIMEN MOUNTAIN AREA IN SOUTHERN NORWAY IN THE LATE STONE AGE}

When Norway was deglaciated some 9,000-10,000 years ago, many species of fish gradually invaded inland waters. In southern Norway, a relatively large number of species reached Lake Mjøsa in the Gudbrandsdalslågen watershed, a branch of the River Glomma. At that time, the sea level was about 60 meters above the present altitude of Lake Mjøsa. However, Mjøsa's inlet river had steep gradients and several waterfalls that were insurmountable topographical barriers for fish. Thus, waters upstream of these barriers were barren of fish. However, man began to carry fish into mountain lakes in order to establish an important food resource. In this study, we sketch out the possible distribution of fish, e.g., browntrout (Salmo trutta), in lakes in the Jotunheimen mountain area in southern Norway during the late Stone Age, i.e., about 3800-2350 BC. We base our suggestions on archaeological studies of human occupation sites and ageing of fish bones and fishing gears, estimated by carbon-14 dating. Browntrout probably occurred in more than 30 lakes in Jotunheimen in the late Stone Age. These lakes are still some of the best browntrout lakes in this area. Possible donor releases intended to establish browntrout populations in this mountain area are also discussed.
TAKK

Ein takk til Axel Mjærum, Elling Utvik Wammer, Reidar Borgstrøm og ein anonym fagfelle for verdfulle kommentarar til artikkelen. Takk også til Terje H. Bargel (NTNU) for kommentarar til den kvartærgeologiske delen. Kari Sivertsen (NINA) har stått for det grafiske arbeidet, og Liv Turid Storli har gjeve gode språklege råd. Stefan Blumentrath (NINA) utarbeida kart over auren si utbreiing i Oppland. 


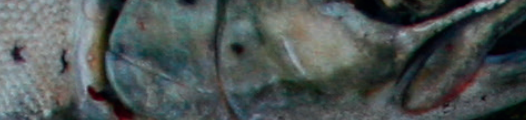

2nowis

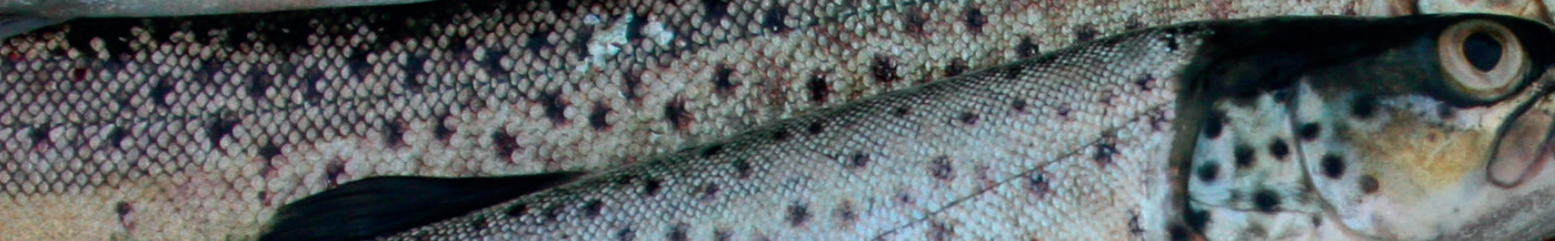

,

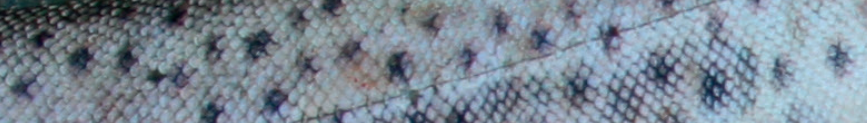

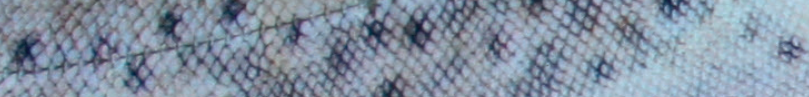
+ $\ldots+c$

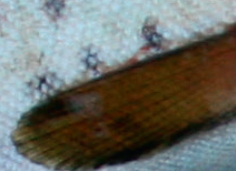

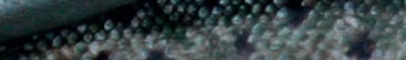

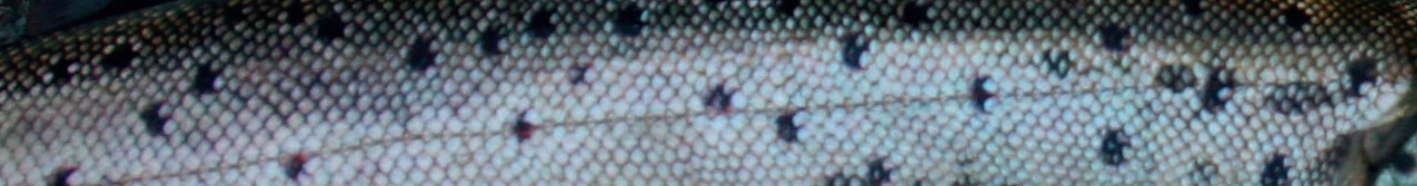

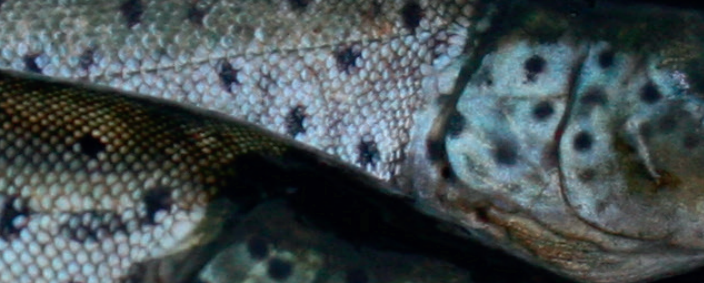

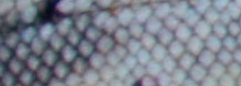
\&.8000

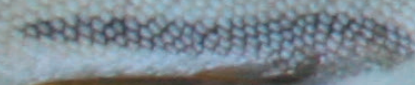

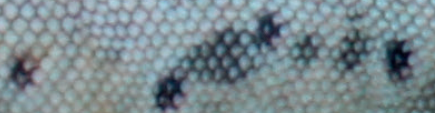 $\star$
क.

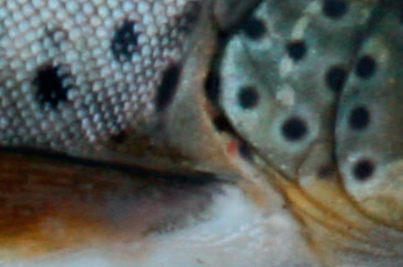

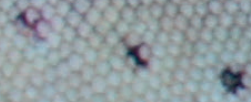

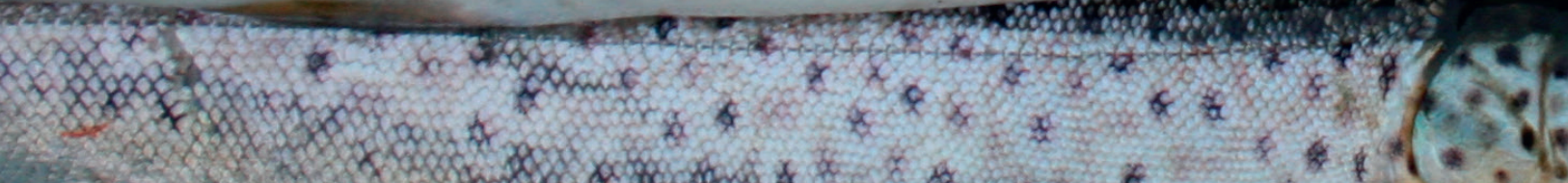

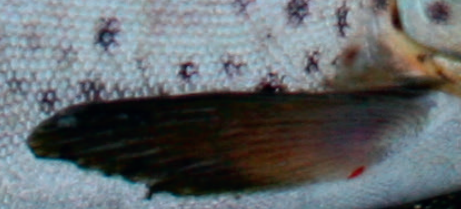




\title{
DE FØRSTE FISKERNE I FJELLET
}

\author{
Axel Mjarum, Kulturhistorisk museum, Universitetet i Oslo
}

Om lag 8300 f.Kr. var den siste istiden over. Klimaet hadde blitt langt mildere, og store områder med fjell, vidder og vann var smeltet frem fra innlandsisen $i$ Sør-Norge. Inn i dette fremtinte landskapet fant både menneskene og viltet sin vei fra kysten. Fisken spredde seg også naturlig til de østlige innlandsområdene, mens bratte fosser og stryk hindret ørret og andre fiskearter fra å etablere seg i de sentrale fjellområdene i landsdelen. ${ }^{1}$

En stor andel av innlands- og fjellvannene var altså fisketomme, og et fiske her forutsatte utsetting. Kunnskaper om ørretens biologi og DNA-forskning kan belyse denne innvandringshistorien. ${ }^{2}$ I denne artikkelen vil jeg imidlertid tilnærme meg det eldste fisket ut fra en kulturhistorisk synsvinkel.

Den generelle forståelsen av fiskets betydning i steinalderen danner et kunnskapsmessig bakteppe for diskusjonen, og jeg vil derfor først presentere enkelte overordnede trekk ved det utbredte steinalderfisket langs kysten og fra de innlandsområdene i Skandinavia hvor fisken har kunnet vandre inn ved egen hjelp etter istiden. Deretter vil jeg foreta en kritisk gjennomgang av de få og delvis mangetydige arkeologiske kildene som kan bidra til å kaste lys over det tidlige fisket i de høyereliggende delene av innlandet, over og under tregrensen ${ }^{3}$. Kan valget av bosteder, et fåtall redskaper og gamle fiskebein gi kunnskap om når og hvorfor det ble satt ut fisk i fjellheimen?

\section{DEN «USYNLIGE» FISKEREN}

Den profilerte fiskebiologen Hartvig Huitfeldt-Kaas skrev allerede i 1918 at «ørreten i hele den indre del av landet er indsat av mennesker, idet de formodentlig allerede paa et meget tidlig tidspunkt efter sin bosættelse i landet bar denne fisk med sig». ${ }^{4}$ Helt siden fjellarkeologien fikk et betydelig omfang på slutten av 1950-tallet, har også arkeologer diskutert fiskets rolle i fjellheimen i steinalderen, og spesielt har tre kildekategorier blitt fremhevet i debatten.

For det første har det blitt lagt vekt på at boplassene gjerne ligger ved gode fiskeplasser, slik som ved grunner og elveos, og man har trukket konklusjoner om fjellfiskets betydning ut fra dette. ${ }^{5}$ Mye viktig informasjon ligger da også i studier av landskapsbruken, men som jeg vil komme tilbake til senere, kan aktiviteten langs vassdragene også ha andre forklaringer. Det er ofte krevende å gi entydige svar på hvor stor betydning fjellfisket har hatt, ut fra beliggenheten til de mange sporene etter steinaldermenneskene.

For det andre har arkeologer ofte tatt utgangspunkt i redskapsfunnene når de har diskutert erverv. Et tydelig eksempel i så måte er de mange tusen 
pilspissene i stein fra innlandsområdene, spisser som i stor grad har vært benyttet til jakt på elg, rein og hjort. ${ }^{6}$ Til forskjell fra dette har de fleste fiskeredskapene i steinalderen blitt laget av organisk materialer. Garn og liner har blitt fremstilt av fiber fra planter og dyr, og det ble i hovedsak anvendt tre og bein til å lage ruser, fiskefangstanlegg, fiskekroker, lystergafler og andre fangstredskaper. Med få unntak har alle slike gjenstander råtnet bort $\mathrm{i}$ innlandet i Sør-Norge. ${ }^{7}$ Man står da igjen med de få fiskeredskapsdelene som har blitt tilvirket i stein. Fra steinalderen dreier det seg i første rekke om søkker benyttet til garn- og linefiske. Steiner kan imidlertid ha mange bruksområder, ${ }^{8}$ og søkkesteiner behøver ikke nødvendigvis å bli bearbeidet før bruk. ${ }^{9}$ Det kan derfor tidvis være vanskelig både å finne og å funksjonsbestemme slike garntyngder. Et tilleggsproblem er at en del søkker har hatt en form som har blitt benyttet i årtusener, noe som bidrar til at det ofte også er krevende å tidfeste dem.

Fiskebeinene er den siste kildekategorien man i vesentlig grad har trukket inn for å underbygge at det har forgått et steinalderfiske i fjellet. ${ }^{10}$ Slike bein er imidlertid små og skjøre, ${ }^{11}$ og frem til for få år siden hadde man kun lyktes å finne slike bein på boplasser ved Langesjøen og Halnefjorden på Hardangervidda. ${ }^{12}$ Fiskebeinfunn gjort de siste årene bringer imidlertid ny kunnskap inn i diskusjonen, og både gamle og nye oppdagelser er viktige grunnlag for den videre argumentasjonen her.

Bevaringsforholdene og de mange tolkningsmulighetene har lett for å usynliggjøre fiskeren i fremgravd kildemateriale, og det er følgelig utfordrende å fremskaffe kunnskap om et fiske som foregikk i skriftløse samfunn mange tusen år tilbake i tid. Derfor er det heller ikke uproblematisk å svare på når fisket i dette området tok til, og hvilken karakter det da hadde. Man står allikevel ikke helt på bar bakke. Overordnede trekk ved steinalderfisket, både i Europa, i kyststrøkene i Sør-Norge og i de østlige lavlandsstrøkene, gir verdifull innsikt $i$ hvordan steinalderfisket foregikk. Denne kunnskapen vil danne et springbrett for en mer inngående diskusjon av gamle og helt nye funn fra den sørnorske fjellheimen.

\section{MENNESKET, FISKEREN}

Tallrike studier over jegere og sankere i moderne tid viser at næringsgrunnlaget som hovedregel er bredt og som oftest er basert på både jakt, sanking og fiske. ${ }^{13}$ Studiene viser store variasjoner, men i mange tilfeller utgjør fiske minst en tredjedel av ressursgrunnlaget.

Fiske er heller ikke en aktivitet som har blitt praktisert kun i nyere tid. Analyser av skjelettmateriale viser at menneskene som vandret inn til Europa for mer enn 40000 år siden, utnyttet et bredt spekter av ressurser, trolig også ferskvannsfisk. ${ }^{14}$ På flere boplasser fra siste istid i Mellom- og Sør-Europa er det bevart bein av laks og ørret på boplasser, noe som underbygger at ferskvannsfisket på kontinentet har pågått i om lag 40000 år. $^{15}$

Etter som istiden nærmet seg slutten, ble større deler av kyststripen i Norge isfri, og gradvis smeltet også breene i innlandsområdene. Deler av Sør-Norge ble etter hvert beboelig, og om lag 9000 f.Kr. krysset de første menneskene over datidens gigantiske Oslofjord og befolket raskt store deler av norskekysten. ${ }^{16}$ Man vet relativt lite om ressursgrunnlaget til pionerbefolkningen, men tradisjonelt har det vært antatt at jakt på sjøpattedyr og reinsdyrfangst lokket dem. ${ }^{17}$ Hoveddelen av aktiviteten foregikk imidlertid allerede på dette tidspunktet i de mest ressursrike kystområdene, slik som ved tidevannsstrømmer, sund, øyer og elvemunninger. Fisket kan alt da ha spilt en betydelig rolle. ${ }^{18}$

Forbindelsen mellom menneskene og de rike kystområdene blir enda tydeligere utover i steinalderen. ${ }^{25}$ Mye av aktiviteten foregikk på steder hvor det var 


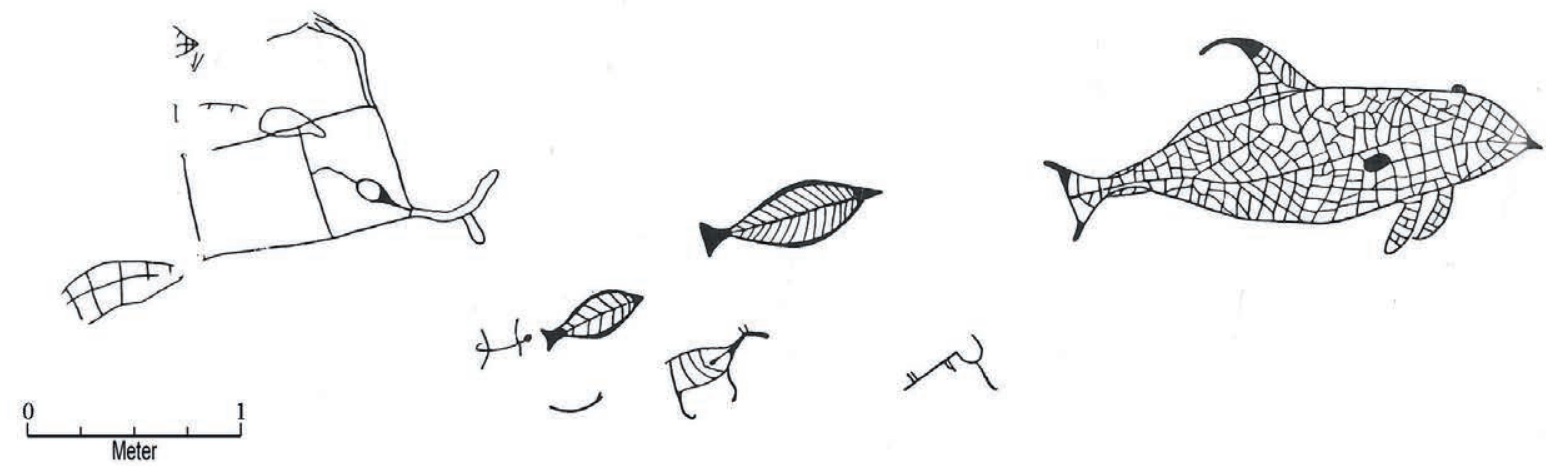

Figur 1: De to helleristningsfeltene fra ca. 4500 f.Kr. ved Skogerveien i Drammen i Buskerud viser et stort artsmangfold. Her fremkommer blant annet de to eneste fiskene som er kjent i sørøstnorsk veidekunst. Flyndrefiskene (kveiter?) er blant annet avbildet sammen med en liten tannhval (kvitnos eller kvitskjeving) og elg. ${ }^{19}$ Illustrasjon: Eivind S. Engelstad. ${ }^{20}$

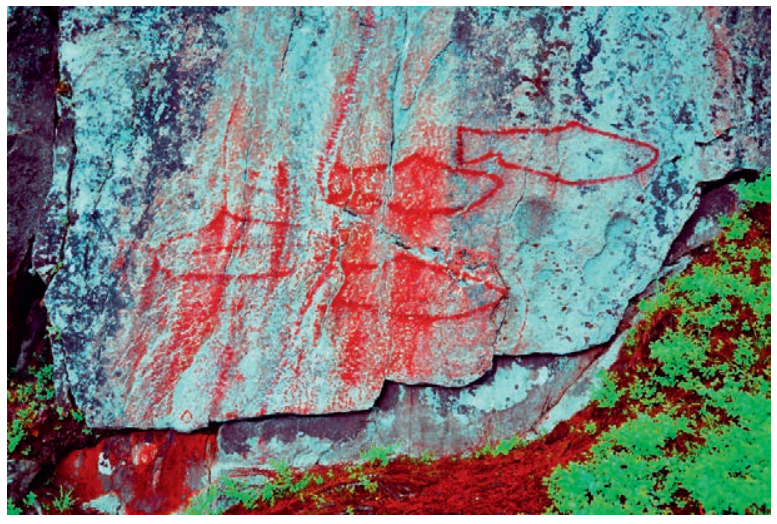

Figur 2: Avbildninger av laks på Honnhammaren ved Tingvollfjorden i Møre og Romsdal. Trolig er disse bergmaleriene fra yngre steinalder. ${ }^{21}$ Foto og fotobearbeiding: Trond Eilev Linge. ${ }^{22}$

mulig å sanke skalldyr, å jakte på sjøfugl og sjøpattedyr og å fiske. Fra enkelte steder som har vært bebodd etter år 8000 f.Kr., fremkommer det da også fiskebein, både langs Skagerakkysten og i de ytre kystområdene i Vest-Norge. ${ }^{26}$ Beinfunnene oppviser en stor artsrikdom, og de forteller om målrettet fiske etter arter på dypt og grunt vann og etter fisk som levde i de frie vannmassene. Klebersteiner, trolig knyttet til linefiske, forekommer i stort antall på vestlandskysten i en nokså kort tidsperiode omkring 5000 f.Kr., og steinsøkker finnes også mer spredt i kystområdene. ${ }^{27}$ I bergkunsten fra steinalderen dominerer avbildninger av elg, hjort og rein, men i et fåtall tilfeller blir også fisk avbildet (jf. figur 1 og 2). Kveite er den dominerende fiskearten på bergflatene, og mer sjelden forekommer også laks. ${ }^{28}$ Artsmangfoldet er følgelig ikke på langt nær like rikt som blant beinfunnene, og det er nok derfor lite trolig at avbildningene på bergveggene er noen direkte avspeiling av fisket og de ulike fiskeartenes ernæringsmessige betydning.

I enkelte huler og hellere langs kysten er bevaringsforholdene ekstraordinært gode, og funnene herfra synliggjør fiskets betydning i de sørvestre kyststrøkene i Norge på en spesielt god måte. ${ }^{29}$ Redskaper som fiskekroker, harpuner, spyd/lystre og fiskelokkende blink utgjør en svært vesentlig del av funnmaterialet, og funnene gir innsikt $i$ hva som har gått tapt av organisk materiale på boplasser som har ligget åpent til. ${ }^{30}$ Det er gjort tilsvarende funn langs Finnmarkskysten ${ }^{31}$ og i Sør-Skandinavia ${ }^{32}$. Fra 


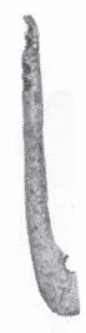

1.

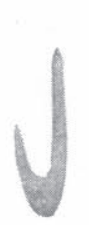

4.

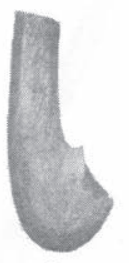

8.

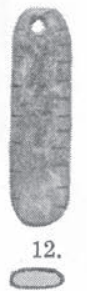

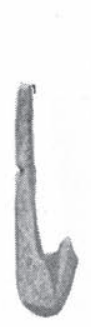

2.

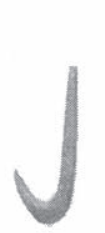

5.

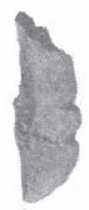

9.

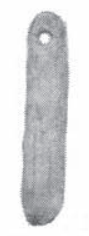

13.

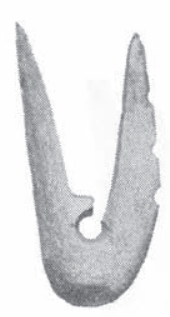

3.

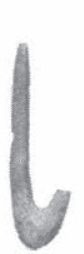

6.

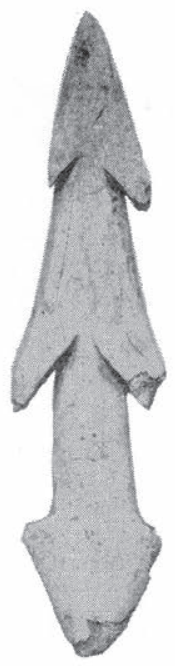

18.
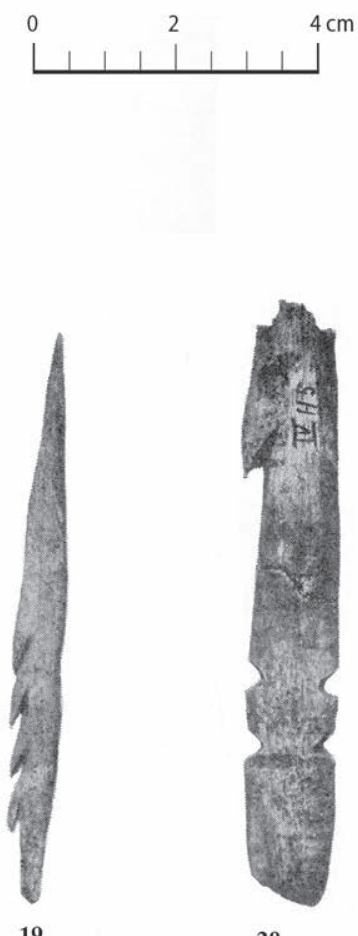

20.

10.

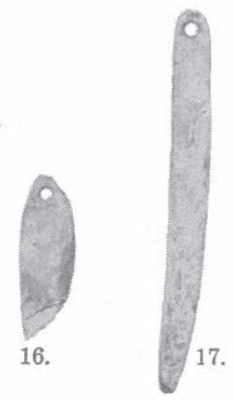

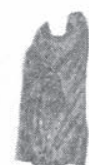

15.
19.

Figur 3: Fiskekroker (nr. 1-10), beinplater tolket som blink for å tiltrekke seg fisk ved linefiske (nr. 13-17) og harpuner (nr. 18-20) fra Vistehola i Randaberg kommune i Rogaland. Beinfunnene fra hula er tidfestet til 6000-tallet. ${ }^{23}$ Illustrasjon: Harald Egenæs Lund. ${ }^{24}$ 
Danmark er det også kjent store fiskeanlegg med stengsler, ruser og rester av garn langt tilbake i eldre steinalder. ${ }^{33}$ Kanskje er det bare et tidsspørsmål når det blir gjort slike funn i det sørlige Norge?

Et tydelig brudd i dette marint rettede bosetningsmønsteret i kyststrøkene inntrer først ved jordbrukets endelige gjennombrudd mot slutten av steinalderen. ${ }^{34}$

Det er grunnlag for å konkludere med at mennesker nærmest til alle tider har behersket kunsten å fiske, og at de ofte har benyttet seg av disse ferdighetene når naturforholdene har ligget til rette. Funn fra kyststrøkene viser også at det har vært en levende fiskertradisjon og et omfattende fiske i Sør-Norge gjennom store deler av steinalderen. Fisket har vært målrettet og spesialisert, med bruk av en rekke fangstmetoder. En slik virksomhet har forutsatt inngående kunnskap om biologien til ulike arter og en vilje til å investere tid og krefter i å lage og vedlikeholde store og små redskaper.

\section{INNLANDSFISKET I DE LAVERELIGGENDE OMRÅDENE I SKANDINAVIA}

Fisket i elver og innsjøer foregår gjerne nærmere land og på grunnere vann enn i kystområdene. Elver og bekker har skapt forhold som ikke forekommer i saltvann, og artssammensetningen er nokså forskjellig. Det er derfor ikke selvsagt at fisket $\mathrm{i}$ innlandet hadde samme form og omfang som det langs kysten. Det er imidlertid svært gode holdepunkter for at det også ble drevet en omfattende fangst i skandinaviske elver og vann der fisken har kunnet vandre inn på egen hånd etter siste istid. Funn av garn, stengsler og harpuner viser at disse redskapene også var $\mathrm{i}$ bruk i ferskvann i eldre steinalder i Skandinavia. ${ }^{35}$

Kunnskap fra det indre av det østlige Skandinavia har spesielt stor relevans for diskusjonen om det tidlige fisket i den sørnorske fjellheimen. I de østlige innlandsområdene er det nemlig mulig å studere hvordan spor etter et steinalderfiske blir bevart, og hvordan fisket fortoner seg i et mange tusen år gammelt kildemateriale.

Vannet fra den store innsjøen Vättern i Sverige renner ut i Motala ström. Funn ved dette utløpet gir en sjelden innsikt i én form for innlandsfiske i tidsrommet 5500-5000 f. $\mathrm{Kr}^{36}{ }^{36}$ Ved boplassen Strandvägen er det funnet et større antall lysterspisser tilvirket av bein. Hoveddelen er små stykker fra bosetningsområdet, men over 20 ble funnet på en fiskegrunne som lå utenfor boplassen. Spissene fra vannet var velbevarte, og mange av dem sto i mudderet rundt to steinplattinger. Plattingene kan ha blitt bygget for å gi et godt underlag til de som drev med lystringen. ${ }^{37} 1265$ bein av blant annet abbor, gjedde, ål og karpefisk gir sannsynligvis et lite innblikk i fiskefangsten. ${ }^{38}$

Det er ikke mange andre eksempler på slikt veldokumentert steinalderfiske i lavlandsregionen, men Jan Ekman og Elisabeth Iregren ${ }^{39}$ sine analyser av 232768 bein fra 107 funnsteder i Innlands-Sverige gir betydningsfull innsikt. De har skilt ut 2237 fiskebein og 109 fuglebein, mens det resterende materialet er av pattedyr. Det opplyses at det er gjort fiskebeinsfunn på 34,5 prosent av de utgravde plassene. En presis tidfesting av funnene har ikke vært disse forfatternes hovedanliggende, og materialet gir heller ikke alltid grunnlag for eksakte dateringer. ${ }^{40}$ De opplyser imidlertid at det har vært aktivitet før 1700 f.Kr. på 25 av 28 funnsteder som presenteres i større detalj. På 15 av dem er det imidlertid også notert yngre aktivitet. ${ }^{41}$ Spredningen vitner om at innsjøfiske har foregått mange steder, og etter alt å dømme har bevaringsforholdene og utgravningsteknikkene ført til at fiskebein kun utgjør en knapp prosent av det totale materialet. ${ }^{42}$ Det er uvisst hvor mange av disse fiskebeinene som er fra steinalderen.

Gjedde, brasme og abbor dominerer blant beinene på svensk side av grensen ${ }^{43}$, mens det samlet bare har fremkommet 45 skjelettdeler av laksefisk i materialet 
som Ekman og Iregren gjennomgikk. ${ }^{44}$ Den totale beinmengden tilsvarer således ikke engang det som kommer fra én enkelt levende laks eller ørret. Ved gravninger i Glomma-vassdraget i Norge har innslaget av laksefisk vært noe større. Laks og ørret er faktisk de eneste artene man har kunnet påvise blant de om lag 40 fiskebeinene som har foreligget frem til nylig. ${ }^{45}$ Artssammensetningen i funnmaterialet må derfor forstås som et resultat både av hvilke arter menneskene anså som attraktive, og av hvilke arter som levde i vassdragene. I tillegg er det relevant at bein fra laksefisk generelt bevares dårligere $\mathrm{i}$ jorden enn bein fra andre arter. ${ }^{46}$

Søkker er det eneste fiskeredskapet som har en vid distribusjon i de indre svenske områdene og i de østlige innlandsområdene i Norge. Disse søkkene er små og flate, gjerne strandrullede steiner med to tildannede, motstående hakk. ${ }^{47}$ Vekten behøver ikke å være mer enn 75-420 g, og de blir gjerne funnet på steinalderboplasser med gode fiskemuligheter. ${ }^{48}$ Formen, funnstedene og vekten taler for at steinene har vært festet langs bunntelnen til garn, og steinene har dermed bidratt til å stramme opp garnet når det har stått i vannet. ${ }^{49}$ Hoveddelen av de forsøksvise dateringene av denne gjenstandstypen samler seg til midten av yngre steinalder (ca.3300-2350 f.Kr.), men det finnes også funn som sannsynliggjør bruk både før og etter dette tidsrommet. ${ }^{50}$

Fragmenter av fiskekroker i bein er ikke uvanlige på funnsteder langs kysten, selv på steder der beinmaterialet er nokså sparsomt. Det er imidlertid et påfallende fravær av beinkroker fra boplassene i innlandet, selv der det foreligger fiskebein. Små stykker av slike kroker er helt sikkert lette å overse ved utgravningene, men allikevel gir det grunnlag for å vurdere om dette fraværet gjenspeiler trekk ved det eldste fisket. Fra historisk tid er det kjent et mangfold av fiskemetoder i elver og vann, ${ }^{51}$ og i svært mange tilfeller har trolig ikke lokking av fisk med agn gitt den største avkastningen. Muligens er fraværet av kroker derfor en refleksjon av tilpasningene steinaldermenneskene har gjort til de ulike vannmiljøer.

Selv om det er et sparsomt kildegrunnlag, kan man konkludere med at fiske var viktig for menneskene i store deler av den lange steinalderen, både langs kysten og i de østlige områdene med naturlige fiskebestander. Det neste og sentrale spørsmålet blir da hvordan menneskene forholdt seg til de fisketomme vannene. Valgte man å sette ut ørret, og når fant dette i så fall sted?

\section{Å TIDFESTE STEINALDEREN I FJELLET}

Steinalderen strekker seg fra ca. 9500 til 1700 f.Kr., og tidsrommet favner følgelig et tidsrom på over 7500 år med utvikling, variasjon og ulike levesett. På tross av at det finnes gode arkeologifaglige og naturvitenskapelige metoder for å datere forhistorisk virksomhet, møter man imidlertid betydelige utfordringer når man skal tidfeste hendelser i steinalderen.

Kronologi er et nøkkelbegrep i arkeologien, og muligheten til å studere tidsrekkefølger for utviklingen av bruk av råmaterialer, redskapstyper og teknologi har vært en grunnleggende og sentral del av faget i de om lag 200 årene det har eksistert. ${ }^{52}$ Et stort antall undersøkelser og studier har bidratt til at vi i dag vet forholdsvis mye hvordan redskaper $\mathrm{i}$ stein endret form over tid og om når råstoffer som flint, skifer og kvarts ble anvendt til redskaper. ${ }^{53}$ Denne kunnskapen kan gi grunnlag for å tidfeste aktiviteten på boplassene, i heldige tilfeller innenfor tidsrammer på et fåtall århundrer.

Radiologiske målemetoder, og da spesielt C14dateringer, har også vært til svært stor hjelp når man har skullet tidfeste sporene etter steinalderen i innlandet. Dagens dateringsteknologi gjør det i heldige tilfeller mulig å datere små stykker trekull, bein og annet organisk materiale innenfor et tidsintervall på et fåtall tiår. En rekke feilkilder kan 


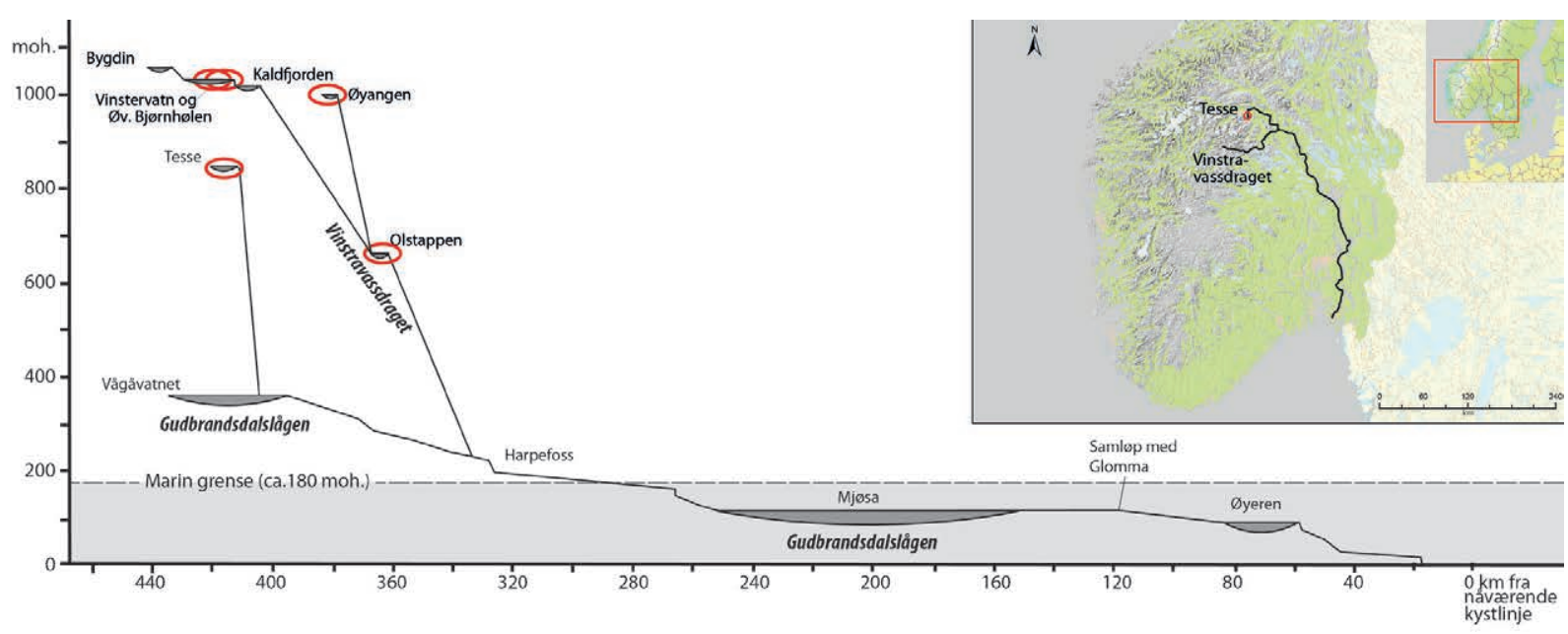

Figur 4: Vannsystemene knyttet til Vinstravassdraget og Tesse. Mot slutten av siste istid var Mjæsa saltvann, og havet sto opptil 180 meter høyere enn i dag (marin grense). Fisken har imidlertid hele tiden møtt hindringer ved Harpefoss nord for Mjøsa. Derfra er det flere partier med stryk og fosser som har stanset fiskens vandringer, både i Vinstravassdraget og frem til Tesse. Vann som er nærmere omtalt i teksten, er markert med rød ring. Illustrasjon omarbeidet med utgangspunkt i Skulberg. ${ }^{61}$

imidlertid gi dateringer som gir et grunnlag for gale konklusjoner. Både skogbranner, trær med høy egenalder og dødt trevirke som steinaldermenneskene har samlet, vil kunne resultere i en feilaktige aldersbestemmelser av boplassene. ${ }^{54}$ Delvis som en følge av dette har man de siste årene i større utstrekning anvendt brente bein for å tidfeste førmoderne opphold i fjellet. Det er imidlertid også feilkilder med denne type dateringer; blant annet kan de ha blitt påvirket av kalkrikt ferskvann i dyrenes levetid og av brenselet som har blitt anvendt når beinene har blitt brent..$^{55}$

I tillegg kompliseres det hele ytterligere av at hovedregelen i fjellet er at boplassene der har blitt besøkt gjentatte ganger, både i steinalderen og i senere perioder ${ }^{56}$ Dette skyldes åpenbart at de mange oddene, vikene og strendene har vært attraktive gjennom mye av fortiden. Når målet er å finne spor etter de første fiskerne, er det ikke vilkårlig hvilken fase med aktivitet fiskebein og fiskeredskaper skal knyttes til, og gjenbesøkene skaper derfor betydelige tolkningsmessige problemer.

Dagens teknologi setter grenser for hva som kan tidfestes ved hjelp av C14-metoden. Et enkeltbein av ørret er i de alle fleste tilfeller for lite til å kunne aldersbestemmes, og redskaper i stein kan heller ikke aldersbestemmes med denne metoden. Det er derfor nødvendig å diskutere funnforholdene for de enkelte boplassene med spor etter fiske. I den følgende hoveddelen vil enkelte overordnede trekk, diskusjoner og konklusjoner knyttet til fjellfiske bli løftet frem. Ytterligere detaljer om funnstedene og kildekritiske diskusjoner finnes i et vedlegg.

\section{PÅ JAKT ETTER FISKEPLASSENE - ET EKSEMPEL FRA TESSE (CA. 850 MOH.) I JOTUNHEIMEN}

Det ca. $12 \mathrm{~km}^{2}$ store fjellvannet Tesse nord i Jotunheimen er et velegnet utgangspunkt for en diskusjon av en eventuell utsettelse av fisk på bakgrunn 
av landskapsbruk i steinalderen. Grunnen er at de høye fossefallene ned fra Tesse har vært umulige å forsere for fisken (figur 4), og vannet må følgelig en gang ha vært fisketomt. ${ }^{57}$ Samtidig er Tesse kjent som et meget godt ørretvann, og fisket har trolig stått sentralt i bruken av området helt fra det ble satt ut fisk i vannet. Fiskeplassene i vannet er velkjente og godt dokumenterte; ${ }^{58} \mathrm{i}$ tillegg vitner skriftlige og arkeologiske kilder om bruken av dem helt tilbake til vikingtiden på en enestående måte. ${ }^{59}$ Kulturminnene rundt Tesse er også systematisk kartlagt, slik at man vet forholdsvis mye om hvor aktiviteten rundt vannet foregikk i steinalderen. ${ }^{60}$

Tesse ligger 850 moh. og er omgitt av dyrket mark, setre og skog. Mindre menneskelig aktivitet og en generelt høyere tregrense bidro til at vannet i større grad var omsluttet av furu- og løvskog i store deler av steinalderen. ${ }^{62}$ Det har imidlertid aldri vært langt fra Tesse til de høye og skogfrie toppene i Jotunheimen.

Rundt vannet er det kjent 20 funnområder fra steinalderen, hvorav 9 har blitt undersøkt nærmere. Ved utgravningen fremkom både steingjenstander og ildsteder, og det kan konkluderes med at det var aktivitet rundt Tesse på 4000-tallet eller tidligere, men hoveddelen av virksomheten foregikk i den yngre delen av steinalderen (ca. 3800-2350 f.Kr.). ${ }^{63}$ De som besøkte Tesse, anvendte i stor utstrekning lokale råstoffkilder for redskapene de tilvirket i stein, noe som viser at de hadde inngående kunnskap om tilgjengelige ressurser i nærmiljøet. Dette er kunnskap som trolig har blitt opparbeidet gjennom langvarig og regelmessig bruk av området, og menneskene man finner spor etter, må ha hatt en form for tilknytning til den nordre delen av Jotunheimen. ${ }^{65}$

Bevaringsforholdene for bein i området er generelt dårlige, og ut fra fragmentene isolert sett er det ikke mulig å vurdere om steinaldermenneskene drev fiske. Tre steinsøkker av typen med motstående hakk langs sidekantene er imidlertid funnet i Tesse, høyst sannsynlig utenfor området med steinalderboplasser i sørvestdelen av vannet (jf. figur 5). To av dem er nærmere dokumentert, og de veier 131 og $134 \mathrm{~g}$. Utforming og vekt er følgelig svært lik den man kjenner fra steinalderen i de østlige innlandsstrøkene. Som alt nevnt er dateringsrammen for denne gjenstandstypen flytende, og en langt senere datering kan ikke utelukkes.

Kunnskapspotensialet knyttet til fisket ved Tesse ligger imidlertid ikke først og fremt $i$ de enkelte funnene, men heller $i$ at det på en sjelden måte gir et grunnlag for å belyse bruken av landskapet. Tidligere konklusjoner om fjellfiske er nemlig trukket ut fra steinaldermenneskenes valg av oppholdssteder. ${ }^{66}$

Boplassene ved Tesse er i stor grad samlet innenfor fiskebankene på vestsiden og ved inn- og utoset, og spesielt tydelig synes denne sammenhengen å være i yngre steinalder. Dette er steder som må regnes som meget gode fiskeplasser. ${ }^{67}$ At innsjøen har et visst areal $\left(12 \mathrm{~km}^{2}\right)$, gjør også Tesse sammenlignbar med de større vannene i det indre av Sverige hvor man vet det har vært fisket. ${ }^{68}$

Det kan imidlertid ikke utelukkes at stedene heller har blitt valgt fordi villreinen har hatt sine trekkruter langs sør- og nordvestenden av Tesse, og at disse stedene har vært blant de beste for å beskatte reinflokkene som tradisjonelt har trukket mellom fjellområdene i Vågå og skogområdene i Lom. ${ }^{69}$ Aktiviteten innenfor fiskegrunnene kan derfor alternativt forstås som jaktboplasser. Som ellers er det da også funnet pilspisser på boplassene, noe som bidrar til å underbygge hypotesen om at aktiviteten var jaktrettet. Steinaldermenneskenes bruk av vannveiene som ferdselsårer kompliserer tolkningen ytterligere. ${ }^{70}$ Tesse har vært en viktig innfallsport til jakt- og fangstressursene i det indre av Jotunheimen, og det er også mulig å forstå aktiviteten i strandsonen ved odder og elveos som spor 


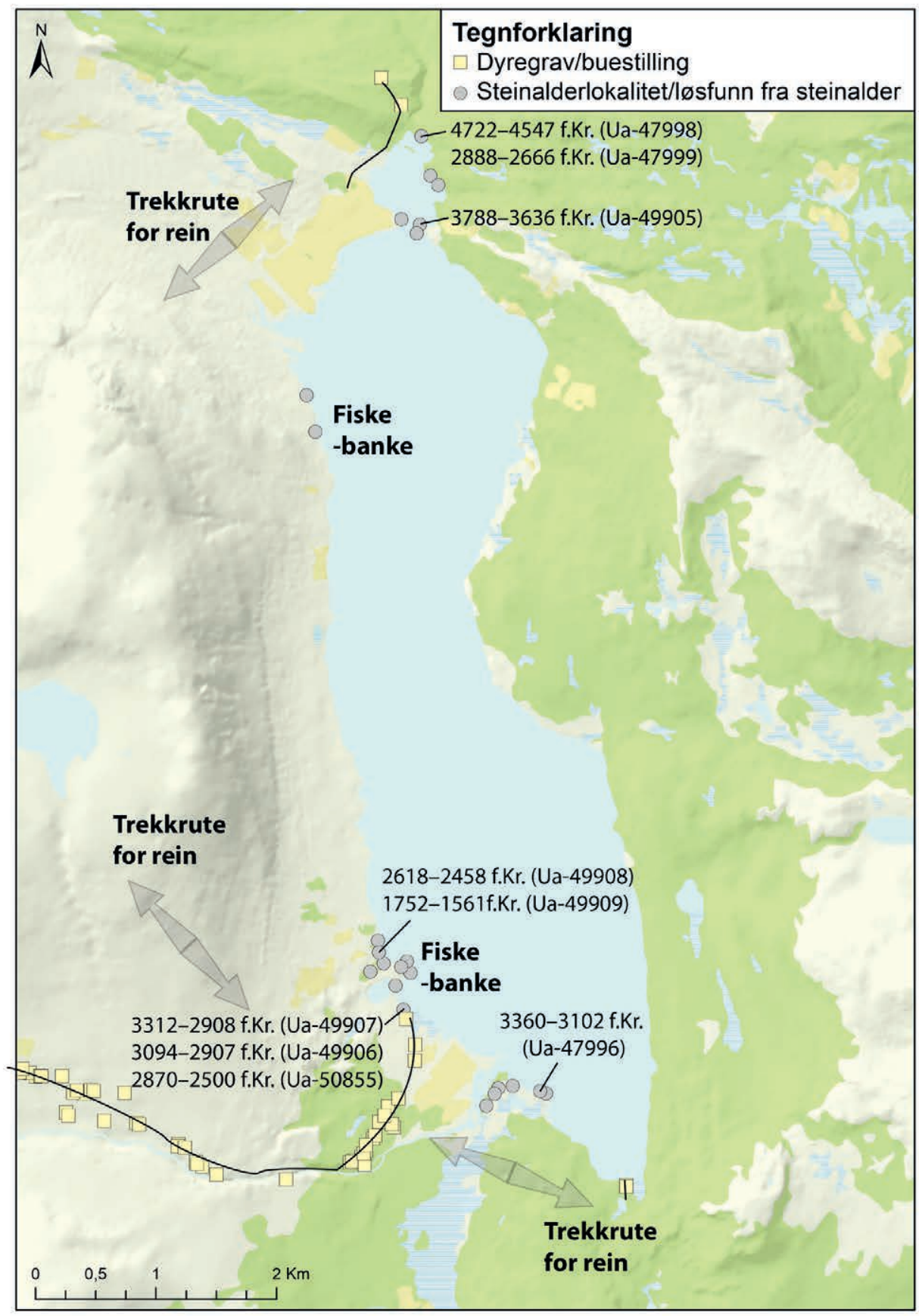

Figur 5: Kart over Tesse med steinalderboplasser og dateringer. I tillegg vises de omfattende fangstsystemene knyttet til reinsfangst fra jernalder eller middelalder. ${ }^{64}$ Illustrasjon: Axel Mjærum, KHM. 
etter ferdsel med båt. Tesse er allikevel et vann som ligger noe isolert til, og trolig har det derfor vært mindre gjennomgående ferdsel her enn eksempelvis langs det langstrakte Vinstravassdraget. ${ }^{71}$

Det kan konkluderes med at de som oppholdt seg ved Tesse i yngre steinalder, kjente området godt og trolig besøkte området regelmessig. Videre var strendene innenfor de gode fiskeplassene blant de best besøkte stedene i yngre steinalder, og det kan være gjort funn av garnsøkker fra yngre steinalder i vannet. På tross av at det foreligger mye kunnskap, gir ikke en slik diskusjon med utgangspunkt i landskapsbruk noen definitive holdepunkter for et tidlig fiske. I tilfeller hvor det mangler funn av fiskebein eller fiskeredskaper, vil det som oftest kunne fremmes alternative forklaringsmodeller for valg av oppholdssted.

\section{NUMEDALSLÅGEN}

Med en lengde på ca. $350 \mathrm{~km}$ er Numedalsvassdraget et av de større vannsystemene i Norge. Det har sine kilder sentralt på Hardangervidda, 1200-1300 moh., og renner ut ved Larvik i Vestfold. Den øvre delen har få bratte fall, og fisk kan derfor bevege seg mellom mange av vannene. Fra Tunhovdfjorden til Norefjorden er det stor høydeforskjell, ca. 400 meter på en om lag $7 \mathrm{~km}$ lang elvestrekning (se figur 6). Det er også flere fossefall i den nedre delen av elven som i dag danner barrierer for fisken. Disse befinner seg imidlertid lavere enn det maksimale havnivået mot slutten av den siste istiden, og fisken kan følgelig ha etablert seg i midtdelen av vassdraget før landhevingen endret situasjonen.

Røye og ørekyt har blitt satt ut i nyere tid i den øvre delen av Numedalsvassdraget. ${ }^{72}$ Før dette tidspunktet fantes det bare ørret her, og vassdraget er kjent for en stor produksjon av kvalitetsfisk. Den øvre, opprinnelig fisketomme, delen av vassdraget har vært gjenstand for flere arkeologiske undersøkelser. Hardangervidda-prosjektet på 1970tallet ${ }^{73}$ og utgravningene ved Røyrtjønna i vestdelen av Pålsbufjorden på 2000-tallet ${ }^{74}$ er spesielt relevante i denne sammenhengen. Datamaterialet fra disse feltarbeidene omfatter ca. 290 lokaliteter, hvorav 83 ble nærmere undersøkt. De eldste sporene er tidfestet til om lag 7300 f.Kr., det vil si 500-1000 år etter at området ble isfritt. ${ }^{75}$ Mange av funnene er gjort i tilknytning til de store innsjøene, og særlig ved utløpsosene. Dette er punkter i landskapet som kan ha vært sentrale for både jakt, fiske og ferdsel. På fem funnplasser i den øvre delen av vassdraget er det funnet brente fiskebein, noe som belyser denne artikkelens hovedtematikk på et spesielt godt vis. ${ }^{76}$

\section{Røyrtjonna, Pålsbufjorden (ca. 740 mob.), Hol og Nore og Uvdal kommuner i Buskerud}

Røyrtjønna var frem til nyere tids vassdragsreguleringer et område med to små vann og korte elvestrekninger i vestenden av Pålsbufjorden (figur 7). Her ble det i 2011 og 2012 undersøkt 21 boplasser med et delvis rikt gjenstands- og beinmateriale. ${ }^{77}$ Feltarbeidet viste at området ble besøkt gjentatte ganger i perioden ca. 6500-5800 f.Kr., og at aktiviteten fikk en fornyet intensitet etter ca. 4500 f.Kr. Hovedmotivet for de mange oppholdene ved Røyrtjernene har utvilsomt vært de gode jaktmulighetene som har blitt skapt av de sesongvise elgtrekkene som går forbi stedet. ${ }^{78}$ Det kan tillegges at Pålsbufjorden befinner seg i forholdsvis tett skog $\mathrm{i}$ dag, noe innsjøen har gjort siden om lag $6500 \mathrm{f} . \mathrm{Kr}^{79}$

På tre av de undersøkte boplassene fremkom det fiskebein..$^{80}$ Lokalitet RT12-15 lå langs bredden av ett av Røyrtjernene (figur 7), på et sted der to større steinblokker og et høydedrag har skjermet for vær og vind. Det foreligger 1020 gjenstandsfunn fra denne utgravningen. Femten pilspisser i skifer og andre funn kan utvilsomt knyttes til jakt og fangst i midten av yngre steinalder (ca. 3300-2350 f.Kr.). Denne 


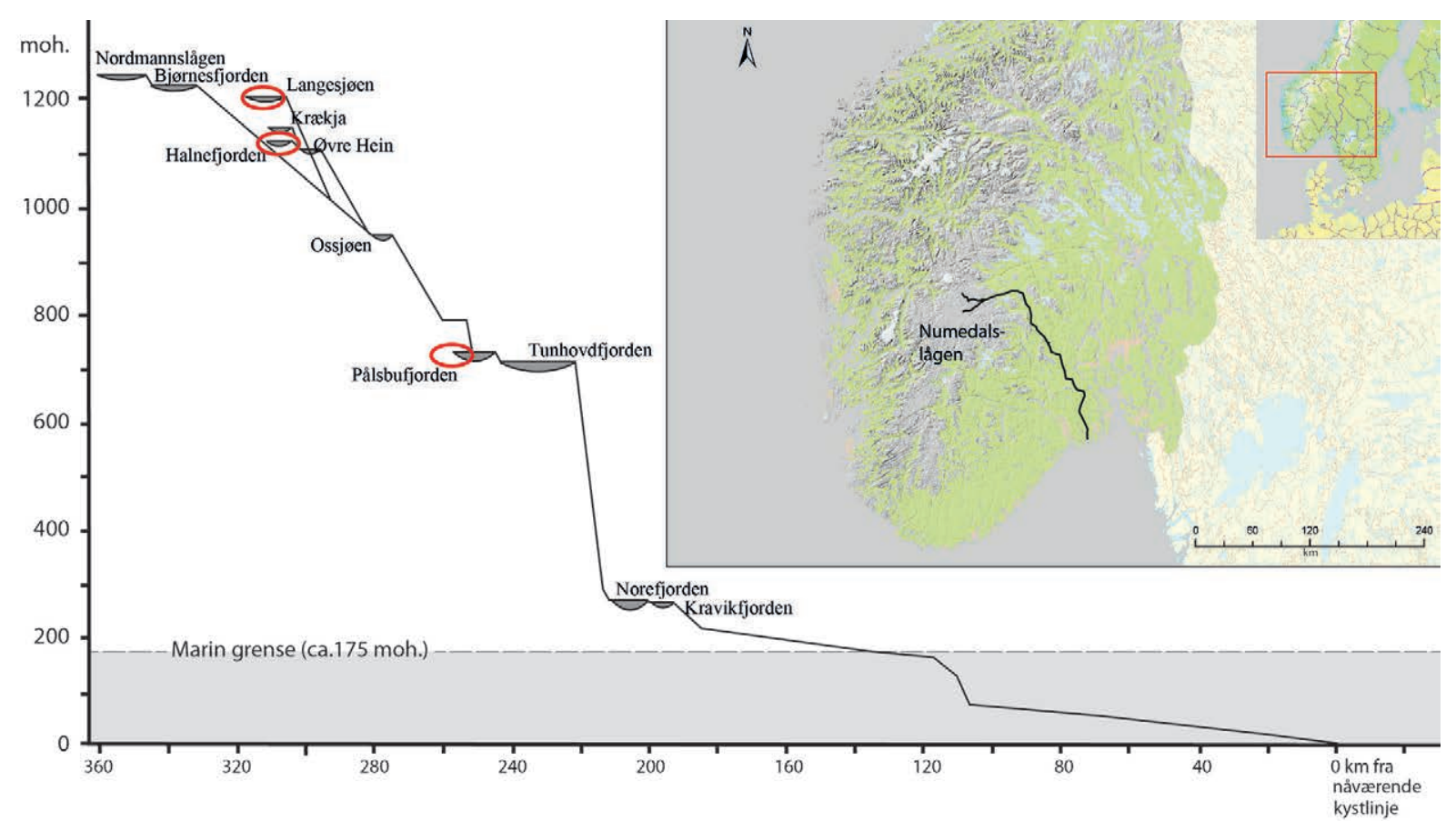

Figur 6: Numedalslågen er om lag $350 \mathrm{~km}$ lang, og den har sine kilder langt inne på Hardangervidda. Rett etter siste istid sto havet 175 meter høyre enn i dag (marin grense), og ørret og andre arter kunne fritt etablere seg i den nedre delen av vassdraget. Fosser og stryk mellom Tunhovdfjorden har derimot hindret fisket i å ta seg videre opp i vassdraget. Flere av strykene i den øvre delen av vassdraget har det vært mulig å passere for fisken, noe som innebærer at fiskebestanden i den øvre delen av vassdraget kan ha blitt etablert med et begrenset antall utsettinger. Vann som er nærmere omtalt i teksten, er markert med rød ring. Illustrasjon: Axel Mjærum, KHM.

tidfestingen er underbygget av to C14-dateringer, en på pattedyrbein og en på bek som var anvendt til å skjefte en av spissene.

Sentralt i funnområdet fremkom også $200 \mathrm{~g}$ brente bein, blant annet 111 ryggvirvler og tre kranieknokler $(15,8 \mathrm{~g})$ av laksefisk. Hoveddelen av fiskebeinene ble funnet innenfor en halv $\mathrm{m}^{2}$, umiddelbart under torven, sammen med bein av pattedyr og fugl. Beinene lå konsentrert, men uten en klar tilknytning til et ildsted.

Den store beinmengden ga mulighet for en direkte radiologisk analyse (C14-analyse), noe som ellers ikke har blitt gjort av fiskebein fra Innlands-Norge.
Analysen har tidfestet beinene til 1624-1461 f.Kr., det vil si eldre bronsealder. Det er imidlertid kjent at det er problemer med radiologisk tidfesting av dyr som lever i ferskvann, ${ }^{81}$ og i enkelte tilfeller kan den målte alderen være flere århundrer yngre enn den reelle. Eksemplet synliggiør på en god måte hvordan gjenbruk av oppholdsstedene skaper utfordringer når man skal forsøke å tidfeste det eldste fisket. Man må utvilsomt være varsom med å trekke konklusjoner om alderen ut fra de overordnede dateringsrammene til boplassene. Tidfestingen gir allikevel belegg for å si at det har blitt spist, og trolig også fanget, fisk ved Pålsbufjorden langt bakover i tid. 


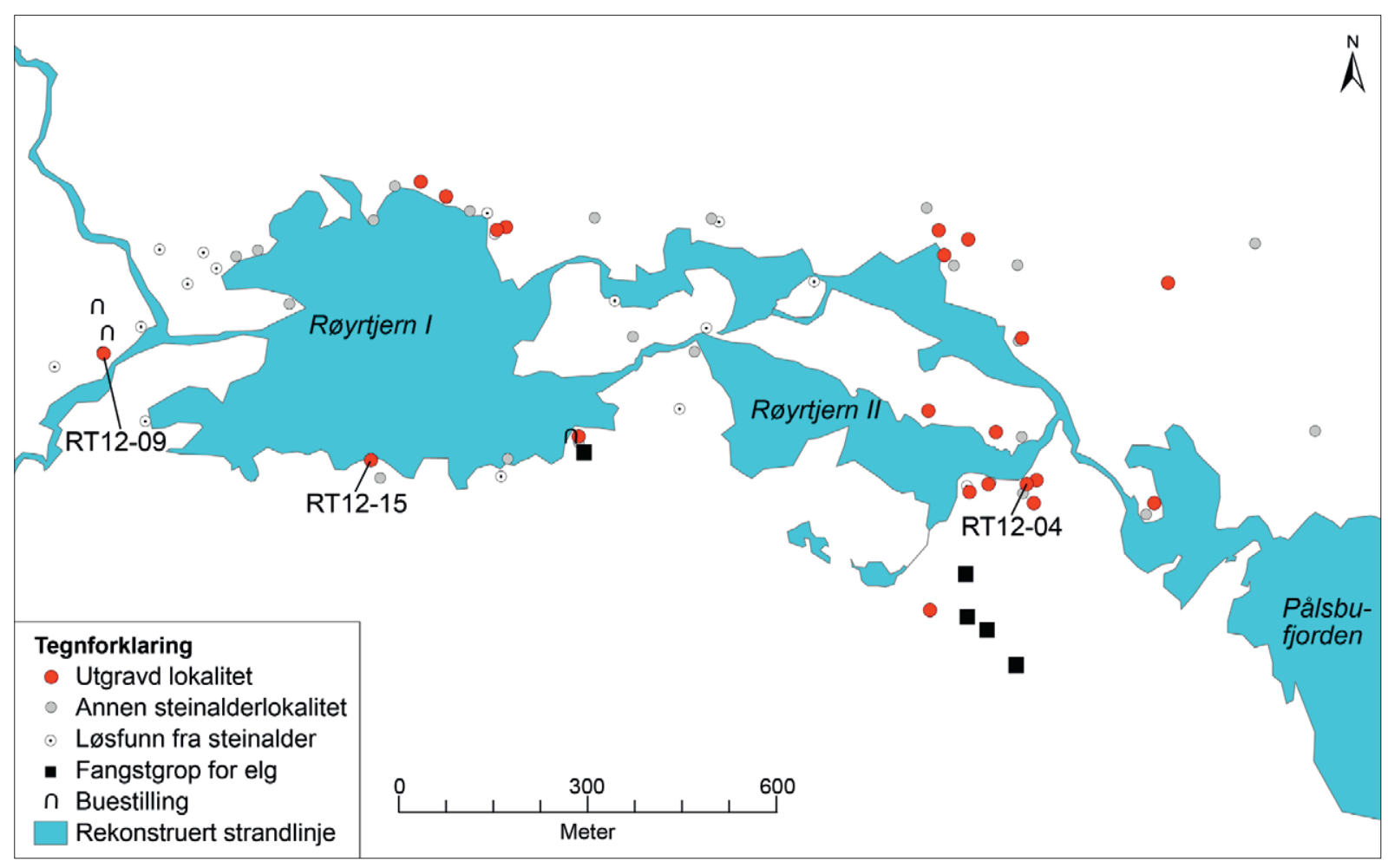

Figur 7: Boplassene ved Røyrtjønna. Stedet ligger nå under vann store deler av året. Strandlinjen har derfor blitt rekonstruert ut fra en kartlegging i 1846 og på bakgrunn av flyfoto. Kart: Axel Mjærum, KHM.

Det er også verdt å merke seg at en ørret har 58-59 rygghvirvler, ${ }^{82}$ så man kan uten videre slå fast at beinene fra RT12-15 er fra flere fisk. Selv om antallet ikke er svimlende stort, skiller de seg fra dem på de andre innlandslokalitetene med steinalderdateringer. Funnmengden vitner om gode bevaringsforhold, men kanskje kan også det forholdsvis store antallet fiskebein forklares med at beinene er godt under 4000 år gamle, noe som i denne sammenheng faktisk kan være forholdsvis ungt.

En annen av Røyrtjønna-boplassene (RT1209) har opprinnelig ligget ved bredden av elva Rambergåi, ca. 250 meter ovenfor innløpsoset (figur 7). Denne elvestrekningen har trolig tidligere vært et viktig gyteområde for ørreten i Pålsbufjorden. ${ }^{83}$ Oppholdsstedet var noe mindre steinrikt enn området rundt, og små omliggende høydedrag skjermet lokaliteten mot vind fra nord, vest og sør. På stedet ble det samlet inn ca. 3100 gjenstander i stein innenfor to samlinger med funn, og om lag ti meter sørøst for hovedkonsentrasjonen med steinalderfunn lå det en kokegrop tidfestet til omkring Kristi fødsel (50 f.Kr.-25 e.Kr., jf. figur 18 i vedlegg).

På RT12-09 lå det flekker av kulturlag som var rike på gjenstander i stein fra eldre og yngre steinalder, men som også inneholdt bein. I det største av utgravningsfeltene ble det samlet inn $58 \mathrm{~g}$ brente bein, og innenfor $0,25 \mathrm{~m}^{2}$ som var rik 


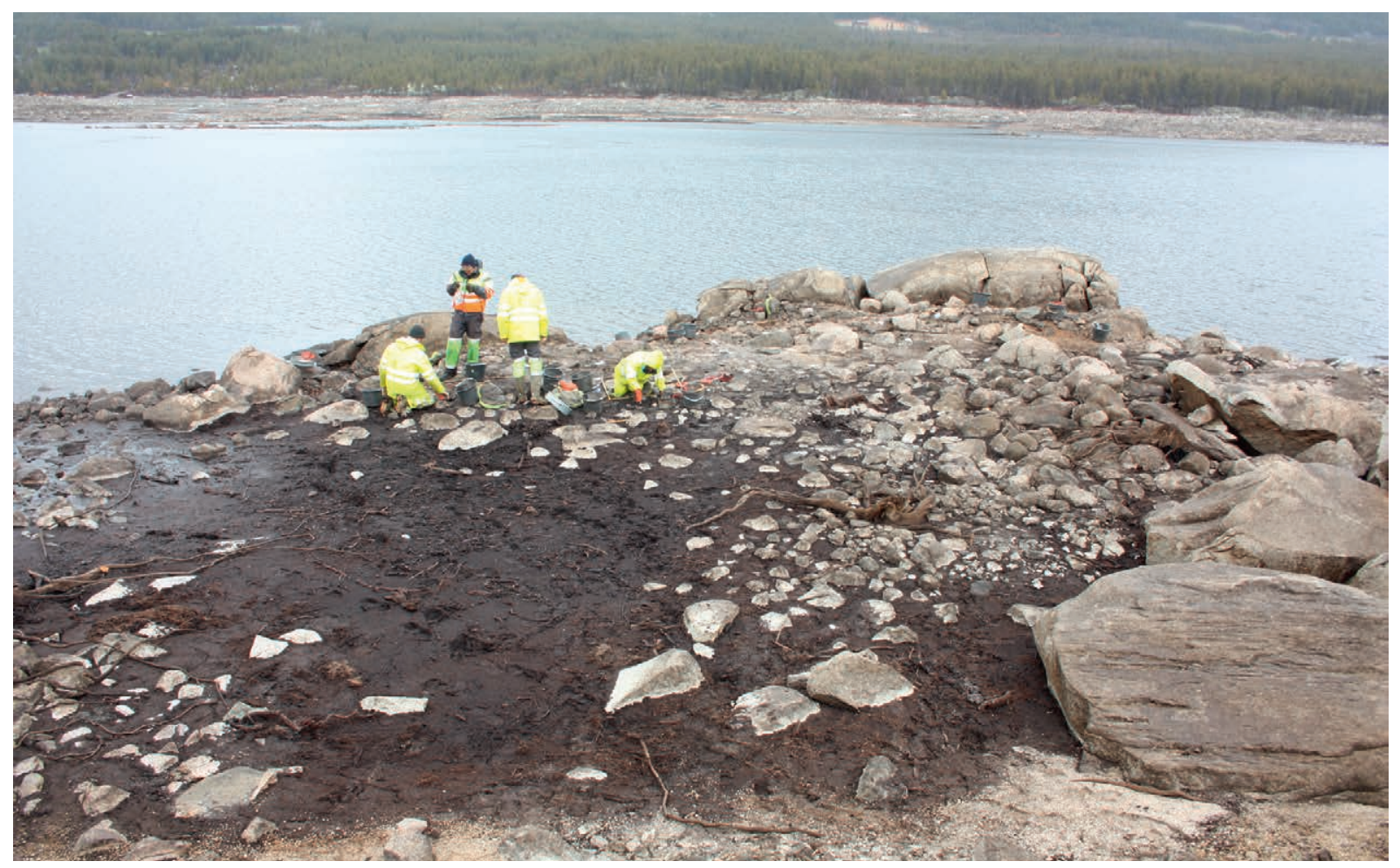

Figur 8: Boplassen RT12-15 lå skjermet av svaberg og flyttblokker, men helt nede ved Røyrtjønna. På stedet lå de pilspisser og andre gjenstander fra yngre steinalder. De 114 fiskebeinene ble funnet i området der arkeologene arbeider. Foto: KHM.

på steingjenstander, fremkom også en rygghvirvel av fisk. Det er utvilsomt nærliggende å knytte beinene til kulturlaget og de øvrige funnene på denne delen av feltet. Erfaringene med de sprikende dateringene fra RT12-15 og tilstedeværelsen av kokegropen leder til at konklusjon om at fiskebeinet er fra steinalderen, bør trekkes med forbehold.

De mest entydige holdepunktene for et steinalderfiske ved Røyrtjønna foreligger fra lokaliteten RT12-04, et funnområde som lå på en liten morenehøyde ved utløpet av det østre av Røyrtjernene (figur 7). I tilknytning til en liten steinfri flate fremkom ca. 4300 gjenstander og om lag 2070 gram brente bein (figur 10). Lokaliteten kan således betegnes som rik på gjenstander, og beinmaterialet er uvanlig omfattende. Funnmaterialet gjenspeiler aktiviteten mot slutten av eldre steinalder (frem til ca. 3800 f.Kr.), men også aktivitet i yngre steinalder (3800-1700 f.Kr.). Én av spissene har imidlertid en noe yngre dateringsramme (ca. 2350-1300 f.Kr.).

Sentralt på boplassen var det spor etter flere ildsteder. I bålmassene lå nær $490 \mathrm{~g}$ brente bein, hvorav ett var av fisk. I massene ved strukturen ble det funnet ytterligere et fiskebein (figur 10 og 19 i vedlegg). Pattedyrbein fra et kullag i ildstedet er tidfestet til 4500-4340 f.Kr., mens pattedyrbein fra laget over ildstedet har gitt alderen 4830-4550 f.Kr. Det foreligger altså to radiologiske dateringer 


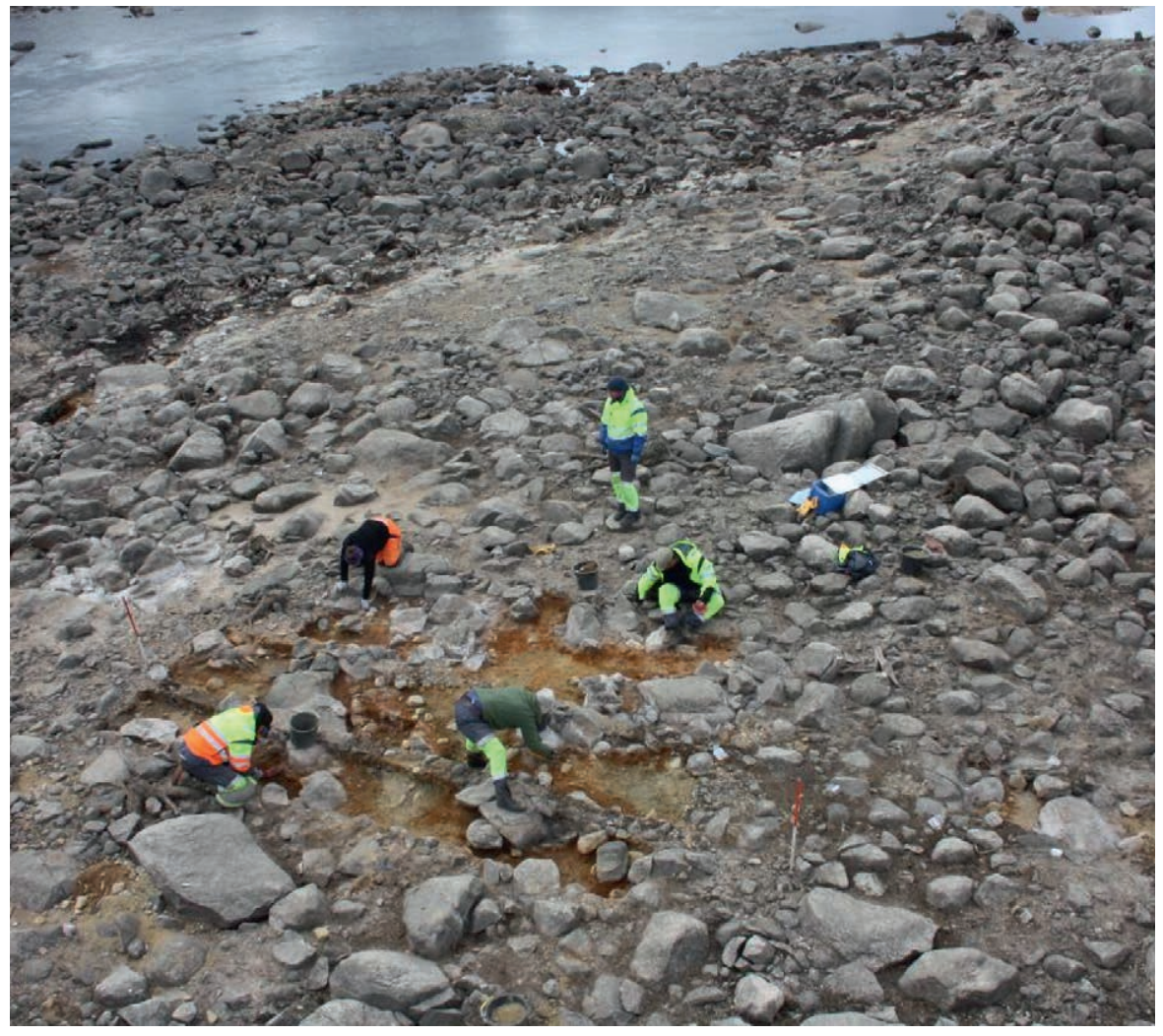

Figur 9: Utgravning av RT12-09. Fiskebeinet ble funne t.v. i utgravningsfeltet. I bakkant sees Rambergåi. I store deler av steinalderen var bredden av Røyrtjernene skogbunn og strand. Ca. 100 år med vannkraftregulering har imidlertid omdannet den tidligere strandlinjen til et månelandskap. Foto: KHM.
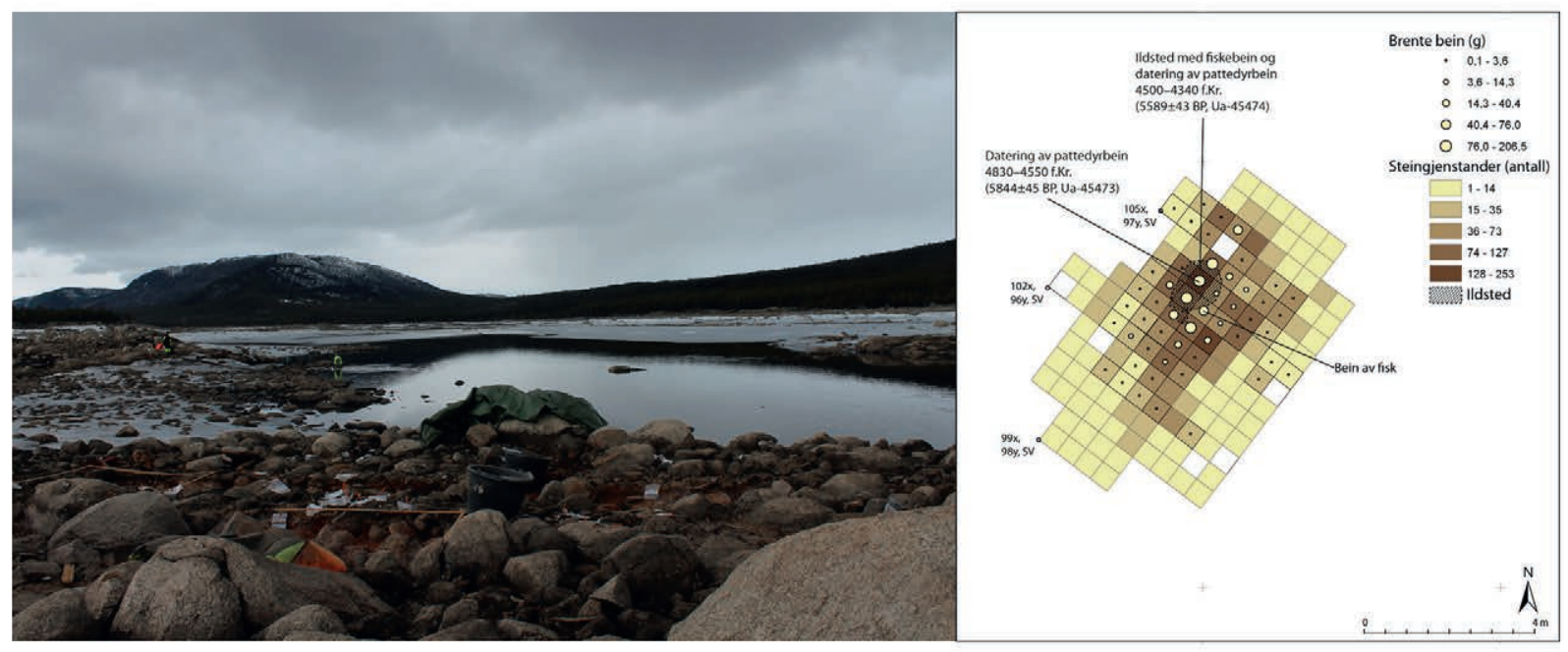

Figur 10: T.v. utsyn fra steinalderboplassen RT12-04. T.h. C14-dateringer, spredning av gjenstander, brente bein og beliggenhet til ildsteder. Foto: Johannes Bülow. Kart: Kim Darmark og Axel Mjærum, KHM. 
til eldre steinalder som i liten grad overlapper. Mest sannsynlig er det tidfestet bein som er etterlatt ved ulike besøk.

Tidfestingen må vurderes ut fra det samme kildekritiske bakteppet som tidfestingen av de øvrige lokalitetene, og i denne sammenhengen er det relevant at det foreligger funn fra et vidt tidsrom $\mathrm{i}$ området. Det er imidlertid vanskelig å se bort fra de to beindateringene, og en tidfesting av rygghvirvlene til slutten av eldre steinalder fremstår som det mest sannsynlige. For å komme videre i diskusjonen om hvorvidt det faktisk var satt ut fisk, og hvorvidt det ble fisket i Pålsbufjorden, må man trekke inn de øvrige to lokalitetene med fiskebeinsfunn i Numedalsvassdraget.

\section{Langesjoen (ca. 1206 mob.), Nore og Uvdal kommune i Buskerud}

Lokaliteten 1039 ligger på sørsiden av den ca. $11 \mathrm{~km}^{2}$ store Langesjøen, på en tange ca. $4 \mathrm{~km}$ fra utløpsoset. Vannet befinner seg i dag i et høyfjellsområde, men da klimaet var på sitt mest optimale, ca. 6900 f.Kr., var det trolig glissen furuskog i området. ${ }^{84} \mathrm{I}$ de påfølgende tre årtusenene var klimaet mer gunstig enn i dag, og tregrensen var generelt høy, men varierende. Dette innebærer at skogen sto nærmere Langesjøen enn den gjør i dag.

Funnområdet her dekket et areal på over $200 \mathrm{~m}^{2}$, og på begynnelsen av 1970-tallet ble $9 \mathrm{~m}^{2}$ av flaten gravd ut. ${ }^{85}$ Det fremkom da 1000 gjenstandsfunn. Det var en klar konsentrasjon av gjenstander og skjørbrent stein i den nordligste delen av feltet som ble åpnet, og her lå det også et kullholdig lag. Ved utgravning av laget fremkom 61 bein av pattedyr og 1 bein av ørret. ${ }^{86}$ Trekull fra laget har blitt tidfestet til tidsrommet 5317-4839 f.Kr. ${ }^{87}$ Funnmengden var størst i dette feltet, og en del av gjenstandene var tydelig skadet av varme. Det kan derfor konkluderes med at gjenstandene ikke er yngre enn trekullet.
Lokaliteten er stor, og det er tenkelig at det har vært flere bruksfaser. Innenfor det undersøkte området er imidlertid gjenstandsmaterialet enhetlig og har et klart preg av å være fra eldre steinalder. ${ }^{91}$ Funnene og C14-dateringen sannsynliggjør her en tidfesting av fiskebeinet til tidsrommet omkring år 5000 f.Kr., selv om erfaringer med kildekritiske problemer tilsier at konklusjonene må trekkes med varsomhet.

\section{Halnefjorden (ca. 1130 moh.) i Hol kommune $i$ Buskerud}

Den velundersøkte boplassen Hein 33 lå på sørvestsiden av den om lag 13,5 $\mathrm{km}^{2}$ store Halnefjorden, ca. 1130 moh. ${ }^{92}$ Boplassen har befunnet seg sentralt i forhold til historisk kjente reinstrekk, og det er sannsynlig at dette har vært en viktig årsak til bosetningen på stedet (Indrelid 1973: 94-95). Bosetningen var anlagt på en terrasse 3-4 meter over vannflaten, og den hadde resultert $i$ at det lå avfall innenfor et område på 75-100 m². Avfallslagene fra steinalder var hele 0,5 meter tykke, og de gjenspeilet omfattende aktivitet over lang tid. Lagene inneholdt sjikt og samlinger med kull og ildskadet stein. Arkeologen Svein Indrelid har gjennomført en detaljert studie av lokaliteten, og han fremholder at kulturlagene har bygget seg opp over tid..$^{93}$ Sporene etter den yngste aktiviteten ligger derfor følgelig på toppen, mens det eldste materialet ligger ned mot bunnen. I enkelte tilfeller kan man imidlertid ha gravd seg ned i eldre lag og forstyrret dette bildet. Lagdelingen, funnmaterialet og seks C14-dateringer gir grunnlag for å skille minst tre perioder med besøk i eldre og yngre steinalder (se figur 11).

Det foreligger seks ørretbein på lokaliteten, 20-40 cm under overflaten. ${ }^{94}$ Indrelid $^{95}$ har knyttet to av fiskebeinene til den eldste fasen med besøk (5297-4373 f.Kr.) og fire av beinene til aktivitetsfasen i overgangen mellom eldre og yngre steinalder (innenfor 4312-3525 f.Kr.). Sammenhengen mellom 


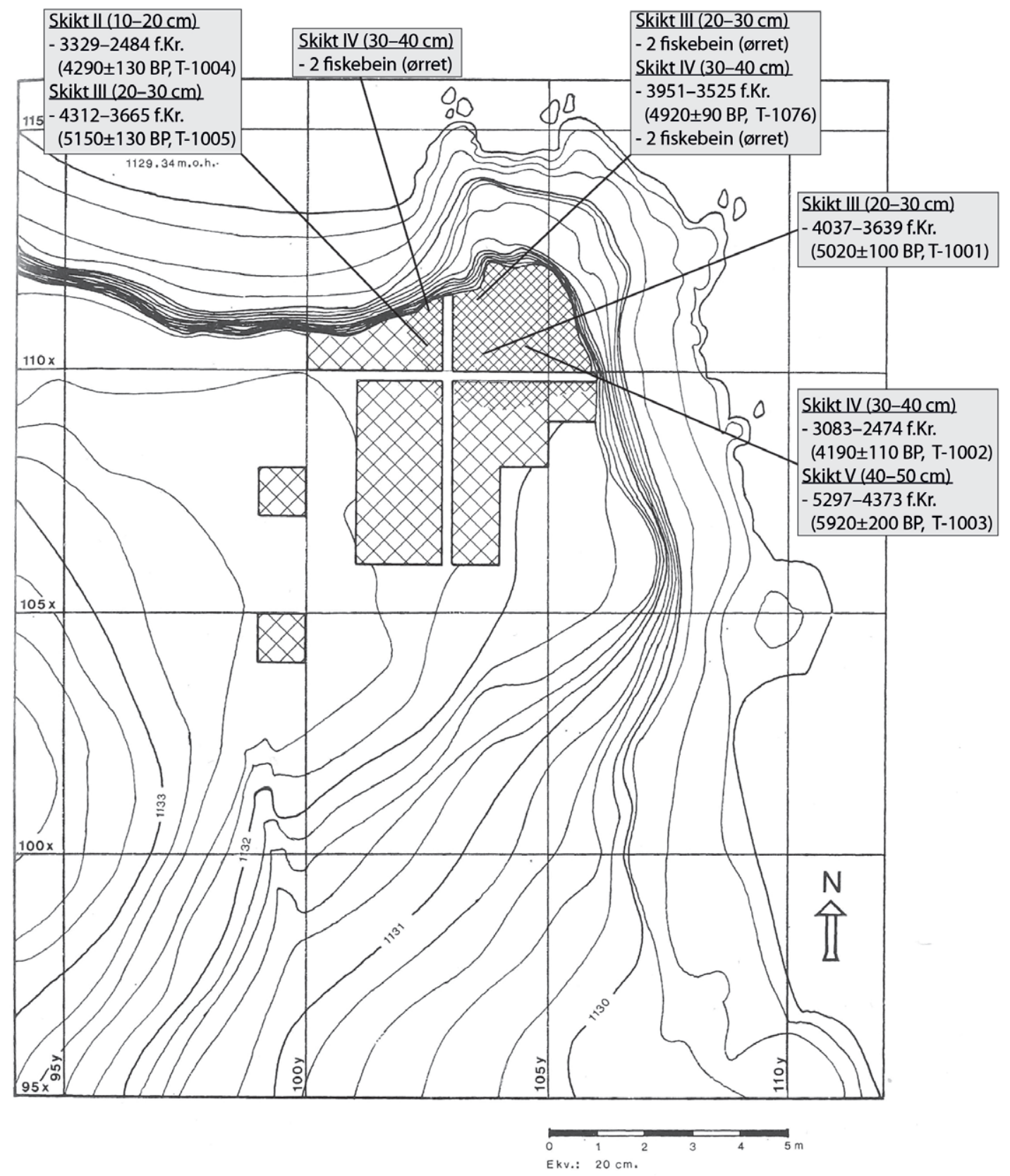

Figur 11: Kart over lokaliteten Hein 33 ved Halnefjorden. Illustrasjonen er utarbeidet med bakgrunn i Svein Indrelids omtaler av boplassen. ${ }^{88} \mathrm{~Pa}$ illustrasjonen gjengis også nye beregninger av C14-dateringene som foreligger fra boplassen. ${ }^{89}$ Funnene kan relateres til graveenheter med en størrelse på 1 x 1 meter og en tykkelse på 10 $\mathrm{cm}$. Én av dateringene ${ }^{90}$ er utført på bein av pattedyr, de øvrige er gjort på trekull (grunnlagskart: Svein Indrelid, bearbeidet av Axel Mjærum). 


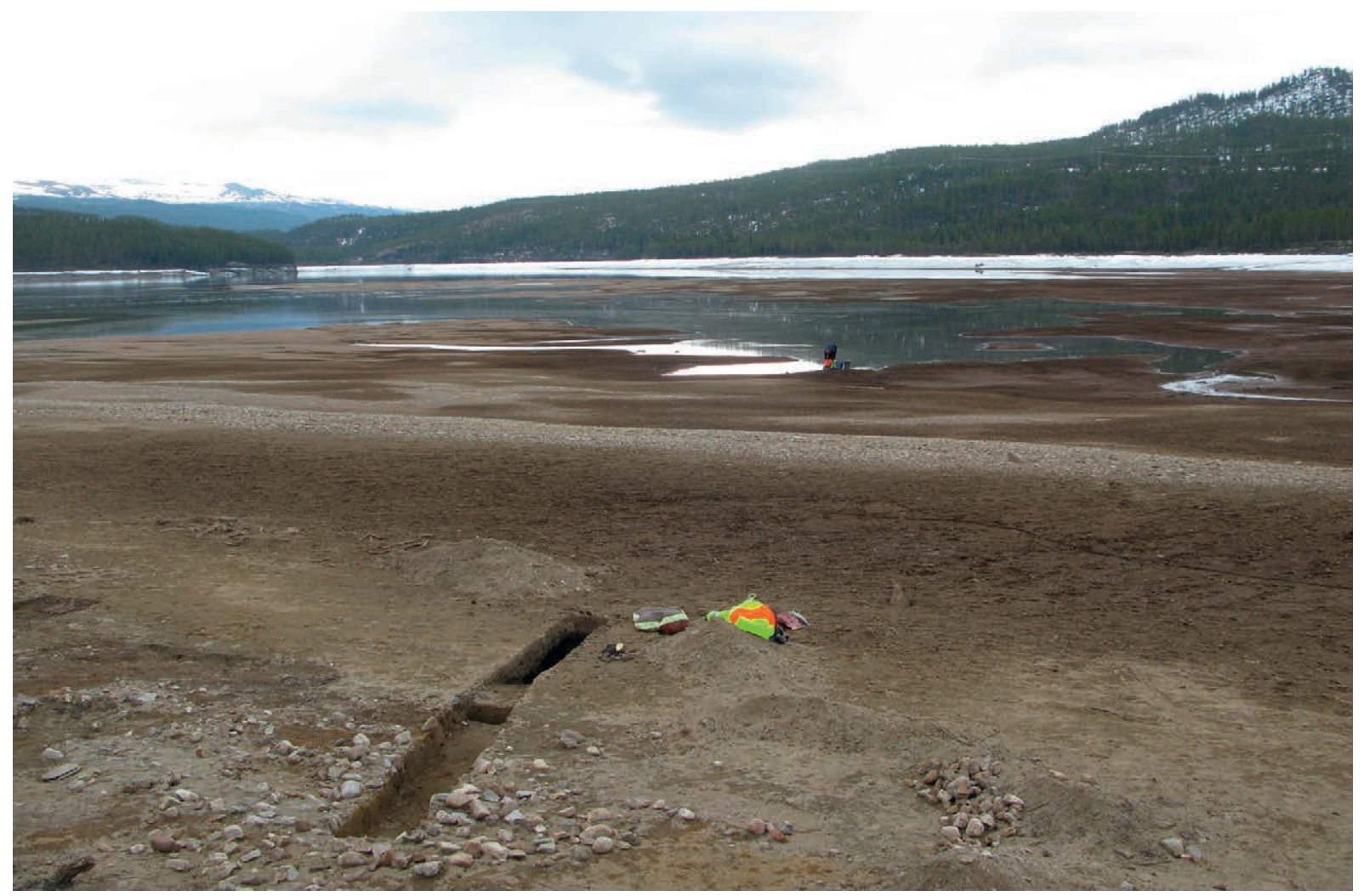

Figur 12: Funnområde V ved Olstappen. Stedet har opprinnelig ligget tett ved strandlinjen ved en langgrunn del av innsjøen. Søkkene er funntomme lag midt i den avbildede sjakten sammen med brente bein og steinredskaper. Foto: KHM.

fiskebein og denne fasen er spesielt godt belagt i ett tilfelle, hvor to fiskebein og C14-daterte pattedyrbein har fremkommet innenfor samme kvadratmeter og $\mathrm{i}$ det samme $10 \mathrm{~cm}$ tykke sjiktet. Det er mindre trolig at beinene er fra siste bruksfase i midten av yngre steinalder (innenfor tidsrommet 3329-2474 f.Kr.). Funnene fra Hein 33 kan følgelig tas til inntekt for det ble spist ørret øverst i Numedalslågen alt før 3500 f.Kr.

\section{VINSTRAVASSDRAGET}

Det andre området som vil belyses i større detalj, er det $120 \mathrm{~km}$ lange Vinstravassdraget sør i Jotunheimen.
Også dette vassdraget består av flere større vann, deriblant Bygdin og Vinstre, som begge ligger om lag 1000 moh. Vannet Olstappen befinner seg 340 meter lavere i terrenget, og herfra faller elva Vinstra ytterligere 400 meter før den møter Gudbrandsdalslågen (figur 4). Harpefoss i Gudbrandsdalslågen danner et nedre hinder for fiskens vandringer, og høydeforskjellene i Vinstravassdraget har til alle tider skapt ytterligere sperrer. Det er derfor forståelig at det kun var ørret i vassdraget frem til nyere tid, ${ }^{96} \mathrm{og}$ også denne fiskearten har trolig fått menneskelig hjelp ved etableringen. ${ }^{97}$ 
Både det tidlige fisket og andre sider av forhistorien har i vesentlig grad blitt belyst gjennom et pågående utgravningsprosjekt i Vinstravassdraget. ${ }^{98}$ Gjennom dette arbeidet har sentrale deler av de opprinnelige strandlinjene blitt saumfart på jakt etter kulturminner, og fagmessige utgravninger har så langt blitt gjennomført ved både Olstappen, Kaldfjorden, Vinstre, Øvre Bjørnhølen og Øyangen. I tre områder, ved Olstappen, Vinstrevann og $\varnothing$ vre Bjørnhølen ${ }^{99}$, har det blitt gjort funn som er spesielt relevante i denne sammenhengen.

\section{Olstappen (ca. 662 mob.) i Nord-Fron kommune $i$ Oppland}

Årlig trekker et stort antall elg forbi sørvestbredden av det om lag $3 \mathrm{~km}^{2}$ store vannet Olstappen, et vann som ligger $662 \mathrm{moh}$. Sporene etter steinaldermenneskene i dette skogområdet er tallrike, og de dekker store arealer langs vestbredden av vannet. Frem til og med feltsesongen 2015 var 8 områder med aktivitet nærmere undersøkt, og 7200 brente bein av pattedyr har blitt samlet inn. Aktiviteten strekker seg helt tilbake til ca. 8000 f.Kr., og dette er så langt de eldste sporene vi kjenner fra Vinstravassdraget og i Jotunheimen for øvrig. ${ }^{100}$

Olstappen er langgrunn i sørvestdelen, med sandbanker som har vært velegnet for bruk av stående garn. Det er imidlertid ikke funnet fiskebein som forteller om et slikt fiske. Derimot foreligger det to 44,4 og 87,2 g tunge søkker i skifer med hakk langs sidekantene og fragmenter av et tredje. Olstappensøkkene fremkom samlet i en smal sjakt som ble gravd gjennom et avfallsslag (se figur 12 og 20 i vedlegg). Funn av skiferspisser, andre gjenstander og en C14-datering til tidsrommet 3011-2538 f.Kr. underbygger at søkkene er fra midten av yngre steinalder.

Det er ikke uvanlig å finne garnsøkker fra steinalderen ved sandgrunner i innlandsområdene lengre

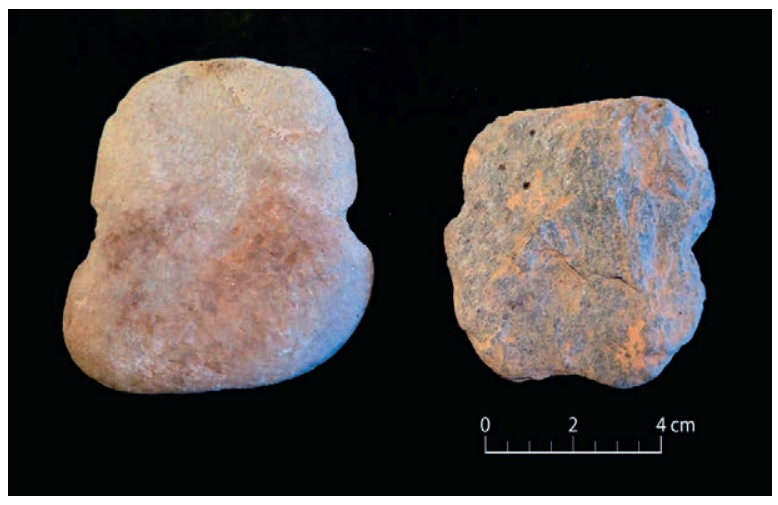

Figur 13: Garnsøkkene fra Olstappen. Foto Ellen Friis, KHM.

øst i Skandinavia, ${ }^{101}$ og funnstedet er et argument for at steinene med hakk har blitt benyttet som garnsøkker. Formen ligner da også på søkkene fra steinalderen som er funnet lengre øst, en type gjenstander som ut fra funnomstendighetene, vekten og formen i hovedsak blir tolket som garnsøkker. ${ }^{102}$ At det fremkom flere slike redskaper innenfor et svært begrenset utgravningsareal, samsvarer også med at det kan ha vært deler av et sett med slike tyngder.

Det er verdt å merke seg at den mest sammenlignbare gruppen av slike østlige søkker oppgis å ha en noe høyere vekt (75-420 g), ${ }^{103}$ og at de yngre garnsøkkene fra vannet Tesse veier 55,7-321 g. ${ }^{104}$ Det må derfor konkluderes med at Olstappensøkkene er lette. Kan det derfor tenkes at de har hatt andre funksjoner?

Det er foreslått en rekke andre tolkninger av steiner med hakk og furer fra steinalderen, eksempelvis at tyngre steiner ble anvendt som klubber til beverfangst, kobberutvinning eller klubbefiske. ${ }^{105}$ Den skifrige steinen og den lave vekten underbygger imidlertid ikke at gjenstandene skal ha vært benyttet som køller. Det er heller ikke funnet beverbein på stedet som kan underbygge klubbejakt knyttet til 


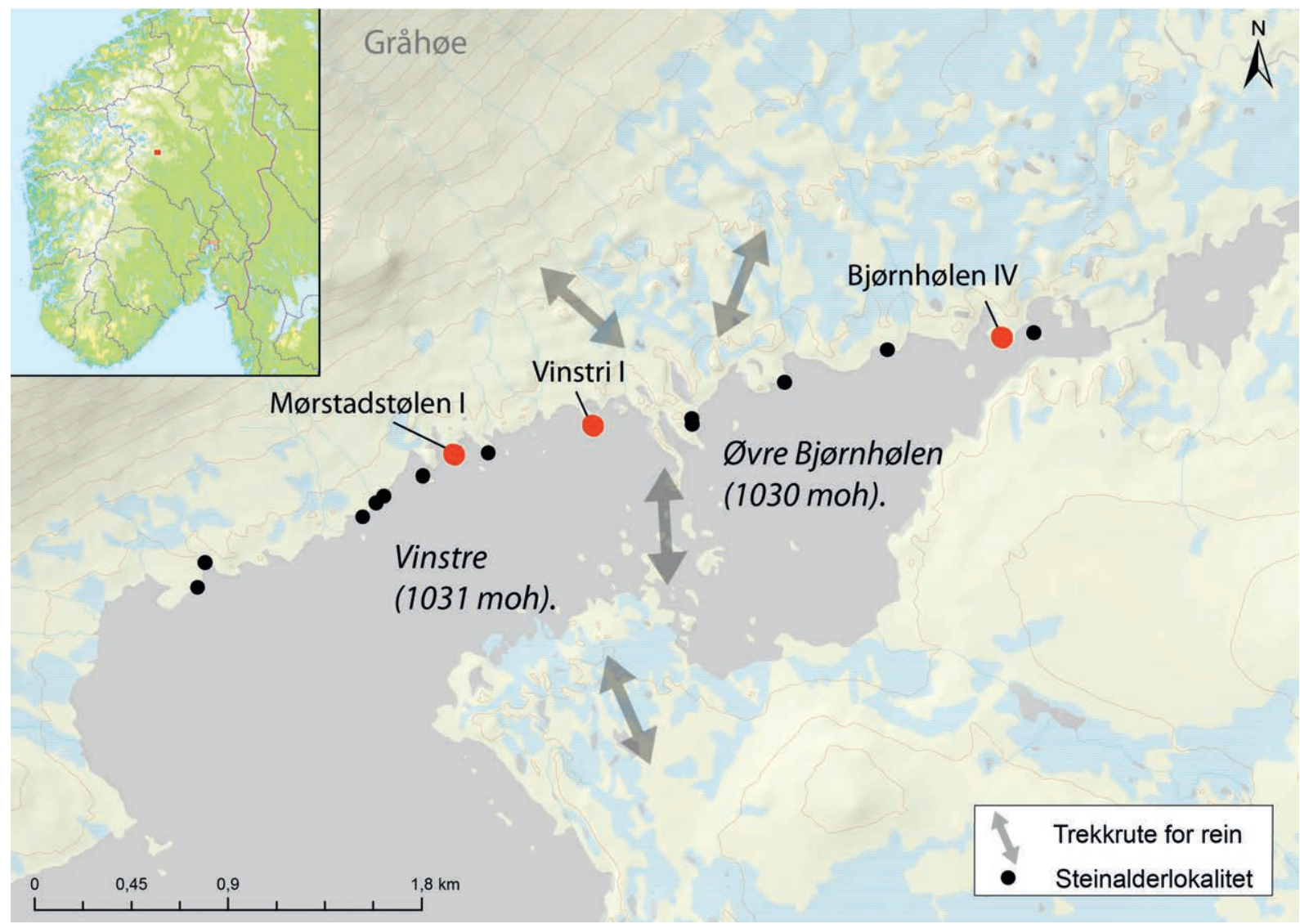

Figur 14: Østdelen av Vinstre og Øvre Bjørnhølen. Kart: Axel Mjærum, KHM.

beverhyttene. Det foreligger derfor få gode tolkningsalternativer, og mye tilsier at de ble anvendt som fiskegarnsøkker.

Vinstre (ca. 1031 moh.) og Øvre Bjørnhølen (ca. 1030 mob.) i Øystre Slidre kommune i Oppland

Lenger oppe i Vinstravassdraget ligger det fire boplasser som også belyser det tidlige fisket. I østenden av den om lag $28 \mathrm{~km}^{2}$ store Vinstre og ved den nærliggende Øvre Bjørnhølen har det blitt jaktet rein tilbake til 6000-tallet (se figur 14 og 15). I dag befinner vannene seg ved tregrensen, men i mye av steinalderen var klimaet mer gunstig. Strendene var da i stor grad omgitt av skog. ${ }^{106}$

På Mørstadstølen I ved Vinstre har det pågått utgravninger i korte perioder siden 2013. ${ }^{107}$ Her er avfallslagene stedvis opp mot 1 meter tykke, med enorme mengder brente og ubrente bein, skjørbrent stein og gjenstander som vitner om aktivitet fra 6000-tallet og frem til om lag 1000 f.Kr. Helt i toppen lå det i tillegg en grav fra jernalderen. Som ellers på steder med svært mye aktivitet har grunnen til en viss grad blitt rotet om, og det er derfor ikke gitt at funn fra samme lag har samme alder. Mange 


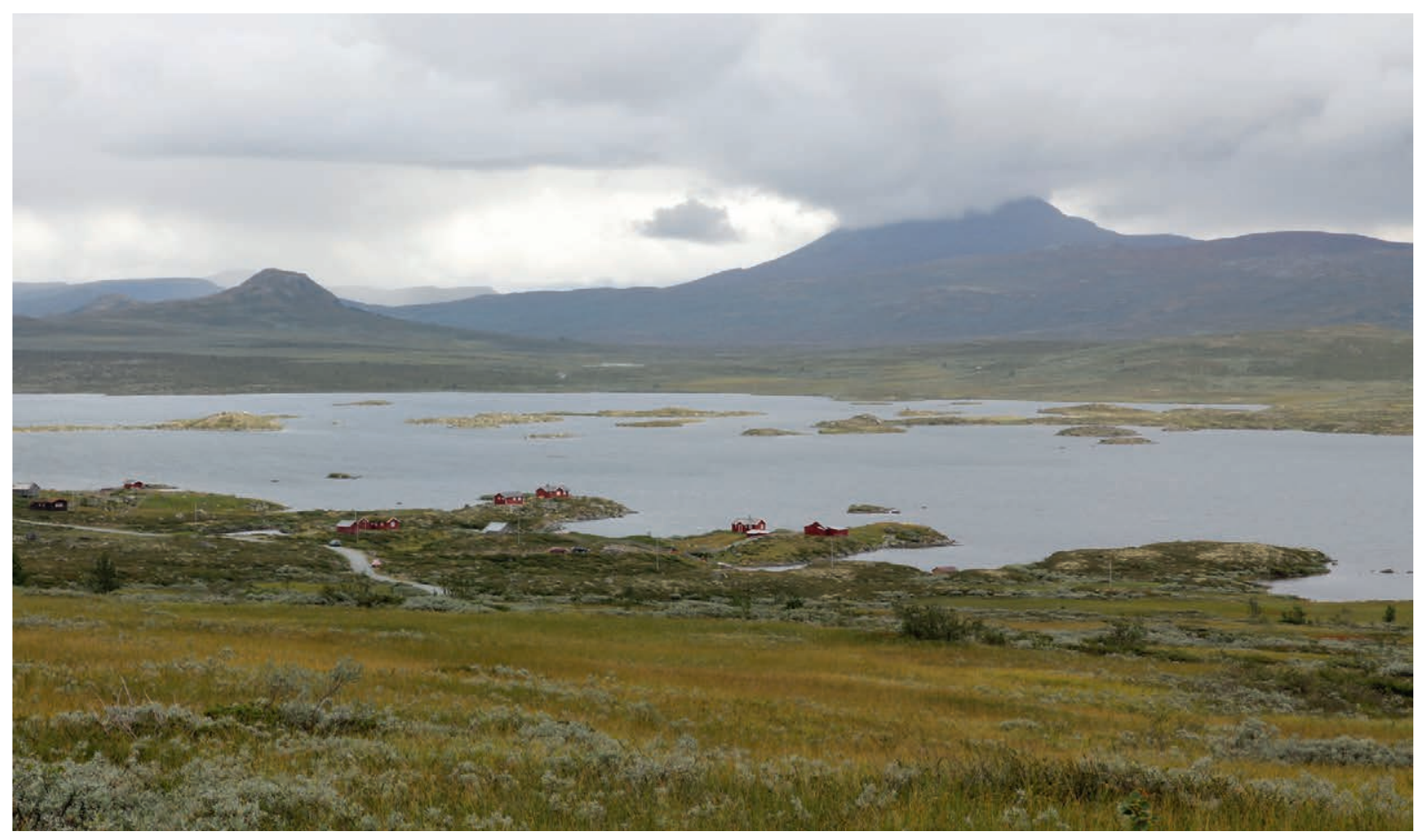

Figur 15: Østenden av Vinstre sett fra nord. Mørstadstølen ligger ved den nærmeste stranden. Det ligger boplasser fra steinalderen på nær sagt alle oddene på nordsiden (det vil si nærmest kameraet). Foto tatt mot sørøst av Kirsten Helgeland, KHM.

av de totalt 29 ørretbeinene som så langt har fremkommet, lå imidlertid dypt nede i jorden (figur 16 og 21 i vedlegg). Det foreligger C14-dateringer av brente pattedyrbein som gir grunnlag for å datere enkelte av fiskebeinene til sluttfasen av steinalderen (2121-1883 f.Kr.). Fiskebein ble imidlertid funnet opptil $50 \mathrm{~cm}$ under nivået med denne dateringen (figur 21 i vedlegg), noe som kan indikere at enkelte av fiskebeinene er vesentlig eldre. $\mathrm{Om}$, og eventuelt hvor mye, kan imidlertid ikke avgjøres ut fra informasjonen som foreligger per i dag.

En knapp kilometer vest for Mørstadstølen ligger lokaliteten Vinstri I (se figur 14 og 22 i vedlegg). Også dette funnstedet befinner seg på en odde. Her er det et opptil $30 \mathrm{~cm}$ tykt kulturlag med gjenstander, brente bein og store mengder skjørbrent stein.
Inntrykket er at aktiviteten har vært omfattende, selv om bruken av stedet har vært mer begrenset enn på Mørstadstølen I. Det er foretatt en liten utgravning, og fra dette arbeidet foreligger det et bein av ørret 10-30 cm nede i kulturlaget sammen med mikroflekker fra eldre steinalder (før ca. 4200 f.Kr.) ${ }^{108}$ Det har ikke blitt funnet gjenstander som kan knyttes til andre perioder, men en C14-datering forteller om opphold innenfor tidsrommet 28662504 f.Kr., det vil si midten av yngre steinalder. Det konkluderes med at beinene på dette funnstedet har fremkommet på en steinalderboplass med spor etter aktivitet i eldre og yngre steinalder, men som det har blitt påpekt tidligere, er det vanskelig å utelukke at beinene er etterlatt ved senere aktivitet, på slike åpne boplasser. 


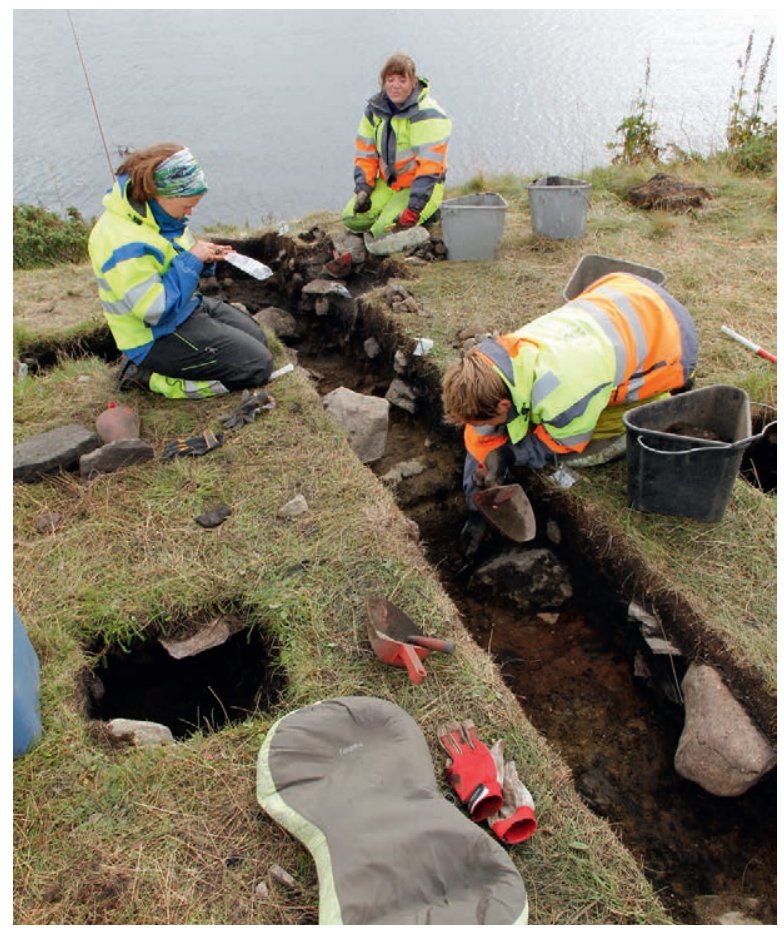

Figur 16: Utgravning på Mørstadstølen I i 2014. I sjakten sees det mørke kulturlaget og store mengder varmepåvirket stein. Hildegunn Ruset t.v., Kjersti Tidemansen i midten, og Knut Ivar Austvoll t.h. arbeider i sjakten. Foto: Kirsten Helgeland, KHM.

En tilsvarende funnsituasjon har blitt påvist på Bjørnhølen IV, ytterligere $2 \mathrm{~km}$ lenger vest (se figur 14 og 23 i vedlegg). På en odde er det spor etter omfattende steinalderaktivitet, $i$ form av gjenstandsfunn, kulturlag og brente bein. Ved kartleggingen av dette funnområdet fant man en ryggvirvel av ørret sammen med ti bein av pattedyr. I et nærliggende avfallsslag lå en samling av pattedyrbein og brent stein, trolig et ildsted. To dateringer til ca. 4700 f.Kr. samsvarer med funnmaterialet i stein. Som ved Vinstri I er det uklart hvorvidt tidfestingen angir alderen på fiskebeinet.

Funnene fra den øvre delen av Vinstravassdraget viser at fisk lenge har spilt en rolle, langt tilbake i tid og langt inn i Jotunheimen. De mange gjenbesøkene har imidlertid skapt et noe kaotisk funnbilde, og materialet gir derfor ikke entydige holdepunkter for å fastslå om alt dette skjedde på 4000-tallet f.Kr., slik enkelte dateringer indikerer, eller først på et senere tidspunkt. Funnene herfra bekrefter derimot et mer generelt inntrykk, nemlig at det har vært en tett forbindelse mellom jakt og fiske.

\section{FJELLFISKE I STEINALDEREN?}

Hva kan vi trekke ut av kunnskap ut fra denne gjennomgangen? Isolert kan det settes spørsmålstegn ved tolkningene av de enkelte funnstedene og de ulike dateringene. Landskapsbruk, fiskebeinsfunn og redskaper kan imidlertid totalt sett vanskelig forklares på annet vis enn at det har blitt satt ut fisk og fisket i flere av de store vassdragene i den norske fjellheimen svært langt tilbake i tid. En rekke tolkningsmessige problemer knyttet til kildematerialet gjør det derimot krevende å angi et eksakt tidspunkt for utsettingen, også i de vassdragene hvor det arkeologiske materialet er best egnet til å belyse spørsmålet.

Det finnes indikasjoner på at fisket i den øvre delen av Numedalsvassdraget strekker seg så langt tilbake som til 4000-tallet f.Kr. (figur 24 i vedlegg), men det er et gjennomgående problem at det er vanskelig fullstendig å utelukke at beinfunnene er langt yngre. Mange av de samme utfordringene møter man ved tolkningen av funnene i den øvre delen av Vinstravassdraget. Også her er det indikasjoner på at fisket ble etablert alt i eldre steinalder (på 4000tallet f.Kr.), men fisket kan belegges med en større grad av sikkerhet mot slutten av yngre steinalder.

Hypotesen om at det høyst sannsynlig er etablert et fiske mot slutten av steinalderen, kan til en viss grad underbygges av at det er et fullstendig fravær av fiskebeinsfunn i kontekster som tidfestes til før om lag 5000 f.Kr., til tross for at det er dokumentert 
aktivitet helt fra slutten av istiden, og at det også finnes bein fra noen av disse eldre oppholdsstedene. ${ }^{109}$ Man kan til en viss grad forklare en slik forskjell med at det eldste kildematerialet er spinklere, og at en høyere alder reduserer muligheten for at fiskebein bevares. De klare forskjellene mellom eldre og yngre boplasser styrker allikevel vurderingen av at sporene etter fiske faktisk er av relevans.

Videre danner landskapsbruken, fiskebein og mulige garnsøkker fra den sørnorske fjellheimen et samlet bilde som minner om det man kjenner østover i Skandinavia, det vil si i områder hvor fisken selv har funnet veien til vannene. Forskjellen $i$ artssammensetningen mellom beinmaterialet $i$ fjellet og det i de østre områdene er også interessant. Begge steder gjenspeiler nemlig artsbestemmelsene den lokale faunaen i nyere tid. Dette taler mot at det har skjedd en utstrakt transport av død fangst, eksempelvis i tørket form som niste til fjellområdene fra kysten eller lavlandet. ${ }^{110}$

Man vet at mange vann har vært fisketomme frem til nyere tid, ${ }^{111}$ og steinaldermenneskene har derfor helt sikkert ikke satt ut fisk overalt. I enkelte vassdrag er det da også vanskelig å se at fisket har spilt noen betydningsfull rolle. Dette gjelder eksempelvis Lærdalsvassdraget, hvor boplassene i liten grad ligger ved de gode fiskeplassene, ${ }^{112} \mathrm{og}$ Nyset-Steggjevassdragene i Sogn, hvor det er et påfallende fravær av ørretbein på alle funnsteder med spor etter førmoderne aktivitet. ${ }^{113}$ Steinalderfisket kan derfor ha hatt størst betydning i store vann og vassdrag, slik tilfellet også er i de lavereliggende, østlige innlandsstrøkene. ${ }^{114}$

På tross av en rekke tegn som tyder på svært gammelt fiske, på boplasser og det vi vet om steinaldersamfunnene, må det konkluderes med at det fortsatt er et stort behov for å fremskaffe mer informasjon om tematikken, og ikke minst å få nye og presise dateringer av fiskebeinsfunnene. $\mathrm{Ny}$ utgravd kunnskap vil sammen med DNA-studier av fjellfisken kunne belyse fiskens innvandring og innvandringsveiene på en langt bedre måte enn det man har mulighet til i dag. ${ }^{115}$ Inntil denne kunnskapen foreligger, er det uråd å angi et eksakt tidspunkt for den tidligste bæringen av fisk til de fisketomme vannene.

\section{HVORFOR FISKE I FJELLET?}

Det kan gjøres et skille mellom to hovedgrupper av jeger- og sankersamfunn. ${ }^{116}$ Et fătall slike samfunn baserer seg i hovedsak på jakt og sanking på en måte som gir umiddelbar avkastning, og hvor det som sankes, blir konsumert etter kort tid. Redskaper $\mathrm{og}$ våpen som anvendes i slike samfunn, kan være produsert med mye kunnskap og dyktighet, men uten at det investeres en stor arbeidsinnsats. Maten som skaffes til veie ved jakt og sanking, blir i liten grad bearbeidet eller lagret. James Woodburn har blant annet et mindre antall jeger- og sankersamfunn i regnskog- og ørkenområder i Afrika i tankene som utgangspunkt for en slik modell. ${ }^{117}$

I kontrast til dette står samfunn hvor det i større grad investeres i fremtiden. ${ }^{118}$ I denne sistnevnte gruppen finner man ikke bare jordbrukssamfunn og husdyrnomader, men også et stort antall jeger- og sankersamfunn. Blant slike jegere og sankere benyttes det båter, garn, fiskestengsler og fangstsystemer for dyr. Ofte anvendes det også mer permanente boliger, og man lagrer mat i større utstrekning. I slike samfunn griper menneskene ofte inn i naturens gang, eksempelvis ved målrettet avskyting av vilt og ved at man bedrer vekstforholdene for ville vekter. Det investeres altså betydelige ressurser i å sikre fremtidig avkastning. Woodburn knytter også sin modell til samfunnskompleksitet og utvikling, men i denne sammenhengen er det mest vesentlig at modellen synliggjør planmessigheten og investeringene som gjøres av jakt- og fangstfolk. Han 
forbeholder dermed ikke denne type planmessighet dem som holder husdyr og dyrker jorden.

Både båter og garn har vært brukt i Skandinavia siden begynnelsen av eldre steinalder, og også fiskestengsler kom trolig tidlig i bruk. I innlandet intensiveres bruken av naturen mot slutten av eldre steinalder. På 4000-tallet f.Kr. tar man blant annet i økende grad i bruk permanente bygninger i form av nedgravde hytter, noe som kan være spor etter en mer omfattende aktivitet og vinterbosetning. ${ }^{119}$ Menneskene tar også i bruk ny pilspissteknologi som har vært godt egnet til storviltjakt på dette tidspunktet, ${ }^{120}$ og fangstgroper og sperregjerder kan ha vært en etablert jakttradisjon fra da av. ${ }^{121}$ Det har også blitt hevdet at man fra slutten av eldre steinalder drev forvaltning av storviltet, for eksempel med planmessig uttak av bestemte årsklasser, jakt på rovdyr, ${ }^{122}$ og ved at man svidde av skog for å bedre beiteforholdene for viltet. ${ }^{123}$ Det er heller ikke tvil om at steinaldermenneskene hadde en inngående kjennskap til innlandet, noe som blant annet utnyttelsen av lokalt steinråstoff og den målrettede beskatningen av storviltets trekkveier er et uttrykk for. Planmessig og langsiktig utnyttelse av naturen er hovedregelen for jakt- og fangstfolk og en forutsetning for jordbrukere, og det er godt grunnlag for å hevde at mye av aktiviteten $\mathrm{i}$ innlandet etter ca. 5000 f.Kr. nettopp var basert på utsatt avkastning, først av jakt- og fangstfolk og etter ca. 2350 f.Kr. i stor grad av jordbrukere. ${ }^{124}$ Det kan derfor konkluderes med at uansett tidspunkt ble den første fisken båret oppover i vassdragene av folk som grep inn $i$ innlandsnaturen på mange ulike vis.

Avslutningsvis kan man reise spørsmålet om hvorfor menneskene valgte å sette ut ørret langt bakover i forhistorien. Ressursutnyttelsen til jegere og sankere er velstudert, og man har fremhevet allmennmenneskelige trekk som at de foretrekker mat som er velsmakende, næringsrik og variert. ${ }^{125}$
Utsettingen av ørret har utvilsomt bidratt til å sikre slik mat, både for jaktfolk og for bønder i fjellet. De som driver med jakt og sanking, ser også gjerne på planter og fisk som sikre og lite risikable ressurser, mens jakt ofte vurderes som en mer risikofylt aktivitet med lavere avkastning og høyere prestisje. ${ }^{126}$ Disse vurderingene av jakt, sanking og fiske er også trolig i stor grad overførbare til steinalderen i Sør-Norge. Det er liten tvil om at storviltjakten har hatt stor økonomisk og kulturell betydning i innlandet i Skandinavia fra steinalderen til våre dager. ${ }^{127}$ Hjorteviltjakten har nok også tidvis vært uforutsigbar, og det er trolig ikke tilfeldig at fiskebein så ofte opptrer på de gode jaktplassene for elg og rein. Mennesker tar gjerne i bruk ny teknologi for å gjøre ressursgrunnlaget mer stabilt og pålitelig. ${ }^{128}$ Flytting av fisk er med andre ord ikke bare en «teknologi» som skapte et bredere næringsgrunnlag, men har også redusert risikoen forbundet med å oppholde seg i innlands- og fjellområdene.

\section{SUMMARY}

\section{THE EARLIEST FISHING IN THE SOUTHERN NORWEGIAN MOUNTAINS}

From around 9500 BC, a rapid deglaciation took place in the inland. This enabled the migration of species less well adapted to a cold climate into these areas. Mammals and birds could quite easily move into this new landscape, while waterfalls and steep elevation made it impossible for the fish to naturally migrate to large parts of these areas. The first human visitors thereby met a special situation, a large area with rivers and lakes without fish. This article discusses when the practice of transporting 
fish and the cultivation of the watercourses started. The vantage points are archaeological material from sites in the mountain areas as well as the knowledge of the importance and complexity of Scandinavian Stone Age fishing in general.

The article discusses the possibility of using the location of Stone Age sites to approach the question of early fishing and the context and age of burned fish bones found along the shores of two of the main watercourses in the southern Norwegian inland.

The article emphasizes the many source-critical aspects related to the material but concludes that the mountain fishing most likely started in the Stone Age (before $1700 \mathrm{BC}$ ) and maybe already in the last part of the Mesolithic (before 3800 BC). It is also argued that the transportation of fish to mountain lakes and rivers made it possible to base the existence on a wider specter of activities, and combine unpredictable activities like big game hunting with more predictable net fishing. 
DE FØRSTE FISKERNE I FJELLET 


\title{
FISKEN I FJELLET I FORTID OG NÅTID. HVA KAN DNA-ANALYSER FORTELLE?
}

\author{
Jan Heggenes, Høgskolen i Sørøst-Norge
}

\section{INNLEDNING}

Forskning på «arvestoff» begynte i 1860-årene, men DNA (DeoxyriboNucleic Acid) ble først oppdaget for vel 60 år siden. ${ }^{1}$ Deretter har analysemetoder og kunnskap om DNA akselerert, særlig de siste tiårene, og det kulminerte i manges øyne med den fullstendige kartleggingen av menneskets DNA i àr 2000. ${ }^{2}$ Enklere, mer automatiserte, billigere og mer presise analysemetoder gjør at vi stadig anvender og henter mer kunnskap fra DNA om ulike organismer og deres utvikling, både i fortid og i nåtid. ${ }^{3}$ Kan DNA også fortelle oss noe om fisken i fjellet - hvor den kom fra, når den kom, og hvordan? Ja, men da må vi først kjenne litt til det i noen henseender særegne genetiske «univers», forstå noen grunnleggende begreper i økologisk genetikk og vite litt om genetiske markører. Så kan vi nøste opp kunnskap om hvor fisken i det sørnorske fjellet opprinnelig kom fra (fylogeografiske studier), og sannsynligvis også hvor og hvordan den kom seg til fjells i vår nære fortid og i vår egen tid (populasjonsstudier). Det er også interessant å se på i hvilken grad vi kan bruke DNA-analyser til å spore mer moderne menneskelige inngrep, for eksempel utsettinger og vassdragsreguleringer.

\section{DET SÆREGNE GENETISKE UNIVERSET}

Det genetiske «univers» kan være noe litt for seg selv. Vi mennesker tenker gjerne rom og tid slik vi opplever dette i våre umiddelbare omgivelser. Slik er ikke tid og avstand i genetikken. Likhet i utseende og økologisk funksjon, det vil si samspill med andre organismer og miljø i sanntid, gjenspeiles ikke nødvendigvis så direkte $i$ genetisk likhet og mengde. Tilsynelatende store forskjeller mellom mennesker i ulike deler av verden skriver seg bare fra mindre enn 1 prosent genetiske ulikheter, mens vi har mer enn 99 prosent av vårt DNA felles, det vil si det å være «menneske» (fig. 1). ${ }^{4} \mathrm{Og}$ av dette er kanskje 97 prosent det som vi inntil videre kaller «ikke-kodende DNA», det vil si at vi egentlig ikke vet om eller hva det brukes til. Slike tall kan variere litt i litteraturen, blant annet avhengig av hva slags genetiske markører som er brukt, hva slags genetiske avstander som er beregnet, og hvordan, men størrelsesordenen er den samme. Vi skal senere utdype disse begrepene. Og selv om det er en betydelig funksjonell forskjell mellom en sjimpanse som skreller og spiser en banan, og et menneske som spiller Chopin på klaver, har de 98 prosent av sitt DNA felles. Dette forklares ved at det meste av vårt 
DNA brukes til å kode for grunnleggende former og prosesser ved det å være en levende organisme. Derfor har mennesket også ca. 90 prosent av sitt DNA til felles med mus og 60 prosent til felles med en bananflue (fig. 1). Rart, kan hende, men tenker vi oss om, så har for eksempel de store forskjeller i arkitektoniske bygningsuttrykk også det meste grunnleggende felles; de består som regel av gulv, vegger og tak. Det er heller ikke slik at mengde DNA nødvendigvis er et uttrykk for hvor avansert en organisme er. Laks kan ha dobbelt så mange gener som mennesket og salamander kanskje fem ganger så mange. ${ }^{5} \mathrm{Vi} \mathrm{må} \mathrm{derfor} \mathrm{forsøke} \mathrm{å} \mathrm{legge} \mathrm{vår}$ mer intuitive forståelse av tid, avstand og likhet litt til side når vi studerer genetikk.

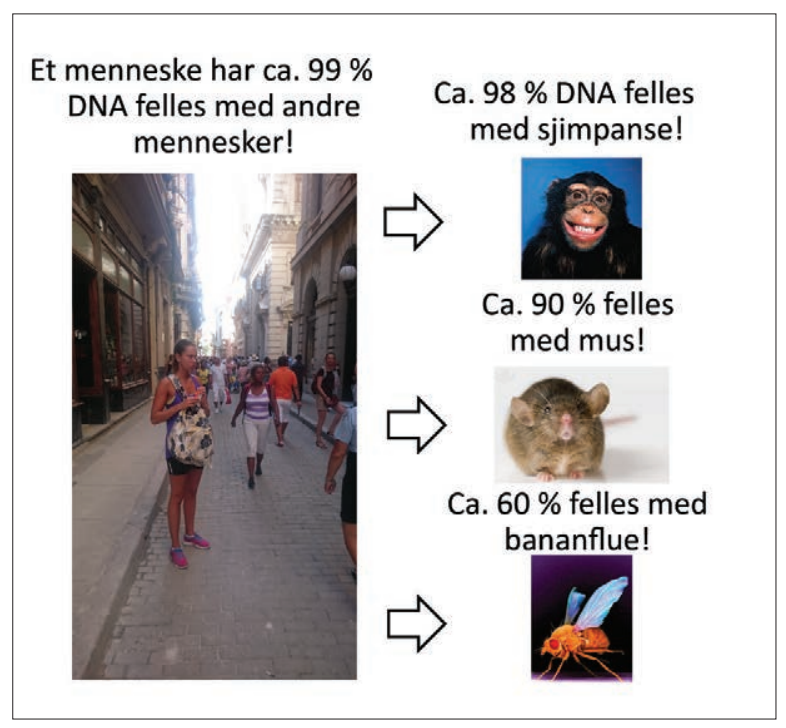

Figur 1: Det genetiske univers kan være en virkelighet litt for seg selv. Det kan tilsynelatende være liten intuitiv sammenheng mellom hvor like eller ulike to organismer er, hvilken økologisk funksjon de har, og hvor mye DNA de har felles.

\section{ØKOLOGISK GENETIKK}

I økologisk genetikk undersøker vi betydningen av arv i forhold til miljø for variasjonen mellom individer i forskjellige bestander (= populasjoner). I våre fjell er ørret (Salmo trutta) langt den vanligste og mest utbredte fisken. Det er også en svært variabel og mye studert art med hensyn til både arv og miljø. ${ }^{6}$ Endring i forekomst av karaktertrekk over tid er knyttet til to forhold: økologiske faktorer og naturlig seleksjon. Naturlig seleksjon bestemmer genotypen, det vil si det fulle sett av gener eller arv. Fenotypen er slik fisken faktisk er og ser ut, det fulle sett av morfologiske, fysiologiske, biokjemiske og atferdsmessige trekk. Fenotypen er summen av arv og miljø. Hvordan kan vi så skille genetiske fra miljømessige effekter, og i hvilken grad er fenotypen uttrykk for genotypen? Som vi så over, kan det være til dels liten sammenheng mellom genetiske og ytre morfologiske forskjeller. Det er velkjent at det kan være mye variasjon i ytre kjennetegn hos ørret, for eksempel i farge og prikker, og i atferd, for eksempel i hvorvidt de er stasjonære eller vandrende. Ørret er en fenotypisk sett plastisk art (fig. 2), ${ }^{7}$ og siden 1758 er det derfor beskrevet ca. 50 «arter» av ørret. ${ }^{8}$ Et grunnleggende viktig økologisk spørsmål blir derfor: Skyldes denne variasjonen arv eller miljø eller kanskje begge deler? Svaret er ofte at forskjellene skyldes miljømessige påvirkninger mer enn arv. Men selve denne evnen til fenotypisk plastisitet som ørreten har, er i seg selv ofte en genetisk regulert evne. ${ }^{9} \mathrm{Vi}$ mennesker er jo også i så måte en tilpasningsdyktig art.

I økologisk genetikk prøver vi å få mønster i dette puslespillet mellom arv og miljø. Vi leter etter mønster i arters, populasjoners og individers struktur og fordeling $\mathrm{i}$ tid og rom. Til det trenger vi genetiske (molekylære) markører som ikke påvirkes eller kompliseres av miljømessige faktorer, og som heller ikke påvirkes (for mye) av naturlig seleksjon, det vil si er stabile over generasjoner. Slike genetiske markører finner vi derfor fortrinnsvis i de deler av DNA-et som er nøytrale (for seleksjon), og 


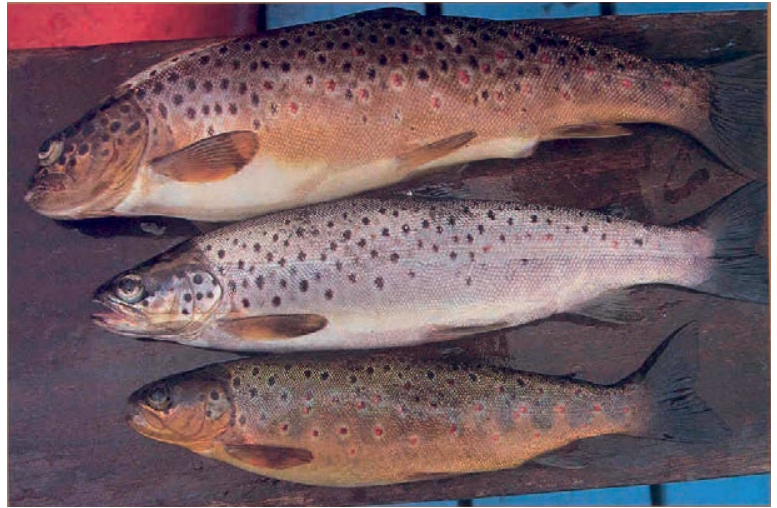

Figur 2: Ørret er en plastisk art med mye fenotypisk variasjon. Her er tre ulike typer ørret i Lough Melvin i NordIrland. Typene er også genetisk undersøkt. ${ }^{10}$ Bilde hentet fra www.flyfishing.co.uk. ${ }^{11}$

med utgangspunkt i dem kan vi lete etter mønster og dermed etter populasjonsstruktur og historie (fylogeografi). ${ }^{12}$ Forutsetningen er da at mutasjoner er eneste kilde til ny genetisk variasjon. Slike genetiske (molekylære) markører «måler» derfor antall mutasjoner over tid. Ulike markører i ulike deler av DNA-et egner seg til å estimere dette med ulik tidsoppløsning, fra mutasjoner som kan måles over én eller noen få generasjoner, til markører som måler så lange tidsrom som hundretusener av år. ${ }^{13}$

\section{GENETISKE MARKØRER}

Genetiske (molekylære) markører er (svært) små biter av DNA på en bestemt plass på DNA-tråden (= locus). De har mange alternative varianter, alleler, og er lette å identifisere (fig. 3). Markører som ikke eller bare i liten grad påvirkes av seleksjon, er mest brukt for å undersøke populasjoner i nåtid og nær fortid fordi de viser mer variasjon enn selekterte markører. Andre typer genetiske markører brukes for å undersøke historiske prosesser (nedenfor).

$\mathrm{Vi}$ antar at disse bitene er representative for nedarvingen av DNA. I 1988 revolusjonerte oppdagelsen

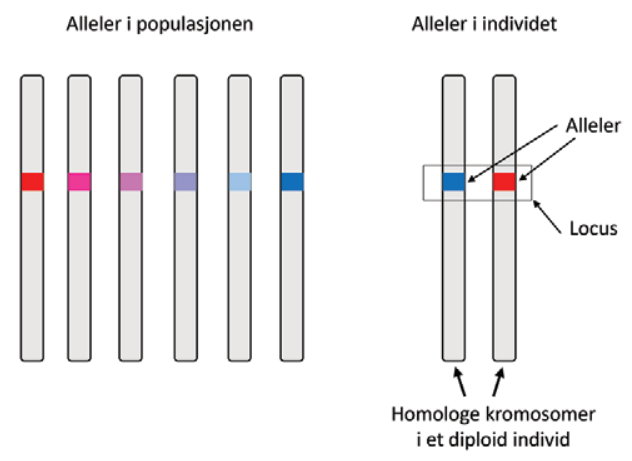

Figur 3: Genetiske markører er små biter av DNA på en bestemt plass på DNA-tråden (locus), og «gode» markører har mange alternative varianter (alleler) i populasjonen. Ved kjønnet formering får et individ ett kromosom (DNA-tråd) med ett allel fra mor og ett fra far (homologe kromosomer, alleler).

av PCR (Polymerase Chain Reaction) genetiske analyser ved at det ble lett å «oppformere» utvalgte biter av DNA for videre analyser. ${ }^{14}$ Etter dette har et forvirrende stort antall av ulike typer genetiske markører blitt brukt i genetiske studier. ${ }^{15}$ I vår sammenheng med ørret og fjellfiske trenger vi å kjenne til to typer, men disse er også de vanligst brukte: mitokondrielt DNA (mtDNA), som er molekylære markører for de lange tidsrom (fylogeografiske studier, tusener av år), og mikrosatellitt-DNA, som er markører for nåtid og vår nære fortid (populasjonsstudier).

Mitokondrier er selvstendige strukturer inne i cellene, og de er cellenes energiprodusenter. De har sitt eget lille DNA; for eksempel koder humant mtDNA for 13 gener, mye knyttet til energiomsetning. Mitokondrier nedarves kun via eggcellen, det vil si i rene morlinjer. Sædceller har også mitokondrier med DNA, men de ødelegges ved befruktningen. Derfor påvirkes mtDNA ikke av rekombinasjon, men bare av mutasjoner. Siden mutasjonsrater ofte er 1-2 prosent per million år, fungerer de som 


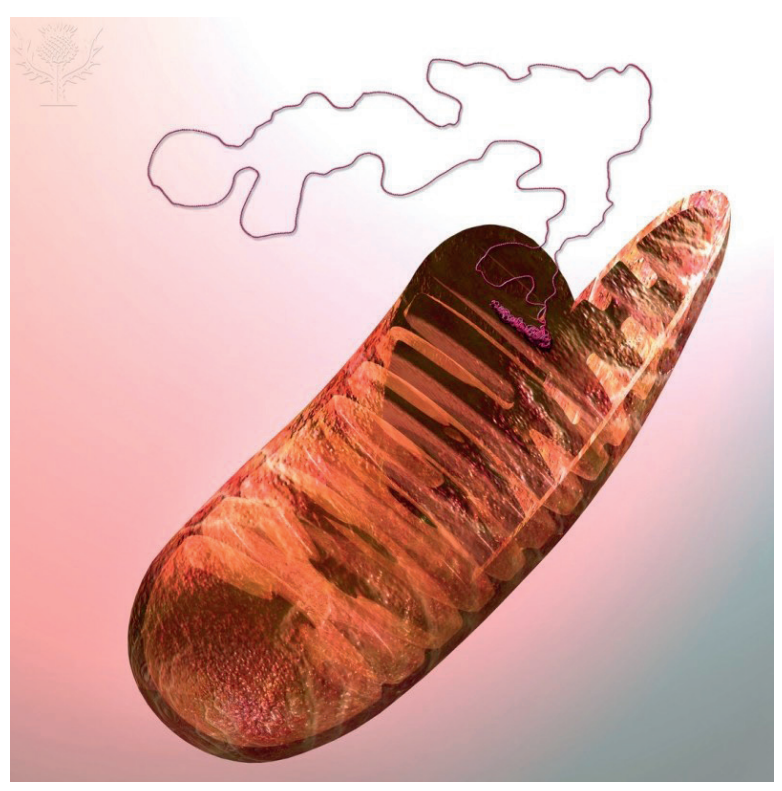

Figur 4: Mitokondrier er selvstendige strukturer inne i en celle. Deres viktigste oppgave er å produsere energi for cellen. Mitokondrier har sitt eget DNA (mtDNA), som nedarves bare via eggceller. De påvirkes derfor bare av mutasjoner. Ettersom mutasjonsrater ofte er lave og stabile (1-2 prosent per million år), kan mtDNA fungere som evolusjonære «klokker» og vise viktige historiske endringer hos arter og populasjoner. Illustrasjon fra quest.eb.com ${ }^{17}$. langtidsmarkører og er derfor velegnet til fylogeografiske studier. For eksempel baserer «Out of Africa»-hypotesen om det moderne menneskets opprinnelse og spredning seg på studier av mtDNA. ${ }^{16}$

Mikrosatellitt-DNA er derimot korte DNAbiter fra ikke-kodende deler av cellekjerne-DNA-et. Mikrosatellitter består av tandemrepeterte DNAsekvenser ( $2-6$ basepar), det vil si at en sekvens er repetert flere ganger etter hverandre, for eksempel -CACACACACA- (fig. 5). Disse muterer mye lettere enn vanlig DNA (100-10 000 ganger) i form av at antall repetisjoner endrer seg (lengdepolymorfisme). Det blir derfor mange alleler (fig. 5). Mikrosatellitter har derfor stor følsomhet og er mye brukt i populasjonsstudier over nåtid og nær fortid. ${ }^{18}$

\section{HVOR KOMMER ØRRETEN FRA?}

Det er gjort omfattende undersøkelser av mitokondrielt DNA hos ørret. ${ }^{19}$ Innenfor det naturlige utbredelsesområdet til ørret $\mathrm{i}$ Eurasia og Nord-Afrika finner vi fem evolusjonære morlinjer (mtDNA-haplotyper; fig. 6): «vår» atlantiske ørret, som hører hjemme i elver og vann i Vest-Europa (AT), en

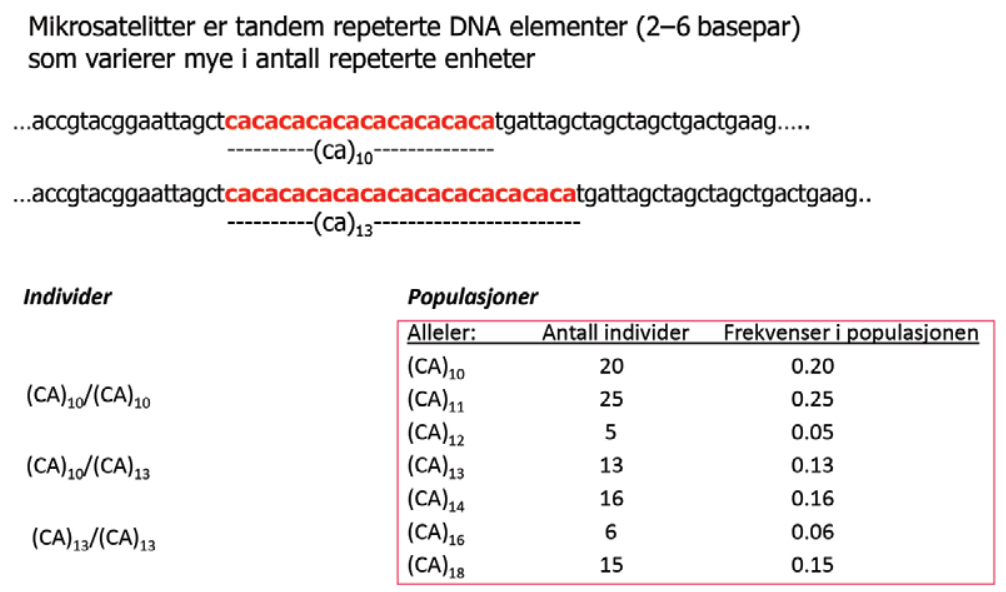

Figur 5: Mikrosatellitter er korte DNA-sekvenser (2-6 basepar) som er repetert i tandem. Ettersom antall repetisjoner lett muterer, blir det mange alleler som er karakterisert ved ulikt antall repetisjoner. Dette gir mikrosatellittbaserte analyser stor følsomhet. 


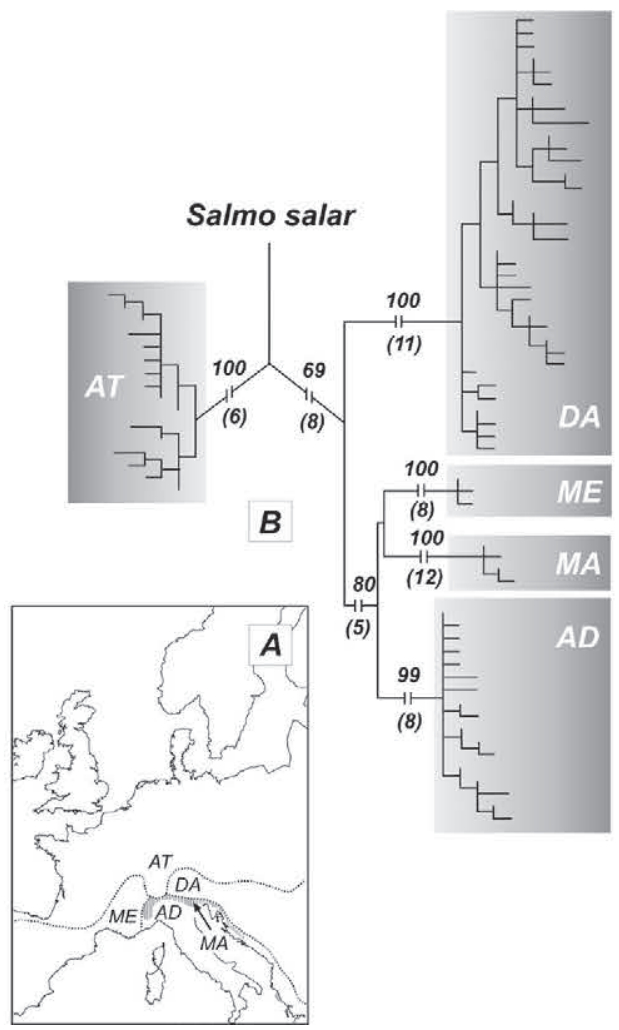

- Fem evolusjonære morlinjer: AT $=$ Atlantisk DA = Danubisk $\mathrm{ME}=$ Mediterranean MA = Marmoratus $A D=$ Adriatisk

- Fra fragmentering under istidene $0.5-2$ mill. år siden (særlig 0.7 mill. år siden)

Figur 6: Det er til nå indentifisert fem evolusjonære morlinjer (mtDNA-haplotyper) hos ørret: en atlantiske ørret (AT), som hører hjemme i elver og vann i Vest-Europa, en danubisk (DB) og en knyttet til Middelhavet (ME), som har to underlinjer, marmorørret (MA) og adriatisk ørret (AD). Morlinjene oppsto for 0,5 til 2 millioner år siden da ørretbestanden ble delt opp og isolert av isbarrierer. Bearbeidet etter Bernatchez mfl. ${ }^{20}$

danubisk (DB) og en knyttet til Middelhavet (ME), som har to særegne underlinjer, marmorørret (MA) og adriatisk ørret (AD). Disse linjene oppsto for 0,5 til 2 millioner år siden under de siste istidene, da ørretbestandene ble delt opp og isolert i forskjellige områder av isbarrierer.

Nærmere undersøkelser av den atlantiske morlinjen indikerer at «vår» ørret overlevde et tidligere istidsmaksimum for ca.230-190 000 år siden i noen isfrie elver og områder i Sør-Frankrike. Deretter spredte ørreten seg nordover som sjøørret til Skandinavia etter hvert som isen smeltet, og den består i dag av begge de to genetiske undervarianter, eller clades (fig. 7), som også fantes i Sør-Frankrike. Dette er relativt krevende analyser, så det er ikke mer enn en håndfull norske bestander som er undersøkt genetisk på denne måten (Cortey mfl.2009). Men en av de undersøkte bestandene som viser slikt slektskap, er fjellørret fra Bjornes på Hardangervidda. ${ }^{21}$ Denne bærer i seg DNA som viser at vår fjellørret antagelig opprinnelig kommer fra elver i Sør-Frankrike for ca. 200000 år siden. 


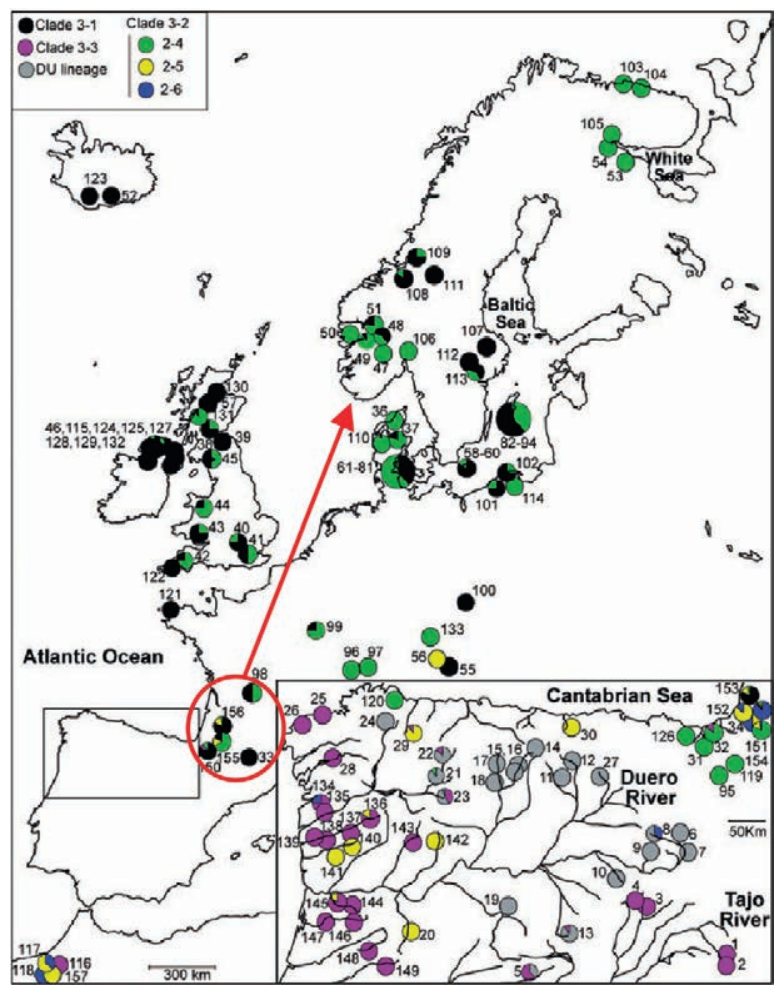

Figur 7: Ørret overlevde en stor istid for ca. 200000 år siden i elver i Sør-Frankrike. Etter hvert som isen smeltet, koloniserte ørret områder nordover i Europa, og til slutt Skandinavia. Etter Cortey mfl. ${ }^{22}$

\section{NÅR OG HVORDAN KOM ØRRETEN OPP I FJELLET?}

For undersøkelser av ørretens sannsynlige vandringsveier i vår nære fortid må vi støtte oss på populasjonsundersøkelser via mikrosatellitt-DNA. Det er ennå ikke gjort omfattende undersøkelser av dette på mange ørretbestander i fjellområdene i Norge, så her ligger det et stort forskningspotensial. Mest kunnskaper har vi om populasjonsgenetikken til ørreten på Hardangervidda, vårt klart største sammenhengende fjellområde i Sør-Norge, som har tre hovedvannområder: Lågen og Kvenna i øst og Eidfjord i vest (fig. 8). ${ }^{23}$ Ørreten vandret inn i
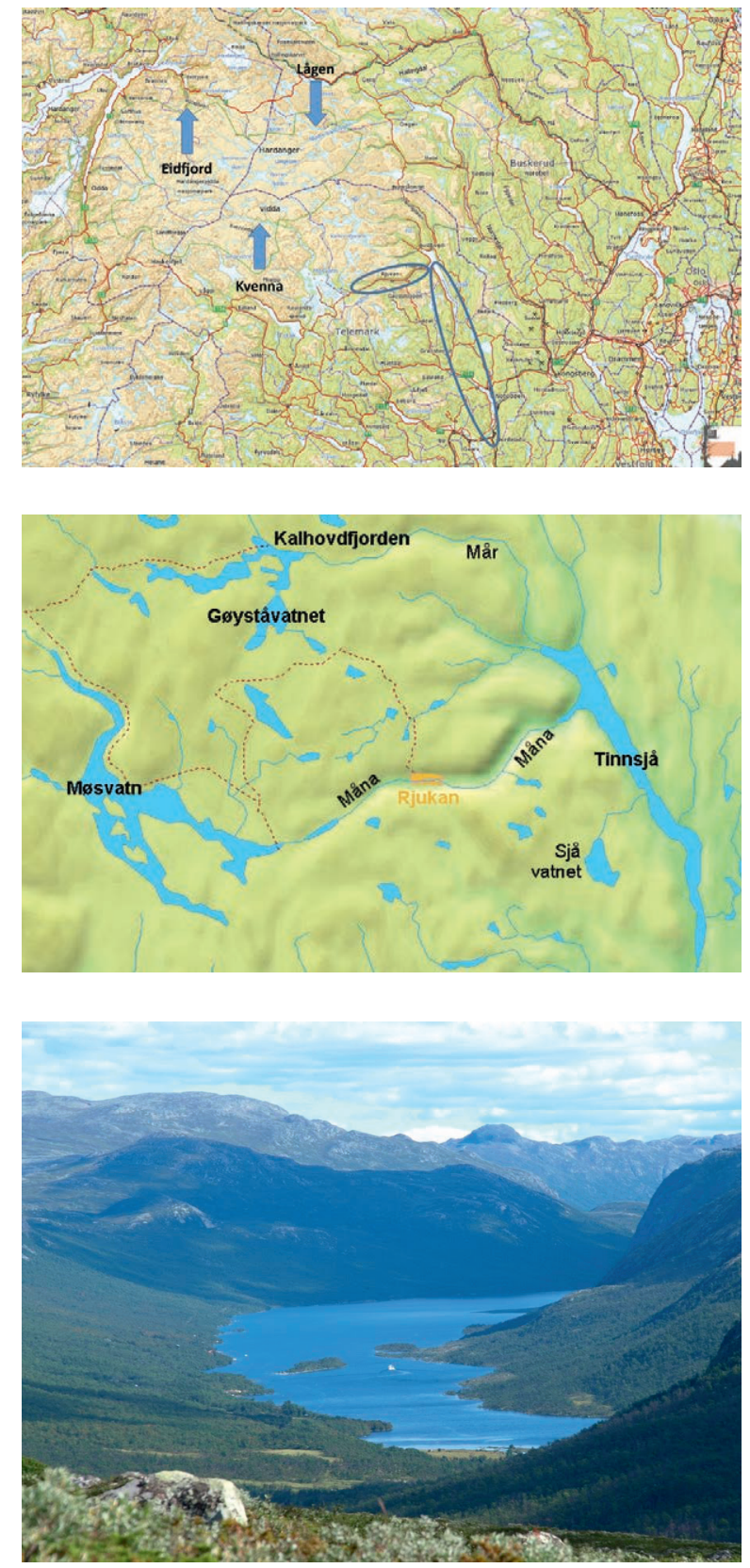

Figur 8: Kart over Hardangervidda (øverst) med de tre hovedvannområdene Lågen og Kvenna i øst og Eidfjord i vest. Nedre del av Kvenna (i midten) var etter siste istid antagelig enkleste vannvei for ørret inn fra havet (innringet på kartet øverst). Hovedbassenget i Kvenna er Møsvatn (nederst). 


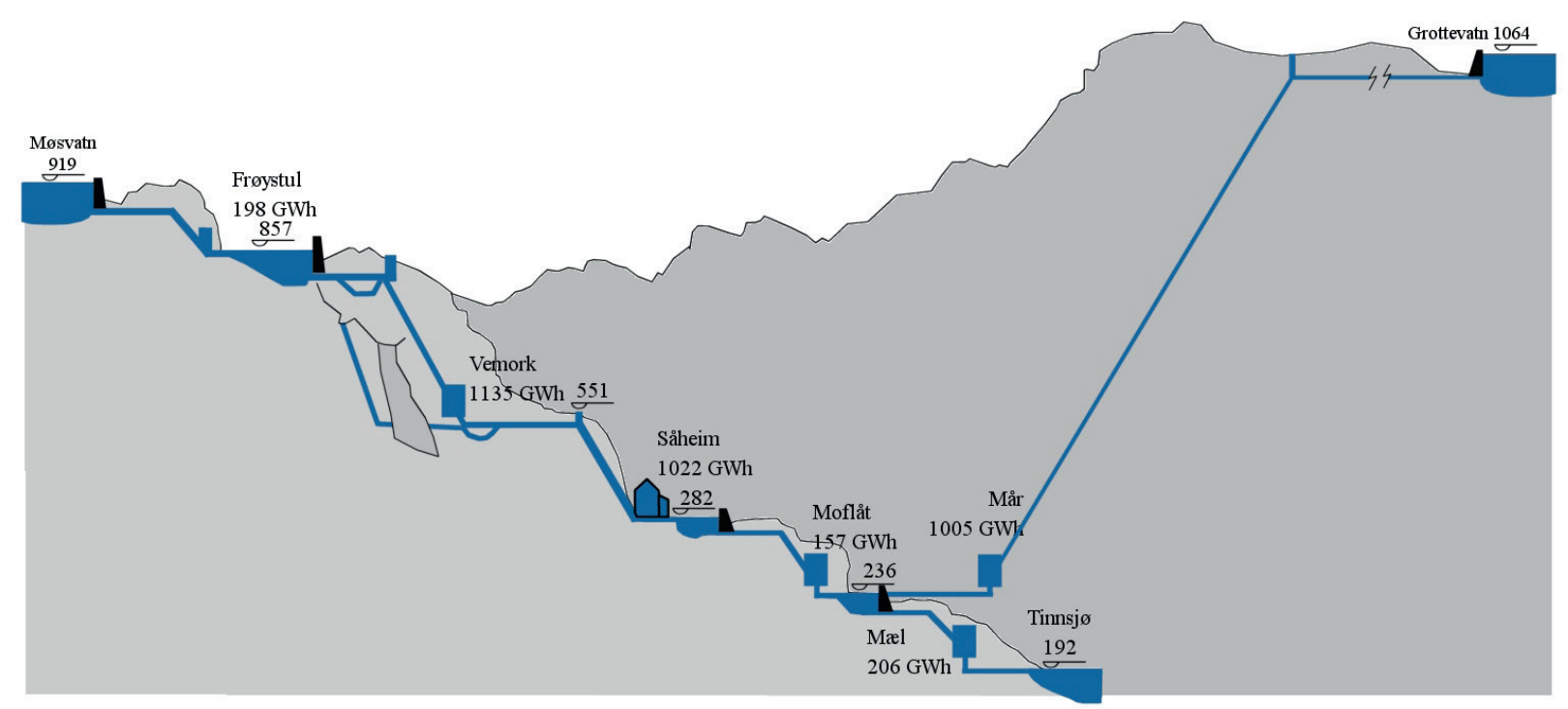

Figur 9: Skjematisk oversikt over Måna elv fra Møsvatn på Hardangervidda og ned til Tinnsjø, hvor ørret vandret inn naturlig. Rjukanfossen var det store vandringshinder. Omfattende reguleringer på 1900-tallet har nå påvirket vassdraget sterkt og vanskeliggjort naturlige vandringer. Stasjoner i Måna hvor ørreten er undersøkt genetisk («Måna-1-6») korresponderer med navn i figur 10.

Norge via vannveiene etter siste istid. Den kunne da naturlig komme tett opp mot Hardangervidda, særlig via den østlige gren av Telemarksvassdraget $\mathrm{og}$ via Lågen. Men i Lågen var det tidlig flere fosser, og på vestsiden av vidda går fjellet nesten rett $\mathrm{i}$ havet. Telemarksvassdraget med Tinnelva, Tinnsjø og Måna representerer den enkleste vannvei opp i fjellet (fig. 8).

Vi ser ut fra analyser av DNA at ørret trolig har vandret inn i Telemarksvassdraget ved egen hjelp, først til Tinnsjøen og opp i Måna elv helt til Rjukanfossen oppunder Hardangervidda (fig. 8, 9) ${ }^{24}$ Ørreten i Tinnsjø har en variant av et spesielt gen $\left(L D H-C^{*} 100\right)$ som er en markør for fisk som vandret tidlig inn etter siste istid, antagelig ca. 8000-9000 år f.Kr. I alle fall regner vi med at hoveddelen av innlandsisen var avsmeltet før $8000 \mathrm{f} . K r .{ }^{25} \mathrm{Ved}$ å sette opp et slektskapstre (fig. 10) ser vi at ørreten i Måna elv klart kommer fra
Tinnsjø, selv om de omfattende reguleringsinngrepene i Måna i nyere tid også har påvirket ørretens genetiske struktur gjennom bygging av dammer som fungerer som (delvise) vandringshinder (fig. 9, 10). Det er videre gjort mikrosatellittanalyser av DNA-et til ørreten i Møsvatn oppe på selve Hardangervidde-platået (fig. $8,10)$. Disse viser også nært slektskap med ørret i Måna, og den er opprinnelig den samme ørreten som i Tinnsjø (fig. 8, 10). Vi finner for eksempel flere stedegne genvarianter i Tinnsjø som vi også finner igjen i Møsvatn. Derimot er det ikke funnet egne genvarianter av ørret i Møsvatn som kunne skille den fra den i Tinnsjø. Dette vil være en konsekvens av at ørreten har blitt flyttet videre oppover i vassdraget. ${ }^{26}$ Fra Møsvatn kan ørreten lett ha blitt spredt videre innover Hardangervidda, særlig langs hovedvassdraget Kvenna (fig. 8). Men hvordan kom ørreten seg opp på fjellet? Selv om det her var kortest 


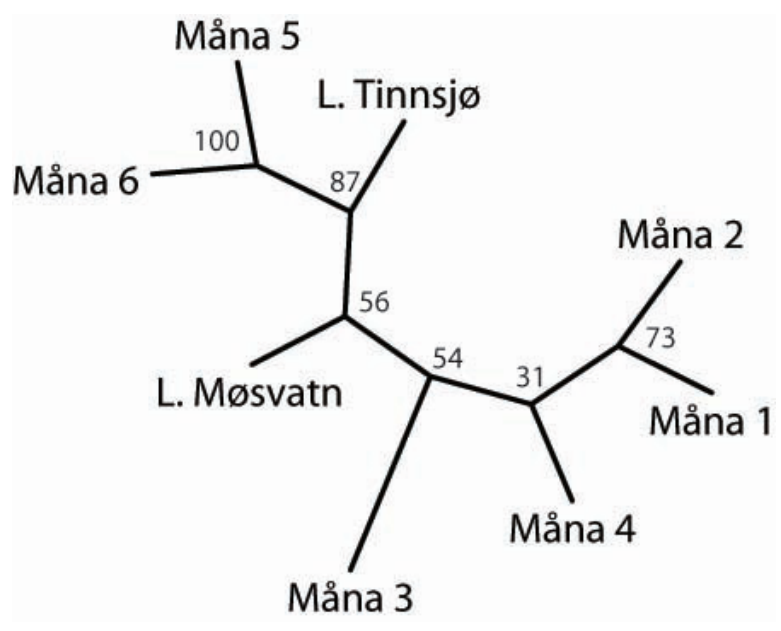

Figur 10: Genetisk slektskapstre for ørret i Tinnsjø, Måna og Møsvatn. Ørreten vandret naturlig inn i Tinnsjø og Måna, men ble så stoppet av Rjukanfossen. Likevel viser analysene at ørreten i Møsvatn kommer fra Måna/Tinnsjø. Ørreten må ha blitt båret opp av mennesker, sannsynligvis i tidlig steinalder. Navn i Måna korresponderer med stasjoner i Måna hvor ørreten er undersøkt genetisk (figur 9, «Måna-1-6»).

mulig vei geografisk sett, var den eneste barrieren, Rjukanfossen, umulig å passere naturlig. Ørreten må derfor ha blitt båret opp av mennesker, noe som var lett med de korte avstandene. Arkeologiske funn kan indikere at dette har skjedd i steinalderen. Vi vet fra arkeologisk materiale at steinaldermennesker var på villreinjakt på Hardangervidda allerede for 10000 år siden, ${ }^{27}$ og kanskje til og med før det. Det er også funnet ørretbein på slike boplasser. Å styrke næringsgrunnlaget ved å bære opp ørret til de mange tomme vann på Hardangervidda var nærliggende, særlig om høsten, når ørret var på gyting i elver og bekker og dermed lett å fange.

Selv om dette er best dokumentert for Telemarksvassdraget og Kvenna, kan det nok hende at ørreten også har kommet seg opp på Hardangervidda på lignende vis via de andre hovedvannveiene, Lågen og Eidfjord, som hadde enda større naturlige hindringer i form av fossefall. Undersøkelser av mikrosatellitt-DNA tyder i hvert fall på at ørreten på Hardangervidda i hovedsak genetisk sett er forskjellig mellom disse tre hovedvannområdene (fig. 8). ${ }^{28}$

\section{HVA KAN DNA FORTELLE OSS OM UTSETTINGER AV ØRRET I FJELLET?}

$\mathrm{Vi}$ ser at ved at vi legger sammen puslespillbiter, kan DNA vise oss hvor ørreten kom fra i et langt tidsperspektiv, og hvordan og hvorfra den kom seg opp i fjellet med menneskets hjelp. Her ligger en stort videre forskningspotensial i årene som kommer, blant annet fordi vi nå via bedre metoder kan ekstrahere DNA fra arkeologisk materiale, for eksempel fiskebein, og dermed rekonstruere innvandringsveier mer i detalj.

Vi kan også bruke DNA til å spore vår egen tids påvirkninger fra mennesket. Det er allment kjent at det har vært mange utsettinger og flytting av ørret i nyere tid. Historien til, og effekter av, slike utsettinger kan vi også spore ved hjelp av DNAanalyser. En viktig grunn til at disse undersøkelsene av mikrosatellitt-DNA-et til ørret er gjennomført, er at man ville undersøke om utsettinger, særlig utsettingspålegg i forbindelse med vassdragsreguleringer, har hatt noen virkninger. Dersom det er brukt ikke-stedegen fisk til utsettinger, noe som har vært vanlig praksis inntil nylig, vil disse ha en egen mikrosatellitt-DNA-signatur som er lett å skille fra den opprinnelige, stedegne ørreten. I Tinnsjø ble det for eksempel årlig i mer enn 30 år satt ut ca. 50000 ørreter av stammen fra Tunhovd (og Slidre). Dette antall utsatt fisk er i omtrent samme størrelsesorden som total beregnet naturlig rekruttering. Likevel var det svært få genetiske spor å finne av denne utsatte ørreten, som rett og slett ikke syntes å bidra til gytingen til tross for store og langvarige 


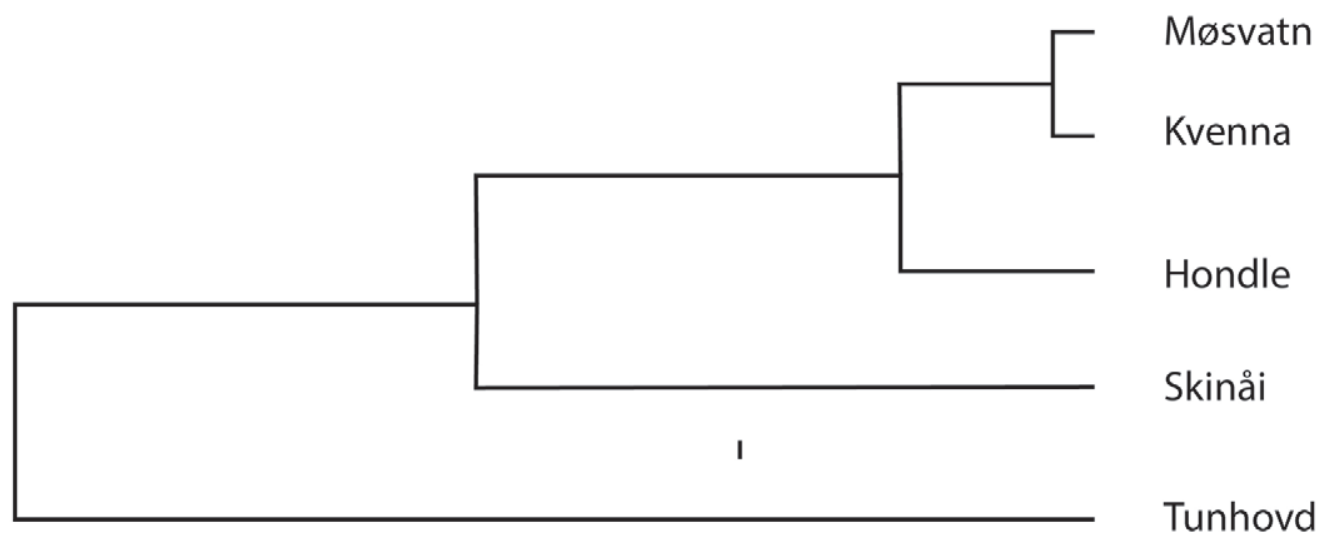

\begin{tabular}{|l|l|l|l|}
\hline 0,12 & 0,08 & 0,04 & 0,00
\end{tabular}

Genetisk avstand

Figur 11: Genetisk slektskapstre og genetiske avstander for naturlig og utsatt ørret i Møsvatn. Tunhovd-ørret ble systematisk satt ut i Møsvatn i over 30 år (siden 1959), men synes ikke å ha påvirket de naturlige genetiske populasjonene vesentlig.

utsettinger. ${ }^{29}$ Tilsvarende har det i Møsvatn blitt satt ut 3500 ensomrige og 700 tosomrige ørreter siden 1959, i all hovedsak Tunhovd-ørret, uten at dette har hatt vesentlig genetisk effekt. ${ }^{30} \varnothing$ rreten i Møsvatn er fremdeles i all hovedsak rekruttert naturlig via de tre elvene inn i Møsvatn, og ørreten har her hver sin genetiske signatur (fig. 11). Spredte og mindre systematiske utsettinger forstår vi da intuitivt kanskje ofte kan ha enda mindre genetisk effekt. ${ }^{31}$ Men motsatt har også utsettinger på Hardangervidda stedvis ført til genetisk innblanding av «fremmed» ørret (introgresjon) ${ }^{32}$ og har også resultert i at ørretbestander enkelte steder på Hardangervidda har endret karakter helt. ${ }^{33}$

Det blir naturligvis fort et svært komplisert puslespill når det blir utsatt ulike typer ørret i ulike mengder og til ulike tider. Men vi finner så langt ikke noe entydig svar på om og i hvilken grad utsatt ørret etablerer seg og tilpasser seg, og om den blander seg med eventuelt tidligere utsatt eller naturlig ørret. Dette synes å være et svært sammensatt bilde, hvor svarene avhenger av de lokale forhold. ${ }^{34}$ DNA kombinert med skriftlige og eventuelt muntlige kilder er her de redskapene vi kan bruke for å 
rekonstruere utsettingshistorier, og DNA gir oss uansett dagens tilstand.

På lignende måte kan vi også bruke DNA til å spore mulige effekter av fragmentering og isolasjon gjennom for eksempel reguleringsinngrep og bygging av vandringsbarrierer som dammer i moderne tid. Dette var hovedmålet med undersøkelsene i Måna elv, hvor det er bygget dammer til ulike tider (1906-1957) nedover i elva (fig. 9). ${ }^{35}$ Her viste det seg at de nyere dammene i den nedre delen av elva hadde hatt liten innvirkning på den genetiske strukturen. Derimot skilte ørret i den øvre delen av Måna, som ble først fragmentert og isolert i 1906, rett nedstrøms fra Møsvatn, seg fra resten av ørreten (fig. 9, 10). I løpet av ca. 100 år hadde derfor denne bestanden endret seg vesentlig genetisk sett. Dette skyldtes antagelig en liten gytebestand og dermed tilfeldige genetiske endringer, noe som kalles genetisk drift.

Utgangspunktet vårt var: Hva kan DNA-analyser fortelle oss om fisken i fjellet? Som vi har sett, kan DNA fortelle oss mye. Det er et relativt nytt og kraftfullt verktøy i vitenskapens tjeneste. Det vil bli stadig mer brukt i årene som kommer, særlig nå når teknikkene har blitt enklere og rimeligere, selv om det fremdeles er krevende analyser. Så langt vet vi på grunn av undersøkelser av mitokondrielt DNA at vår «norske» ørret kom fra elver i SørFrankrike for ca. 200000 år siden. Vi kan spore innvandringsveier fra kysten og innover i landet ved å kombinere geografi, arkeologi, historie - og nå også Mikrosatellitt-DNA. Hver ørretbestand har sin egen DNA-signatur som vi kan analysere. Vi kan derfor også spore nyere tids påvirkninger, for eksempel i form av flyttinger og utsettinger, eller effekter av naturlige og kunstige barrierer og lignende inngrep. Vi vil i økende grad bruke DNA som grunnlag for forvaltningsstrategier og som responsvariabel i konsekvensanalyser. Med mer kunnskap vil det også komme flere anvendelsesområder.

\section{SUMMARY}

What can DNA analysis tell us about fish in alpine areas? Brown trout (Salmo trutta) is the most common and widespread freshwater fish species in alpine areas in Norway. Brown trout is also one of the most widely studied vertebrates within evolutionary and ecological genetics, i.e., genetics that is concerned with the relative importance of genotypic and phenotypic variation between individuals and populations in space and time. Genetic markers and the discovery of the Polymerase Chain Reaction in 1988 (PCR, which replicates targeted DNA segments) help us study such evolutionary and ecological genetic structures and patterns. Mitochondrial DNA is inherited via the egg cell and is consequently subject to mutation (at a relatively constant rate), but not recombination. Therefore, mtDNA is useful for studying evolutionary genetic changes (thousands of years). Microsatellite DNA, short tandem repeated pieces of nucleus DNA, tends to be genetically variable (many alleles) and is therefore frequently used for (near) present population studies, i.e., genetic changes within recent generations. MtDNA studies of brown trout indicate that there are five maternal lines within the natural distributional area in Eurasia and North Africa. Brown trout that naturally colonized Norway via the sea and fjords as the last glacial period receded (13-11 000 before present) appear to stem from populations surviving in Ice Age refugia in rivers in southern France some 230-190 000 years ago. However, because of natural waterfalls, brown trout were unable to colonize the alpine areas in Norway. Colonization here must have happened by the help of man. Microsatellite DNA tracking studies suggest that in some main alpine areas (Hardangervidda, 
southern Norway), this happened several thousand years ago, probably by Stone Age reindeer hunters. Unfortunately, detailed genetic studies are however lacking for most alpine areas. Moreover, more recent stocking of alpine watersheds tends to complicate analysis and confound results. 


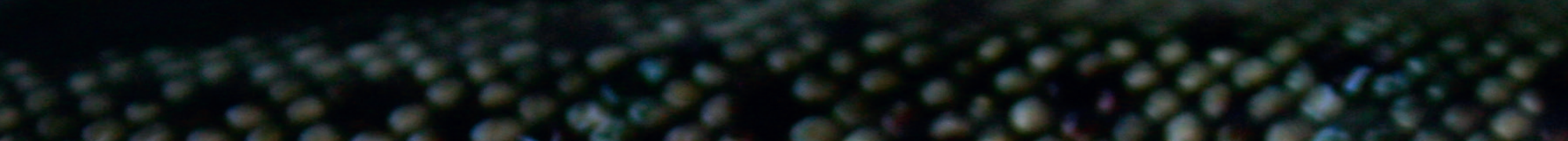

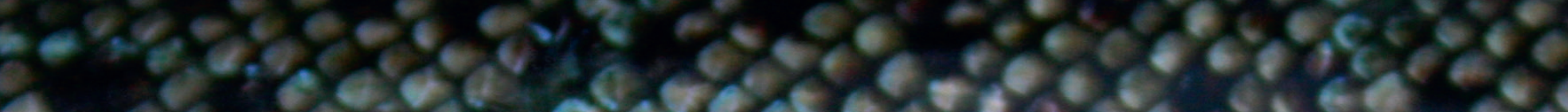

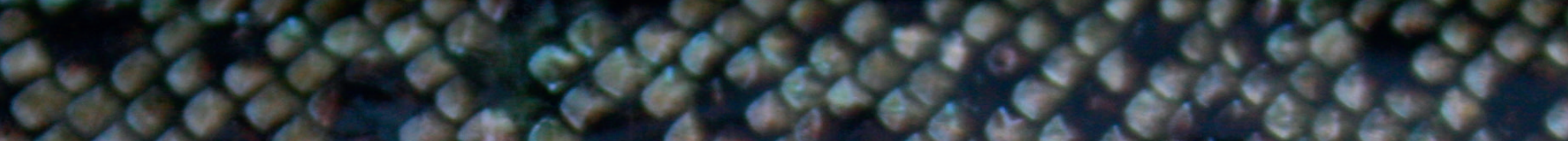

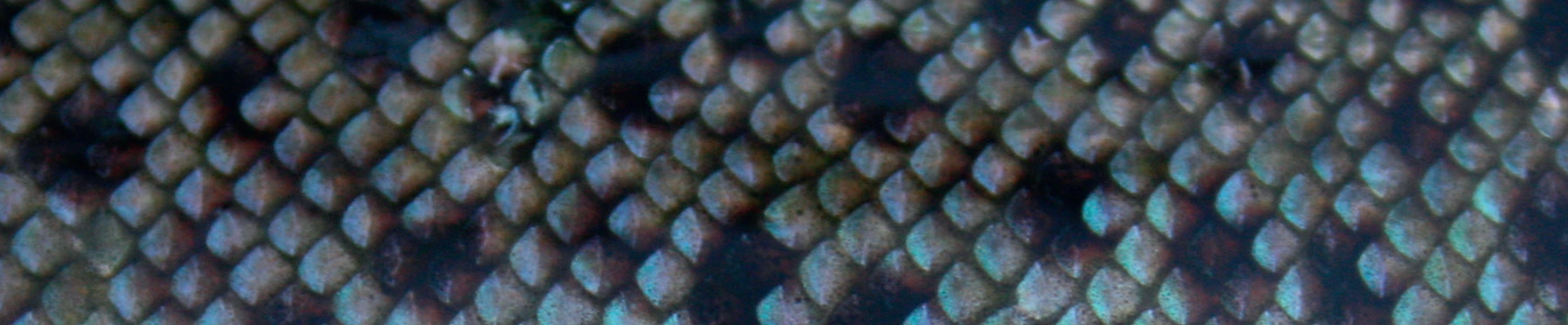
08000808000008

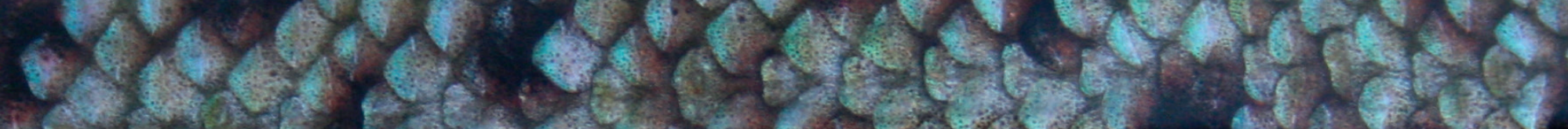

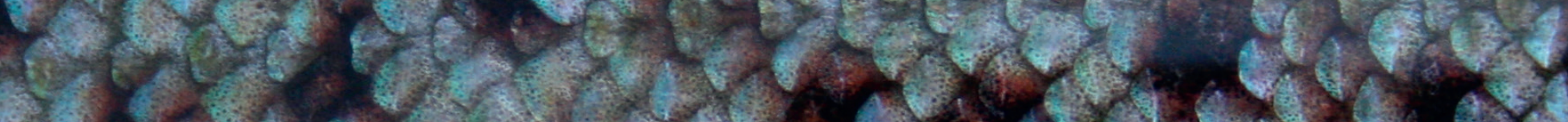
100000000000

100020

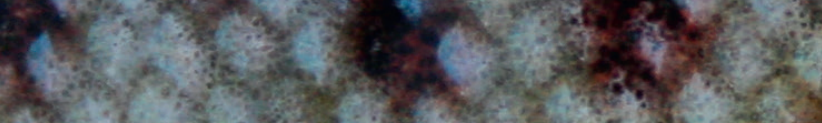

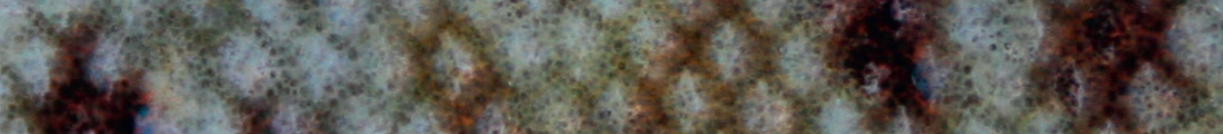
(2)

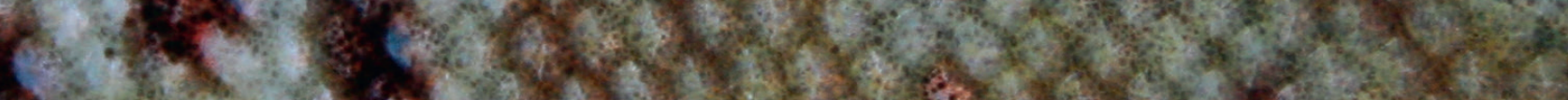

Q

5.

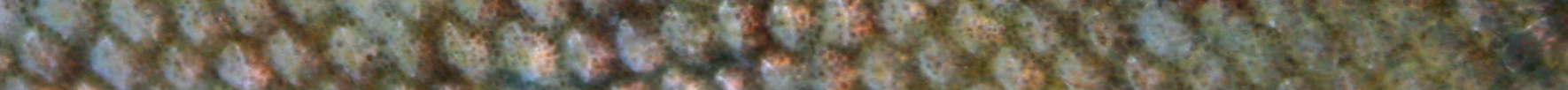

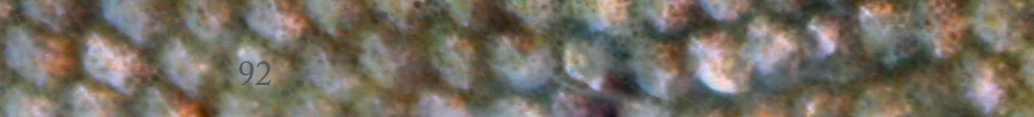

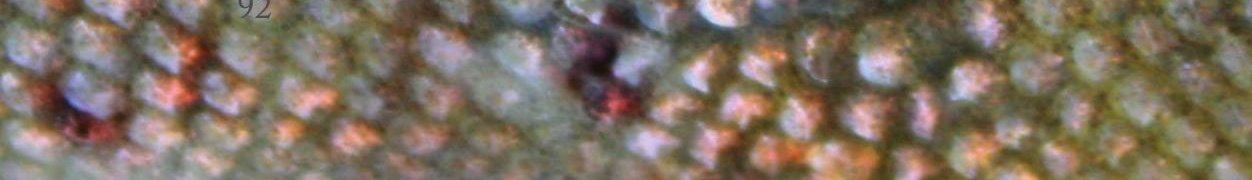




\title{
FISKEMÅTAR I FJELLET I ELDRE TID
}

\author{
Trygve Hesthagen, Norsk institutt for naturforskning, Trondheim og \\ Einar Kleiven, Norsk institutt for vannforskning, Grimstad
}

\section{INNLEIING}

Jakt og fiske var hovudnæringvegane her i landet heilt fram til ca. 2350 f.Kr. ${ }^{1}$ Etter den tid spela husdyrhald, og til ein viss grad åkerbruk, ei vesentleg økonomisk og kulturell rolle. Men framleis vart det drive eit til dels omfattande jakt og fiske. Frå gamalt av var fisket i allmenningsfjella fritt for alle. ${ }^{2}$ Omgrepet allmenning vart i byrjinga nytta om skog og fjell som ikkje var tekne i bruk. ${ }^{3}$ Ifølgje Gulatingslova frå 900-talet, den eldste av landslovene i Noreg, skal ingen øydeleggja for annan manns fiskestad. ${ }^{4}$ For fjellvatna slo Magnus Lagabøters lov frå 1274 fast at alle skulle ha den same retten til fiske $\mathrm{i}$ fjellet. ${ }^{5}$ Men etter kvart vart fiskeretten i fjellvatna ofte lagt til bygder eller bestemte gardar. ${ }^{6}$ Dette hadde truleg mellom anna samanheng med eit auka press på naturressursane etter kvart som folketalet steig. I vikingtid (800-1050 e.Kr.) og middelalder (1050-1500 e.Kr.) slo folk seg ned på stadig nye plassar i høgareliggjande strøk. ${ }^{7}$ Det medførte nok også at fiskeressursane i aukande grad vart utnytta.

Enkelte plassar vart fisket regulert i lottar og uskrivne lover blant sambygdingar eller grupper av folk. Grensegangen i fjellet tyder på at fisket har hatt større verdi enn jakt og fangst. Dette ser vi fordi grensene stort sett følgjer vasskilja. ${ }^{8}$ Eigde du land, hadde du fullt herredøme over vatn, elv og os på eigedomen din. Men det har vore mykje ufred og strid mellom grannar og bygdelag om fiskerettane. Og svært tidleg vart dei gjenstand for kjøp og sal. ${ }^{9}$ Striden kunne i beste fall bli avgjort i retten, men øydelagd reiskap, nedbrende hus og drap høyrer òg med til historia. Dei gamle fiskeria var ofte dei fyrste til å bli eksklusiv eigedom innover kjølar og fjell. ${ }^{10}$ Alt på 1400 -talet kunne det vera klare avgrensingar av kor heimrasten slutta og allmenningen byrja. ${ }^{11}$ Etter kvart såg både kongen og kyrkja seg mon i verdiane som fiskevatn og fiskerettar representerte. ${ }^{12}$ Kongen kunne selja eller bygsla dei til enkeltpersonar og grupper av bønder eller krevja inn landskyld og skattar. Bøndene og staten hadde same synet på eigedomsretten til allmenningane, og småkårsfolket vart taparane. ${ }^{13}$ Verdien av ein god fiskeplass kjem tydeleg fram i ei historie frå Vang i Valdres frå 1800-talet. Når ei gjev jente skulle gifta seg, kunne det bli spørsmål om ho i heimfølgjet «hadde del i os [elveos] og grav [dyregrav] i fjell». ${ }^{14}$ Elveos har alltid vore gode fiskeplassar, der det vart nytta ymse fastståande reiskapar. ${ }^{15}$ 
Med den store verdien som fisket kunne representera, vart det naturleg nok nytta og utvikla ulike fiskemåtar. I denne artikkelen vil vi greia ut om dei ulike fiskemåtane, og vekta vil liggja på fiske i fjellet i Sør-Noreg i eldre tid. Vi vil også diskutera nærare korleis enkelte reiskapar har utvikla seg gjennom tida. Dette vil i hovudsak dreia seg om aure (Salmo trutta), som med få unntak var einaste fiskeslaget $\mathrm{i}$ desse områda i tidlegare tider.

\section{ULIKE FANGSTPRINSIPP}

Det har vore vanleg å skilja mellom fire prinsipp med omsyn til fangst av innlandsfisk her i landet: (1) angrep eller direkte fiskemåtar, (2) lokking med agn, (3) innsnørings- eller bundne reiskapar og (4) innesperring eller faste anlegg. ${ }^{16}$ I den fyrste kategorien inngår tumming (å ta fisken med hendene) og fangst med hjelp av spjut, lystergaffel og liknande reiskapar. Ved lokking med agn skil ein mellom beinveges fangst med krok, oter og dorg og seinare tilsyn og opptak ved bruk av til dømes reiv (line). Innsnøringsreiskapar eller bundne reiskapar omfattar ulike typar garn, som stågarn og drivgarn. Blant innesperringsreiskapane inngår både dei i rørsle, som not, draggarn (jagegarn) og trål, og sjølvfiskande reiskapar, som kuper, teiner, ruser, rysju, mælkrakk, sløer og kattiser. I tillegg til dei fire nemnde fangstprinsippa foreslår vi å innføra eit femte prinsipp, nemleg tidsavgrensa demming av utløpsos i innsjøar med påfølgjande turrleggjing av nedstrømsliggjande elv. Der kunne ein lett plukka fisken med hendene i vasskulpar som stod att. Same prinsipp kan òg nyttast ved avleiing av vatn i elver og bekkar.

\section{ANGREPSPRINSIPPET}

\section{A ta fisken med hendene-tumming}

Blant dei beinveges fiskemåtane er nok tumming den eldste og mest primitive. ${ }^{17}$ Dei tok auren når han gjekk opp i bekkar og mindre elver, spesielt under gytetida om hausten. Fisken stilte seg gjerne under jordbankar langs land eller under ein stein. Fangstmåten gjekk ut på å stryka fisken frå sporden og framover mot hovudet, deretter klemme til og kasta han på land (figur 1). Tumming må ha vore sett på som ein effektiv og skadeleg fiskemåte, for den vart forbode i mange kommunar i siste del av 1800-talet. I Lom vart tumming til dømes forbode i tida frå 16. august til 31 . oktober, da det vart innført nye fiskereglar i $1885 .^{18}$

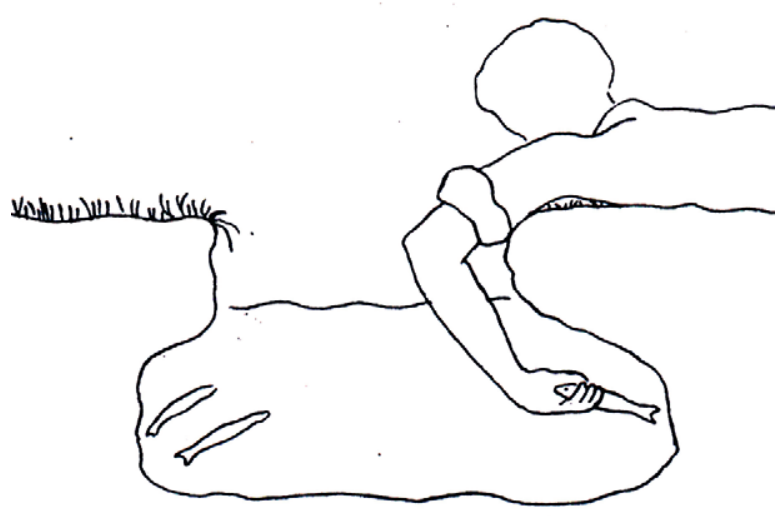

Figur 1: Tumming, det vil si å ta fisken med hendene, er den mest primitive måten å fanga fisk på. Teikninga er henta frå Ord og Sed, av Norsk Etnologisk Gransking, Institutt for kulturstudier, Norsk folkeminnesamling, Det historisk-filosofiske fakultet ved Universitetet i Oslo.

\section{Spjut og lystergaffel}

Lysterfiske i ei eller anna form har spela ei viktig rolle i innlandsfiskekulturen heilt attende frå eldre steinalder (9000-3800 f.Kr.) og fram til yngre steinalder (3800-1800 f.Kr.). ${ }^{19}$ Denne fiskemåten er veldokumentert i Skandinavia i store delar av steinalderen. ${ }^{20}$ I byrjinga vart det truleg òg brukt spjut av hardtre eller flint til å spidda fisk med. Faklar (ljostring) av tyri vart nok òg etter kvart teke i bruk. 


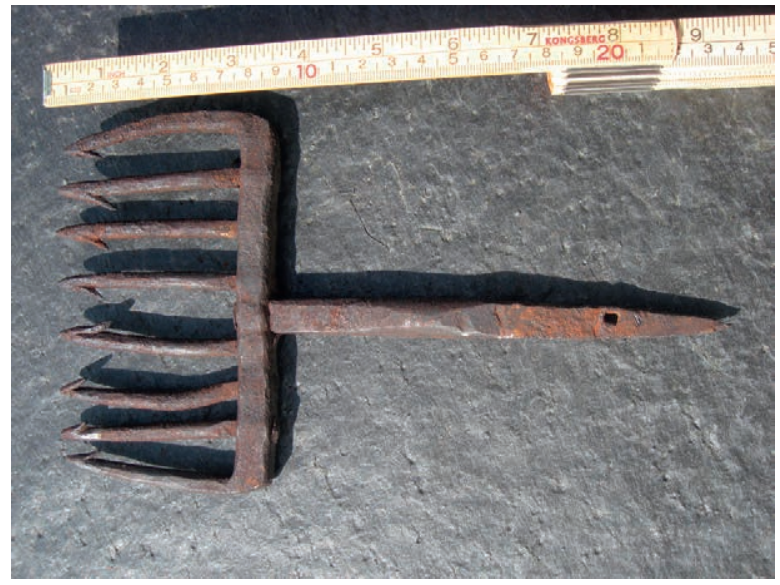

Lystergaffel av jarn. Foto: Trygve Hesthagen.

Med jarnproduksjon kom ein meir effektiv reiskap av denne typen, lystergaflar med fleire tindar. ${ }^{21}$

Utgravingar frå fleire stadar både i innlandet og i fjellet i Sør-Noreg fortel om jarnproduksjon frå fleire hundre år før Kristi fødsel. ${ }^{22} \mathrm{Og}$ etter kvart vart det nok vanleg å nytta jarn til ymse reiskapar, som lystergaflar. I si mest primitive form kan difor denne reiskapen ha vore brukt i minst 2000 år. Blant dei eldste av slike funn er to fiskespjut og truleg ein lystergaffel frå Hande i Vestre Slidre, datert til folkevandringstida. ${ }^{23}$ Ved Storevatn i Vestre Slidre er det funne ein spjutspiss av jarn frå yngre jarnalder som òg kan ha vore nytta ved fiske. ${ }^{24}$ Ved Frengstad i Kvikne i Hedmark er det funne ein lystergaffel frå same periode. ${ }^{25}$ Det same vart gjort på Størkestad i Ål i Hallingdal, tidfesta til 600 e.Kr. I Valdres er det funne fleire lystergaflar og spjutspissar med agnorer som truleg er frå vikingtida. ${ }^{26}$ Frå Mosenden i Lesja i Nord-Gudbrandsdalen vart det funne to jarntindar som kan ha vore del av ein lystergaffel frå tida ikring $500 \mathrm{e.Kr}{ }^{27}$

Før vi går vidare, skal vi ta med eit glimt inn i norsk kvardagsfiske på tidleg 1800-tal som omhandlar lystring, skildra av ein utlending. I 1817 reiste den norsk-svensk konsulen til Marseille, Edw. Gustaf Fölsch, over Dovrefjell, ${ }^{28}$ og han skriv følgjande frå turen:

Jag hade till den andra Fjell Stugan, Jerkin, 21/4 mil god och jemn väg, som jag utan fara kunde køra i mørkret. Solen hade gömt sig bakom de snøbetäckta Fjellen, men natten var skön. Jag for en stund längs ut åt några Sjöar, ller, som man här kallar dem, Fiskvand, på hvilka ljustrads [lystring] Laxöring (på Norske Öret) som fångas i ymnighet och af utmärkt godt slag.

\section{LOKKEPRINSIPPET}

\section{Stongfiske}

Historikar Knut Liestøl stilte spørsmålet om nordmennene i norrøn tid fiska med fluge. ${ }^{29}$ Sigvat Skald var kanskje ein av dei som brukte denne reiskapen. ${ }^{30}$ Liestøl viser til at i den norrøne litteraturen finst det fleire døme på at ordet fluge er nytta i tydinga «lokkemat, freisting» på ein måte som ser ut til å sikta til flugefiske. Liestøl konkluderer naturleg nok med at det er vanskeleg å vita sikkert kor vanleg flugefisket har vore i norrøn tid. Men uansett må det ha vore så kjent at det var utgangspunktet for faste og vanlege uttrykk i språket.

Fiskekrokar vart før dei fekk tilgang på metall, laga av hardtre eller bein. ${ }^{31}$ Fiske med stong og snøre, anten med fluge eller krok agna med til dømes meitemark, har vore kjent langt attende i tida. ${ }^{32}$ Fiskesnøre var laga av ymse vyrke, som tvinna hestetagl (to- eller tredobbelt), einerbast og tørka geittarmar som vart klipte opp og tvinna til sener. ${ }^{33}$ I Skåbu i Nord-Fron i Gudbrandsdalen var fiskesnøret på 1800-talet laga av hestetagl. ${ }^{34}$ Det var to- eller trelagt, oftast med 15 hår i det 


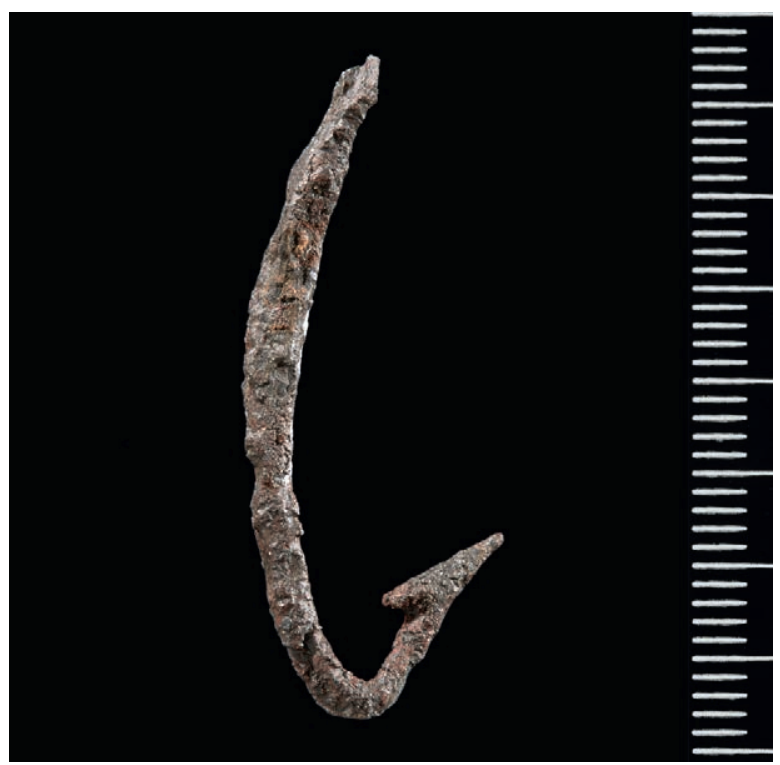

Figur 2: Denne fiskekroken av jarn er funnen på Vesle Hjerkinn på Dovrefjell. ${ }^{175}$ Han har ei lengde på kring 3,5 centimeter. Foto og kjelde: Kulturhistorisk museum, Universitetet i Oslo. Kroken har nr. C37230_761.

heile. Hestetaglet var som regel svart eller brunt. Til fortaum vart det brukt ei lengde med kvit hestetagl, for at det ikkje skulle vera så lett synleg. Hovudlina eller åsen (vaden) kunne vera heilsnudd, men oftast vart fleire lengder knytte i hop.

\section{Fiske med metallonglar}

I seinare år er det funne onglar (fiskekrokar) av jarn under fleire utgravingar i fjellet. ${ }^{35}$ Ved Langesæ i Tokke-Vinje-vassdraget i Telemark hadde ein slik fiskekrok ei lengde på 2,7 centimeter. ${ }^{36}$ Her var dei eldste daterte funna av andre gjenstandar av jarn, som pilspissar, frå vikingtida. Det er difor grunn til å tru at denne fiskekroken er frå same tidsepoke. På Vesle Hjerkinn på Dovrefjell i Oppland er to jarnonglar daterte til 900-talet. ${ }^{37}$ Dei var ikring 3,5 centimeter lange (figur 2). Det har altså vore fiska med krokreiskapar fleire plassar i fjellet i Sør-Noreg i vikingtida, anten med stong, reiv (line), støkrok eller isonglar. ${ }^{38}$ Men fiske med jarnkrokar var nok meir vanleg på den tida enn det dei få funna tilseier. Slike små gjenstandar er nemleg vanskelege å finna ved arkeologiske utgravingar. ${ }^{39}$

Frå jarnalderen er det funne mange fiskekrokar av jarn både i innlandet og langs kysten. ${ }^{40}$ Dei er noko større enn dei som tidlegare er omtala, mellom 4,8 og 8,0 centimeter. Krokar frå jarnalderen er aldri gjort av bronse, men elles i tillegg til jarn laga av bein og horn. ${ }^{41}$ Dette gjeld både i eldre jarnalder (500 f.Kr.-575 e.Kr.) og i yngre jarnalder/vikingtid (575 e.Kr.-1050 e.Kr.). ${ }^{42}$ Frå middelalderen er det derimot funne fleire fiskekrokar i bronse, til dømes langs strendene av Mjøsa. ${ }^{43}$ Seinare, som på 1800talet, vart fiskeonglar etter kvart laga av messing som fiskarane sjølv gjorde. ${ }^{44}$

\section{Støkrok}

Støkrok er ein enkel reiskap som truleg har vore brukt langt attende i tid. Han består som regel av ei 1-2 meter lang stong av bjørk eller anna trevyrke, der snøre med krok og agn er festa i toppen..$^{45}$ Stonga vart så sett nedi breidda av ei elva eller ein innsjø. Meitemark var truleg det mest nytta agnet, men småfisk har nok òg vore brukt. Fiske med støkrok under isen (isonglar) om vinteren er lite kjent frå eldre tid. I Vinstravassdraget på grensa mellom Gudbrandsdalen og Valdres vart reiskapen brukt på 1500 -talet. ${ }^{46}$ Her blir isfiske òg omtala av lokale fiskarar på slutten av 1800-talet. ${ }^{47}$ På den tida var lina eller snøret laga av heimspunne lingarn, anten svart eller kvitt. Dei brukte heimlaga messingkrokar og blysøkke på lina.

\section{Dorging $i$ eldre tid?}

Ved Gjende i Vågå er det funne ein kleberstein i ei hustuft som kan ha vore brukt ved fiske. ${ }^{48}$ Han var 10,9 centimeter lang og 4,1 centimeter brei, med ei krum og usymmetrisk form og hol i båe endar (figur 3). 


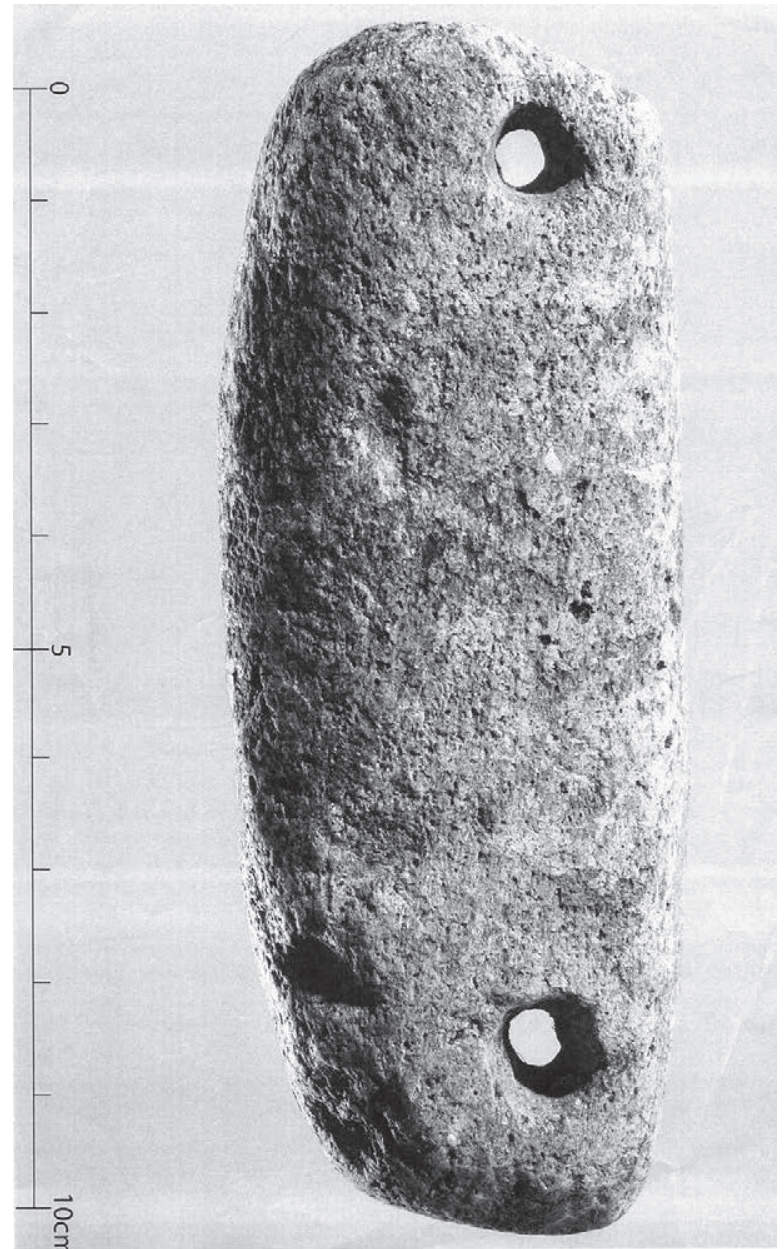

Figur 3: Denne klebersteinen vart funnen i ei tuft ved Gjendeosen. ${ }^{176}$ Han har truleg vore brukt i samband med fiske i Gjende. Foto og kjelde: Kulturhistorisk museum, Universitetet i Oslo, nr. $32362 \mathrm{a}-\mathrm{b}$.

Det er funne ein stein med ei liknande form i ei grav på Borger i Skiptvedt i Østfold. ${ }^{49}$ Denne steinen er datert til yngre jarnalder. Ole Nordgaard trur at steinen har vore brukt i samband med dorgefiske. Både den usymmetriske forma om medianplanet og plasseringa av hola var gjort med hensikt for at steinen skulle få ei anna likevekt. Snøret ville difor ikkje tvinna seg når det vart senka nedi vatnet og trekt framover under fiske. I andre kystnære strøk er det funne liknande steinar som den på Borger, vurdert som både dorgesøkke og garnsøkke. ${ }^{50}$

Det er funne ein liknande kleberstein ved Melingen i Vågå. ${ }^{51}$ I det nærliggjande Tessemagasinet i Lom er det nyleg funne ni slike steinar som vart vurderte som eldre, med ein variasjon i lengde og breidde på høvesvis 5,3-11,8 og 3,2-6,6 centimeter. ${ }^{52}$ Dei vart funne i strandsona saman med ulike garnsøkke medan innsjøen var nedtappa. Øvrekanten av båe hola i to av steinane hadde slitespor etter snor. Men dei har likevel ikkje den same usymmetriske forma som andre steinar frå førhistorisk tid på Borger. ${ }^{53}$ Om desse særeigne steinane har vore nytta som tyngde på garn, til dorging eller fiske med line og krok, kan ikkje avgjerast. At det vart drive eit slags dorgefiske i fjellvatn i eldre tid, er nok usikkert. Men da landsdekkjande fiskereglar vart innførte på slutten av 1800-talet, vart sluk (dræg) i alle fall nemnd som ein eigen reiskap. ${ }^{54}$

Oteren vart fyrst teken i bruk her i landet i 1860åra. ${ }^{55} \mathrm{I}$ Skåbu var det før den tid brukeleg å hengja ein halv alen (vel 30 centimeter) lang fiølstubb, kvesst i båe endar, i ei snor etter båten når dei rodde. ${ }^{56} \mathrm{I}$ fjøla var det festa eit kort snøre med ei fluge i enden. Flugene laga dei sjølve, sikkert av ymse fjær og tråd.

\section{Reiv (line)}

Reiv er sett på som ein gamal reiskap. ${ }^{57} \mathrm{I}$ ordsamlinga til Edvard Storm frå Vågå, forfatta i andre halvdelen av 1700-talet, har han nemnt «Reyv» og forklart det med «et Instr: Til at fiske med». ${ }^{58}$ På Gudbrandsdalsmuseas DigitaltMuseum finst omtale av reiv (langreiv) frå Lesja. ${ }^{59}$ Den består av ei line [ås] av lintråd med korte fortaumar der fiskekrokane vart festa. Fortaumane er innerst av lintråd, medan den yste delen er av hestetagl. Fortaumane er festa på beinringar som er tredde inn på hovudlina. Lina 
vart reiva på ei vinde. I dette tilfellet er ho laga av furu, med kork til å festa krokane i.

Ei reiv vart vanlegvis agna med meitemark. Krokane vart lagde i ei kasse og dekte med eit tynt jordlag, så ikkje reiskapen skulle bli ugrei. Reiva har steinsøkke i kvar ende og flæ [flottør] som ber ho i vatnet. Men reiv vart også nytta utan flottør. Dei vart sett ut frå land eller i ymse andre retningar. Dei eldste reivene var nok ikkje særleg lange og vart truleg kasta ut frå land. I Valdres var det helst om hausten når åkrane tok til å «skjærna», at det vart fart i line- eller reivefisket. ${ }^{60}$ Dei dreiv dette fisket i alle vatn både i bygda og på stølen. Det var vanleg med ikring 50 krokar på ei reiv. Men frå Kvie i Valdres høyrer vi om at oldefar til Ove Wangensteen hadde liner med 400 til 600 krokar! I Olstappen i Skåbu hadde eit av gardsbruka i bygda rett til å fiska med 120 krokar. ${ }^{61}$

\section{INNSNØRINGSPRINSIPPET}

I denne kategorien står stågarnet i ei særstilling, og det er nok den reiskapen som opp gjennom tida har hatt mest å seia i det norske innlandsfisket. ${ }^{62}$ Men vyrket i eit fiskegarn rotna lett, og det er ikkje funne leivningar som kan gje haldepunkt om alder. Det er difor berre ymse slags garnsøkke og flottørar som kan vitna om kor lenge stågarn har vore i bruk her i landet. Og funn av slike tygder i fjellvatn tyder på at stågarn har vore nytta heilt sidan steinalderen. ${ }^{63}$ Ved tre vatn i Oppland - Olstappen, Tesse og Dokkfløyvatnet - er det funne skifersteinar som ein trur har vore garnsøkke i vikingtid og heilt attende til yngre steinalder. ${ }^{64} \mathrm{I}$ desse vatna har det difor vore fiska med garn i ein tidsbolk på fleire tusen år. På ein annan lokalitet i Oppland, ved Grynningen, som no er ein del av Aursjømagasinet i Lesja, er det funne fiskesøkke både i kleber og i glimmerskifer som truleg også er av eldre dato. ${ }^{65}$ Det er i alle fall funne materiale som kan vera frå to ulike kronologiske fasar: frå den eldste til mellomste eldste steinalder

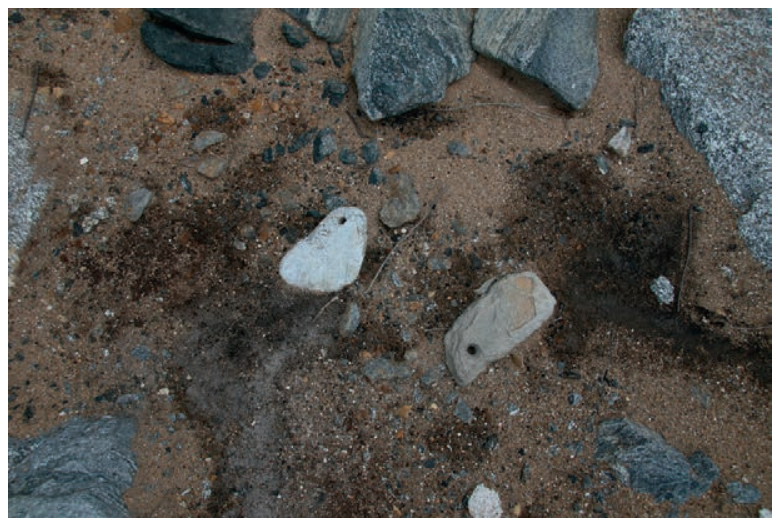

Garnsøkke frå Grynningen i Lesja. Foto: Per Jordhøy.

og frå bronsealder. Så i Grynningen kan det også ha vore garnfiske i fleire tusen år.

ITessemagasinet er det funne nokre heilt spesielle trinseforma gjenstandar som ein trur har vore tyngder på stågarn. ${ }^{66}$ Dei kom til syne i strandsona etter at vatnet vart tappa ned fyrste gong på 1940-talet. Dei består av ein stein som er surra med bjørkenever i midten av ein vidjering (figur 4). Den fyrste C14dateringa gjekk attende til 800-1000 e.Kr. ${ }^{67} \mathrm{Nyleg}$ er fem andre slike søkke daterte til tidsepokane 721-946 og 1279-1395 e.Kr. ${ }^{68}$ Også i andre strøk av landet er det funne garnsøkke som ut frå forma truleg er frå vikingtida, men også mykje lenger attende i tid. ${ }^{69}$ I dei no turrlagde Lesjavatna er det

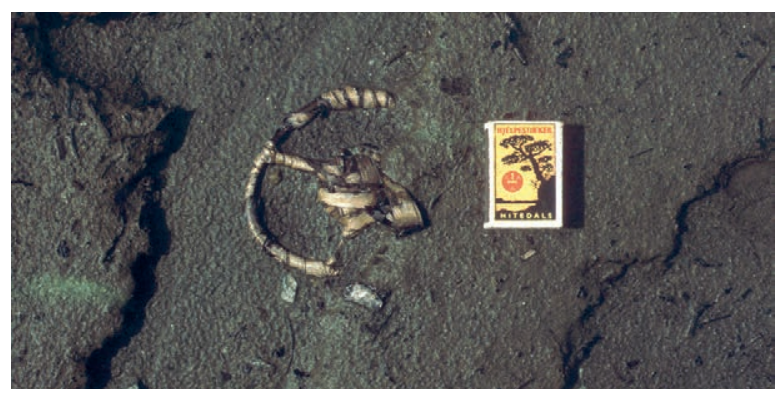

Figur 4: Trinseforma garnsøkke frå Tesse. Foto: Trygve Hesthagen. 


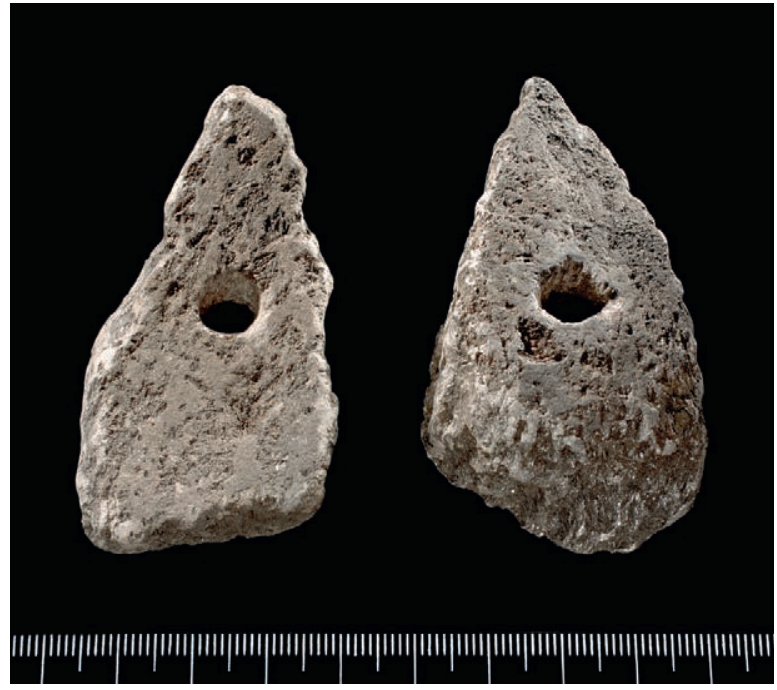

Figur 5: Desse to klebersteinane med ei høgde på ikring åtte centimeter vart funne i samband med utgravingane av Vesle Hjerkinn på Dovrefjell. Ut frå utforming og vekt trur ein at dei har vore nytta som garnsøkke (Weber 2007c). Foto og kjelde: Kulturhistorisk museum, Universitetet i Oslo, undernummer C37230_252 og 266.

funne liknande trinseforma søkke som i Tesse. ${ }^{70}$ Desse søkka frå Lesjavatna er ikkje daterte.

På Vesle Hjerkinn på Dovrefjell er det funne to klebersteinar som ein ut frå utforming, funntilhøve og vekt trur har vore garnsøkke i vikingtida ${ }^{71}$ (figur 5). Også ymse funn av nettflæ (garnflottør) av tre vitnar om garnfiske i vikingtida. Slike garnflottørar blir også kalla garnkavl. ${ }^{72}$ På Fiskevollen ved Sølensjøen i Rendalen i Hedmark i vart det i 1914 funne eit nettflæ i ei vikinggrav. ${ }^{73}$ I 1990 vart det funne ein 10 centimeter lang garnflottør av furu ved Flønesodden i Selbusjøen i Sør-Trøndelag (figur 6). Han er datert til tidsrommet 900-1275 e. Kr. ${ }^{74} \mathrm{Han}$ har hol i midten for at ein skal kunna træ han inn på ei garnstikke.

Dei trinseforma søkka som mellom anna er funne i Tesse, kan òg ha vore brukt som tyngder på nøter.

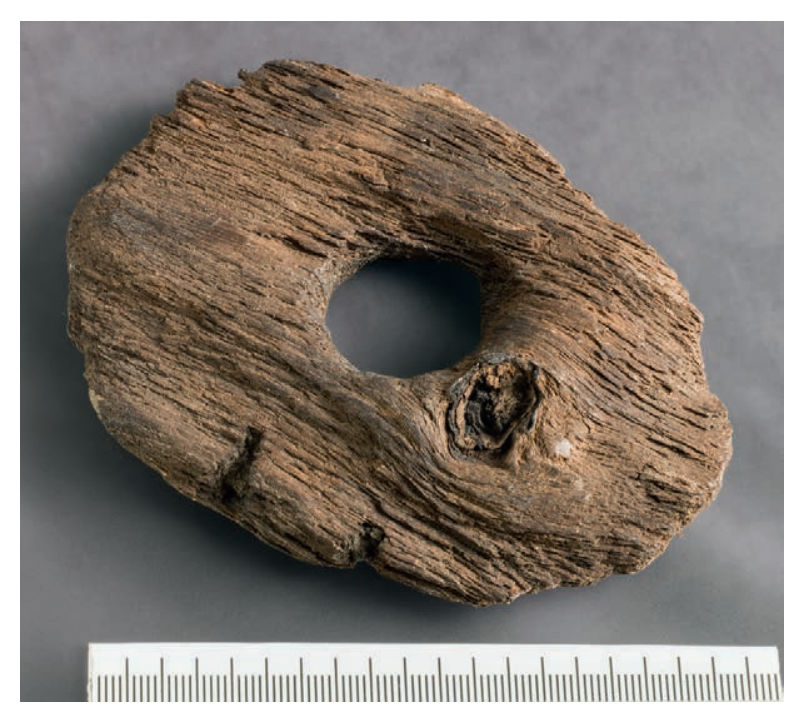

Figur 6: Dette garnflæet vart funne i nærleiken av Flønesodden ved Selbusjøen i $1990 .{ }^{177}$ Seksjon for arkeologi ved Vitenskapsmuseet, NTNU, Trondheim. Nr. T-22246. Det er laga av furu og ikring ti centimeter langt. Foto: Åge Hojem, NTNU Vitenskapsmuseet.

Men fordi dei består av noko trevyrke, så vil dei ha større oppdrift enn eit steinsøkke. Tyngda vil difor truleg ikkje bli stor nok til å halda ei not ned mot botnen. Utforminga gjer også at dei lettare vil festa seg til stein og trevyrke når nota blir drege inn. Desse tyngdene er elles funne for langt frå land til at dei kan ha vore nytta på nøter (jf. s. 21). Vi har heller ingen kjennskap til at det var brukt not på Tesse attende i vikingtida.

Stågarn er ein type reiskap som opp gjennom tida har hatt ymse utformingar. Og ikkje minst har vyrket i det endra seg mykje. Råmateriala har frå gamalt av vore ymse slags plantefibrar. Neslefibrar har til dømes vore brukt i garnproduksjon hjå samane. ${ }^{75}$ Kanskje har bast med vyrke av furu også vore nytta til garnbinding. I Bråtå i Skjåk i Ottadalen skal det i eldre tid ha vore drive bastehandverk, og bastsnora 
vart nytta til tog, reip og like til fiskegarn. ${ }^{76}$ Det skal ha vore uvanleg fin furuskog på denne plassen, med rein og blank bork som gav særskilt fin bast. Det voks visstnok også eit spesielt tre, Bastbutreet, oppi Bråtå. Ein kjenner ikkje til om dette var furu eller eit anna treslag. I Valdres kunne ein eldre mann fortelja at dei tidlegare brukte raggenet. ${ }^{77}$ Dei laga med andre ord fiskegarna av geiteragg.

I Gudbrandsdalen vart heimspunne hamp og lin nytta til garnbinding. ${ }^{78}$ Dyrking av båe slag har nok vore vanleg i distriktet langt attende i tida. ${ }^{79}$ Spinninga av hamp og lin vart ofte sett bort åt ei spinnekjerring, som tvinna det ein gong (eingjengt). Derimot var det vanleg at fiskarane sjølve stod for garnbindinga. Tennolen i fiskegarna var som regel av grovt, tvilagt hampegarn. Attende på 1500-talet var garn og garnbinding husindustri og salsvare i søre delen av Gudbrandsdalen. ${ }^{80}$ Dette hadde nok ein viss samanheng med eit rikt fiske med både landnot og ymse garntypar i Mjøsa og nedre delar av Lågen. ${ }^{81}$ Fleire bokføringar i lensrekneskapen frå åra 1557-1558 syner kjøp av fiskegarn (wodegarn) til «slotz behoff»» ${ }^{82}$ Det nemnde «wodegarn» er vel helst notbus, men orda garn og not vart brukte om einannan. ${ }^{83}$

\section{ULIKE TYPAR GARN}

I eldre tid vart det nytta ulike typar stågarn, avhengig av bruksmåte. To eldre fiskarar frå Skåbu, Martinius Omundsen Fosse (f. 1853) og Ole Olsen Megarden (f. 1852), skilde mellom osgarn (osband), kjøgarn og vanlege stågarn..$^{84}$ Osgarna var 1,5-2,0 alen $(0,9-1,3$ meter) djupe og hadde ei moskevidde på mellom 2,0 og 3,5 tommar (63-89 millimeter). Dei hadde også grøvre tråd enn vanlege stågarn fordi dei var tiltenkt å fanga større fisk. Som namnet seier, vart dei brukte til stenging av elveos i gytetida om hausten. Det hende også at fisken vart jaga på garna frå båt med ein bikk eller ved steinkasting. Ein bikk er eit skålforma eller uthola trestykke, som var festa på eit 1,0-1,5 meter langt skaft. Når bikken vart støytt nedi vatnet, steig lufta som vart ført ned, etter kvart mot overflata i form av store bobler. Dei ville skremma fisken inn i garnet. I Valdres hadde osgarn (osnet) same funksjon, der dei også var spesielt storbanda. ${ }^{85}$ Folk sette elles ut osgarna i stille hølar i elvene om hausten, samstundes som dei jaga fisken ved å kasta stein. I Skåbu vart kjøgarna sette ut både i strandsona og i elver. Dei hadde mindre moskevidde enn osgarna, helst 1,0-1,25 tommar (25-32 millimeter). ${ }^{86}$ Bruk av småmoska kjøgarn var òg vanleg i Valdres. ${ }^{87}$

Korleis sette dei ut stågarna i eldre tid? I Tesse er mange av dei trinseforma garnsøkka frå vikingtida, og elles andre søkke, funne ikring 100-200 meter frå land. ${ }^{88}$ Det må difor ha vore nytta båt eller andre farkostar under garnsettinga. Men garnfiske kan også ha vore drive utan båt og mykje lenger attende i tid. I elver vart garna sette i kulpar, hølar og djupare straumsvake parti, og da var det berre å vada dei ut. Osgarna kunne ein dra ut med line, i alle fall i mindre tjern..$^{89}$ Denne teknikken kunne ein òg nytta i større innsjøar med smale sund. Teknikken med å stikka garn ut med lange stenger eller skøyta fleire stenger saman er også kjent. ${ }^{90} \mathrm{I}$ Valdres brukte dei «netstong», ei lang stong med pigg til å trekkja inn garna med. ${ }^{11}$

I eldre tid vart det også fiska med garn under isen. ${ }^{92}$ Men det var fyrst i jarnalderen at dei fekk reiskapar som trongst for å driva eit slikt fiske, nemleg isbiler til å laga hol $\mathrm{i}$ isen med. Isgarna vart dregne ut ved at ein hogg fleire hol $\mathrm{i}$ isen, og med ein slik avstand at ein fekk tak i garnenden frå det eine holet til det andre. ${ }^{93} \mathrm{I}$ ei dyregrav i Veodalen i Jotunheimen er det funne ei isbile som ut frå form er datert til folkevandringstida (figur 7). ${ }^{94}$ Denne isbila kan ha vore nytta ved fiske med isgarn eller isonglar i Tesse. Det er i alle fall det næraste vatnet til Veodalen og 
ligg eit par mil i sørvestleg retning. I Gudbrandsdalen er isgarn omtala på slutten av 1700 -talet. ${ }^{95} \mathrm{I}$ Valdres har eit slikt fiske vore drive inn i vår tid. Dette skjedde helst tidleg på vinteren, når isen enno ikkje var tjukkare enn at det var lett å laga hol og halda dei opne. ${ }^{96}$ Isbila har vore brukt i samband med vinterfiske langt inn på 1900-talet.

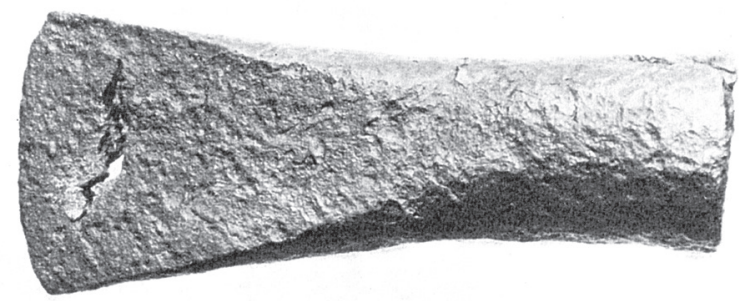

Figur 7: Denne isbila vart funnen i ei dyregrav i Veodalen i Jotunheimen og skal vera frå folkevandringstida. ${ }^{178}$

\section{INNESPERRINGSREISKAPAR}

Den fastståande innesperringsreiskapen er ei stor og variert gruppe. Her finn ein både sløer, mæler, teiner, ruser, kuper, garnsekk og kattiser. ${ }^{97}$ Eit felles trekk ved denne reiskapen er altså at fisken på eit eller anna vis blir stengd inne. Men virkemåten er likevel forskjellig.

\section{Sløer}

Sløer er fastståande og sjølvfiskande reiskapar som vart brukte i elver og bekkar. ${ }^{98}$ Dei er bygde av langsgåande slinder med ein avstand på nokre få centimeter. Det var helst fisk som vandra nedstrøms, som vart fanga med sløer. Fisken vart halden attende oppå slindene, medan vatn, lauv og rask forsvann mellom slindene (figur 8). Han vart anten liggjande mot tverrstokken nedst på sløa eller ført ned i ei kasse som stod i vatn. Ofte vart det mura eit vifteforma leidegjerde av stein (sløegardar) ned til sløa.
På den måten vart det meste av vasstraumen ført inn på sløa.

Sløene blir rekna blant dei eldste fangstinnretningane i ferskvatn og kan ha vore brukte i førhistorisk tid. ${ }^{99}$ Den eldste daterte sløa var inntil nyleg frå tidleg 1600-tal og vart funne på Tesse i 1976. ${ }^{100}$ Ho låg eit godt stykke uti reguleringssona, utanfor innløpselva (Smådøla). Ho var nesten intakt og hadde nok vorte teken av flaum og ført ned i Tesse. I 2014 vart ei liknande sløe funne i same område, i tillegg til ein del slinder og tverrstokkar. Den eldste sløa vart datert til $1218-1405$ e.Kr. ${ }^{101}$ Elles vart tre andre sløerestar daterte til ikring 1450-1635 e.Kr. I Oppland har sløer vore ein mykje brukt reiskap i mange fjellvatn langt attende i tida. ${ }^{102} \mathrm{I}$ Diplomatarium Norvegicum går det fram at sløefiske gjekk føre seg på fleire stadar i Gudbrandsdalen og Valdres alt på 1300- og 1400-talet. ${ }^{103}$

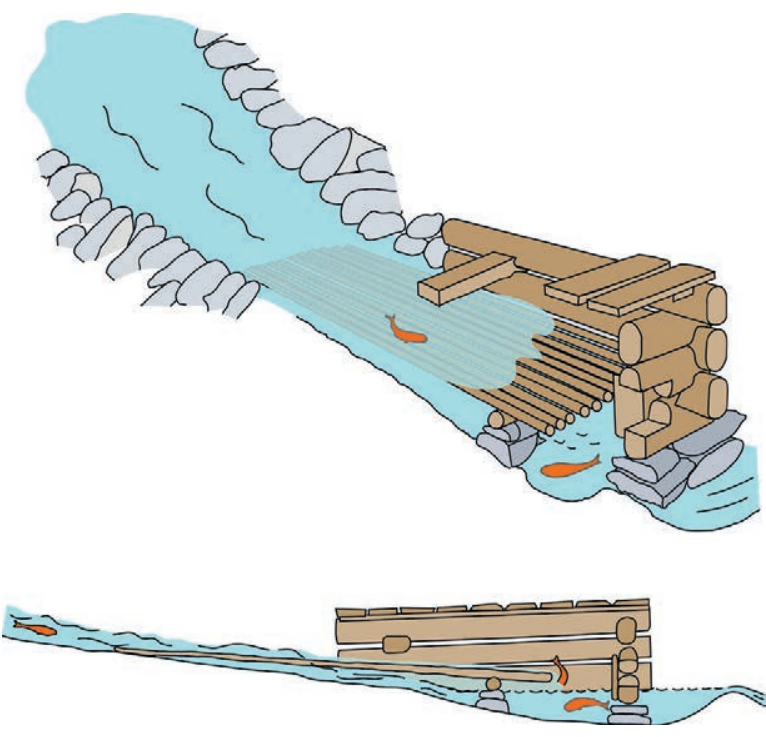

Figur 8: Sløer er fastståande og sjølvfiskande reiskap brukt i elver og bekkar. Dei er bygde av langsgåande slinder som vart lagde med ein avstand på nokre få centimeter. ${ }^{179}$ 


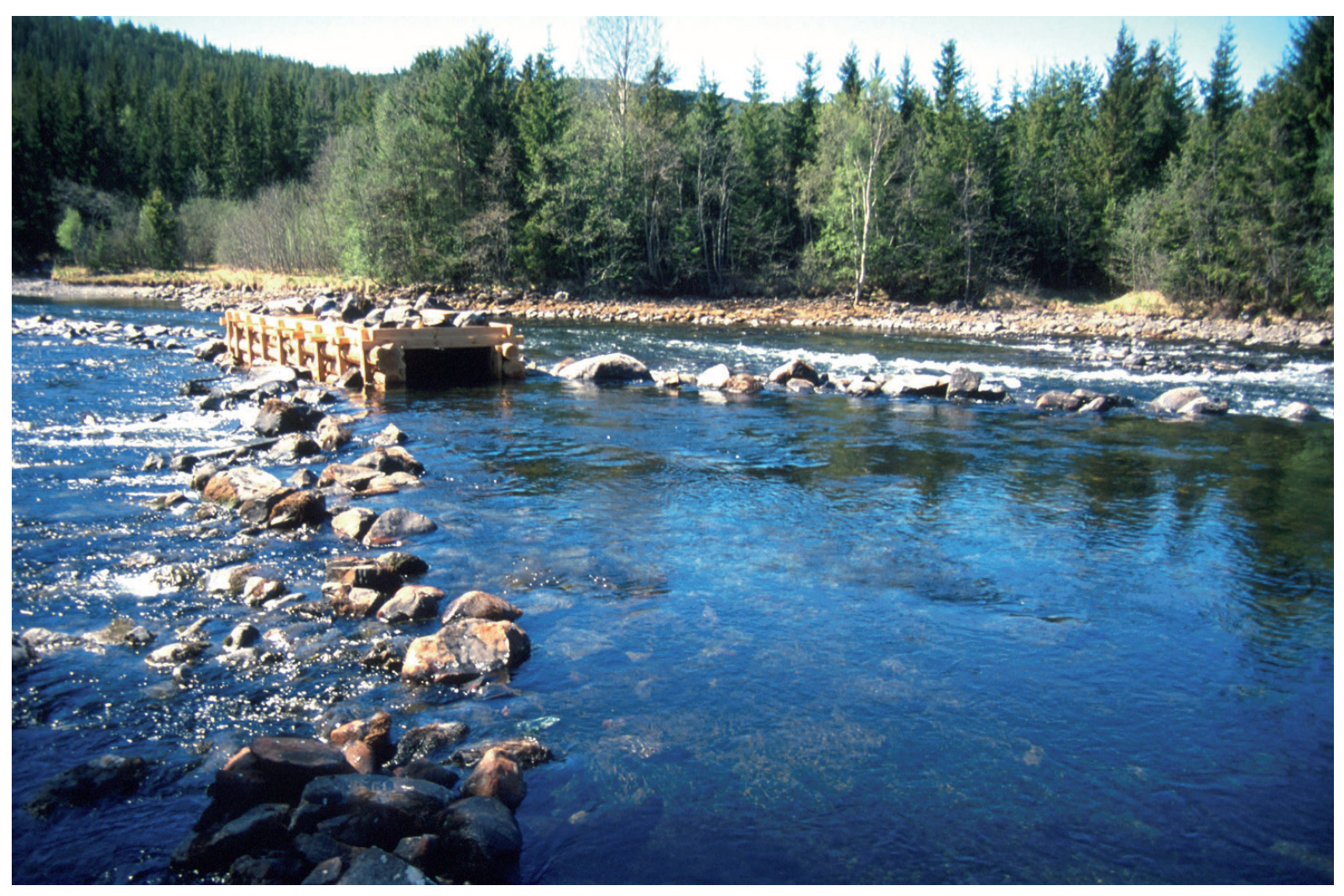

Skjeftesløa i Storåne i Vang i Valdres er framleis i bruk. Foto: Ola Hegge.

Sløer skil seg mykje i byggemåte og storleik, noko som blant anna var bestemt av kor dei var plasserte. ${ }^{104}$ I Gudbrandsdalen er dei delte i tre grupper: hussløer, kassesløer og slindsløer. ${ }^{105} \mathrm{I}$ Hardanger skilde dei mellom kippesløer og faste sløer. ${ }^{106}$ Slind- og kippesløene var dei minst forseggjorde og samansette berre av nokre slinder. Sløer i fjellet var gjerne enkle og berre brukt i ei kort tid på hausten. I Valdres kunne fiskarar ha med seg nokre staurar til sløebotn når dei drog til fjells, eller dei hadde liggjande vyrke ved sløestøet. ${ }^{107}$ Når dei drog ned frå fjellet, tok dei sløene på land for å unngå at dei vart øydelagde av isgang og flaum. Men i enkelte elver vart det også bygt større og faste sløer, som i Smådøla ved Tesse og fleire andre stadar i Oppland. ${ }^{108}$

\section{Ruser, teinar og mal}

Det er ingen klar definisjon av korleis denne reiskapen var utforma. Spørsmålet avheng òg av kva slags vyrke som vart nytta. ${ }^{109}$ Grunnordet tein har tydinga oppspirande tre, skot, grein eller tunn stong. ${ }^{110}$ På Austlandet er nemninga ruse brukt om same reiskap. Her vart mal og mjal brukt om kvarandre, medan namn andre stadar i landet er mjard, mer, mele eller merd. ${ }^{111}$ I Lom vart truleg mælen kalla garnsekk eller fiskesekk. ${ }^{112}$ I Sør-Aurdal gjekk ein liknande reiskap under namnet straumsekk. ${ }^{113}$ Skilnaden 


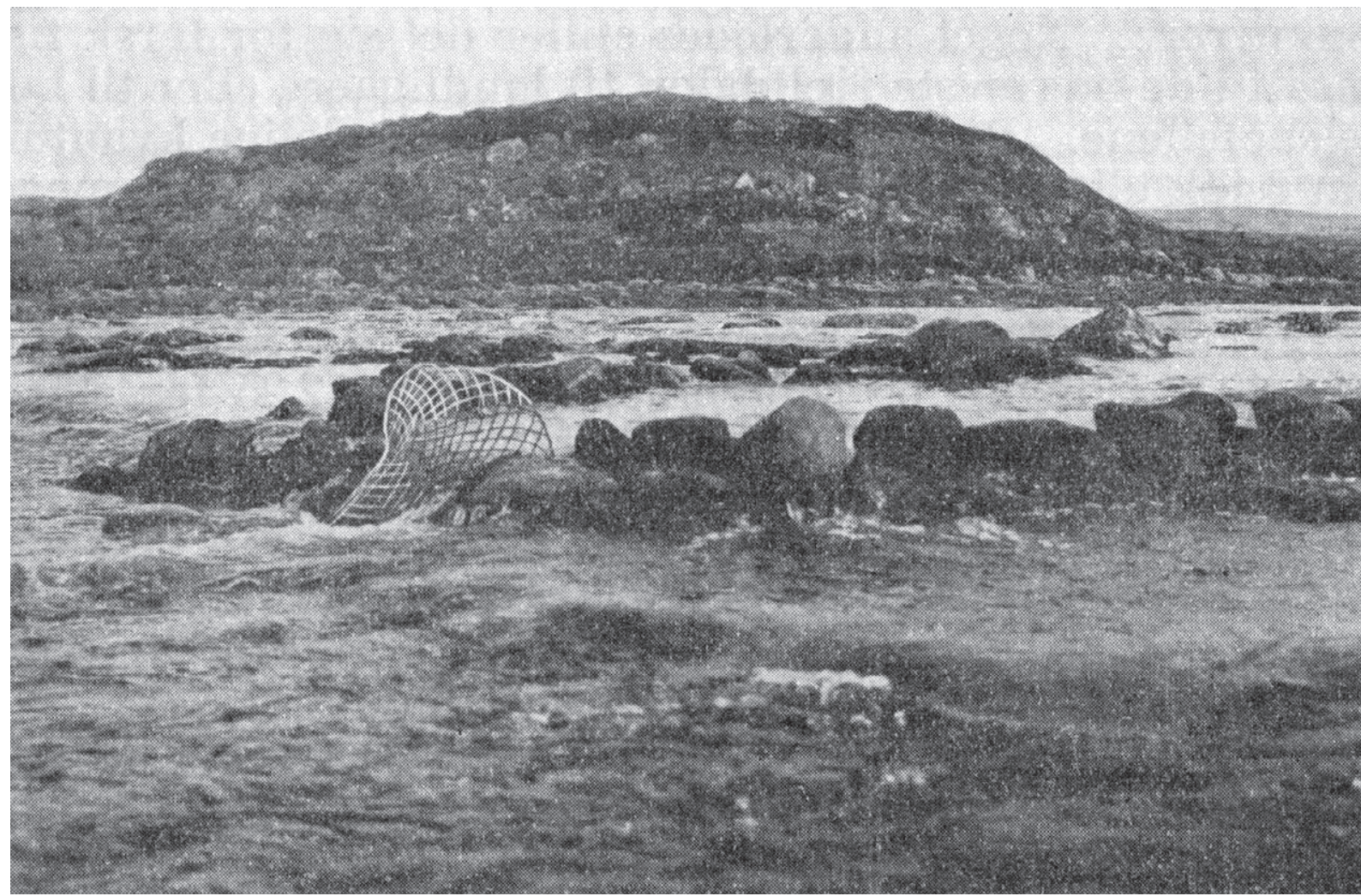

Figur 9: Mælen av vidje med mælgard mura av stein i Djupe på Hardangervidda. Biletet av mælgarden er frå 1932, og han vart lagd ned eit år seinare.

mellom til dømes ruse, teine og mæl kan også avhenga av om det vart nytta leidegjerde eller ikkje. Vyrket i denne reiskapen var anten trådnett knytt i mosker (mæl) eller spildreverk som fisken kom seg inn i, men ikkje ut att frå, som teiner, ruser og kuper. Den siste typen hadde kalv (spalte), medan det Tor Ile ${ }^{114}$ frà Øyer omtala som mæl, mangla stengsel i inngangspartiet. Mælen har til dømes to ulike fangstprinsipp: med og utan trakteforma inngangsparti (stengsel) som endar i ein kalv. I fjellet vart ruser og mæl for det meste nytta i elver og bekkar for å fanga fisk på nedvandring. ${ }^{115}$ Truleg var det vanleg å leggja opp eit trakteforma leidegjerde av stein (jf. sløer). I si mest primitive form hadde ikkje denne reiskapen kalv. Ruser og mæl måtte difor bli plasserte på straumharde parti, slik at fisken ikkje kom seg ut att.

Opp gjennom tida har det truleg vore store endringar i både utforming og vyrke i reiskapar som mæl og teine. I den eldste typen innan denne gruppa vart det nok nytta vidjer eller tæger. Ymse materiale frå dyr, som hud og lær, kan òg ha vore brukt. Mæl er kjent frå nordisk middelalder med denne forklaringa: «Ruse, ymist fletta av kvist eller tæger og ymist laga av net [garn] nytta til fangst i småelver og elver serleg då av aure o. likn.». ${ }^{116} \mathrm{I}$ Christians amt (Oppland) har mæl i ei eller anna form vore kjent i mange hundre år, ifølgje amtmann 
Christian Sommerfeldt. ${ }^{117}$ Han skriv i 1795 om «mindre Ruser, som kaldes Kuper, Teener eller Meeler, ved hvilke fornemmelig fanges abor i Mjøsen, Øret og Harr i Elvene». På same tid skriv prost og sokneprest Hugo F. Hiorthøy om bruken av teiner og kjegleforma kurver (mæler). ${ }^{118}$ I Øyerfellet i Gudbrandsdalen er bruken av teinar kjent heilt attende til slutten av 1400-talet. ${ }^{119}$

I fleire bygder i Gudbrandsdalen har mæl eller teineliknande fiskereiskapar vore vanleg. ${ }^{120}$ Dei var 1-2 meter lange og laga som ei korg av spildrer. Fleire stadar i Vågåfellet vart det tidlegare fanga aure med slik reiskap. ${ }^{121}$ Korgehølen i Sjoa elv mellom Øvre og Nedre Sjodalsvatnet har fătt namn etter denne reiskapen. I Valdres brukte dei også kuper av vidje, teger og smale bjørkestrimlar, som var fletta som ei korg. ${ }^{122}$ Dei kunne vera 1,5 meter lange og like vide. Inni var det plassert ei mindre kupe som hadde ei lita opning i botnen, og som var noko smalare og kortare. Ho var festa til den ytre kupa med vidjer. På Hardangervidda har mæl og andre ruseliknande reiskapar av vidje frå gamalt av vore sett på som særleg verdifulle. ${ }^{123}$ Mange plassar kunne ein så seint som på 1930-talet finne restar etter slike fangstinnretningar. Mælgarden i Djupe var spesielt godt kjent og skal ha høyrd til Langsjø-fisket (figur 9). Også ved Møsvatnet på Hardangervidda vart teiner i eldre tid laga av tynne kvistar (teiner), helst av bjørk. ${ }^{124}$

Mælen vart seinare laga av lin- og hampegarn knytt i mosker. På tidleg 1900-tal vart reiskapen omtala som ein lang garnpose utan kalv. ${ }^{125}$ Overgangen til garnvev i mælen var nok ei stor vinning på fleire måtar. Mælen var enkel å laga og lett å leggja ut, og vekta gjorde at han kunne bli frakta overalt i fjellet. I Skåbu var mæl kjent på slutten av 1800-talet, men ikkje teine. ${ }^{126}$ Her var mælen laga som ein sekk av grovt garn - vid framme og smalare bakover. Framme var det ein boge som heldt mælen oppe. Mælen vart ofte plassert på straumbrekk i elver eller bekkar, og fisken kunne bli jaga inn.

I elver og bekkar ved Tyin på Filefjell brukte fiskarane mæl av grov tråd. ${ }^{127}$ Den var vid oppe og festa til ein treboge og smalna ned til ein spiss. Denne mæltypen kunne vera 3-4 meter lang og ha eit tverrmål i opninga på 1,5 meter. Dei var gjerne plasserte i eit utgrave elvefar der vatnet rann stritt. Mælen kunne også bli lagt der elva smalna inn, i elvestryp, under små fossar eller andre stadar der fisken gjekk. Stundom vart mælen liggjande natta over, andre gonger jaga dei fisken inn.

\section{Rysju}

I Lesjavatna vart det på 1800-talet nytte ein ruseliknande reiskap dei kalla rysju. ${ }^{128}$ Fisket gjekk føre seg ved at dei sette stolpar eller grinder i vatnet utover frå land, slik at fisken vart bægd inn i rysjua (figur 10). Ho var sett saman av fleire posar av småbanda garn som vart haldne oppe av gjorder. Rysju i innsjøar med leidegjerde av stolpar er ikkje kjent frå andre stadar. Lesjavatna var grunne og eigna seg difor sikkert godt til ei slik fangstinnretning. At det elles var uvanleg stor fisk (aure) her, gjorde nok denne reiskapen spesielt effektiv. ${ }^{129}$ Dette viser at dei lokale naturtilhøva har skapt nye utformingar av fiskereiskapar. Da Lesjaskogen sokn endra fiskereglane sine i 1891, vart det innført totalforbod mot bruk av både rysju, teine og ruse i ti år. ${ }^{130}$

Rysju frå Lesjavatna byggjer på eit liknande fangstsystem som katisser. Her vart kløyvde trespilar sette kant $\mathrm{i}$ kant på botnen av eit vatn. Spilane leia fisken inn i eit rom som han ikkje kom seg ut av. ${ }^{131}$ Liknande fangstinnretningar med ymse typar leidegjerde er kjent frå fleire innsjøar på Austlandet. ${ }^{132} \mathrm{I}$ Brandval i Hedmark var ein slik reiskap særleg brukt til gjeddefiske. ${ }^{133}$ Her var både rysju og veggane laga av notlin, og heile reiskapen var berre nokre få meter lang. Rysju er òg kjent frå Sør-Aurdal i Valdres: 


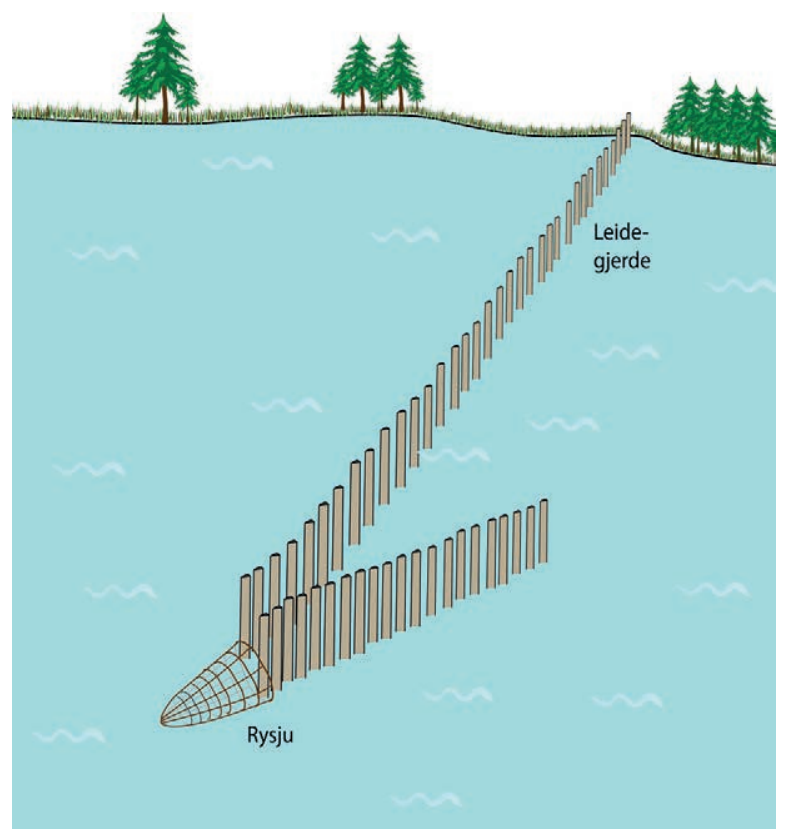

Figur 10: I Lesjavatna vart det fram til 1800-talet nytta eit ruseliknande reiskap dei kalla rysju (Anonym 1936; Hesthagen 2008). Det vart sett grinder i vatnet utover frå land, som bægde fisken inn i rysju. Kanskje var det plassert eit kortare leidegjerde på den andre sida av rysju.

I Hedalen fiska dei både med mæl og rysju. Den siste ser ut som ein mæl, men er mykje vidare og lengre. Ho blir utspent med gjyrer. Ut frå rysju går det rysjuvengjar. Med rysju stenger dei elveosane. ${ }^{134}$

I Beito hadde osgarn same funksjon som rysju, nemleg å fanga fisk utanfor elveløp. ${ }^{135}$ I Hedalen i Valdres såg rysju ut som ein mæl, men var mykje vidare og lengre. ${ }^{136} \mathrm{Ut}$ frå rysjua gjekk det rysjuvengjer, slik at dei kunne stengja elveosar.

\section{Not}

Nota eller vad skil seg blant anna frå stågarn på fleire måtar. Ho er ein innesperringsreiskap som verkar etter silprinsippet, og blir brukt i både innsjøar og elver. ${ }^{137}$ På den måten blir ikkje fisken hengjande i moskene, som på eit stågarn. Ei not er vanlegvis ikring 20-30 meter lang med ei høgde på 2-5 meter. Nota har som regel ein pose (kalv) på midten som fisken går inn i. Forma og storleiken på nøtene har nok endra seg opp gjennom tida. Nota blir sett ut frå båt i ein passe avstand frå land, avhengig av djupet. Så blir ho drege inn til land med tog i kvar ende av minst to personar. Botnen der nota blir trekt inn må vera relativt slett utan større stein, elles vil ho hengja seg opp. I eit vatn kan det difor berre vera eit fătal plassar som er eigna for notfiske. I mange vatn kan ein ikkje nytta not i det heile. Nota må bli halden langs botnen, slik at fisken ikkje stikk seg under og forsvinn. Botntelna er difor forsterka med grovt tog. I tillegg kunne det vera festa diverse tyngder, som jarnringar, stein og horn.

Not er ein fiskereiskap som kan ha vore brukt heilt attende i førhistorisk tid. Hermundstad ${ }^{138}$ skriv at $\mathrm{i}$ Valdres har det vore laga primitive nøter av vidjelekkar som sopa fisken inn til land i grunne viker. Han meiner at dette er ein så primitiv reiskap at han godt kunne ha vore nytta i stein- og bronsealderen. Ein liknande fiskemåte med vidjelekkar har vore brukt i viker og loner i Gudbrandsdalslågen ved Kvam, fortalde Ola O. Røssum. I Njålssoga frå Island er not nemnd i eit ordtak. ${ }^{139}$ Soga er knytt til hendingar som skjedde på sagaøya i tida 930-1020 e.Kr. ${ }^{140}$ Not er òg nemnt i den eldre Edda for 1000-1200 år sidan. ${ }^{141}$ På Tesse kan not ha vore brukt alt i vikingtida. ${ }^{142}$ Ved Nørdre Byrtnes skal Kjæstad i Lom ha hatt eit notkast, som vart kalla Kjæstadkastet. Ifølgje lokal tradisjon gav garden bort nokre tømmerstokkar da Garmokyrkja vart bygt på 1000 -talet. ${ }^{143}$ Som vederlag fekk Kjæstad eit notkast på Tesse. Her i landet har det vore brukt not i mange hundre år. Eit diplom, Diplomatarium Norvegicum, frå 1336 omtala notfiske (vådfiske) etter 


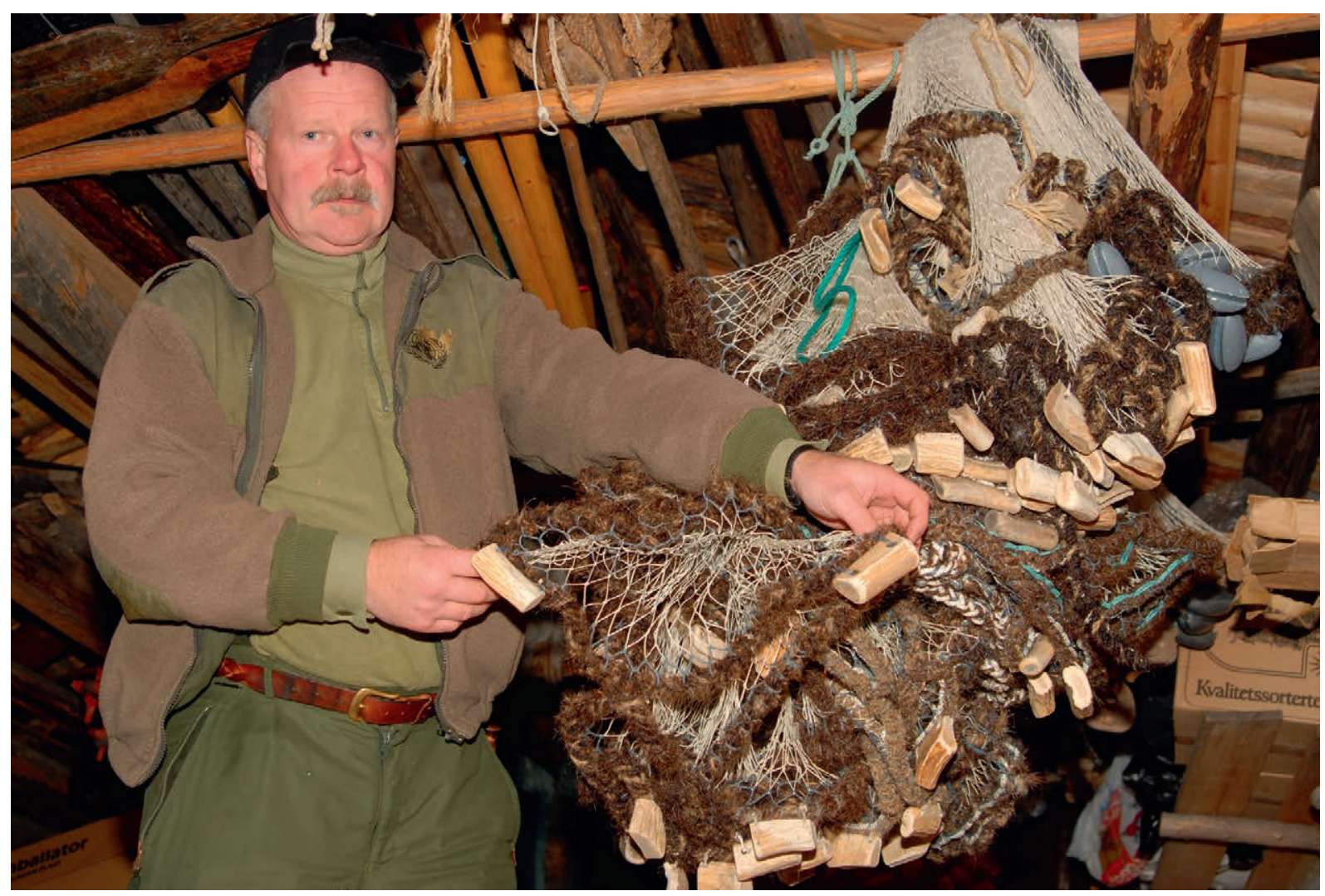

Not som framleis er i bruk i Sølensjøen. Legg merke til tyngder av bein. Hans Erik Hangaard på biletet er barnebarnet til den siste Sølensjøkongen, Haagen Hangaard. Foto: Morten B. Stensaker.

laks i Drammenselva. ${ }^{144} \mathrm{Og}$ i dei mest fiskerike innsjøane våre kan vi også tøya bruken av not langt attende i tid. I det største innlandsfisket som har vore her i landet, lågåsildfisket i Mjøsa og nedre delar av Lågen, er notfiske dokumentert attende til 1400-talet. ${ }^{145}$

Bygdehistorikar Ivar Kleiven i Vågå skildrar notfiske under isløysinga på Melingen tidleg på 1860-talet. ${ }^{146}$ Slik kan det ha vore i hundrevis av år. Landingsplassen for not blir kalla «Notvarp», noko som skulle tyda på gamal bruk. ${ }^{147} \mathrm{Vi} \mathrm{kan} \mathrm{gå}$ stegvis attende i tid for å finna opplysningar om notfiske. Prestesonen Edvard Storm frå Vågå nemner i ordsamlinga si, som er nedteikna i andre halvdelen av 1700-talet, «Noot» med forklaringa «En Vod». ${ }^{148}$ Også presten Hans Frisak i Lom har ført opp «noet» eller «vod fiske-vaed» i ei ordsamling frå $1743 .{ }^{149}$

I Sølensjøen i Østerdalen har det vore drive notfiske i fleire hundre år. ${ }^{150} \mathrm{Her}$ var nota forsterka både øvst og nedst med eit tjukt tog av ku- eller hestetagl. Sjølve nota var i eldre tid laga av heimavla lin, og bindinga gjorde fiskarane ofte sjølve. ${ }^{151} \mathrm{I}$ Skåbu var nota bunden av heimspunne og sterkt hampetog. ${ }^{152}$ Nøtene her var ikring 50 alen lange og 7-8 alen djupe (ikring $32 \times 5$ meter). Ei not som var brukt på Lesjavatna på 1800-talet, var 26 meter lang og 5 
meter djup. ${ }^{153}$ Botntelna likna som regel grove reip. «Bustetog» kallar Ivar Kleiven desse dragtoga. ${ }^{154}$ Det er nok det Sigurd Grieg og Gustav Adolf Norman ${ }^{155}$ kallar «bustreip». Det vart spunne av grisebust og nauthår. Det er ei kjent sak at grisebusta «slo av seg vatnet». Ho trekte altså ikkje vatn, slik hampen gjorde.

\section{TIDSAVGRENSA DEMMING AV UTFALLSOS}

Denne typen oppdemming vart gjort ved at ein fyrst la tømmerstokkar over utfallsosen. Så vart det sett opp steinheller mot desse stokkane, og til slutt tetta dei demninga med torv (figur 11). Utløpselva vart da etter kvart nesten turrlagt, eller det stod att berre små kulpar. Ein kunne da lett plukka fisken med hendene. Slike demningar var nok ikkje særleg høge, og dei stod berre i nokre timar. Vasstanden ville nemleg etter kvart stiga over demninga.

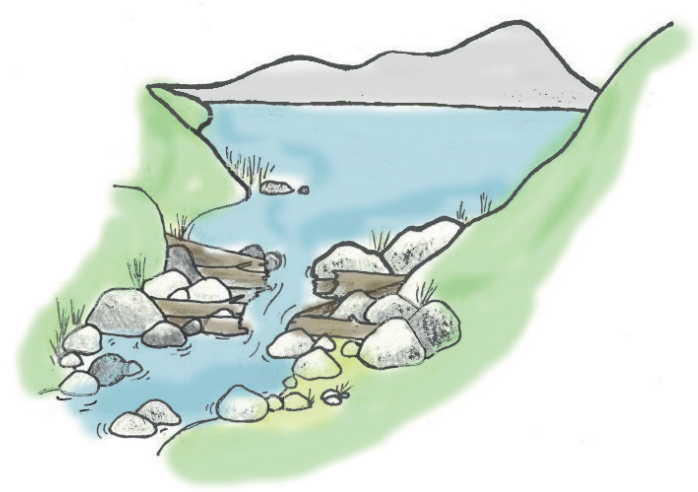

Figur 11: Demming av utfallsos vart gjort ved bruk av tømmerstokkar, steinheller og torv.

Tidlegare var truleg demming av utfallsosar ein vanleg fiskemåte i fleire bygder her i landet. Denne fangstmåten er mellom anna kjent frå fjellvatn i Hardanger. ${ }^{156}$ I Oppland vart demming av utfallsos forbode i fleire bygder på slutten av 1800-talet da dei innførte fiskereglar. Denne fiskemåten må difor ha hatt eit visst omfang og ha vore vurdert som skadeleg. For Selsvatnet i Sel kom forbodet i $1884 .{ }^{157}$ I Vågå vart det innført eit tidsavgrensa forbod i 1891. I åra 1903-1909 vart demming av elveos forbode i både Sør-Fron, Sel, Ringebu og Nord-Fron. ${ }^{158}$ I Fåberg kom ikkje forbodet før i 1923. ${ }^{159}$

I Lemonsjøen i Vågå har demming av utfallsosen vore mykje brukt. ${ }^{160}$ Utløpselva (Grovi) var kjent for å vera fiskerik, så dette fisket kunne nok gje eit godt utbyte. Namnegranskaren Eivind Vågslid har sett namnet på Lemonsjøen i direkte samband med denne fiskemåten. ${ }^{161}$ Han støtta seg til ein eldre skrivemåte av namnet på innsjøen. Den gamalnorske forma var Lemundsjor, eller Hlembundr, som er ein enda eldre skriftmåte. Det skal bety «fiskestad attmed eit fiskestenge med ein lem eller ei luke». Vågsli meiner altså at namnet kom av at ein demte opp utfallsosen for å fanga fisk i Grovi etter at ho vart turrlagt. Oppdemminga skjedde ved at ein fyrst la eit par tømmerstokkar mot nokre store steinar på kvar side av utløpet. Eit par småøyer i elvefaret gav ekstra stønad for stokkane. Ut frå landskapet ved osen kunne ikkje demninga vera meir enn toppen ein halv meter høg. Utfallsosen til Lemonsjøen var spesielt godt eigna til denne fiskemåten, for han er berre 20-40 centimeter djup og 10-12 meter brei. ${ }^{162}$ Det var truleg særleg om hausten at det var vanleg å demma Lemonsjøosen. På den tida var det mykje stor fisk som vandra ned i bekken for å gyta, spesielt etter regnvêr med påfølgjande stor vassføring. Ola Storviksæter fortalde at dette fisket vart drive heilt fram til ikring 1910-1920. Han hadde sjølv vore med på det mange gonger.

\section{Båtbruk $i$ eldre tid}

Det har truleg vore brukt ymse primitive farkostar ved fiske langt attende i tid. Av dei er flåtane dei mest primitive. ${ }^{163}$ Stokkbåten er kjent frå mange plassar i låglandet. $\mathrm{Og}$ alt i steinalderen hadde dei 
reiskap til å hogga ut slike båtar med. Ved den gamle strandlina til dei turrlagde Lesjavatna er det funne ei 4000 år gamal flintøks. ${ }^{164}$ Eggen er bogeforma og difor godt eigna til eit slikt formål. Skinnbåten, som er vanleg $i$ andre fangstkulturar, kan også ha vore brukt svært tidleg i innlandet. ${ }^{165}$ Det er elles indirekte prov på bruken av farkostar eller båtar ved ymse fjellvatn i eldre tid $i$ samband med fangst av rein. I Reinheimen finst det fleire fangstanlegg der ein ved hjelp av bægjer har styrt reinen ut på innsjøar. Der må dei ha vorte innhenta i båt og avliva av jegerar. ${ }^{166}$ Også steinalderfolket på Glitreøyni i Hemsedalsfellet, med busetnad attende til ikring 7000 år f.Kr., har truleg fanga rein på same måten. ${ }^{167}$ Den meir tradisjonelle båten kan også vera svært gamal. I ei myr på Hemsing i Vang $\mathrm{i}$ Valdres er det funne spant av ein båt. ${ }^{168}$ Ved Dokkfløyvatnet i Gausdal Vestfjell vart det rundt ein eldstad funne jarnnaglar som ein meiner har høyrt til ein utrangert båt. ${ }^{169}$ Denne hustufta er C14-datert til tidsepoken 670-880 e.Kr.

\section{AVSLUTNING}

I mange fjellområde i Sør-Noreg har truleg fisken vore ein viktig matressurs gjennom mange tusen år. ${ }^{170} \mathrm{Og}$ spennvidda i reiskapstypen som vart nytta attende i steinalderen, kan ha vore stor. Mykje av reiskapen dei brukte, var truleg godt utvikla alt på den tida og hadde mykje av dei same fangstprinsippa som i dag. Men mange reiskapstypar har hatt ei lang og varierande utviklingshistorie basert på både erfaring og tilgang på nytt og betre vyrke. Utviklinga av ulike reiskapar må ein sjå i ljos av kva råstoff og teknologi folk til ei kvar tid hadde til rådvelde. Her danna jarnalderen eit viktig skilje. Det har òg vore naudsynt å nytta ymse reiskapar ut frå varierande naturtilhøve og vassdragsnatur, til dømes storleik og djupn på vatn og elver. Vekslinga mellom korte elvestubbar og lange og djupe fjordar med osar og bekkar gjorde det naudsynt å nytta ulike fiskemåtar og reiskapstypar. ${ }^{171}$ Reiskapen si form og sin bruk, det vil seia reiskapskulturen, kan også endra seg ut frå endringar i naturtilhøva. ${ }^{172}$

Buplassane til steinalderfolket låg ofte ved eller $\mathrm{i}$ nærleiken av inn- eller utløpsosen til ein innsjø. ${ }^{173}$ Her fann dei kan henda dei beste fiskeplassane, ikkje minst dit fisken søkte for å gyta. Tumming eller stikking av fisken med spjut er den enklaste fangstmåten. Enkle sløer kombinert med oppmuring av leidegjerder av stein (sløegardar) er truleg blant dei eldste reiskapane i elver og bekkar. Til det trong ein berre vyrke frå naturen - stein og trestokkar. Ein like gamal reiskap er enkle typar av teiner og mæl, tilverka av ymse tremateriale eller råstoff frå dyr. Stågarn i ei eller anna form har nok spela ei viktig rolle i utnyttinga av fisken i mange fjellvatn gjennom fleire tusen år. ${ }^{174}$ Oppdemming av utløpsos med påfølgjande turrlegging av elva nedstrøms har også vore vanleg mange plassar. Denne fangstmåten kravde heller ikkje andre råstoff enn det dei fann i naturen - tømmer, stein, steinheller og torv. Slik oppdemming var rett nok avgrensa til mindre vatn og dei som låg høgt i nedbørfeltet og hadde lite vasstilførsel.

\section{SUMMARY:}

\section{FISHING GEARS USED IN PREHISTORIC TIMES IN NORWEGIAN MOUNTAIN LAKES AND RIVERS}

People have fished in Norwegian mountain lakes and rivers ever since they first settled in these areas, probably at least as far back as the late Stone Age at about $3800-2350 \mathrm{BC}$. Hunting and fishing were 
the principal occupations of Norwegians until about $2350 \mathrm{BC}$. A wide range of fishing gears were developed already in prehistoric times. However, most of them have been lost, as they were made of organic materials. Gill nets were probably used in the late Stone Age given the many findings of special stones used as weights to keep the nets on the river- and lakebeds. Various kinds of traps and fish pots made of willow were probably used in streams and rivers to catch fish during their spawning migration. Closing nets may also have been used in the late Stone Age. In the Iron Age (500 BC-AD 1030), more efficient gears using hooks and spears were developed. Temporary dams built to block lake outlets were probably also used in prehistoric times. These enabled the fish in the river to be easily gathered up. No special equipment was necessary to build such dams other than timber, rock slabs, and turf.

\section{TAKK}

Ein takk til Axel Mjærum, Elling Utvik Wammer og ein anonym fagfelle for nyttige kommentarar til fyrste utkastet til denne artikkelen. 


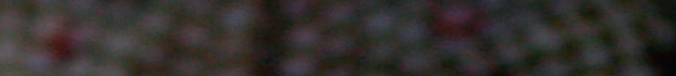

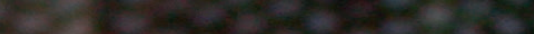

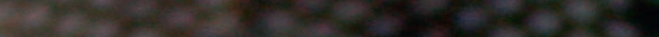

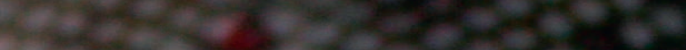

ase

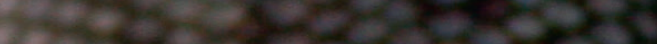

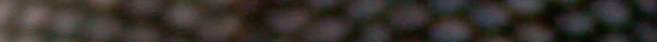

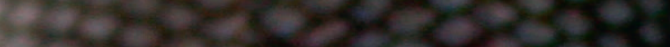

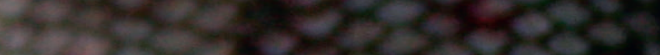

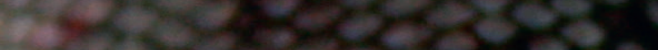

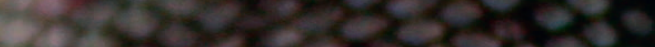

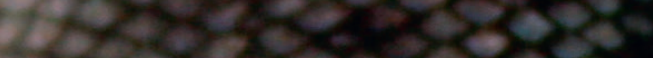

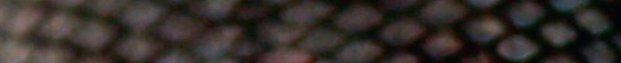

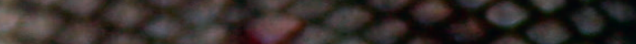

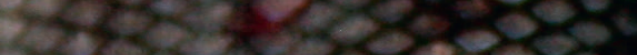

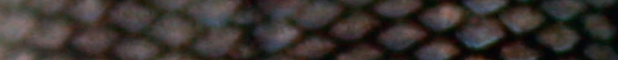

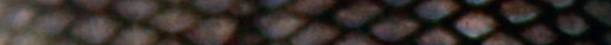

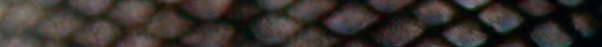

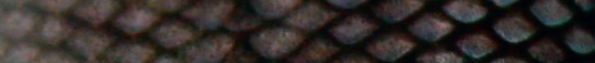

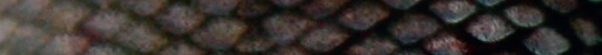

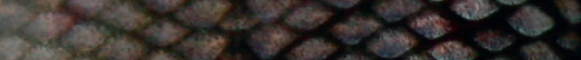

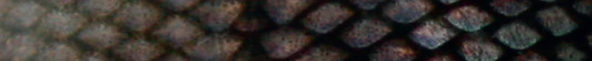

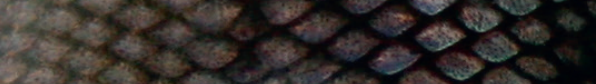

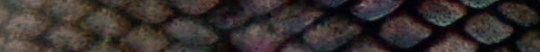

103208200

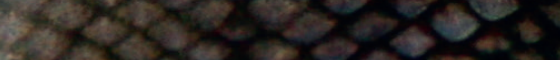

$200 \times 900 \times 4$

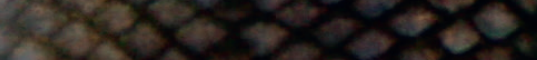

$3 \times 2 \times 100000$

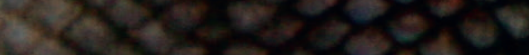

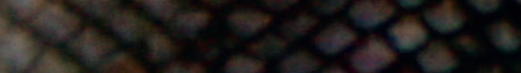

$0 \times 1 \times 980$

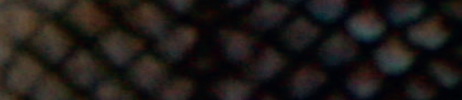

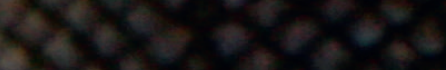

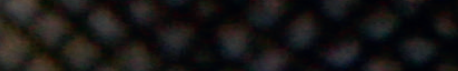

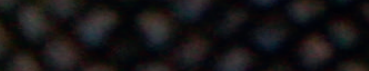

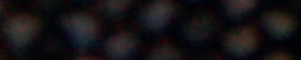

$110 \times 0^{2}=$

(e) $110+20$

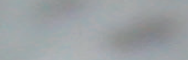

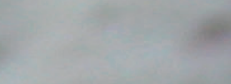

$\sin ^{2}$

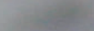

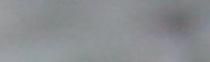

axi

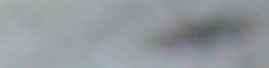
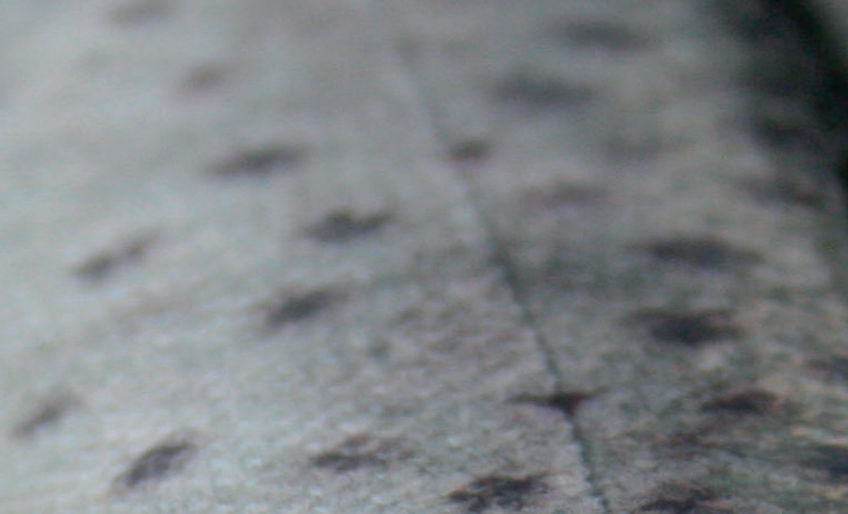

\section{ats}

$$
\text { (1): }
$$

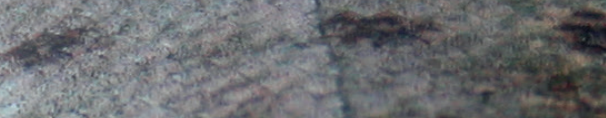

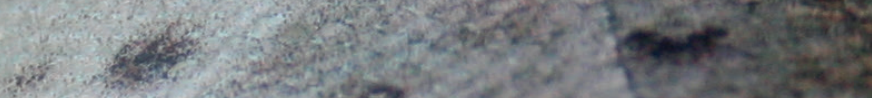

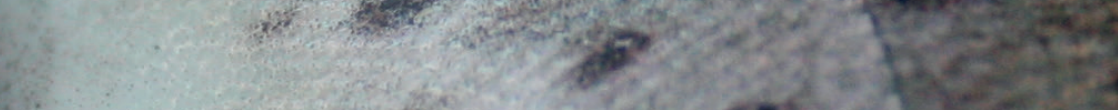

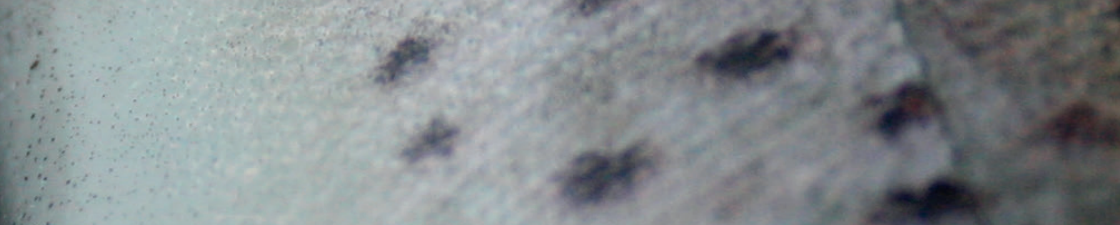
t)

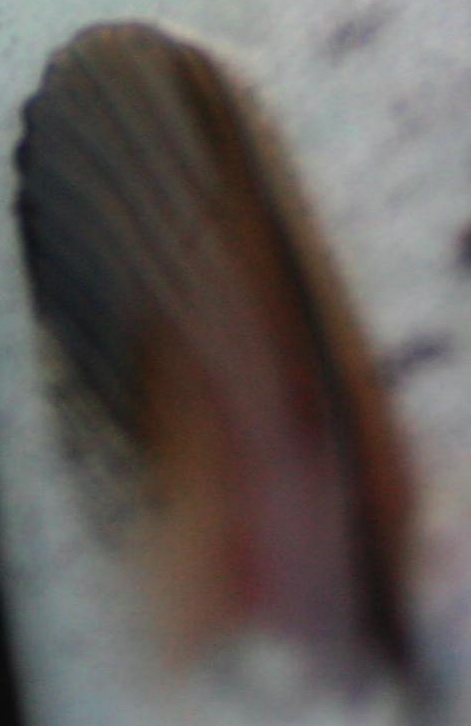




\title{
FJELLFUNN OG FISKEBEIN - OM FISKE OG BRUKEN AV FJELLET I FORTIDEN
}

\author{
Anne Karin Hufthammer, Universitetsmuseet, Universitetet i Bergen og Axel Mjarum, \\ Kulturhistorisk museum, Universitetet i Oslo
}

Både fjellvannet Tesse i Jotunheimen, Møsvatn på Hardangervidda og Bosvatn i det øvre av Setesdalen er kjent som ypperlige fiskevann. Skriftlige kilder og muntlige tradisjoner forteller at det har blitt fisket i disse innsjøene mange århundrer bakover i tid. ${ }^{1}$ Vannene har også til felles at det har blitt gjennomført arkeologiske utgravninger ved dem, og at det har fremkommet fiskeredskaper, slik som fiskekroker og garnsøkker. ${ }^{2}$ Det finnes ytterligere en likhet: Disse utgravningene har ikke frembrakt et eneste fiskebeinsfunn. Andre steder i den sørnorske fjellheimen har arkeologer derimot gravd frem bein av ørret. Tidvis har de funnet et fåtall ryggvirvler, mens fiskebeina i andre tilfeller foreligger i tusentall. ${ }^{3}$

I denne artikkelen vil vi løfte frem fiskebeina som kilde til kunnskap om fortidens fiske. $\mathrm{Vi}$ vil diskutere hvordan disse små og skjøre beina i enkelte tilfeller kan bevares i jorden i flere tusen år, mens de svært ofte bare forsvinner, uten å etterlate seg spor. Bevaringsforholdene skaper utfordringer i bruk av fiskebein som en kulturhistorisk kilde, og vi vil derfor også diskutere kildeproblemene og kunnskapsverdien til det beinmaterialet som faktisk foreligger.

Det er undersøkt beinmaterialer fra mange arkeologiske utgravninger i sørnorske fjellområder, ${ }^{4}$ både fra førhistorisk og fra historisk tid. Det blir imidlertid sjelden identifisert ferskvannsfisk. I alt er det funnet ørret i 29 beinfunn og sik i 2. Flest funnsteder ligger i Hordaland (8), Oppland (8), Buskerud (4) og Hedmark (4), men også i Sogn og Fjordane (2), Telemark (2) og Aust-Agder (1) er det funnet bein av fisk (se figur 1, figur 4 og vedlegg).

At fiskebeina har ulik alder og forekommer i ulike kulturhistoriske sammenhenger, gir et grunnlag for å diskutere hva fisket har betydd, og hvordan det har blitt kombinert med andre gjøremål. Vi vil derfor ikke bare vie oppmerksomheten til fiskebeina i seg selv, men også presentere jaktplassene, overnattingsstedene, hellerne og de andre kontekstene hvor bein opptrer. Hovedvekten vil ligge på funnstedene i de høyereliggende innlandsområdene og den alpine sonen med spor etter aktivitet fra slutten av yngre steinalder (fra ca. 2350 f.Kr.) og helt frem til 1700-tallet e.Kr., det vil si fra begynnelsen av det tidsrommet da også husdyrhold og dyrking har hatt en stor betydning som næringsveier i det indre av Sør-Norge. Men ferskvannsfisket kan være eldre, noe som omtales inngående i en egen artikkel i denne boken. ${ }^{5}$ 


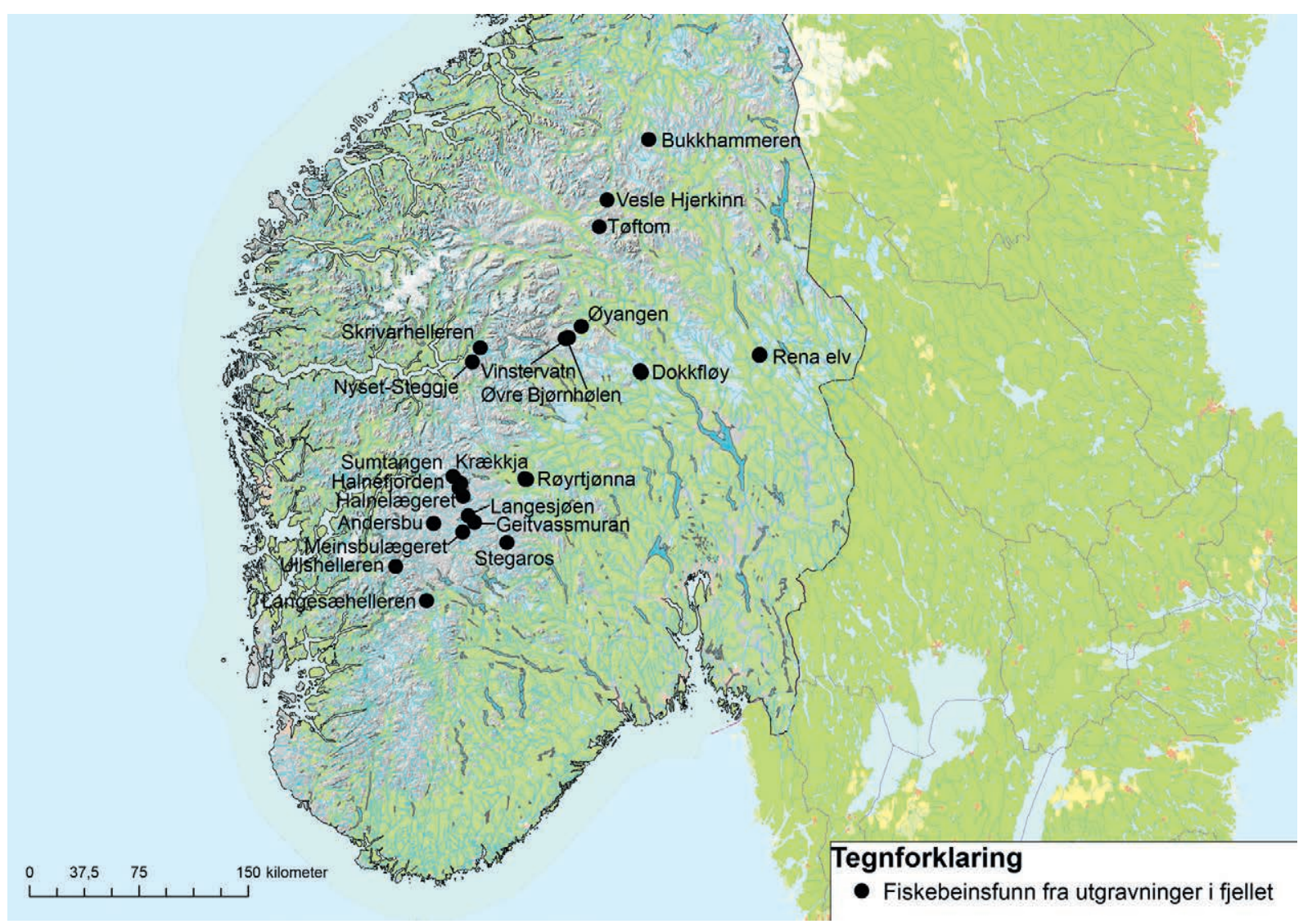

Figur 1: Funnsteder for fiskebein ved arkeologiske utgravninger i fjellheimen. Kart: Axel Mjærum, KHM.

\section{TAFONOMI, LÆREN OM DET SOM FORSVINNER, OG DET LILLE SOM BEVARES}

Tafonomi er studiet av alle de faktorer som påvirker en organisme fra den begraves, til restene av den blir gravd ut eller hentet frem fra jorden, ${ }^{6}$ i vårt tilfelle som enkeltbein eller hele skjeletter. Selv om fisk utgjør en betydelig del av kostholdet og er vanlig i mange kulturkontekster, er bein av fisk i mange arkeologiske funn mye sjeldnere enn eksempelvis bein av pattedyr. Det kan være flere årsaker til dette, eksempelvis at mange fiskebein er små og tynne (figur 2). Dette innebærer at de knuses lett, og at de gjerne blir oversett under utgravninger. ${ }^{7}$ I tillegg fører den kjemiske sammensetningen i kollagenet og forholdet mellom kollagen og mineraler til at fiskebein, spesielt bein av enkelte fiskeslag som laks og ørret, lettere brytes ned enn bein av pattedyr. ${ }^{8}$

De aller fleste fiskebein vi finner fra innlandet, er brente, og de gjenfinnes ofte som hvite, små fragmenter (figur 3). Når bein brennes, vil de ulike kalsiumsaltene i den uorganiske delen bli omdannet til kalsiumapatitt, som er nærmest uoppløselig. Samtidig vil beina krympe, noen ganger så mye 
Days Patt \& IRTSH SATMONTDE. Plate II

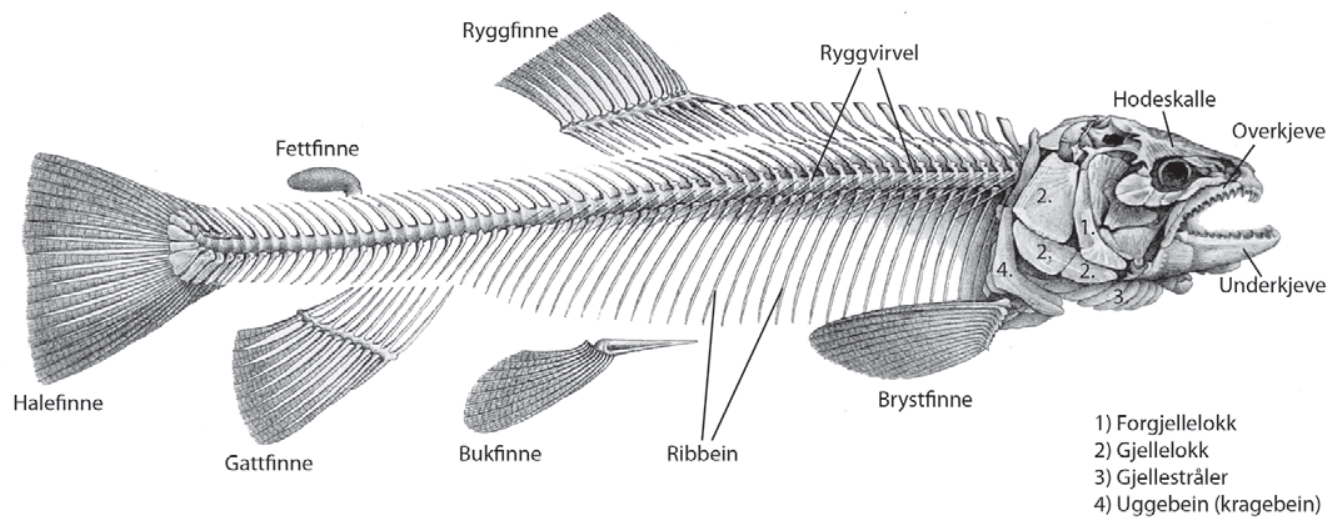

Figur 2: Ørretens skjelettanatomi. Illustrasjon: Axel Mjærum. Bearbeidet med utgangspunkt i Day 1887: table 2.

som 25 prosent. Det betyr at brente bein bevares betydelig bedre enn ubrente, men at de krymper og sprekker opp og blir vanskelige å artsbestemme. Katariina Nurminen ${ }^{9}$ har brent bein av en rekke ferskvannsfisk og finner stor variasjon i hvor mye av beinmaterialet som bevares, og som kan artsbestemmes. Generelt forsvinner alle kraniebein av ørret og fet hvitfisk, som lagesild, ved brenning, mens virvlene bevares relativt bra. Ikke uventet bevares bein av større arter eller individer bedre enn bein av små fisk.

Sammensetningen av jordsmonnet har også betydning for bevaringsforholdene, og tilstedeværelsen av store mengder pattedyrbein er vesentlig for at fiskebein skal kunne bevares (jf. figur 4). Årsaken er at bein har en form for «selvkonserverende» effekt, der blant annet en stor samlet kalkmengde sikrer at beina ikke går i oppløsning.

Ulike tafonomiske prosesser virker altså på ulike vis og i ulik grad. Samlet kan de imidlertid skape et fordreid bilde av fortiden. Denne mulige fordreiningen er viktig å ha med seg videre når vi nå skal presentere og diskutere utgravningsstedene $\mathrm{i}$ den norske fjellheimen hvor det er funnet fiskebein.

\section{FISKEBEINA OG FUNNSTEDENE}

I skildringer av bruken av fjellområdene de siste århundrene fortelles det om en variert ressursbruk med husdyrhold, jakt, snarefangst og fiske som viktige elementer, men også med noe korndyrking. ${ }^{10}$ Denne allsidigheten er ikke bare knyttet til at man har utnyttet et bredt spekter av ressurser, 


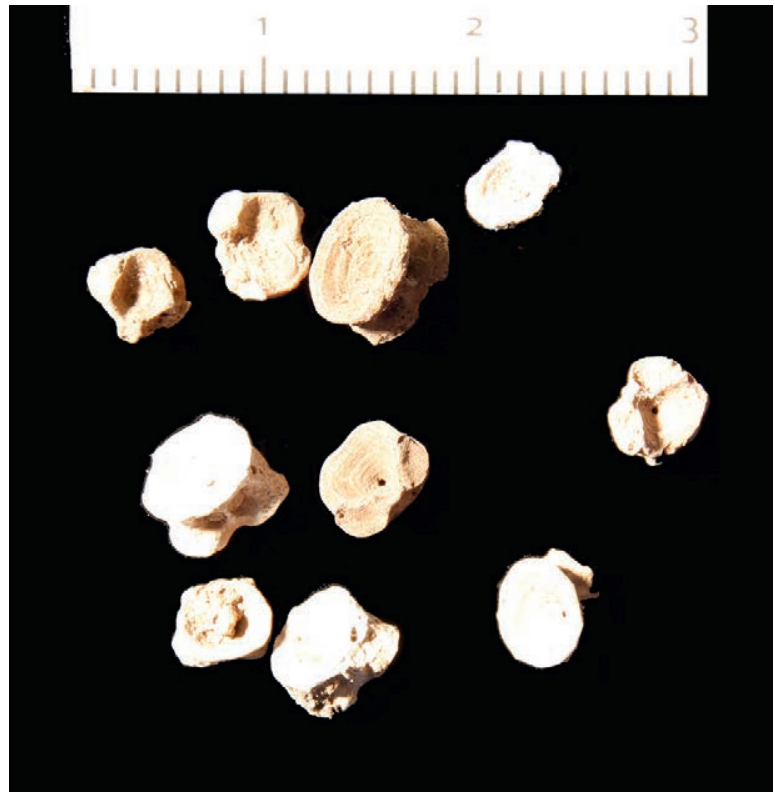

Figur 3: Ryggvirvler datert til bronsealderen fra Røyrtjønna ved Pålsbufjorden (ca. 740 moh.) på østsiden av Hardangervidda. Foto: Axel Mjærum, KHM.

men også til at man ofte har kombinert jakt, fiske og husdyrhold, og at steder har spilt ulike roller og hatt ulike funksjoner gjennom tidene. Det arkeologiske materialet gjenspeiler denne allsidigheten, blant annet ved at det nokså hyppig fremkommer redskaper som kan knyttes til jordbruk, jakt og fiske, på samme funnsted, og ved at bein fra både ville og tamme dyr finnes i de samme avfallslagene. I tillegg har det ofte foregått aktivitet i mange perioder på funnplassene. Det er derfor ikke alltid enkelt, og tidvis heller ikke helt korrekt, å knytte ett funnsted til én bestemt aktivitet.

Ofte gir allikevel beliggenheten og det fremgravde materialet et grunnlag for å skille mellom funnsteder som har vært rettet mot ulike aktiviteter. I den følgende gjennomgangen har vi forsøkt å gjøre nettopp et slikt skille for å få frem allsidigheten og for å synliggjøre i hvilken utstrekning fisket har blitt drevet i kombinasjon med andre gjøremål og næringer. Det vil også diskuteres hvilken betydning fisket har hatt sammenlignet med den øvrige aktiviteten $\mathrm{i}$ innlands- og fjellområdene.

\section{MASSEFANGSTANLEGGENE OG FISKET}

De eldste lokalitetene fra fjellheimen med fiskebeinsfunn er fangstboplasser hvor jakt på elg og rein har vært en hovedaktivitet, men hvor fisket har inngått som en binæring. ${ }^{12}$ Helt siden steinalderen har jakten vært både planmessig og målrettet, og de store jaktplassene har ofte ligget langs de sesongmessige trekkrutene til storviltet. ${ }^{13}$ I jernalderen og middelalderen skjer det stedvis en ytterligere intensivering av fangsten, med økt bruk av fangstgroper, sperregjerder og store og komplekse fangstanlegg. Både sentralt på Hardangervidda og på Dovre har det blitt gravd ut steinbuer og avfallslag knyttet til denne massefangsten, ${ }^{14}$ og disse undersøkelsene belyser også fjellfiskets betydning for jegerne.

\section{Fangstanleggene sentralt på Hardangervidda}

På Sumtangen ved Finnsbergvatn sentralt på Hardangervidda og ved de nærliggende vannene Store Krækkja og Ørteren har det blitt gjennomført undersøkelser av steinbuer og avfallslag knyttet til massefangst seint på 1200-tallet e.Kr. ${ }^{15}$ Ved Sumtangen ligger det i tillegg spor etter en eldre fase med jakt, tidfestet til 200-400-tallet e.Kr. (figur 5). Denne samlingen med undersøkte anlegg gir mulighet til å studere aktiviteten ved vannene over tid, men også til å sammenligne fangstplassene fra middelalderen.

Avstanden mellom Finnsbergvatn og Store Krækkja er kun noen få kilometer, men det er én vesentlig forskjell som er relevant i denne sammenhengen. Mens det har vært fisk i Store Krækkja langt tilbake i tid, har blant annet den over 180 meter høye 

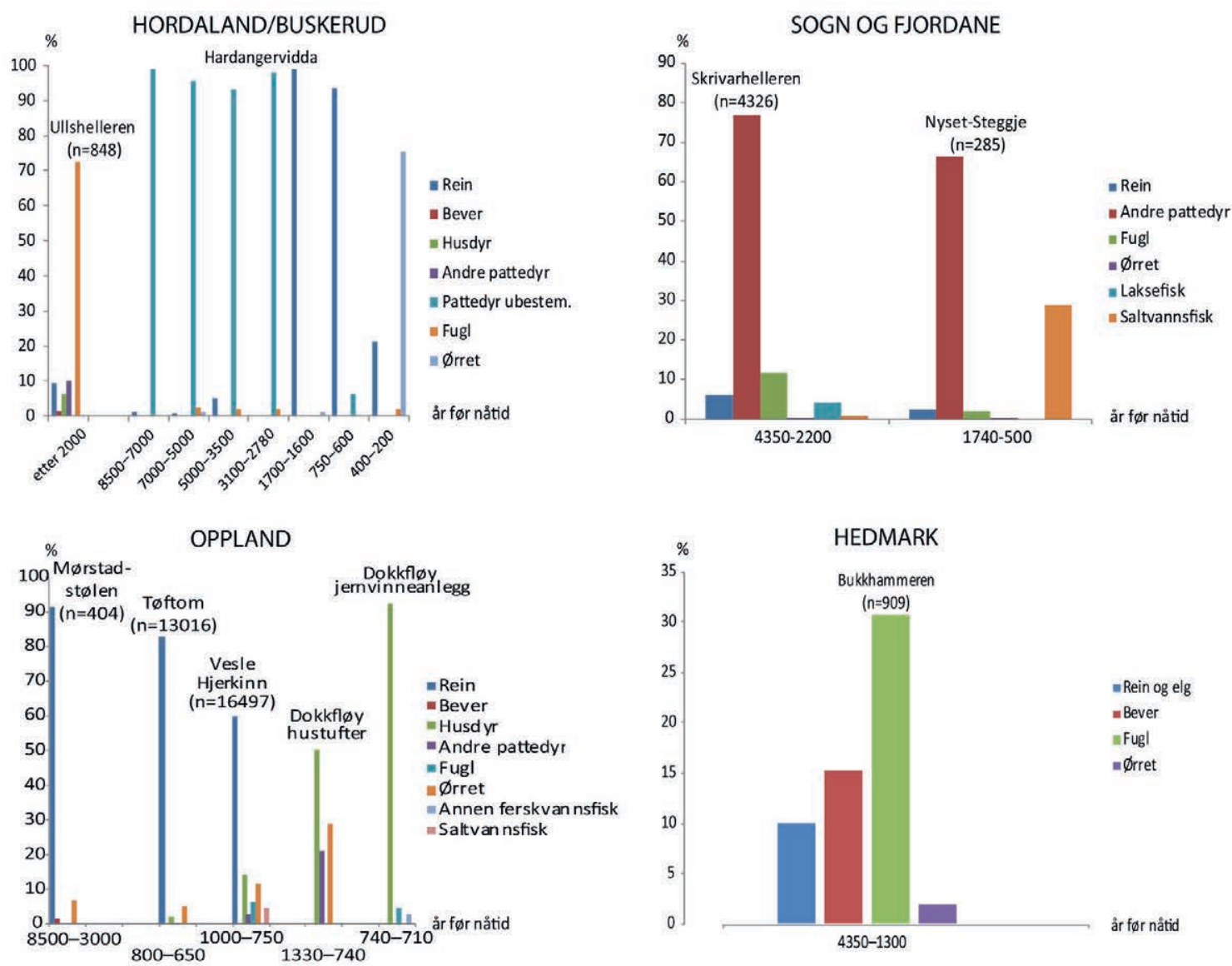

Figur 4: Artsfordelingen av beinfunn på sentrale funnsteder i de sørnorske innlandsområdene. Antall artsbestemte bein angis med $\mathrm{n}$ i de tilfellene det er bevart ubrente bein. ${ }^{11}$ Tallmaterialet bygger på arkivopplysninger knyttet til beinmaterialet som er analysert og magasinert ved Universitetsmuseet i Bergen.

Vøringsfossen nede i Måbødalen hindret ørreten fra å etablere seg i Finnsbergvatn. Vannet var trolig fisketomt frem til utsetting i 1927. ${ }^{16}$ Denne forskjellen kan man også ane i faunamaterialet som er bevart. Ved Sumtangen foreligger det kun 13 skjelettdeler av fisk av et gjennomgått materiale på over 23000 bein i middelalderlagene. ${ }^{17}$ Tre av disse er artsbestemt til ørret, mens også hyse, sild og torsk er representert. I tillegg fortelles det om funn av brosme og makrell i avfallsdyngene. ${ }^{18}$ Saltvannsfisk er med andre ord vel så godt representert som ørret, og ellers er det slående at antallet fiskebein totalt sett er svært lite. Selv om man skal være varsom med å trekke bastante konklusjoner ut fra funnmengden, er det nærliggende å tro at ørretfisket har hatt en minimal betydning $\mathrm{i}$ forbindelse med massefangsten her i 


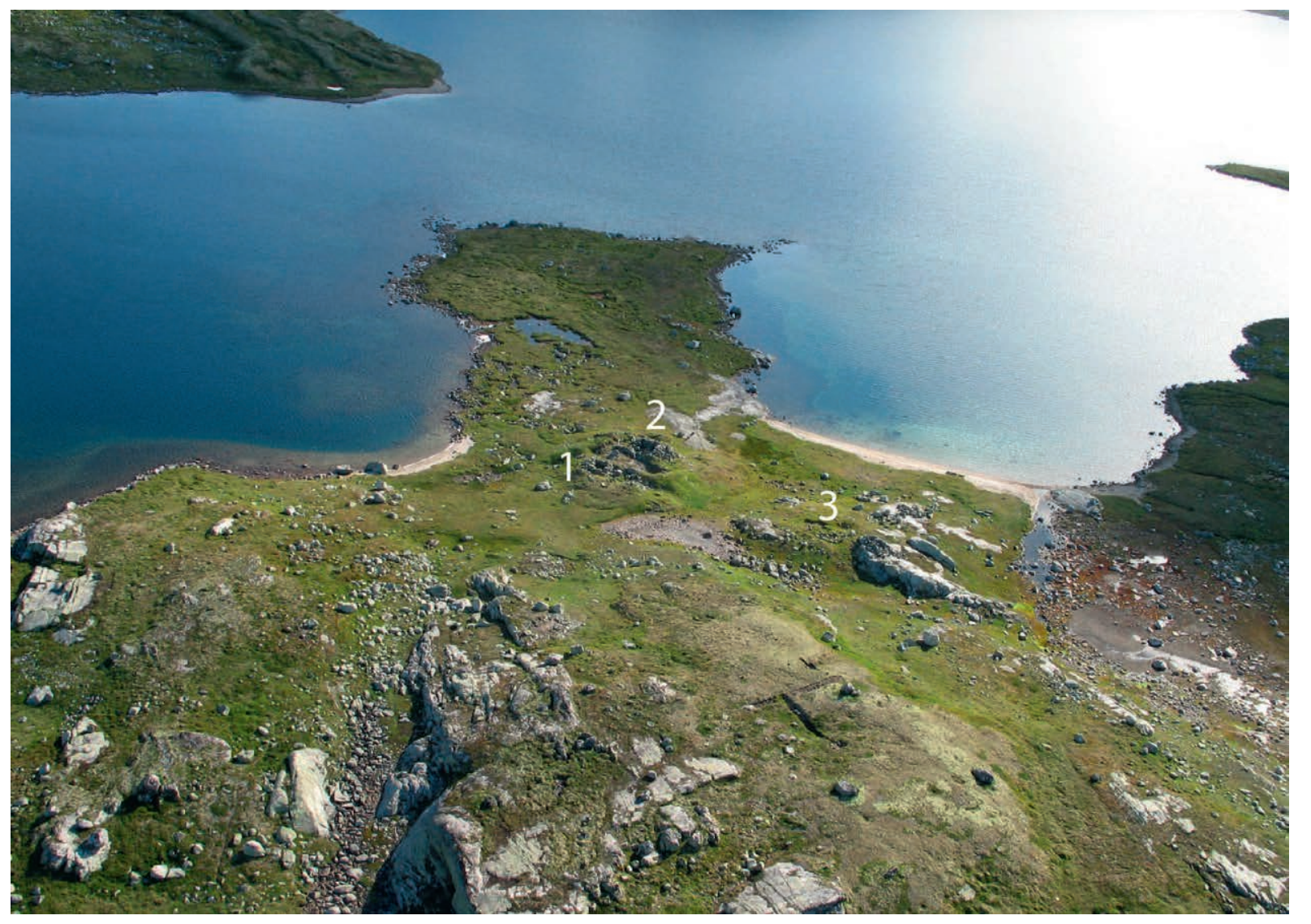

Figur 5: På Sumtangen ved Finnsbergvatn ligger både de to middelalderruinene Vestbu (1) og Austbu (2) og den 1000 år eldre tuften Sørbu (3). Foto: Svein Indrelid.

middelalderen, noe som da også er som forventet ved et fisketomt vann.

Én beindynge er imidlertid nesten 1000 år eldre, og fiskebeinsmaterialet herfra skiller seg noe ut fra middelalderfunnene. Det forteller ikke bare om andre tradisjoner knyttet til reinsjakten, ${ }^{19}$ men også om at det i større grad har blitt spist fisk. Det har vært flere utgravninger i denne beindyngen. I en av undersøkelsene er det funnet 2113 bein av rein og hele 107 bein av ørret, men bare 4 av torsk og 2 av brosme. Høyst sannsynlig var det heller ikke fisk i Finnsbergvatn i eldre jernalder, så beinfunnene kan tyde på at man har fisket ørret i andre vann på vidda, og at man brakte den med seg som niste til Sumtangen i århundrene etter Kristi fødsel.

Beindyngene ved Store Krækkja er fra slutten av 1200-tallet, og fangsten må ha foregått samtidig med jakten på Sumtangen. ${ }^{20}$ Her er det totalt 58 fiskebein spredt i avfallslagene, hvorav 33 er bestemt 

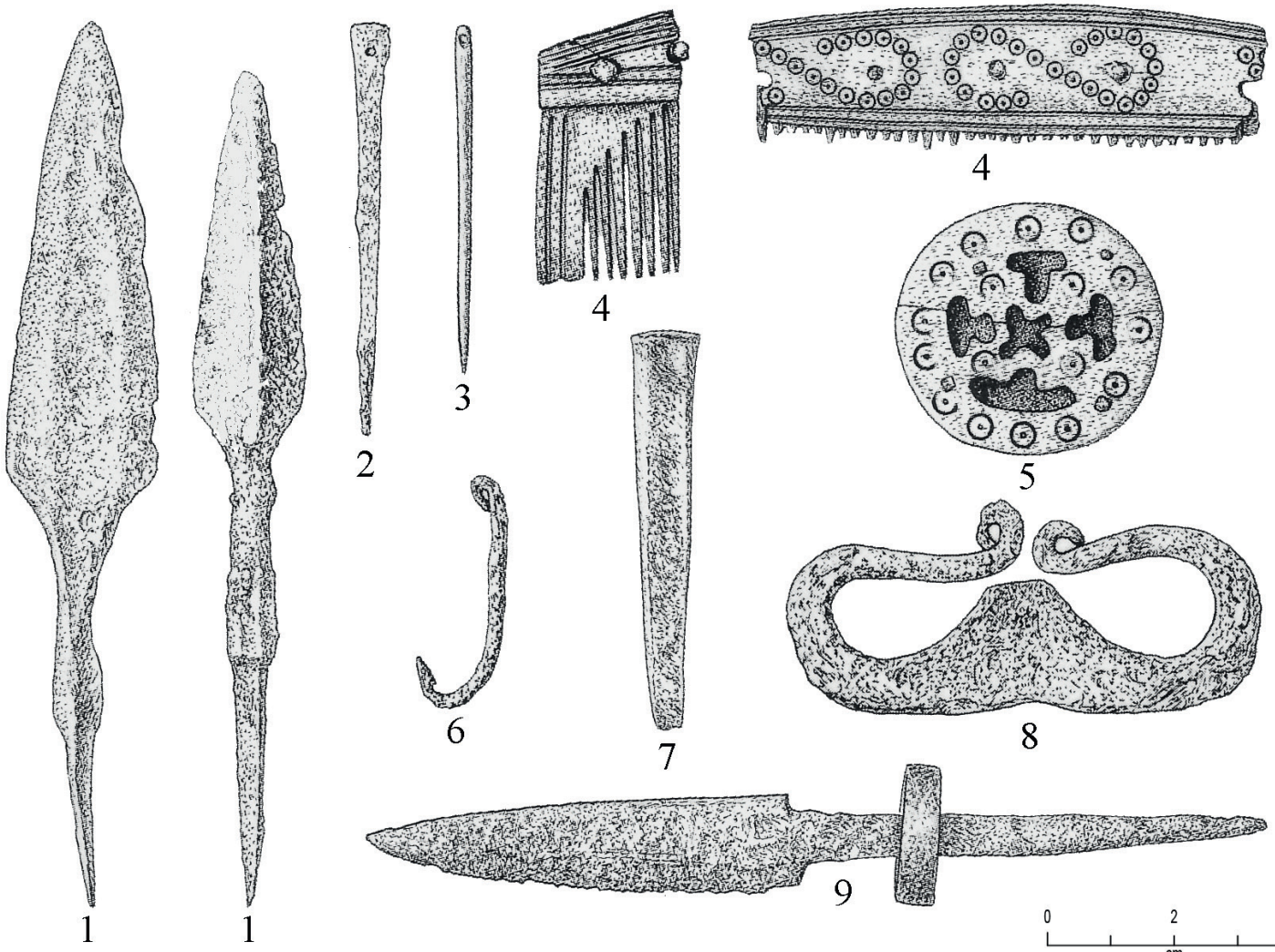

4
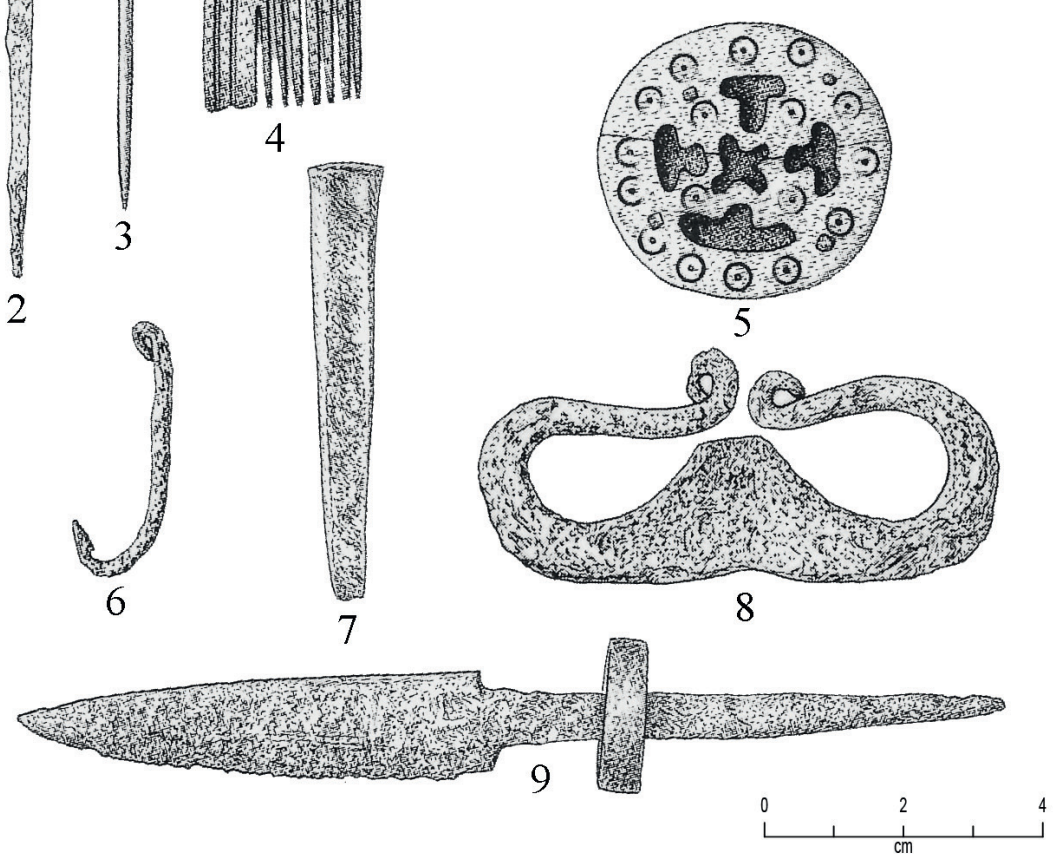

Figur 6: Gjenstander datert til tidsrommet 600-1300 e.Kr. som viser en allsidig aktivitet på Tøftom: (1) pilspisser av jern, (2) anheng eller nål av jern, (3) (sy?)nål av jern, (4) kammer av gevir, (5) spillebrikke av gevir, (6) fiskekrok av jern, (7) meisel av jern, (8) ildstål, (9) kniv av jern. Illustrasjon: Tone Strenger, KHM.

til ørret og resten er ubestemt. Beinmaterialet viser med all tydelighet at reinfangsten også her har vært hovedmålet ved besøkene, men fiskebeinsfunnene antyder allikevel at det har blitt fisket i Store Krækkja. Bevaringsforholdene gjør det imidlertid vanskelig å bedømme betydningen av dette fisket. At det faktisk har blitt fisket ved siden av jakten, underbygges av at det foreligger to fiskekroker fra steinbuene knyttet til den tredje fangstplassen fra 1200-tallet i området, nemlig Ørteren. ${ }^{21}$

\section{Toftom i Rondane}

I andre fjellområder er det også massefangstanlegg for rein. Et av disse er Einsethø i Grimsdalen i Rondane. Bare om lag 150 meter fra enden av dette anlegget ligger Tøftom, et sted hvor det har stått flere buer, og hvor det har blitt lagt igjen store mengder med slakteavfall. ${ }^{22}$ På Tøftom har det vært aktivitet siden 400-tallet og frem til nyere tid, men med en hovedbruksfase fra ca. år 1000 til 1200 -tallet. ${ }^{23}$ 


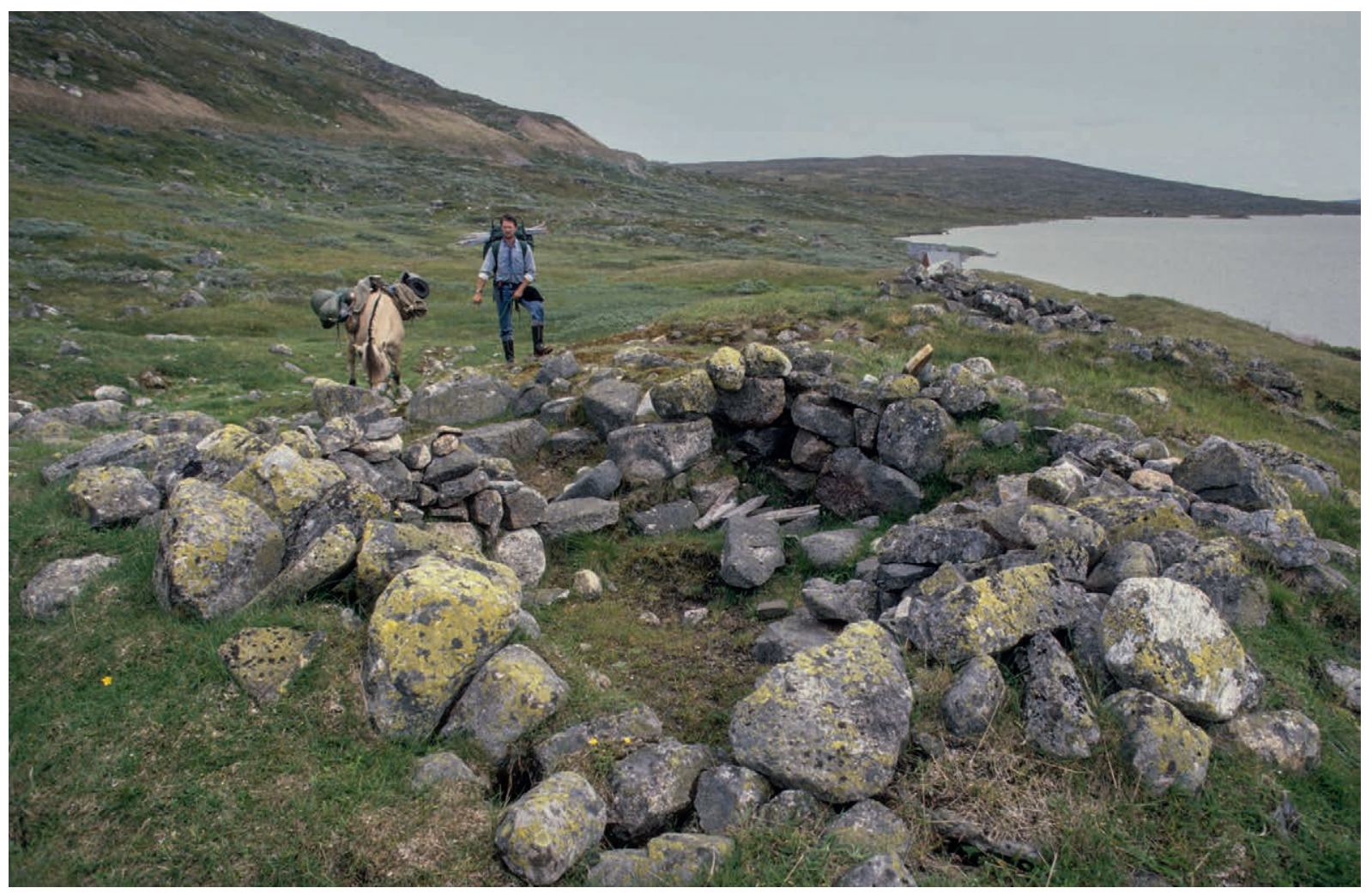

Figur 7: Grunnmurene til steinbuene ved Halnelægeret, tett ved Normannsslepa på Hardangervidda. Stedet har vært besøkt av ferdafolk og buskap. I avfallslagene i tilknytning til buene var det store mengder fiskebein. Foto: Helge Sunde.

Én av bygningene på Tøftom har blitt inngående undersøkt. Den ble trolig reist på 1200-tallet, og den fikk forfalle etter år 1300, men det er sannsynlig at det også har stått buer på tomten på et tidligere tidspunkt. ${ }^{24}$ Fra ildstedet i bygningen ble det samlet inn masser, som ble finsiktet, og i disse ble det funnet over 1270 fiskebein, med ørret som den klart dominerende arten. Fra tufta foreligger også én fiskekrok (figur 6). Funnene viser at fisk var et betydelig tilskudd til kosten. ${ }^{25}$ Det er også verdt å merke seg at det har blitt funnet enkelte ryggvirvler av sild og torsk i de samme lagene, noe som trolig kan forklares med at tørket fisk ble brakt til plassen som handelsprodukt. ${ }^{26}$

\section{SÆLEHUS, LÆGRENE OG FISKET}

Den sørnorske fjellheimen skiller øst fra vest og sør fra nord, men ferdselen til lands og til vanns gjennom fjellheimen har bidratt til å binde landsdelene sammen. Langs ferdselsrutene har det ligget stoppesteder hvor mennesker og dyr har kunnet finne ly og hvile. Både på Hardangervidda og på Dovrefjell ligger det slike oppholdssteder, som har blitt gjenstand for arkeologiske granskinger. 
Halnefjorden har ord på seg for å være det beste fiskevannet på Nordvestvidda, og i nordenden av vannet har også den nordre Normannsslepa gått, en ferdselsvei som har forbundet Hardanger og Hallingdal. ${ }^{27} \mathrm{I}$ nordenden av vannet ligger Halnelægeret (figur 7). Navnet forteller om et sted der folk lå med flokker av husdyr i sommerhalvåret, men tradisjonen sier også at det har blitt benyttet som overnattingssted for reisende langs Normannsslepa frem til tidlig på 1800-tallet. Ved en utgravning av to steinbuer ble det funnet store mengder hesteskosøm og hestesko samt mynter, små stykker av krittpiper, glass og annet som vitner om ferdsel og kontakter langt utenfor fjellheimen. ${ }^{28}$ Materialet som fremkom, gir grunnlag for å datere aktiviteten til en periode på 200-300 år, fra om lag 1600 e.Kr. Det var også mye bein i tilknytning til bygningene, i hovedsak av rein, men også levninger av husdyr og rype. Sikting gjennom finmasket nettingduk frembrakte om lag 7400 fiskebein. Foruten ett bein av hyse og to av torsk har fiskebeina utelukkende blitt bestemt til ørret. ${ }^{29}$ Fiske var en viktig aktivitet for dem som lå på stedet med husdyr eller reiste gjennom fjellheimen, og tre fiskekroker i jern viser hvordan noe av dette fisket foregikk. De store mengdene fiskebein antyder også trolig et mer intensivt fiske, og kanskje ble både garn og båt benyttet?

Veien fra Gudbrandsdalen til Nidaros går over Dovrefjell, og på Hjerkinn ble det reist 6 bygninger, deriblant en 20 meter lang og 8 meter bred hall. Dette store anlegget tjente som sælehus og var utgangspunkt for reinsjakt, og stedet kan ha vært en kongsgård fra Harald Hårfagres regjeringstid. ${ }^{30}$ Det bød på et usedvanlig rikt funnmateriale, med mynter, smykker, hesteutstyr, jaktredskaper og ellers rester av svært mange av de redskapene man kan forvente fantes på en velutstyrt fjellgård i vikingtiden og middelalderen. På 1980-tallet ble det undersøkt en avfallshaug med bein tidfestet til ca.1050-1265
e.Kr. på tunet. I denne store haugen utgjør reinsdyrbein om lag 70 prosent av knokkelmaterialet, mens ørret er den mest tallrike fiskearten. Det ble ellers fremgravd bein av ferskvannsfisken harr, men også sild og en rekke andre saltvannsarter. Beinfunnene vitner om en ustrakt bruk av lokale ressurser, og det har utvilsomt blitt fisket ørret, og kanskje harr, i nærområdet. ${ }^{31}$ Mye fisk har også blitt brakt til gården av dem som reiste til og fra. Det foreligger to fiskekroker som kan knyttes til det lokale fisket, ${ }^{32}$ og garnsøkker i kleber antyder at lette ørretgarn har vært $\mathrm{i}$ bruk i vannene. ${ }^{33}$

\section{JERNVINNA OG FISKET}

Jernproduksjonen basert på myrmalm og brensel strekker seg tilbake til århundrene før Kristi fødsel i Sør-Norge, men helt frem til vikingtiden foregikk hoveddelen av produksjonen i lavlandet og i sonen mellom lavland og fjell. Omkring år 1000 e.Kr. ekspanderer produksjonen, og den får nærmest industrielle dimensjoner i enkeltområder frem til store deler av produksjonen avvikles på 1300- og 1400-tallet. ${ }^{34}$ I den skogkledde randsonen til mange fjellområder utnyttet man da myrmalm og store mengder brensel i form av trevirke.

Både antallet anlegg og produksjonsmengden er iøynefallende trekk, et annet er graden av spesialisering som preger disse anleggene. Sporene etter andre aktiviteter er som oftest få. Blesterplassene har altså blitt etablert med et klart hovedmål, produksjon av jern. Flere titalls anlegg har blitt undersøkt, og i enkelte områder er det ikke uvanlig å finne bein i ildsteder og i slagghaugene. ${ }^{35}$ Skjelettmaterialet som har fremkommet, er ofte ganske lite, men variert; både husdyr, reinsdyr, fugl og hund er representert. Den nokså begrensede mengden bein, variasjonen i materialet og beliggenheten til ildstedene kan tale for at det er rester etter måltidene til arbeiderne ved anleggene. 
På slike anlegg har arkeologene i minst tre tilfeller funnet fiskebein. ${ }^{36}$ To av funnene er gjort i produksjonsanlegg i Bykle i Setesdalen, et sted hvor man vet at det foregikk fiske da jernvinneanleggene ble etablert i vikingtiden og middelalder. ${ }^{37} \mathrm{I}$ et ildsted på Dokkfløy i Oppland foreligger det fem bein, hvorav ett har latt seg artsbestemme til laksefisk og to til sik. Det har etter alt å dømme vært spist fisk, men her er usikkerheten knyttet til hvor det ble fisket, større. Sik ble nemlig introdusert til Dokkavassdraget først på 1900-tallet. ${ }^{38}$ Sikfisket har derfor neppe skjedd lokalt, og heller ikke laksefisken behøver nødvendigvis å ha blitt fanget i Dokkavassdraget, selv om det meget vel kan ha blitt fisket i dette vannet i middelalderen. ${ }^{39}$

På jernvinneanleggene er det samlede beinmaterialet ofte lite. Av denne grunnen er det sjelden det dannes kalkrike miljøer hvor fiskebein kan bevares. Det er derfor vanskelig å sammenligne jernvinnefunnene med funnene fra større beindynger, men det er interessant at det forekommer fiskebein på steder med jernproduksjon. Samtidig bør det konkluderes med at jernproduksjonsplassene nettopp har vært produksjonsplasser for jern, og de var neppe betydningsfulle utgangspunkt for fjellfisket.

\section{HELLERNE OG FISKET}

I fjellheimen danner en rekke bergutspring naturlige oppholdssteder. Under disse små og store hellertakene og i enkelte huler har det vært bosetning langt bakover i tid, og funnene i dem gjenspeiler i stor grad hvilke ressurser som ble utnyttet i nærområdene i fortiden. Hellerboplassene er således ikke resultat av én bestemt aktivitet. De har allikevel fellestrekk som gjør det hensiktsmessig å fremstille fiskebeinfunnene fra hellerne i fjellheimen samlet.

Mange av disse naturgitte boligene har på kysten vært i intensiv bruk gjennom store deler av steinalderen, ${ }^{40}$ mens de som befinner seg i fjellområdene, ser ut til å ha hatt begrenset betydning så lenge jakt og sanking var viktigste næringsvei. Mot slutten av eldre steinalder (fra ca. 2350 f.Kr.) fikk jordbruket imidlertid sitt endelige gjennombrudd, og fjellheimen ble viktig som beitemark for husdyr. ${ }^{41}$ Samtidig ble de indre områdene trolig tettere knyttet til kysten, og skinn og gevir kan i økt grad ha blitt fraktet til kyststrøkene. ${ }^{42}$ Kanskje derfor fikk hellerne en viktigere rolle, blant annet som utgangspunkt for jakt, som tilholdssteder for husdyr og gjetere og som plasser for lagring av fôr. Det foreligger indikasjoner på at kontakten mellom kyst og innland blir redusert i århundrene før Kristi fødsel, og flere av hellerne i fjellheimen går samtidig ut av bruk. ${ }^{43}$ I mange av dem finner man imidlertid også spor etter besøk helt frem til nyere tid, og flere av dem som har ligget nær setre og jordbruksstrøk, har spilt en viktig rolle gjennom jernalderen og middelalderen. ${ }^{44}$

Avfallslagene i huler og hellere har fått ligge beskyttet fra vær og vind, noe som i mange tilfeller har sikret svært gode bevaringsforhold. I utgangspunktet skulle da materialet være svært godt egnet utgangspunkt for å studere fangst og fiske. ${ }^{45}$ Det har imidlertid ikke alltid blitt lett målrettet etter de små fiskebeina ved utgravninger, og mange av dem har trolig blitt oversett. Et annet problem er at hellerne kan ha vært i bruk i flere perioder, noen ganger over svært lang tid. Gjentatte opphold fører til at avfallslagene i helleren ofte blir rotet om og det er vanskelig å tidfeste enkeltfunn ut fra lagdelingen og dateringer. Det er allikevel funnet fiskebein i en stor andel av hellerne hvor det har blitt foretatt omfattende utgravninger, og disse oppholdsstedene kan gi et innblikk i fortidens fjellfiske.

Skrivarhelleren ligger i bjørkeskogsbeltet i Moadalen 790 moh., i et dalføre som strekker seg fra Årdalsvatnet og opp mot fjellvannet Tyin i Sogn og Fjordane. ${ }^{46}$ Innsjøene som ligger nærmest denne helleren, er Torolmen og det lavereliggende 


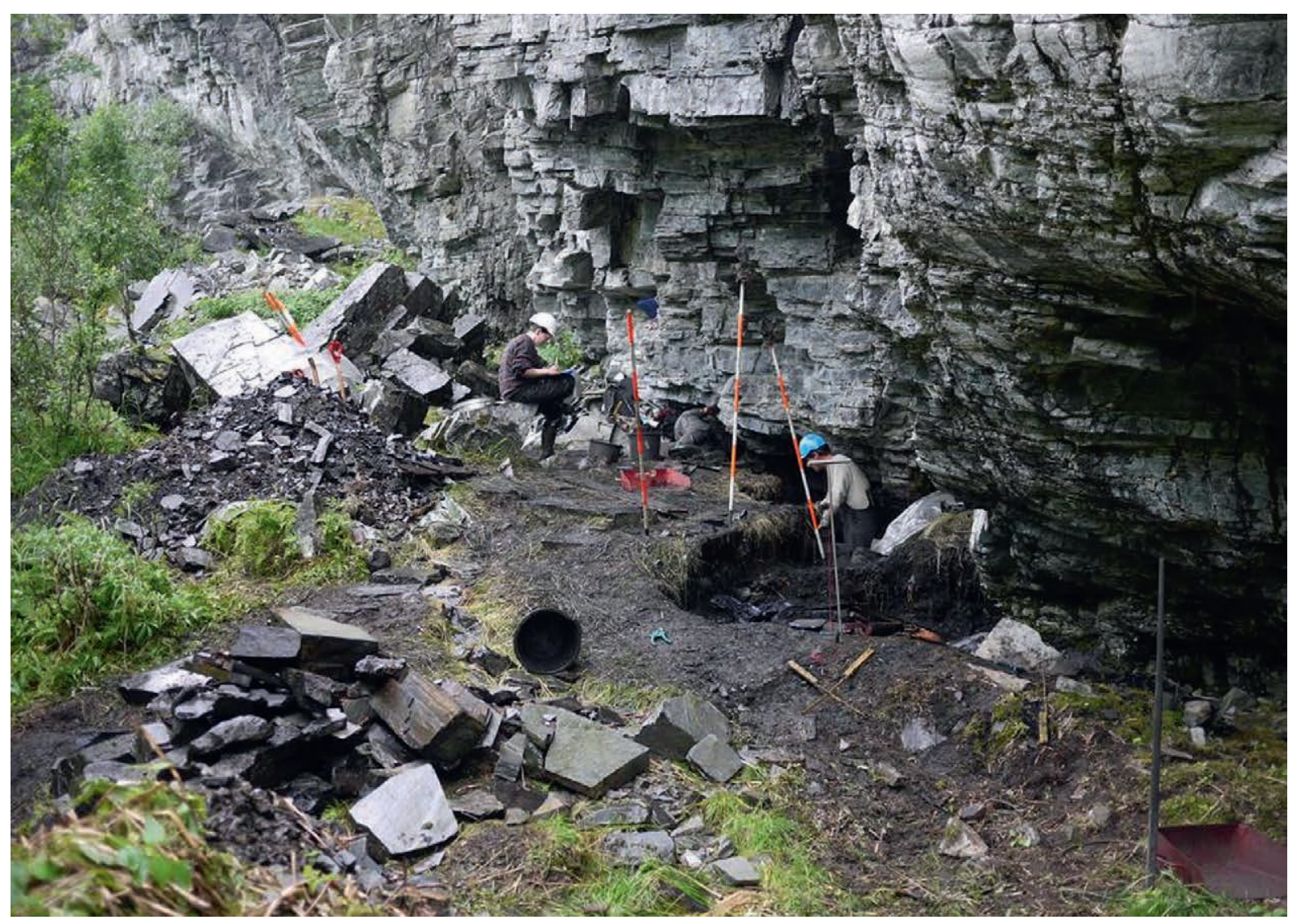

Figur 8: Utgravninger i Skrivarhelleren i Moadalen (790 moh.) i Årdal. Foto: Forsknings- og utgravingsprosjektet Arkeologi i Skrivarhelleren.

Årdalsvatnet. I tillegg renner elven Tya noen hundre meter nedenfor helleren. Både Tyin, Torolmen og Tya var kjent for stor ørret i tidligere tider. ${ }^{47}$ Omfattende forskningsutgravninger med målrettet sikring av bein og inngående beinanalyser gir en innsikt i ressursgrunnlaget (figur 8), spesielt etter landbruksrevolusjonen ca. 2350 f.Kr. ${ }^{48}$ Beinmaterialet fra Skrivarhelleren utmerker seg med stor artsrikdom, og en rekke husdyr og sjø- og landpattedyr er representert, både fra lavlandet og den alpine sonen. Hare er det det vanligste pattedyret mens det er betydelig mindre rein enn eksempelvis sau og geit. En tilsvarende variasjon er representert i fiskebeinsmaterialet. Arter som sild, sei, torsk og laks vitner om nær kontakt med kyststrøkene og lavlandet, mens kun ett bein er bestemt til ørret. I gruppen på 172 bein av laksefisk kan det imidlertid være flere bein av ørret som har vært fisket i fjellet, men ut fra funnene av saltvannsfisk, sel og husdyr er det vel så sannsynlig at det er fisk fra lavlandet. Det er også påfallende at det mangler fiskeredskaper blant det rike og varierte materialet i helleren, ${ }^{49}$ 
noe som kan underbygge at fiske ikke har vært en viktig del av grunnlaget for aktiviteten på stedet. Materialet forteller således om en variert tilgang på ressurser fra et stort område heller enn et målrettet ørretfiske i Moadalen.

Funnene som er gjort i Bukkhammeren i Rondane, vitner tydeligere om fjellfisket. ${ }^{50}$ Denne helleren ligger rett ved bredden av elven Inna i et dalføre uten innsjøer. Helleren har en brukshistorie som strekker seg tilbake til eldre steinalder, men store deler av kulturlagene har blitt dannet i tidsrommet ca. 2300 f.Kr.-700 f.Kr. Spredd i disse lagene fremkom det totalt 18 ørretbein, 1 bein av gjedde og 11 fiskebein som ikke har latt seg bestemme til art. ${ }^{51} \mathrm{I}$ lagene er det også funnet et steinsøkke av en type som på en rekke steinalderboplasser i det sentrale av Skandinavia har blitt tolket som garnsøkke. ${ }^{52}$ I dette tilfellet har det imidlertid blitt foreslått at søkket kan knyttes til garnfangst av bever. Uansett sannsynliggjør funnene at elvefiske ble praktisert i kombinasjon med jakt. Elvefiske er også dokumentert i Glommavassdraget i steinalderen, ${ }^{53}$ men slikt fiske er ellers lite synlig i det arkeologiske materialet.

Både hellerne på Langesæ i Vinje og de ved Stegaros (lok. 1058) ligger i typiske reinsjaktområder på Hardangervidda, og funnmaterialet er klart preget av dette. ${ }^{54}$ Begge steder ligger nokså nær utløpsosene til større vann, og i begge tilfeller er det funnet et fåtall ørretbein (se vedlegg). I Langesæhelleren ble det funnet bein av rein i alle lag, men også ett bein av sau, fem av rype og tre ørretbein. At det ble fisket på Langesæx, understøttes av funnet av en fiskekrok 50-60 cm nede i jordlagene, det vil si i lag som er tidfestet til jernalderen. Også i helleren ved Stegaros er det påvist et fåtall fiskebein (se vedlegg). Skjelettmaterialet fra Stegaros er imidlertid bare delvis analysert, og det foreligger derfor begrenset med kunnskap om disse beinfunnene.
Selv om enkelte funn taler for et tidlig fiske, er det vanskelig å trekke klare konklusjoner om omfanget og oppstartstidspunktet. Noen av de samme problemene gjelder beinfunnene fra Ullshelleren i Røldal. I den ellers så funnrike helleren foreligger det kun to ørretbein - i topplagene. I en avhandling om utgravningen skrev Knut Odner i $1969^{55}$ at «det er påfallende at fisk er så dårlig representert, men at resistensen av fiskebein i forhold til ben av pattedyr og fugl kan ha forskjøvet mengdeforholdet». I alle fall når det gjelder kraniebein av fisk, er denne konklusjonen korrekt. Bein av fugl og pattedyr bevares utvilsomt bedre enn kraniebein av fisk.

\section{FJELLGÅRDER, STØLER OG FISKE}

Det er få utgravninger av fjellgårder, støler og setre $\mathrm{i}$ de høyereliggende områdene. To av de best studerte gårdsanleggene, Møsvatn på Hardangervidda og Bosvatn i øvre del av Setesdalen, nevnes i innledningen. Begge steder er det funnet fiskeredskaper, mens fiskebeinsfunnene er fraværende. ${ }^{56}$ Det er mest sannsynlig at mangelen på fiskebein skyldes bevaringsforholdene, og at fiske har vært en viktig del av næringsgrunnlaget i jernalder og middelalder. ${ }^{57}$ Situasjonen for de tallrike gårdene og stølene langs Nyset- og Steggjevassdragene øst for Sognefjorden er en annen. I 925-1025 meters høyde har arkeologer gravd frem ca. 1900 fiskebein, i all hovedsak lavlands- og saltvannsfisk som ål, sild og torsk ${ }^{58}$ Dette er fangst som må ha blitt båret til fjells, trolig den forholdsvis korte og bratte veien fra Sognefjorden. Ørretbein er nærmest fraværende, og det rapporteres heller ikke om funn av fiskeredskaper ved den omfattende undersøkelsen. ${ }^{59}$

Det har blitt foreslått at fraværet av ørret på funnplassene i Nyset- og Steggjevassdragene lokalitetene kan skyldes at fisken har blitt tilberedt fersk, og at beina i etterkant har blitt brent opp på bålet. Ut fra en slik tankegang vil bein av tørket saltvannsfisk 
hatt bedre muligheter til å bevares. ${ }^{60}$ Muligheten for å gjenfinne fiskebein er utvilsomt avhengig av hvordan fangsten har blitt behandlet, og skiftende og varierende mattradisjoner er trolig et problem som er lett å undervurdere i tolkningsarbeidet. De mange funnstedene med ørretbein i vassdrag lengre øst svekker imidlertid hypotesen om at beina systematisk skal ha blitt oppbrent. Mangelen på ørretbein og fiskeredskaper gjør det mer nærliggende å anta at ferskvannsfiske har spilt en underordnet rolle i de høyereliggende delene av enkelte vestnorske vassdrag, slik situasjonen også synes å ha vært i den nærliggende, men mye eldre Skrivarhelleren (se ovenfor).

Nyset-Steggje er det eneste stedet hvor det har blitt funnet fiskebein i gårds- og stølskontekster i den sørnorske fjellheimen, og funnene sier ikke nødvendigvis så mye om den generelle kombinasjonen av landbruk og fjellfiske. Sammenholdt med vurderingene fra Bosvatn og Møsvatn gir allikevel materialet grunnlag for en vesentlig konklusjon. Naturforholdene, regionale kulturelle variasjoner og muligens også tidspunktet for utsettingen av fisk må ha vært avgjørende for den betydningen ferskvannsfisket fikk lokalt; dessuten har fisket neppe hatt den samme betydning i alle distrikter.

\section{ANDRE BYGNINGER I INNLANDET OG FISKET}

Det er ikke alltid enkelt å knytte boplasser og bygninger i de høyereliggende innlandsområdene til én form for aktivitet eller bruk. En bygning i de skogkledde jernvinne- og jaktområdene ved nordvestenden av Dokkfløyvatn (ca. 700 moh.) i Oppland kan være et eksempel på nettopp dette. ${ }^{61}$ Det en gang nokså enkle, ca. 8,5 x 4 m store huset har latt seg tidfeste til jernalder og middelalder (670-1260 e.Kr.). I husrestene ble det blant annet funnet nagler etter en båt og syv gram bein, hvorav fire rygghvirvler av ørret. ${ }^{62}$ Selv om bygningens funksjon er ukjent, er funnet en kilde til kunnskap om både gammelt ørretfiske og tidlig båtbruk i Dokkavassdraget.

I tiden 1970-1974 ble det undersøkt flere steinbuer med allsidig bruk på Hardangervidda. ${ }^{6}$ Eksempler på slike er de to steinbuene som ligger tett ved strandlinjen på sørsiden av fjellvannet Halnefjorden. ${ }^{64}$ Beinmaterialet fra buene domineres av reinsdyr og ørret. Det er også et lite innslag av rype, mens husdyrbein mangler. De over 1350 fiskebeina er svært velbevarte, noe som kan tyde på at mange av dem er fra nyere tid. ${ }^{65}$ At de ble funnet i nærmest alle deler av avfallslagene, peker imidlertid i en noe annen retning; kanskje har fisket vært utstrakt i hele brukstiden, ca. år 1000-1700 e.Kr. De fleste ørretbeina er av 40-50 cm store fisker, noe som tyder på at ørreten som ble fisket i Halnefjorden, hadde en jevn og stor størrelse. ${ }^{66}$ Et sylinderformet neverhylster viser at en del av fangsten ble tatt med garn, ${ }^{67}$ mens deler av en fiskekrok viser at det også, mens buene var i bruk, ble fisket med krok og snøre.

Tilsvarende innhold av fiskebein er funnet i avfallslagene knyttet til steinbuer ved Geitvassmuran ved Geitvatn og ved Meinsbulægeret ved Bjornesfjorden. Begge steder har det blitt gravd frem om lag 3500 fiskebein i nærmest alle deler av avfallslagene. ${ }^{68}$ Trekulldateringer og et myntfunn viser at også disse buene ble reist i middelalderen, mens funn av geværkuler, bly og krittpipedeler forteller om en lang brukstid. ${ }^{69}$

Beliggenheten nær vann i fjellheimen, beinfunnene i seg selv og redskapene gir grunnlag for å tolke alle disse bygningene som fangst- og fiskebuer, og de er således blant de tydeligste fremgravde eksemplene på at fiske har vært en hovedaktivitet.

\section{INNLANDSFISKETS BETYDNING UT FRA ET BEINPERSPEKTIV}

Denne artikkelen tar utgangspunkt i funn av fiskebeina, en nokså begrenset og til tider vanskelig 
FJELLFISKE I FORTIDEN | ANNE KARIN HUFTHAMMER - AXEL MJÆRUM

tolkbar kildekategori, og gjennomgangen synliggjør at det kreves ekstraordinære bevaringsforhold og målrettet utgravningsmetodikk for at man skal finne dem. Slike bevaringsforhold finnes i hovedsak i store avfallshauger og under hellertak.

Derfor er det kanskje ikke så uventet at fiskebein mangler i funnmaterialene fra utgravningene på de fjellgårdene som ble trukket frem innledningsvis. Skriftlige kilder og stedsnavn forteller om eksistensen av naust, fiskebuer, fiskevoller og fiskevær i fjellheimen i middelalderen og i nyere tid, ${ }^{70}$ men det har så langt knapt blitt funnet fiskebein på slike steder. ${ }^{71}$ Noe av forklaringen på at slike beinfunn mangler, er at denne type kulturminner bare helt unntaksvis har blitt undersøkt av arkeologer, ${ }^{72}$ men det er heller ikke sikkert at fortidens behandling av fisken og bevaringsforholdene sikret bevaring av store mengder fiskebein på disse stedene.

Gjennomgangen vår viser imidlertid at det faktisk er funnet fiskebein på svært mange steder hvor det har vært folk, og hvor bevaringsforholdene og utgravningsomstendighetene har giort det mulig å finne dem. Dette er lokaliteter som representerer jakt, ferdsel og jernproduksjon og bruken av dem spenner over et tidsrom på mange årtusener. Beinfunnene gir derfor et svært godt grunnlag for å slå fast at fjellfisket ofte, men ikke alltid, har vært et vesentlig aspekt ved den fortidige bruken av de høyereliggende innlandsområdene.

Mange av fiskebeinsfunnene må forstås som måltidsrester, og funnene er således et uttrykk for det brede næringsgrunnlaget og kostholdet til dem som holdt til i de indre delene av landet. Funn av fiskebein ved det fisketomme Finnsbergvatnet forteller at ørret har blitt tatt med som niste. Det at rettigheter til fiske nevnes i middelalderdiplomene, $\mathrm{i}$ rettsdokumenter, i matrikler og muntlige tradisjoner ved flere anledninger, forteller nettopp om at fiskerettene var viktige, og det at de har vært grunnlaget for mange stridigheter, underbygger betydningen. ${ }^{73}$ Fisken har utvilsomt vært en betydningsfull del av et variert næringsgrunnlag $i$ de indre dalstrøkene og i fjellheimen, og det er sannsynlig at mye av ørreten har blitt fraktet ned til gårder og bygder. En del av den har nok blitt spist fersk, men man har også hatt mulighet til å lagre den gjennom eksempelvis røking og raking. ${ }^{74}$

De skriftlige kildene fra 1100-1400-tallet etterlater seg også et inntrykk av at fiskeressursene har vært viktig for byene i middelalderen, men at fangsten i stor grad har kommet fra havet, og de bynære innlandsstrøkene. ${ }^{75}$ Fra og med begynnelsen av 1500-tallet beretter regnskaper derimot om eksport av fisk fra innlandsdalene til Oslo, og i nyere tid har mye av fisken blitt fraktet ut av fjellbygdene. ${ }^{76} \mathrm{En}$ slik eksport av store volum med røkt eller gravet ørret fordrer gode transportmuligheter, noe som kan ha vært til hinder for omsetning og eksport av ørret fra enkelte fjellbygder til lavlandsstrøkene tilbake i middelalder og forhistorisk tid. At eksporten faktisk har vært svært begrenset, er tydelig i det ellers så rike funnmaterialet av fisk fra middelalderbyene Bergen, Oslo, Trondheim og Stavanger. ${ }^{77}$ Materialet domineres av saltvannsarter, og av totalt 16601 fiskebein er kun 2 fra disse byene bestemt til ørret. ${ }^{78}$ På vikingtidshandelsplassen Kaupang $i$ Larvik i Vestfold er det tilsvarende lave tall. Kun 3 av 732 fiskebein er artsbestemt til ørret og annen laksefisk. ${ }^{79}$ Selv om man tar bevaringsforholdene i betraktning, er det grunnlag for å konkludere med at det var svært begrenset, om noen, konsumpsjon av fjellfanget ørret i mange kystområder. Fangsten fra fjellet noen århundrer tilbake i tid var i all hovedsak knyttet til innlandet og fjellområdene.

Ut fra dette kan man også slutte at menneskene $\mathrm{i}$ liten grad har drevet fisket for å produsere et stort overskudd som kunne byttes eller selges videre. Dette skiller fisket fra enkelte andre aktiviteter 
som har vært et betydelig grunnlag for makt og rikdom, slik som enkelte deler av jernproduksjonen, reinsdyrfangsten ${ }^{80}$ og enkelte produkter fra husdyrholdet. Ferskvannsfisket bør kanskje heller sammenlignes med andre former for matproduksjon, slik som korndyrking. Tilbake i forhistorisk tid var det vanskelig å flytte store mengder korn på land, og omsetningen var begrenset. Dyrkingen ble derfor i større grad drevet med sikte på å forhindre matmangel og sult enn å maksimere utbyttet i gode år. ${ }^{81}$ På samme måte har innlandsfisket etter alt å dømme i stor grad blitt drevet for konsumpsjon i fjellområdene og i de tilgrensende dalstrøkene, og dette fisket har vært en av flere næringsveier som har bidratt til å sikre mot uår og katastrofer, og som har gjort bosetningen av innlandsområdene mulig.
It is concluded that from $2350 \mathrm{BC}$ to $\mathrm{AD} 1700$, fishing was to a large extent combined with other tasks and must in certain cases have been of great importance for securing sustainable life in the inland. It also concluded that the catch was predominantly consumed locally and that export to the coastal region seems to be of less importance, at least until the Middle Ages.

\section{SUMMARY:}

\section{CREMATED FISH BONES: A SOURCE OF KNOWLEDGE OF SOUTHERN NORWEGIAN MOUNTAIN FISHING IN THE PAST}

Cremated bones are an important source of knowledge of pre-modern fishing traditions in the southern Norwegian inland. This article assesses the value of fish bones as a source of knowledge of past subsistence and presents twenty-nine archaeological sites with fish remains.

We use this osteological record to discuss the importance of fishing in the region on a general level and to discuss to which extent fishing was combined with other activities, such as hunting, farming, animal husbandry, iron production, and traveling in the mountain areas. 


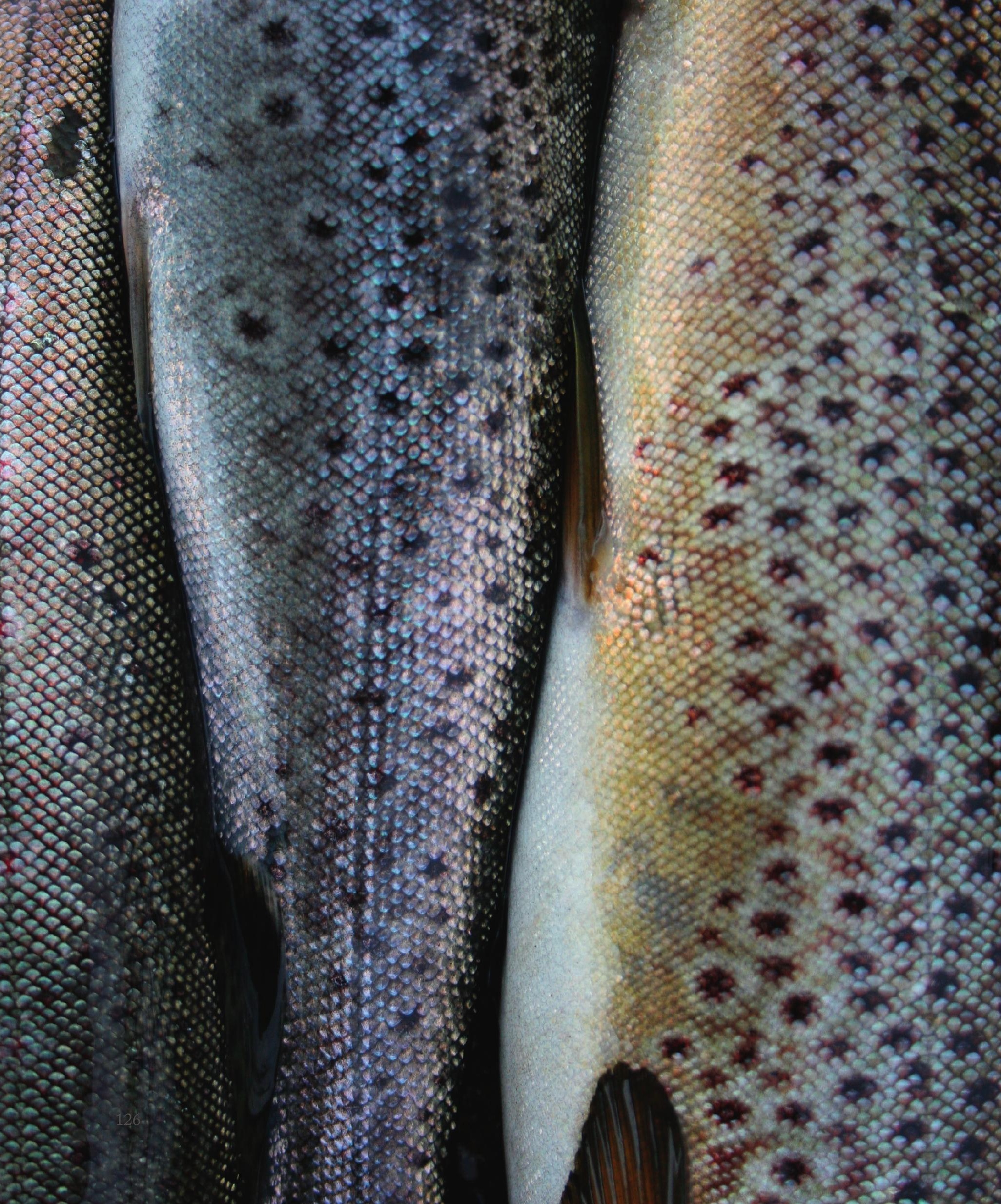




\title{
TESSE-DOKUMENTET OG FJELLFISKET I MELLOMALDEREN
}

\author{
Jo Rune Ugulen, Riksarkivet
}

Tesse-dokumentet har vorte den vanlege nemninga for eit brev som var utferda av biskop Ivar (Skjalge) av Hamar i embetstida hans, mest truleg ein gong mellom 1202 og 1220, og som seier noko om vatnet Tesse i Lom i Gudbrandsdalen og om fiskerettane i det. Dokumentet er særskilt interessant sidan det skriftlege kjeldetilfanget om fjellfisket i mellomalderen er svært magert. Det er dei arkeologiske kjeldene som fortel mest om korleis fisket gjekk føre seg. Dei skriftlege historiske kjeldene frå eldre tid omhandlar først og fremst rettar knytte til fisket, og det er nettopp eigenskapen som dokumentasjon på desse rettane som gjer at dei relativt få skriftlege dokumenta frå mellomalderen som omhandlar fjellfisket, har vorte tekne vare på. Eigarskap til fiskevatnet Tesse er typisk nok òg tema for Tessedokumentet.

Oppbevaringstilhøva i Noreg har heller ikkje vore gunstige for gamle dokument, slik at svært mykje har gått tapt på grunn av dette. ${ }^{1}$ Då eg skreiv om mellomalderen i trebandsverket om Hardangers historie, var det ikkje noko som helst å finna i dei skriftlege kjeldene om dette fisket i mellomalderen. Det eldste skriftlege dokumentet eg kom over, handla om ein grenseoppgang kring det store vatnet Nordmannslågen på Hardangervidda i 1560-åra.
Det tyder sjølvsagt ikkje at det ikkje finst mengder av arkeologiske spor etter fisket på Hardangervidda, og emnet er handsama fleire stader i verket. ${ }^{2} \mathrm{Av}$ relativt få skriftlege kjelder til fjellfisket i Noreg i mellomalderen er det fleire frà Gudbrandsdalen, og det som peikar lengst bakover i tid, er Tessedokumentet.

Ifølgje Tesse-dokumentet gav Olav den heilage vatnet til Torgeir Gamle på Garmo då kongen var på Lom og kristna bygda, det vil seia oppimot 200 år tidlegare. Olav var konge frå kring 1015 til 1028. Skal ein tru på det som er skrive i soga om Olav den heilage, skjedde dette då han hadde vore konge i sju år, altså i 1022. ${ }^{3}$ Meir om dette seinare. Originalbrevet til biskop Ivar er for lengst gått tapt, men det eksisterte framleis i original då det $\mathrm{i}$ 1333 vart vidimert, det vil seia då det vart teke ein stadfesta kopi av det. Tesse låg i den nordvestlege delen av Hamar bispedømme, eit bispedømme som i mellomalderen strekte seg frå øvre Telemark i sørvest til dei no svenske bygdene Idre og Särna i nordaust. ${ }^{4}$ Bispedømmet femna delar av dagens Telemark, Buskerud, Oppland og Hedmark, slik kartet (figur 1) viser, og Hamar-biskopen var den øvste geistlege autoriteten i området. Kor vidt biskopen sjølv hadde nokre økonomiske interesser i Tesse, veit 


\section{Hamar bispedømme i middelalderen}

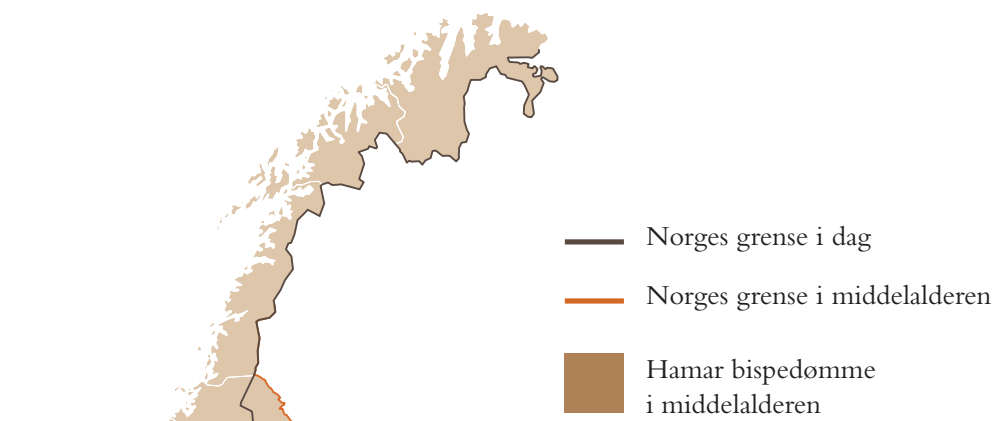

Kartet viser den mest sannsynlige avgrensningen av Hamar bispedømme ved reformasjonstiden (rundt 1536). Usikkerheten gjelder områdene fra Kviteseid og sørover, men sannsynligvis lå disse til Hamar bispedømme på denne tiden. Sognene nord i Østerdalen ble trolig tillagt Hamar bispedømme i forbindelse med reformasjonen.

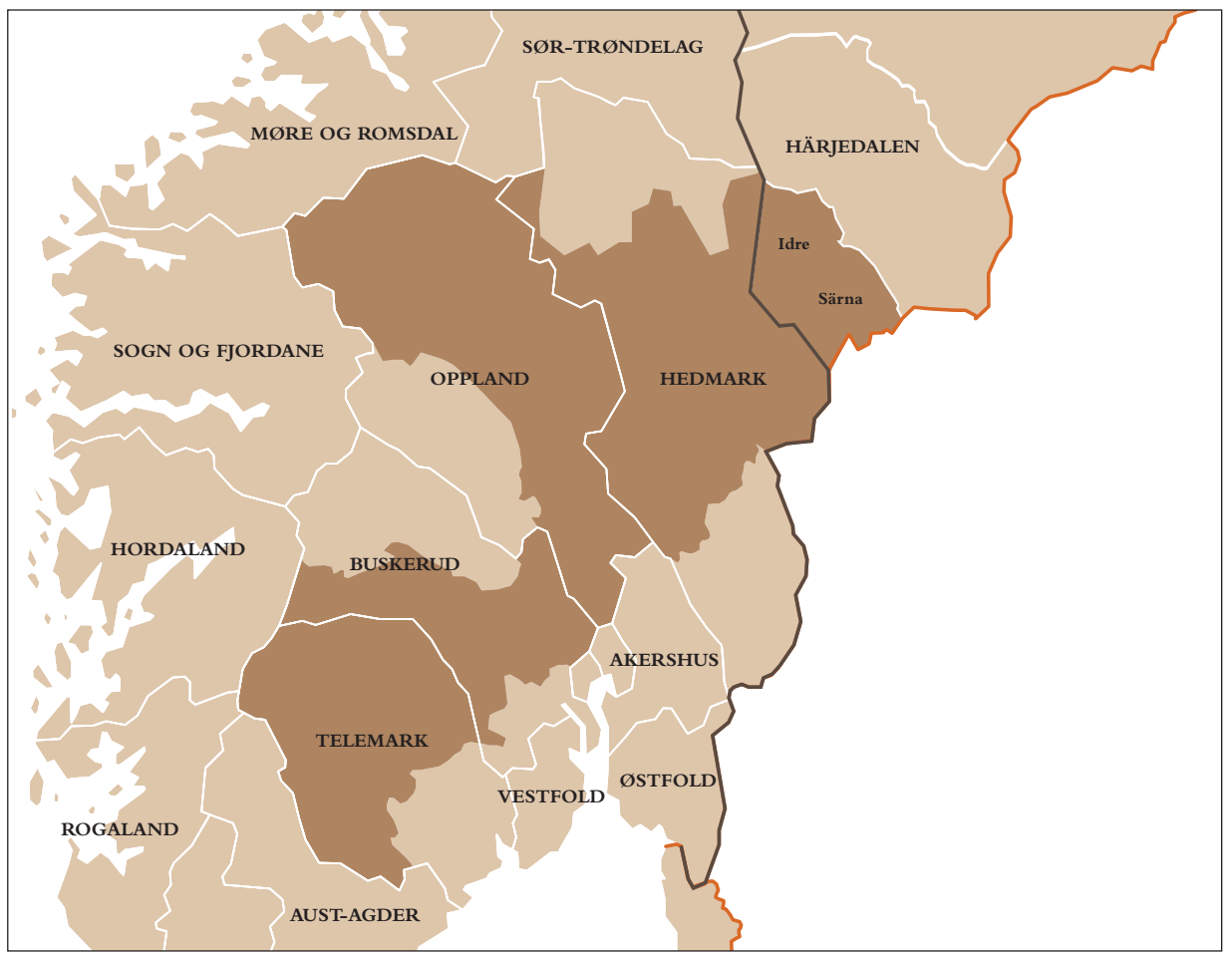

Figur 1: Utstrekninga av Hamar bispedøme i mellomalderen. 
vi ikkje, men det ser ut til at domkyrkja på Hamar har hatt rettar der, utan at vi no kan peika på kva for slag rettar det var tale om.

Ein seinsommardag i året 1333 samla fleire av dei framståande mennene i Hamar og på Opplanda seg og utferda eit brev. Eksakt kvar dei var då dei gjorde dette, lèt seg ikkje sikkert fastslå, men mest truleg var det på Hamar dei var. Brevet lyder som følgjer: ${ }^{5}$

Ollum monnum peim sem petta bref sea æder hœyra. senda capitulum ok korsbrœddr Cristkirkiu j Hamre Æirikr Steinarsson loghmader aa Vpplandum ok Andres skulæmeistare j pan sama stad. q. g. ok sinæ. yder se pat kunnigt at daghen nestæ æftir Lafwranzs vaku aa fighurtandæ aare rikis vaars vyrduleghs herræ Magnuser med guðs miskun Noreghs Swya ok Gota konongs saom ver ok ifuir lasom bref virdulegs herræ Jwers med guðs miskun fordom biscups j Hamre med hangande insigli hæilu ok vskoddu er vatar swa ord fra orde sem hær fyllghir. Ollum guðs vinum ok sinum pæim sem petta bref sea æder hœyra verandom ok vider komandom. sendir Jfwer biscup quædiu guðs ok sinæ. sia hærmingh var aat hofuud kirkiu a Lom firir mer Porgæiri ærkidiakne Pore loghmanne Simone kapalin Atla preste Paale j Bœiom Æiriki vnga Gunnare bior Birni bratta (ok) morghum odrum godom monnum lærdom ok olærdom at pa er hin hælghi Olafuer konongr kom kristni aa Loar pa gaf han Porgæiri gamlæ a Garmoe vatn pat er Pessir hæitir ok ollu hans afspringhi. en han snerez sidan till truar ok het pui sem han let gera kirkiu a bœ sinom. ok baroz hær æftir twæggiæ manna vithni peira hinna ællzto j Varlldale at swa hermdo fæder peira ok forælldri firir pæim ok swa var satt. Ok pa ænn aðr er a gango men gerdoz till pa gerdo peir pæim till a alpinghi vatta stæfnu till vazsens ok komo pesser $\mathrm{j}$ stæfnu dagh rettan en æighi hinir leto peir pa læida stæfnu vithni sin. en sidan leto pæir bera fyrnu vitni sin sua at peir hafdo radet priatighu vettra budar vallum sinum bode ok banne a netrostom sinum ok netloghum ok ollum jværka vkuidiat ok vbannat firir huærium manne. Ok sætto pæir tollf manna dom æftir ok twa hœyringia ok leto dœme karle ok kononge ok huærium manne logh en ser handa værk sin oll. ok sagde sua loghmader at pa var allt retlægha ok engi komo anduitni j mote. En Kristkirkia j Hamre ok margher adrer hælghir stader æigho pær æighner j. Nu lægh ek pær allar æighnir ok vatn pat j guðs hæghnad ok allra hæilaghra manna. firir bidod ek huærium manne rikum ok orikum a pa at ganga. en ef peir ero nockrer er a ganga pa lægh ek pæim vider bann guðs ok hæilaghra manna pauens ok ærkibiscupsens ok allra annara biscupa. en guðs miskun pæim ollum sem petta hallda væll. Ok till sanz vithnisburdar settom ver vor insigli firir petta transscriptum er gort var a deighi ok aare sem fyr seghir.

I omsetjing til moderne norsk lyder det omtrent som her nedanfor. Eg har dessutan delt opp teksten i bolkar med markeringar av kva som er teksten frå 1333, og kva som stod i det opphavlege brevet til biskop Ivar.

[1333] Til alle dei menn som ser eller høyrer dette brevet, sender kapittelet og korsbrørne i Kristkyrkja i Hamar, Eirik Steinarsson, lagmann på Opplanda, og Andres, skulemeister i den same byen, Guds helsing og si. For dykk 
vert det kunngjort at dagen nest etter lavransvake i fjortende styringsåret [dvs. den 11. august 1333] til vår vyrdelege herre Magnus, med Guds miskunn Noregs, svears og gøtars konge, såg og las vi gjennom brevet til den vyrdelege herre Ivar, med Guds miskunn tidlegare biskop i Hamar, med hengande segl, heile og uskadde, som lyder slik ord etter ord som her følgjer:

[1202-1220] Til alle Guds og sine vener, dei som ser eller høyrer dette brevet, nolevande og kommande, sender Ivar biskop Guds og si helsing. Denne forteljinga vart gjeven ved hovudkyrkja i Lom for meg, Torgeir erkediakon, Tore lagmann, Simon kapellan, Atle prest, Pål i Bø, Eirik Unge, Gunnar Bjor, Bjørn Bratte og mange andre gode menn, lærde og ulærde, at då den heilage Olav konge kom med kristendomen på Lom, då gav han til Torgeir Gamle på Garmo og alle hans etterkomarar det vatnet som heiter Tesse. Og han [Torgeir] vendte seg sidan til trua og lova det som han lèt gjera: kyrkje på garden sin. Og heretter vart det bore vitnesbyrd av dei to eldste menn i Vardal at slik fortalde fedrane deira og forfedrane før dei, og så var sant. Og då vidare andre menn kom fram som gjekk mot dette, då sette dei [oppsitjarane på Garmo] dei vitnestemne til vatnet på alltinget. Og dei [oppsitjarane på Garmo] kom på rett stemnedag, men ikkje dei andre. Dei lét då føra fram sine stemnevitne, og sidan lét dei bera fram sine vitnesbyrd om fortida slik: at dei i 30 vintrar hadde rådd for buvollane sine med påbod og forbod, for notrastene sine og notplassane og all verksemd, upåtalt og uhindra, for kvar mann. Og deretter sette dei ein tolvmannsdom og to høyringsvitne og lét dømma lov for kar og konge og kvar mann og for seg sjølv alle sine henders verk. $\mathrm{Og}$ lagmannen sa at då var alt lovleg, og det kom ingen motvitne imot. Og Kristkyrkja i Hamar og mange andre heilage stader eig eigedomar der. No legg eg alle dei eigedomane og det vatnet under Guds og alle heilage menns vern. Eg forbyr kvar mann, mektig eller ikkje, å gjera overgrep mot dei, og om det finst einkvan som gjer overgrep, då lovar eg dei Guds og heilage menns, pavens og erkebiskopens og alle andre biskopars bann. Og Guds miskunn til alle dei som held dette vel.

[1333] Og til sant vitnesbyrd set vi våre segl for dette transkriptet, som var gjort dag og år som før er sagt.

Brevet frå 1333 finst framleis i Riksarkivet i Oslo, og det er sigillatorisk bunde saman - det vil seia at det er hefta saman ved hjelp av segl og seglreimar - med to andre brev som stadfestar innhaldet i det (figur 2). Desse breva er høvesvis frå 1334 og 1344. Dette samsvarar elles i tid med ei av dateringane på ei fiskefelle (sløe) som vart utgraven i Tesse i 2014, ${ }^{6}$ noko som viser at det føregjekk fiskeaktivitet på same tidspunktet som spørsmålet om eigarskap var aktuelt.

Dei tre samanbundne breva kom til Riksarkivet i Christiania i 1821 frå det som då heitte Geheimearkivet (forløparen til det noverande Rigsarkivet) i København. Kvar det opphavleg hadde kome frå, lèt seg ikkje avgjera sikkert, men det er ymse som kan tyda på at breva opphavleg har vore i domkapittelarkivet i Hamar fram til reformasjonen, ettersom det er nemnt eigedom som Kristkyrkja på Hamar hadde ved Tesse, og det dessutan er kapittelet og korsbrørne der som utferdar vidissen i 1333. Det hadde dei ikkje late gjera utan at dei sjølv hadde interesser $\mathrm{i}$ det. 


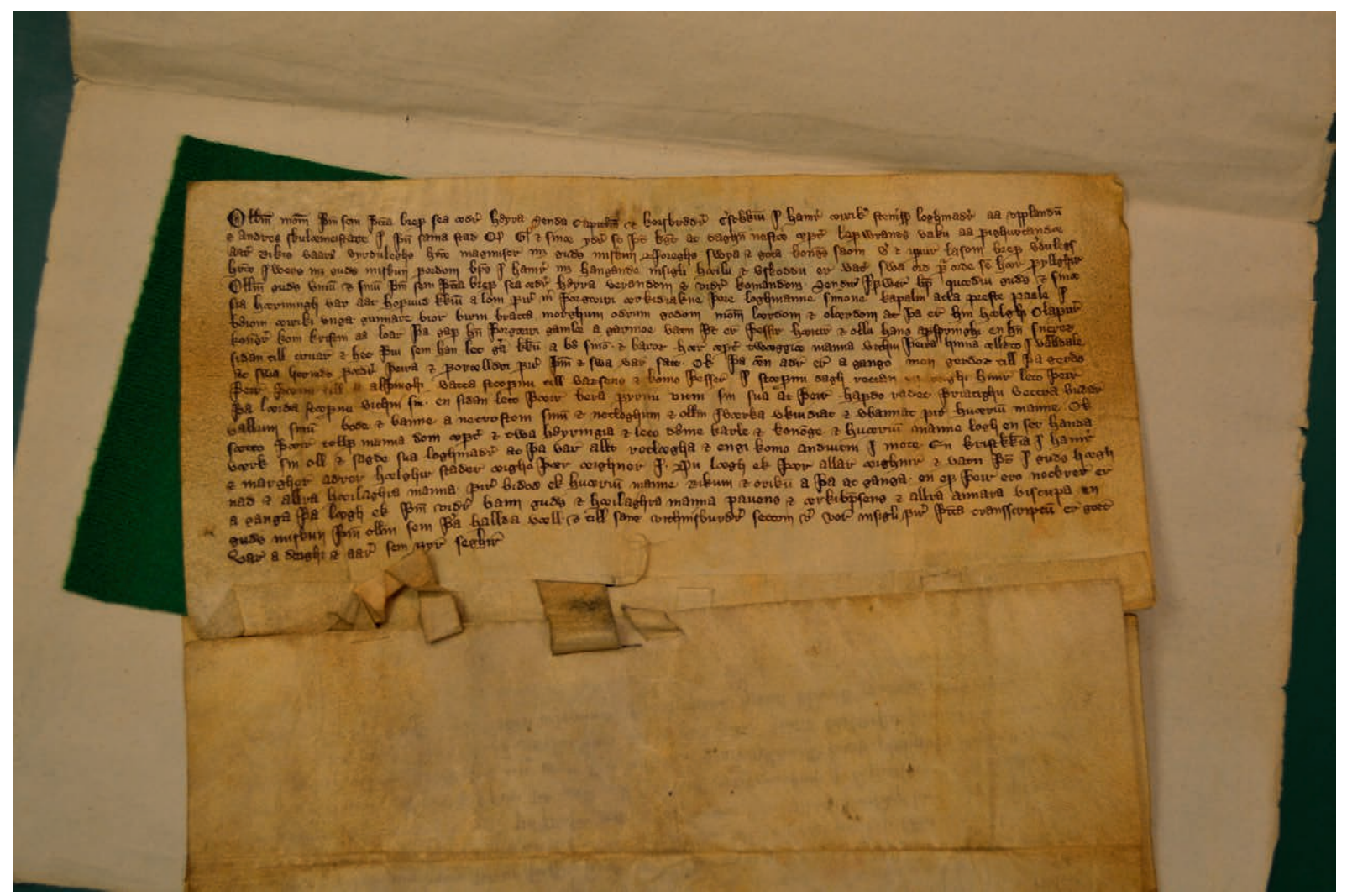

Figur 2: Avskrifta av Tesse-dokumentet frå 1333. Original på pergament i Riksarkivet, Oslo.

Brevet frå 1333 er altså ein rettsleg stadfesta kopi av brevet frå starten av 1200-talet. Det opphavlege brevet vitna om ein rettstvist mellom folket på Garmo i Lom på den eine sida og nokre andre folk som det ikkje vert sagt meir om enn at dei ikkje møtte opp då dei vart stemna for å høyra vitneprov om kven som hadde rettane i Tesse. Lagmannen hadde stadfesta at Garmo-folket sine rettar i Tesse var lovlege, og biskopen forbaud alle å forbryta seg mot desse rettane. Omtalen av at dei i 30 vintrar upåtalt har rådd for buvollane, notrastene og notplassane sine, er etter alt å døma eit uttrykk for at dei har opparbeidd seg hevdsrettar etter lova. ${ }^{7}$
Det kjem som nemnt også fram at Kristkyrkja på Hamar og andre heilage stader (dvs. geistlege institusjonar) hadde eigedomar der, men stort meir enn det er det vanskeleg å trekka ut av informasjon om eigedomsrettane. Eg kjem attende til rettane til fisket nedanfor.

Innhaldet i brevet er svært konkret og levande, og det er ikkje nokon grunn til å tvila på at det gjev att ei realistisk framstilling av korleis det gjekk føre seg på kyrkjebakken på Lom tidleg på 1200-talet då Garmo-folket førte prova sine. At motparten ikkje møtte opp, kan ha mange årsaker, men det ikkje urimeleg å gissa på at det kan ha vore mangel 
på provsvitne for saka hans som var årsaka til det. Noko meir enn ei gissing vert det likevel ikkje.

\section{DEI ANDRE BREVA}

Dei to breva som er hefta ved, og som stadfestar innhaldet i 1333-brevet, lyder om lag som følgjer på moderne norsk:

[1334]: Magnus, med Guds miskunn, Noregs, svears og gøtars konge, sender alle dei menn som ser eller høyrer dette brevet, Guds og si helsing. Vi og rådet vårt har sett avskrifta som her er festa ved dette vårt brev, under seglet til kapittelet i Hamar og dei andre som er nemnde i sjølve brevet, vitnande om det prov og sanning som vyrdelege herr Ivar, med godt minne tidlegare biskop i Hamar, Torgeir erkediakon og mange andre gode menn har teke om det vatnet som heiter Tesse, og ymse menn no held urette påtaler mot. $\mathrm{Og}$ av di at vi vil at kvar mann skal nyta sin rett, [og] særskilt den heilage kyrkja og hennar styrarar, då forbyr vi kvar mann å hindra eller minka [bruken av] førnemnde vatn på nokon måte imot førnemnde prov og sanning. Med mindre alle som gjer det, vil svara oss åtte mark i brevbrot og i tillegg bli utsett for vår sanne vreide. Dette brevet var gjort i Tunsberg [på] dei to apostlane Filips og Jakobs messedag $i$ det femtande styringsåret vårt [1. mai 1334] $\mathrm{i}$ nærvære av vyrdeleg herre og vår kjæraste ven herr Salomon, med Guds miskunn biskop i Oslo, herr Håkon Ogmundsson innsegla, og Pål klerk skreiv. ${ }^{8}$

[1344]: Til alle dei menn som ser eller høyrer dette brevet, sender Guttorm Eiriksson og Trond Krakeson Guds helsing og si. For dykk vert det kunngjort at onsdagen nest etter helgemesse i det tjuesjette styringsåret [3. november 1344] til vår vyrdelege herre Magnus, med Guds nåde Noregs, svears og Skånes konge, då drog vi omkring heile Oslo fehirdsle etter hans bod og brev for å sjå og etterprøva alle dei saker som var til ansvar for han i førnemnte fehirdsle og har vorte gjort sidan han vart konge i Noreg. Vi såg og las nøye gjennom på alminneleg ting på Mo på Lom dei breva som her er festa ved, og vitnar om det vatnet som heiter Tesse, at den heilage Olav konge hadde gjeve det til Torgeir Gamle på Garmo og hans etterkomarar til evig tid, og at førnemnte Magnus konge hadde stadfesta det med sitt brev. $\mathrm{Og}$ saker så omstendelege har vorte reist $\mathrm{og}$ frå gammalt av som før er sagt, etter dei prova som her følgjer. Då syntest oss der å ha vore rett lovleg framferd, og [vi] stadfestar det igjen på ny frå no av på vår herre konges vegner etter det ombodet har gjeve oss, for han og hans etterkomarar. Og til sanning set vi våre segl for dette brevet som var gjort på dagen og i året som før er sagt. ${ }^{9}$

Desse to breva vitnar i det minste om at det ikkje har vore ro i saka omkring rettane til Tesse-fisket gjennom mellomalderen, og dette viser oss at fisket der må har vore av ein viss tydnad. Det er referert til at det har vore reist omstendelege saker om rettane i Tesse, og det har vore ført vitne om desse rettane også på 1300-talet, utan at vi no har kjelder som fortel i detalj om dei.

\section{RETTANE TIL FISKET}

At rettar til fiske vart sett på som viktig i historisk tid, viser også til dømes ei sak frå 1645 om vatnet Hajeren på grensa mellom det noverande Buskerud og Vestfold, der det vart lagt fram tre brev som vart 


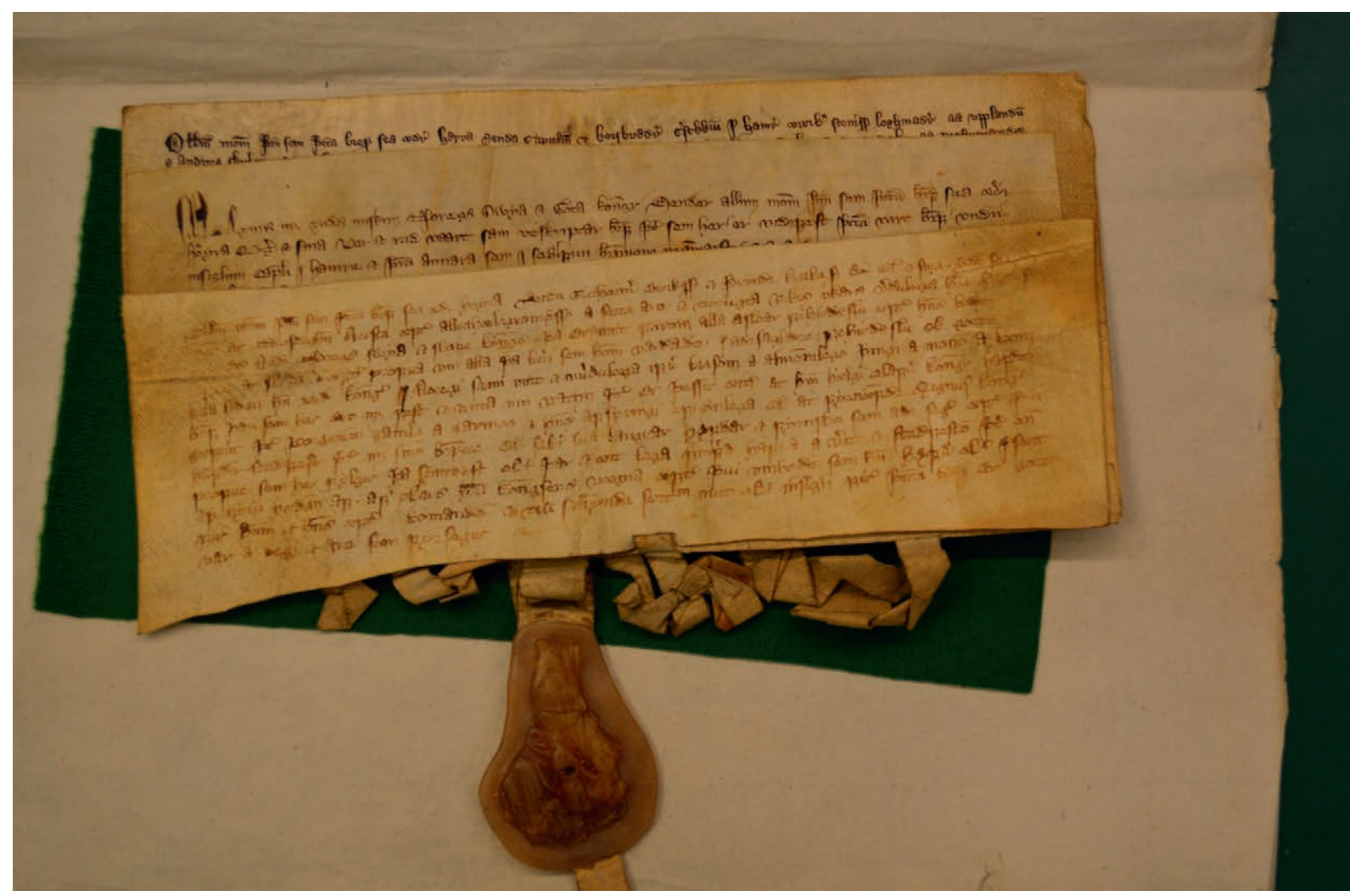

Figur 3: Dei tre samanhefta breva frå 1333, 1334 og 1344. Restane av seglet til kong Magnus Eriksson heng under brevet frå 1334, medan berre seglreimane er bevarte frå dei andre segla som tidlegare hang ved dei ulike breva. Originalar i Riksarkivet, Oslo.

sagt å vera frå 1299, 1515 og 1546, men som alle har vist seg å vera falske. ${ }^{10}$ Forfalsking av dokument for å opparbeida seg ulike rettar var slett ikkje eit ukjent fenomen i gammal tid. Det er lite eller ingenting av informasjon om korleis fisket gjekk føre seg, i dei eldste skriftlege kjeldene. I all hovudsak er det først frå slutten av 1500-talet, då vi får fyldigare kjeldetilfang, at vi har meir informasjon om korleis fisket gjekk føre seg, gjennom referat frå rettssaker og liknande.

Rettane til fiske i elvar og vatn vart i mellomalderen delvis regulert gjennom landslova av 1274, som i landsleigebolken kap. 48, «Om lakseelvar og fangstgreier som folk oppfører», der det mellom anna vert sagt at «kvar [mann] eig vatn og veidestad framfor sitt land, slik som det har vore frå gammalt av, med mindre det lovleg er fråkome». Dessutan kjem fjellfisket inn under reglane for bruken av allmenningar, sjølv om det ikkje er direkte omtalt. Allmenningsbruken er handsama i landsleigebolken kap. 61, der tvist om allmenningar er emne. «Det skal vera allmenningar dei som har vore det frå gammal tid, både det øvre [dvs. fjellet] og det ytre [dvs. havet]», og det vert mellom anna 
sagt at «alle fiskevatn $\mathrm{i}$ allmenningar er jamnheimla». ${ }^{11}$ Formuleringane om allmenningar er truleg henta frå den eldre landskapslova for Trøndelag, Frostatingslova, som seier det same. ${ }^{12}$ Kva den eldre landskapslova for Austlandet sa om dette, veit vi ikkje ettersom Eidsivatingslova ikkje er bevart. Tilsvarande formulering finst ikkje i Gulatingslova. ${ }^{13}$ Tesse ser ikkje ut til å ha vore rekna for allmenning om ein skal døma etter dei skriftlege kjeldene, men ligg slik til at det fort kunne ha vore det, ut frå den geografiske plasseringa til fjells.

$\mathrm{Vi}$ veit at fiskevatnet Tesse vart brukt under prestegarden på Lom i $1570-$ åra, ${ }^{14}$ men kor langt dette går tilbake i tid, er uvisst. Diverre har vi ikkje jordebøker som gjev oss eit oversyn over jordeigedomane til bispestolen eller domkapitlet på Hamar i mellomalderen, slik at det ikkje er mogleg å seia om den retten som prestegarden på Lom hadde til fisket i Tesse i 1570-åra, opphavleg kan ha lege til domkapitlet på Hamar. Jordeboka for kapittelgodset på Hamar i 1540 gjev ingen opplysningar om Tesse. ${ }^{15}$ Dette kan tyda på at fiskerettane på det tidspunktet var overførte til prestegarden på Lom. Det er elles mange eksempel på at fiskerettar var eigd av geistlege institusjonar, til dømes Lyse kloster i Os utanfor Bergen (1328-1329, om fisket i Oselva) ${ }^{16}$ eller Hovedøya kloster i Oslo (1347, fisket i Sandvikselva i Bærum $)^{17}$. Det var ofte mykje kiv og trette omkring rettane til dette fisket. I 1530-åra kjem det til dømes fram eit forlik om fordeling av fiskerettar mellom to bønder i Hedrum på den eine sida og prestane på Sande, Hedrum og Tjølling på den andre. ${ }^{18}$ Rimelegvis var det også usemje om fiskerettar som ligg bak det andre dokumentet frå 1300-talets Gudbrandsdal som omhandlar rettane til eit vatn - nemleg det om Heimdalsvatnet, som kong Sverre (1177-1202) i si tid skal ha tilstått Ivar gamle Gjesling på Sandbu. ${ }^{19}$

\section{ER TESSE-DOKUMENTET EKTE?}

Er det eit ekte brev frå biskop Ivar vi har attgjeve i avskrifta frå 1333? Til det kan vi nok svara eit nokså sikkert ja. Biskop Ivar sitt brev var nok ekte, og det eksisterte i 1333 med seglet til biskopen og det heile. Det er svært tvilsamt om både domkapittelet i Hamar, lagmannen på Opplanda og skulemeisteren i Hamar skulle ha rotta seg saman og dikta opp biskopen sitt brev eller jamvel forfalska det. Dei kan teoretisk sett ha vore førte bak lyset av ein dyktig forfalskar, men det er ingen grunn til å tru at så har skjedd i dette tilfellet. Det var kunnige folk som utferda vidissen $\mathrm{i}$ 1333, og ein skulle tru at dei var i stand til å avgjera om gamle brev var ekte. Dei seier også sjølv at dei «såg og las [...] gjennom brevet til den vyrdelege herre Ivar, med Guds miskunn tidlegare biskop i Hamar, med hengande segl, heile og uskadde».

Kva med tilvisinga til Olav den heilage og Torgeir Gamle på Garmo (kring 1022 om ein skal følgja kronologien i soga om Olav den heilage)? Er den truverdig, slik til dømes Elling Utvik Wammer har stilt spørsmål om i den maritimarkeologiske rapporten om Tesse frå 2015 og gjentek i artikkelen sin i denne boka? ${ }^{20}$ Det lèt seg ikkje sikkert avgjera. Det var slett ikkje uvanleg til dømes å visa til HeilagOlavs lov når ein skulle leggja fram gammal hevd $\mathrm{i}$ mellomalderen, ${ }^{21}$ og dette kan godt vera eit døme på nettopp det. På den andre sida er det ikkje usannsynleg at det kan ha vore ei munnleg overlevering av ein reell 180-200 år gammal tradisjon i Lom. Korkje Torgeir Gamle på Garmo eller Tessevatnet er nemnt i soga om Olav den heilage, og det kan i seg sjølv vera eit moment som styrkar truverdet til påstanden i brevet frå starten av 1200-talet. Men det er og blir uvisst, og spørsmålet om Olav den heilage verkeleg gav vatnet Tesse til Torgeir Gamle på Garmo, vert dermed til sjuande og sist mest eit spørsmål om tru. 


\section{SUMMARY}

The Tesse document has become the common denomination for a charter given by bishop Ivar of Hamar sometime between 1202 and 1220. It gives information about the mountain lake of Tesse in Lom parish in Gudbrandsdalen in present-day Oppland County and about the fishing rights in the lake. The document is particularly interesting given the fact that written sources of information about medieval Norwegian mountain-lake fishing are exceedingly rare. According to the charter, the lake was given to Torgeir Gamle («the Old») at Garmo by King Olav (St. Olav) when the king visited Lom and christened the area around 200 years earlier. The original charter of bishop Ivar is long lost, but its contents are preserved in an attested copy from 1333 by the chapter of Hamar together with the local lawman. It witnesses a legal dispute between the people on the Garmo farm in Lom on the one side and their counterpart on the other. The charter does not say much about the counterpart except that they did not show up to hear the evidence of the rights to the Tesse lake. The lawman confirmed that these rights belonged to the Garmo people, and the bishop forbade anyone to commit offences against these rights. In addition, the document implies that the cathedral in Hamar, together with other «holy places» (i.e. ecclesiastical institutions), had properties in Tesse, although it doesn't say anything about what kind of property. 


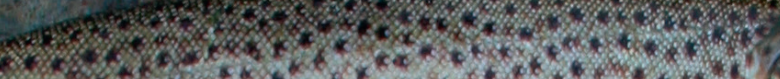

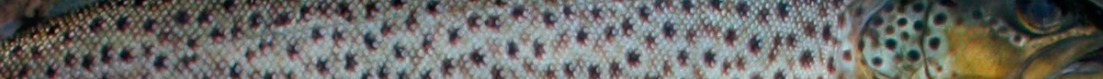

\section{2. \\ B)}

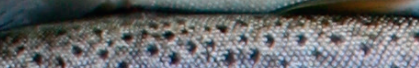

3
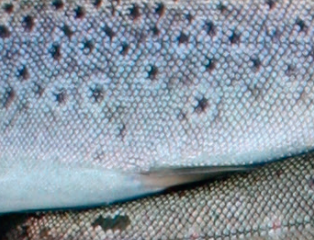

s.x.

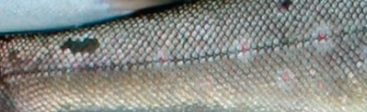

7

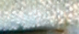

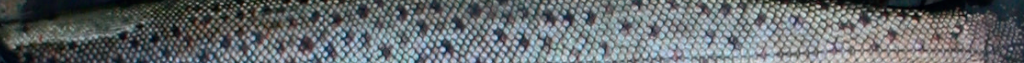

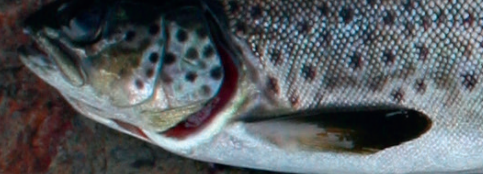

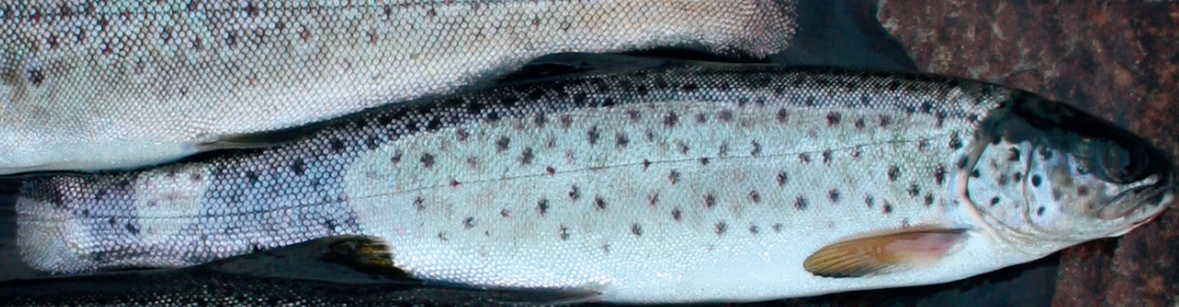

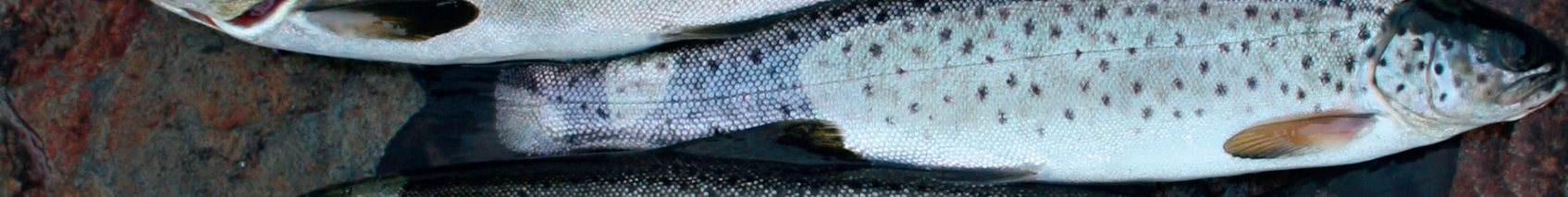

,

5

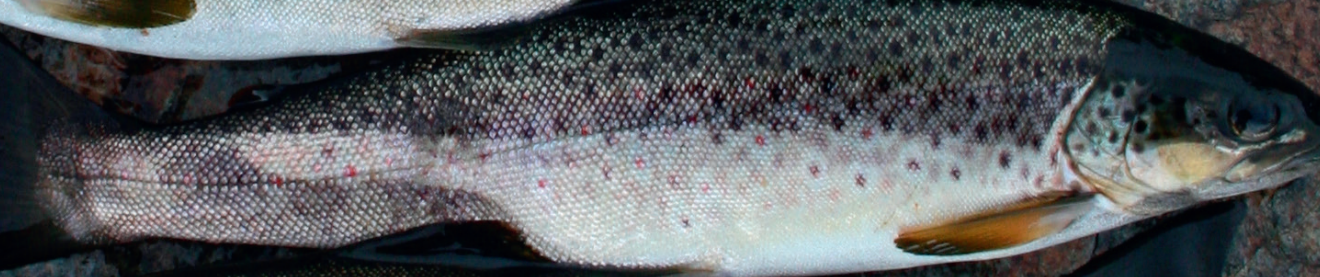

20

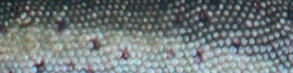

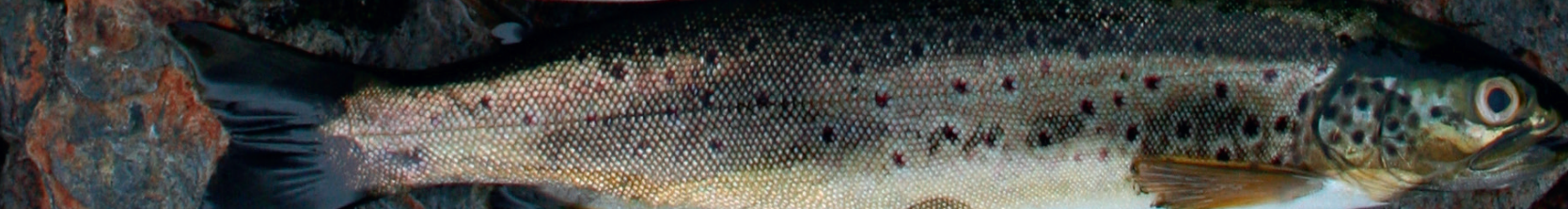




\title{
OM LANDSKYLDVARA "BERGEFISK" I GUDBRANDSDALEN
}

\author{
Arnfinn Kjelland, Hogskulen i Volda
}

\section{INNLEIING}

I norsk historie har fisk og fiskeri vore nært knytte til kysten. Innlandsfiske har ikkje vore like viktig, når ein ser bort frå dei store innsjøane og laksefiske i dei større elvane, særleg i den relativt korte perioden slikt fiske her i landet var populært blant den engelske overklassen.

Det er ting som kan tyde på at innlandsfiske i eldre tid har vore viktigare enn det som er kome fram i historieskrivinga. Det kan ha samanheng med at mykje av denne skrivinga bygger på kjelder skrivne av embetsmennene i form av rapportar, svar på spørsmål frå sentraladministrasjonen i København og etter kvart topografisk-statistiske skildringar interesserte embetsmenn skreiv på eige initiativ. Eit fellestrekk for desse embetsmennene var at dei i alle fall til ein viss grad tenkte fysiokratisk - dei sette jordbruket og bonden i høgsetet og underkommuniserte kanskje annan form for næringsverksemd. ${ }^{1}$ Det er til ein viss grad tilfellet for Gudbrandsdalen òg. ${ }^{2}$

I dei eldste systematiske skriftlege kjeldene med vareinformasjon frå Gudbrandsdalen vi har, frå 1500-talet, dukkar nemleg bergefisken opp. Desse eldste kjeldene er lister over innbetalingar til eller lagerhald hos statsmakta, som var lokalisert på
Akershus festning. Varene er i hovudsak komne inn i form av leigeavgifter av den jordeigedomen staten eigde, landskylda, og andre inntekter staten hadde i form av bygsel, skatt og bøter for lovbrot (sakefall).

Dei eldste av desse kjeldene er ikkje samanhengande, dei finst berre for enkelte år eller nokre få år etter kvarandre. Det er derfor ikkje råd å kvantifisere nøyaktig. Men oppgåvene syner likevel at det her er snakk om ei vare av eit ikkje ubetydeleg omfang; på Akershus var det ifølgje jordeboka for rekneskapsåret 1557-58 lagra over 315 bismarpund (over $1700 \mathrm{~kg}$ ) slik fisk.

Kva for fisk dette var, kor han kom frå, og kor mykje av landskylda i forskjellige delar av Gudbrandsdalen han utgjorde, er spørsmål eg skal ta for meg i denne artikkelen.

\section{STATSINNTEKTENE: LANDSKYLD OG SKATT}

Landskylda er den viktigaste kjelda som systematisk syner kor fisken kom frå. Ho var opphavleg den årlege leigeavgifta som leiglendingane betalte til jordeigarane for leige av gardane, og denne avgifta vart truleg fastsett ut frå bruksverdien og altså betalt med varer av det slaget garden produserte mest av. ${ }^{3}$ 
Dermed kunne ho òg fungere som ein fast målestokk for jordeigedom og kunne nyttast ved mellom anna arveskifte, kjøp og sal. Landskylda hadde òg, seinast i samband med Magnus Lagabøtes landslov frå 1274, blitt til ein fast, landsomfattande takst på alle eigedomar og grunnlag for skattlegging. ${ }^{4}$

Regionale undersøkingar tyder på at storleiken på landskylda til vanleg kan ha vore på 1/6 av det gardane produserte. Folketapet ved svartedauden og dei etterfølgjande pestepidemiane førte til at dette rimeleg faste verditilhøvet vart skipla - vi fekk det velkjente landskyldfallet $\mathrm{i}$ siste del av 1300- og 1400-talet. Skylda festa seg så att sist på 1400-talet. På denne tida begynte folketalet å vekse att, og dei store jordeigarane (den katolske kyrkja, kongen og adelen) prøvde å auke inntektene sine av eigedomane ved å skru opp att landskylda. Det vart i betydeleg grad stoppa i samband med reformasjonen, da det nye danskestyret alt i 1539 i lovs form (recess) gav bygdefellesskapet kontroll med fastsettinga av landskylda - ho skulle vere i samsvar med «Jordens Afvext». Landskylda vart i alle fall ståande utan nemnande endringar til matrikkelrevisjonen først på 1800-talet, medan jordeigarane fekk høve til å auke inntektene gjennom nye bygselsavgifter: ved brukarskifte (førstebygsel) og ei mindre avgift, holding, kvart tredje år. ${ }^{5}$

«Det nordisk ødegårdsprosjekt» granska i 1970-åra busetnadsutviklinga i Norden i seinmellomalderen og starten på tidleg nytid i samanliknande perspektiv. ${ }^{6}$ Landskyldfallet var da eit viktig tema. For Gudbrandsdalen er det indikasjonar på at den landskylda som jordeigarane kunne rekne med ved inngangen til nytida, ikkje var høgare enn $13 \%$ av det ho hadde vore i høgmellomalderen, men ho hadde betydelege variasjonar. ${ }^{7}$

Innkrevjinga av landskylda var i utgangspunktet sjølvsagt den enkelte jordeigar sitt ansvar. Den samla jordeigedomen i Noreg fordelte seg etter landskylda kring 1500 med 7,5\% til kongen (staten), 47,5\% til den katolske kyrkja, $13 \%$ til adelen og resten, ca. 32 $\%$, til andre private, mest bønder. ${ }^{8}$ Ved reformasjonen gjekk kyrkjeeigedomen over til staten, og i tida fram mot 1661 gjekk om lag $4 \%$ frå adelen sine eigedomar same veg, slik at staten da kontrollerte ca. $52 \%$ av all eigedom i landet. Av dette vart ca. $21 \%$ nytta til å finansiere den nye lokale kyrkjeorganisasjonen; den sentrale statsmakta i Danmark fekk inntektene av ca. $31 \% .^{9}$

I denne samanhengen må også det særnorske skyldeigesystemet nemnast. Det var ikkje uvanleg at det var fleire eigarar av ein gard, men dei eigde eigentleg berre ein del av landskylda, ikkje ein fysisk part av jorda eller skogen. Slik deling kunne ha skjedd ved at ein brukar gav ein part til den katolske kyrkje for sjelemesse eller betalte ei bot til kongen, men mest vanleg var nok at ho skjedde ved arveskifte, der jordeiga kunne bli fordelt på arvingane på same måte som anna formue. Den som da tok over garden, laut betale landskyld til medarvingar inntil han hadde løyst inn att desse partane. ${ }^{10}$

Frå sist på 1500-talet får vi etter kvart systematisk oversyn over landskylda på jordeigedom i eiga til staten gjennom lensrekneskapa. For andre eigarar er slik informasjon berre fragmentarisk bevart. Men ut på 1600-talet auka statsmakta sitt behov for inntekter dramatisk på grunn av aktiv krigføring, og det førte til at dei faste inntektene av offentleg jordeigedom åleine ikkje vart nok - skattane måtte opp. Det var framleis i lang tid fast jordeigedom som var skattegrunnlaget, og statsmakta måtte få samla oversyn over eigarskapen til han. Det fekk ho gjennom å registrere all jordeigedom med eigarar og landskyld, sjølv om skylda framleis stod på det nivået ho var på i byrjinga av 1500-talet. Med det skatteregisteret som vart etablert etter ei forordning frå 1647, fekk vi for første gong eit slikt samla oversyn 


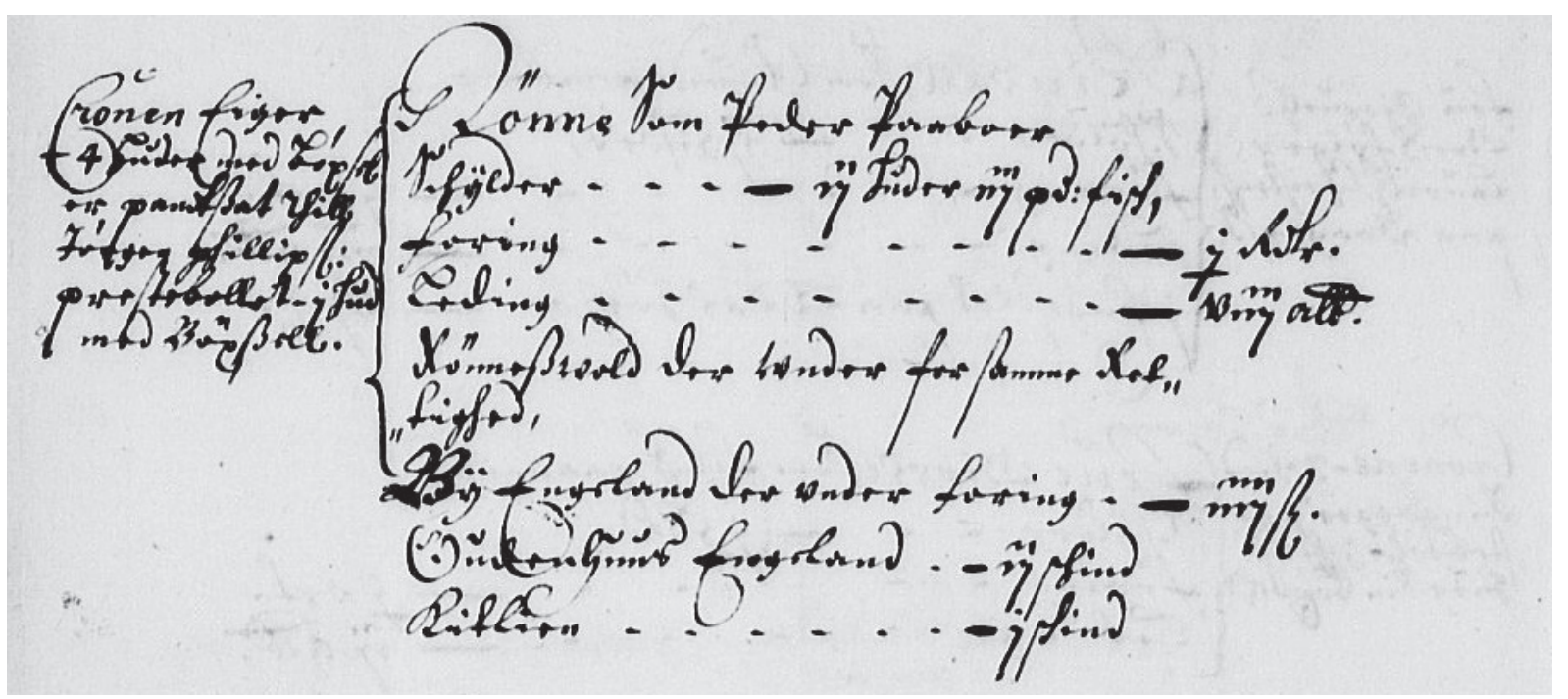

Figur 1: Utsnitt frå landkommisjonsjordeboka 1661 for Heggen i Follebu. Vi ser den inneheld mykje interessant gardshistorisk stoff. Brukaren er Simon, og under står det at garden «skylder» (det vil seie at landskylda var) 1,2 huder og 2 bismarpund 4 bismarmerker fisk $(12,1 \mathrm{~kg})$ og «nock» $1 / 2$ hud (?). Til venstre går det fram kven som eig garden og skal ha landskylda: Krona (staten) eig størsteparten, medan Dal prestebord (presten) eig den siste halve huda. Så ser vi at under garden vart ein øydegard kalla «Surenflot» på 1 hud brukt, og på same måte «Mageløs» og «Wundslet» (truleg òg øydegardar) på 1 hud til saman. Denne jordeigedomen er det brukaren på Heggen som eig sjølv. Skatten foring på $1 / 2$ riksdaler er han fri for, men leidangen på 8 «alba» (à 1/3 skilling) og skatten for ei bekkekvern på 8 skilling må han betale. ${ }^{63}$

over all eigedom i landet, etter kvart nemnt i eintal som matrikkelen. ${ }^{11}$

Historikaren Kåre Lunden har elles hevda at den «bondevenlege» politikken til danskekongen på 1500-talet først og fremst kom av at han (staten) berre kontrollerte en tredjepart av jordeigedomen: «Kongen var difor meir interessert i å 'tappe' alle bøndene for skatt enn for jordleige av nokre.» ${ }^{12} \mathrm{Med}$ denne prosessen hadde nemleg statsmakta lagt til rette for overgangen frå det som i norsk historie har vore kalla domenestaten, som i stor grad fekk inntektene sine frå jordeigedom staten eigde sjølv, til skattestaten, som kunne skattlegge alle verdiar i landet. Landskylda vart dermed ein nøkkel til fordeling av skattebyrdene, både på eigarar og på brukarar (leiglendingar). Det neste elementet i staten sin skattepolitikk vart så å selje frå staten sin eigedom, til sist til bøndene gjennom den prosessen som er kalla overgangen til sjølveige.

\section{MATRIKKELEN}

Frå 1500- og 1600-talet er det så tre slag kjelder som fortel om landskylda: ein del jordebøker, dei etter kvart meir fullstendige seriar av lens- og futerekneskap og så matriklane. Jordebøkene og matriklane må reknast som normative kjelder - dei har registrert landskyld og andre ytingar som var pålagt eigedomane. Lensrekneskapa inneheld i prinsippet det som faktisk vart innbetalt av varer eller pengar, ikkje kva som stod i ei jordebok som gamal takst eller skyld. Det var futane som forvalta dette materalet, og som etter kvart sendte det til sentralforvaltinga i København for revisjon og kontroll. Frå omkring 1600 er rekneskapsseriane rimeleg komplette år 
for år og tilgjengelege for analyse, men dei inneheld i hovudsak skattelister. Nokre få av desse har landskyldoppgåver, men dei fleste berre namn på gardane, brukarane og innbetalt skatt.

I samband med innstramminga av skattlegginga fann staten det etter kvart nødvendig å få skikkeleg oversyn over den samla landskylda. I 1647 godkjente derfor riksstyret i København landskylda i Noreg som mål på kor mykje som skulle betalast i den viktigaste skatten på denne tida, kontribusjonsskatten. ${ }^{13}$ Samstundes og i dei næraste åra vart det samla inn oversyn over skylda på alle skattepliktige gardar. Desse oversyna er transkriberte og trykte. ${ }^{14}$

Berre knapt 15 år seinare sette så den nye eineveldige statsmakta i gang ein ny gjennomgang av jordeigedomen i Noreg. Det resulterte først i jordebøker etter den såkalla landkommisjonen frå 1661 og så ein fullstendig gjennomgang for heile landet etter påbod frå 1665. Den vart utført i åra fram til $1670 \mathrm{og}$ førte til det som er kalla den gamle matrikkel. Målet var også å gjere om og regulere («redusere») den gamle skylda til tre vareslag, korn, smør og fisk, men det vart gjennomført berre på Vestlandet. I dei andre landsdelane vart dei gamle landskyldvarene i hovudsak ståande som skattegrunnlag, men da etter ei distriktsvis norm for forholdet mellom dei. Den var situasjonen heilt fram til den nymatrikuleringa som den nye norske staten sette i gang i 1818, og som førte fram til ein ny matrikkel frå $1838 .{ }^{15}$ Denne vart gjeven ut i trykt form med både gamal og ny skyld oppgjeven for alle eigedomar, no oftast nemnd «matrikkelskyld» og ordna etter rettsdistrikt, tinglaga. I Gudbrandsdalen samsvarar desse stort sett med den geistlege inndelinga i prestegjeld.

Først i 1720-åra (1723 i Gudbrandsdalen) vart det gjort eit forsøk på å revidere matrikkelen frå 1660-åra, ${ }^{16}$ men den reviderte vart ikkje sett i verk. Hausten 1802 kom det så ei forordning om ein jordtakst som grunnlag for skattlegging på ein betre måte enn den gamle matrikkelskylda, som i mindre og mindre grad spegla den reelle verdien av eigedomane. Protokollane etter takseringsarbeidet i 1803 inneheld gamal skyld og ny takst. ${ }^{17}$ Taksten har dessverre betydelege manglar fordi det vart sett avgrensingar i gjennomføringa, ${ }^{18}$ men det har likevel ikkje noko å seie for registreringa av den gamle skylda.

Desse listene er altså sentrale kjelder til å vise oss kvar i Gudbrandsdalen eigedomsverdien vart sett i bergefisk, og kva som var omfanget av vareslaget. Når eg i denne samanhengen ikkje nemner den første matrikkelen, frå 1647, er det av ein særskilt grunn som syner dei kjeldekritiske utfordringane vi står overfor: I 1647 er nemleg all skylda rekna om til huder og skinn (av høvesvis ku og kalv - ei kuhud var delt i tolv kalvskinn). Ingen av dei to andre hovudskyldvareslaga som var brukt i dalen, fisk og vadmål, er med. Dette syner truleg at innbetaling i form av forskjellige varer var på veg ut, og at landskylda stort sett vart betalt med mynt etter fastsette takstar (sjå nedanfor).

I jordavgiftsoppgåvene frå 1803 har eigedomane nummer som samsvarar med dei som er gjevne att $\mathrm{i}$ den reviderte matrikkelen frå $1838^{19}$ som «Gammelt Matr.-No.» og kopla til det nye matrikkelnummeret. Dette er i sin tur i den siste matrikkelen frå 1886 kopla til dagens gardsnummersystem. Dermed er det muleg å lokalisere eigedomane meir nøyaktig enn berre ved dei eldre matrikkellistene, der det kan vere mange med same namn («Lien», «Haugen», «Bakke» og så vidare). Eg har derfor brukt jordavgifta i den detaljerte gjennomgangen nedanfor. Registreringane inneheld i alt litt i overkant av 2000 eigedomar med gamal skyld i Gudbrandsdalen medrekna Gausdal og Fåberg tinglag.

Det kan vere verd å nemne at neppe nokon av matriklane lister opp nøyaktig dei gardsbruka eller driftseiningane som fanst på det tidspunktet dei 
vart skrivne ned. Dette var først og fremst lister berekna på å registrere skattegrunnlaget, og det var det sjølve eigedomane som var. Driftseiningane var jo i betydeleg grad dynamiske gjennom bruksdelingar og -samanslåingar og varierte over tid. I dei eldre matriklane er det nemnt namn på brukaren som var ansvarleg for å betale skatten for matrikkelgarden, ${ }^{20}$ men det kan ofte stå fleire namn på same eininga, eller same person kan stå som eigar (skattytar) av fleire einingar. Slikt kan da tyde på at det har skjedd bruksdeling eller -samanslåing, men det var ikkje så interessant for futen så lenge skatten av all eigedom vart betalt.

\section{LANDSKYLDA: VARIERANDE VARESLAG OG PENGAR}

Når brukaren, leiglendingen, ikkje eigde landbruksjorda, skulle han altså betale landskyld til eigaren $\mathrm{i}$ form av varer garden produserte. Det kunne i høgog seinmellomalderen vere eit særs breitt spekter av produkt; ein kan til dømes sjå vareslag som hogde bord, tjøre, reip, never og til og med ferdigprodukt som trekoppar nytta til å betale landskyld med. ${ }^{21}$ Det gav jordeigarane utfordringar - dei kunne sjølvsagt ha behov for ein del av desse varene i eiga forvalting, men dei fekk ikkje så lett inn inntektene i form av gangbar mynt. Jordbruksvarene kunne nyttast og vart nok nytta til kost for hushaldet og til anna vedlikehald av hus og utstyr. Men dei varene jordeigaren ikkje sjølv kunne nyttiggjere seg, måtte han omsette for å få kapitalisert eigedomen, og dermed voks det etter kvart fram eit press på leiglendingane om å betale landskylda i form av mynt.

No var ikkje dette ein prosess som gjekk berre ein veg-marknadsprisane kunne for den saks skyld vere til fordel også for leiglendingane. I tider med høge prisar på landskyldvarene, til dømes smør, kunne dei ha interesse av å betale i mynt. Statsmakta greip ved fleire høve inn til fordel for leiglendingane,

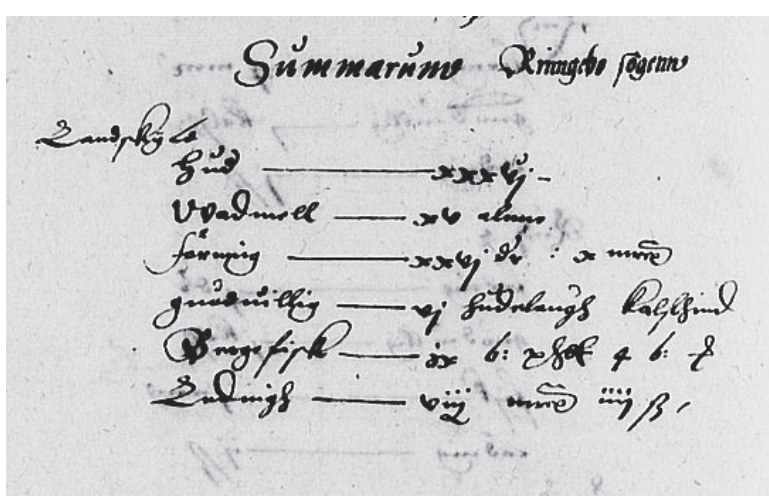

Figur 2: Summerte inntekter som kongen (staten) kunne forvente seg av Ringebu sokn i skatteåret 1577-78. I landskyld var det 36 huder og 15 alner vadmål. I dei gamle jordebokskattane foring var det 26 riksdaler og 10 merker (det er usikkert kva det siste galdt), godvilje 6 hudlag (svarar til kuhuder) og 9 bismarpund 4 merker (svarar til drygt $50 \mathrm{~kg}$ ) bergefisk og leidang 8 merker 4 skilling (det er uklårt kva det galdt). ${ }^{64}$

mellom anna ved forordning i 1684 å fastsette takst for landskyldvarene når dei vart betalt med pengar i staden for varer. ${ }^{22}$

Dette kompenserte kanskje statsmakta til ein viss grad med dei aukande skattane som dei norske bøndene vart pålagde frå sist på 1500-talet - dei ser ut til å vere kravd inn i form av mynt, i alle fall når ein ser på rekneskapsbilaga, til dømes bygningsskatten til jonsok $1594 .^{23}$

Dei eldste nokolunde samanhengane oversyna vi har over innbetaling av landskyld, er frå siste del av 1500-talet. Dei gjeld jordeigedom staten hadde eigarskap til etter reformasjonen: det gamle krongodset, «thett gamle kronegotz», ${ }^{24}$ og det sentralkyrkjelege og lokalkyrkjelege godset etter den katolske kyrkja. Det var lensherrane som forvalta dette godset, og dei skulle som nemnt sende årlege rekneskap over inntekter og utgifter til sentralmyndigheitene $\mathrm{i}$ København.

Dei to eldste oversyna frå Gudbrandsdalen, frå rekneskapsåra 1557-58 og 1560-61, er trykte. ${ }^{25}$ I 


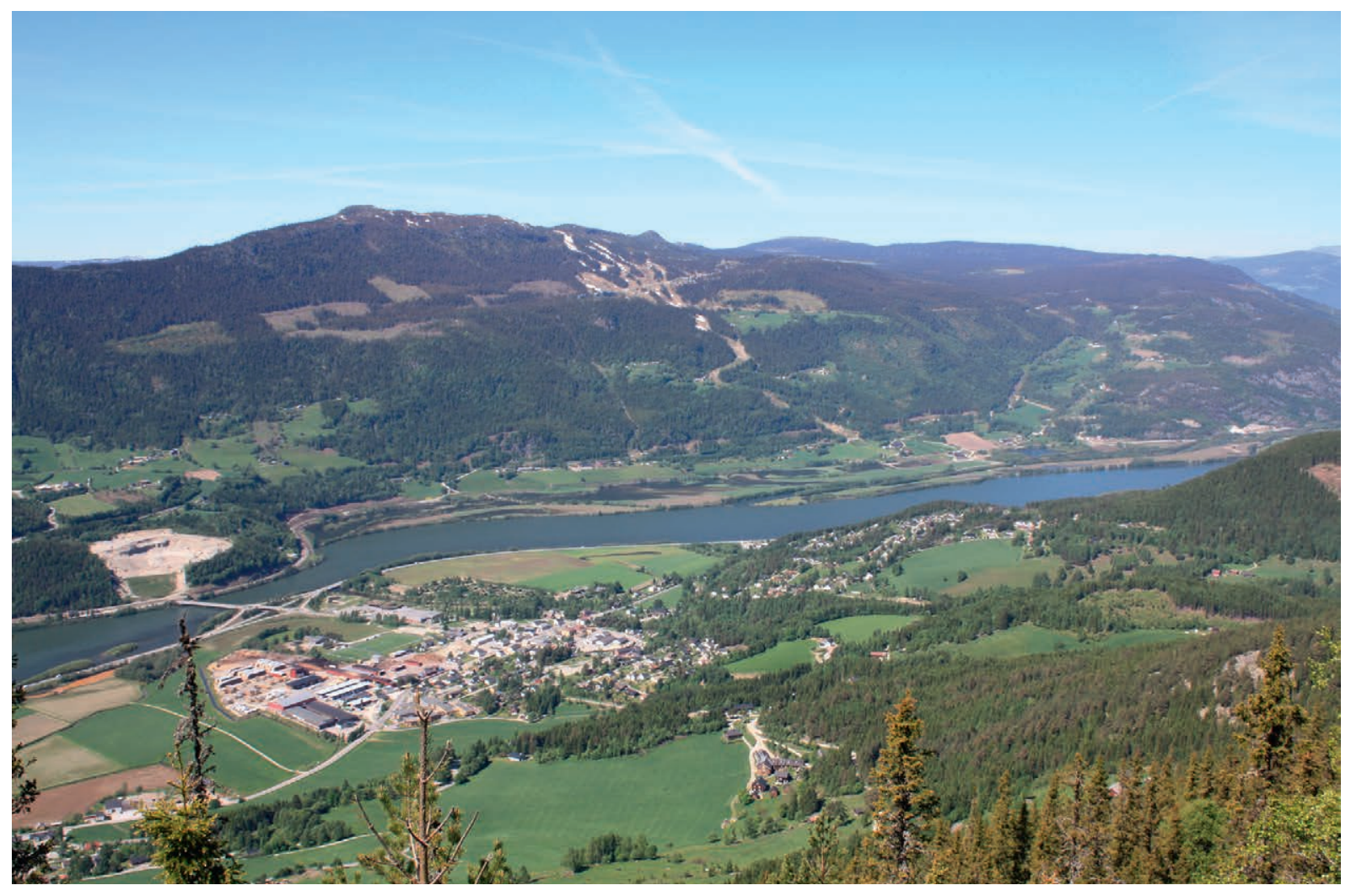

Figur 3: Utsyn mot Fåvang frå Oppsalåsen i 2014. Vi ser mellom anna Nordrum i nedre kant av bildet. Foto: Arnfinn Kjelland.

desse er eigedomane lista opp med innbetalingar av landskyld av høvesvis gods etter erkebispen og hamarbispen, men av ein eller annan grunn ikkje det førreformatoriske krongodset. Vi kan sjå at landskylda ikkje låg fast på eitt vareslag, men vart betalt på forskjellige måtar frå det eine rekneskapsåret til det andre. Innbetalingane vart i hovudsak gjort med dei faste vareslaga huder, fisk og vadmål, men av og til òg med mynt, der det er innført til dømes «1/2 daler for 1 hud».

Den første komplette jordeboka for dalen, frå 1577-78, har med alle eigedomar som kongen hadde faste inntekter av i form av skatt eller landskyld. ${ }^{26}$ Det mest påfallande med den er føringa. Kvart av dei åtte prestegjelda er delte i tre bolkar: Den første er utan overskrift, men innføringa under kvar gard startar med «gods», enten krongods, «Hammersgoudz» eller «Erkebispens goutz», før dei gamle, nokså ubetydelege skattane frå mellomalderen er lista opp. Så kjem ein bolk med «Ødegaarde og smaa iordparte», som i hovudsak ser ut til å vere oppgjevne med landskyld av Hamar- eller erkebispetype, i huder, skinn eller vadmål. Den siste, men gjerne den største gruppa er gardpartar som betalte berre gamle skattar: «nvirke bønder, Prestebønder, Kirkebønder, Hermandsbønder og Andre Odelsbønder» - altså 
der jorda var eigd av andre enn krona. Frå Fron og sørover resten av dalen er det i tillegg til dei andre ytingane kome inn ei rad som i oppsummeringane for kvart prestegjeld, og for heile Gudbrandsdalen, er skrive bergefisk. Det er altså ikkje sett opp fisk som landskyld i denne jordeboka, slik det er gjort både før og seinare. $\mathrm{Og}$ framleis får vi altså berre vite landskylda når ho skal svarast til kongen; andre eigedomar er førte berre med dei faste skattane.

I 1589 klaga bøndene i Gudbrandsdalen til den nyutnemnde lensherren, Axel Gyldenstjerne, på at jordeigarane no kravde all landskylda innbetalt i huder, medan dei tidlegare hadde betalt halvt i huder og halvt i fisk. Lensherren gav dei att den gamle retten. ${ }^{27} \mathrm{Na}$ ar fisken eigentleg festa seg som fast landskyldvare, er elles uklårt. Samanlikningar i form av stikkprøver i jordebøkene frå 1661, matriklane frå 1668 og matrikkelutkastet frå 1723 med jordavgifta frå 1803 syner visse avvik, ikkje så mykje i samla skyld, men i vareslag. Huder er heile tida dominerande, men det kan variere litt mellom fisk og vadmål - til dømes er tre Listad-gardar i Fron ført opp med hudskyld i 1661 og 1668, men med vadmålskyld i 1723 og 1803. Øvre Kleive og ein av Kjos-gardane i Gausdal er ført berre med hudskyld i 1661, men med skyld i både huder og fisk i 1668 og seinare. Nordrum på Fåvang er ført berre med huder i 1723, men med huder og fisk i 1803.

Eg tolkar dette som at skylda, i alle fall for nokre gardar, framleis vart betalt med varer utover mot slutten av 1600-talet. Jordebøker og matriklar kan til ein viss grad vere brukte som grunnlag for å registrere faktiske innbetalingar, og viss dei var gjorde i varierande vareslag, kan det vere forklaringa på dei avvika ein kan sjå. Men i all hovudsak er dei vareslaga som står som skyld på gardane på 1600talet, dei same som dei på 1800-talet.

Vekteininga for fisken var bismarpund. Ho endra seg - i mellomalderen var ho truleg på litt over $5 \mathrm{~kg}$.
I første halvdel av 1500-talet kom såkalla kølnsk vektstandard i bruk, og da utgjorde pundet 5,6 kg. Den vekta som er kjent frå nyare tid, skålvekt der pundet er nesten nøyaktig $6 \mathrm{~kg}$, kom ikkje i bruk i Noreg før sist på 1600-talet. ${ }^{28}$ I vektoppgåvene nedanfor er derfor det kølnske pundet på $5,6 \mathrm{~kg}$ brukt. Nå gjeld dette altså sannsynlegvis tørka fisk, der $1 \mathrm{~kg}$ svarar til om lag $4 \mathrm{~kg}$ fersk fisk. ${ }^{29}$

Ei norm for innbyrdes omrekning mellom skyldeiningar, det vil seie kor mykje av dei enkelte vareslaga det skulle skattast likt av, kom første gang i 1625 og vart endeleg fastsett i 1685 . I samband med matrikuleringa i 1660-åra vart det fastsett kor mykje av dei andre varene som skulle svare til ei av dei tre hovudvareslaga - korn (tunge mjølvarer), smør eller fisk (sjøfisk) - som skylda skulle fordelast på. Det tok ei tid før dette kom i fast bruk. ${ }^{30} \mathrm{I}$ Gudbrandsdalen festa forholdet 1 hud = 1,5 pund bergefisk $=4$ eller 5 alner vadmål seg. Desse var òg lik 1/2 skippund tunge, ${ }^{31}$ som berre vart teke i bruk i Fåberg og Gausdal. Det skjedde nok ved overføringa av desse tinglaga frå Gudbrandsdal til Totens futedøme i 1815. Huda vart elles som nemnt delt i 12 skinn og pundet fisk i 24 merker.

\section{OMGREPET BERGEFISK}

Omgrepet bergefisk eller bergerfisk i ymse bokstaveringar ser ut til å vore brukt frå seinmellomalderen i fleire tydingar. Det er neppe tvil om at det kan knytast til «fisk frå Bergen», ${ }^{32}$ sannsynlegvis òg til fisk tørka på berg eller tørka fjellfisk i innlandet. ${ }^{33}$ Når det også er brukt i Gudbrandsdalen, har mange lurt på kva slags fisk dette kan vere.

Lars Reinton drøfta omgrepet i ein artikkel i tidsskiftet Heimen i 1958, eigentleg som tilsvar til to artiklar av Aksel Hattestad i Årbok for Gudbrandsdalen for 1948 og 1957. Hattestad ${ }^{34}$ konkluderer, på litt tynt grunnlag, med at denne fisken «var ein slags lettsalta, velsmakande rakefisk 


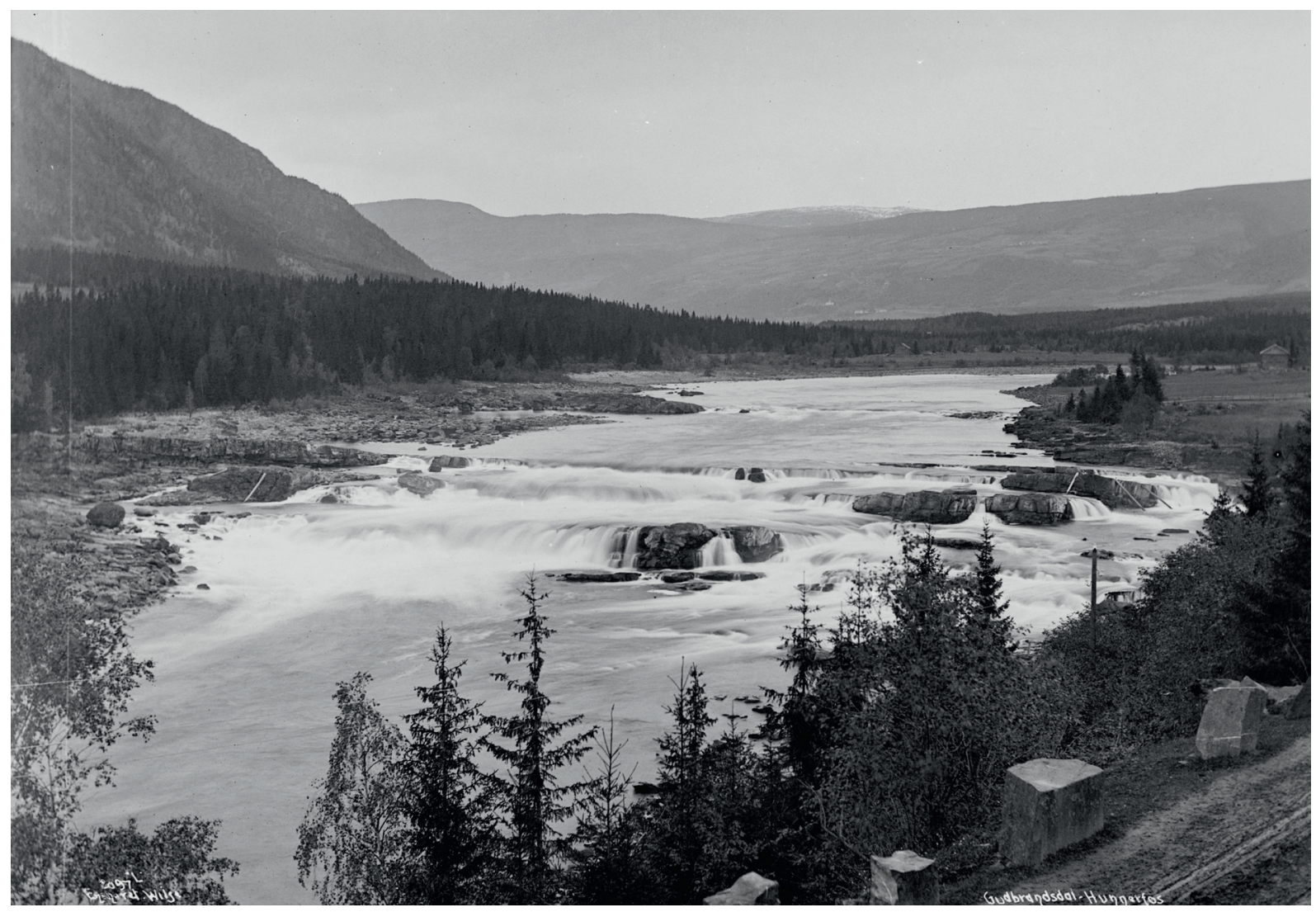

Figur 4: Utsyn over Hunderfossen i 1880-åra - dette var ein svært viktig fiskeplass, som det vart betalt 1,5 pund (8,4 kg) bergefisk i landskyld av i 1595. Foto: Axel Lindahl. ${ }^{65}$

som dei kunne laga serleg god i Gudbrandsdalen». Reinton på si side hadde, gjennom kjeldearbeidet bak storverket Seterbruket $i$ Noreg (Instituttet for sammenlignende kulturforskning 1955-1961), funne mange innførslar han meinte kunne stadfeste «tolleg sikkert at bergefisk i Gudbrandsdalen og sume andre Austlands indre bygder var turka ferskvassfisk, truleg aure» (kursivert av Reinton). ${ }^{35}$

Arnved Nedkvitne drøfta i 1980 Lars Reintons ${ }^{36}$ gjennomgang av kjeldegrunnlaget for dette vareslaget som skatte- og skyldeining i Gudbrandsdalen. Han meiner Reintons tolking ikkje er umuleg, men at det ikkje er dokumentert noka slik meiningsforskyving i ordet frå «fisk frå Bergen» til «fisk tørka på berg». Sidan Reinton òg refererer dokument som viser at tørka sjøfisk av same type som vart eksportert frå Bergen òg vart sendt til Gudbrandsdalen, meiner Nedkvitne at: «Inntil det kan skaffes direkte belegg for at tørket aure produsert i Gudbrandsdalen ble kalt Bergerfisk, er det mest rimelig at denne betegnelsen også i Gudbrandsdalen sto for tørket sjøfisk».

Nedkvitne refererer Reinton ${ }^{37}$ overflatisk. Argumentet han framfører, er at Reintons «viktigste argument [...] er at Bergerfisk forekommer 
i skattelister fra det indre Østlandsområdet på 1500-tallet». Reintons viktigaste argument er ikkje at omgrepet førekjem i dei skriftlege kjeldene, men at det førekjem i så stort omfang, og særleg følgjande relativt sjølvsagte forhold:

Når landskyld og leige av elvar, fossar og vatn i Gudbrandsdalen vart betalt med bergerfisk, så må bergerfisk i det tilfelle vera autentisk med den fisken som verkeleg vart fiska der [...] Det er urimeleg å tenkje seg at rente og landskyld av fossar og vatn i Gudbrandsdalen vart betalt med sjøfisk frå Vestlandet. ${ }^{38}$

Reinton bygger altså si drøfting på eit stort kjeldemateriale. Han refererer mellom anna at det $\mathrm{i}$ 1595 vart betalt $1 / 2$ pund «bergerfisk» av eit vatn «Thennelaugid» og 1,5 pund av Hunderfossen i Øyer. At det skulle vere tørrfisk som var komen over Lesja, Strynefjellet eller Sognefjellet, er særs lite sannsynleg. Reinton peiker rett nok altså på ei kjelde som omtalar slik transport av tørr sjøfisk frå Romsdalsmarknaden over til Gudbrandsdalen, Peder Claussøn Friis’ skildring av Noreg frå 1631. Reinton konkluderer likevel med at det «ville vere så utanom det vanlege og er så lite truleg at det umogeleg kan vere løysinga på problemet», mellom anna bygd på den betydelege mengda slik fisk som kom inn til Akershus i $1529 .{ }^{39}$ Også Ivar Kleiven refererer til at domkyrkja på Hamar tok «landskylda i fisk (turrfisk) frå Gullbrandsdala». ${ }^{40}$

Hans Hosar $^{41}$ påviser at skjåkværane handla med tørrfisk utover flatbygdene tidleg på 1700-talet. Han konkluderer på det grunnlaget, i samsvar med Ivar Kleiven, ${ }^{42}$ med at slik handel er «den mest sannsynlege bakgrunnen» for at ein del gardar i Skjåk hadde landskyld fastsett i bergefisk. Men Hosar og Kleiven sannsynleggjer likevel ikkje at slik handel var like omfattande $p a ̊$ det tidspunktet vareslaga gardane skulle takserast $i$, vart fastsette. Det skjedde altså fleire hundre år tidlegare.

Ivar Teigum $^{43}$ drøfta òg denne landskyldvara i Vågå, og sjølv om han ikkje er kategorisk, er det grunn til å tolke han til å vere samd med Reinton $\mathrm{i}$ at dette var fisk fanga og tørka i nærområdet. Asgaut Steinnes ${ }^{44}$ har òg festa seg ved at «eit anna slag fisk [enn torsk] vart nytta til å betale sume avgifter med i Søre Gudbrandsdalen».

Éi kjelde ser ikkje ut til å ha vore teke med i dei tidlegare drøftingane av omgrepet. I det reskriptet av 23. januar 1665 som danskekongen, Fredrik 3., gav ut som pålegg til kvar lagmann om å starte arbeidet med ein ny matrikkel, er det mellom anna nemnt ein del landskyldvarer som frå gamalt av har vore brukt, men som «ikke i Brug eller fornøden er, saasom Vadmel, Graaskind [...] Kalveskind, Huder [...] Salt, Humle, saa og tør Fisk af de som boe til Fjelds».45 Dette vart altså ikkje følgt opp i Gudbrandsdalen; både vadmål og tørrfisk vart ståande i matrikkelen som «landskyldspecie».

Min konklusjon er derfor stort sett i samsvar med Reintons: Det kan neppe vere tvil om at i alle fall den «bergefisken» som er nemnd som landskyldvare, er tørka fisk fanga i distriktet. At mindre regelmessige avgifter og skattepålegg kan ha vore betalt med innført tørr sjøfisk eller annan fisk, kan ein likevel ikkje sjå bort frå.

Det er elles verdt å merke seg at forsteleddet, bergeeller berger-, stort sett går ut av bruk i kjeldene tidleg på 1600-talet. I odelsmanntalet for Gudbrandsdalen 1615 er til dømes alle eigedomar med slik skyld berre innført med «fisch» ${ }^{46}$ eller tilsvarande. Slik er det i dei seinare matriklane òg så langt eg har sett.

\section{FORDELING AV BERGEFISKSKYLD SIST PÅ 1500-TALET}

Dei eldste oversyna over delar av landskyldinnbetalingane i Gudbrandsdalen finn ein som nemnt i dei bevarte lensrekneskapa frå 1557-1558 og 


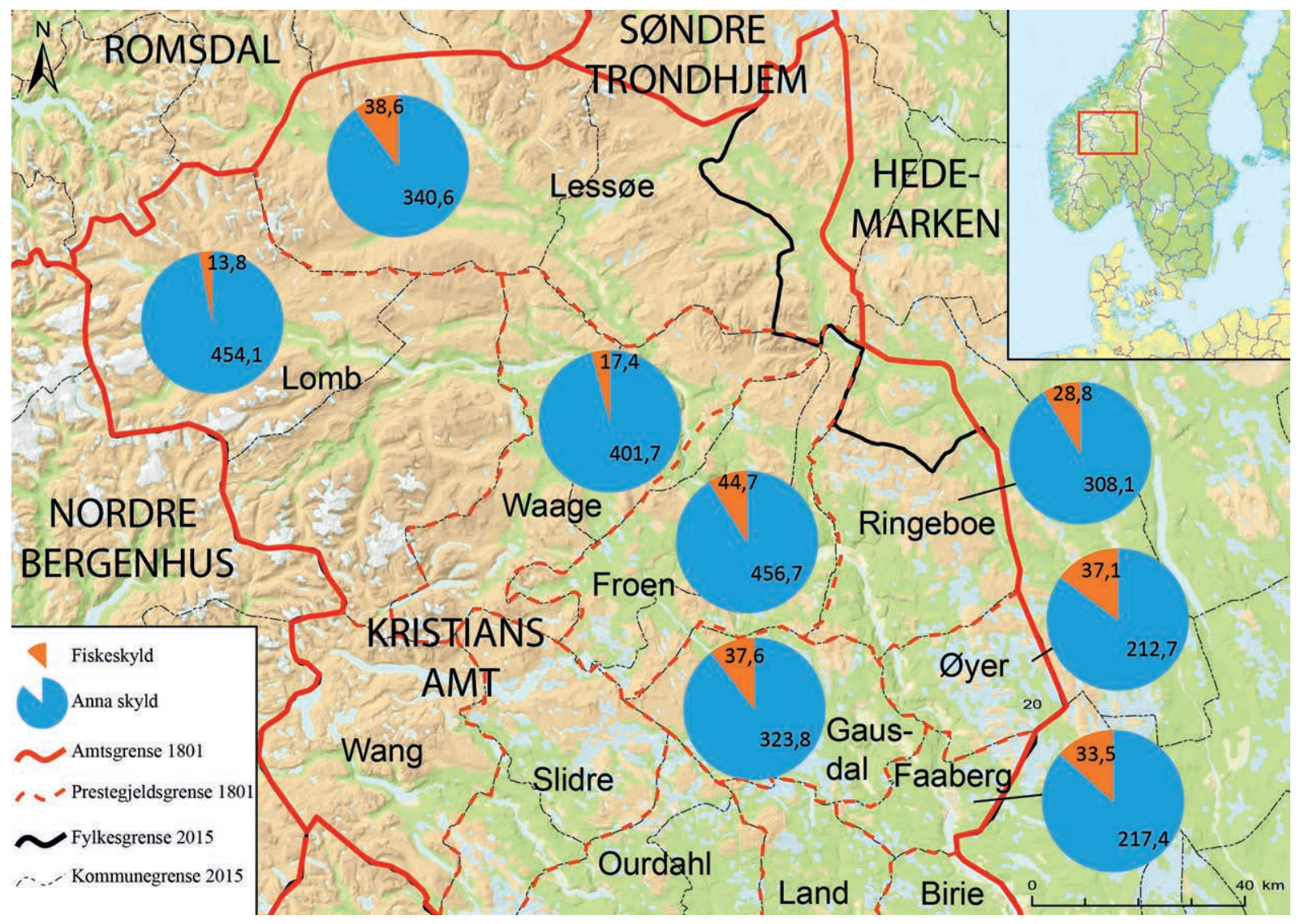

Figur 5: Dette kartet syner den samla skylda for kvart prestegjeld i Gudbrandsdalen omrekna til huder og kor stor del av ho som var i bergefisk i 1803. Jf. tabell 1. Kartproduksjon: Espen Uleberg og Axel Mjærum ved Kulturhistorisk museum.

1560-1561 (trykte). ${ }^{47}$ Dei består av landskyld av jord som hadde vore i katolsk sentralkyrkjeleg eige - ho hadde høyrt til erkebispen i Nidaros og bispen på Hamar. Krongodset frå før reformasjonen manglar altså i desse listene. Nærare gjennomgang stadfester at vareslaga skylda var sett i, ikkje hadde festa seg. Dei samla innbetalingane av bergefisk frå 92 eigedomspartar i 1557-1558 var litt over 150 pund og tre år seinare nesten 160 pund av 89 partar.

Desse to seriane syner altså ikkje ubetydeleg variasjon i korleis landskylda vart innbetalt enno på 1500-talet. I Fåberg var det til dømes betalt knapt 30 pund fiskeskyld for 17 partar i 1557-1558, men berre drygt 20 pund av 13 partar tre år seinare. Det er fleire av partane som manglar i den eine av listene - det ser ut til at minst 21 forskjellige partar er med i enten ei eller begge. Systematisk samanlikning med oversynet frå 1803 viser òg at fleire partar som er nemnde med ikkje heilt små fiskeskyldpartar kring 1560, ikkje er med i 1803. Det gjeld i alle fall i Børke, Diserud og Smestad. 


\begin{tabular}{|l|l|l|l|l|l|l|}
\hline Prestegjeld & $\begin{array}{l}\text { Tal, } \\
\text { eigedomar }\end{array}$ & $\begin{array}{l}\text { Samla } \\
\text { skyld i } \\
\text { huder }\end{array}$ & $\begin{array}{l}\text { Eigedomar } \\
\text { med fiske- } \\
\text { skyld }\end{array}$ & $\begin{array}{l}\text { Fiskeskyld i } \\
\text { pund }\end{array}$ & $\begin{array}{l}\text { Fiskeskyld } \\
\text { rekna om til } \\
\text { huder }\end{array}$ & $\begin{array}{l}\text { Fiskeskyld i } \\
\text { prosent av all } \\
\text { skyld }\end{array}$ \\
\hline Fåberg & 246 & 250,9 & 25 & 33,5 & 22,3 & $8,9 \%$ \\
\hline Gausdal & 252 & 361,4 & 35 & 37,6 & 25,1 & $6,9 \%$ \\
\hline Øyer & 194 & 249,8 & 37 & 37,1 & 24,8 & $9,9 \%$ \\
\hline Ringebu & 224 & 336,9 & 25 & 28,8 & 19,2 & $5,7 \%$ \\
\hline Fron & 312 & 501,4 & 37 & 44,7 & 29,8 & $5,9 \%$ \\
\hline Vågå & 262 & 419,1 & 18 & 17,4 & 11,6 & $2,8 \%$ \\
\hline Lom & 290 & 467,9 & 11 & 13,8 & 9,2 & $2,0 \%$ \\
\hline Lesja & 275 & 379,3 & 40 & 38,6 & 25,8 & $6,8 \%$ \\
\hline Sum & 2055 & 2966,6 & 228 & 251,4 & 167,6 & $5,7 \%$ \\
\hline
\end{tabular}

Tabell 1: Fordelinga av fiskeskylda på prestegjelda i Gudbrandsdalen etter jordavgifta 1803

Det var sannsynlegvis i samband med matrikkelarbeidet i 1660-åra at dei systematiske skyldoppgåvene vart fiksert. Da møtte kommisjonane representantar for bygdefolket, og informasjonen om skyldvarer var truleg i samsvar med det desse representantane meinte det hadde vore «frå gamalt», truleg utan omsyn til dei varierande vareslaga innbetalingane eigentleg vart gjort i til forskjellige tider. Dei kan jo som nemnt ha vore styrt av marknadssituasjonen. Eg nyttar derfor registreringane frå 1803 for å få oversyn over korleis fiskeskylda fordelte seg i dalen.

\section{FORDELING AV (BERGE-)FISKSKYLD PÅ DEI ENKELTE BYGDENE I 1803}

Jordtakseringa i 1803 syner som nemnt gamal skyld for drygt 2000 matrikkelgardar i dalen (sjå framanfor). Ho fordeler seg som vist i tabellen. Som vi ser, var altså hudskylda desidert størst, med $90 \%$ av det heile, medan fisken utgjorde 5,7\% og vadmålet resten. Det var 228 matrikkelgardar i dalen som hadde delar av eller heile skylda fastsett i fisk.
Fiskeskylda hadde altså forholdsvis størst omfang i Sørdalen, Øyer, Fåberg og Gausdal, med 43 \%. Midtdalen, Ringebu og Fron stod for litt over $29 \%$, og resten, knapt $28 \%$, finn vi i Norddals-bygdene. Rekna om til vekt var den samla fiskeskylda slik ho vart registrert i 1803, litt i overkant av $1400 \mathrm{~kg}$, litt over $600 \mathrm{~kg}$ i Sørdalen, drygt $400 \mathrm{~kg}$ i Midtdalen og i underkant av $400 \mathrm{~kg}$ i Norddalen. Dette er som nemnt fiskevekta som tørr vare - det gjekk 4 $\mathrm{kg}$ fersk fisk per $\mathrm{kg}$ tørrfisk. Ein må likevel hugse at dette var skylda som takst, skattegrunnlag, og det var berre delar av desse mengdene som faktisk vart leverte til ein jordeigar - bønder som var sjølveigarar, trong ikkje betale.

Seks av matrikkelgardane i 1803 hadde berre fiskeskyld (100 \%): to relativt små (rekna etter skylda) på Lunde i Fåberg (delar av gnr. 99), Haugen (del av gnr. 153) i Ringebu, som hadde blitt heilt øydelagt i Storofsen i 1789 og truleg gått inn i Øvre Sylte (gnr. 152). I Vågå er ein del av Nedre Kvarberg (gnr.71) oppgjeve berre med fiskeskyld i 1803, men 35 år seinare er den delen tydelegvis slegen saman 


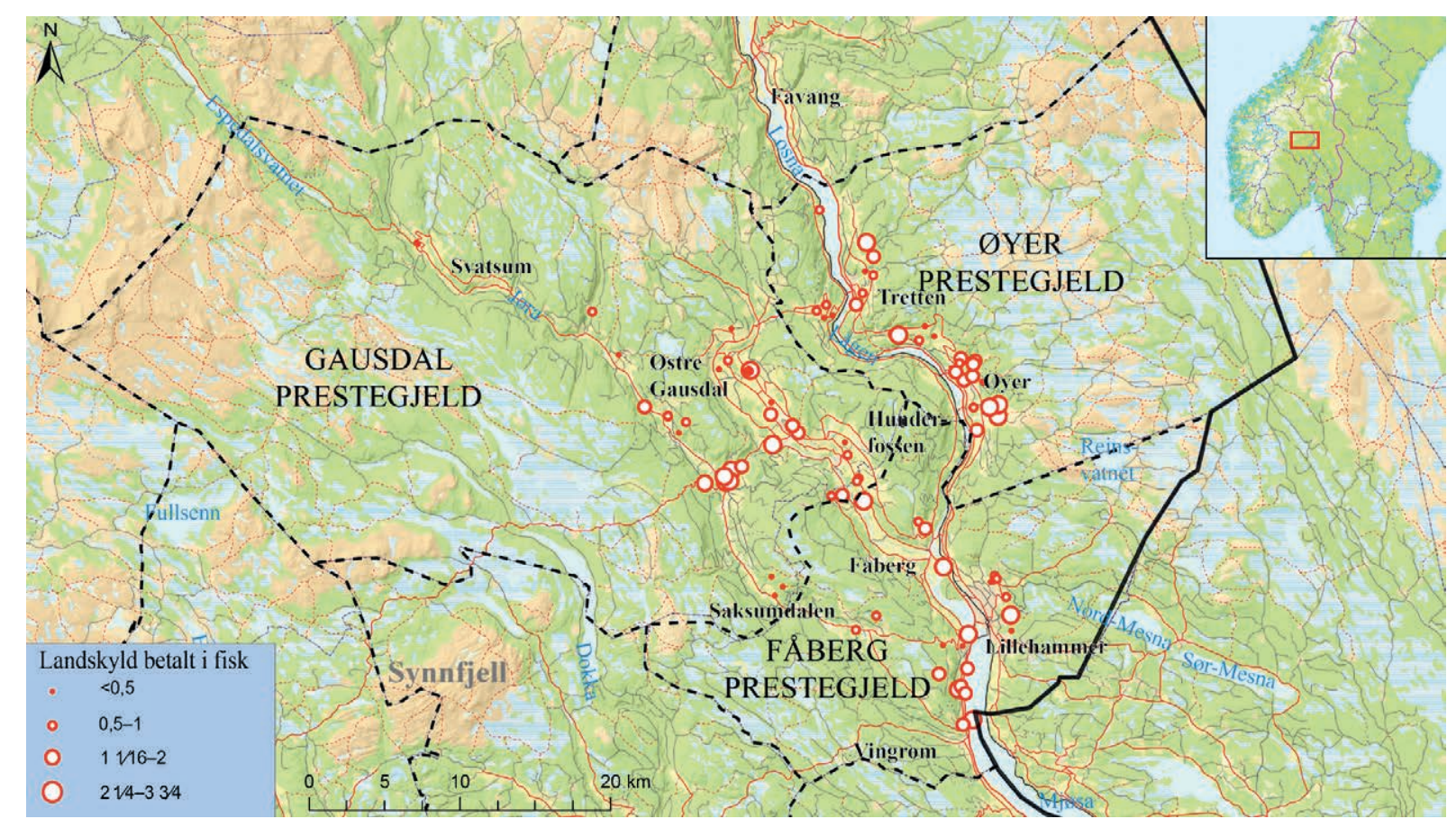

Figur 6: Kart over plasseringa av gardar med fiskeskyld i bygdene i Sørdalen. Markeringane viser til den interne storleiken på skylda rekna i pund (á 5,6 kg). Merk at dette berre var ein mindre del av all landskyld for området - sjå prosentfordelinga i tabell 1. Kartproduksjon: Espen Uleberg og Axel Mjærum ved Kulturhistorisk museum.

og den skyldeininga borte. I same bygda hadde Skårsroe (gnr. 155) berre fiskeskyld. Størst var det eine bruket på Hole i Skjåk (gnr. 2), med fiskeskyld tilsvarande ei hud.

Oppgåvene frå kring 1560 gir oss altså ikkje høve til å vurdere fordelinga like detaljert. Men vi kan sjå at den samla skylda i fisk er i overkant av 100 pund høgare i 1803. Det kan kome av to forhold: Godset staten eigde, er ikkje med kring 1560, og det har vore ei reell tilvekst gjennom den omfattande gjenryddinga av gardsbruk som vart avfolka i seinmellomalderen, men tatt $\mathrm{i}$ bruk att og skyldsett utover heile 1600-talet.

La oss så sjå på dei enkelte bygdelaga.

\section{Gausdal}

I det som i 1803 var Gausdal prestegjeld, var det 35 eigedomar med delar av skylda i form av fisk. Innanfor prestegjeldet finn vi konsentrasjonar av slike gardar i Follebu på austsida av Gausa og ved Segalstad bru og langs Jøra ved Forset, i Bødalen og ved Svatsum. I Follebu var det to Toft-gardar, Heggen, Holen og Manstad med 10,8 huder i samla skyld og 3,1 som fisk. Ved Segalstad bru to Einstad-gardar med 3 huder i samla skyld og halvparten i fisk. I Østre Gausdal på aust-/sørsida av Gausa var det Myre, Austereng, Reistad, Ovre og Borgard med 18,1 huder i samla skyld og 5,8 som fisk. På vest-/nordsida av Gausa var det Engeland, Kleva og Kjos med 5,5 huder i samla skyld og 2 i form av fisk. 
Ved Forset var det Søre Kallstad og fire av fem Forset-garder med 16,3 huder i samla skyld og 8,3 fisk. Mot Bødalen var det Øvsthågå, to $\mathrm{B} ø$-gardar, Brettingen og Brattland med 12,5 huder samla og 2,8 som fisk. Lenger oppe i dalen hadde Aulstad og Snertingdalen 0,8 huder i form av fisk av til saman 4,6 huder. I Øvre Svatsum finn vi to Synstgard-bruk og så Lia og Melbø i Auggedalen med til saman 3,6 huder skyld og 1 hud i fisk.

$\mathrm{Vi}$ ser at konsentrasjonen var sterkast ved Forset, der fire av dei fem eigedomane i 1803 hadde over halvparten av den samla skylda i form av fisk, og ho utgjorde over halvparten (svara til 7 huder av 13,8). Desse eigedomane hadde vore i eiga til bispen på Hamar før reformasjonen, ${ }^{48}$ og det var kanskje at det var godt fiske i Jøra, som var grunnen.

\section{Fåberg}

I Fåberg prestegjeld medrekna garden Veslehamar (Lillehammer) var det i 180325 eigedomar med skyld rekna i fisk. Vi finn dei konsentrert langs Vingromstranda og Vingnes, i Saksumdalen, kring Veslehamar og på vestsida av Lågen.

Langs Vingromstranda var det Ovren, Røyne, Boro, Hov, Bulung, Øyre, Reistad og Ramberg med 23,8 huder i samla skyld, og av dette var 13,1 i form av fisk. I Saksumdalen betalte to av bruka på Nygard Saksum og Sæter 3,5 huder i samla skyld - av det var 1,5 som fisk. I området der byen kom, hadde Veslehamar, Lysgard, Skårset, tre Lundegardar og Vesleberget 12,5 huder samla og knapt 5 huder skyld i fisk. På vestsida av Lågen finn vi Øvre Jørstad, Mælum og Øvstdal, og så oppover mot Follebu Struksrud og Simenrud med heile eller delar av skylda i fisk. Til saman er desse gardane taksert til nesten 19 huder, og 7,3 skulle vere i form av fisk.

Gardane langs Vingromstranda stod altså for nesten $40 \%$ av fiskeskylda i Fåberg. Her kan ein lure på om skyldsettinga kan ha samanheng med det omfattande lågåsildfisket. ${ }^{49}$ Skyldfisken kom nok frå Mjøsa som aure eller lågåsild, men lågåsilda vart likevel ifølgje Hiorthøy ${ }^{50}$ aldri tørka, berre salta og kokt. Elvefisket var kanskje det viktigaste - slik Hiorthøy ${ }^{51}$ skildrar det. Han nemner òg at Mælum hadde «et skiønt Giedde Fiskerie», og at Vingnes hadde det «betydeligste» gjedde- og krøklefiskeri i Fåberg. Men eg har ikkje funne kjeldebelegg for at nokre av desse fiskeslaga vart nytta som landskyldvare.

\section{Øyer}

Øyer var prestegjeldet med forholdsvis størst fiskeskyld av den samla skylda. Her finn vi som nemnt Hunderfossen, der aurefisket frå gamalt av «lyt ha vore ei overlag stor og gjæv herlegheit». ${ }^{52} \mathrm{I}$ 1803 var det 37 gardar med fiskeskyld i bygdene, og gardane med slik skyld finn vi nokså jamt fordelt på austsida av Lågen frå Hunder og oppover til prestegjeldsgrensa mot Ringebu. På vestsida har vi ein konsentrasjon i Musdalen oppover til Ingeridskogen, der bruk på Hong, Berg, Offigstad og Holen hadde noko fiskeskyld: Ho svara til 2 huder av ei samla skyld på drygt 13 huder.

Lågen går stille ved Øyer. I Jemne- og Gillebufjorden var det nok bra fiske. Her stod bruk under Bryn, Vedem, Høvre, Bergom, Moshus, Skjønsberg, Lånke, Gillebu og Kvam med ein betydeleg del, 11 av 27 huder til saman.

Lågen nedanfor Tretten hadde truleg òg gode fiskeplassar. Holmen og Mælum var enkeltbruk, og halvparten av den samla landskylda på desse gardane, som svara til 1,5 huder, var sett i fisk.

Elles startar Losna her ved Tretten, og vatnet og fisket var sjølvsagt ein «herlighed» for mange. Dei gardane på austsida som hadde fiskeskyld her, frå Langgard, Torstad, Tande og Kleva, står òg med over fjerdeparten av skylda, som svara til 3,5 av 13,7 huder, i form av fisk. 


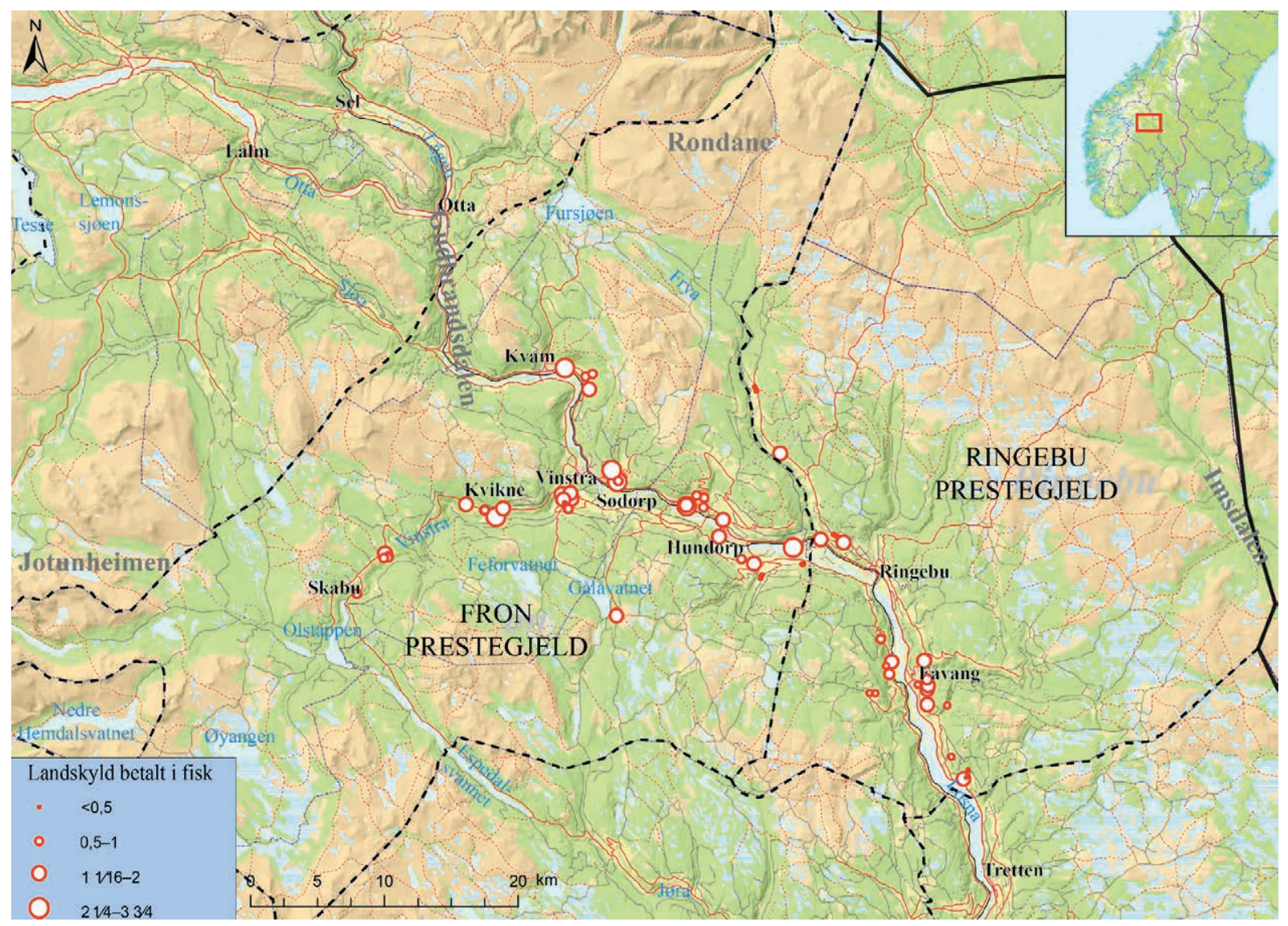

Figur 7: Kart over plasseringa av gardar med fiskeskyld i bygdene i Midtdalen. Sjå forklaringa til figur 5. Kartproduksjon: Espen Uleberg og Axel Mjærum ved Kulturhistorisk museum.

\section{Ringebu}

I Ringebu prestegjeld var det i 1803 i alt 25 bruk med delar av skylda i fisk. Her finn vi litt sterkare konsentrasjonar - på austsida litt oppover frå Øyergrensa gjeld det fire bruk frå Øfstgard, Steinumgard, Torsgard og Haugen med 2,7 av 6 huder i form av fisk.

Frå Løysnes og opp til Fåvang var sju bruk frå Oppsal, Bakke, Løysnes, Lunde, Nordrum og Rørvik førte med fiskeskyld. Reknar vi med Hjelle på nordsida av Tromsåe på vegen opp mot Brekkom, hadde alle desse det som svara til 8,3 huder, av skylda på 25,4 huder i fisk. Her var det nok fiske både i Lågen og i fjellet, særleg Imsdalen, som gjorde utslaget. Brukarar i Fåvang kom tidleg i konflikt med austerdøler om denne fjelldalen med dei fiskerike vatna, ${ }^{53}$ og i alle fall Nordrum har hatt fiskerett der. ${ }^{54}$

I dalen på vestsida av Fåvang var det to bruk, Tullia og Godlia, som stod med tre huder i skyld til saman; av desse var ei fisk. Litt lenger oppe i dalen nede ved elva var det fiskeskyld på Berge og to Strande-bruk, og når vi reknar med Rotås i dalen 


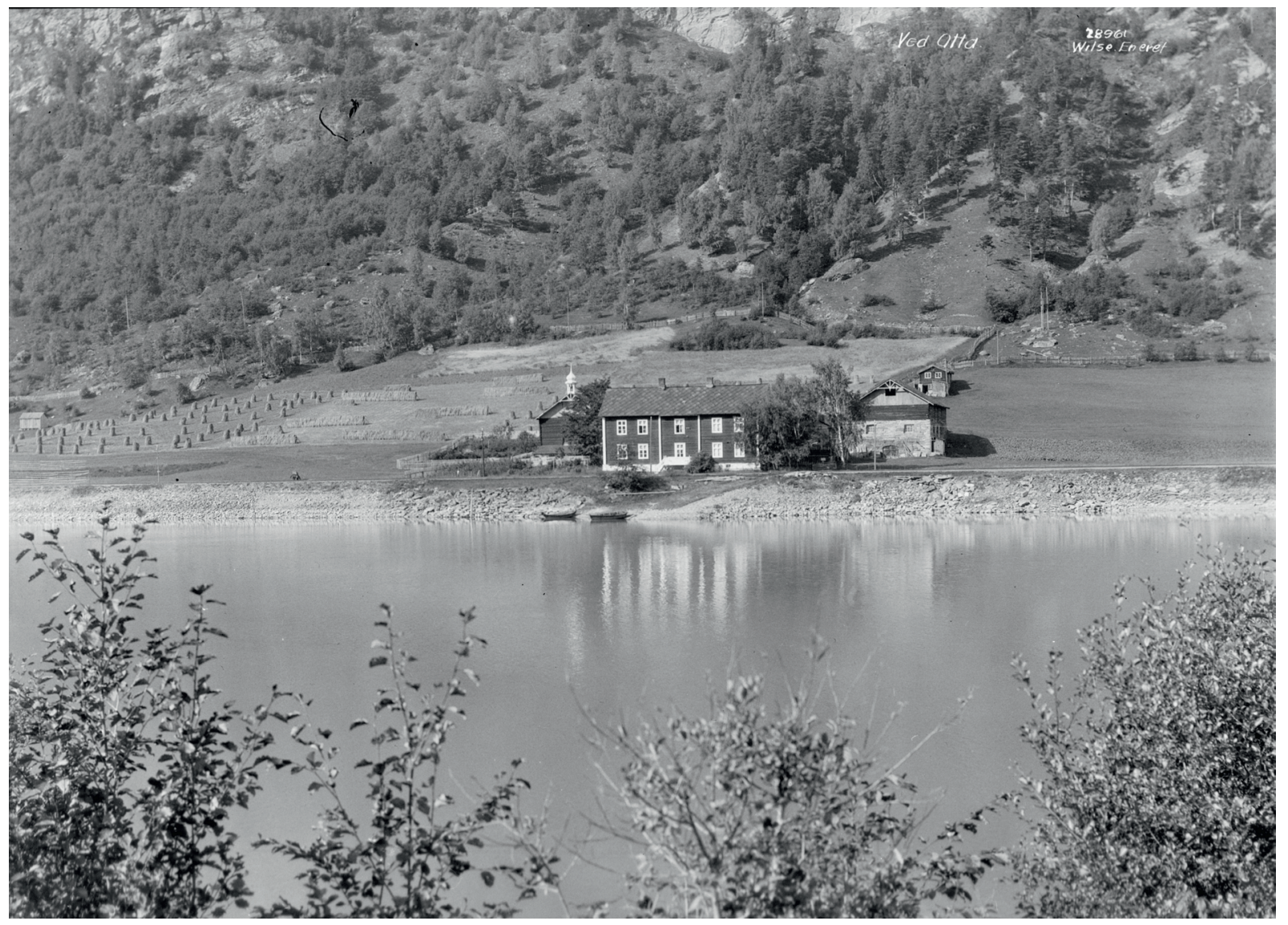

Figur 8: Utsyn over Lågen ved Sandbu i Sel 1926. Garden var ikkje sett i fiskeskyld, men det var nabogardane $\varnothing_{v r e ~ o g}$ Nedre Bu like ovanfor. Foto Anders Beer Wilse. ${ }^{66}$

ovanfor Strande, hadde desse fire bruka ei fiskeskyld som svara til 3,5 av 13 huder.

Den siste konsentrasjonen av fiskeskyld i Ringebu finn vi i Kjønnåsgrenda og Venabygda. Der hadde sju bruk frå Mælum, Nordrum, Rudi, Bø og Venåsen knapt 4 huder i fiskeskyld av ei samla skyld på 16,5 huder. Frå gamalt av gav nok fjellvatna mange av desse òg høve til å skaffe seg fisk til å betale gardleige med.

\section{Fron}

Fron var det prestegjeldet med høgst samla skyld, og 37 bruk er registrert med fisk. Dei i sjølve dalen ligg i stor grad på begge sider av Lågen. På austsida frå prestegjeldsgrensa sørfrå gjeld det 14 bruk frå Forr, Odenrud og Oden, Rudi, Kjørstad, Tåkåstad, Brandvål og Ilstad. Desse var til saman sette i 38,4 huder, og av desse var nesten $10 \mathrm{i}$ form av fisk.

På vestsida av Lågen rekna sørfrå var det 12 bruk frå Bakke, Bue, Haverstad, Skarstad i Nørdre Lia og Lunde, Bø og Bryn i Ruste førte med litt over 
7 huder av det som til saman svara til litt over 25 huder skyld. Oppover Vinstradalen, i Kvikne, hadde 10 bruk av Sylte, Silli, Vistad og Tune, Åsmundstad, Nedre Fosse og Slåa, Kvålen og Skåbu ei fiskeskyld på det som svara til litt over 7 huder, av knapt 21. I Kvam var det fire bruk: Stormorke (Sønstebø), Sigstadvollen, Forbrigd og Klomstad, som til saman var sette i drygt 4 huder av det som samla svara til 16,5 huder.

Det er vel neppe grunn til å tru anna enn at gardane nede i hovuddalen hadde fisk frå både Lågen og fjellvatna. I Kvikne, og særleg Skåbu, var fiske og fangst viktige næringsgreiner såpass seint som på 1800 -talet..$^{55}$

I Fron er det elles belegg for ei anna fiskeavgift enn skyld: «ridefisk» til soknepresten. Det var ei fast avgift for at presten sjølv skulle halde seg med ridehest. Heil- og halvgardar (etter det gamle gardklassesystemet $\left.{ }^{56}\right)$ i annekssokna Kvam, Kvikne og Sødorp skulle betale 1 pund fisk $\mathrm{i}$ året til soknepresten for å sleppe plikta til å skysse han frå prestegarden til annekskyrkjene. ${ }^{57}$ Dette var nok fisk av same slag som skylda var sett i, bergefisk.

\section{Vågå}

I Vågå prestegjeld var det $\mathrm{i} 1803$ ikkje fleire enn 18 eigedomar som var registrerte med fiskeskyld. Dei det gjeld, er ikkje spesielt konsentrert. Ein gard ovanfor Vågåmo, Nedre Øy, hadde ei halv av den samla skylda på det som svara til litt over 5 huder, oppført som fisk. To av bruka på Øygarden i Skårvangen hadde ei halv av det som svara til 1,3 huder, i fisk. To gamle gardar på sørsida av Vågåvatnet, Klones og Valle, var registrerte med 2,5 av den samla skylda på 7 huder i form av fisk. På nordsida av vatnet hadde Fellese ein halv av 5 huder som fisk, medan ein eigedom på Kvarberg som nemnt hadde berre fiskeskyld, 1 pund eller 2/3 hud. Eit av bruka på Øvre Skår ved Lalm hadde det same. I Sjårdalen var det berre eitt bruk på Kleppe som var registrert med litt fiskeskyld, det som svara til ei halv hud, av drygt 4,5 huder.

I Øvre Heidalen hadde to bruk, Holen og Åseng, ei skyld på 3/4 hud i fisk av til saman 4 huder i 1803 . I Bræebygda, på vestsida av Lågen, hadde tre bruk av Bu og Bræe 1,5 huder av 5,3 i fisk. Ovanfor Otta hadde to mindre bruk, Kleivrud og Kolobekken, halvparten av skylda på til saman ei hud i form av fisk, og på Nord-Sel hadde to bruk av Skårå og Romundgard tre huder av den samla skylda på åtte huder i form av fisk.

Ivar Teigum har funne dei fleste av desse gardane med fiskeskyld i ei jordebok frå 1607/08 og peiker på at alle var gardar som kunne rå over gamle rettar i elvar og vatn. Dei fleste låg lagleg til for fiske på Vågåvatnet, Lalmsvatnet, Lågen sør for samløpet med Otta eller vatna i heimfjellet mellom Randsverk og Vågå. ${ }^{58}$

Ein kan likevel lure på kvifor fiskeskylda var såpass lita i høve den samla landskylda i denne bygda.

\section{Lom}

Lom medrekna Skjåk var det prestegjeldet i Gudbrandsdalen med lågast fiskeskyld i 1803, rekna både i mengd (knapt 14 pund eller drygt $77 \mathrm{~kg}$ ) og i del av den samla skylda frå bygdene (sjå tabellen). Det var berre elleve bruk i Lom som vart registrerte med fiskeskyld i 1803.

Dette er påfallande så lenge også bygdene i Lom har hatt gode fiskeri i både vatn og elvar på båe sider av dalføra og i sjølve Ottaelva. I søre delen av bygda, ved Garmo, er ho ein del av Vågåvatnet, og nedst i Skjåk til Fossbergom flyt ho òg så stilt at ho er rekna for eit vatn, Skim, kjent for godt fiske i eldre tid. ${ }^{59}$

Av dei elleve eigedomane med fiskeskyld var berre tre i hovudsoknet. Andberg i Nedre Bøverdalen hadde det som svara til 0,8 huder, av 2 huder i fisk. 


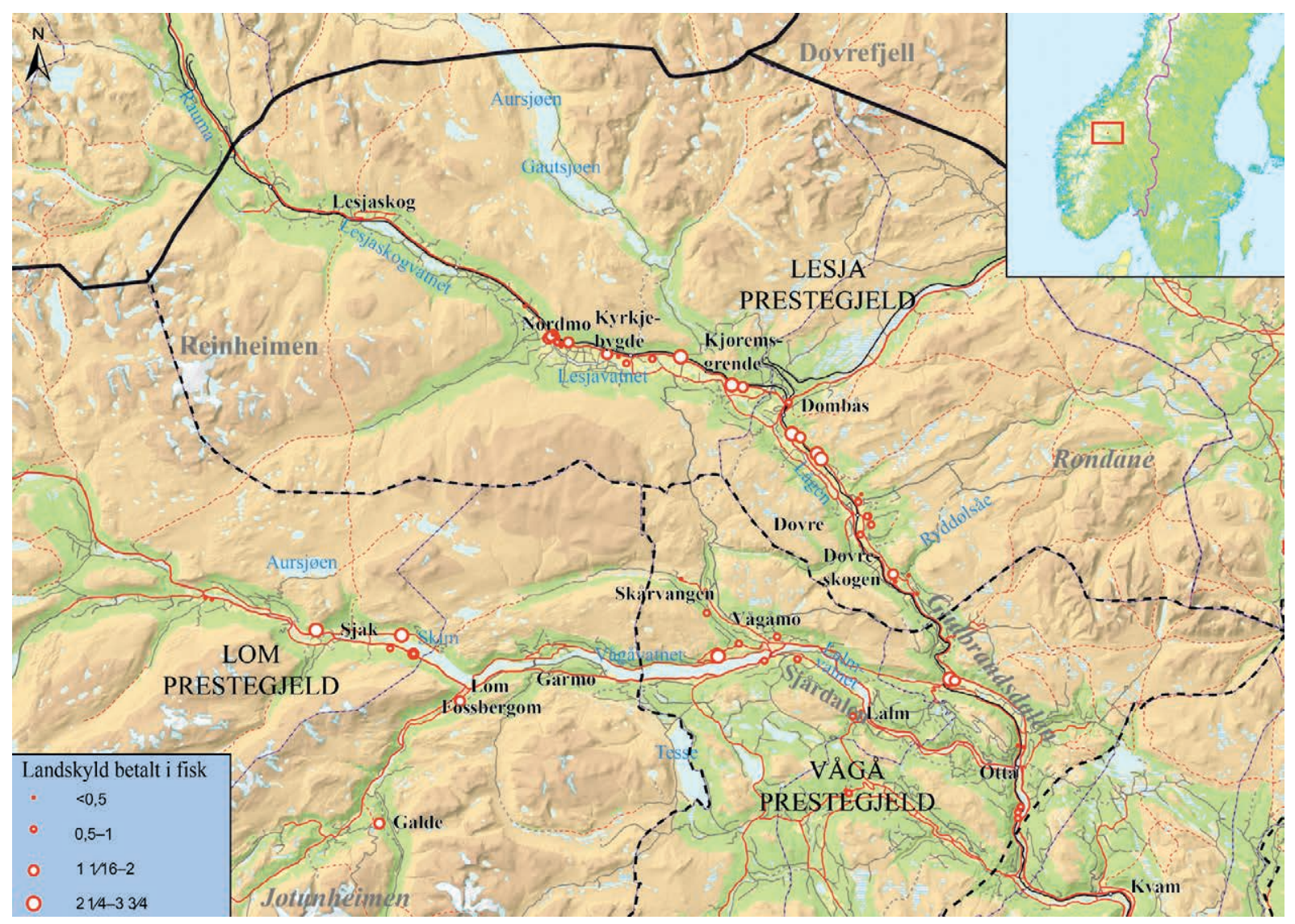

Figur 9: Kart over plasseringa av gardar med fiskeskyld i bygdene i Norddalen. Sjå forklaringa til figur 5. Kartproduksjon: Espen Uleberg og Axel Mjærum ved Kulturhistorisk museum.

Dei to Bakkeberg-bruka på Galde i Øvre Bøverdalen hadde nesten halvparten av den samla skylda på 3,4 huder i fisk. Resten låg i Skjåk, og her finn vi òg konsentrasjon langs breddene på Skim. Fem bruk, to av Hole, Maurstad, Nørdre Ånstad på sørsida og Bøje på nordsida, hadde det som svara til 5 huder, av den samla skylda på drygt 13 huder oppgjeve $\mathrm{i}$ fisk. I tillegg hadde eine Forberg-garden det som svara til 1,5 huder, i fiskeskyld av samla 3,3 huder, og to av eigedomane på Dagsgardsøygarden («Hov Engeland») er òg førte med ei lita fiskeskyld (3 skinn av 5 skinn samla).
Særs påfallande er det nok at ingen gardar på Garmo er registrert med fiskeskyld sjølv om dei frå mellomalderen hadde fiskeretten i Tesse (sjå s. 127-135).

\section{Lesja}

I Lesja prestegjeld finn vi altså i alt 40 eigedomar med fiskeskyld i 1803. Det var det høgaste talet $\mathrm{i}$ dalen, men den samla fiskeskylda var elles, som vi ser av tabellen, ikkje så høg. Fisking var likevel truleg ei viktig attåtnæring, i alle fall slik Ivar Kleiven såg det; både Lesjavatnet og dei store vatna i fjellområda 


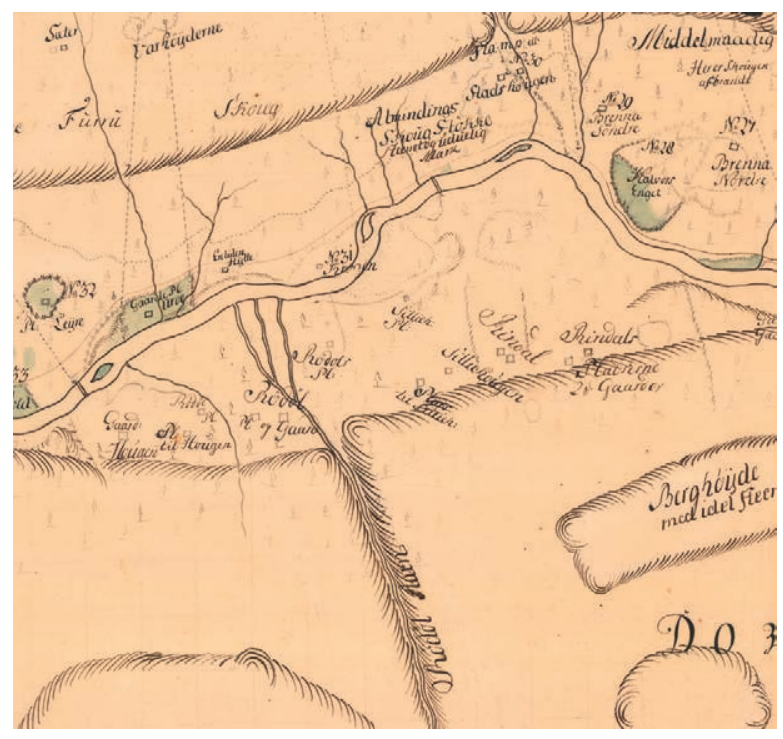

Figur 10: Utsnitt av kart over Dovrebygda, anneks til Lesja prestegjeld, teikna av landmålar Christian Basballe i 1758-1759. Vi ser gardane med fiskeskyld på sørsida av Lågen i søre delen av bygda: Haugen, Ryddøla, Siljehaugen og Rindal. Frå Kartverket, Amtkartsamlinga.

særleg på nordsida mot Dovrefjellet førte til at bygdene «ha flust upp med aure te kvar ti' både fersk og gomal». ${ }^{60}$

Bruka med fiskeskyld i Dovre ligg i nokre konsentrasjonar. Nedst i bygda, på Dovreskogen, var det fire gardar nokså samla på sørsida av Lågen: Søre Haugen, Ryddøla, Siljehaugen og Rindal. Dei hadde knapt 4 huder i samla skyld, og av detta var 1,75 i fisk. Gardane her hadde vel kanskje godt fiske innover langs Ryddøla og i fiskevatna innanfor? På solsida i Åsagrende var det òg fire eigedomar med fiskeskyld: Engelshus, Vigerust og to på Slette. Skylda på desse var til saman drygt 5,5 huder, og av dette var ca. fjerdeparten i form av fisk. Desse gardane hadde $i$ alle fall god tilgang til fjellfiske austover. Lenger nord i Dovre var det fire bruk med fiskeskyld: to i Arnkleiv - Engjom og Hjelle - med 5,5 av til saman 12 huder som fisk. Eine Dombås-garden hadde òg ei halv hud eller ein tredjedel av skylda i fisk. Desse gardane ser ikkje ut til å ligge like lagleg til for fjellfiske, men dei hadde sjølvsagt tilgang til Lågen.

I Lesja er gardane med fiskeskyld meir spreidde. I Kjøremsgrende var det Ommondgard og Nørdre Rolstad, der 2,5 av 8 huder i samla skyld vart rekna i fisk. Så var det som svara til ei hud, av tre huder på Nordigard Bø sett som fisk, medan ei halv av drygt 2 huder i Flågåstad stod i fisk.

Vidare nordover finn vi to konsentrasjonar av gardar med fiskeskyld i 1803. I nørdre delen av Kyrkjebygde var det fem eigedomar: Vesl-Kollstad og to på både Hogsvål og Belle. Skylda på dei var til saman drygt ti huder, og av dette var det som svara til tre huder, i fisk. Den nørdste og høgaste konsentrasjonen av slik skyld var på Nordmo, der i alt 13 eigedomar er sett med delar av skylda, drygt 7 av knapt 21 huder, i fiskeskyld. Det var dei to Tordhol-bruka, Skarphol, Nørstegard, to bruk på Norderhus, alle fire Bjøkne-gardane, dei to i Hågån og Motterud.

\section{OPPSUMMERING}

Tørka ferskvassfisk må ha vore ein etter måten viktig del av vareproduksjonen i Gudbrandsdalen $\mathrm{i}$ overgangen til tidleg nytid, på 1500- og 1600-talet. Mange krav frå statsmakta, der landskylda kanskje berre var ein mindre del, ser ut til å ha vore betalt med denne vara. Det er likevel dessverre vanskeleg å finne noko mønster i kva det var for gardar som på eit tidspunkt faktisk leverte slike varer i form av landskyld eller til dekning av andre krav frå statsmakta - til det er kjeldegrunnlaget for dårleg.

Det er til dømes påfallande at forholdet mellom fiskeskyld og den samla skylda var såpass mykje lågare i Vågå og Lom enn i resten av dalen. Ein kan kanskje tru at det hadde samanheng med avstanden til dit innbetalinga skulle skje. Men det argumentet held ikkje når vi ser at fiskeskylda frå Lesja og Dovre, 
rekna om til vekt, var meir enn dobbelt så tung som den frå Ottadals-bygdene til saman. Ein skulle altså trudd at dei bygdene, med dei gode og godt dokumenterte fisketilhøva ein finn der, skulle ha blitt taksert i form av fisk i større grad. Eit moment til å forklare dette kan kanskje vere at Ottadals-bygdene var klimatisk og topografisk særleg godt eigna for kornproduksjon, ein produksjon gardbrukarane der vidareutvikla gjennom den omfattande kunstige vatninga langt attende i tida. Bygdene eksporterte som kjent kornvarer i betydeleg omfang mellom anna til Røros. Men Fron var trass alt den viktigaste kornbygda i dalen ${ }^{61}$ og hadde likevel forholdsvis høg skyld i fisk.

Som nemnt har vi ikkje gode kjelder til kunnskap om fordelinga av jordeigedomen før kring 1660. Da var nok forholda relativt mykje omsnudd i høve til tidleg på 1500-talet, da vareslaga landskylda skulle betalast i, vart fastsette. For gardar som ikkje var i sjølveige, var det nok i betydeleg grad eigarane som dikterte kva vareslag leiglendingane skulle betale,jf. klaga til lensherren i 1589 . No veit vi ikkje omfanget av sjølveige i Gudbrandsdalen på denne tida, men Fartein Valen-Senstad ${ }^{62}$ rekna med at det kan ha vore om lag ein tredjedel. Han peiker likevel på at det nemnde skyldeigesystemet nok førte til at mange bønder var delvise leiglendingar og måtte betale delar av skylda til forskjellige eigarar. Det ser vi tydeleg særleg i kjeldene frå kring 1660. Det kan derfor vere grunn til å seie seg samd med Ivar Kleiven, som altså konkluderte med at hamarbispen var den jordeigaren som ville ha slik fisk (sjå framanfor), og denne var nok til bruk i hushaldet på bispegarden. Omfanget av bergefisk i landskyldoppgåvene også seinare kan der neppe seiast å vise anna enn eit muleg omfang av jordeigedom han kontrollerte før reformasjonen.

Noko detaljert oversyn over kor mykje fisk som totalt vart fanga i Gudbrandsdalen ved inngangen til nytida, er derfor ikkje råd å kome fram til. Mengda svarar til kyststroka våre, der det å ro ut og fiske til dagleg matkonsum var vanleg. Det var det nok til ein viss grad her i dalen òg, slik det er dokumentert frå markaslåttearbeidet i Ringebufjellet på slutten av 1800-talet - slåttefolket som skulle arbeide i eit par veker, hadde med seg noko mjøl- og mjølkemat, men det første dei gjorde, var å fiske seg nokre «kjø’e» i næraste bekk eller vatn, så dei hadde til «sulmat».

\section{SUMMARY:}

\section{ABOUT THE LAND RENT "BERGEFISK" IN GUDBRANDSDALEN}

In Norway, the only way landowners could get any profit from their property was by leasing it to a free tenant. The rent the peasant had to pay for the farm was a certain part of the yield: grain, meat, hides, wool, butter, cheese, or products from nearby available resources, such as fish, furs, and timber. Already in the 14th century, the Crown had had all farms valued and given a land rent, also farms that were allodium ("odel") or regular freeholds, where the peasant owner had no obligation to pay anything to anybody for the use of the farm. The reason was of course that the system was also well fitted to calculate ordinary tax payment.

Saltwater fish, mainly dried, was a very important land rent along the coast, and for hundreds of years the most important goods for export from Norway. But we can also find fish as land rent from inland farms as early as the beginning of the 16th century. This fish is called bergefisk, which may be translated in two different ways: as meaning "freshwater fish from the mountains" (in the written form berg) or 
"saltwater fish from Bergen," the major export harbor in the country.

The article discusses the findings and distribution of "bergefisk" as land rent on farms in Gudbrandsdalen based mainly upon a complete taxation list from 1803. The conclusion is that the "bergefisk" as land rent in this area must have been freshwater fish from the lakes and rivers, and the amount given in land registers indicates that such inland fishing must have been of a certain significance in early modern times. 



\title{
SØRSAMENES FJELLFISKE. ØRRET, SIK OG RØYE - ET SVØMMENDE MATFORRÅD
}

\author{
Anne Severinsen
}

\section{INNLEDNING}

Fisket er i liten grad omtalt i litteraturen om samenes liv og virke. Hele det samiske bruksområdet fra Finnmark til Hedmark er inndelt i reinbeitedistrikter der tamreindriften danner grunnlag for reineiernes bruksrettigheter på både privat og statlig grunn. Samenes fjell- og innlandsfiske har - isolert sett gitt reindriftssamene rett til å fiske i tilknytning til utøvelse av reindrift på statens grunn i reinbeitedistrikt. Formålet med denne artikkelen er å forsøke å vurdere betydningen av fisket både som næring og som binæring i det sørsamiske området fra 1500tallet og opp mot vår tid. Hvor viktig var fisken $\mathrm{i}$ den sørsamiske naturalhusholdning? ${ }^{1}$

\section{Forskningsstatus og kilder}

I historiske beskrivelser fra det sørsamiske området i Norge blir fisket viet liten eller ingen interesse. Det skyldes trolig to forhold: For det første har fisket som aktivitet etterlatt seg få materielle spor, ${ }^{2}$ og det har ikke hatt funksjon som etnisk markør. Det spesielle og interessante ved samene og deres kultur har vært knyttet til reindrift, klesdrakt, ornamentikk, håndverk, kåter eller gammer og den eldre samiske religion. Fisken som ressurs er blitt utnyttet av mange, uavhengig av etnisitet, og har derfor vært av sekundær interesse.

I Sverige er det utgitt to avhandlinger fra sørsamisk område der fisket er spesifikt beskrevet: Sigrid Drakes doktorgradsavhandling om samer i Västerbotten fra 1918 er basert på håndskrifter etter den svenske presten Jonas A. Nensén (1791-1881), som samlet inn materiale $i$ de samiske områdene $i$ Norrbotten og Västerbotten i perioden 1818-1841. ${ }^{3}$ Kristoffer Sjulssons minnen bygger i hovedsak på samtaler som den svenske folkeminnesamler Olof Petter Pettersson hadde med den eldre samen Kristoffer Sjulsson (1828-1908), som bodde i Västerbotten, i grensetraktene mot Norge. ${ }^{4}$ Christer Westerdahl nevner også fisket i sin beskrivelse av næringsgrunnlaget for skogssamene i Ångermanland og Åsele Lappmark, som ligger omtrent rett øst for Nord-Trøndelag. Han har også skrevet en bok om samiske båter.

En viktig trykt originalkilde er utkast til jordebok for Ume lappmark fra $1670 .{ }^{5}$ Blant ikke trykte originalkilder er folketellinger fra Tärnaby-traktene i tillegg til eldre dokumenter fra norsk side der fisket nevnes, ofte bare med få ord. Flere rettssaker om samenes rett til fiske i det sørsamiske området 
indikerer at fisket må ha hatt betydning som næring. I dette materialet er det få opplysninger om hvordan fisket foregikk, men dommene gir et visst innblikk i bruk av fiskevatn og samisk rettsoppfatning tilknyttet bruken.

Sist, men ikke minst nevnes de muntlige kilder. De er naturligvis begrenset til hva nålevende personer husker, i praksis ned mot 1930-tallet. De muntlige kildene er likevel meget verdifulle fordi man kan gå ut fra at de fangstredskaper som de eldste informantene kan huske, også var i bruk på 1800-tallet. Det samme gjelder konserveringsmetoder for fisk.

\section{Det geografiske området}

Det sørsamiske området strekker seg i dag fra Rana i Nordland til Elgå i Hedmark og på svensk side fra og med Västerbottens län til Idre i Dalarna (figur 1). ${ }^{6}$ Riksgrensen mellom Norge og Sverige ble fastlagt i 1751. Både før og etter den tid har samer flyttet med reinflokkene fram og tilbake til tradisjonelle beiteområder på begge sider av riksgrensen. Sigrid Drake skriver at det var så godt som fullstendig kulturell overensstemmelse mellom «Nordlandslappar och Västerbottenslappar» på 1700-1800-tallet. ${ }^{7}$ At det skulle være større kulturforskjeller mellom samer på begge sider av Kjølen lenger sør eller i tidligere tider, er lite sannsynlig. Det betyr at det er relevant å benytte kilder fra det sørsamiske området i Sverige når man skal utfylle et ganske spinkelt kildemateriale på norsk side.

\section{Eldre samisk bosetting $i$ sor-norge}

Historikerne har hatt ulike teorier om den sørlige grense for samenes utbredelse. Rudolf Keyser og P.A. Munch var av den oppfatning at nordmennene vandret inn i Norge ved inngangen til jernalderen og møtte spredte grupper av nomadiserende «finner og lapper» også i Sør-Norge. I 1874 mente Oluf Rygh å kunne påvise at det i steinalderen var en

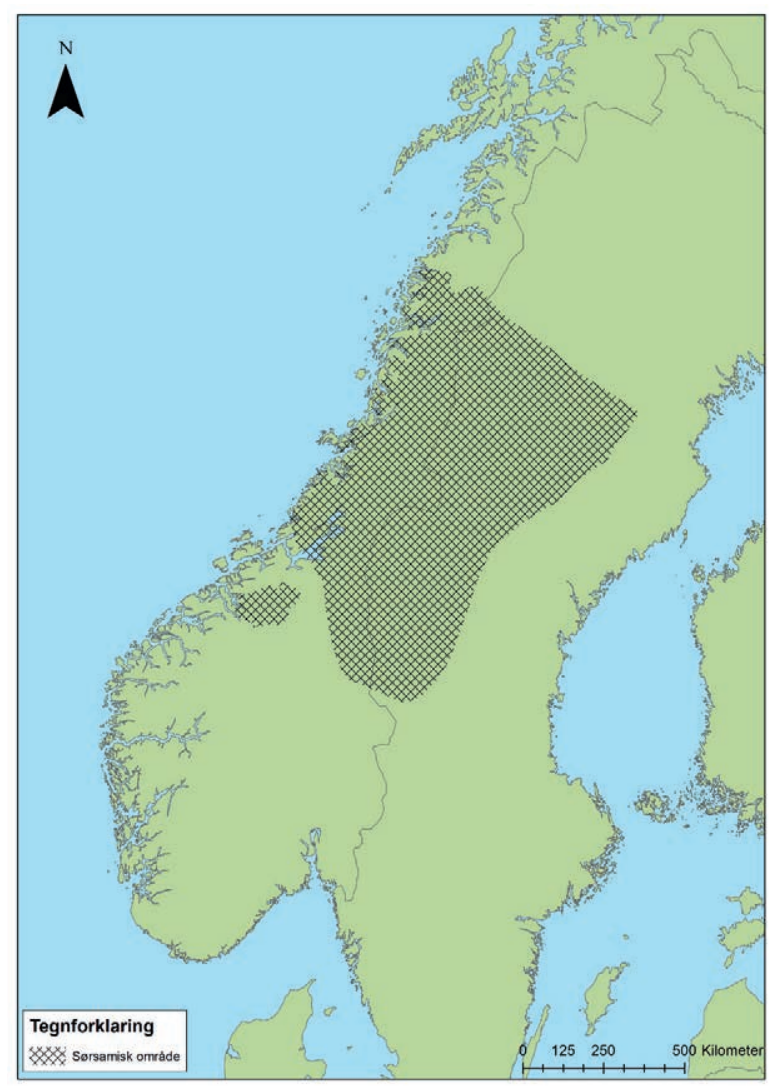

Figur 1: Med betegnelsen «sørsamisk område» forstås det sørsamiske språkområdet i et historisk perspektiv. På norsk side er vestgrensen på dette kartet i hovedsak sammenfallende med reinbeitedistriktsgrensene som ble opprettet på 1890-tallet, men sørsamer har benyttet områder både vest og sør for dette området. På svensk side kan det argumenteres for at grensen går både lenger sør og lenger øst mot Bottenviken. For eksempel har reindriftssamer rett til beiteland på vinterstid i Nordmaling sør for Umeå i Västerbotten. Kart: Elling Utvik Wammer.

skandinavisk folkegruppe sør for den 65.breddegrad og en arktisk gruppe med tilhold i Nord-Norge. Også i sør er det gjort spredte arkeologiske funn som er karakteristiske for den arktiske gruppen, ifølge Rygh. ${ }^{8}$ 


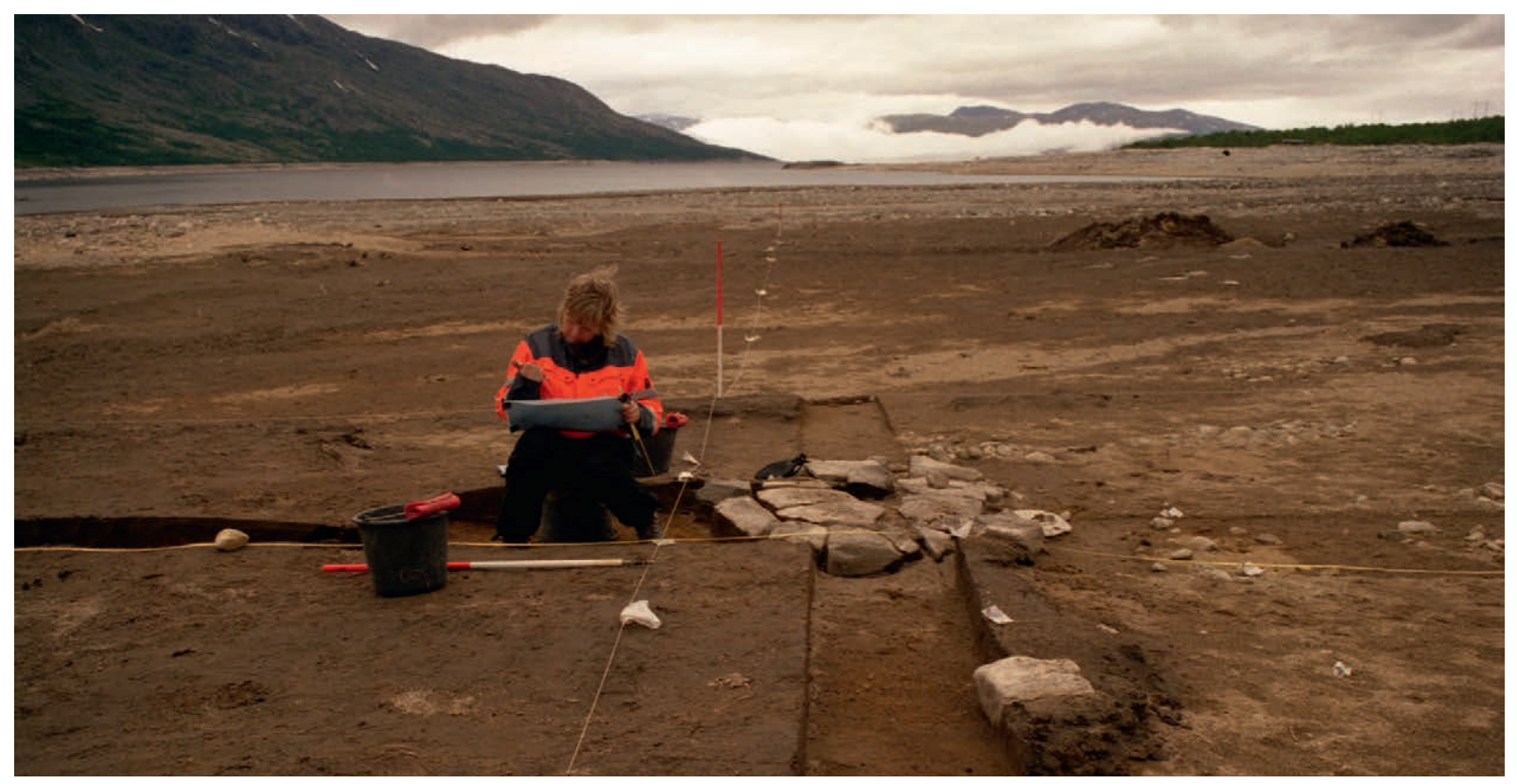

Figur 2: Arkeologisk utgraving ved Aursjøen i Lesja i 2006. Det ble avdekket fire samiske ildsteder (aernie på sørsamisk) som ligger på rekke, noe som er typisk for samiske boplasser i vikingtid og middelalder. Steinen i forgrunnen kalles bassjoegierkie. Den ligger på motsatt side av aernie, sett fra inngangen, og markerer et hellig sted i rommet, der trommen ble oppbevart. Ved siden av ildstedet ses Line Grindkåsa i arbeid med sine notater. I bakgrunnen Aursjøen, som regnes som et godt fiskevatn. Foto: Gaute Reitan, KHM.

Yngvar Nielsen publiserte i 1891 en artikkel der han hevdet at samene hadde vandret nordfra og var kommet så langt sør som til Tydal ved år 1700 og til Røros-traktene om lag 1750. ${ }^{9}$ Yngvar Nielsens teori var dominerende lære helt fram til 1960-tallet, da professor i finsk-ugriske språk Knut Bergsland ble engasjert som sakkyndig $\mathrm{i}$ to rettssaker og analyserte en rekke samiske stedsnavn og skriftlige originalkilder. ${ }^{10} \mathrm{I}$ en artikkel i Historisk tidsskrift i 1974 kritiserte Bergsland Yngvar Nielsens innvandringsteori. ${ }^{11}$ Som utreder for Samerettsutvalget I, oppnevnt av Justisdepartementet, skrev Bergsland utredningen Sørsamenes historiespråklig belyst $\mathrm{i}$ 1987. I konklusjonen skriver han at sørsamene i eldre tid hadde norsktalende naboer og tok opp i sitt samiske språk et stort antall lånord. $\mathrm{Og}$ noen av «de spesielt sydlige lånord må være lånt så tidlig som omkring år 500, andre iallfall før år 800, andre igjen i vikingtid eller tidlig middelalder». Ordforrådet tyder på at de sørlige samer har melket rein fra før vikingtiden. Næringsgrunnlaget var ellers jakt og fiske. «Ennå på 1700-tallet spilte jakt en stor rolle, og fiske har alltid vært en samisk hovednæring. ${ }^{12}$

Bergslands konklusjon er at samene har bebodd de sørlige fjelltrakter langt tidligere enn det Yngvar Nielsen hevdet, men det kan neppe gis noe objektivt svar på når samene kom «dit og dit». ${ }^{13} \mathrm{I}$ den sammenheng er det i den senere tid gjort to arkeologiske funn som er av interesse.

\section{Samer på Dovre i vikingtida}

Sommeren 2006 ble det gjort et arkeologisk funn ved Aursjøen i Lesja i forbindelse med nedtapping 
av det store kraftmagasinet i denne sjøen (figur 2). Under ledelse av arkeolog Jostein Bergstøl ble det avdekket fire rektangulære til ovale ildsteder på rekke. Det best bevarte av disse ble totalgravd, og bortenfor ildstedet fant man en stein som ble tolket som båassjoesteinen. Slike båassjoesteiner ble også funnet på de tre andre lokalitetene, og både funnmaterialet og ildstedenes form hadde vesentlige trekk som er kjent fra tidligere registrerte samiske rekkeildsteder på Nordkalotten. Ikke mer enn hundre meter nedenfor boplassen ligger et fangstanlegg for reinsdyr. En kullprøve fra det utgravde ildstedet ble datert til rundt år 900 e.Kr. Det arkeologiske materialet bekrefter at det har vært en samisk bosetting i Dovrefjellområdet i vikingtiden, skriver arkeologene Jostein Bergstøl og Gaute Reitan i en artikkel i Historisk tidsskrift. ${ }^{14}$

I Snorres kongesagaer fortelles det at Harald Hårfagre var på Tofte i Oppland i et julegjestebud og møtte samejenta Snøfrid, som han giftet seg med. I sagaen står det om Snøfrids far, Svåse, at han var «den finnen som kongen hadde gitt lov til å sette gammen sin på den andre siden av bakken der». ${ }^{15}$ Historikere har oppfattet dette som et sagn, uten verdi som historisk kilde, men sagnet stemmer godt med dateringen av de tuftene som er registret ved Aursjøen. Dessuten blir Aursjøen regnet som et meget godt fiskevatn, noe som tyder på at fisket var viktig i den tidsperioden da boplassene var i bruk.

Disse eksemplene viser at sørsamenes bosettingsområde i jernalder og vikingtid kan ha gått lenger sør og vest enn det bruksområdet som i dag er definert som reinbeitedistrikt, og som i prinsippet skal være basert på alders tids bruk.

\section{Samer i Vestre Slidre i jernalderen}

I 2009 ble det avdekket et ildsted i ei tuft under arkeologiske utgravinger ved Rensennvatnet i Vestre Slidre statsallmenning i Valdres. Inne i tufta lå et

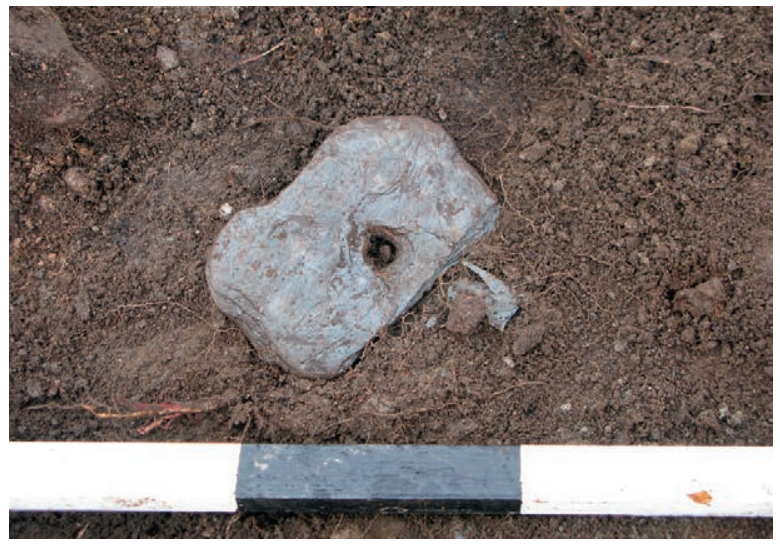

Figur 3: I Vestre Slidre i Oppland er det funnet ei tuft med flere garnsøkker, deriblant denne. Tufta har rundoval voll med steinsatt ildsted (aernie). Ildstedet blir tolket som typisk for de førkristne samiske boligene. Utgravingene ble foretatt i 2009 av Kulturhistorisk museum, Universitetet i Oslo.

tydelig rektangulært ildsted (sørsamisk: aernie) med ei stor, flat helle i midten. Her ble også funnet flere fiskesøkker (figur 3). Hege Skalleberg Gjerde skriver i rapporten at dette er et ildsted som er typisk for de førkristne samiske boligene. Steinen i utkanten/ forlengelsen av det rektangulære ildstedet vil dermed være båassjoesteinen, som var det innerste og helligste området i de samiske boligene. Lokaliteten hadde hatt tre ulike bruksfaser, først kokegrop fra eldre jernalder, deretter smie og så en bosetting. Den siste fasen tolkes som samisk bosetting. Ei anna tuft lignet i stor grad på den førstnevnte. Denne tufta ble ikke utgravd i sin helhet, men det ble tatt ut kull fra to kullag i ildstedet for C14-datering. Disse ble datert til henholdsvis 540-600 og 1020-1150 e.Kr. Arkeologene tolker også denne tufta inn i en samisk kontekst. ${ }^{16}$ Dette sannsynliggjør at det også har bodd samer i Valdres langt tilbake i tid, noe som bygger opp under teorien om en eldre samisk tilstedeværelse i Sør-Norge. ${ }^{17}$ For øvrig blir også Rensennvatnet ansett som et meget godt fiskevatn. 


\section{SAMISKE FISKEVATN I SVERIGE}

\section{De eldste skriftlige kilder}

I mangel av eldre skriftlige kilder om sørsamenes fiske på vestsiden av Kjølen kan som nevnt skriftlige kilder fra svensk side være relevante. I en kilde fra 1273 fortelles det om Gunnil Snälla, ei kvinne i Sollefteå som omtales som «lapp» eller «finn». Hun lot sine folk fiske i et vatn som ikke tilhørte henne, og det førte til en konflikt, som er bakgrunnen for en skriftlig kilde. ${ }^{18}$ Ifølge et rettsdokument (svensk: dombrev) fra 1511 var det en same som eide Esseån (Ässan i Ångermanland). Westerdahl mener dette tyder på at elven med fiske og eventuell reinbeitemark var et oppholdssted for samer allerede i middelalderen. ${ }^{19}$

Det var vanlig at samene betalte skatt i form av fisk og pelsverk. Som eksempel nevnes et fogdregnskap fra 1539 som viser at det ble betalt opptil 90 mårskinn og et halvt skippund beinløse gjedder i lappskatt for Umeå sogn. ${ }^{20}$

Fiskevatn var skatteobjekt i Sverige på slutten av 1500-tallet, og det gir en indikasjon på verdien av innlandsfisket. ${ }^{21}$ Et skattedokument fra 1595 for fem lappmarker gir en oversikt over til sammen 207 skattepliktige samer og de sjøer «för hvilka de skatta». Her tas med ett eksempel: «I Laisbyn i Pite lappmark funnos 12 skattelappar, af hvilka 1 fiskade i Kyine Jaur [...], 3 i Kautze Jaur, 1 i Store Wendell Elf, 2 i Ellikien Jaur, [...]» $»^{22}$

Sigrid Drake beskriver den rettslige status for fiskevatn slik i sin doktorgradsavhandling Västerbottenslapparna fra 1918:

Redan i de äldsta tingsprotokollen från Lappmarken (midten af 1600-talet) finner man lappbyarnas traditionella område uppdeladt i ett antal'land' med traditionella gränser, till hvilka land de olika familjerna ha nyttjanderätt eller, åtminstone hvad fiskevattnen $i$ vissa trakter beträffar, eganderätt [uthevet her]. ${ }^{23}$

Det er en interessant tanke at samene i Västerbotten i det minste hadde eiendomsrett til sine fiskevatn på 1600-tallet. Drake kan forstås slik at samene kanskje hadde en sterkere rett til fiskevatn enn til landområder.

\section{"Landh och fiskierwattn"}

En annen interessant kilde fra 1600-tallet er landshövding Johan Graans utkast til jordebok for Ume lappmark i 1670. Landshövdingen laget en fortegnelse over «hwar och eens landh och fiskiewattn» i fire samebyer langs Ume älv i Västerbotten, til sammen 37 land (senere kalt skatteland) og om lag 140 fiskevatn. De vestligste deler omfattet områder som etter fastsettelsen av riksgrensen i 1751 ble norsk område. Her er et par eksempler:

Lais eller Raan:

Siul Andersson, Hans Landh heeter Kallfïll, fiskiewattn Kall träsk på Nåriges sijdan, Wiris träsk har och sitt Vtlopp Wäster Vth,...

De omtalte fiskevatn er Kallvatnet og Virvatnet i Rana.

Wapsten:

Jacob Larsson, Hans Landh heeter Oxefiäll, fiskiewattn Rautzwattn, Rodewattn.

Oxefiäll er Okstindan, Rautzwattn er Røssvatnet og Rodewattn er Rauvatnet, alle på norsk side av riksgrensen, som ble fastlagt i 1751. Et interessant spørsmål er: Hva la landshövdingen i formuleringen 
«hwar och eens landh och fiskiewattn» eller «Landh som hwar och een Lapp besitter, medh dess särskilte fiskiewattn»? ${ }^{24}$

Familiene var sterkt knyttet til sine områder ved at beiteområder,jaktområder og fiskevatn ble brukt i generasjon etter generasjon, skrev presten Samuel Rheen omkring 1670:

Fast egendom, som är land, sjöar, fjäll eller fiskevatten skiftas icke bland barnen, utan såväl broder som syster åbor faders och moders land. Därför räknar de vara sitt land, sina skogar, fjäll och fiskevatten, där deres förfäder levat och bott haver. ${ }^{25}$

Denne kilden tolkes slik at i den grad samene innenfor skatteland hadde en nomadisk livsstil på 1600-tallet, holdt de seg innenfor sine respektive «land». Det største av disse var om lag 4,5 mil langt og 2,5 mil bredt. ${ }^{26}$ Dette stemmer overens med hva Bergsland skriver om samene i Nord-Trøndelag:

Før 1620 må de respektive grupper eller «Selskap» ha beveget seg innenfor relativt små områder, med bestemte grenser mot naboene, mens langflytninger hører til den moderne form for reindrift. ${ }^{27}$

To svenske karttegnere, Carl Magnus Robsahm og Anton Swab, besøkte sommeren 1796 Tomas Olsen, som bodde sammen med familien ved den nordlige Helagssjön i Jämtland. Han hadde en reinflokk på 300-400 dyr og drev sommerfiske i Helagssjöarna, som ikke ble ansett som gode fiskevatn. Likevel fortalte Tomas at han kunne regne med å fả en kvart tønne ørret og fjellrøye i uka når han fisket med 20 garn. Fisken ble saltet ned til vinterforråd. ${ }^{28}$

I en rapport fra en befaring i november 1817 i lappskattelandet Koppsele ${ }^{29}$ (nord for Malå) omtales beitelandet og samenes kåter i tillegg til at ti fiskevatn med fiskeslag beskrives utførlig og selve sjøen vurderes. Et par eksempler tas med: «3. Stenträsket som har sik, gädda, och Abbor är god fisksjö. [...] 7. Sarjelsjaur har Gädda och Abbor är liten och ofiskelig.»" Kilden viser at fisket fremdeles var av vesentlig betydning for samene $\mathrm{i}$ Umeå lappmark nesten 150 år etter at Johan Graan hadde fått utarbeidet oversikten over «landh og fiskiewattn».

Ifølge Kaisa Korpijaakko, som har skrevet en større avhandling om samenes rettslige stilling $\mathrm{i}$ Sverige og Finland, var det landshøvding Graans utgangspunkt at samene eide sine land, men det var nødvendig å utarbeide en jordebok dersom man $ø$ nsket en fullstendig likestilling med de svenske bøndenes «hemman» (gårdsbruk). ${ }^{31}$ Erik Solem skriver i boka Lappiske rettsstudier at svenske kilder viser at det først og fremst var retten til fiskevatn og fiskeplasser som hadde trengt seg fram som en særrett med utelukkelse av andre. ${ }^{32}$

\section{"Fiskarlappar» i svenske folketellinger}

Selv om riksgrensen deler det sørsamiske området, er det liten grunn til å tro at norske og svenske samers livsvilkår i grenseområdene var vesentlig forskjellig. Rolf Kjellström beskriver hvilke kategorier samiske fiskere ble delt inn i:

De svenska samer för vilka insjöfisket spelade en avgörande roll har benämnts fiskarlappar, fiskesamer eller insjösamer. Samer som inte var renskötande benämdes tidigt fiskarlappar. ${ }^{33}$

Ifølge Kjellström var fisket en profesjon for en del samer. Svenske folketellinger fra slutten av 1800tallet gir et interessant tidsbilde som bekrefter dette. I folketellingen fra 1870 for Tärna kapellförsamling (svensk nabokommune til Rana) finner vi yrkeskategoriene «nomadiserende lappar», «fiskarelappar» 
og «fattig lappar». Her er det oppført 122 samer, både barn og voksne. De aller fleste er nomadiserende samer, men et ektepar i femtiårene med fire barn er oppført som «fiskarelappar». Det samme er et ektepar i slutten av førtiårene og to ugifte menn. Dette må oppfattes slik at disse personene hadde fisket i elver og vatn som sitt livsgrunnlag. I en tilsvarende folketelling for 1880 er det oppført tjue «fiskarelappar» i alderen 30-71 år. Ti år senere er det registrert atten personer som «fiskarlapp» og ingen «fattiglappar». I folketellingen for 1900 finnes derimot ingen «fiskarlapp» i Tärna kapellförsamling, men flere «fattiglappar» i tillegg til «nomadlappar» og «renskötare».

Et nærmere studium av folketellingene i Västerbotten på slutten av 1800-tallet ville kunne gi svar på om fiskerne ernærte seg som fiskere gjennom hele livet, eller om de tidligere hadde vært reineiere. Datidens reindrift var meget krevende. Man måtte følge flokken mil etter mil, til fots eller på ski. Eldre personer og personer med dårlig helse kunne ikke ha dette som yrke.

Ifølge K.B. Wiklund var fisket redningsplanken hvis man ikke var reineier eller hadde andre inntekter. Han skriver at noen samer måtte tigge til livets opphold, mens andre måtte «bo i en kåta eller en usel stuga vid någon sjö och skaffa sig ett magert uppehälle genom fiske (dessa har man stundom sammanfört i en särskild klass, fiskarlappar)». ${ }^{34}$ Det var altså fisk på de fattiges bord, og det er ikke noe som tyder på at situasjonen var vesentlig forskjellig blant norske sørsamer.

\section{Wilhelm Peterson-Bergers fisketur i 1903}

Før vi forlater de svenske samenes fiske, tar vi med en historie fra en fjelltur sommeren 1903. Den kjente svenske komponisten Wilhelm Peterson-Berger dro ut på tur til Oldfällen i Jämtland med «påbörjat partitur och en - kaffepanna». «Lappmannen»
Per Pålsson var med som los. En dag kom de til Burvattnet, og «etter en timme i oländigaste mark» var de kommet fram til en torvdekt grønn kåte der noen slektninger til Pålsson bodde. Her dro kokken Erik ut på fiske, og Peterson-Berger forklarer sammenhengen slik:

En av lapparna i manskapet är nämligen yrkesfiskare i dessa fjällvatten och har sina don förvarade i de kåtor som av denna anledning finnas uppförda här och där vid stränderna. Tack vare detta av lappar bedrivna fiske finnas även båtar i sjöarna, vilket rätt väsentligt kan underlätta en resa genom dessa trakter. ${ }^{35}$

Takket være komponistens interesse for fjellfiske får vi her en beskrivelse av hvordan en same innrettet seg som yrkesfisker ved noen fjellvatn i Jämtland. Han hadde båt, og fiskeredskapene ble oppbevart $\mathrm{i}$ kåter som var oppført ved strandkanten.

\section{SAMISKE FISKERE PÅ HELGELAND OG I TRØNDELAG}

\section{Norske kilder om samiske fiskere på 1600 og 1700- tallet}

Bergsland har i en svensk kilde funnet en reintelling fra 1609 som viser at reineiere i Rana, Vefsn og Bindal i gjennomsnitt hadde $12-14$ rein. Svenske skogssamer hadde på samme tid omtrent like store flokker. Bergsland kommenterer dette slik:

Det er da klart at tamreinen hovedsakelig må ha vært brukt til transport, resp. melking. Livsgrunnlaget må ellers ha vært fiske og jakt, spesielt villreinsjakt, samt salg av pelsverk til birkarlene, $[\ldots]^{36}$ 
I 1680-årene ville den dansk-norske kongen ha oversikt over de finner (personer fra Finland) som hadde bosatt seg i grensetraktene på Østlandet. På grunn av dobbeltbetydningen av ordet finn gikk denne ordren også til fogdene nordover i landet, og dette har gitt oss interessant kunnskap om samer og hva de levde av i deler av det sørsamiske området. Her er noen eksempler fra Trøndelag og Helgeland:

«Morten Johansen, gammel och meesten blind. Opholder sig paa Skiecher, Werre och Gouldals fielde [...], Hand nærer sig af sine Reensdiur, huor af hand siger sig at eje 100 støcher, Jtem af Schøtterj saaVelsom fischerj i fieldwand, $[\ldots]$ »

Torkill Olsen oppholdt seg på «børefield» (Børgefjell?). Han levde av «fugell schytterj och fischefang» i tillegg til «20 Milke Reins dyr».

Peder Olsen forsørget sin familie av «schytterj og fischefang» i tillegg til «5 Milke Reine».

Jon Jensen, født i Bindalsfjellene, forsørget kone og fem barn «med lige nering som dj andre». Han hadde fire «Melke Reine». ${ }^{37}$

Denne kilden viser at samtlige oppgir fiske som en del av næringsgrunnlaget. Alle, bortsett fra én, hadde et fåtall tamme rein som ble melket. Erik Bylund skriver at de svenske skogssamer på denne tida hadde en begrenset reindrift, ofte bare 20-100 dyr, noen enda færre, og geiter var like viktige som rein. Han legger til følgende: «Fisket i de ofta små sjöarna på skattelanden var ett livsvillkor för dem.» ${ }^{38}$

Westerdahl påpeker det samme blant Ångermannasamene på 1600-tallet. De hadde små reinflokker, men hver husholdning disponerte opptil tre fiskevatn i tillegg til elver og bekker. ${ }^{39}$

I anledning av fastsettelsen av riksgrensen mellom Norge og Sverige fikk major Peter Schnitler i oppdrag å innhente informasjon fra samer og andre om hvor grensen gikk. Han foretok vitneavhør av samer som hadde kunnskap om grensetraktene, deriblant Ole Nilsen, som ble avhørt i 1742. Han bodde ved Jormsjön, på svensk side av grensen, og hadde festeseddel fra 1699 på et stort skog- og fjellområde på begge sider av riksgrensen som også omfattet sjøene Limingen, Utnesvandet (Huddingsvatnet), Vektaren og Jormsjön (figur 4). Ole Nilsen fortalte majoren at han brukte dette store området til fôr og beite for reinflokken. Han dreiv jakt i skogene og «fiskerie i vandene». Røye og ørret nevnes. ${ }^{40}$ Også Ole Nilsens far og farfar hadde bodd ved Jormsjön.

I Vefsn-distriktet ble blant andre samen Lars Nilsen avhørt av Schnitler i 1742. Lars Nilsen var født i Lycksele og gift i Vefsn. Hans fjellbeiter bestod av tre navngitte fjell i Hattfjelldalen og dalene omkring, som var gressland. Han opplyste at området strekte seg over én mil mellom elva Vefsna og Røssvatnet, og det var to mil langt fra vest til øst. «Fiskerie har hand i Rysaae-vandet» (Røssvatnet), står det i protokollen. ${ }^{41}$ Begge disse vitnene forteller at samer på 1600-1700-tallet kombinerte tamreindriften med jakt og fiske, også de som hadde store reinbeiteområder til disposisjon.

Finnelensmann Nils Clemetsen Brands-field fortalte Schnitler at samene i Rana ernærte seg som «andre Finner af Reendyer, Fiskerie og Skytterie». ${ }^{42}$

I Jonas A. Nenséns samlinger finnes notater fra samtaler med Anna Thomasdotter (1751-1833). Hennes foreldre var norske samer som om vinteren oppholdt seg med reinflokken i Hemnes på Helgeland og om sommeren i Tärna i Västerbotten. Anna fortalte at hennes mor eide Akersvatnet i Rana. Faren gav pastoren i Hemnes ost og røye som var 


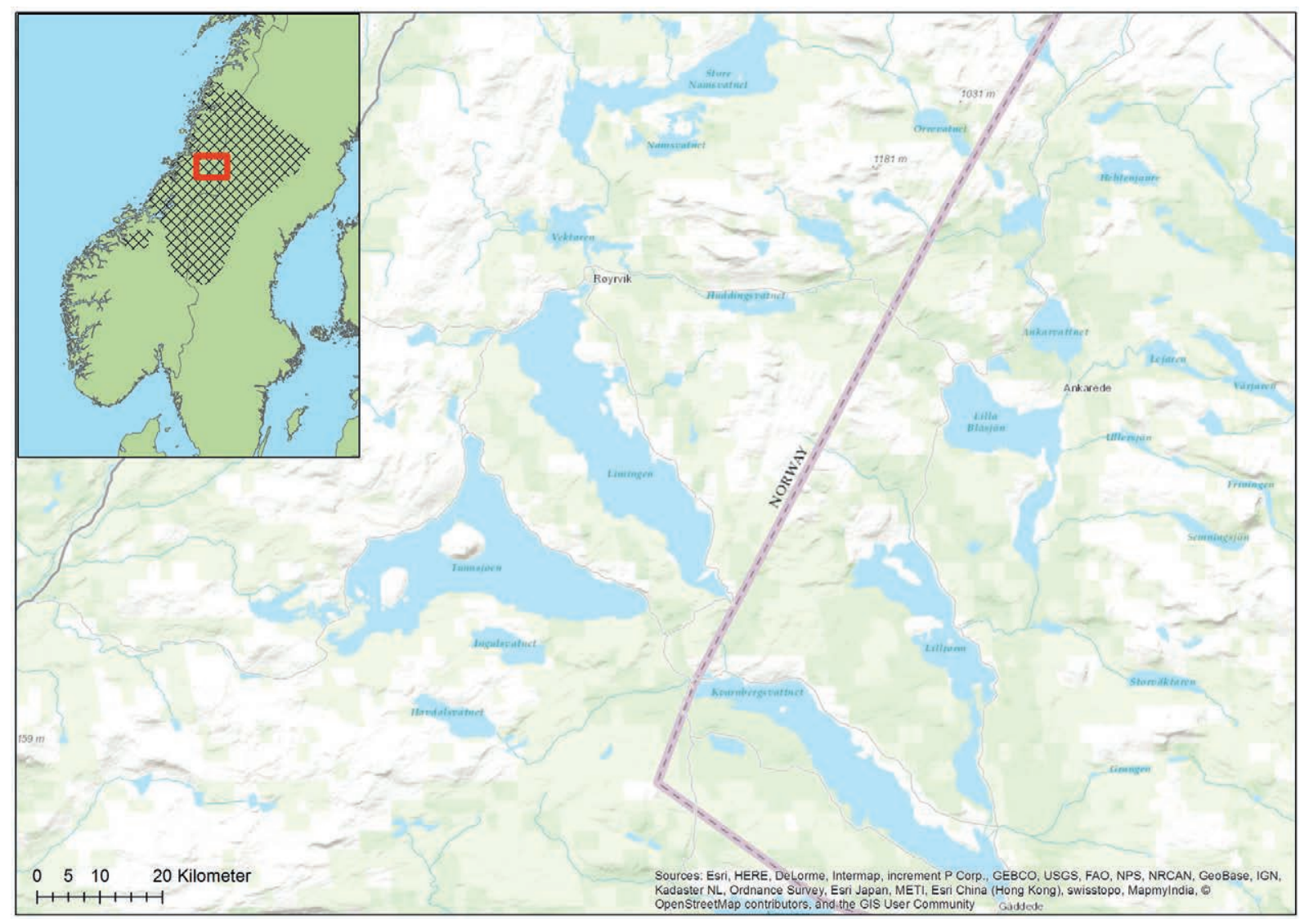

Figur 4: I kilder fra 1700-tallet omtales fiskevatna Limingen, Utnesvandet, Vektaren og Jormsjön som fiskevatn der samer hadde rett til å fiske. I en kilde fra slutten av 1800-tallet ble Orvatnet, som ligger tett inntil svenskegrensen, omtalt som et vatn forbeholdt samene. Også i dag er dette sentrale områder for reindriften i Nord-Trøndelag. Kart: Elling Utvik Wammer.

flekt og tørket. Hennes svenske frier ble ansett som en fattig reineier med kun 30 simler, mindre enn en fjerdedel av det antall simler som Annas far hadde, men frieren hadde ei heil not, 20 garn og 4 båter plassert i 4 forskjellige vatn. Mor til Anna la vekt på at «han hade något av varje slag», altså tilgang på både reinkjøtt og fisk, ${ }^{43} \mathrm{og}$ han fikk gifte seg med Anna. Dette viser at fisket var en så viktig del av 1700-tallets naturalhusholdning at det veide opp for en liten reinflokk.

\section{Fiskets betydning etter uhell i reindriften}

Håkon Hermanstrand har påvist at fisket var så viktig for samene at det var tatt med i bygselkontrakter. Det ble konflikt hvis nybyggere som tok opp nytt land nær de samiske bruksområdene, også overtok fisket i vatn som samene hadde fisket i. Et eksempel på dette er et brev fra Fjeldfin John Nilsen Ohrfield (f. 1810) i Røyrvik til amtmannen datert 26. mars 1860 der samen ber om tillatelse til å fiske $\mathrm{i}$ tre fiskevatn ved svenskegrensen som hans avdøde 
far hadde hatt bygselseddel på, deriblant Ohrvand. Etter at faren var død, hadde en bonde (nybygger) overtatt disse fiskevatna, og John Nilsen Ohrfield mente det var underlig at bonden «kan have ret at tage ifra en andens Rettigheder» uten å vise at han hadde rett til det. Samens egen begrunnelse for at han trengte de tre fiskevatna, er interessant:

Da jeg verken har Aker eller Eng at leve af og tillige har haft et stort Uheld at miste en 29 Rensdyr [...] dræbt af SneSkred den 6 januar 1860 tillige har Gaupe og Ulv revet igjel nogle og jeg har ikke saa nogen Erstatning eller Hjelp for denne mig rammede Ulykke Saa er det jeg herved beder den høie Øvrighed Hjælpe mig at faa mine Fiskevande igjæn af bonden da vi $[\ldots]$ er Berettig dertil. ${ }^{44}$

Dette er et eksempel på interessekonflikt tilknyttet retten til fiske, men dokumentet viser også at fisket ble ekstra viktig når reinsdyr gikk tapt på grunn av snøskred eller rovdyr, og det var ikke uvanlig.

\section{Fisker ved Essandsjøen i Sør-Trøndelag}

Lappekommissionen af 1889 hadde som oppgave å kartlegge samenes tamreindrift og foreslå opprettelse av reinbeitedistrikter i Hedmark, Nord- og Sør-Trøndelag. Kommisjonen snakket med en rekke informanter om samenes bruk av utmarksområdene og skriver følgende om Ole Andersen Kant: «Familien Kant har tidligere regnet sig hjemmehørende i Tydalen, men nu bor dersteds af denne Familie kun Ole Andersen Kant, der lever ved Essandsjøen som Fisker.» ${ }^{45}$

Ole Andersen Kant var midt i 70-årene da Lappekommissionen omtalte han som yrkesfisker rundt 1890. Femten år tidligere, i folketellingen for 1875, står det at Ole Andersen Kant har «Næringsveien af Rensdyr» med hundre rein. Dette er et eksempel på at en tidligere reindriftsutøver gikk over til å ernære seg som fisker på sine eldre dager. En tilsvarende kilde finnes fra grenseområdet til Hattfjelldal. Torkel Tomassen skriver fra et vitneavhør av lappordningsmann Nils Andersson Skott fra Södra Storfjället i Tärna at vitnets «fader var renlapp, men mot slutet af sin lefnad stannade han och lefde delvis af fiske vid Abelvattnet och $\operatorname{dog} 1895 \Perp^{46}$

I 1925 og 1926 ble Anders Barrock i Essand reinbeitedistrikt intervjuet av Kristian Nissen, og han fortalte at det kun var enkelte familier med meget få rein som drev «fiskeri». ${ }^{47}$ Ordet fiskeri oppfattes som «fiske for salg» ettersom de aktuelle familier hadde få rein; det framgår av andre kilder at så godt som alle reindriftssamer drev fiske til egen husholdning.

\section{Et udmarket fiskevand forbeholdt lapperne}

I Den Norske Turistforenings Årbok for 1887 er det publisert en artikkel fra en reise $\mathrm{i}$ «Namdalens ukjendte egne». Forfatteren er forstassistent Johan Aas Krag (1853-1911), som hadde vandret til fots gjennom et landskap der det også ble drevet tradisjonell tamreindrift. Han skriver følgende om Orvatnet, som ligger helt inn mot svenskegrensen, øst for Namsvatnet i Nord-Trøndelag:

\section{...Orijaure eller Orvandet; der strækker sig i henved 3 kilometers længde til grænselinien mod Sverige; det er ligesom Namsvandet et udmærket fiskevand, hvor retten til at drive fiskeri er forbeholdt lapperne - og hvem andre skulde vel her gjøre dem denne ret stridig? ${ }^{48}$}

Kragh var forstassistent i Namdalen fra 1883. Det er dermed sannsynlig at hans vandring gjennom indre Namdalen foregikk en gang mellom 1883 og 1887. På den tida var det trolig en allmenn oppfatning at 
retten til fiske i Orvatnet, som ligger milevis fra fast bosetting, var forbeholdt samene. Dette er sannsynligvis det samme Ohrvatn som John Nilsen Ohrfield skrev til amtmannen om i 1860. Rent teoretisk kan samene ha hatt en akseptert fiskerett i mange vatn i det sørsamiske området uten at denne kunnskap er blitt tatt vare på for ettertida.

Lenge etter forstkandidatens fottur gjennom «Namdalens ukjendte egne» var ungjenta Skjoldvor Jåma sammen med familien på høstfiske i Orvatnet. De hadde en gamme ved østenden av vatnet, og her bodde de mens de fisket med garn. Fisken ble saltet og lagret i kagger. Skjoldvor husker at familien drev dette fisket opp gjennom 1950-tallet og inn på 1960-tallet. Sommerfisket foregikk i Namsvatnet:

Vi fiska jo var dag, men itj no' store mengder. $\mathrm{Vi}$ åt stekt fisk og kokt fisk, og vart det fisk til overs, så salta vi på og hengt' opp og røkt' det. Vi åt veldig mye fisk då på sommar'n. ${ }^{49}$

\section{Fisket holdt sulten borte}

Reineier Peder I. Jåma (1909-1985) fortalte til sin nevø, Albert Jåma, at bærplukking, jakt/fangst og fiske var av stor betydning for husholdningen, men

viktigst var fisket i vann og elver. Det var helst ungenes oppgave å holde familien med matfisk. På fjellet reddet fisken oss mang en gang fra å sulte. Vi fisket helst med stang og snøre. Vi brukte da en rognkjepp som vi bandt snøret på. Vi brukte også garn, men ikke så mye, for det var dårlig med båter $\mathrm{i}$ fjellet. I fjellvatna var det samene som har satt ut fisken. ${ }^{50}$

Dette er en tidstypisk beskrivelse av fiskets betydning for reindriftssamene i Midt-Norge omkring 19201925. Slik var det også på svensk side. I forbindelse med et dokumentasjonsarbeid i 1979-1980 sa en 73 år gammel informant i det nordlige Jämtland dette:

Vår stuga i Västra Värjaren ${ }^{51}$ bestod bara av ett rum. Det var kallt og trongt. Vi var mycket fattiga och måste fiska och slöjda för att få in lite kontanter. ${ }^{52}$

Selv om fisken var av vesentlig betydning i naturalhusholdningen, var det mat med lav status. Sjulsson fortalte følgende: «Fisk räknades emellertid ej såsom ett näringsämne af större värde. [...] Att taga sig litet fisk ur en annans förråd räknas knappast såsom snatteri.. ${ }^{53}$

\section{Fisket i melkingstida}

Tsjekkeren Václav Marek kom til Susendalen på Helgeland på 1930-tallet og bodde der til 1948. I denne perioden intervjuet han mange personer $\mathrm{i}$ bygda, også samer, og hans materiale er publisert i boka Samene i Susendalen. Gunhild Børgefjell (1868-1959) forteller at samenes kosthold i stor grad bestod av reinkjøtt, men «i melkingstida ${ }^{54}$ så vart det ofte mye melk eller ost - og fisk forståss.- Det var bare sjelden at vi slakta rein om sommarn». ${ }^{55}$ Formuleringen «fisk forståss» sier egentlig alt om hvor selvfølgelig fisken var som sommermat. K.B. Wiklund gir den samme beskrivelsen av de svenske samenes kosthold i 1910: «Sommartiden ersättes köttet till stor del av kokad fisk och allehanda slags mjölkmat.» ${ }^{56} \mathrm{Om}$ selve fisket fortalte Gunhild Børgefjell dette: «Og så fiska vi og, veit du, i bekker, ofte bare me' hendene og me' garn, stang og krok.» ${ }^{57}$ Igjen er det samsvar mellom hennes og Sjulssons beskrivelser. Enklere og mer praktisk fiskeredskap enn hender i småbekker kan man knapt tenke seg. 


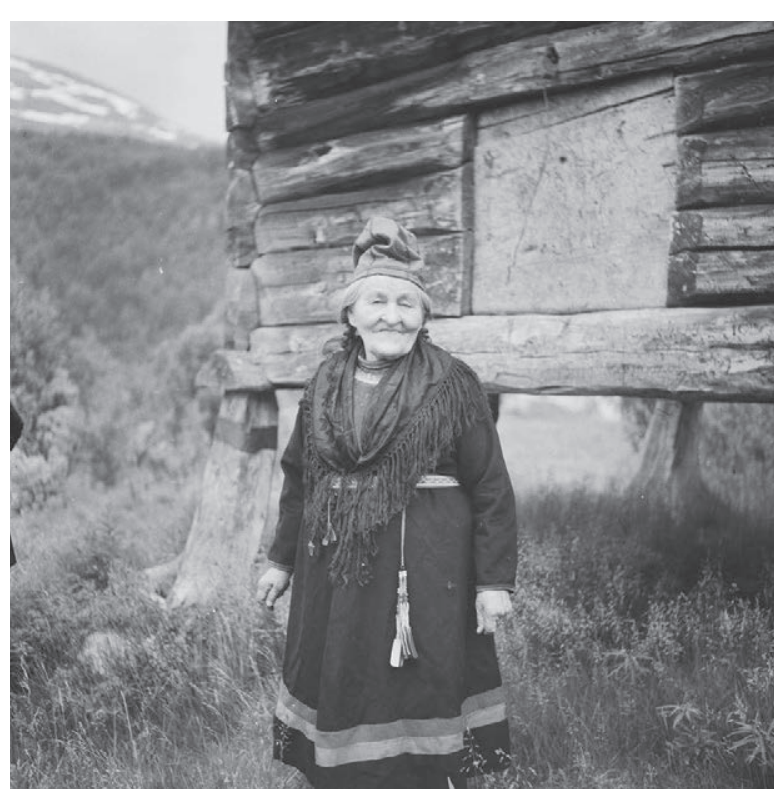

Figur 5: Gunhild Børgefjells (1868-1959) beretninger om samenes levemåte i Susendalen gir et godt innblikk i fiskets betydning for reindriftssamene på Helgeland. Det var ikke vanlig å slakte rein i sommerhalvåret, og både reinmelk og fisk utgjorde derfor en vesentlig del av sommermaten. Bildet er tatt på Fjellheim i Susendalen. Foto: Václav Marek. Mareks bildearkiv / Nasjonalbiblioteket.

\section{Sommerfisket i Majavatnet}

Sofie Kappfjell tilhører den generasjon som under oppveksten ved Majavatnet på 1930-tallet deltok i fisket om sommeren og høsten:

Fisket var det vi levde av den gangen. Vi som ikkje holdt på med rein, vi satte ut garn og fisket og solgte hvis vi fikk så mye. Vi solgte enten til Samvirkelaget på Brekkvasselv, eller sendte ned til en privat forretning på Fellingfors.

Om antall garn sier hun følgende:
Nei, det husker eg ikkje. Det var mange nok i hvert fall! Vi var jo så lei ...! Fisket i Steinvatnet, Frosktjønna og Dunfjelltjønna, og så drog vi båten mellom der. Gamle spissbåter drog vi på. For noen år siden lå det fremdeles en gammel båt i Dunfelltjønna. Når vi hadde dratt opp fisken, måtte vi skynde oss å sløye den og få den av gårde hvis vi skulle selge den, så det var jo litt av en jobb. For eget bruk, tok vi enten fersk fisk som kokt eller stekt fisk, eller vi saltet og røkte til pålegg. Når isen hadde lagt seg på alle vatn, var det slutt på fiskesesongen. ${ }^{58}$

\section{Hostfisket i Rogen}

Alf Willenfeldt fra Tännes i Härjedalen forteller om sommerfisket i perioden fra ca. 1945 til 1980. Fisket foregikk i Myskelsjöarna og andre sjøer øst om Rogen, som er grensesjø mot Norge, øst for Femundsmarka. Fisken ble solgt fersk til hotellene i Tänndalen mot kontant oppgjør. Fisket man to netter, ble første natts fangst lagt i en balje som ble dekket med never og trebord. Baljen ble satt ned i ei grop i bakken med ei stor grastorve over. De fisket med garn fra båt. Skulle man fiske fra en annen sjø, ble båten dratt over land fra den ene sjøen til den andre (figur 6).

Det store høstfisket i Rogen startet ca. 25. september Det var sju-åtte samiske fiskelag som fisket med garn. Alf og far Edvard hadde 60-70 garn ute hver natt, og fangsten kunne komme opp i 100 kilo. Fisken ble renset, saltet og lagt ned i kvartel (1/4 tønne, figur 7). Etter om lag tre uker ble fisket avsluttet, og alle kvartel med salt fisk skulle transporteres ned til veg. Hver mann tok med seg to kvartel på ryggen og bar dem fra Rogen til Tandsjön. Derfra dro de langs Tandsjön med båt til østenden, og så var det å ta børa på ryggen igjen og gå over til Abborvikarna. Deretter var det båttransport over 


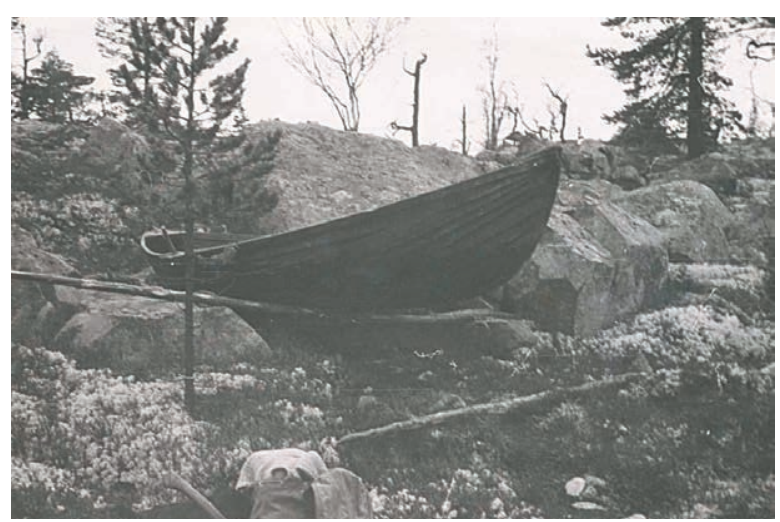

Figur 6: Om sommeren - under kalvemerkinga - fisket Edvard Willenfeldt (1912-1998) med garn i mindre sjøer i Rogen-området i Härjedalen. Han brukte båt, og den ble dratt over land fra det ene fiskevatnet til det andre. Her ser vi at det er lagt ut kjepper i ulendt terreng for at båten skulle gli lettere. Bildet er tatt i 1959. Foto: Alf Willenfeldt. Privat eie.

denne sjøen til ei vik i nordøstenden. Herfra var det mulig å få hesteskyss over til Myskelåsen, der det var veg. De måtte ta flere slike strabasiøse turer for å få ned all fisken. Alf anslår at samene fisket 5000-6000 kilo røye hver høst i Rogen, og fisken var en meget viktig inntektskilde. ${ }^{59}$ Rogen-fisket var trolig det mest omfattende fjellfisket i hele det sørsamiske området.

\section{BÅTER OG FISKEREDSKAPER}

Igjen må man til forskning på det sørsamiske området i Sverige for å finne opplysninger om fiskeredskaper og båter. Den tidligere omtalte svenske samen Kristoffer Sjulssons minner er i hovedsak fra traktene ved Södra Storfället, ${ }^{60}$ som ligger på svensk side øst for Hattfjelldal. Sjulsson drev fiske på sine eldre dager og hadde en egen fiskerkåte ved Ropenjavre, ${ }^{61}$ ei mil fra riksgrensen. Ettersom det ikke foreligger noen tilsvarende beskrivelser fra norsk side, gis et kort sammendrag av det Kristoffer Sjulsson fortalte fra de svenske nabotrakter:

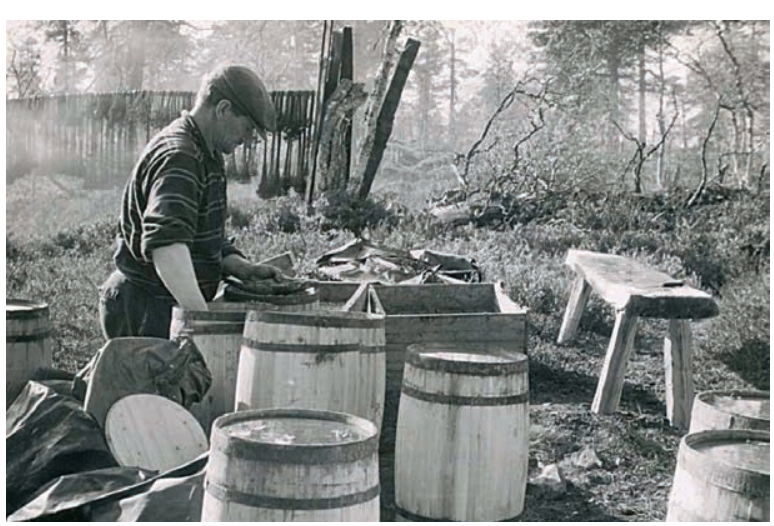

Figur 7: Salting av røye under samenes høstfiske i Rogen, på svensk side, øst for Femunden. Edvard Willenfeldt strør salt i buken på fisken før den legges lagvis i tønna. Han fisket med 60-70 garn hver natt i om lag tre uker. Bildet er tatt på 1950-tallet. Foto: Evald Wiberg. Privat eie.

«Fisket idkades med ifver at alla lapper», eller i norsk oversettelse: Alle samer fisket med stor iver. Fra gammelt av var det vanlig at samene tok fisk med hendene. På sensommeren gikk røyr opp i små bekker med lite vatn. Teknikken bestod i å skremme fisken, se hvor den gjemte seg, og så ta den med hendene. På denne måten kunne man fange så mye fisk man klarte å bære, fortalte Sjulsson. Samene brukte garn som fra gammelt av var laget av lintråd, spunnet av samekvinnene. ${ }^{62}$ Det var ikke mer enn et par alen $(\mathrm{ca} .120 \mathrm{~cm})$ dypt. Til fløyte brukte man tre eller never, til søkke et stykke reinhorn eller en stein som var innpakket i never, en såkalt «taska». Man dro garnet ut med tau tvers over elver eller tjern. I en sjø kunne flere garn hektes sammen og legges ut fra stranda og utover sjøen. ${ }^{63}$

Sigrid Drake skriver at not ${ }^{64}$ var et forholdsvis sjeldent fiskeredskap, som mest ble benyttet av de samene som i hovedsak levde av fisket. Slik oppfattet hun at det stort sett også var på Nenséns tid, og som nevnt er det meste av hans nedtegnelser 


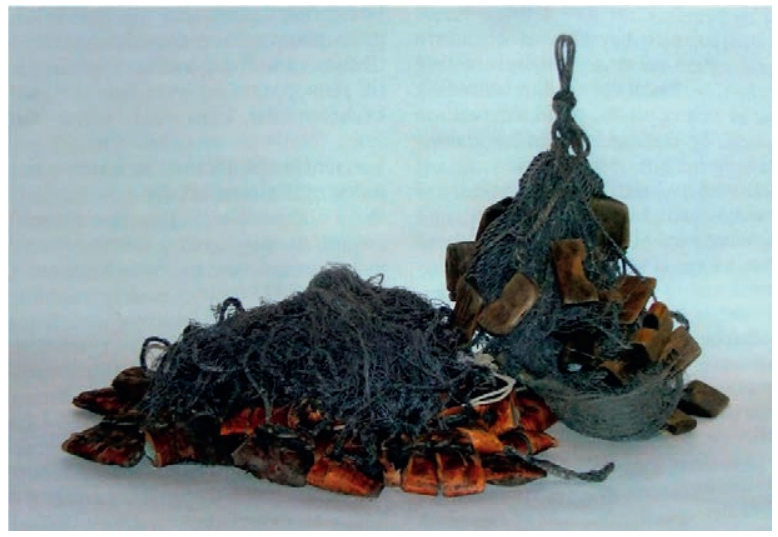

Figur 8: Dette garnet har søkker av stein som er innpakket i never, med treklosser som fløyte, i tråd med Kristoffer Sjulssons beskrivelse. Garnet er 32 meter langt og $140 \mathrm{~cm}$ høyt. Siste eier var Martin Steinfjell (1916-1976), som bodde i Røyrvik i Nord-Trøndelag. Fiskegarnet inngår nå i Stiftelsen Saemien Sijtes samlinger på Snåsa. Foto: Stiftelsen Saemien Sijte.

fra Västerbotten datert til perioden 1818-1841. ${ }^{65}$ Samejenta Greta Sjulsdotter fra Tärna-distriktet (øst for Rana) var en god informant for Nensén. Hun hadde ikke noe å fortelle om not, for hennes far hadde ikke råd til å ha not. ${ }^{66}$ Videre nevnes her et spesielt fiske som har funnet sted i Keika, en sjø vest om Fatmomakke, som ligger 2,5 mil fra svenskegrensen på høyde med Majavatn. Her fisket man ørret med stang (mete) og edderkopper (spindel) som agn. ${ }^{67}$ Det var enkelt og lett å ta med i sekken for en som vandret over skog og fjell. En annen ytterst enkel metode var å spenne gamle bukser eller skinnfrakker over rennende bekker. ${ }^{68}$

Det er funnet flere båter av tre under arkeologiske utgravinger i Norrland, de fleste i skogssamisk område i Västerbotten og Ångermanland. Det er også funnet noen få båter av bark eller never. ${ }^{69}$ Christer Westerdahl skriver at de daterte båtfunnene viser en samisk båtkultur fra 600-700-tallet fram til 1800tallet i dette området.Litterære og muntlige kilder bekrefter denne båtkulturen for perioden fra 1100 til begynnelsen av 1900-tallet. ${ }^{70}$ Johannes Schefferus hevder i boka Lapponia (1673) at båtbygging var den andre «kunsten» blant samene nest etter jakt. Ifølge en beretning fra 1743 av Arvid Ehrenmalm hadde samenes båter slik utforming: Kjølen var fra 1,8 til 3,6 m lang. Den var spissformet i begge ender med tynne sidebord av furu på $0,4 \mathrm{~cm}$. Bordene var festet til hverandre, eller sydd, med teger fra granrøtter eller sener fra rein. Dette gav betegnelsen sydde båter. De var lette, og samene bar dem fram og tilbake mellom sjøene. Ehrenmalm forteller at når en same møter sterk strøm eller en strid foss, løses problemet slik: Han tar båten opp på land, legger ausekaret av never på hodet, trer årene på hver sin side av kjølen gjennom vidjer, tar matsekken på ryggen og bærer båten over hodet forbi fossen. Øksa binder han til årene litt framfor hodet for å holde båten $\mathrm{i}$ jamvekt mens han vandrer mellom busker og trær til et sted der det passer å sette båten på vatnet igjen. ${ }^{71} \mathrm{Carl}$ von Linné forteller i reiseskildringen fra $1732 \mathrm{om}$ en same som bærer båten på hodet. ${ }^{72}$

I en beretning fra 1742, undertegnet J.A. Norman, omtales samenes små båter som var i bruk på sjøene øst for Tärnafjellet i Västerbotten: «...disse ere gandske smaa og smale, de ere bunden saman med tæger, i stæden for søm, og klinede med fedt af rensdyr i stæden for tjære.» ${ }^{73}$ Ifølge beretningen ble båtene ikke bare brukt til fiske - de var også et viktig framkomstmiddel når sjøer og elver skulle krysses.

\section{Tilberedning og oppbevaring av fisk}

Ifølge både Drake og Sjulsson var salting uvanlig. Sistnevnte forteller at fisken ble kokt eller stekt på spett. Man skar av en bjørkekvist, spisset den i ene enden og stakk den inn langs ryggraden på fisken. Så skar man flere små tverrsnitt i fisken og satte kvisten fast i bakken i bøyd stilling over ilden, og slik stod den til fisken var stekt. ${ }^{74}$ Drake skriver at 


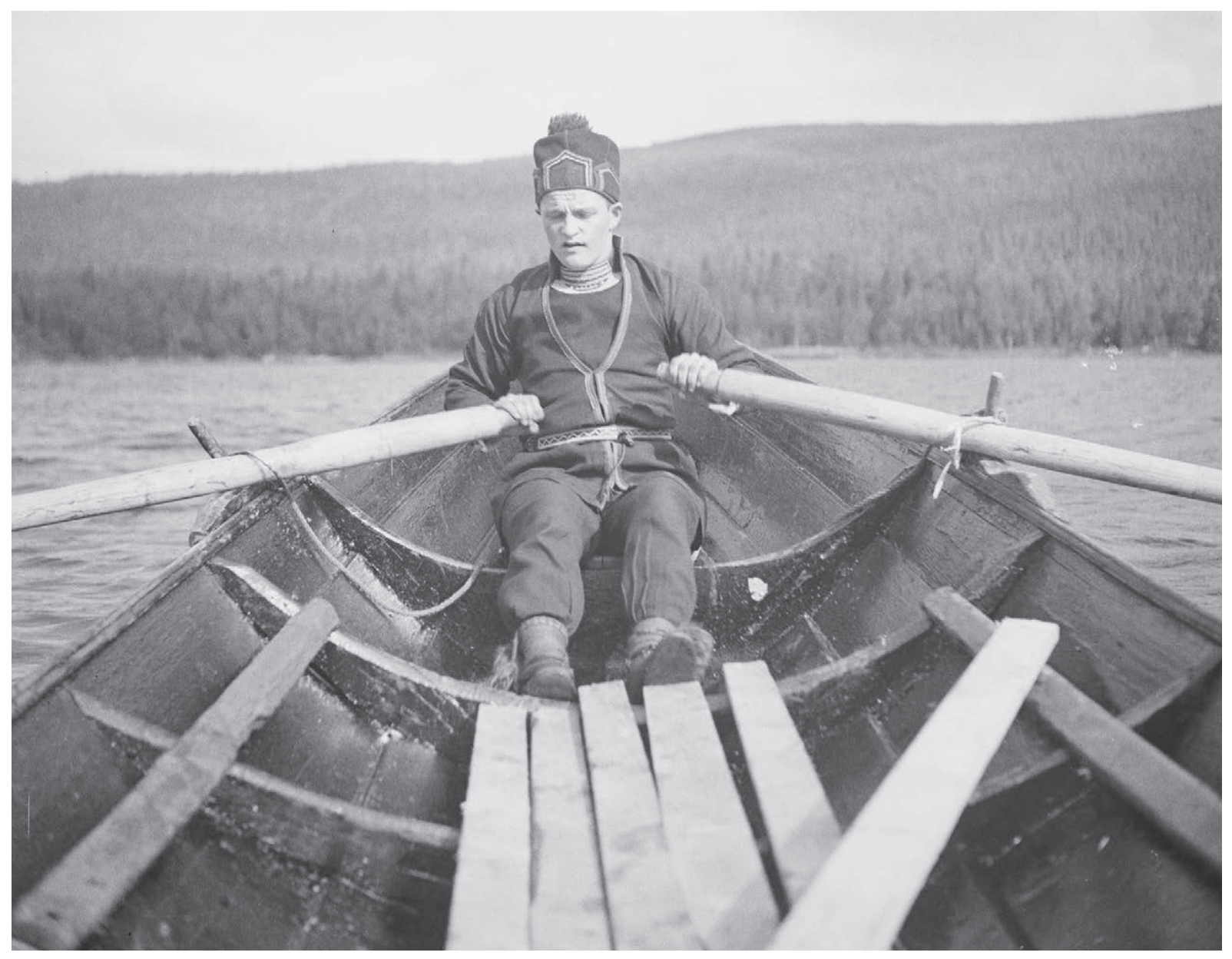

Figur 9: Lars Børgefjell (1914-1987) fra Susendalen ved årene i en båt av svensk type som ble brukt til fløyting av tømmer. Ifølge Christer Westerdahl er disse båtene en videreutvikling av samiske sydde båter (jf. Westerdahl 1987: 82). Børgefjell er kledd i den sørsamiske mannsdrakten og sitter på den fremre langsgående tofta, som ligger mot fremre spant. Bildet er tatt 25. juni 1936, og kanskje ror han på Kultsjön ved Fatmomakke, der samene fra gammelt av samles for å feire midtsommer eller sankthans. Foto: Václav Marek. Mareks bildearkiv / Nasjonalbiblioteket.

også tørket fisk kunne stekes litt på glør. ${ }^{75}$ Fisk som skulle oppbevares, ble tørket. Sjulsson beskriver denne prosessen slik: Fisken ble skåret opp etter ryggen ned mot spolen. Hvis fisken var stor, satte man bjørkepinner mellom de to halvdelene for å holde dem fra hverandre. Så ble fisken hengt over staurer i solskinnet til den hadde tørket noe. Deretter hengte man den i røykåpningen i kåta for røyking og videre tørking før den ble lagt til forvaring. Tørrfisken ble kokt eller stekt på spidd. Samene spiste ikke store, magre fisker, som man mente førte sjukdom med seg. Dessuten trodde de at det i noen fjellsjøer fantes svært store, feite saivofisker som det var meget vanskelig å få tak i. ${ }^{76}$ 
John Kappfjell, oppvokst ved Majavatnet, forteller om oppbevaring av salt fisk:

Høstfisket etter ørret og røye foregikk med garn fra omkring midten september. Da var gytefisken gått opp i bekkene. Den var mager og av dårlig kvalitet, så den ville man ikke ha i garnet. Det foregikk også et fiske seinhøstes etter ørret før vatna fraus, og den fisken ble gjerne lagt i en trekagge eller kvartel for lang oppbevaring. Den ble bløgga og sløyd og alt vatnet ble omhyggelig tørka vekk. Litt grovsalt ble strødd over botnet på kaggen. Så strødde man litt salt $\mathrm{i}$ buken på fisken og la den ned tett $\mathrm{i}$ tett om hverandre med buken opp til trekaggen ble fullt. Litt salt ble også strødd mellom lagene, men ikke mye salt. Saltet trekker væske ut av fisken, og denne laken konserverer fisken. Lokket ble lagt på slik at litt av laken kom over lokket som ei forsegling. Heile kaggen ble så satt ned i ei kaldkilde, ei gaeltie, slik at det meste av den sto støtt under vatn. Slike kaldkilder finner man alltid i nærheten av gamle kåteplasser. Temperaturen på kaldkildevatn er 4-5 grader året rundt. Når vinteren kom, dro man med rein og pulk eller slede og hentet kaggene til vinterboplassen. Fisken hadde da fătt omtrent samme konsistens som rakfisk. Men det er saltfisk, saeltie guelieh. Den ble spist sammen med brød eller potet, hvis man hadde det. ${ }^{77}$

Gunhild Børgefjell fortalte at de oppbevarte lett saltet fisk i noen kvartel som ble gjemt i ei steinur på fjellet for senere avhenting. Hun fortalte også at både fisk og reinmelk ble lagret i melkekjeller. Det var ei ganske stor og djup grop som var steinsatt, både i bunnen og i vegger. Et lag med bjørkenever ble lagt i steinbunnen før man satte ned kaggen med fisk eller melk. Så dekket man over med never, jord og store, flate steiner. «Men til tross for dette, vart desse steinkjellaran ofte besøkt, lensa og plyndra av jerv», fortalte Gunhild. ${ }^{78}$

John Kappfjell forteller om røyking av fisk slik han husker det fra barndomstida:

Fisken flekkes og tørrsaltes et par døgn slik at den blir hard. Fisken med salt kunne legges den på en planke som lå diagonalt opp mot en vegg, slik at laken renner av. Ettersalting legges $i$ «iskaldt» kildevatn en times tid, henges opp og tørkes ett døgn. Så henges den opp over ildstedet inne i gammen. Når man kokte kaffen om morran, starta røykinga. Røkt fisk var pålegg som ble med til fjells.

Beskrivelsen er ganske lik Kristoffer Sjulssons, bare med den forskjell at Sjulsson tørket og røkte fisken uten salting og utvatning etterpå. Både han og Drake hevder at samene i eldre tider ikke benyttet salt. Drake skriver at det var praktiske grunner til det: «Insalting i egentlig mening förekommer av praktiske skäl ej i allmänhet hos ett nomadfolk som lapparna.» ${ }^{79}$ Ingen nærmere forklaring gis, men det bør kunne forstås slik at både salt og saltfisk var tynge å transportere over lange avstander enn tørket og røkt fisk.

\section{UTSETTING AV FISK}

I alle fall fra slutten av 1800-tallet og oppigjennom 1900-tallet ble det satt ut fisk i utallige fjellvatn på Helgeland og i Trøndelag. Her tas med utdrag fra noen kilder.

\section{Nils Olav Kappfjells notater}

Nils Olav Kappfjell (1910-1987) laget en oversikt over utsetting av fisk i 124 vatn og tjern på SørHelgeland og i Nord-Trøndelag. I oversikten er det 


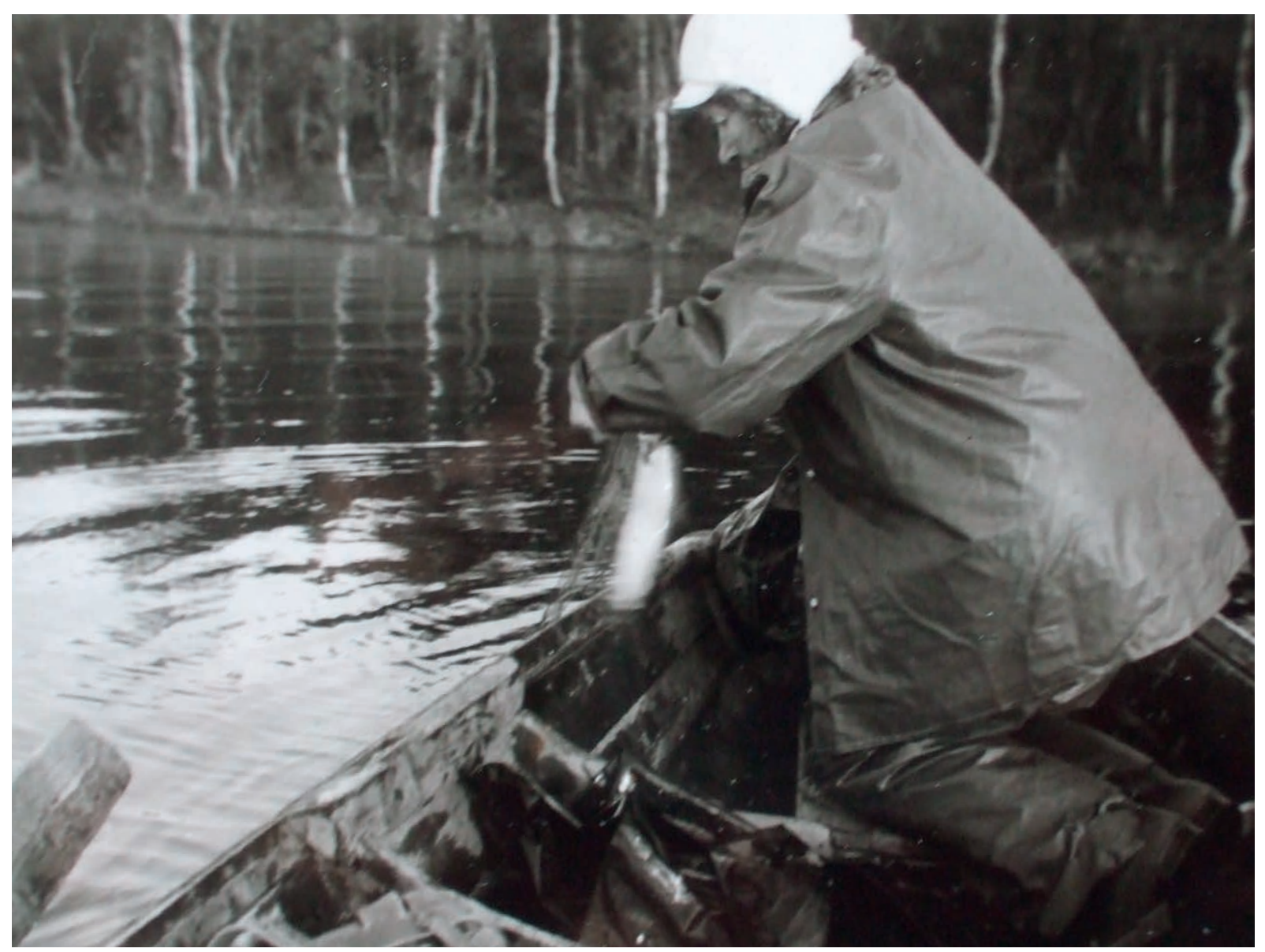

Figur 10: Gunhild Israelsson (1925-1975) bodde ved Björkvatnet i Tärna og fisket med garn i dette vatnet hele sommerhalvåret fra isen gikk og det ble «landvåk» om våren, til isen la seg på senhøsten. Her står hun på kne på en langsgående tofte og drar opp garnet. Fram til midten av 1950-tallet ble både røye og ørret saltet og lagt i kvartel (1/4 tønne) eller åtting (1/8 tønne). Under høstfisket ved Abelvattnet eller Akelen ble kvartel og åttringer med saltet fisk lagt under båten til snøen kom. Før jul ble den hentet med skikjelke. Strøm ble innlagt i Tärnamo midt på 1950-tallet, og fryseboksen kunne erstatte salting. Bildet er tatt ca. 1960 enten ved Abelvattnet eller ved Akelen på svensk side. Foto: Kjell-Åke Lundström. Privat eie.

oppgitt hvem som satte ut fisken, og hvilket år det ble gjort. Den tidligste noterte utsetting skjedde i 1894, da Bendik Johnsen satte ut fisk i Grobtemahkie jaevrie, Grytendalsvatnet, i Bindal. Utover 1890tallet var det flere samer som også satte ut fisk både på Helgeland og i Nord-Trøndelag. I Bindal og
Velfjord herred satte Anders Pedersen Nordfjell ut fisk i ni vatn spredt over et stort område på slutten av 1800-tallet. Under oversikten har Kappfjell notert følgende: «Var det ikke en samfundsgavnlig person?» De som bar fisk for John Olsen Stinnerbom, fikk betalt. Han var handelsmann og distriktets største 
reineier på slutten av 1800-tallet. Stinnerbom leide folk til å bære fisk fra Namsvatnet til Lill-Gåsvatnet, ei vegløs strekning på nærmere 2 mil i luftlinje. En av dem som bar, fikk ei simle og en del butikkvarer i betaling.

Hvordan denne fisketransporten skjedde, sier kildene ikke noe om, bortsett fra at de bar fisken. I praksis må det bety at de bar spann eller trekagger med vatn og fisk kilometer etter kilometer i ulendt skog- og fjellterreng. Det var ingen lett jobb, men også kvinner deltok. Nilsine Westerfjell bar flere ganger fisk til noen tjern på Kalvfjellet i Bindal på 1940tallet, og et av de vatna har fått navnet Nilsinetjønna.

I Kappfjells oversikt finnes også et lite notat om fisken lake og solblindhet:

På Burgfäll, rett syd frå Klimpfjäl findes den eneste fjällsjö hvor det findes: laka [...] Dit har samene utplantet laka i medisinsk interesse. Denne fisket man på våren, isfiske, aller mest for levra sin del. Av den laget man øienmedisin (solblind) «glou'pere/=blir solblind».

Det ser ut til å ha vært stor aktivitet tilknyttet fiskeutsetting fram til 2. verdenskrig, og man diskuterte hvordan man kunne gjøre dette for å få best mulig resultat. Kappfjell skriver om samen Anders Vestfjell på Høylandet, som blant bumenn ${ }^{80}$ var kjent som den rene ekspert når det gjaldt viten om ferskvannsfisk, det gjaldt fordeler og ufordeler med utplanting av de forskjellige fiskeslag, ørret, røye, lake osv.

\section{Et svommende matforråd i fiellet}

Peder I. Jåma (1909-1985) fortalte til sin nevø, Albert Jåma, at samene bar ut småfisk til mange vatn i Vestre Namdal reinbeitedistrikt, fiskevatn som lå på statens grunn. Han forteller følgende:
I fjellvatna er det samene som har satt ut fisken. Det gjorde de for at de skulle ha et matforråd. Jeg har sjøl vært med å bære fisk til flere fjellvann og tjern. Eksempelvis var det jeg og Lars og John Vesterfjell som bar fisk til Folldalsvatnet. Vi bar fra Lindsetdalen.Jeg og John var bare smågutter da, så det må ha vært like før 1920 eller deromkring. Vi slapp da fisken i tjønna lengst øst. Derfor ble denne tjønna kalt «Barnehjemmet» fordi det ble så mye småfisk der. Derfra spredde fisken seg videre nedover vassdraget. ${ }^{81}$

Legg merke til begrunnelsen for dette slitsomme arbeidet: et svømmende matforråd i fjellet, der de alltid kunne hente fersk mat når de var ute og passet reinflokken. Dette har vært viktig for fjellets folk til alle tider, uavhengig av reinflokkenes størrelse.

\section{Erstatning for fisk i private vatn}

I tilknytning til Helgeland Kraftlags regulering av Åbjøravassdraget i Bindal på Helgeland laget sivilagronom og tidligere reindriftsagronom Loyd Villmo i 1978 en utredning, basert på intervju med reineiere i området. De forteller at det var Nilsine Westerfjell som satte ut fisk i Nilsinetjern, og etter det ble det fin ørret i dette vatnet. Rundt 1901 fisket Nils Johan Kappfjell småfisk i Åbjøra og bar den opp til Kalvkruvatn og Kalvvatn. Senere bar Peder Johan Westerfjell settefisk fra Kalvkruvatnet til det midterste Kalvvatnet. Det ble også båret settefisk fra Holmvatnet til de øverste vatn i vassdraget, og den spredte seg nedover til Øvre Kalvvatn. Også til Ringvatnan bar samene fisk. Alle disse vatna inngikk i vassdragsreguleringen.

Ifølge Loyd Villsoms informanter var det ikke fisk i noen av de nevnte vatnene før samene begynte å sette ut småfisk, og noen ble meget gode fiskevatn. I 1965 fikk John Aron Westerfjell så mye fisk i ett av vatna at han saltet i ei halvtønne. Paul Westerfjell fortalte 


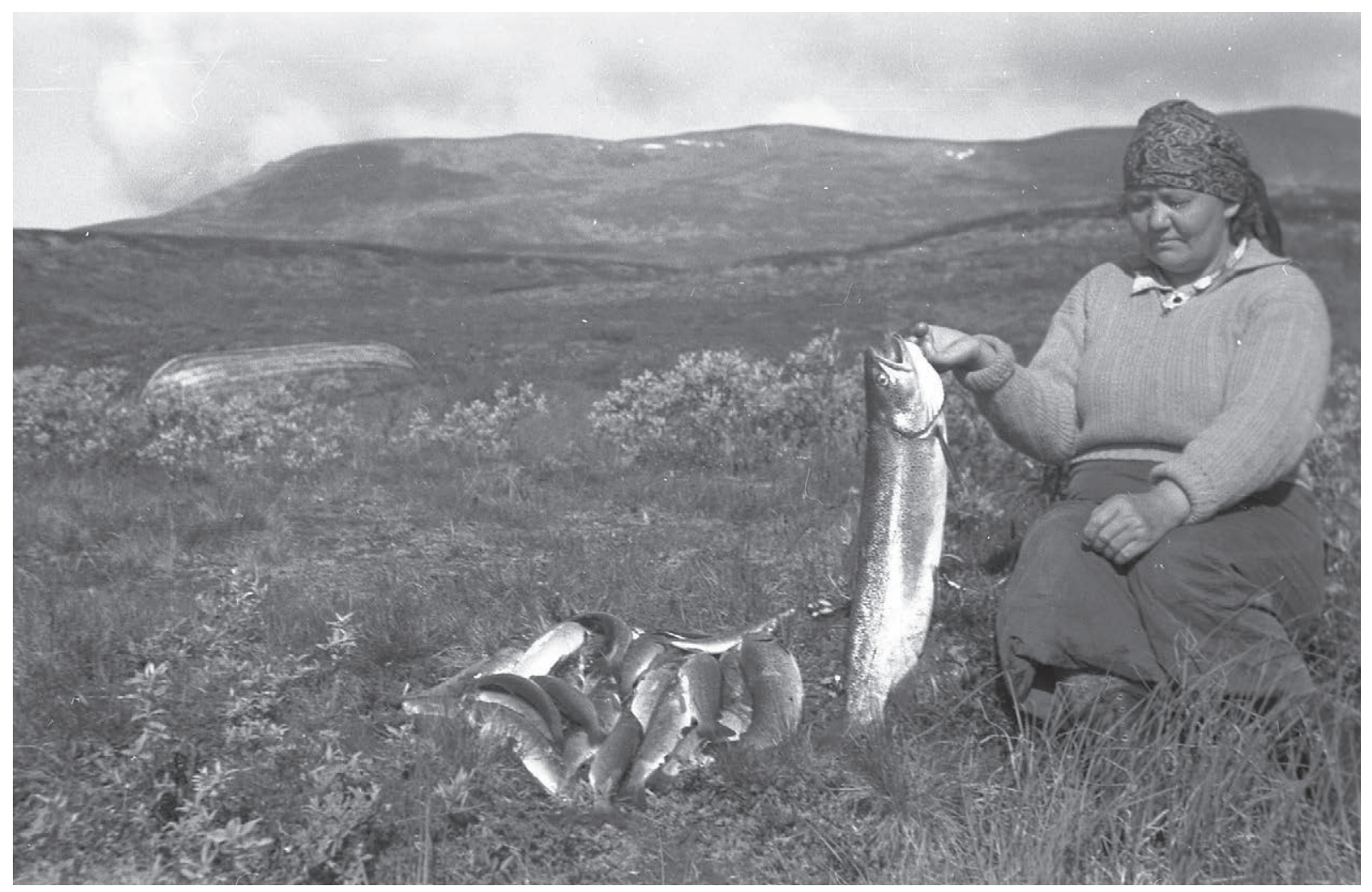

Figur 11: Margrete Danielsen (1905-1996) med fangsten ved Lille Grøvelsjøen, som ligger mellom Elgåhogna og Digerhogna i Engerdal. Hun og ektemannen, Lars Danielsen, hadde reindriften sin her i Elgå reinbeitedistrikt. Lille Grøvelsjøen ligger i sommerbeitelandet for reinflokken og var et viktig fiskevatn for reindriftsfamiliene i området. Foto: Lars Danielsen. Rørosmuseets arkiv.

at hans familie fisket minst $1500 \mathrm{~kg}$ per år, for det meste i de vatn som ble omfattet av reguleringen. ${ }^{82}$

Namdal herredsrett avsa dom i Åbjøra-skjønnet i 1979. De to berørte reinbeitedistriktene BindaKappfjell og Frøyningsfjell ble tilkjent en årlig erstatning på til sammen $\mathrm{kr} 5000$,- for tapt fiske i Åbjøravassdragets øvre del. ${ }^{83}$ Retten la til grunn «den aktuelle bruk av fiskeressursene» og begrensning av fisket på grunn av reguleringen. Det interessante ved dette skjønnet er at reineierne fikk erstatning for tapt fiske i vatn der de i henhold til reindriftsloven ikke hadde rett til å fiske. Herredsretten behandlet
Åbjøravassdraget som et privat vassdrag tilhørende Plahtes eiendommer i Bindal, og samenes fiskerett er i reindriftsloven begrenset til fiske i tilknytning til utøvelse av reindrift på statens grunn.

\section{DEN SAMISKE FISKERETTEN}

Det er allerede omtalt at fisket ble nevnt i enkelte eldre bygselkontrakter. Her er et eksempel fra Hemnes på Helgeland: I en bygselkontrakt fra 1903 mellom lappelensmann E. Hansen Langfjeldsæter og lapp Nils Pedersen Fjellström angående Spjeltfjelldalen i Hemnes står det blant annet følgende: «Forsaavidt 
ickke nogen kan legimitere sin bedre Ret med Hjemmels dokument for Fiske i Græsvandet gives Byxleren Ret til ogsaa at fiske der inden Lovens Begrændsning.» ${ }^{84}$ Det oppgis ingen hjemmel for «Lovens Begrændsning», men det er rimelig å anta at det her er tale om felleslappeloven av $1883^{85} \S 3$, som gir samene frihet til å oppholde seg der hvor de har vært etter gammel sedvane,

samt at betjene sig af Land og Vand saavel til deres egen og deres Rens Underholdning med Iagttagelse af denne Lovs Forskrifter, som til Jagt og Fiskeri lige med Rigets egne Undersaatter. [uthevet her].

Her blir samenes fiskerett likestilt med den fiskerett som landets øvrige innbyggere hadde. I all senere reindriftslovgivning er samenes fiskerett knyttet til fiske i vatn som tilhører staten.

\section{Konflikt om fisket}

Det kan ikke benektes at det fra tid til annen har vært konflikt mellom de fastboende og reindriftssamene om utnyttelsen av fiskeressursene innenfor dagens reinbeitedistrikter. Ett eksempel er konflikten mellom reineier og formann i Ildgruben reinbeitedistrikt Anton Lifjell (1915-1971) og Rana kommune. I 1966 fastsatte kommunen nye fiskeregler med forbud mot garnfiske i den hensikt å forbedre fisket i kommunens vassdrag. Bakgrunnen var en stor befolkningsøkning i Rana etter etableringen av Norsk Jernverk på 1950-tallet, med et sterkt økende sportsfiske innenfor reinbeitedistriktet. Anton Lifjell protesterte mot at regler som hadde som formål å regulere sportsfisket, også skulle ramme samene, som drev fiske til eget livsopphold. I et brev til Landbruksdepartementet skrev han dette: «Ferskvassfisket er en meget viktig binæring for reindriftsamerne, og samernes fiskerett er en meget urgammel og hevdvunnen rettighet.» ${ }^{86}$ I 1967 skrev

Lifjell igjen til Landbruksdepartementet:

Flyttsamenes jakt eller fiskerett på Helgeland bygger på sedvanerett, bruk i alderstid. Etter min mening er denne rett ukrenkelig, og det finnes ikke en lovparagraf eller regel som kan forby samene å bruke garn som fiskeredskap. ${ }^{87}$

\section{Departementet svarte at det}

ikke kan komme på tale å gjøre unntak for samenes fiske fra de i 1966 fastsatte regler om redskapsbruk m.v. i Rana. [...] Reglene gjelder generelt for alle, uten hensyn til hvilket grunnlag en måtte ha for fiskerett. ${ }^{88}$

Anton Lifjell fikk ikke medhold i sin påstand om at samene hadde rett til å drive garnfiske, men han gikk ikke til retten med saken. Det ble gjort i flere andre tilfeller, og to av fiskesakene gikk helt til Høyesterett.

\section{Hoyesterettsdom 1955}

I 1943 reiste grunneiere ved Namsvatnet i NordTrøndelag sak mot reineier Jonas Marsfjell for å få fastslått ved dom at reineieren verken hadde rett til å fiske, ha gammer eller ta trevirke på deres eiendommer. Marsfjell tapte i Namdal herredsrett og anket dommen til lagmannsretten. Dessverre døde han før saken kom opp, men enka, Maria Marsfjell, førte saken videre. I 1950 ble det avsagt dom i Frostating lagmannsrett, og Marsfjell tapte når det gjaldt retten til fiske i de privateide sjøene Vestre Rækarvatn og Namsvassflyene. Saken ble anket til Høyesterett, som stadfestet lagmannsrettens dom, men i Høyesteretts dom står det at lovgivningen i flere henseender hadde «begrenset samenes rett i forhold til den bruk de fra gammelt tid hadde utøvet». ${ }^{89}$ 


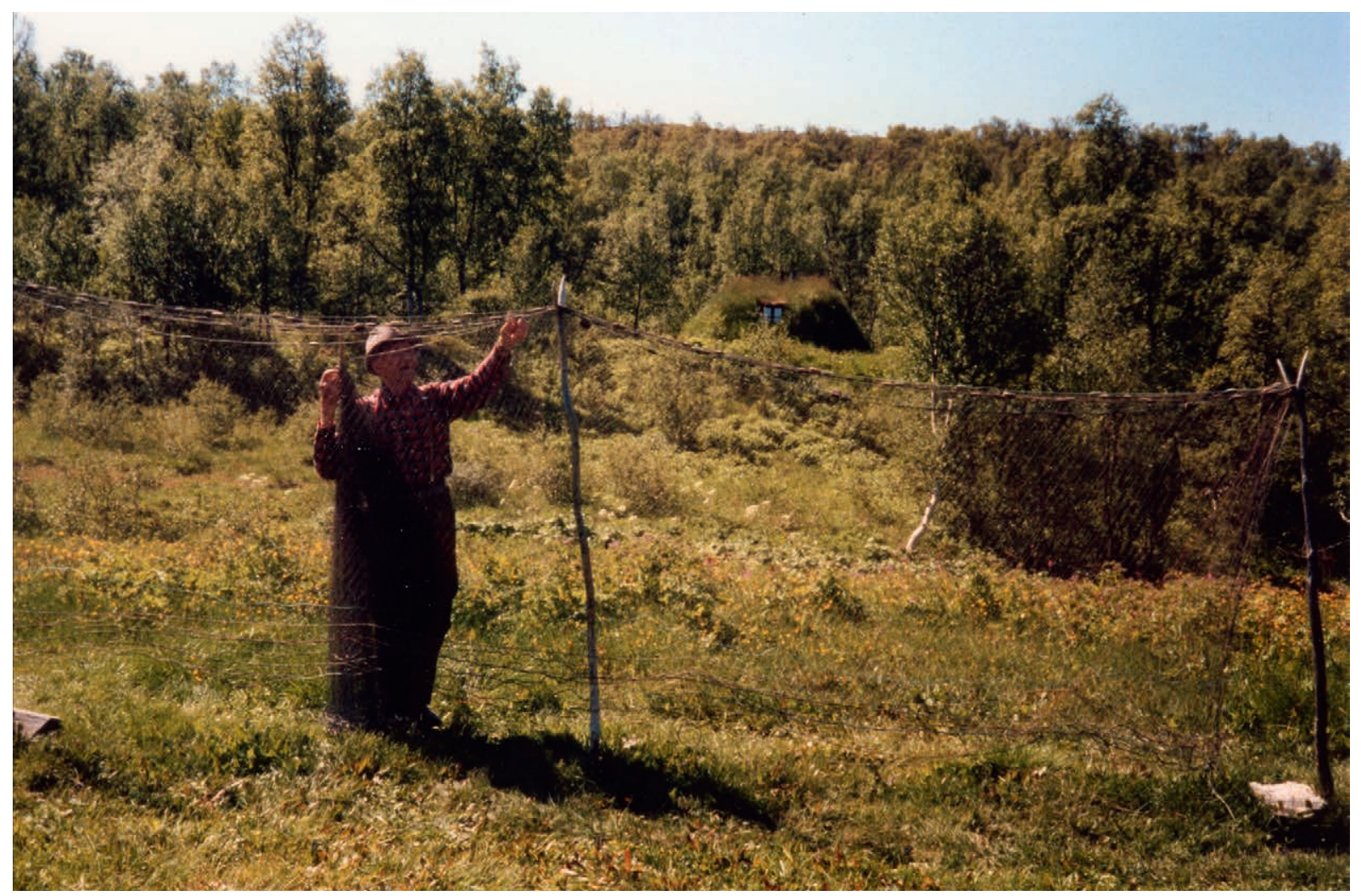

Figur 12: Ole August Fjellheim (1905-1999) «gisner garna» på Jonasvollen i Hyllingsdalen i Røros kommune. Her blir garna hengt opp til tørk på bjørkestengler etter fiske i Øvre Hyllingen. Høyesterett stadfestet i 1968 reineiernes rett til å fiske blant annet i dette vatnet. I bakgrunnen ses gammen som en av de andre reineierne, Jonas Barroch, satte opp på 1970tallet for å oppholde seg i når han var ved Hyllingen for blant annet å fiske. Bildet er tatt omkring 1990.

Foto: Jenny Fjellheim. Rørosmuseets arkiv.

\section{Hoyesterettsdom 1968}

Denne saken gjaldt reineiernes rett til jakt, fangst og fiske i Brekken sameie i Sør-Trøndelag i et område øst for den såkalte finnelinjen mellom Hyllingsjøen og Dagvolsjøen til riksgrensen. Frostating lagmannsrett la til grunn samme rettsoppfatning som Høyesterett bygde på i Marsfjell-saken, og kom fram til at samene ikke hadde rettigheter øst for finnelinjen. ${ }^{90}$ Saken ble anket til Høyesterett med Knut Bergsland som sakkyndig på samenes side. På bakgrunn av hans utredning ${ }^{91}$ hevdet høyesterettsadvokat Nils Daae Rogstad at samene var de første brukere av store fjellområder i Norge, at de ved alders tids bruk hadde oppnådd en virkelig rett til blant annet jakt, fangst og fiske, og at denne eldgamle bruksretten ikke gikk tapt ved at bøndene gjennom hevd eller på annen måte hadde ervervet eiendomsrett til sametraktene. ${ }^{92}$ Høyesterett kom fram til at samene i Riast-Hyllingen reinbeitedistrikt hadde rett til å drive jakt, fangst og fiske øst for finnelinjen mellom Hyllingen og Dagvolsjøen (figur 12), og at de også hadde rett til å drive fiske i 
Øvre Hyllingen og Dagvolsjøen. ${ }^{93}$ Høyesterett anså ikke Marsfjell-dommen av 1955 som et avgjørende prejudikat i Brekken-saken, som ble et vendepunkt i synet på samenes rettigheter, ikke minst takket være Bergslands grundige historiske utredning. Tidligere var det en akseptert oppfatning at reindriftssamenes rettigheter hadde sitt grunnlag i den til enhver tid gjeldende reindriftslov. I Brekken-dommen uttaler Høyesterett at blant annet samenes fiskerett er basert på alders tids bruk, og den ble ikke fratatt samene ved lappeloven av 1883 eller reindriftsloven av 12. mai 1933. Sistnevnte lov var fremdeles gjeldende da høyesterettsdommen ble avsagt i $1968 .{ }^{94}$

\section{OPPSUMMERING}

Hvor viktig har fisket vært i den sørsamiske naturalhusholdning? Før 1600-tallet er kildematerialet spinkelt. Arkeologiske funn i Sverige viser en samisk båtkultur så tidlig som på 600-700-tallet. Boplasser ved Aursjøen og Rensennvatnet, begge regnet som gode fiskevatn, tyder på samisk bosetting og indikerer at fisket var en viktig del av deres næringsgrunnlag $\mathrm{i}$ eldre tid. Knut Bergsland hevder på språklig grunnlag at samene melket tamrein også før vikingtiden, men at næringsgrunnlaget for øvrig var jakt, fangst og fiske.

Av svenske kilder fra 1500-tallet framgår det at samer betalte skatt i form av fisk og pelsverk, og at også fiskevatna var skatteobjekt, noe som viser verdien av å ha tilgang til disse ressursene. Hvor viktig fisket var i forhold til jakt og fangst, er det imidlertid vanskelig å ha noen begrunnet oppfatning om, men Bergsland hevder at fisket alltid har vært en samisk hovednæring. Erik Bylund skriver at fisket for de svenske skogssamer var et livsvilkår. Fra nyere tid vet vi at fisket var redningsplanken for eldre og sjuke eller når uhell inntraff $\mathrm{i}$ reinflokken. Man kan tenke seg at fisket kan ha hatt den samme funksjon også i det gamle jakt- og fangstsamfunnet.
Bergslands påstand om at fisket alltid har vært av stor betydning, må oppfattes slik at fisken har vært en viktig del av samenes levebrød både før og etter at tamreindriften ble en dominerende del av næringsgrunnlaget. Svenske kilder bekrefter dette. I et utkast til jordebok på 1600-tallet er samer ført opp som brukere av navngitte fiskevatn og landområder både i Västerbotten og på indre Helgeland. En kilde fra 1680-årene forteller om familier som levde av fuglejakt og fiske i tillegg til noen få reinsdyr. Samene hadde små og lette båter, som det var uproblematisk å bære forbi fosser og mellom fiskevatn. Båtene ble brukt under selve fisket og for transport over sjøer og på elver og i vassdrag. Dermed var det ingen motsetning mellom en nomadisk livsstil og fjellfiske med den lette båttypen. I nyere tid med større båter ble båtene dratt på land og forlatt ved fiskevatnet til neste sesong.

I folketellinger fra Tärna-traktene på slutten av 1800-tallet finnes samer oppført i kategoriene «fiskarelappar» eller «fiskarlapp», noe som betyr at de levde av innlandsfisket. I tillegg var «fattiglappar» en kategori, og de drev trolig også litt fiske med enkleste utstyr. Forstassistent Krag hevdet på 1880tallet at retten til fisket i Orrvatnet i Nord-Trøndelag var forbeholdt samene, en interessant rettshistorisk observasjon som trolig gjaldt de fleste avsidesliggende innsjøer i det sørsamiske området. Fra slutten av 1800-tallet og fram til 2. verdenskrig bar samene tusenvis av småfisk til fjellvatn på Helgeland og $\mathrm{i}$ Nord-Trøndelag. De ville ha et svømmende matforråd i fjellet, der de i sommerhalvåret kunne hente fersk mat når de var ute og passet reinflokken.

Fisken inngikk i naturalhusholdningen for alle reindriftssamer i tillegg til at fisket var hovednæring for noen. Snøras tok mange reinflokker, bjørn og ulv var farlige fiender, og sjukdom kunne bryte ut i flokken. Ingen erstatning var å få ved slike tildragelser. 
Også den rike reineier kunne bli fattig, og et svømmende matforråd i fjellsjøene kom godt med.

To rettssaker for Høyesterett understreker betydningen av fiskeretten for samer tilknyttet reindriften i vår tid. Reineier Anton Lifjell i Rana formulerte seg slik i et brev fra 1966: «Ferskvassfisket er en meget viktig binæring for reindriftsamerne, og samernes fiskerett er en meget urgammel og hevdvunnen rettighet.»

Det innledende spørsmål om fiskets betydning i den sørsamiske naturalhusholdning kan kort besvares med at fisken har vært en meget viktig del av samenes levebrød, i alle fall fra vikingtida til vår tid. Trolig har fisket til alle tider vært en sørsamisk næring, som har vært kombinert med jakt, fangst og tamreindrift.

\section{SUMMARY:}

\section{THE SOUTHERN SAMI PEOPLE AND THE MOUNTAIN FISHING}

This article discusses how important fish were in the household of the Southern Sami people.

The area where the Southern Sami people were known to exist reaches from Rana in Nordland to Elgå in Hedemark and to the adjoining areas on the Swedish side.

According to an overview from the year 1670, the Sami people frequented approximately 140 fishing lakes along Umeälv in Västerbotten and further into Norway. A Norwegian source from the year 1680 claims that the Sami people in the south of Helgeland lived on fishing and bird hunting except for the four or five reindeers they kept and milked.
The Sami people used different types of fishing equipment, among which were nets made from flax yarn that the Sami women spun. The fish were often dried or smoked. During the first half of the 20th century, the Sami people planted small fish in the mountain lakes, where fish did not previously exist. The purpose of doing this was to ensure that there were fishing waters available in those areas where the Sami people stayed with their reindeer herd.

The Norwegian Supreme Court has twice ruled on the Sami people's fishing rights. In 1955, the Sami people lost their case. In 1968, however, in recognition of the length of time the Sami people had been fishing and hunting in a particular area, the Supreme Court concluded that the Sami people were to be awarded the right to fish and hunt in this particular area, east of Røros.

Both lawsuits, including the old written sources, demonstrate that fishing in lakes has been of significant importance to the Sami people's way of living, as an addition to their reindeer husbandry. 


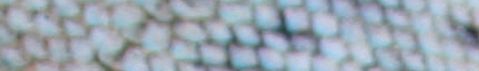

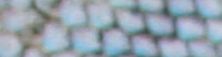

4 विकित

2,3 ardigy

$+x^{2}+x^{2}+20 y=$

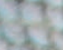

\section{asco}

antet

a.co

(n)

$\sin ^{2}$

\section{coste}

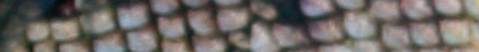

rofter cepore

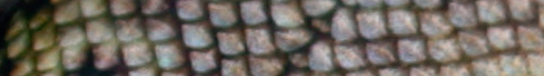

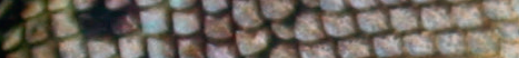

ispotores?

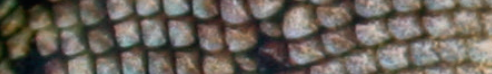

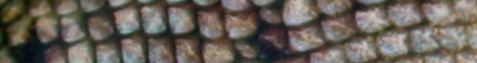

\section{Strote}

\section{0 is}

$7=$
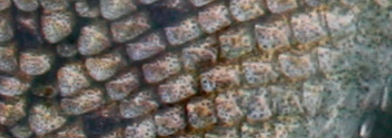
sit

\section{(3)}

\section{a.} .

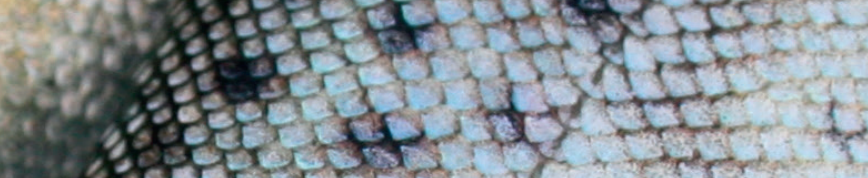
Wh Whut unt औ保

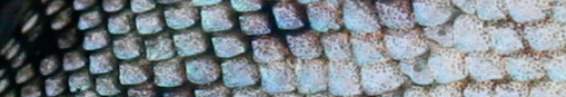

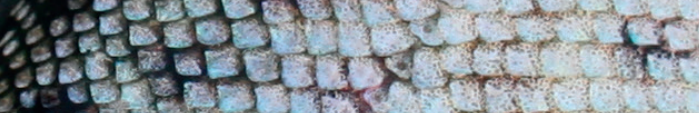

tive

20 sent 1 in
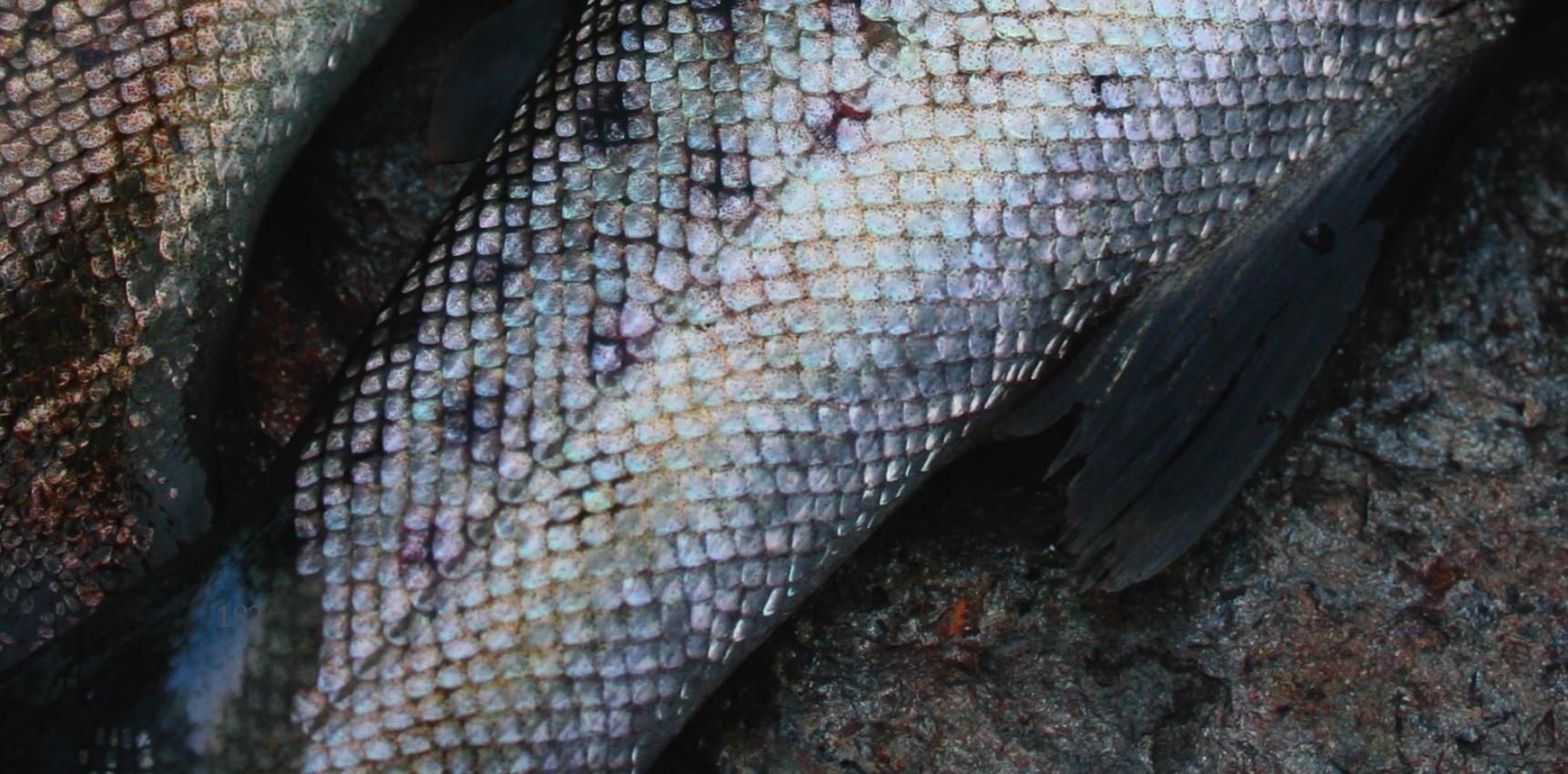

\section{得㩆} ioges of

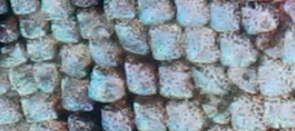

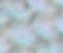




\title{
FJELLFISKE I GRENSELANDET MELLOM FANGSTMARK OG JORDBRUKSBYGD I YNGRE JERNALDER OG MIDDELALDER
}

\author{
Av Elling Utvik Wammer, Norsk Maritimt Museum
}

Fisket i fjellet i yngre jernalder og middelalder er et lite utforsket tema innenfor norsk arkeologi. Perioden har etterlatt begrenset med skriftlige kilder, og arkeologiske funn og kulturminner er derfor viktige for forståelsen vår av dette emnet. I fjellet har man imidlertid fram til nå sjelden funnet spor etter fiske som sikkert har kunnet dateres til dette tidsrommet.

Fjellvannet Tesse i Lom er et unntak. På sjøbunnen i dette vannet har man funnet et betydelig antall gjenstander laget av organisk materiale i tillegg til stein, og som derfor lar seg datere. To typer av søkker til fiskegarn eller not er blitt datert til vikingtid og tidlig middelalder i Tesse. Begge gjenstandstypene har antakelig vært festet langs bunntelna på garnet eller nota for å holde den nede. Den ene typen er hjullignende gjenstander hvor senkesteinen har vært festet til en vidjering ved hjelp av fire eiker. Søkkene kalles gjerne trinseformet på grunn av sin formlikhet med nederste del av en skistav (figur 1). Den andre typen er laget av én eller flere steiner innrullet i et bredt flak av never, som et hylster.

Søkelyset som ble satt på de trinse- og hylsterformete søkkene av never i forbindelse med

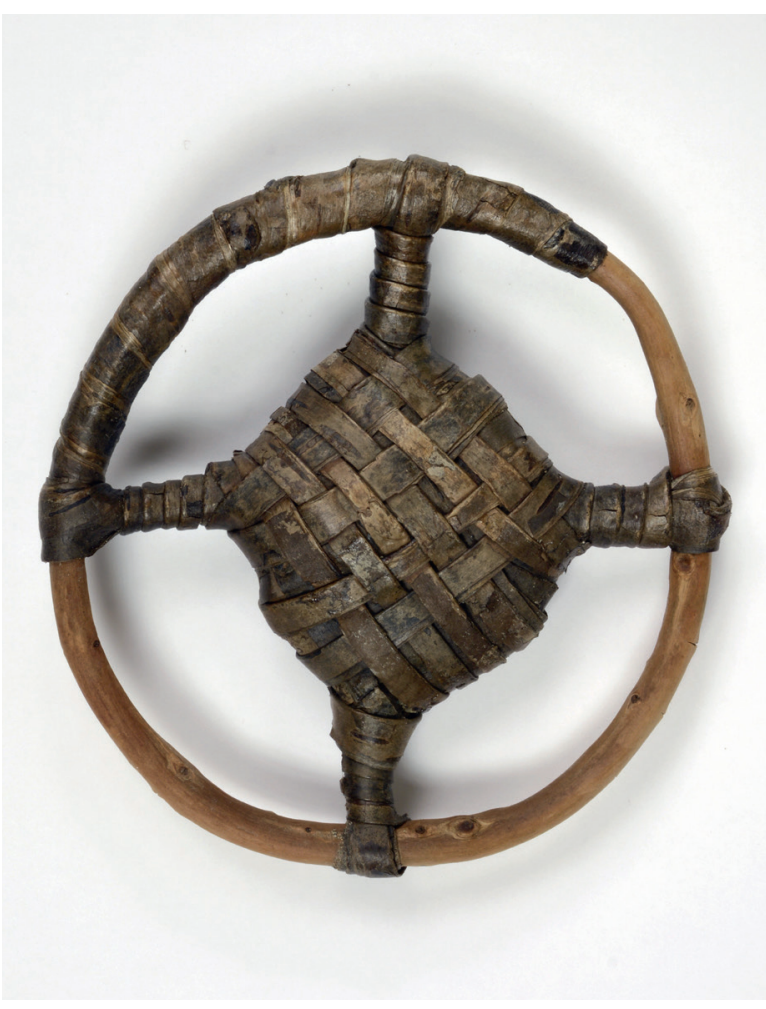

Figur 1: Trinseformet søkke fra Tesse, datert til tidlig middelalder. Diameteren til vidjeringen er ca. $11 \mathrm{~cm}$. Foto: Vegard Vike, Kulturhistorisk museum. 


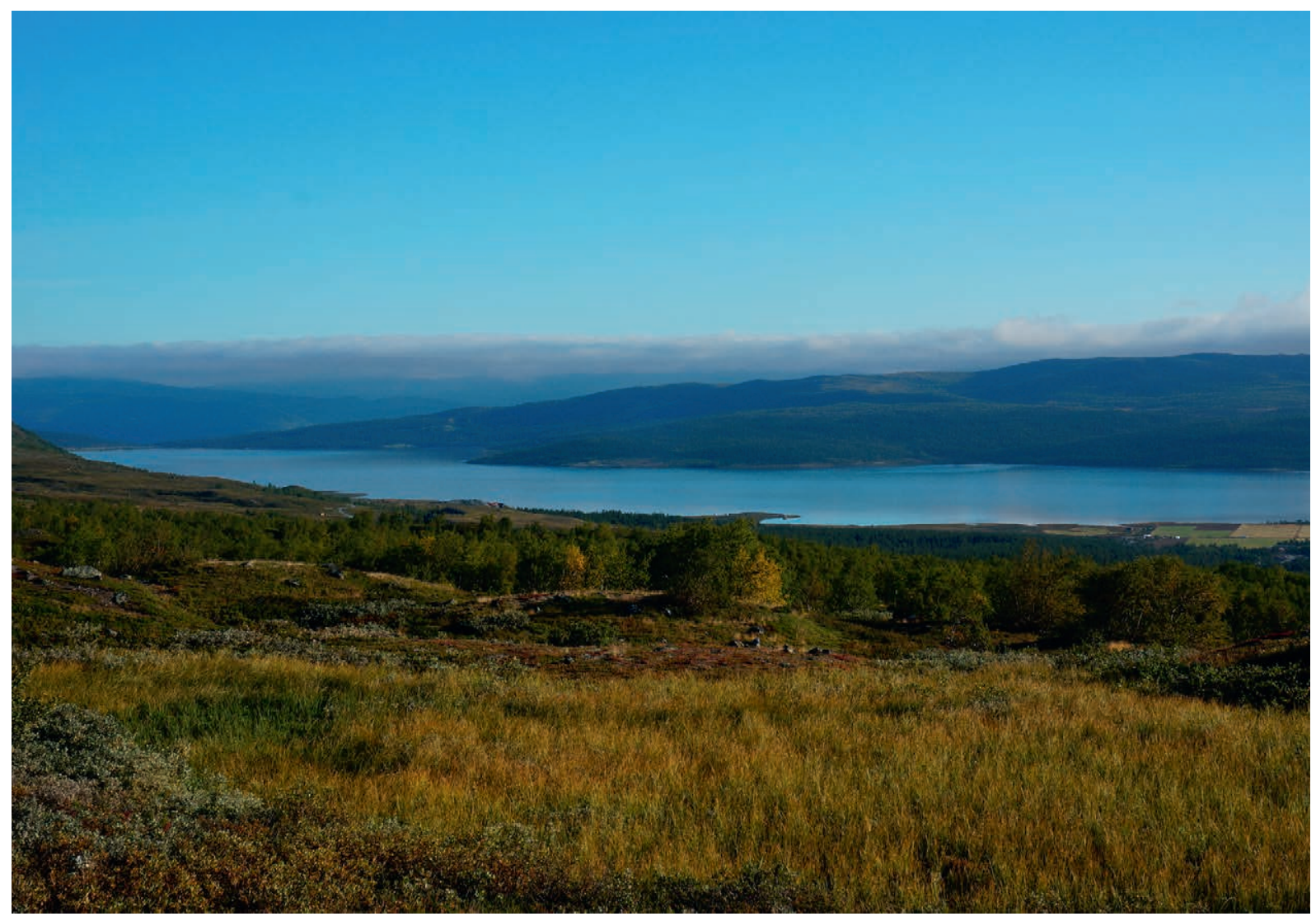

Figur 2: Tesse sett fra enden av Smådalen mot nordøst. Bortenfor nordenden av vannet stuper terrenget ned i Ottadalen. Foto: Espen Finstad, Oppland fylkeskommune.

sektoravgiftprosjektet «Tesse - svømmende rikdom» i 2014, gjorde at det arkeologiske fagmiljøet i Norge for alvor fikk øynene opp for dem. Gjenstander som er så godt bevarte og har slik håndverksmessig kvalitet, er ekstraordinære både nasjonalt og internasjonalt.

Den store mengden funn av daterbare søkker fra Tesse er en unik kilde og danner grunnlaget for min artikkel. Jeg ønsker å gripe tak i noen av de spennende spørsmålene vi satt igjen med etter de arkeologiske undersøkelsene i Tesse: Hvem var det som hadde drevet med fiske i dette fjellvannet i vikingtiden og starten av middelalderen? Hvilke næringsmessige og sosiale sammenhenger kan fisket i fjellet ha hatt tilknytning til i disse periodene? Jeg tar utgangspunkt i det arkeologiske materialet fra et fjellvann i Nord-Gudbrandsdalen, men vil også trekke inn funn av søkker fra andre steder i Norden. Gjennom dette prøver jeg å gjøre funnene fra Tesse og diskusjonene i artikkelen relevant også i et større Sør-Skandinavisk perspektiv. 


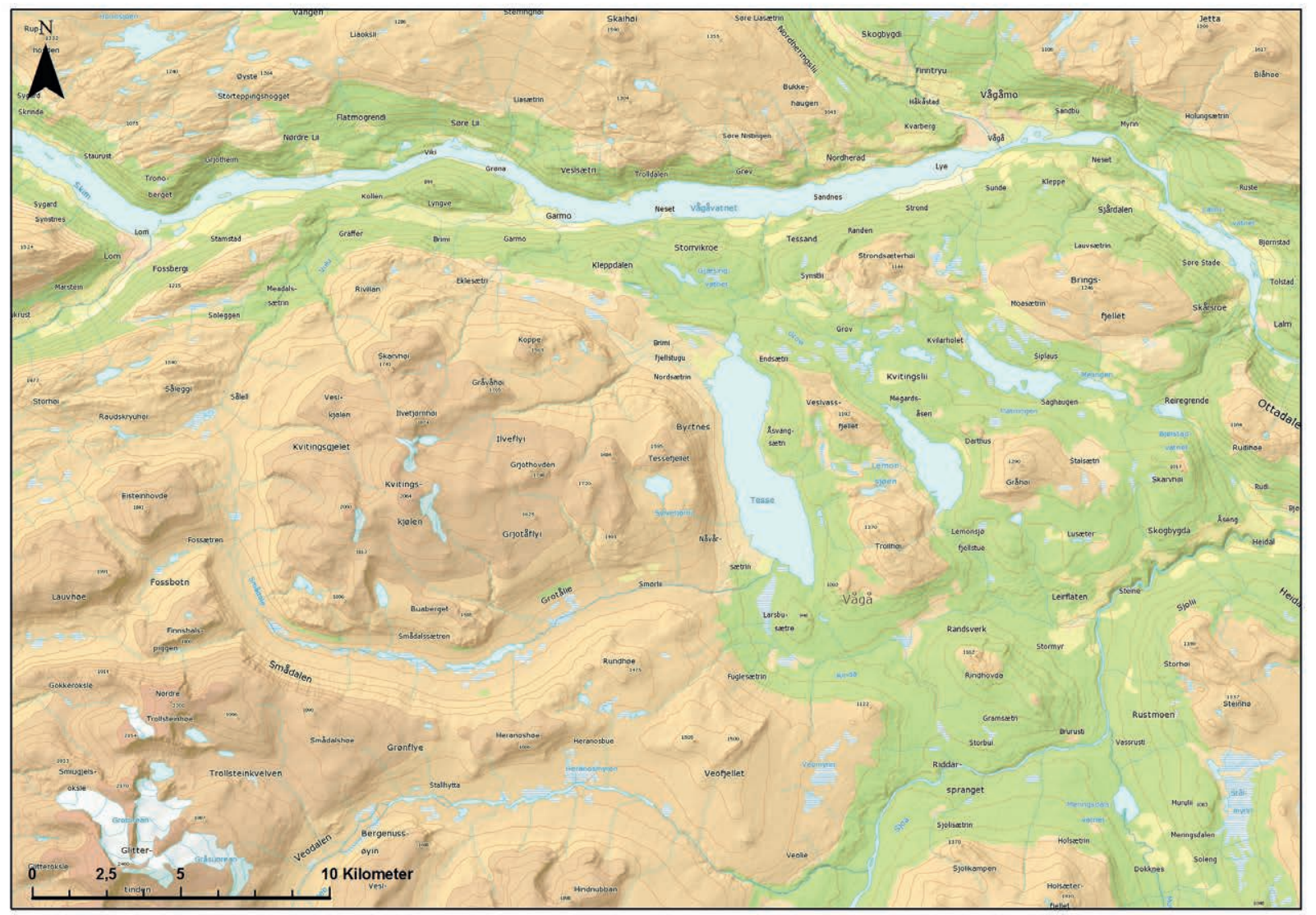

Figur 3: Oversiktskart over fjellområdene ved Tesse og den nærmeste jordbruksbygda, Garmo. Kart: Elling Utvik Wammer.

\section{TESSE I GRENSELANDET MELLOM FANGSTMARK OG JORDBRUKSBYGD}

Innsjøen Tesse ligger i et opprinnelig fjellskogsmiljø, ca. 850 moh (figur 3). Fra bygda Garmo i dalbunnen ved Vågåvatnet og opp til nordenden av Tesse er det om lag 500 høydemeter. Terrenget er stedvis bratt og avstanden i luftlinje ca. $6 \mathrm{~km}$. Til sørenden av vannet er avstanden ytterligere $6-7 \mathrm{~km}$. Tilsvarende høydeforskjell og avstand er det fra Tesse og opp til de nærmeste fjellområdene vest for vannet, hvor jakt på villrein har foregått, særlig på snøfonnene sommerstid. ${ }^{1}$ Tesse ligger derfor i noe vi kan kalle et geografisk grenseland mellom jordbruksbygdene og jakt- eller fangstmarkene i fjellet.

En klassisk tilnærming i den sørnorske arkeologien er følgende: «Hvem bodde og hadde sitt virke i fjellområdene?» Denne fagdiskusjonen har ofte dreid seg om forholdet mellom kategoriene fangstmann og bonde. ${ }^{2}$ Også forholdet mellom norrøn og samisk etnisitet har stått sentralt i den samme debatten og er særlig blitt aktualisert i de senere årene. ${ }^{3}$ Fiskeressursene blir i liten grad konkret vurdert i 
vitenskapelige arbeider som omhandler fjellet, men nevnes ofte i en bisetning. Gjennomgående virker det som om fjellfiskens betydning som handelsvare blir nedvurdert i perioden, ${ }^{4}$ men at fisk kan ha vært avgjørende i den lokale livbergingen for begge de to gruppene. ${ }^{5}$

Det er tidligere blitt framlagt to hypoteser om brukerne av fiskevannet Tesse i forhistorisk tid, forklaringer som også kan være relevante for bruken av andre fjellvann. Arkeologen Anders Hagen ${ }^{6}$ mente å se en nordøstlig tilknytning i trinsesøkkematerialet på grunn av lignende funn i Nord-Sverige og Finland. Hagen, som ennå ikke hadde tilgang på C14-dateringer av søkkene, satte dem i sammenheng med steinalderens jegerkultur, alternativt med den finske innvandringen på 16-1700-tallet. En annen oppfatning er at fisket $\mathrm{i}$ Tesse helt siden vikingtid ble drevet av folk fra jordbruksbygda Garmo, slik som tradisjonen er i historisk tid. ${ }^{7}$

I disse to tilnærmingene lå det en motsetning som fanget min interesse under arbeidet med Tesse-funnene. De senere årene har arkeologiske undersøkelser og studier gitt stadig sterkere indikasjoner på samisk tilstedeværelse i Sør-Norge i vikingtid og middelalder. ${ }^{8}$ Med bakgrunn i dette var det interessant å vurdere materialet fra Tesse $\mathrm{i}$ et nytt lys. Det østlige opphavet til trinsesøkkene som Hagen viser til, kunne kanskje ses i sammenheng med samisk etnisitet? Det er en vanlig antagelse i dag at samene i innlandet opprinnelig var et jakt- og fangstfolk, som etablerte seg som tamreinnomader forst i senmiddelalder eller tidlig etterreformatorisk tid. ${ }^{9}$

Tesse-dokumentet fra 1200-tallet kan hevdes å gi belegg for «bygdefolkhypotesen» ettersom det angivelig viser til bygdefolkets bruk av vannet tilbake på 1000-tallet. Det er imidlertid flere kildekritiske spørsmål til vitnebrevet, og vi kan aldri bli helt sikker på at dokumentet forteller den hele og fulle sannheten. ${ }^{10} \mathrm{Vi}$ skal først se litt nærmere på de funnene vi har fra Tesse i perioden, før jeg kommer tilbake til diskusjonen om hvem som kan ha fisket her i vikingtid og tidlig middelalder.

\section{DET ARKEOLOGISKE SØKKEMATERIALET I TESSE}

De første funnene av søkker fra Tesse ble levert inn til Universitetets oldsaksamling på 1940-tallet, få år etter at den store Tesse-reguleringen ble gjennomført. Per i dag finnes det tilgjengelig informasjon om totalt 95 søkker av ulike slag fra Tesse. Da er det sett bort fra gjenstander som med stor sannsynlighet er fra moderne tid. Søkkene fra Tesse kan deles i tre hovedgrupper: trinseformete søkker (50), neverhylstre (14) og steinsøkker (31). ${ }^{11}$

De fleste gjenstandsfunnene er innlevert til museene av fiskere og turgåere, som har funnet dem ved tilfeldigheter mens vannet har vært nedtappet. Posisjonsangivelsene for mange av de eldre funnene er relativt sparsomme, og ofte har man kun opplysning om stedsnavn. Både gjennom innmeldte funn og gjennom arkeologiske feltundersøkelser danner det seg imidlertid et klart inntrykk av at fisket i Tesse har vært konsentrert i den søndre og den nordre enden av vannet (figur 4).

I sør er samtlige funn knyttet til Dågåtjønnvika, området sør for halvøya Volnebben. I historisk tid har Smådøla, som renner inn i vannet her, vært et kjerneområde for sløefiske senhøstes. ${ }^{12}$ Nord i vannet er funnene mer spredt, men mange søkker er funnet mellom utløpet av Ilva og Byrtneset, på vestsiden av vannet. Det var i dette området NMM foretok systematiske kartlegginger i 2014. En god del funn er imidlertid også gjort lenger nordøst, spesielt på Tverrlandet.

Fordelingen av søkketyper i sør og nord er tilsynelatende svært ulik (figur 5). I sør dominerer trinesøkkene; 34 funn er gjort av slike søkker i 


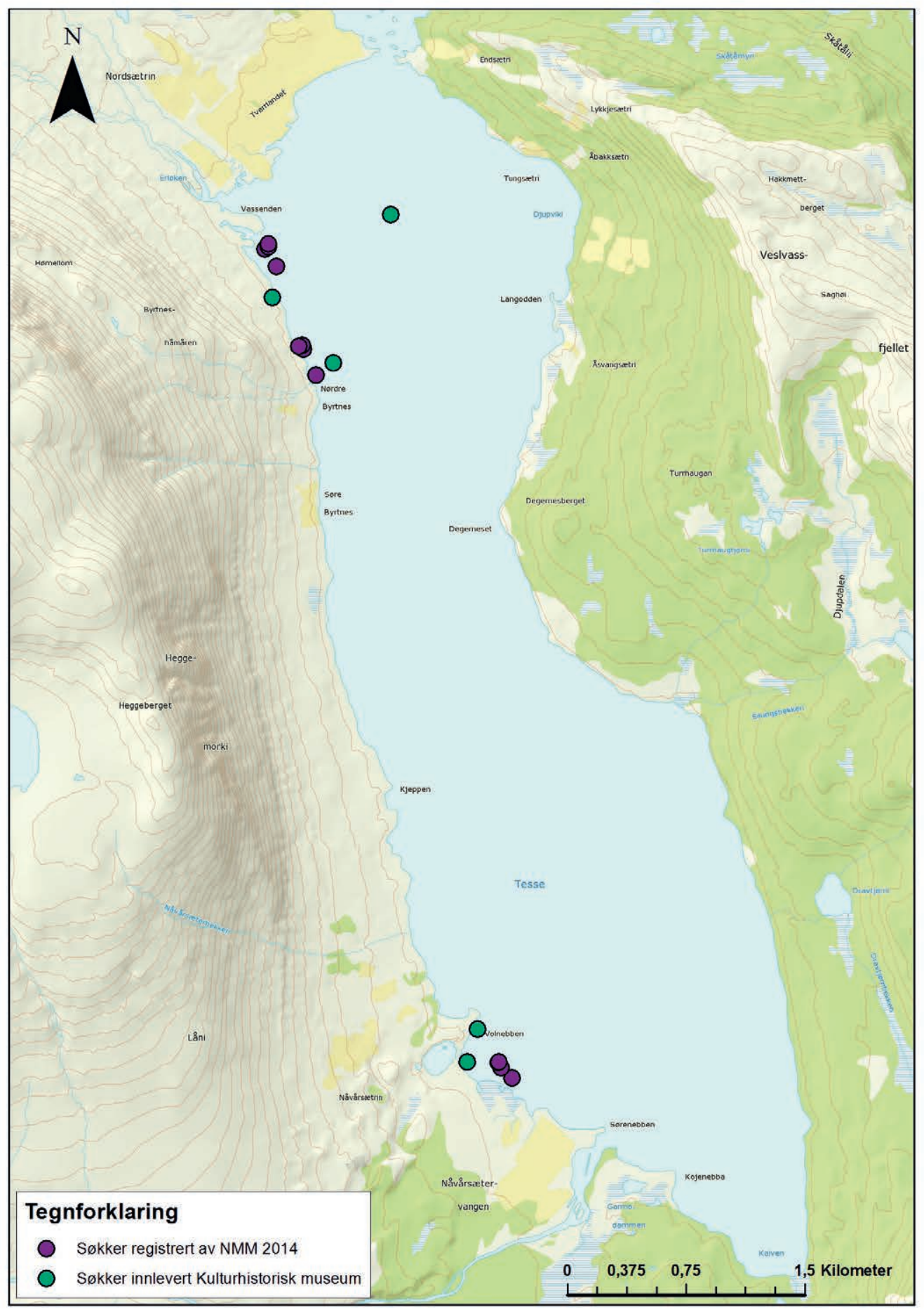

Figur 4: Funndistribusjon av søkker i Tesse. Alle typer er inkludert. Kart: Elling Utvik Wammer. 


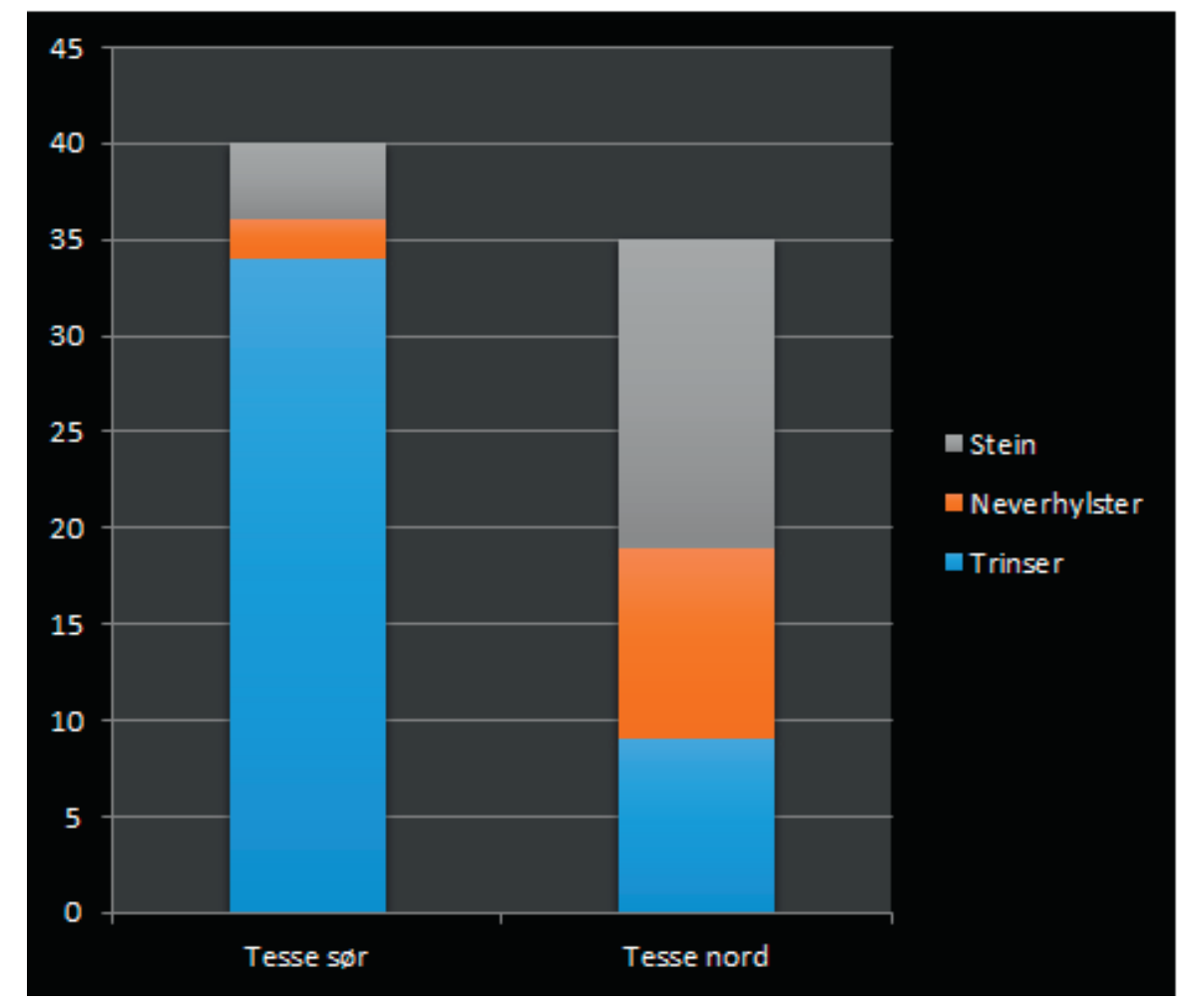

Figur 5: Diagram som viser den store forskjellen i typer av søkker mellom Tesses nord- og sørende.
Dågåtjønnvika. Kun fire steinsøkker og to neverhylstre er funnet i den søndre delen av vannet. I nord er steinsøkkene den dominerende funntypen, med 16 gjenstander. Antallet neverhylstre og trinsesøkker er relativt likt i nordre del av vannet, med henholdsvis ti og ni funn.

Vi har per i dag C14-dateringer av ni søkker fra Tesse. Medregnet funn som var datert før undersøkelsene i 2014, er seks trinsesøkker og tre neverhylstre datert. Alle dateringsprøvene faller innenfor tidsrommet ca. 650-1400 e.Kr. Det ser ut til å være et skarpt skille mellom de to gruppene av funn rundt år 1200 e.Kr. Dateringene gir dermed inntrykk av at det var trinsesøkker som var i bruk før 1200, mens de forsvant rundt 1200 til fordel for neverhylstrene. I tillegg er de mange steinsøkkene av typer som spenner over store tidsrom, og det er ikke usannsynlig at flere av disse kan være samtidige med både trinsene og neverhylstrene. Steinsøkkene lar seg imidlertid vanskelig datere sikkert ettersom de ikke består av organisk materiale som kan dateres direkte. I denne artikkelen har jeg derfor måttet se bort fra dem i sammenheng med diskusjonene.

Fra vikingtid og tidlig middelalder, som er perioden denne artikkelen omhandler, er det altså de trinseformete søkkene som utgjør de sikreste funnene. Når det gjelder endringer over tid, er det verdt å merke seg at dette materialet også viser en relativt stor variasjon innenfor grunnformen. I et appendiks til artikkelen viser jeg fem typer av trinseformete søkker som går igjen. Det virker rimelig klart at trinsesøkker med surret never rundt både ring, stein og eiker er den 

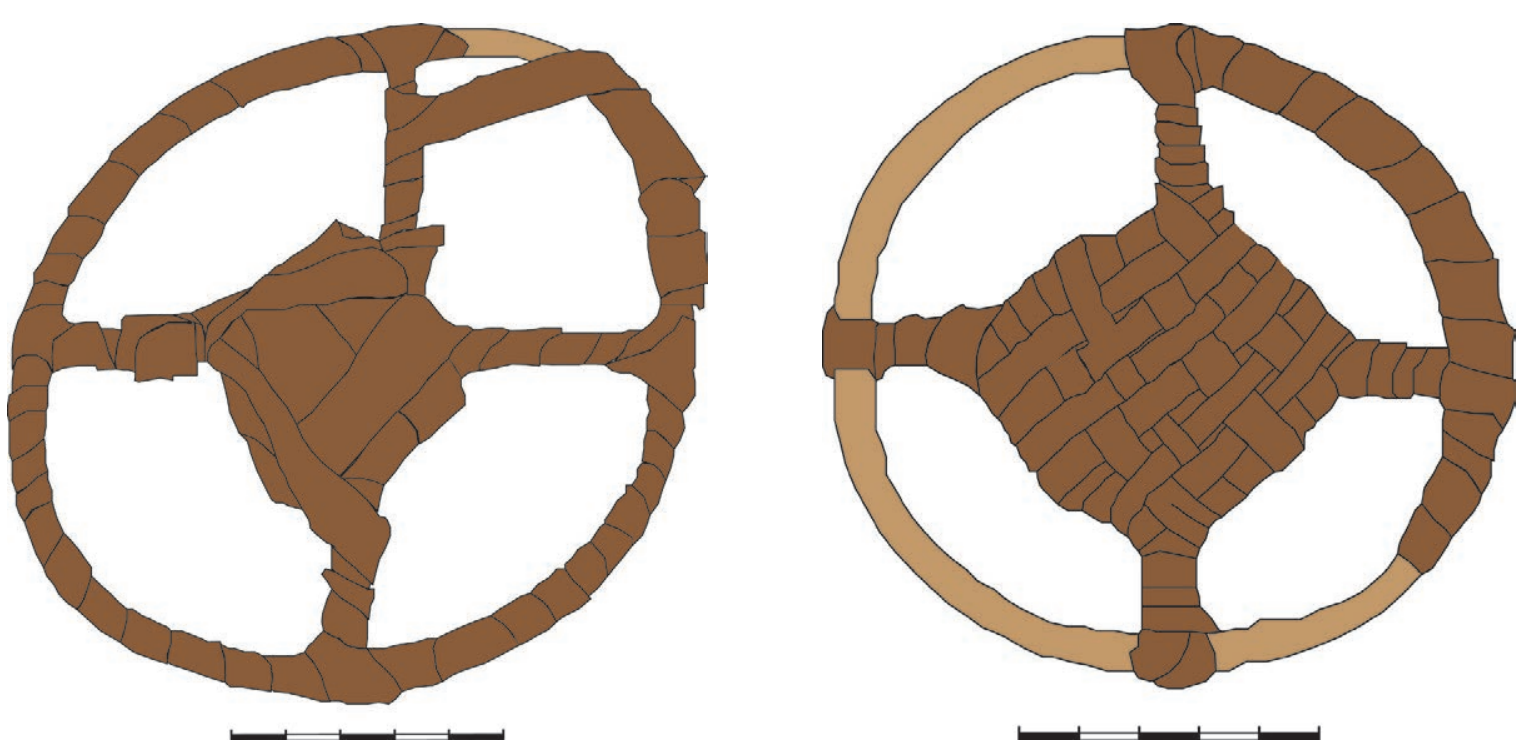

Figur 6: To ulike trinseformete søkker fra Tesse. Til venstre et eksempel på den vanligst forekommende og så langt eldste typen i Tesse, type 1 . Til høyre, et eksempel på det som ser ut til å være en av de nyere typene, med flettverk og surring kun rundt ringens skjøt. Tegning: Elling Utvik Wammer.

vanligste typen i Tesse (figur 6). Dateringene så langt indikerer at disse typene er i bruk fra ca. 700-1000 e.Kr. Det ser ut til at man i perioden 1000-1200 e.Kr. slutter å surre never rundt hele ringen. Surringen rundt steinen erstattes da med flettverk. En typologi basert på så få daterte gjenstander er imidlertid usikker, og ved nye dateringer vil den kunne endres.

De endringene som skjer med trinsene, er det vi kan kalle en «evolusjonær utvikling» innen én og samme tradisjon. Overgangen fra trinseformen til neverhylster rundt 1200, derimot, er fundamental og representerer et tydelig brudd i denne gradvise utviklingen. Forutsatt at de relativt få dateringene gir oss et reelt bilde av forløpet, kan man stille spørsmål om hva dette bruddet skyldes (figur 7). På grunnlag av Tesse-dokumentet vet vi at det har vært strid om fiskerettighetene i den samme tidsperioden som endringen inntreffer.
Vitnebrevet fra 1200-1220 innebærer at Torgeir Gamle og hans etterkommere må ha fått de eksklusive fiskerettighetene på bekostning av noen andre. Brevet sier imidlertid ingenting om hvem dette er. En vanlig oppfatning er at Tesse-dokumentet stadfester at vårdølene (Garmobygda) hadde rett til fisket i Tesse og ikke folk fra nabobygda Vågå. ${ }^{13}$ Et spørsmål med relevans for denne artikkelen er om det nødvendigvis må ha vært andre bønder fra Ottadalen, eller om det kan ha vært en gruppe mennesker med tilhold i fjellet, som i større grad baserte seg på en jakt- og fangstøkonomi.

Vi skal starte med å gå gjennom samtidige kulturhistoriske utviklingstrekk og måten disse kan kobles til det arkeologiske materialet fra innsjøen på. Ettersom de overordnete spørsmålene i artikkelen dreier seg om forholdet mellom fangstmenn og bønder som brukere av vannet, har jeg vektlagt 


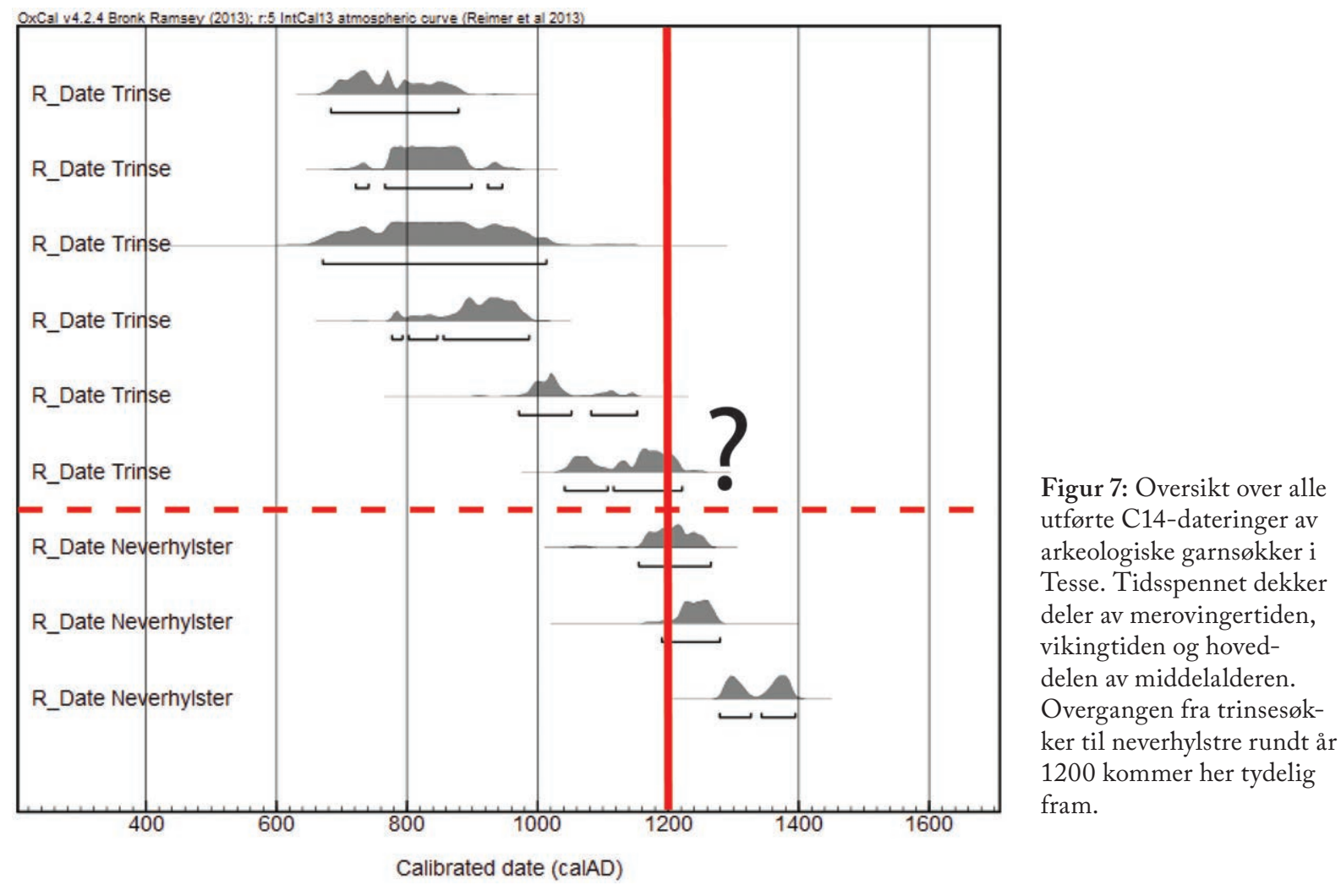

å få et overblikk over jordbruksbygdas utvikling i regionen og sporene etter jakt og fangst i nærområdet til fiskevannet Tesse.

I fjellområdene rundt Tesse er det tallrike aktivitetsspor helt fra steinalderen til middelalderen. Det er først i eldre jernalder (500 f.Kr.-570 e.Kr.) at det dukker opp sikre spor etter bosetning nede i denne delen av Ottadalen. ${ }^{14}$ Arkeologiske funn fra både Lom og Våga vitner om en relativt utstrakt bosetning gjennom store deler av jernalderen. ${ }^{15}$ Funnmaterialet i dalen øker betraktelig i yngre jernalder (570-1030 e.Kr.), og flere har kalt det nærmest en eksplosjon av funn i jordbruksbygdene i denne perioden. ${ }^{16}$

Aktivitetsøkningen i yngre jernalder kommer til syne gjennom førkristne gravfunn nede i dalbunnen.
Som Eknæs ${ }^{17}$ poengterer: «Hele dalen er rik på gravfunn fra dette tidsrommet og det er særlig mange funn fra Ottadalen, dvs. distriktet som grenser opp mot Tesse.» Med kristningen av landet rundt år 1000-1030 e.Kr. opphører jernalderens forholdsvis lett synlige gravformer, og det arkeologiske grunnlaget for å vurdere bygdas videre befolkningsutvikling fram mot år 1200 begrenses. Som i resten av landet er det imidlertid sannsynlig at det har vært en befolkningsøkning i perioden, som kan ha resultert i et økende behov for både ressurser og arealer.

Både i nord- og i sørenden av Tesse er det i dag setrer. Hvor langt tilbake $i$ tid denne bruken av området går, er ennå ikke sikkert kjent. Setring er imidlertid en driftsform som antas å ha svært lange 

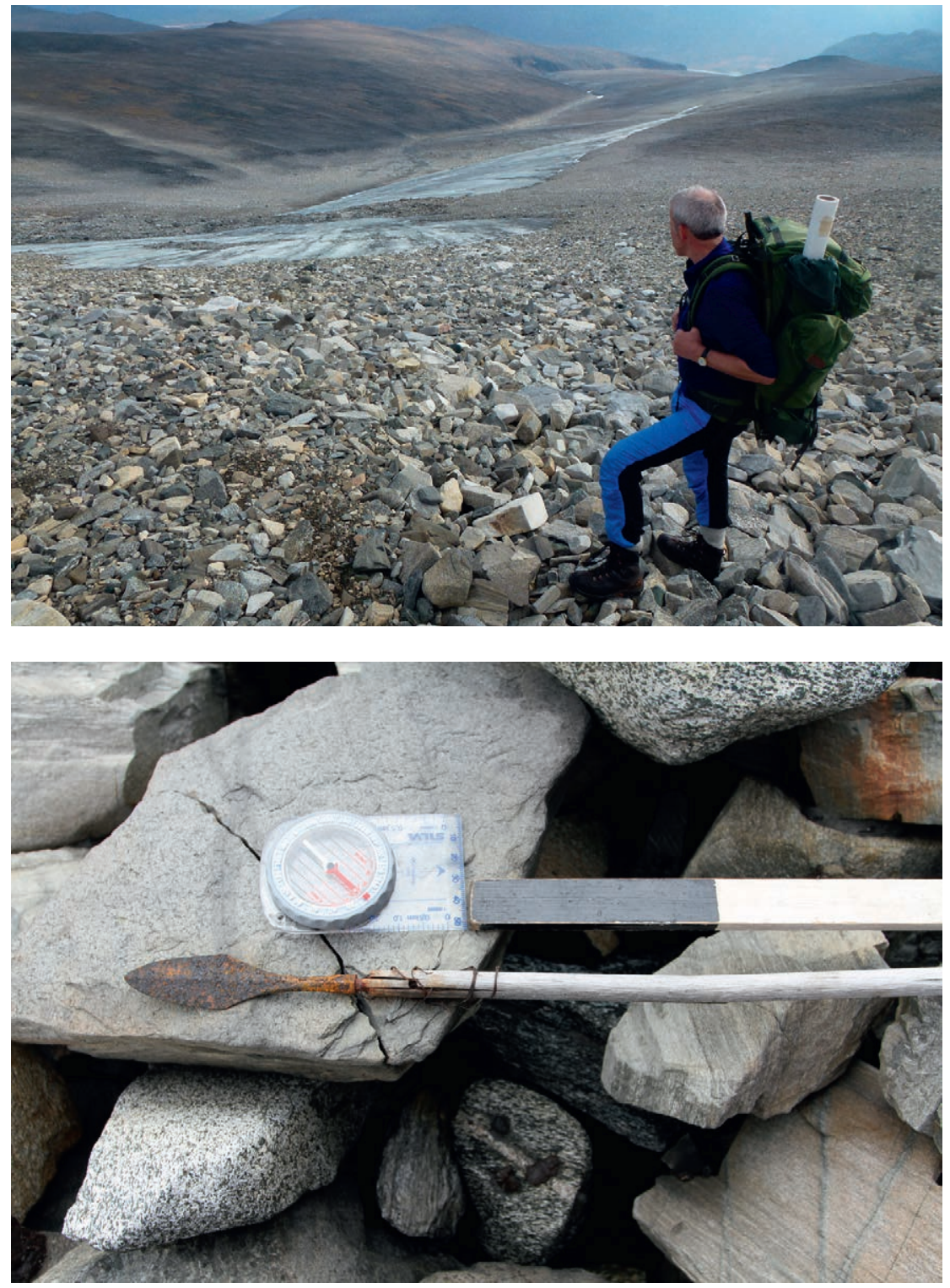

Figur 8a: Langfonne på

Kvitingskjølen er en av snøfonnene som har smeltet mye de senere årene. Smådøla og Smådalen er synlige til høyre i bildet. Foto: Espen Finstad, Oppland fylkeskommune.
Figur 8b: Denne pilen, datert merovingertid eller vikingtid, er blant de framsmeltete funnene fra Langfonne. Foto: Oppland fylkeskommune. kulturhistoriske røtter i norske fjell. ${ }^{18}$ Pollenanalyser fra myrer andre steder i Jotunheimen viser at det gikk husdyr på beite i fjellet allerede i bronsealderen. ${ }^{19}$ Setrene ved Tesse kan derfor godt tenkes å gå tilbake til vikingtid og kan ha vært bosatt av bønder fra dalen. Begrepet buvoller opptrer i forbindelse med fisket i Tesse-dokumentet. ${ }^{20}$ Hvorvidt dette er setre eller fiskebuer, kommer imidlertid ikke fram. Ordet voll brukes som regel i betydningen «gressbakke» og kan indikere setre. Ordet er på den annen side 
også i bruk i andre sammenhenger, for eksempel Fiskevollen ved Sølensjøen i Hedmark, som har vært et fiskevær mer enn tusen år tilbake i tid.

Det er også funnet anlegg for produksjon av jern fra jernalder og middelalder ved Tesse. ${ }^{21}$ Det er en generell oppfatning at jernframstilling knyttes til fast bosetning og til jordbrukssamfunnet. ${ }^{22}$ I fjellet er det imidlertid ikke utenkelig at også en fangstbasert befolkning har produsert jern i småskala til eget forbruk. ${ }^{23}$

Store mengder med velbevarte jaktpiler, ledegjerder og annet utstyr er blitt funnet ved smeltende snøfonner i høyfjellet i Nord-Gudbrandsdalen de senere årene. ${ }^{24}$ Et kjerneområde for slike funn er Kvitingskjølen, like vest for Tesse (figur 8). Det ser generelt ut til å ha vært to faser med spesielt stor jaktaktivitet på snøfonnene i Oppland. Den ene perioden er folkevandringstid (ca. 400-550 e.Kr.), den andre vikingtid og tidlig middelalder. Etter ca. 1300 e.Kr. synes det som om jakta på snøfonnene avtar eller opphører. ${ }^{25}$ De store gropfangstanleggene i Tesses nordre og søndre ende er i liten grad undersøkt. I 2013 ble det foretatt en utgravning av en av gropene langs Smådøla, som tidfestet denne til høy- og senmiddelalder (1270-1450 e.Kr.). ${ }^{26}$

Inne i Smådalen er det funnet en stor ansamling av hustufter som er blitt satt i sammenheng med jakta og fangsten på Kvitingskjølen (figur 9). Dateringer fra to av tuftene viser at de var i bruk mellom 700tallet og 1200-tallet. ${ }^{27}$ Det er også gjort funn av gravlegginger av mennesker i Smådalen. Slike såkalte fangstmarksgraver er en kulturminnetype som av flere anses som spor etter en befolkning med jakt og fangst som basisnæring. ${ }^{28}$

Samlet viser funnene at jakt og fangst rundt Tesse har vært drevet i et svært stort omfang, som må ha involvert et stort antall mennesker og god organisering. ${ }^{29}$ Det er grunn til å tro at produksjonen av skinn, gevir og kjøtt har vært større enn det lokale behovet i vikingtid og tidlig middelalder, og det er naturlig å se jakta og fangsten i sammenheng med eksport av slike produkter både utenlands og innenlands. En sannsynlig tolkning av den økte rikdommen i gravmaterialet i Lom i vikingtid er at det har en sammenheng med en overskuddsproduksjon fra villreinjakta. ${ }^{30}$

Hvem det var som sto bak selve utøvelsen av jakta og fangsten rundt Tesse, er imidlertid ikke enkelt å si. Det er ikke nødvendigvis de samme personene som satt igjen med rikdommen etter at produktene var solgt. Det store omfanget jaktrelaterte kulturminner er blitt tatt til inntekt for at jakt og fangst på rein har vært en spesialisert aktivitet i vikingtid i Nord-Gudbrandsdalen. ${ }^{31}$ Fangstmarksgravene og hustuftene i Smådalen kan også tyde på at det har vært en egen fangstbefolkning i fjellene ved Tesse. Kanskje har disse også drevet med fiske i Tesse?

Eldre spor etter samisk bosetning var fram til for kort tid siden ikke kjent i Jotunheimen eller i umiddelbar nærhet til Tesse. Sommeren 2014 gjennomførte Sametinget og Oppland fylkeskommune en felles befaring sammen med lokale informanter i området. ${ }^{32}$ Under denne befaringen ble det registrert flere kulturminner i Smådalen som ble tolket som spor etter samisk aktivitet. Både en antatt reintrøe og fangstmarksgraver ble dokumentert. Kulturminnene er ennå ikke sikkert datert, men de antas å være eldre enn år 1800. Ettersom samisk nærvær ikke er belagt i skriftlig materiale, kan det være grunn til å tro at disse sporene går tilbake til middelalderen eller enda lenger. I rapporten framgår det også at Smådalen-området utmerker seg med en konsentrasjon av stedsnavn som trolig har et samisk opphav.

Funnene av antatt samiske kulturminner i Smådalen sannsynliggjør at det også kan ha vært samisk tilstedeværelse ved Tesse. Kulturminnene krever grundigere undersøkelser før vi kan avgjøre alderen med sikkerhet. Selv om det ennå ikke er 


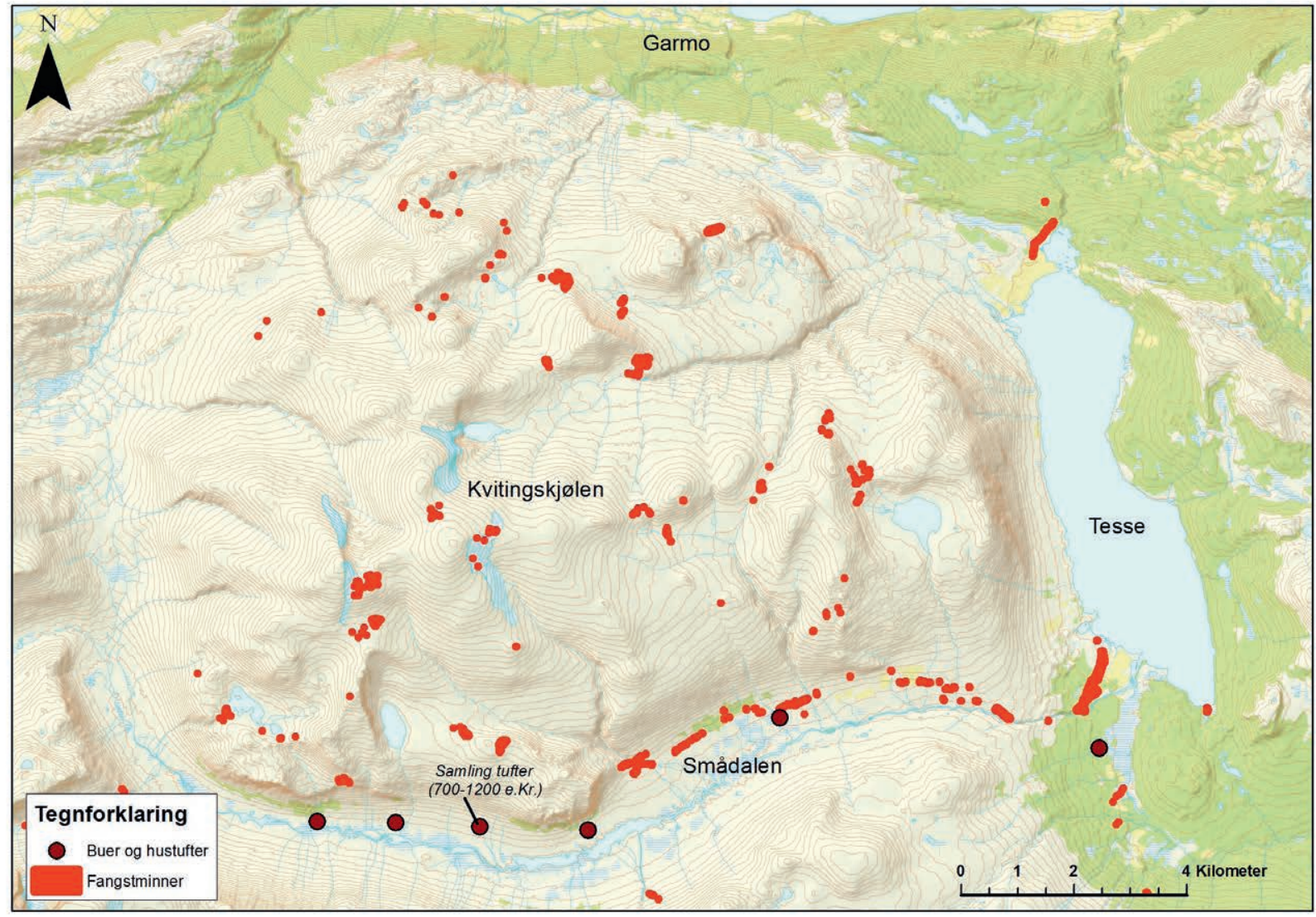

Figur 9: Oversiktskart over jakt- og fangstminner og ansamlinger med tufter i Tesses nærområde. De fangstanleggene som framstår som linjer er gjerne gropanlegg på rekke. De spredte lokalitetene i høyfjellet er i hovedsak buestillinger og funn fra snøfonnene. Kartgrunnlag: Askeladden og Finstad mfl. 2011.

mulig å knytte denne samiske aktiviteten til fisket i vikingtiden, er altså muligheten for at området har vært brukt av samer samtidig med fisket i Tesse til stede.

\section{VAR DET FANGSTFOLK ELLER BØNDER?}

I historisk tid har fisket i Tesse vært kombinert med tradisjonelle gårdsaktiviteter for befolkningen i Ottadalen. ${ }^{33}$ Basert på de historiske kildene er det godt mulig at både jakt, fangst og fiske kan ha inngått som viktige ressurser for den permanente jordbruksbefolkningen i Ottadalen i vikingtid. Jan Eknæs hevder også at «den korte veien fra bygda og inn til fjellsjøen gjorde det lett å utnytte for bygdefolket». ${ }^{34}$ Avstanden mellom bygda og vannet er imidlertid så stor at det virker usannsynlig at fisket skal ha vært drevet på daglig basis fra bosetning $\mathrm{i}$ dalbunnen. Fiske er en tidkrevende prosess, som inkluderer forberedelser av redskapen, utsetting og innhenting av garn samt behandling av fisken. Dette sannsynliggjør at et fiske i Tesse krevde en form for bosetning i fjellet. 
Det er et åpenbart geografisk sammenfall mellom de to konsentrasjonene av søkker og dagens kjerneområder for setring. Dette kan indikere at fisket $\mathrm{i}$ Tesse i vikingtiden har vært drevet av jordbruksbefolkningen i Ottadalen. Utnyttelsen av fiskeressursene i Tesse kan muligens også forstås som en del av det øte aktivitetsnivået i bygda i vikingtid, på lik linje med jakt og fangst av rein. De første dateringene av trinsesøkker stammer fra den samme tid som man får det som kalles en eksplosjon av funn, i dalbunnen.

Som nevnt har omfanget av villreinjakta rundt Lom vært så stort at det har dannet grunnlag for maktkonsentrasjon og rikdom nede i dalen i vikingtid. ${ }^{35}$ Denne jakta kan ha blitt foretatt av bygdefolket selv, men en annen mulighet er at det har vært spesialiserte jegere som har hatt tilhold i fjellene ved Tesse. ${ }^{36}$ Overgangen fra trinseformete søkker til neverhylstre faller noenlunde sammen med opphøret av den mest aktive jakta etter villrein på snøfonnene rundt 1300 e.Kr. Dette sammenfallet i tid kan være tilfeldig, men det kan også være et resultat av at fisket med trineformete søkker i Tesse og jakt i fjellområdene rundt Tesse ble drevet av de samme brukerne.

Det ulike spredningsmønsteret for de forskjellige søkketypene i Tesse kan også trekkes fram igjen her. Funnfordelingen er interessant fordi den kan indikere at trinsesøkkene var hyppigere brukt i sør og de andre typene i større grad brukt i nord. Sørenden ligger nærmest fangstmarkene, mens nordenden er den delen av vannet som er lettest tilgjengelig fra jordbruksbygda. Legger vi en slik analyse til grunn, kan vi hevde at de trinseformete søkkene er sterkere tilknyttet fangstmarkene enn de andre søkketypene. Å legge avgjørende vekt på dette spredningskartet er imidlertid problematisk. En annen forklaring kan for eksempel være varierende bevaringsforhold.

Om jakta i fjellene ved Tesse var en spesialisert aktivitet drevet av en egen fangstbefolkning, eller om den skjedde i sammenheng med jordbruk og setring, er et spørsmål som ennå står ubesvart. Dette får også konsekvenser når vi skal forsøke å forstå hvem det var som drev fiske i Tesse i vikingtiden. Den nyoppdagete samiske tilstedeværelsen er i så måte også et spennende, men uavklart moment. Forhåpentlig vil framtidige undersøkelser av både de samiske kulturminnene og flere undersøkelser omkring Tesse tydeliggjøre det historiske forløpet i vannets nærområde.

\section{FUNN AVTRINSEFORMETE SØKKER UTENFOR TESSE}

Det er mange ubesvarte spørsmål knyttet til NordGudbrandsdalens eldre historie. Dette gjør det foreløpig utfordrende å sette fisket i Tesse i en bestemt historisk kontekst. I den neste delen av artikkelen vil jeg derfor utforske trinsesøkkenes øvrige utbredelse. Hvor i våre nærområder er det funnet trinsesøkker, og i hvilken kulturhistorisk kontekst opptrer de? Er det en nær sammenheng mellom funnsteder for trinsesøkker og fangstmarker andre steder, og er det sannsynlig at disse områdene har hatt en samisk befolkning i vikingtid og tidlig middelalder?

Trinsene er en søkketype som i svært liten grad er kjent brukt i historisk tid i sørnorske fjellstrøk. Vi kjenner kun ett tilfelle, fra Seljord i Telemark, der denne typen søkker skal ha vært i bruk. ${ }^{37}$ Det er per i dag gjort kun fire sikre funn av trinsesøkker i Sør-Norge utenfor Tesse (figur 10). I appendiks 2 foretar jeg en gjennomgang av de fire funnstedene. En oppsummering framgår av tabellen under.

Funnstedet Samsjøen i Midtre Gauldal er det eneste som i dag kan kalles et fjellvann. Både Strandefjorden ved Fagernes, Storsjøen i Rendalen og Lesjavatnet ligger i områder hvor det i dag drives jordbruk, og hvor denne aktiviteten ser ut til å gå langt tilbake i tid. På flere av disse stedene er det imidlertid mye aktivitet knyttet til jakt og fangst. 


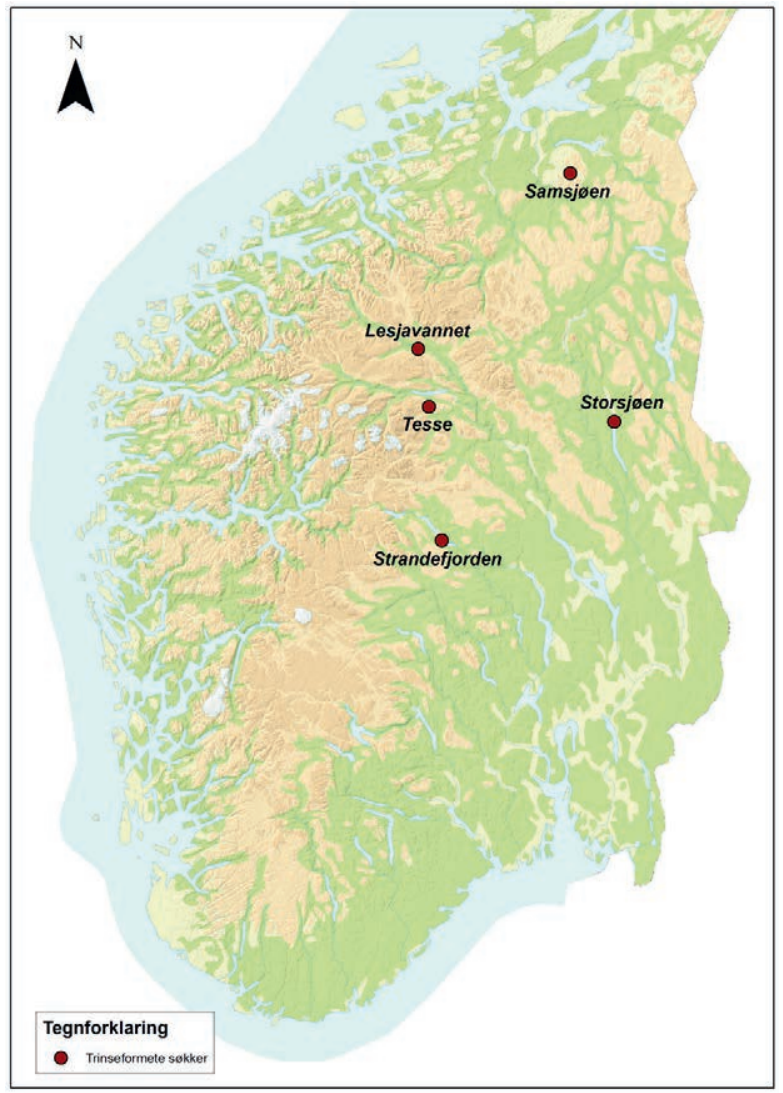

Figur 10: Trinseformete søkker funnet i Sør-Norge, utenfor Tesse. Kart: Elling Utvik Wammer.

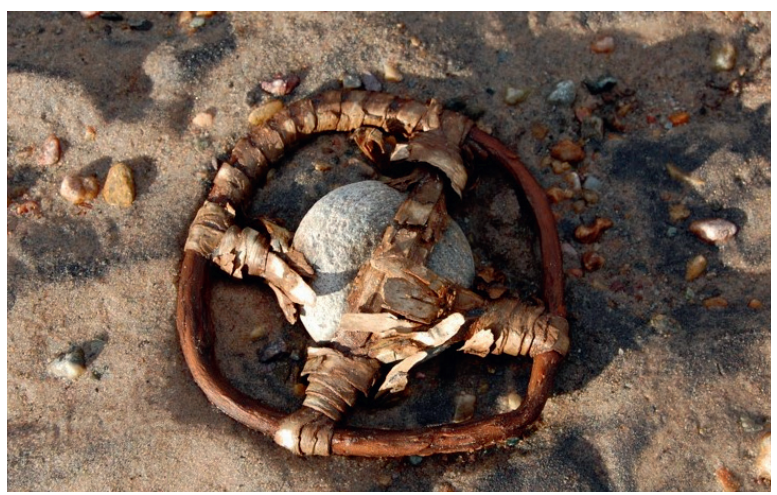

Figur 11a: Funn fra Storsjøen i Rendalen i Hedmark. Foto: Harald Hoel (privat).

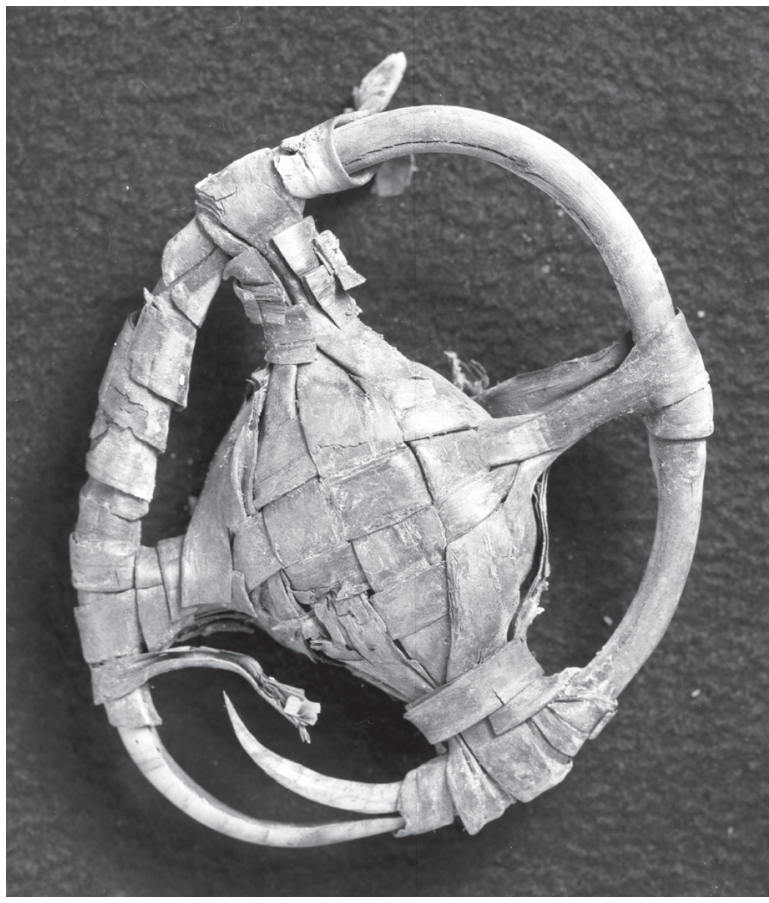

Funn 11b: Funn fra Strandefjorden i Nord-Aurdal i Oppland. Foto: Kulturhistorisk museum.

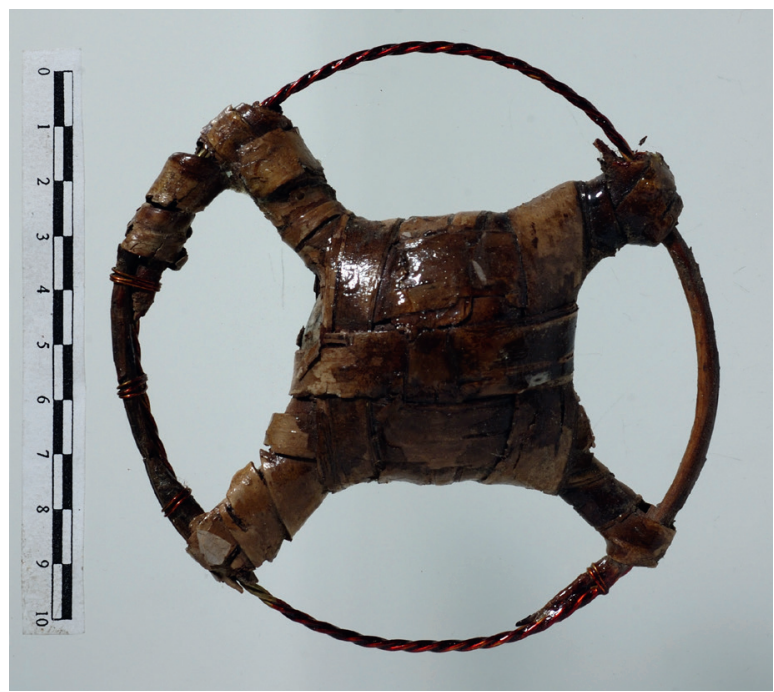

Funn 11c: Funn fra Samsjøen i Midtre Gauldal i Sør-Trøndelag. Foto: Ole Bjørn Pedersen, NTNU Vitenskapsmuseet. 
Her har altså fisket, slik som i Tesse, foregått i et grenseland mellom fangstmark og jordbruksbygd. Et annet og klarere fellestrekk ved funnstedene i SørNorge er at de ligger i områder som kan betegnes som grenseland mellom samisk og norrøn etnisitet $i$ vikingtid og middelalder. De formmessige likhetene i funnmaterialet fra Sør-Norge er påfallende store. Dette åpner for at fiskerne i hele dette området har stått i direkte kontakt, for eksempel i form av handel eller en annen kulturell forbindelse.

Utenfor Sør-Norge er det kjent kun ett trinseformet søkke i Norge (figur 12). Dette funnet stammer fra Mjåvatnet i Vefsn kommune i Nordland. ${ }^{38}$ Mjåvatnet ligger kun 39 moh., ca. 10-15 km fra den indre delen av Vefsnfjorden. Det er ikke registrert større fangstanlegg i nærheten av vannet. Området er et tradisjonelt samisk område, der samiske stedsnavn dominerer i dag. Det er imidlertid også flere hulveier, kullframstillingsanlegg og gravfelt i nærområdet.
Flere av disse kan indikere at man også har hatt en norrøn befolkning i området langt tilbake i tid.

Det er en lignende situasjon i Sverige som i Norge: Trinseformete søkker er en lite kjent funngruppe i arkeologisk sammenheng. I Historiska museet i Stockholms utstillinger finnes et søkke fra Västannortjärn i Leksand i Dalarna. Dette søkket dateres til middelalder (1100-1350). ${ }^{39}$ I tillegg har Nordiska museet flere søkker fra tiden etter 1500. De fleste antas å være fra $1850-1910 .{ }^{40}$ Innenfor rammen av arbeidet med denne artikkelen har det vært mulig å påvise én region i Sverige hvor trinseformete søkker synes å ha en større utbredelse. I samlingene ved lensmuseet Jämtli i Östersund finnes flere trinseformete søkker som stammer fra forskjellige deler av Jämtland (figur 13). Jeg har valgt å se nærmere på Jämtland som en sammenligning for de norske funnene.

\begin{tabular}{|l|l|l|l|l|l|}
\hline Funnsted & Funnets ID & Landskapstype & $\begin{array}{l}\text { Høyde over } \\
\text { havet }\end{array}$ & $\begin{array}{l}\text { Fangstmark } \\
\text { (definert som } \\
\text { registrerte } \\
\text { fangstanlegg i } \\
\text { nærområdet) }\end{array}$ & $\begin{array}{l}\text { Sannsynlig samisk } \\
\text { tilstedevarelse i } \\
\text { vikingtid/middel- } \\
\text { alder }\end{array}$ \\
\hline $\begin{array}{l}\text { Strandefjorden } \\
\text { i Nord-Aurdal } \\
\text { kommune, } \\
\text { Oppland fylke }\end{array}$ & C32604 & $\begin{array}{l}\text { Barskog og } \\
\text { jordbrukslandskap }\end{array}$ & ca. 355 moh. & Nei & Ja \\
\hline $\begin{array}{l}\text { Storsjøen i } \\
\text { Rendalen } \\
\text { kommune, } \\
\text { Hedmark fylke }\end{array}$ & AID 212168 & $\begin{array}{l}\text { Barskog og } \\
\text { jordbrukslandskap }\end{array}$ & 250-252 moh. & Mulig & Ja \\
\hline $\begin{array}{l}\text { Lesjavannet i } \\
\text { Lesja kommune, } \\
\text { Oppland fylke }\end{array}$ & Ikke innlevert & $\begin{array}{l}\text { Fjellbygd med } \\
\text { jordbruksområder }\end{array}$ & $\begin{array}{l}\text { Ca. 500 til } \\
650 \text { moh. }\end{array}$ & Usikker & Ja \\
\hline $\begin{array}{l}\text { Samsjøen i } \\
\text { Midtre Gauldal } \\
\text { kommune, Sør- } \\
\text { Trøndelag fylke }\end{array}$ & T 17199 & $\begin{array}{l}\text { Åpen barskog } \\
\text { og myr }\end{array}$ & $\begin{array}{l}\text { ca. } 473-487 \\
\text { moh. }\end{array}$ & Mulig & Usikker \\
\hline
\end{tabular}

Tabell 1: Oversikt over kjente funnsteder for trinseformete garnsøkker i Sør-Norge. 


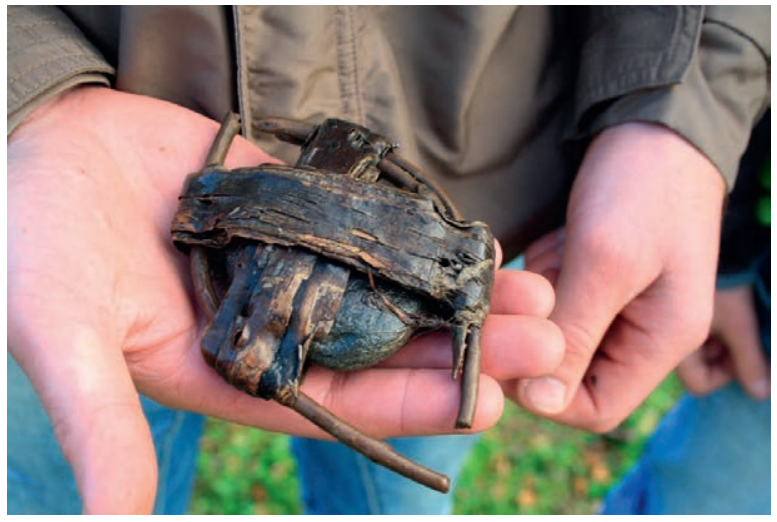

Figur 12: Garnsøkket fra Vefsn skiller seg tydelig fra funnene i Sør-Norge, da det kun består av en vidjering med stein i midten og to kraftige neverbånd, som ligger i kryss rundt ringen og på denne måten holder steinen sammen. Foto: Trine Anna Johnson, Nordland fylkeskommune.

Jämtland er et svensk landskap (tilsvarende de norske fylkene) i det midtre Sverige, som grenser mot Nord- og Sør-Trøndelag og Hedmark. I materialet som oppbevares på Jämtli, er det mulig å skille ut en nyere type (som blant annet er monomgramsignert) og en eldre type, som ligner på de trinseformete søkkene fra Tesse. ${ }^{41}$ Av de eldre typene har Jämtli fem stykker, som er bevart i noe ulik grad. Alle er løsfunn, og ingen dateringer er gjort av noen av dem. Jeg har foretatt en lik analyse av funnstedene i Jämtland som den som ble gjort i Sør-Norge (se tabell 2).

Det antatt eldste trinsesøkkematerialet i Jämtland svarer i stor grad formmessig til materialet i SørNorge. På den annen side er det ingen direkte paralleller til Tesse-materialet blant søkkene fra Jämtland. Søkket som ble funnet i Nord-Aurdal, er det søkket på norsk side som ligner mest på de jemtlandske trinsesøkkene (jf. figur 14).

Som i Norge varierer også funnkonteksten til søkkene i Jämtland. Minst to av søkkene (Locknesjön og Frösöen) er funnet i det som blir oppfattet som

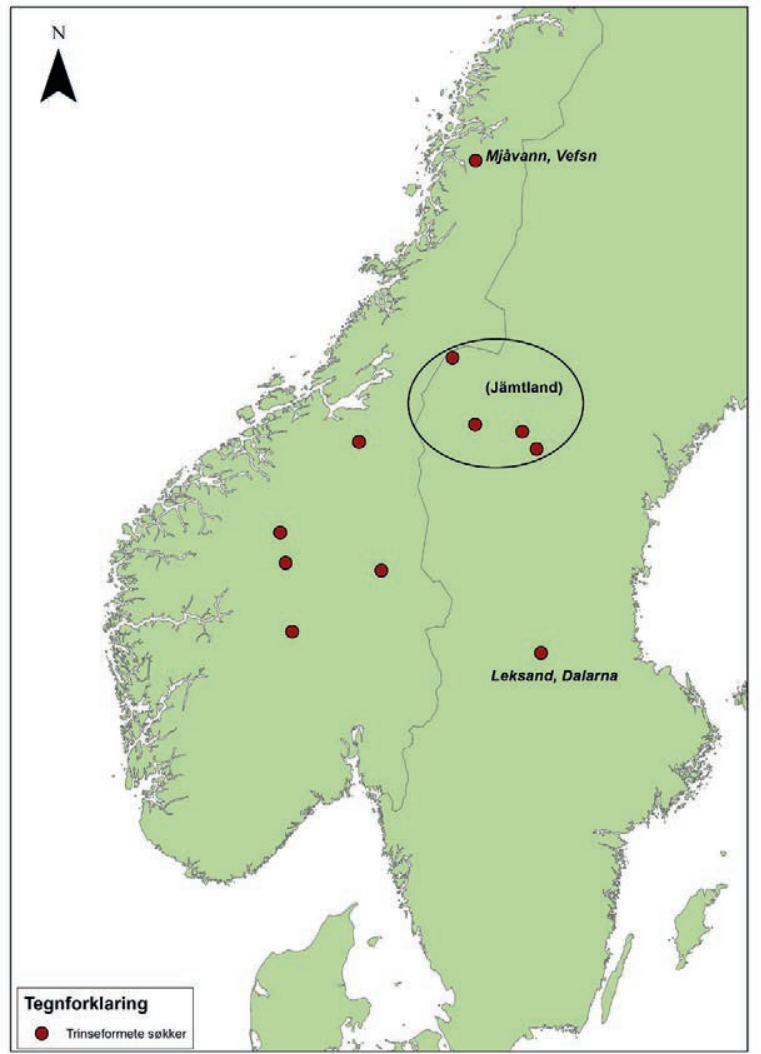

Figur 13: Oversiktskart over kjente funnsteder for trinseformete søkker i Skandinavia. Alle søkkene, bortsett fra det nordlige Vefsn-funnet, befinner seg innenfor det som kan samsvare med det sørsamiske kulturområdet $\mathrm{i}$ jernalder og middelalder (jf. Severinsen 2016). Kart: Elling Utvik Wammer.

gamle jordbruksbygder. ${ }^{42}$ I de samme områdene er det imidlertid også funnet såkalte skogsgraver. ${ }^{43}$ Skogsgraver er sammen med innsjøgraver, under samlebetegnelsen fangstmarksgraver, tolket som spor etter en befolkning med jakt og fangst som basisnæring i Jämtland. ${ }^{44}$ De øvrige funnene ser ut til å stamme fra skogs- eller fjellområder. 


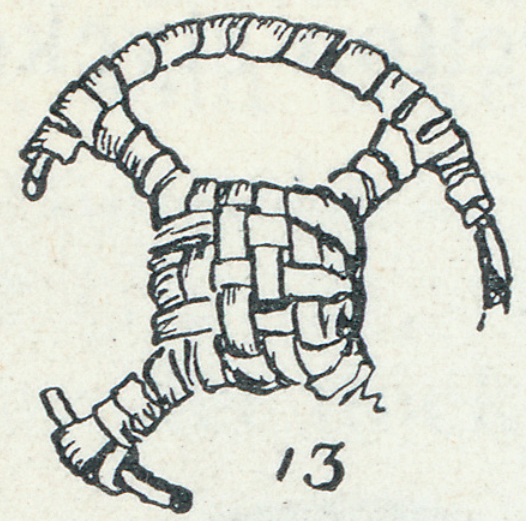

Figur 14: Tegning av søkke fra Locknesjön i Jämtland. Funnet ble gjort på bunnen av sjøen $\mathrm{i}$ forbindelse med notdragning. Gjengitt med tillatelse fra Bjørkquist (1932: 96-97).

For Jämtlands del er det ikke belegg for å si at funnsteder for trinsesøkker er utelukkende sammenfallende med fangstmarker. ${ }^{45}$ Mellom-Sverige er et relativt flatt skoglandskap hvor man ikke finner like klare skillelinjer mellom jordbruksbygd og fangstmark som i Norge. Ingrid Zachrisson har hevdet at det har vært både en samisk og en germansk kultur i Jämtland i hele perioden ca. Kr.f.-1300 e.Kr. Hun mener at det midtre Skandinavia har vært et utpreget tokulturelt område, med både en samisk og en germansk kulturell identitet. ${ }^{46}$ På dette grunnlaget kan man derfor si at trinsesøkkene i Jämtland, på lik linje med de fleste funnene på norsk side, stammer fra områder hvor det sannsynligvis har levd både mennesker med samisk og mennesker med norrøn etnisitet.

I Finland er trinsesøkkene en funngruppe som har vært kjent i lang tid, og søkkene regnes som en del av den finske folkekulturen. ${ }^{47}$ Trinseformete søkker blir også beskrevet i en bok om bruk av never $\mathrm{i}$ tradisjonelt finsk håndverk. ${ }^{48} \mathrm{I}$ det finske materialet som presenteres av Valonen, er det to ulike hovedtyper av trinseformete søkker. Den ene har flettverk rundt steinen, slik vi kjenner fra de sene eksemplene i Tesse. ${ }^{49}$ Den andre typen er konstruert på samme måte som søkket i Vefsn, med enkle, brede neverremser lagt i kors rundt ring og stein. ${ }^{50} \mathrm{I}$ tillegg nevner Valonen en søkkeform som han anser for å være en forgjenger til de to andre, hvor steinen mangler eiker og i stedet er festet direkte til vidjeringens skjøt. Disse garnsøkkene har ikke flettverk, og steinen er kun viklet inn i neverremser. Valonen mener denne steinsøkketypen går tilbake til steinalderen, og viser til lignende funn både i Ural (Russland) og i Piteå

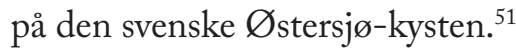

I Finland er altså trinseformete søkker brukt av jordbruksbefolkningen i nyere tid. Hverken Sirelius eller Valonen behandler spørsmålet om bruk av slike søkker i den samiske delen av befolkningen. Ettersom ingen av kildene heller omtaler direkte dateringer av materialet, er de usikre å bruke som sammenligningsgrunnlag for forhold i Sør-Norge i vikingtid og middelalder.

Det har ikke vært innenfor rammen av dette arbeidet å giøre en fullstendig kartlegging av trinseteknologiens utbredelse utenfor Skandinavia. Det finnes imidlertid flere steder opplysninger om at trinseformete søkker skal være velkjent østfra: I handelsbyen Novgorod i dagens Russland skal det blant annet være funnet søkker fra middelalderen med dobbel vidjering. ${ }^{52}$ Anders Hagen mener som nevnt at denne typen søkker har sitt sentrum i Karelen. ${ }^{53}$

Bortsett fra Finland har det lyktes meg å finne kun ett nordisk eksempel utenfor Skandinavia på trinseformete søkker. Dette er et enkeltstående funn gjort under utgravningene i vikingtidsbyen Hedeby, i den nordlige del av dagens Tyskland. ${ }^{54}$ Søkket er ulikt trinsesøkkene fra Tesse, men ligner en hel del på søkket fra Vefsn. Foruten dette ene trinsesøkket ble det i Hedeby funnet en stor mengde garnsøkker 
av stein med boret hull. ${ }^{55}$ Hedeby ligger langt sør og på Østersjø-siden av halvøya Jylland. Byen befinner seg i et jordbruksområde ved kysten og skiller seg derfor fra de andre områdene hvor trinsesøkker er funnet i Skandinavia. Hedeby var en handelsby med langveis kontakter i vikingtid og har trolig stått i kontakt med områder i Skandinavia og ved Østersjøen.

\section{TRINSESØKKER OG FANGSTKULTUR}

Gjennomgangen av funnsteder utenfor Tesse viser at de fleste trinseformete søkkene i Sør-Norge er blitt funnet i fjellvann eller i områder som er relativt marginale i jordbrukssammenheng. Funndistribusjonen i Skandinavia som helhet viser også et godt samsvar med det som flere forskere regner som et sannsynlig sørsamisk område i vikingtid og middelalder. Dette betyr imidlertid ikke at disse områdene ikke har vært utnyttet av en befolkning med jordbruk som basisnæring. Flere av mine drøftinger vanskeliggjøres av at det er et sparsomt materiale å bygge på når man skal vurdere de norrøne bygdenes utbredelse i vikingtid og middelalder.

Ved å trekke inn funnsteder fra andre deler av Skandinavia har jeg altså ikke vært i stand til å slå fast at trinsesøkkene skal forbindes med en spesialisert fangstbefolkning. Det er like mye i denne gjennomgangen som peker mot at søkketypen er brukt av jordbruksbefolkning, som det er som peker mot at den er brukt av fangstfolk.

Trinsesøkkene kan nok heller ikke tolkes som samiske per definisjon. Det at de så langt ikke er kjent fra sikre samiske kontekster, kan kanskje tolkes som det motsatte? Her vil det trolig være behov for mer inngående vurderinger av hvert enkelt funnsted enn hva som har vært mulig innenfor rammen av mitt arbeid. Det er opplagt ganske vanskelig å bruke arkeologiske funn som etniske markører når aktiviteten har foregått i områder hvor det har vært mye kontakt mellom ulike befolkningsgrupper. Noen arkeologiske funntyper anses for å inneha klare etniske kriterier. For eksempel regnes gammetufter ofte som samiske, i motsetning til langhus, som man regner som en norrøn bosetningsform. ${ }^{56}$ Når det gjelder fiskesøkker, må vi foreløpig forholde oss til at det er det konteksten, den samlete sammenhengen materialet inngår i, som avgjør hvem materialet skal tilskrives. Jeg ser ikke bort fra at denne søkketypen kan ha vært brukt av begge grupper.

\begin{tabular}{|l|l|l|l|}
\hline Funnsted & Funnets ID & Landskapstype & Fangstmark \\
\hline Locknesjön & JLM13306 & $\begin{array}{l}\text { Tradisjonelt jordbrukslandskap, } \\
328 \text { moh. }\end{array}$ & $\begin{array}{l}\text { Gropfangstanlegg } \\
\text { i nærområdet }\end{array}$ \\
\hline $\begin{array}{l}\text { «Et tjern» (ukjent hvilket) } \\
\text { i Mattmar sokn }\end{array}$ & JLM16867 & $\begin{array}{l}\text { Usikkert, både fjell- og } \\
\text { skogsområder i soknet }\end{array}$ & $\begin{array}{l}\text { Flere store fangstanlegg } \\
\text { i soknet }\end{array}$ \\
\hline Edeviken ved Torrön & JLM22370 & Fjellskog, 417 moh. & $\begin{array}{l}\text { Flere store fangstanlegg } \\
\text { i nærområdet }\end{array}$ \\
\hline Mellansvartsjön i Frösöen & JLM29767 & Jordbrukslandskap & $\begin{array}{l}\text { Et stort antall kulturminner } \\
\text { av ulike typer, herunder } \\
\text { bygdeborger og gravfelt samt } \\
\text { store fangstgropsystemer }\end{array}$ \\
\hline Mangler stedsangivelse & Umerket fragm. & Uavklart & Uavklart \\
\hline
\end{tabular}

Tabell 2: Oversikt over kjente funnsteder for trinseformete garnsøkker i Jämtland, Sverige. 


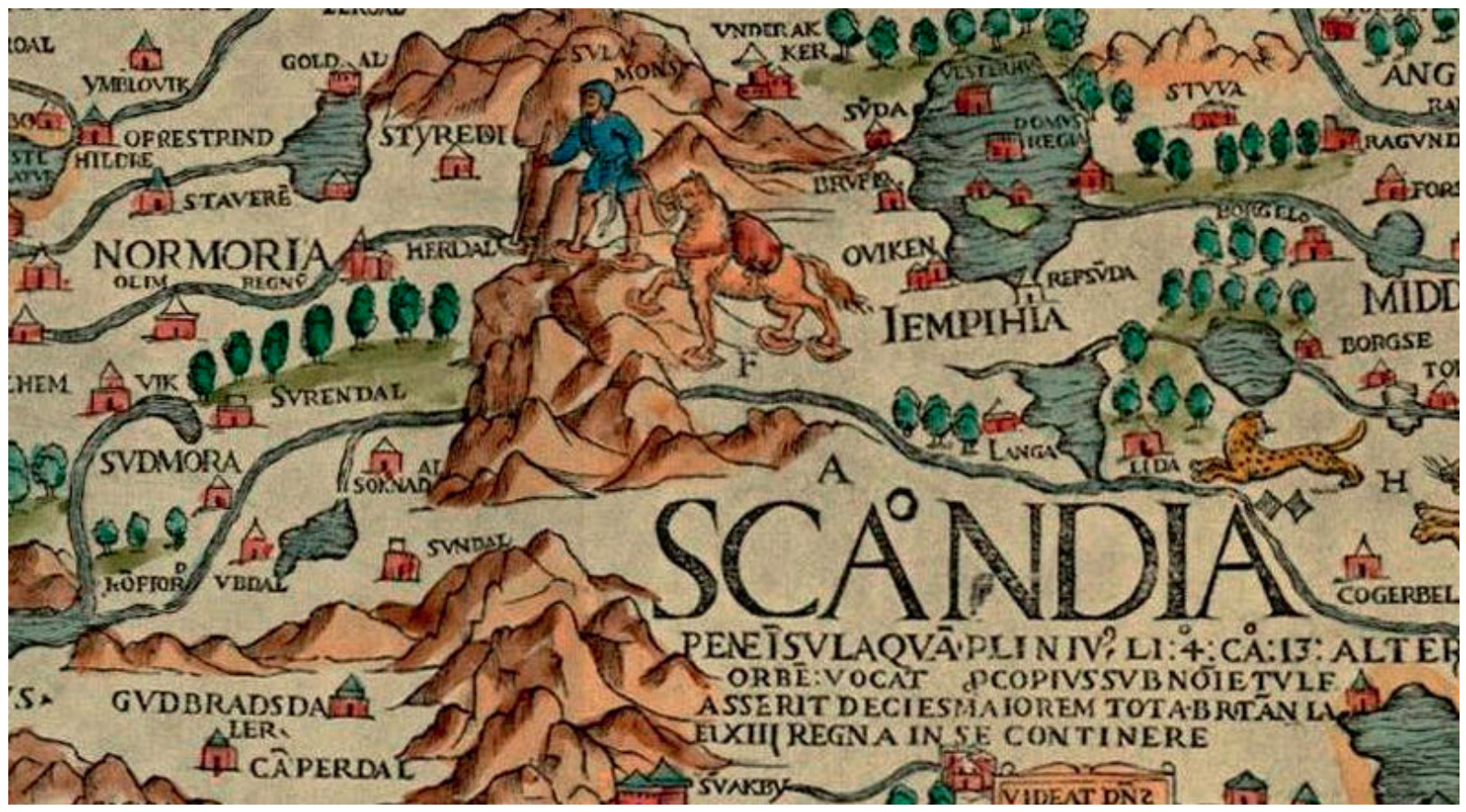

Figur 15: Utsnitt av «Carta Marina», tegnet av erkebiskopen Olaus Magnus på 1500-tallet. Kartet har mange unøyaktigheter geografisk, men regnes som en kilde til viktige deler av kulturlivet i samtiden. Denne delen av kartet, fra sentrale deler av Sør-Skandinavia, viser blant annet ferdsel med hest over Kjølen. Vi finner også igjen stedsnavn som er aktuelle i min artikkel, slik som Gudbrandsdalen og Jämtland (Jempihia). Foto: Wikimedia Commons.

\section{TRINSEFORMETE SØKKER - ET}

\section{SKANDINAVISK INNLANDSFENOMEN?}

De formmessige likhetene blant trinseformete søkker funnet i Sør-Norge er store. Likhetene kan også spores til Jämtland. På hvilken måte gjenstandene henger sammen kulturelt, er derfor et relevant spørsmål. Det er på bakgrunn av disse likhetene grunn til å tro at fiskerne i hele dette området har stått i direkte kontakt eller en annen kulturell forbindelse. Midt-Skandinavia regnes ofte som en korridor for øst-vest-kontakt, med lange røtter. ${ }^{57}$ Også lenger sør, på høyde med Hedmark, regner man med at kontakten over Kjølen har vært stor før opprettelsen av statsgrensen. ${ }^{58}$ Kanskje kan dette være med å forklare de likhetene vi ser i søkkematerialet (jf. figur 15).
Hva så med funnene av trinseformete garnsøkker i Vefsn og Hedeby? Hvilken kulturell kobling er det mellom disse funnstedene og søkkene i Tesse? Vefsn og Hedeby er begge områder som ligger ved kysten, hvor jordbruket har hatt bedre betingelser enn i fjellbygder i innlandet. Sannsynligvis kan ingen av disse stedene regnes som fangstmarker. Det er interessant at de to søkkene funnet i Vefsn og Hedeby er så like samtidig som de er ulike funnene fra innlandet. Muligens kan dette være et tegn på kulturelle kontakter langs kysten.

I Sør-Norge ser trinsesøkkene ut til å være et innlandsfenomen. Selv om vi her bygger på et begrenset materiale, synes de formmessige forskjellene mellom trinseformete søkker funnet ved kysten og $\mathrm{i}$ innlandet 
å forsterke inntrykket av at de trinseformete søkkene binder de indre områdene sammen. Det er derfor mulig å snakke om en felles materiell fiskekultur i Sør- og Mellom-Skandinavias fjell og innland, en som går på tvers av dagens statsgrenser. I Tesse er denne kulturen tidfestet til vikingtid og tidlig middelalder, da den ser ut til å opphøre.

I denne delen av diskusjonen melder et kritisk spørsmål seg: Hvor sikker kan vi være på at de trinseformete søkkene ikke har vært i bruk i større grad på kysten? Dette spørsmålet kan også ha relevans for vår oppfatning av søkkenes kulturelle og etniske tilknytning ettersom kysten, spesielt i Sør-Norge, ofte regnes som et norrønt bosetningsområde $\mathrm{i}$ vikingtid og middelalder. Ferskvann tar spesielt godt vare på organisk materiale, som trinsesøkkene i stor grad består av. I saltvann forsvinner trevirke raskere, gjerne på grunn av større mekanisk nedbrytning (strøm og bølger) og pelemark. Skyldes fraværet av trinseformete søkker i saltvannskontekst dårligere bevaringsforhold og vanskeligheter med å gjøre funn av slike?

Bergljot Solberg skriver i Jernalderen i Norge følgende:

Tatt $\mathrm{i}$ betraktning vår lange kyst og den betydningen fisket må ha hatt, er gjenstandsmaterialet knyttet til fiske lite. Det er vesentlig bare fiskesøkkene av stein og bly og fiskekrokene av jern som forteller om fiske. ${ }^{59}$

Uttalelsen må forstås som at det er et overraskende lite funnmateriale knyttet til fiske langs kysten. Også andre forskere har stilt spørsmål om hvorfor det er så få funn av fiskeutstyr fra vikingtiden på tross av at fisket må ha vært viktig. ${ }^{60}$ Kanskje kan denne mangelen på funn forklares med at man har brukt søkketyper som ikke er blitt bevart i gjenkjennbar form?
Samtidig vet vi nå at trinseformete søkker var kjent både i Hedeby og i Nord-Norge. Dette gjør det mindre sannsynlig at denne typen søkker ikke har vært kjent langs kysten av for eksempel Vestlandet, og styrker hypotesen om at slike funn rett og slett ikke er bevart eller ikke er funnet.

En viktig årsak til at både de trinseformete søkkene og neverhylstrene er blitt funnet i de aktuelle innsjøene, er at vannet er blitt tappet ut, og at søkkene er blitt eksponert gjennom utvasking og annet. Det er svært sjelden at dette skjer i sjøområder på kysten. Likevel kan det hevdes at det er usannsynlig at ikke et eneste trinseformet garnsøkke skal være kjent på kysten av Norge dersom dette har vært en mye brukt redskapstype. Etter de siste 50 år med vannkraftreguleringer i elver og sjøer over hele SørNorge ville det også vært naturlig at slike søkker hadde dukket opp i flere vassdrag. På dette grunnlaget kan vi foreløpig si at funnspredningen trolig er reell, og at de trinseformete søkkene hovedsakelig er et innlandsfenomen i Sør-Skandinavia.

\section{ALTERNATIVE FORKLARINGER PÅ TRADISJONSBRUDDET I TESSE}

I denne artikkelen har vi så langt sett på muligheten for at fisket i Tesse kan ha vært drevet av ulike grupper av mennesker over tid. Det ble stilt spørsmål innledningsvis om overgangen fra trinsesøkker til neverhylstre kunne forklares med et skifte fra fangstfolk til bygdefolk, eventuelt fra samer til norrøne befolkningsgrupper. Selv om vi ikke kan se bort fra et slikt forløp, har en slik tolkning heller ikke latt seg sannsynliggjøre. Det kan derfor være spennende å vurdere andre forklaringer på et tradisjonsbrudd.

Trinsesøkkene er forseggjorte og vakkert utformet, trolig mer enn det som trengs for å gjøre dem funksjonelle som fiskeredskaper. ${ }^{61}$ Man kan derfor spørre om utformingen kan ha hatt en symbolsk betydning knyttet for eksempel til religiøse eller 
mytiske forestillinger. Hesthagen og Gunnerød ${ }^{62}$ drøfter også muligheten for at gjenstandene har vært offergaver i stedet for garnsøkker. Forklaringen på bruddet rundt år $1200 \mathrm{kan}$, med et slikt utgangspunkt, være at trinsesøkkene har hatt et meningsinnhold som ikke lenger var gjeldende. Fiske er tradisjonelt en aktivitet som det knytter seg mange ritualer til. Dette er veldokumentert på kysten, men mindre i innlandet. ${ }^{63}$

Dateringene av trinsesøkkene i Tesse viser at de var i bruk her før kristningen av landet, og at de ser ut til å ha gått ut av bruki en periode da kristendommen var i en tidlig fase i Norge. Én hypotese kan dermed være at en førkristen overtro som kom til uttrykk i søkkenes utforming, på et tidspunkt ble oppfattet som uforenlig med nye trosforestillinger og derfor ble forlatt. Hverken Valonen ${ }^{64}$ eller Itkonen ${ }^{65}$ nevner imidlertid at de trinseformete søkkene i Finland skal inneha symbolske egenskaper. Det er dermed ingen klare indikasjoner på at bruddet i materialet skyldes endring av fiskernes trosforestillinger.

Endringen fra trinser til neverhylster kan også skyldes overgang fra én fiskemetode til en annen. Når det gjelder fiske med bundne redskaper i innlandssjøer og vann, er det to metoder som er vanlige i Norge. ${ }^{66}$ Den ene innebærer stående garn, eller settegarn, som er en passiv fiskemåte. Den andre er not, som dras på bunnen av vannet enten fra land eller båt, og som er en aktiv metode. Maskene i et garn er gjerne større enn de i en not fordi hensikten er at fisken skal feste seg i garnet, mens en not fungerer som en sekk.

I Norge er de trinseformete søkkene så langt benevnt som garnsøkker. ${ }^{67} \mathrm{I}$ forbindelse med innsamling av informasjon om trinseformete søkker i Sverige er det imidlertid blitt avdekket at trinsesøkkene som regel omtales som notsänke, alternativt bare sänke. ${ }^{68} \mathrm{I}$ svensk språk har man det samme skillet mellom not og garn som i Norge, men de benevnes henholdsvis not og nät. Opplysninger fra Jämtland tilsier også at trinsesøkker der skal ha vært brukt til landnotfiske i historisk tid. ${ }^{69}$ I Sør-Norge ser hylstersøkkene på sin side ut til å kunne knyttes til garnfiske. Dette viser blant annet en sammenhengende rekke med 25 neverhylstre funnet ved arkeologiske undersøkelser i Vinstre i Øystre Slidre. ${ }^{70}$ Også i Beito i Valdres ${ }^{71}$ og i Sølensjøen i Rendalen er det blitt brukt denne typen søkker på garn. ${ }^{72}$

Basert på disse opplysningene kan vi altså trekke slutningen at man rundt år 1200 går over fra fiske med not til garnfiske i Tesse. Hvis så er tilfelle, åpner det for interessante perspektiver i vår sammenheng. Notfiske var et aktivt fiske, som innebar et behov for samarbeid mellom flere mennesker. Garnfiske, derimot, er mindre mannskapskrevende og kan i prinsippet gjøres av én person. Her er det fristende å trekke en sammenheng mellom fisket i vikingtid og tidlig middelalder og den øvrige aktiviteten i fjellet på samme tid. Kanskje var et notfiske med mange involverte mennesker mulig å gjennomføre nettopp fordi det var så mye folk i fjellet? Kanskje er fisket med trinseformete søkker et uttrykk for noe av det samme samarbeidet og organiseringen som man ser på snøfonnene i høyfjellet?

Heller ikke er slik forklaringsmodell på bruddet er uproblematisk. Notfiske har nemlig vært viktig i Tesse i nyere tid, ${ }^{73}$ inntil draggarn utkonkurrerte den eldre fiskemåten på 1930 -tallet. ${ }^{74}$ Det kan derfor heller ikke utelukkes at neverhylstrene ganske enkelt har vært en ny oppfinnelse introdusert i Tesse rundt 1200, brukt på samme type garn. Nylige dateringer av et hylstersøkke funnet $\mathrm{i}$ Vinstre sør i Jotunheimen viser at denne typen søkke var i bruk på 1200-tallet også i dette vassdraget. ${ }^{75}$ Hylstrene kan av ukjent årsak ha vist seg bedre egnet enn trinsene og derfor blitt foretrukket. 


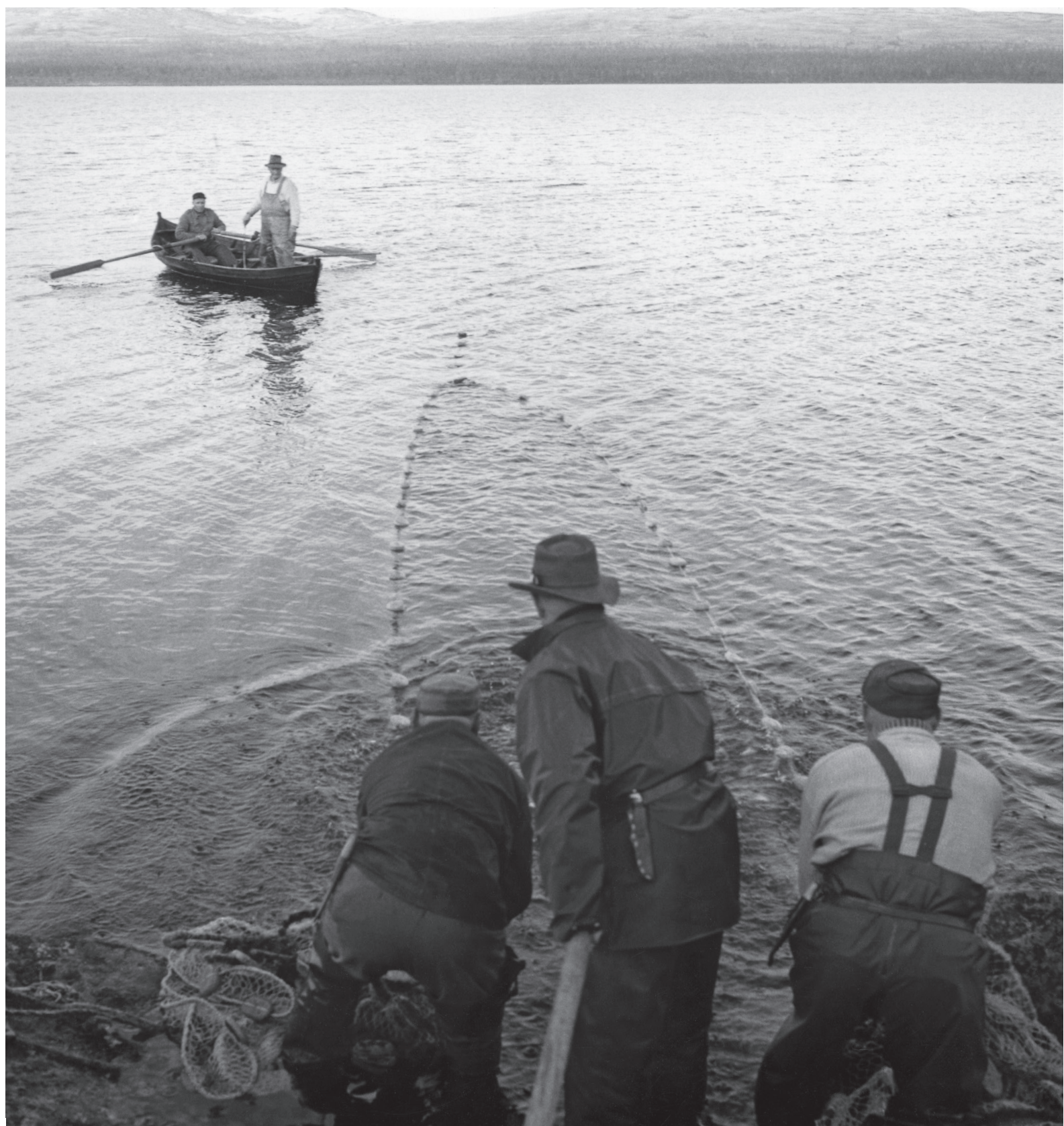

Figur 16: Notfiske i Sølensjøen i Hedmark, antakelig rundt 1965. Fiske med not var et utprega lagarbeid. Minst fem personer og en båt later til å være involvert på bildet. Foto: Tore Fossum, Norsk Skogmuseum. Se også tilsvarende bilde på forsiden av boken. 


\section{AVSLUTNING}

Vi har sett at det skjer et brudd i fiskesøkketradisjonen fra Tesse i yngre jernalder og tidlig middelalder, som i tid og rom har interessante sammenhenger med det øvrige kulturhistoriske materialet rundt vannet. Jeg har gjennomgått ulike forklaringer på tradisjonsbruddet mellom trinsesøkker og neverhylstre rundt år 1200 og vist at det i ytterste konsekvens kan tolkes som uttrykk for en konflikt, hvor én gruppe fortrenger en annen. Materialet gir imidlertid ikke et sikkert grunnlag for å hevde at trinsesøkkene har tilknytning til en eventuell fangstbefolkning.

Forskjellen mellom trinseformete søkker funnet ved kysten og dem som er funnet i innlandet, gir inntrykk av at visse typer av trinsesøkker binder de indre områdene sammen kulturelt. Det er derfor foreløpig mulig å snakke om en felles fiskekultur i Sør- og Mellom-Skandinavias innland, en som går på tvers av dagens statsgrenser, i vikingtid og middelalder. Flere dateringer vil være viktig for å forstå disse gjenstandstypene, noe som vil kunne supplere mine resultater.

De grunnleggende spørsmålene jeg ønsket å finne svar på i min artikkel, var følgende: Hvem var det som drev med fiske i fjellet i vikingtid og middelalder? Hvilke næringsmessige og sosiale sammenhenger har fisket hatt tilknytning til? Selv om det har vært vanskelig å sette garnsøkkene fra Tesse inn i en klar kulturhistorisk kontekst, tror jeg likevel søkkemateriale fra innsjøer i framtiden kan bli viktig når vi skal forstå et områdes kulturhistorie. Diskusjonene i denne artikkelen vil trolig være aktuelle også for andre fjellvann.

Uavhengig av hvem som sto bak fisket i Tesse, er det liten tvil om at fisket har vært en viktig ressurs i vikingtid og tidlig middelalder. Fiskeressursene kan være en sentral brikke i forståelsen av hvordan menneskene bosatte seg og utnyttet fjellområdene, enten det var i forbindelse med jakt, setring eller andre former for utmarksnæring. Kanskje var fisket det som dro folk til fjells? Vi må derfor vurdere å innføre en ny kategori når vi behandler spørsmålet om hvem som holdt til i fjellet. Spørsmålet blir heretter: Fangstfolk, bønder - eller fiskere?

\section{SUMMARY:}

\section{MOUNTAIN FISHING IN THE BORDER ZONE BETWEEN HUNTING GROUNDS AND FARMLANDS}

Within Norwegian archaeology, little attention has been given to the topic mountain fishing in the late Iron Age and medieval periods. Accurate and trustworthy dating in this span of time has been rare so far. The alpine lake Tesse is an exception. At the bottom of this lake, a large number of objects consisting of organic material in addition to stone have been discovered. This organic material is datable.

In Tesse, two types of sinkers for fishing nets have been dated to the Viking Age and late medieval times. Both types were probably fastened to the bottom line of fishing nets to keep them down. The first type is a wheel-shaped object where the sinker stone has been fastened to a wooden ring with four spokes. The shape is similar to the bottom end of a traditional Nordic skiing pole. The second type is made of stones wrapped in a sheet of birch bark.

In this article, some of the interesting questions that remained unanswered after the archaeological surveys in Tesse are addressed: Who had been fishing in this mountain lake in the Viking Age and medieval period? This article focuses on whether it was people from the farmlands in the valley or people living in 
the alpine area, basing their existence on hunting. I also discuss the possibility that the wheel-shaped net sinkers could be related to Sami ethnicity, based on their north-easterly geographic dispersal.

The variation between wheel-shaped net sinkers found in the Scandinavian inland and in the coastal zone gives an impression that certain types bind the inner regions together. It is therefore possible to talk of a common material fishing culture in southern and mid-inland Scandinavia, crossing the modern state borders.

The future may well show that evidence of fishing activity is of central value to our understanding of how people lived in and exploited the alpine region, whether the activity took place in connection with hunting, summer farming or other aspects of outfield usage. Perhaps fishing itself brought people to the mountains. We should therefore consider extending the question to the following: Were they hunters, farmers, or fishermen? 


\section{3}

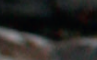
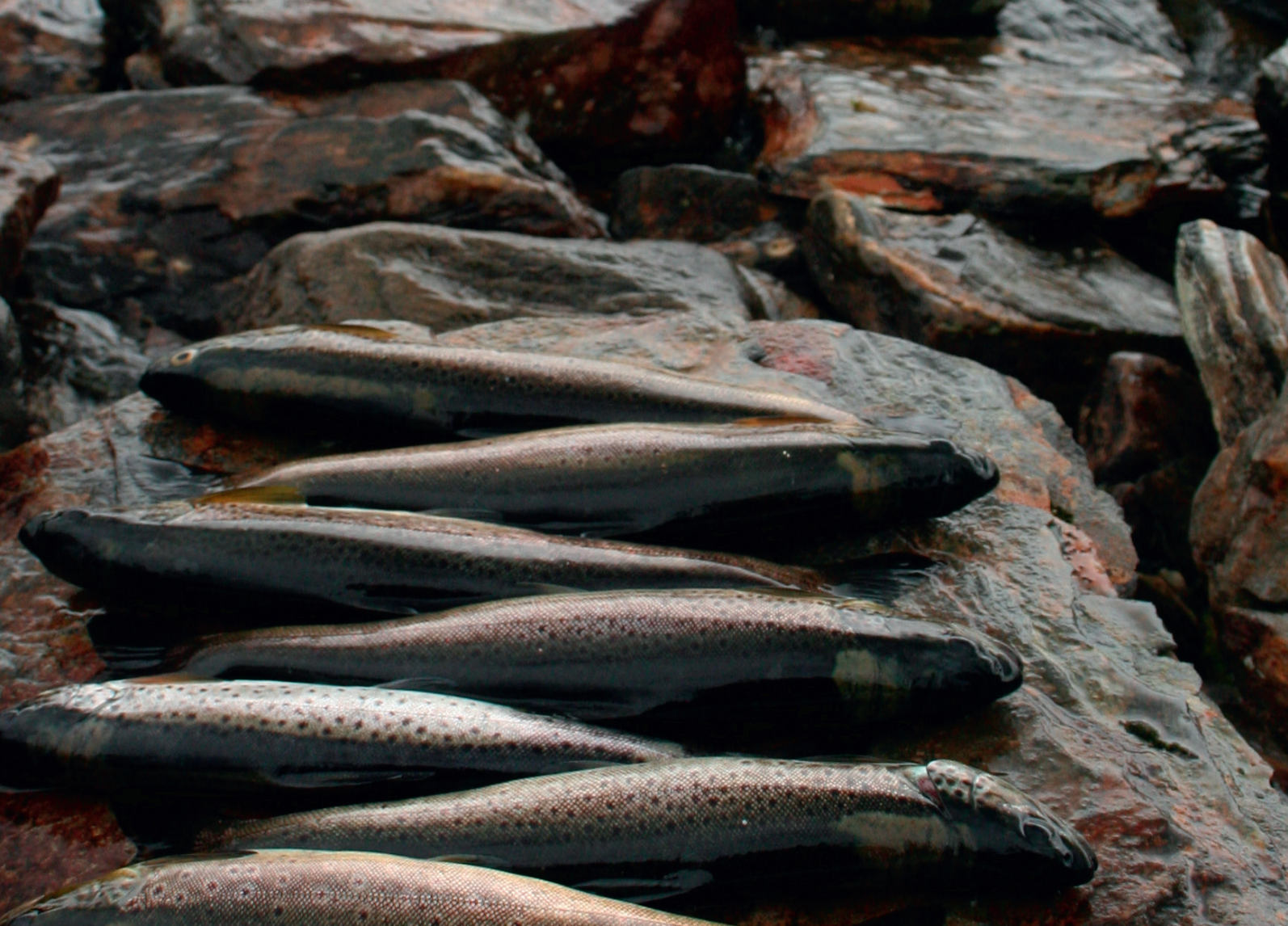

\section{arcosents ons}
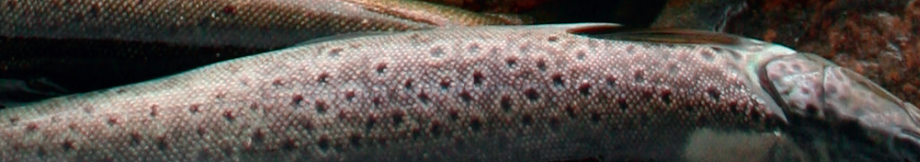

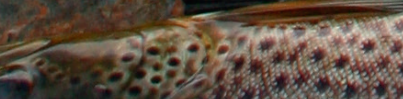

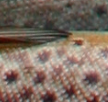




\title{
BÅTRELATERTE KULTURMINNER I FJELLET SOM KILDER TIL KUNNSKAP OM FISKE I FORTIDEN
}

\author{
Charlotte Melsom og Elling Utvik Wammer, Norsk Maritimt Museum
}

Grunnleggende for all ferdsel til vanns i sommerhalvåret i fjellet er båten. Dette gjelder også fiske ettersom mange av de mest utbredte fiskemetodene, som garn, not og krokfiske, i stor grad er basert på opphold på vannet. ${ }^{1}$ At den norske kysten er rik på kulturminner som viser til menneskelig bruk av havet, har relativt lenge vært en kjent sak, og kystkultur er i dag et veletablert begrep. ${ }^{2}$ Kunnskap om at «fjellandet» Norge også inneholder varierte spor av typer man kan sammenligne med vår gamle kystkultur ${ }^{3}$, synes imidlertid ikke å stå like sterkt.

I denne artikkelen vil vi se nærmere på et utvalg kulturminner i fjellet som vitner om ferdsel til vanns. Sentralt vil eksempler fra to større arkeologiske undersøkelser i Vinstravassdraget og Tesse i Oppland være. Vårt mål med artikkelen er å drøfte hvilket kunnskapspotensial som ligger i båtrelaterte kulturminner i fjellet, og vi vil særlig prøve å framheve hvordan dette kan bidra til å belyse fjellfisket.

\section{BÅTER I FJELLET}

Arkeologiske funn av båter i fjellvann forekommer så langt sjelden (jf. figur 1). Noen av de eldste båtfunnene vi kjenner til i Norge, er imidlertid funnet $\mathrm{i}$ ferskvannskontekster. Dette skyldes at det generelt er mye bedre bevaringsforhold for organisk materiale i ferskvann enn i havet. Fra Bingen i Glommavassdraget og vannet Lau i Siljan er det funnet stokkebåter som begge dateres til eldre jernalder (500 f.Kr.-550 e.Kr.). ${ }^{4}$

Et båtfunn fra Sumtangen ved Finnsbergvatnet på Hardangervidda utgjør et helt spesielt funn i nasjonal sammenheng. Under en utgravning inne i en fangstbu ble det avdekket nedbrutte trerester av en kjøl og bordganger med klinknagler. Dessverre er det sparsomt med opplysninger om båtens konstruksjon eller størrelse, men sannsynligvis har den vært rundt 5-6 meter. Det ble samlet inn rester av ulltråd som har vært tetningsmateriale mellom bordgangene. ${ }^{5}$ I forbindelse med prosjektet «Reinsdyr og reinsdyrfangst på Hardangervidda i jernalder og middelalder» ble prøver av dette tetningsmaterialet C14-datert til 980-1015 og 1010-1030 e.Kr. ${ }^{6}$ At det er brukt ull som tetningsmateriale mellom bordgangene, samsvarer med andre, samtidige skipsfunn fra Gokstadhaugen og Oseberghaugen. ${ }^{7}$ For utgraver Johs. Bøe ${ }^{8}$ minnet funnsituasjonen om en begravelse i ubrent båt med neverdekke over og under, men denne tolkningen er langt fra sikker. 


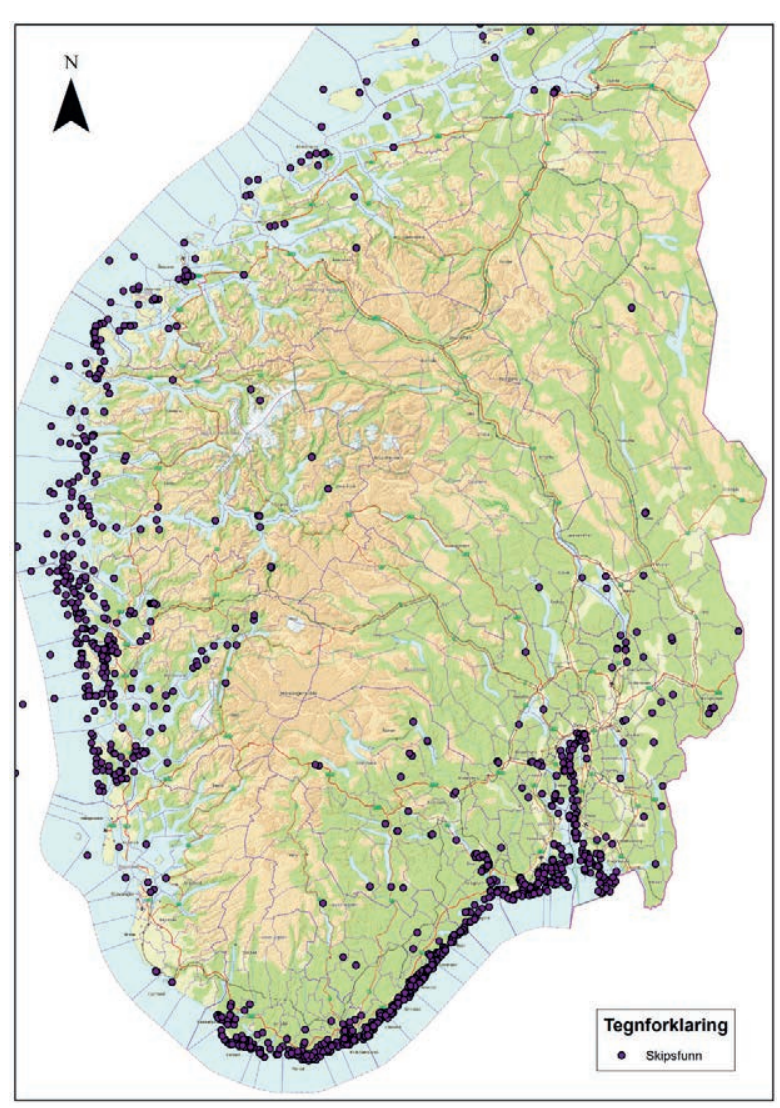

Figur 1: En oversikt over kjente skips- og båtfunn viser at slike kulturminner er færre og mer spredt $\mathrm{i}$ innlandet og spesielt på fjellet enn på kysten. Betyr det at båtens rolle i fjellet er begrenset? Posisjoner fra Riksantikvarens database over automatisk fredete kulturminner, Askeladden. Kart: Elling Utvik Wammer.

Det øverste neverlaget strakk seg sørover og kan stamme fra et nedfelt tak, muligens fra et naust som sto på stedet før fangstbua ble bygd. Hvilke egenskaper og funksjon båten fra Hardangervidda har hatt, er usikkert. Finnsbergvatnet var fisketomt fram til 1927, så det må ha vært noe annet enn fiske. Det er sannsynlig at båten ble fraktet opp til fjellet fra bygdene omkring, enten ved at man slepte den opp på snøen vinterstid eller rodde den over vann og bar den over land. Det er naturlig å tenke seg at folk tok seg bryet med å dra båter opp på fjellet fordi de hadde en viktig oppgave i forbindelse med transport av folk og ulike fangstprodukter. Båten kan også ha blitt brukt under fangst på storvilt for å lede dyrene ut i vannet eller mot boplasser. ${ }^{9}$

Samtidig er det ikke uvanlig at det blir funnet båtnagler og andre sammenføyningsmidler, slik som spiker og kramper, under utgravninger av hustufter i fjellet. Nest etter dyrebein er faktisk slike rester etter båter den største funnkategorien i steinbuer fra 1200-tallet på Hardangervidda. ${ }^{10}$ Det ble også funnet båtnagler og spiker i et jernvinneanlegg datert til vikingtid/middelalder ved Møsvatn (919 moh.) i Vinje i Telemark under utgravninger der på 1960-tallet. ${ }^{11}$ Funn av båtnagler i slike anlegg kan trolig indikere omfattende bruk av båt til organisert transport av ved, jern eller myrmalm i fjellet i jernalder og middelalder.

Mangelen på arkeologiske funn av båter i fjellet fører til at vi i dag har begrenset kunnskap om den båthistoriske utviklingen i høyereliggende vann og innsjøer. Når vi skal si noe om hva slags typer farkoster man kan ha brukt i fjellet i forhistorisk tid, er det mulig å trekke veksler på det vi har bevart av nyere tids kildemateriale fra de lavereliggende vassdragene i $\varnothing$ st-Norge. ${ }^{12}$ Det finnes et relativt omfattende båtmateriale på norske museer. Den største båtsamlingen i innlandet har Norsk Skogbruksmuseum, som har ca. 30 båter. For eksempel er det kjent minst fire båter som skal være bygd av den legendariske Båt-Iva i Vågå. ${ }^{13}$ Båt-Iva levde på slutten av 1700tallet, og båtene hans hadde som andre østnorske innlandsbåter fra nyere tid flere trekk til felles med Vestlandets båttyper. ${ }^{14}$ Båtene på Vestlandet er kjent for å være lettere i vekt enn østlandsbåter fra kysten. ${ }^{15}$ Sannsynligvis har båtbyggingstradisjonene i fjellet lignet den vestlandske. De var lette å trekke på land, samtidig som strøm i elver og lange vintre 


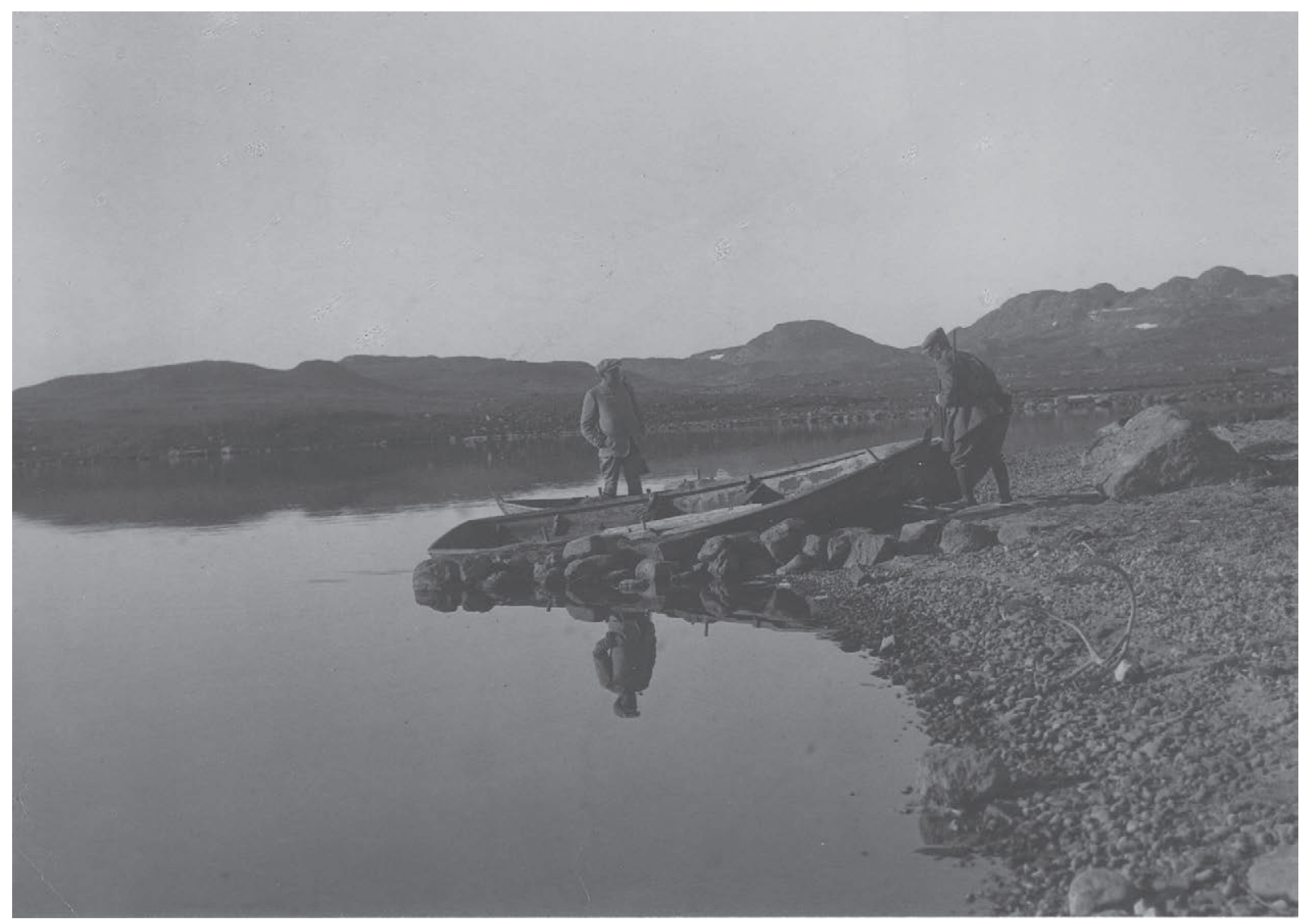

Figur 2: Bildet viser to reinsjegere som har båten liggende i en båtstø på Hardangervidda. Foto fra samlingen til Hardanger folkemuseum.

med islagte vann og elver gjorde at man foretrakk å lagre båten i støer eller i naust.

\section{BÅTRELATERTE KULTURMINNER \\ -BEGREPSAVKLARING}

Maritim arkeologi har tradisjonelt fokusert på kystmiljøer og ferdsel i fjorder og på havet. Disse studiene har lært oss at mange av de sporene som kan si mest om menneskets ferdsel på vannet, ligger på land. Plasseringen av bebyggelse, landingsplasser for båter, ferdselsveier og så videre kan ofte si en hel del om hvordan sjøen og fjorder har vært brukt, selv om framkomstmidlene i seg selv mangler. Denne erkjennelsen kan også overføres fra kysten til vann og vassdrag i innlandet.

Båtrelaterte kulturminner kan være så mangt, og en rekke kulturminner antas ofte å peke på bruk av båt. Et eksempel fra kysten er gravrøyser plassert på nes eller holmer. En vanlig tolkning er at dette indikerer at det her har vært en viktig maritim ferdselsrute, eller led. ${ }^{16}$ På samme måte vil maritime helleristningsmotiver, i særlig grad båt- eller skipsfigurer, ofte tolkes som at sjøfarten har hatt stor betydning i nærområdet. På kysten er 
FJELLFISKE I FORTIDEN | CHARLOTTE MELSOM - ELLING UTVIK WAMMER

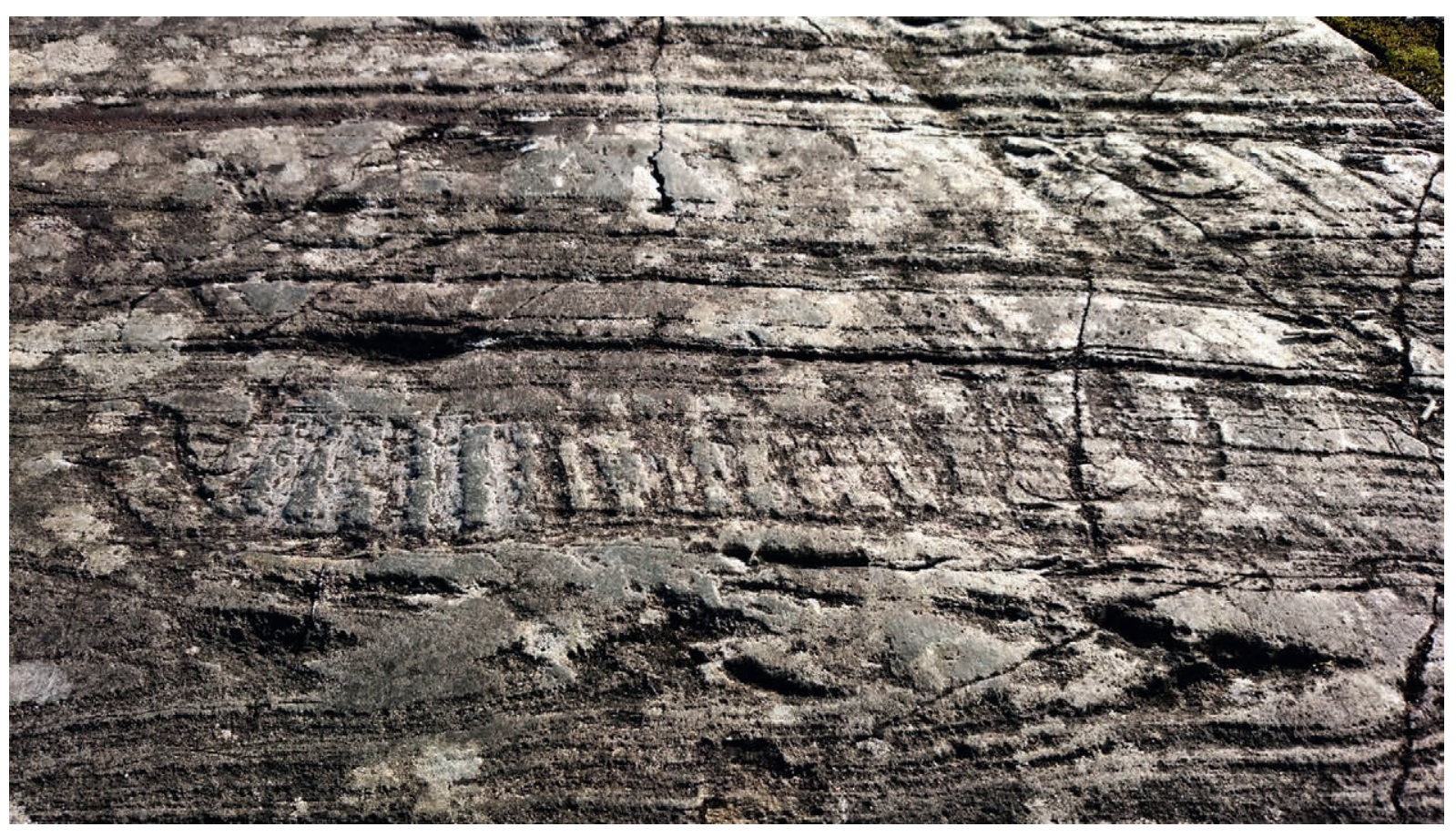

Figur 3: Båtristning på Sporaneset ved vannet Totak i Telemark. Foto: Telemark fylkeskommune.

relasjonene mellom båtbruk og aktiviteter på land selvsagt, mens disse sammenhengene i innlandet og på fjellet ikke alltid er like åpenbare for oss.

Spor som kanskje kan knyttes til den eldste ferdselen med båt i fjellet, stammer så langt heller ikke fra båtfunn. På helleristningsfeltet Sporaneset ved vannet Totak i Telemark, som ligger om lag 680 moh., er det avbildet en båt (figur 3). ${ }^{17}$ Sporaneset ligger på østsiden av Totak i Rauland, ved foten av Hardangervidda. Helleristningsfeltet er etablert på en lite nes som stikker ut i vannet, og har fått navn etter alle fotsålene som er hugget inn i berget. Totalt består feltet av til sammen 61 figurer, hvorav det også finnes motiver av elg, reinsdyr, dyregraver, mannsfigurer med mer. Det har vært diskutert om feltet tilhører én eller to tidsperioder, siden det forekommer både veide- og jordbruksristninger sammen, men Sporanes-ristningene er i overveiende grad tolket som et «blandingsfelt» fra bronsealder. ${ }^{18}$ Skipsfiguren er rundt $40 \mathrm{~cm}$ lang og har 17 mannskapsstreker. Slike avbildninger kan tolkes på ulikt vis, enten som bark- og skinnbåter, tømmerflåter eller stokkebåter med oppbygde og utspente sider. ${ }^{19}$

Skipsfiguren på Sporaneset kan vitne om ferdsel til vanns på Totak kombinert med en mangesidig ressursutnyttelse. Det er rimelig å anta at det har vært drevet fiske i vannet, da det i nærheten av Sporaneset er en god fiskeplass. ${ }^{20}$ Det er imidlertid mindre sannsynlig at skipsfiguren i seg selv viser til dette fisket, ettersom farkoster brukt til fiske i innsjøen sannsynligvis har vært mye mindre. I fjellet er skipsmotiver ellers nærmest helt fraværende. Hvorvidt dette skyldes at ferdsel med båt i fjellet i bronsealderen var uvanlig, er uvisst. 
I denne artikkelen vil vi sette søkelyset på fysiske spor i vannkanten som har direkte sammenheng med båtens tilstedeværelse. I motsetning til indirekte markører, slik som gravrøyser og helleristninger, er de sporene vi nå skal ta for oss, levninger som ikke ville blitt anlagt om det ikke hadde vært brukt båt på stedet. Vi snakker altså om spor knyttet til såkalte landingsplasser, steder der man har sjøsatt eller dratt båten på land. Vi skal først se litt nærmere på de to mest kjente hovedtypene av strukturer som karakteriserer slike steder.

\section{Båtstøer}

En båtstø er et ryddet område i vannkanten som gjør det enklere å sette en båt på land. Båtstøer blir også anlagt for at båtene skal ligge trygt under midlertidig lagring. Støa strekker seg som regel fra under vann til godt over flomålet for at hele båten skal kunne trekkes unna bølgeslag. I områder hvor man har tilgang på treverk, brukes gjerne trestokker, eller lunner, på tvers av støas lengderetning for at båten skal være lettere å dra opp. Restene etter eldre båtstøer er ofte kun synlige som parallelle rekker med stein, også kalt vorrer. Ettersom båtstøer som regel er minimalt bearbeidet, kan det være utfordrende å oppdage dem i terrenget og skille dem fra naturlige fordypninger eller flater. Vann og is kan også ha bidratt til at stein er blitt flyttet fra kanten og inn i støa, slik at konstruksjonen er blitt utvisket, helt eller delvis.

Så tidlig som under Hjalmar Negaards registreringer på Hardangervidda for rundt 100 år siden ble det påvist båtstøer ved fangstboplassene ved Krækkja og Halnefjorden. ${ }^{21}$ Senere registrerte Otto Blehr en båtstø like ved en fangstgrop ved Insta Olavsbuvatnet på Hardangervidda. ${ }^{22}$ I forbindelse med nyere arkeologiske undersøkelser i et større prosjekt på Hardangervidda ble det registrert enda flere båtstøer rundt Krækkja, Insta Olavsbuvatnet, Finnsbergvatnet, Langavatn, Drageidfjorden og
Finnsbergvatnet. Til sammen ble det dokumentert 23 antatt eldre båtstøer nær boplasser, ledegjerder og fangstgroper. Flertallet av båtstøene skriver seg antakelig fra jernalder og middelalder. ${ }^{23}$

Båtstøer har trolig i prinsippet endret seg lite gjennom historien, og de kan følgelig være vanskelige å datere typologisk. I forbindelse med undersøkelsene på Hardangervidda har imidlertid Endre Elvestad avdekket at størrelsen på støene kan være et daterende trekk. Den typiske støen som han daterer til jernalder/middelalder, er rundt fire meter lang og kun én meter bred. Dette er betydelig smalere enn støer fra nyere tid som ble observert under registreringene ved de samme vannene. De smale støene kan tyde på at båter som ble brukt til ferdsel på fjellvann, har vært både kortere og smalere enn tradisjonelle båter, som færingen og oselveren.

\section{Naust}

Ordet naust kommer fra gammelnorsk og betyr «sted hvor man oppbevarer fartøy». Ordet har to ledd, nav-og -sta, som betyr henholdsvis «fartøy» og «sted». Å lagre båter på et sikkert sted for vær og vind, i noen tilfeller også kanskje for uvedkommende, har trolig vært spesielt viktig på utsatte og avsidesliggende steder, slik som på fjellet (figur 4).

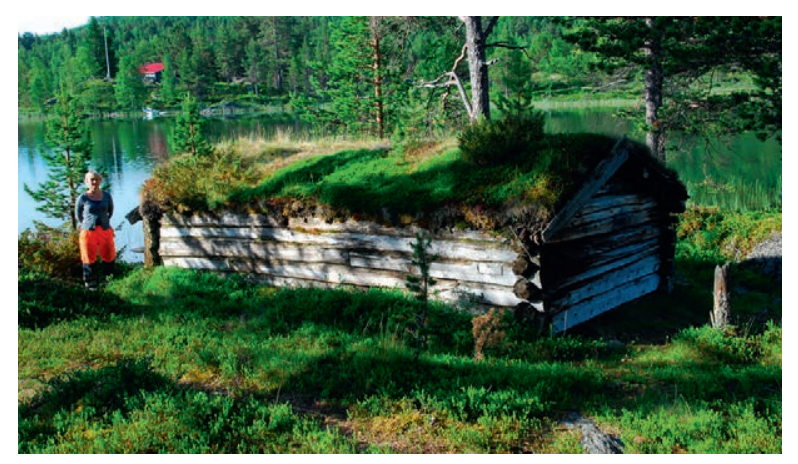

Figur 4: Stående naustbygning ved Lemonsjøen i Vågå kommune i Oppland. Foto: Elling Utvik Wammer, Norsk Maritimt Museum. 
FJELLFISKE I FORTIDEN | CHARLOTTE MELSOM - ELLING UTVIK WAMMER

Det kan i mange tilfeller være problematisk å identifisere eldre strukturer som naust, og kanskje gjelder dette i særdeleshet på fjellet. En tuft undersøkt av Nergaard ved Store Krækkja på Hardangervidda ble først antatt å være et naust, men da det ble avdekket beinrester utenfor, ble den i stedet tolket som en fangstboplass. Arkeologen Hjalmar Nergaard beskrev tufta som svært uanselig, 5 meter lang og 2-3 meter bred. Endre Elvestad hevder i ettertid at tuften har såpass mange trekk til felles med tradisjonelle naustkonstruksjoner at han definerer den som et naust. Tolkningen baserer han blant annet på at tuftens åpning vender mot vannet, og at den er svært smal i forhold til lengden, og dermed er uegnet som bolig. ${ }^{24}$ I tillegg påpeker han at det ble funnet båtnagler inni og utenfor tuften, hvilket styrker hans teori om at den har vært et naust.

Det er ikke registrert flere slike nausttufter på Hardangervidda. Et mulig unntak er den alt omtalte Austbu ved Finnsbergvatnet, hvor en klinkbygd båt ble gravd fram. Johs. Bøe nevnte at båten lå i tuftas nordvestre del under et avfallslag og opprinnelig kan ha vært plassert i en eldre bygning inne i den vi ser spor etter i dag. Det er heller ikke umulig at båter kan ha blitt lagret i fangstbuene når de ikke var i bruk, og ikke i egne båthus eller naust.

\section{NYE PERSPEKTIVER I FJELLHEIMEN}

De båtrelaterte kulturminnene vi innenfor norsk arkeologi og forvaltning så langt har kjennskap til i og rundt fjellvann, har kommet fram mer eller mindre tilfeldig. Den eneste større systematiske registreringen som er utført i Sør-Norge med sikte på slike kulturminner, ble utført av Endre Elvestad fra Stavanger sjøfartsmuseum.

I de siste årene har Norsk Maritimt Museum deltatt i flere større arkeologiske prosjekter i fjellet knyttet til den såkalte sektoravgiften (figur 5). I disse prosjektene tar vi for oss hele vassdrag eller store innsjøer. De fungerer derfor godt til å gi overblikk over større områder innen ulike tema. For museet har det vært naturlig å sette søkelyset på bruken av vannene til ferdsel og fiske. Vi skal i det følgende se nærmere på noen av de kulturminnene vi har dokumentert, og hvilken kunnskap de kan gi om disse temaene. Eksemplene illustrerer også kunnskapspotensialet i arkeologiske undersøkelser av båtrelaterte kulturminner generelt, som diskuteres mot slutten av artikkelen.

\section{VINSTRAVASSDRAGET VED FOTEN AV JOTUNHEIMEN}

Vinstravassdraget strekker seg fra grensen til Jotunheimen nasjonalpark og vestenden av Bygdin til samløpet med Gudbrandsdalslågen ved tettstedet Vinstra. Vassdraget har seks reguleringsmagasiner og berører kommunene Vang, Øystre Slidre, Vågå, Nord-Fron og Sør-Fron. Siden det ligger nær Jotunheimen og Jotunheimvegen, som går langs hele vassdraget, er Vinstravassdraget viktig for jakt, fiske og friluftsliv i området ennå i dag. Skriftlige kilder tilbake til middelalder viser at det hadde vært betydelig ferdsel og fiske på vannene i vassdraget. ${ }^{25}$ Kart fra begynnelsen av 1800-tallet vitner også om at denne typen aktiviteter også har foregått etter middelalderen.

\section{Båtstøer}

I løpet av feltarbeidene i vannet Vinstre (1031 moh.) ble det oppdaget et titalls båtstøer av ulik alder. Av disse er det sannsynliggjort at mange ikke har vært brukt i nyere tid, og at de antas å ha høy alder. ${ }^{26}$

I sørvestre del av Veslefjorden, som ligger lengst vest $\mathrm{i}$ Vinstre, ble det for eksempel påvist fire båtstøer (figur 6). Tre lå samlet, mens den ene lå ca. $30 \mathrm{~m}$ lenger øst. De tre støene lengst vest sto helt under vann da de ble funnet. Den ene støen som lå øst for de tre andre, lå delvis over vann, men hoveddelen 


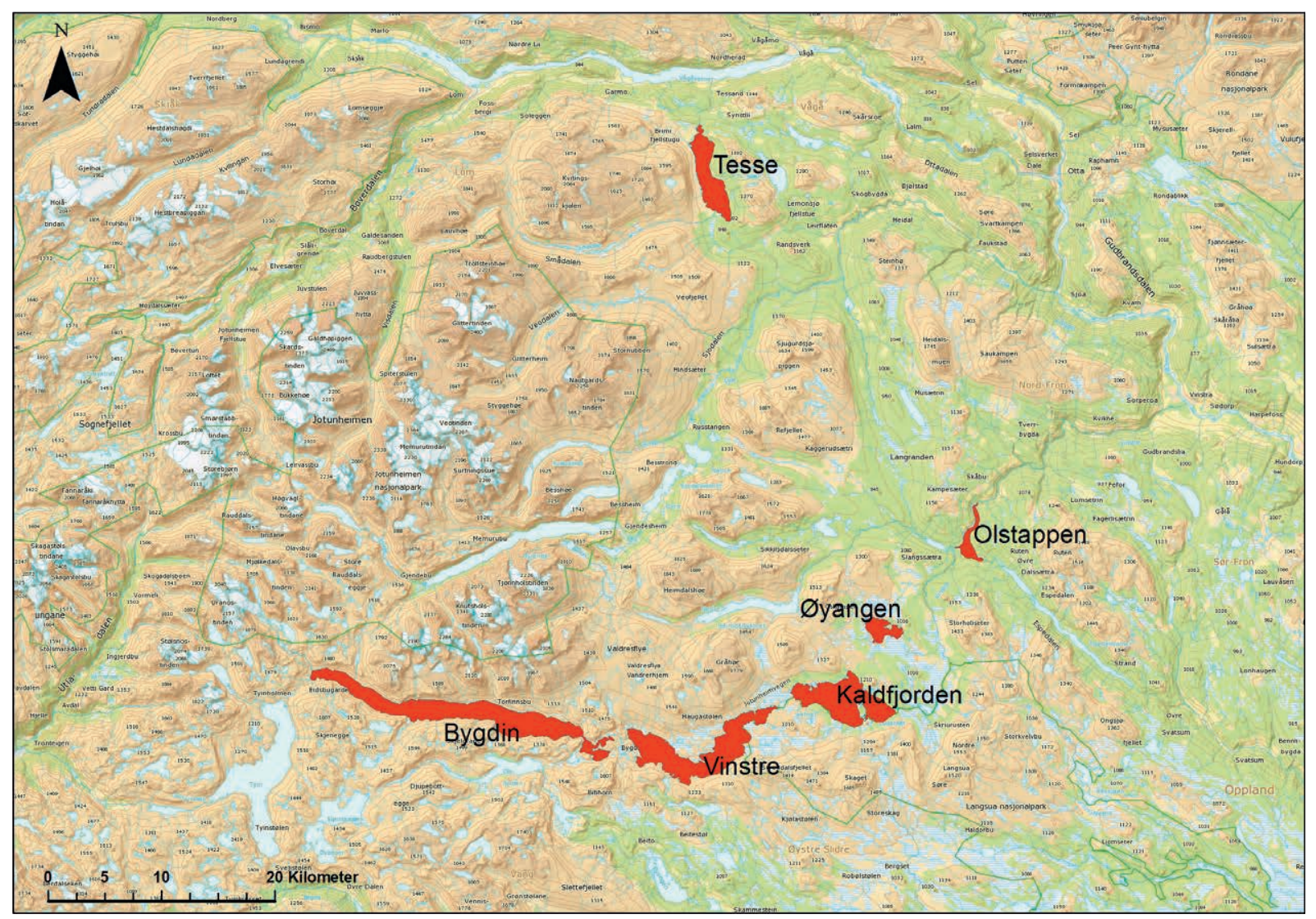

Figur 5: Kart over Vinstravassdraget og Tesse, to vassdrag som er blitt undersøkt arkeologisk de siste årene i forbindelse med fornyelse av kraftkonsesjon. Kart: Elling Utvik Wammer, Norsk Maritimt Museum.

av konstruksjonen var oversvømt. Det skulle være mulig å benytte båtstøene ved lavere vannstand. De tre støene lengst vest besto av ryddete flater med småstein og relativt store kantsteiner. Vorrene på hver side hadde et enkelt lag med store steiner, og det ble ikke observert at steiner var stablet i høyden. På den enkeltliggende støen var steiner tydelig oppstablet i bakkant, men mindre systematisk i ytre del. Det kan ikke utelukkes at båtstøens indre del har vært et fundament for en naustbygning.
Lokaliteten har en interessant beliggenhet i forlengelsen av Søre Båtskaret. Alder på lokaliteten er imidlertid ikke kjent. Det virker sannsynlig at båtstøene har vært ryddet før reguleringen på 1950-tallet, ettersom de ser ut til å være anlagt med utgangspunkt i opprinnelig strandlinje. Det er heller ikke inntegnet hverken veifar eller sti ned til denne delen av Veslefjorden fra sør på kart fra 1887. På dette tidspunktet er det imidlertid et far gjennom Søre Båtskaret og videre nordover, og vi mener det er 


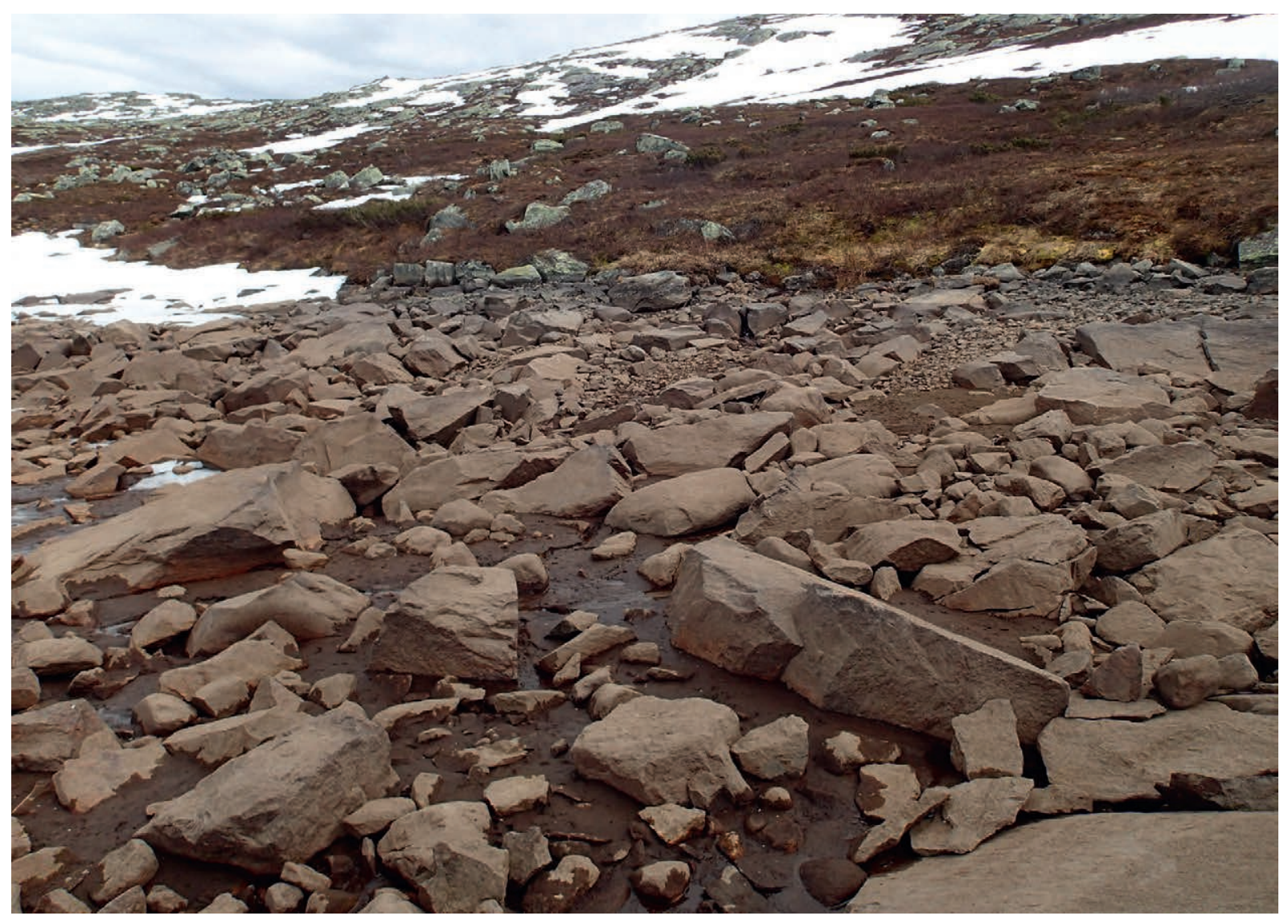

Figur 6: Båtstøer i Veslefjorden på sørsiden av Vinstre. Båtstøene ligger tørt tidlig på våren på grunn av reguleringen. Samtidig befinner de seg godt under dagens høyest regulerte vannstand og stammer derfor trolig fra før Vinstre ble et kraftmagasin. Foto: Elling Utvik Wammer, Norsk Maritimt Museum.

sannsynlig at båtstøene stammer fra denne perioden eller tidligere.

\section{Opplagsplass for båter}

I en liten vik ved Gravolsodden på sørsiden av Vinstre ble det funnet en opplagsplass for båter (figur 7). Med begrepet opplagsplass mener vi en struktur bestående av steiner som er stablet og lagt med et visst mellomrom i oval form. I motsetning til båtstøer ligger opplagsplassen noen meter opp fra vannkanten. Det finnes like eksempler fra Island. ${ }^{27}$ I Sør-Norge ble lokalitetstypen for første gang kjent gjennom undersøkelser på Hardangervidda. Elvestad ${ }^{28}$ antar at båter ble hvelvet over steinleggingene, slik at de ble liggende opp fra bakken. Steinene hindret således fukt og råte fra å trenge inn i treverket. Det er mulig å tenke seg at steinleggingene ble ansett for å være en sikrere lagringsplass enn båtstøer og andre landingsplasser. $\mathrm{Om}$ våren og høsten kunne snøen komme uten forvarsel, og det kunne gå lang tid før man igjen fikk tilgang til båten. 


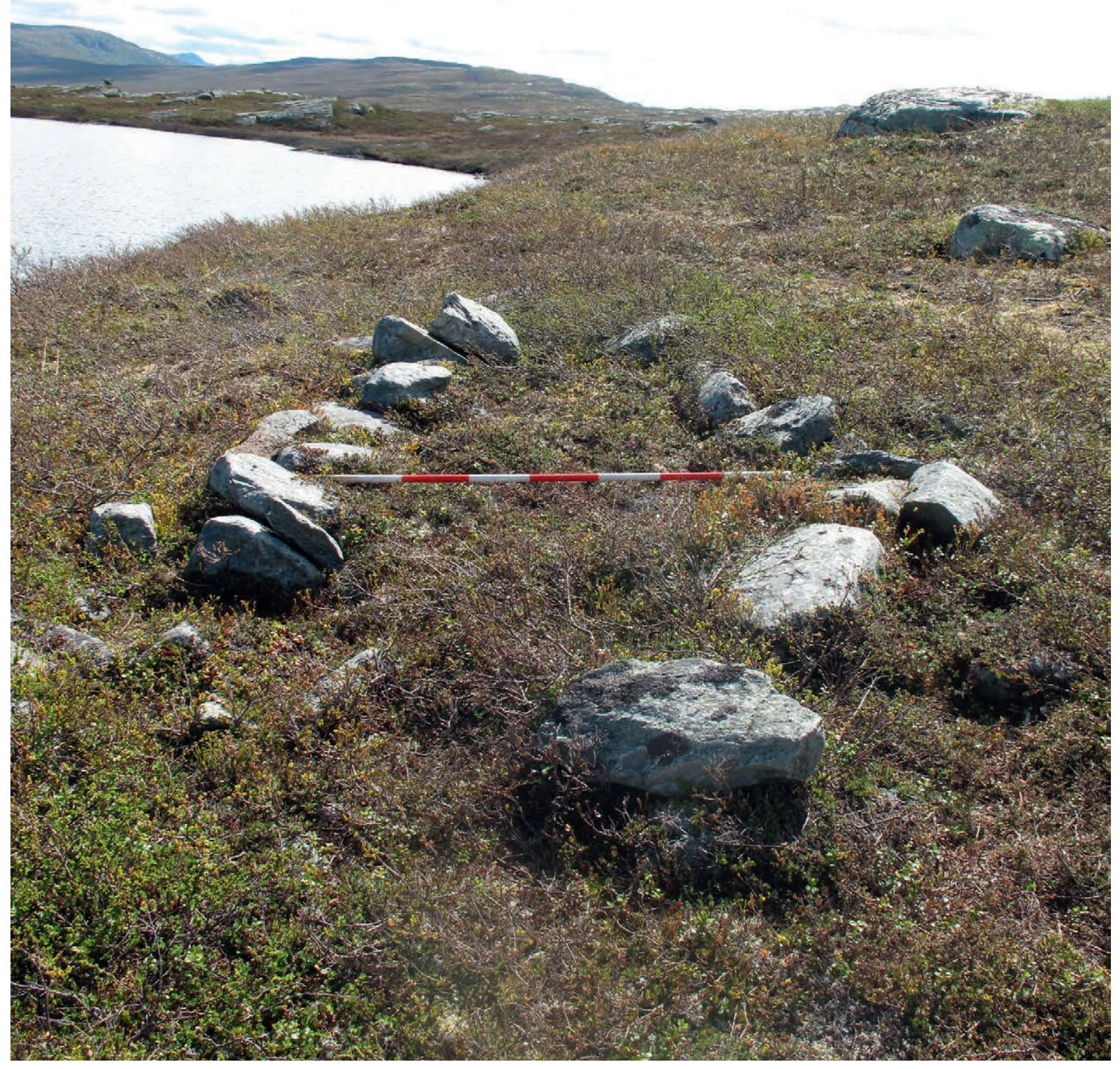

Figur 7: En av strukturene på opplagsplassen ved Gravolsodden på sørsiden av Vinstre. Foto: Elling Utvik Wammer, Norsk Maritimt Museum. 


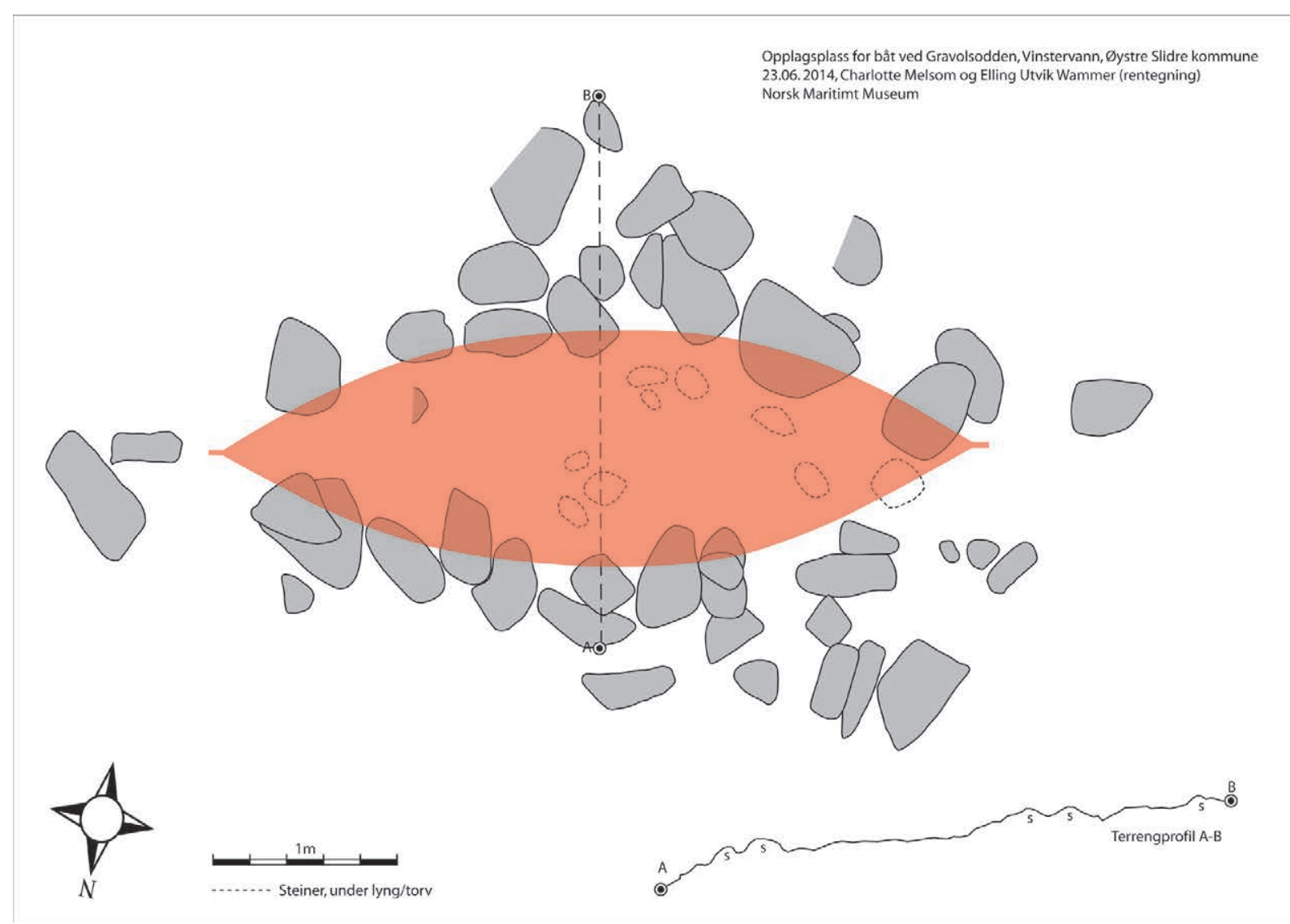

Figur 8: Skisse i plan og profil av den ene av de fire steinstrukturene på opplagsplassen. Her er det plassert omrisset av en småbåt av lokal type over, som samsvarer godt med strukturens form. Tegning: Elling Utvik Wammer, Norsk Maritimt Museum.

Lokaliteten på Gravolsodden har til sammen fire slike opplagsplasser for småbåter. De båtformete steinleggingene ligger i hellingen på et lite nes om lag tre hundre meter sørøst for en stor fangstlokalitet. Fire av steinleggingene ligger helt eller delvis åpent i dagen og er relativt intakte, selv om de stablete steinene i varierende grad har falt inn i eller utenfor strukturen. Strukturene fra Vinstre har større stein i endene som båtens akter- og baugparti hvilte på, og i ett av tilfellene danner det naturlige berget eller jordfast stein deler av strukturen. Steinleggingen som er avbildet nedenfor, er ca. 4,5 meter lang og 2-2,5 meter på det bredeste. Det er blitt gjort forsøk på å rekonstruere hva slags båter anlegget er ment for (figur 8). I illustrasjonene under er det tatt utgangspunkt i formen til en båt fra Vågå som stammer fra sent på 1700-tallet. Dette er den eldste dokumenterte båten fra regionen. Båten er ca. 4,1-4,2 meter lang. Formmessig er det også relativt godt samsvar mellom steinstrukturene og tradisjonelle små robåter. Størrelsen på båtene som 


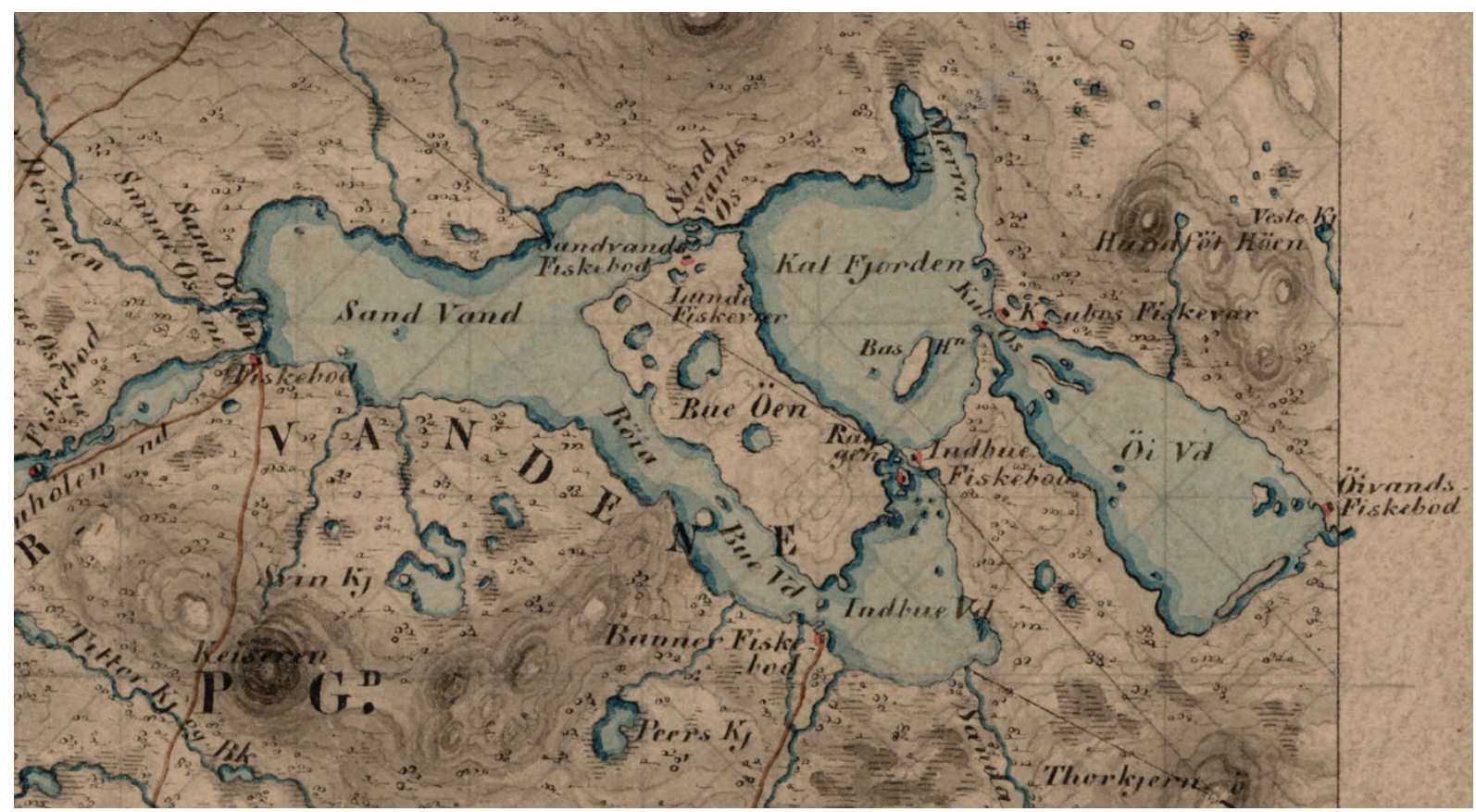

Figur 9: Utsnitt av kart over Sandvatn og Kaldfjorden fra 1831. Kartet viser flere steder fiskeboder og fiskevær rundt vannene. Kart: Kartverket (Norges Geografiske Oppmåling). Rektangelmåling 1: 100 000, 30B 8; 30B 12; 30D 4; 30D 8; 31A 5; 31A 9; 31A 10; 31C 1; 31C 2; 31C 3; 31C 5; 31C 6. 1831.

har vært i opplag ved Gravolsodden, ser imidlertid ut til å ha variert noe.

Steinleggingenes lokalisering ytterst på det lille neset kan sannsynligvis forklares av værforholdene på stedet. Det er grunn til å tro at neset blir tidlig snøfritt om våren fordi vinden blåser bort snøen, samtidig som det vil være god avrenning $i$ hellingen. At alle steinlegningene er orientert nordvest-sørøst, er nok forbundet med den dominerende vindretningen på stedet. Om opplagsplassen ble brukt hele året eller kun i bestemte årstider, er foreløpig uvisst.

Dateringen av lokaliteten ved Gravolsodden i Vinstre er ikke avklart. En av de båtformete steinlegningene på Hardangervidda ${ }^{29}$ er funnet nær boplassen Store Krækkja, som er datert til jernalder og middelalder. Steinleggingene fra Vinstre kan stamme fra samme tidsperiode. Opplagsplassen er ikke markert på historiske kart fra 1881 og 1883, og det er heller ikke tegnet inn veifar eller andre transportveier ned til neset. Dersom stedet hadde vært i bruk etter reformasjonen, ville det trolig vært et viktig knutepunkt for ferdsel i landskapet og mest sannsynlig avmerket på kart. Søk med metalldetektor i og utenfor strukturene førte til funn av ulike metallbiter, blant annet båtnagler. Naglene er av en nyere type som kan ha vært i bruk til opp på 1900-tallet.

\section{Sandvatn og Kaldforden}

I forbindelse med feltarbeid i Vinstravassdraget gjennomførte museet også arkeologisk undersøkelser i Kaldfjorden. På et kart over Kaldfjorden fra 


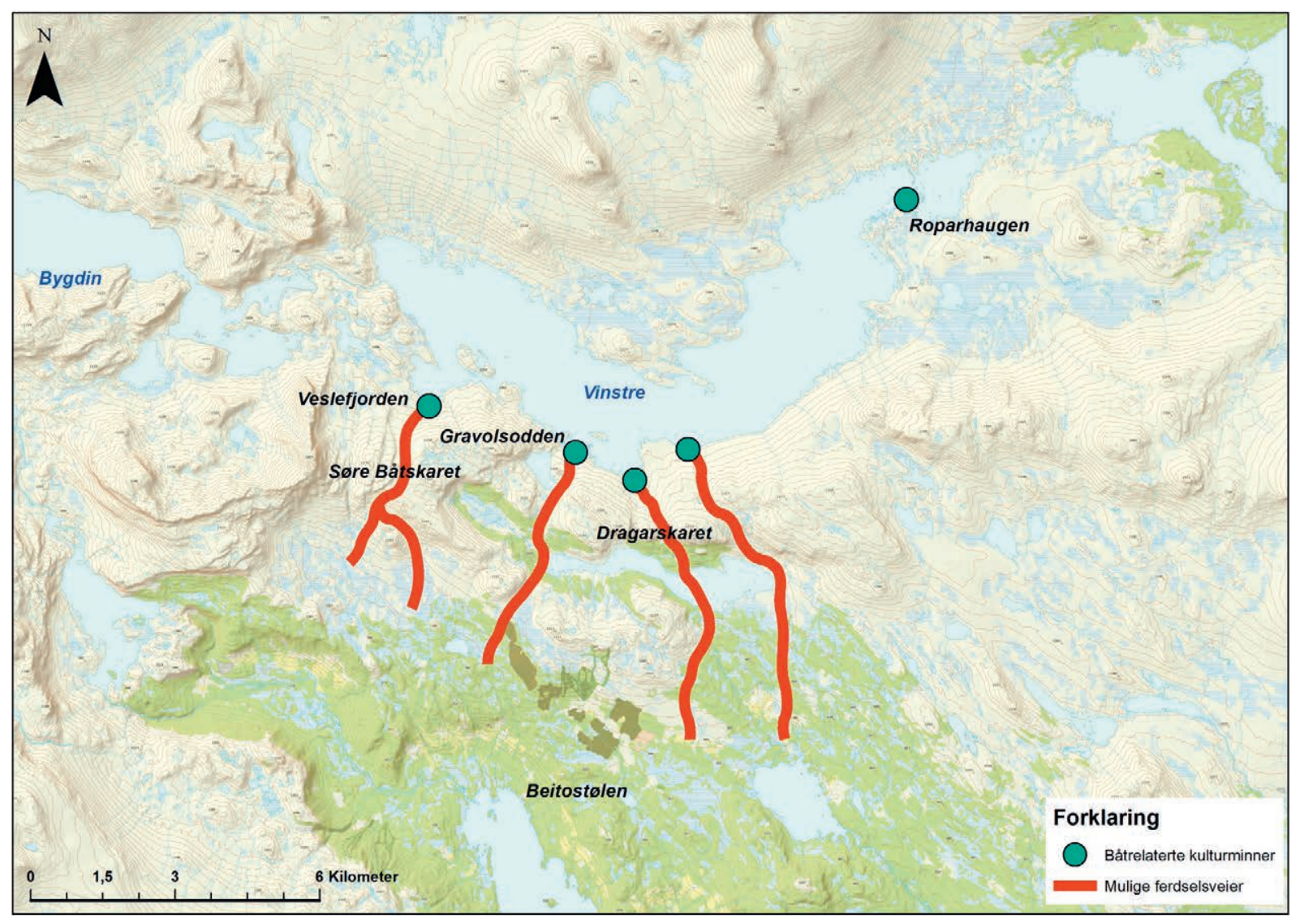

Figur 10: Kart over mulige ferdselsruter og sentrale kulturminnelokaliteter ved Vinstre samt stedsnavn nevnt i teksten. Kart: Elling Utvik Wammer, Norsk Maritimt Museum.

1831 står det flere navn som beskriver forskjellige aktiviteter knyttet til fiske, blant annet fiskevær og fiskebuer (figur 9). Disse navnene er gjerne plassert der det før reguleringen var os mellom vann, eller der bekker renner ut i vannet. Flere av stedene viser også til gården eller familien som har eid fiskebua, og sier noe om rettigheter til fiske.

Museet dykket på flere av stedene der det skal ha stått fiskebuer eller vært fiskeplasser. Da reguleringssonen i Kaldfjorden stedvis er svært utvasket som en følge av reguleringen og av at det er utført anleggsarbeid flere steder, var det vanskelig å påvise rester etter bebyggelse. ${ }^{30}$ Det ble likevel funnet rester etter en mulig fiskebu på om lag 2 meters dybde ved Kubosen fiskevær.

Det har tegnet seg et interessant mønster i de lokalitetene i Vinstre som blir ansett for å ha potensielt høy alder (figur 10). Felles for områdene med konsentrasjoner av eldre kulturminner knyttet til ferdsel på vannet er at de ligger i forlengelsen av naturlige ferdselsårer fra sør. Lokaliteter i Veslefjorden, Gravolsodden, Karifjorden, Oleskarbuene og Store Straumen karakteriseres av en slik beliggenhet. Skar og daler i et ellers vanskelig framkommelig 
fjellterreng har trolig kanalisert ferdselen til visse soner. Det er dermed belegg for å tolke disse stedene som knutepunkter for ferdselen i området og for å kunne si at deler av den historiske ferdselen har gått på tvers av vannet (nord-sør).

I en av de egnete fjellpassasjene til Vinstre fra sør finner man stedsnavnet Dragarskaret. ${ }^{31}$ Muntlig tradisjon knytter stedsnavnet til forflytning av båter inn til Vinstre i eldre tid. Navnet kan være en sammenstilling av drag, som betegnelse på noe som blir slept eller dratt, og skar, det vil si en kløft av en viss størrelse. Her kan vi kanskje se en parallell til drageid, brukt om steder hvor båter ble dratt over land både på kysten og i innlandet. ${ }^{32}$ Ut fra terrengets beskaffenhet er det ikke usannsynlig at båter og/eller varer er blitt fraktet fra Beito, først over Olevann og deretter gjennom Dragarskaret til Vinstre. Ved vannkanten der Dragarskaret ender i Vinstre, finnes en liten bukt, som utpeker seg som en av få egnete steder å sette ut båter langs sørsiden av Vinstre.

Lenger vest finner vi to tilsvarende fjellpassasjer, som bærer navnene Søre og Nordre Båtskaret. Også disse navnene indikerer at det her har vært frakt av båter over fjellet, til bruk på Vinstre. I nyere tid har seterbebyggelsen ligget på den solrike og flatere nordsiden av vannet, mens bygdene som har utnyttet området, lå på sørsiden. Frakt av folk og varer på tvers av vannet kan ut fra dette se ut til å være en ellers lite kjent del av områdets historie knyttet til ferdsel. Et stedsnavn som trolig kan knyttes til det samme ferdselsmønsteret, er Roparbaugen, ved et smalt sund på sørsiden av vannet. Steder med dette navnet kan trolig kobles til historiske fergesteder, det vil si steder hvor folk har tilkalt båtskyss ved å rope over til motsatt side av vannstykket. ${ }^{33}$

Det er grunn til å tro at fiske har vært en betydelig del av næringsgrunnlaget langs nordsiden av vannet, som nevnt tidligere i artikkelen. Også stedsnavn i Vinstre kan antakelig kobles direkte til fiske. Sør for
Holmen, som framstilles som et fiskevær/fiskebu på kart fra 1800-tallet, finner vi navnet Fiskesva. Første stavelse er selvforklarende, mens sva antas å bety «grunne», «banke» eller lignende. Navnet tilsier dermed at stedet har vært et godt og mye brukt fiskested.

\section{BÅTRELATERTE KULTURMINNER I TESSE}

Fjellvannet Tesse ligger i et område med fjell på flere kanter og med et bratt skrånende landskap mot nord, ned i Ottadalen. Tesse er avlangt, men står ikke i forbindelse med andre vann på samme måte som vannene i Vinstravassdraget. Vannstanden i Tessemagasinet er regulert ca. 1 meter over det opprinnelige nivået og tappes helt ned til 10-12 meter under opprinnelig vannstand om våren. Ettersom landskapet ved selve vannet er relativt slakt, fører det til at svært store arealer blir eksponert.

Ørretfisket i Tesse har en svært stor historisk betydning. Rundt fjellvannet Tesse skal det fram til reguleringen ha vært et større antall naust. ${ }^{34} \mathrm{I}$ dag er imidlertid ingen av de eldre naustene i Tesse bevart. Stedsnavn som Naustviki, som finnes på nordsiden av neset Volnebben, forteller at det opprinnelig har stått bygninger av denne typen her. I de to feltsesongene ved Tesse ble strandsonen rundt hele vannet kartlagt. Kun rester av to naust ble gjenfunnet og dokumentert. Årsaken til at så få naust er blitt bevart i Tesse, er i stor grad hevingen av vannet med en meter. Man antar at store flommer og ras også før den tid kan ha dratt av gårde med slike bygninger. Den mest kjente herjingen skjedde nok i forbindelse med flommen Storofsen i 1789.

\section{Naustet på Nordre Byrtnes}

En antatt nausttuft ved Nordre Byrtnes nord i Tesse ble grundigere undersøkt. ${ }^{35}$ Tufta hadde vært kjent av lokalbefolkningen i lengre tid, og funnet hadde vekket undring også blant fagfolk. Hva var dette slags 


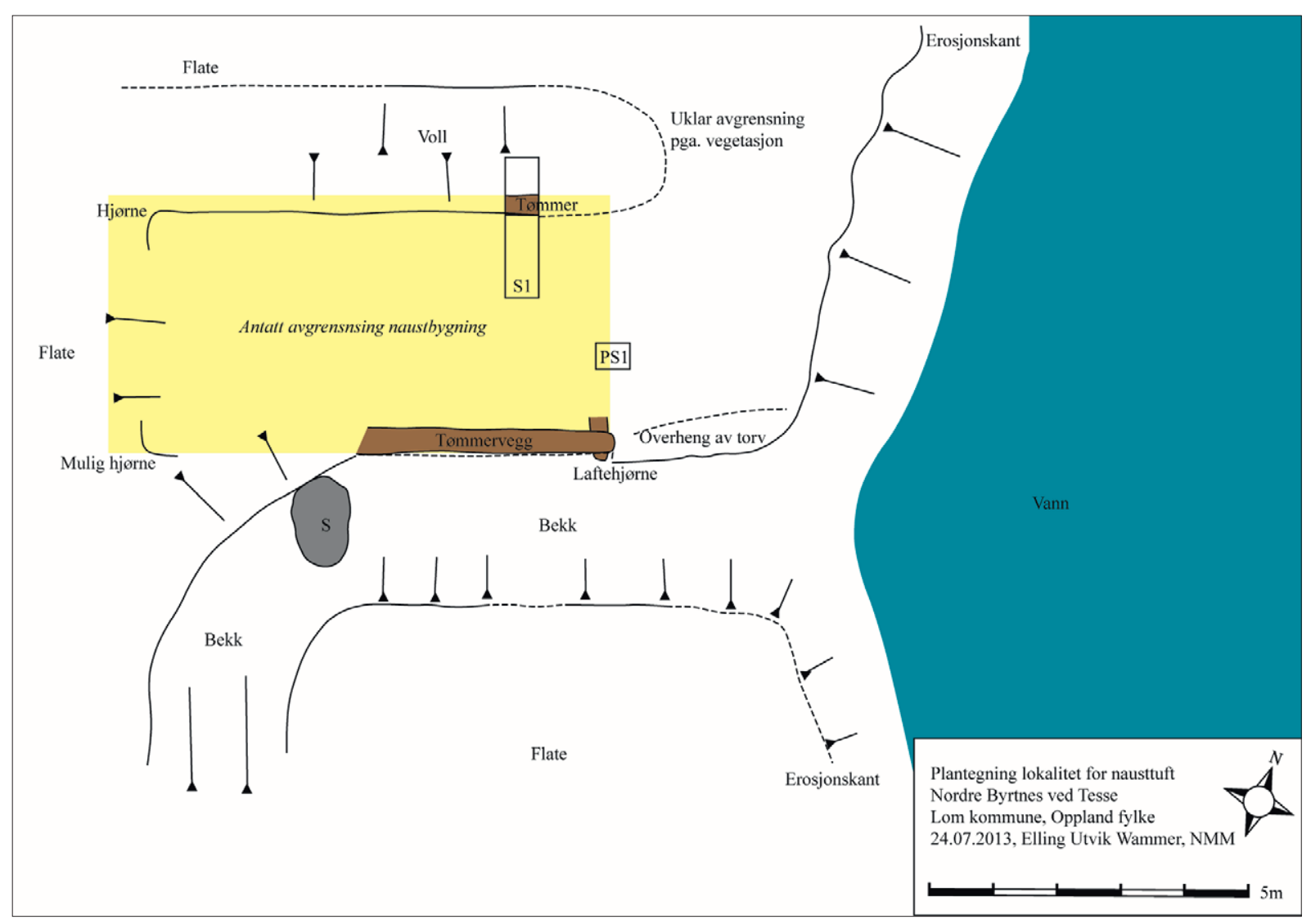

Figur 11: Planskisse over nausttufta på Nordre Byrtnes i Tesse og de undersøkte delene av kulturminnet. Tegning: Elling Utvik Wammer, Norsk Maritimt Museum.

bygning? Hvor gammel kunne den være? Tufta besto av framvasket treverk i et to meter dypt bekkeløp nede ved vannet (jf. figur 11 og 12). Stokkene var begrodd av mose og dekket av sand og grus. Ovenpå øverste synlige stokk lå et ca. 0,5-1 meter tykt lag med løse masser. Noen meter mot nord kunne man også ane en lav voll med tilsvarende lengderetning som stokkene. Området var ellers begrodd av lave einerbusker og vierkjerr.

Undersøkelsen innledet med å rense fram den antatte langveggen i bekkefaret. Under opprensingen av den søndre langveggen ble det i økende grad observert fordypninger og sprekker i treverket, som forsterket inntrykket av at det var laftete stokker. I den østre enden kom det etter hvert til syne lafteknuter, som dermed dannet et hjørne i bygningen. I forbindelse med opprensingen av langveggen $\mathrm{i}$ bekkefaret ble det oppdaget et parti med kullholdig jord i underkant av stokkene. I disse massene ble det funnet et stort antall jernfragmenter, hvorav flere er tolket som korroderte nagler. 


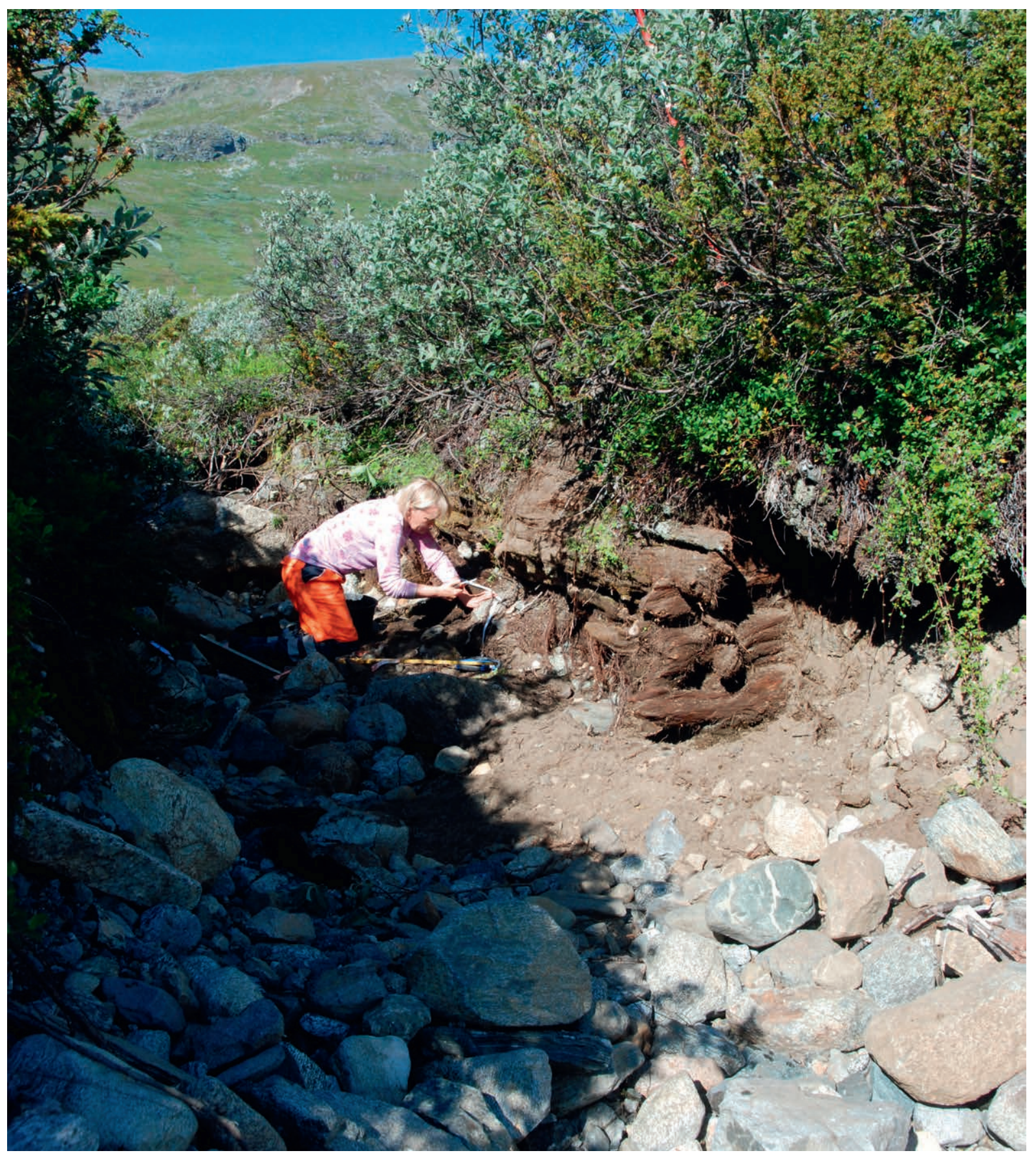

Figur 12: Fra undersøkelsen av naustet på Nordre Byrtnes ved Tesse. Graving og opprensking av søndre langvegg. Foto: Elling Utvik Wammer, Norsk Maritimt Museum. 
Deretter gravde vi en avlang sjakt fra utsida av tufta i nord og inn i tufta gjennom vollen. Hensikten var å avklare om det fantes en laftevegg i vollen. Ca. $70 \mathrm{~cm}$ under overflaten i vollen fant vi sammenhengende treverk parallelt med stokkene i den søndre langveggen. Treverket var ganske nedbrutt i toppen, men ble kraftigere dypere ned. Massene under vollen besto av grov grus med mye stein, mens det inne i naustet var hovedsakelig finkornet, gråbrun sand.

Bygningen på Nordre Byrtnes i Tesse har mange trekk som kjennetegner tradisjonelle naust. Den er avlang og har passende størrelse til å romme en småbåt av for eksempel færingstype. Laftekassen heller svakt ned mot vannet og har kortsiden henvendt den veien, noe som er et typisk trekk ved naust. Funn av båtnagler ved den søndre veggen indikerer også båtreparasjon eller lignende på stedet. Utskiftning av sømmen var en regelmessig nødvendighet.

To C14-prøver ble tatt av ytterved fra de nedre stokkene i søndre vegg, hvorav en ble sendt til datering. Resultatet viste tre mulige dateringer, alle innenfor tidsrommet $1640-1950$ e.Kr. ${ }^{36}$ Sannsynligheten er som nevnt stor for at bygningen er blitt overdekket av løsmasser i forbindelse med et ras eller en flom, og Storofsen i 1789 peker seg naturlig ut som en hendelse som kan ha forårsaket dette. Den eldste av de tre dateringene er derfor mest sannsynlig (16-1700-tallet). Muligheten for at naustet sto da rasmassene kom, gjør det spennende å undres på hva det kan inneholde. Man kan ikke utelukke at naustet på Nordre Byrtnes inneholder både fiskeredskaper og båt.

Med tanke på at et av kjerneområdene for fiskesøkker i Tesse er like utenfor, utgjør naustet et svært spennende kulturminne. Naustet blir stadig mer erodert av både bekken og reguleringen; derfor vil det av både faglige og forvaltningsmessige årsaker bli videre undersøkt ${ }^{37}$.

\section{KUNNSKAPSPOTENSIALET I}

\section{BÅTRELATERTE KULTURMINNER I FJELLET}

I strandkanten langs fjellvann er det gjerne spor i terrenget som viser at båter er blitt satt på land. I mangel av farkoster er de båtrelaterte kulturminnene derfor viktige primærkilder til kunnskap om at et vann eller en innsjø har vært brukt av mennesker i fortida. Felles for disse kulturminnene og det som gjør dem spesielt interessante, er at de kan gi oss kunnskap om knutepunkter for både ferdsel og annen aktivitet i landskapet. Landingsplasser kan dermed være viktige når vi skal forstå beliggenheten til andre typer kulturminner, slik som boplasser, jakt- eller fangstlokaliteter og gamle veifar.

Naust og båtstøer som kildekategorier kan også fortelle oss mye om båtbruk i forbindelse med fiske. ${ }^{38}$ I en innsjø eller et vann vil blant annet antallet naust kunne indikere hvor aktivt fiske det har vært på stedet. Arkeologiske undersøkelser av naust vil kunne gi kjennskap til hvilke tidsperioder bygningene har vært i bruk i; dermed belyses også fiskets historie. Størrelsen på bygningene gir indikasjoner på hva slags båter som har vært i bruk på vannet. I tillegg har gjerne naustet vært et sted hvor også andre aktiviteter har foregått, slik som reparasjoner og vedlikehold av båter, lagring av fiskeutstyr og så videre. I vannet utenfor et naust kan det dessuten forekomme gjenstandsfunn av fiskeredskaper som kan bidra til å belyse hvor stort fisket har vært, og hvilke fiskemetoder som er brukt.

Det ligger trolig et uutnyttet potensial for ny kunnskap om fiske i fjellet gjennom undersøkelser av båtrelaterte kulturminner. Som for de aller fleste kulturminner gjelder det også for disse at de sjelden forstås fullt ut uten å ses i sammenheng med omkringliggende funn eller landskap. Der et større antall og gjerne varierte typer kulturminner inngår i en helhet, snakker vi ofte om kulturmiljøer. 


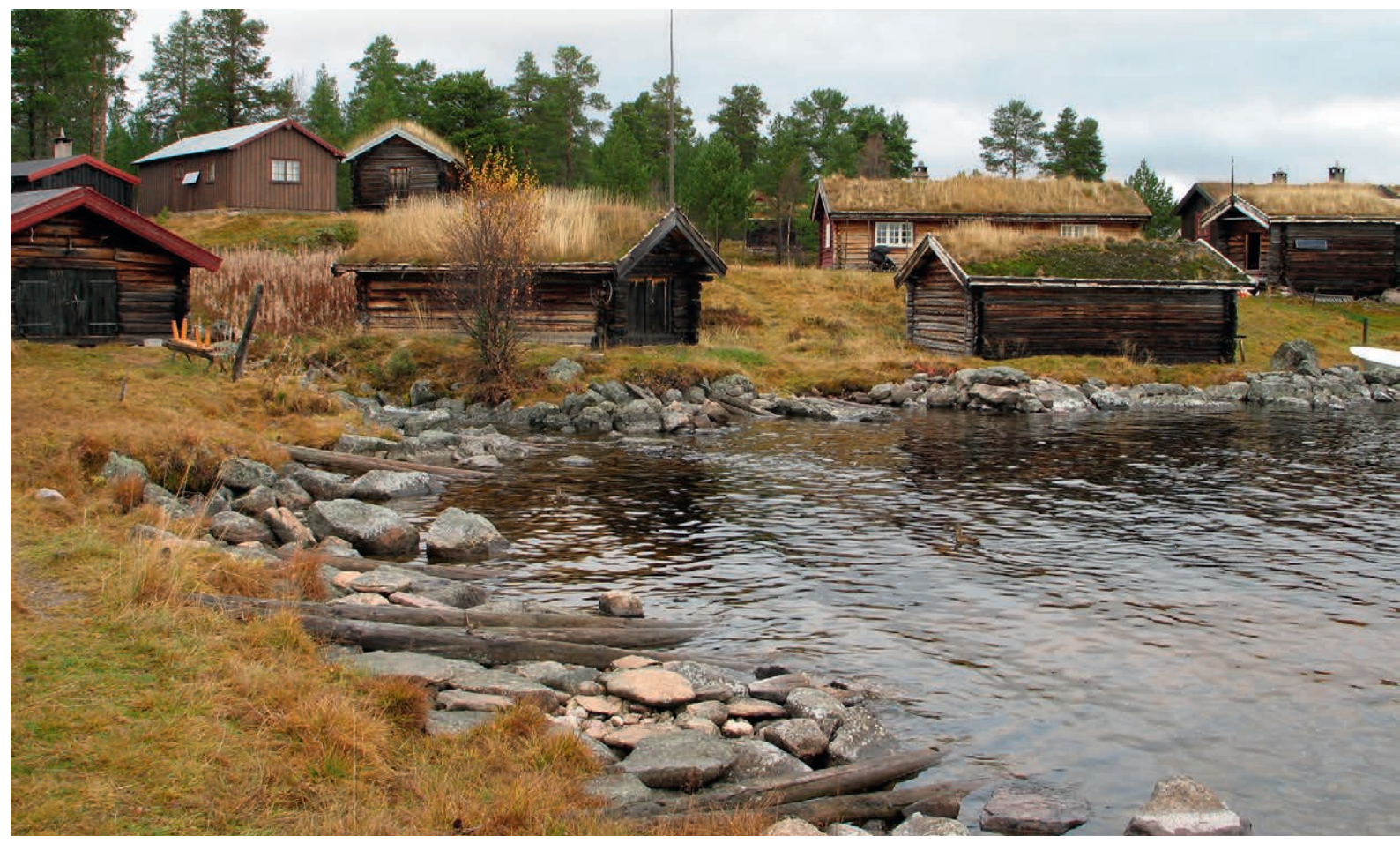

Figur 13: Fiskeværet ved Sølensjøen i Rendalen kommune i Hedmark. Ved Fiskevollen er det er avdekket spor etter fiske med kontinuitet langt bakover i tid. De eldste husene som nå står på Fiskevollen, ble trolig oppført en gang på 1700-tallet. Her er i dag naust, kjell og fiskebuer som ligger tett i tett langs strandkanten. Foto: Sivilarkitekt MNAL Magne Kvam, Hedmark fylkeskommune.

Fiskevær som fenomen forbindes ofte med vestog nordnorsk bosetningshistorie og fisketradisjoner på kysten. I enkelte fjellbygder på det indre Østlandet, hvor man har vært langt fra de fiskerike elvene, ble det imidlertid også etablert fiskevær langt inne i fjellet. Med dette menes sesongvise bosettings- og aktivitetsområder rettet spesifikt mot fiske. På slike steder kan vi finne noe vi kan kalle kulturmiljøer, hvor båten har spilt en sentral rolle. Fiskevollen ved Sølensjøen i Hedmark er et klassisk eksempel og samtidig en illustrasjon på den betydelige båtrelaterte aktiviteten som kan knyttes til et fjellvann (figur 13).

Ifølge Jacob B. Bull går rendølenes lottfiske i Sølensjøen tilbake til tidlig middelalder. ${ }^{39}$ Det er imidlertid vanskelig å si noe om omfanget av det fisket som ble drevet der før 1700-tallet. På den lille halvøya Grøtgarden, omkring 50-100 meter sørøst for dagens bebyggelse på Fiskevollen, ble det i 1913 funnet en vikingtidsgrav. Dette var en branngrav under flat mark som inneholdt et tveegget sverd, en øks, åtte pilspisser, en kniv, et beslag, et ildstål og et flintstykke. Gravgodset er datert til tiden omkring 900 e.Kr. og har vært tolket som en fangstmarksgrav. ${ }^{40}$ Året etter, i 1914, foretok Jacob B. Bull og Reodor Vardenær nye undersøkelser av graven. Omkring en halv meter fra foregående års våpenfunn fant de det som er tolket som en nettflottør. ${ }^{41}$ Ifølge arkeologen Arne Skjølsvold er 
det grunn til å tro at denne nettflåa må ha tilhørt det opprinnelige gravgodset. Funnet av nettflåa skulle derfor tyde på at det alt i det 10. århundre ble drevet fiske i Sølensjøen. Noen fast bosetning er det neppe tale om, men funnet tolkes som spor etter sesongfiske. ${ }^{42}$

På tross av at vi kjenner til at det forekommer fiskevær i fjellet langt tilbake i tid, er vår kunnskap om kulturmiljøer som Sølensjøen mangelfull. I tillegg til Fiskevollen finnes også de noe mindre kjente Elvålsvollen og Haugsetvollen ved Isteren og Buvika ved Femunden i Hedmark fylke. En av grunnene til at vi vet så mye om Hedmark, er at fjellfisket $i$ dette fylket holdes $i$ hevd ennå i våre dager. I vårt arbeid med historisk kartmateriale fra Vinstravassdraget er vi blant annet kommet over flere steder som benevnes som fiskevær. Hva skulle til for at et sted i fjellet ble regnet som et fiskevær?

Både når det gjelder å identifisere slike kulturmiljøer, og når det gjelder å kartlegge bruksperioder, er det et trolig et stort potensial for ny kunnskap, hvor de båtrelaterte kulturminnene står sentralt. Denne kunnskapen vil kunne gi økt forståelse av kompleksiteten i fjellfisket - både dets betydning lokalt for omkringliggende bygder og fiskens betydning som handelsvare. Kanskje ville vi sett på Tesse også som et fiskevær om ikke Storofsen og reguleringen hadde dratt av gårde med naustene? Framtidige kartlegginger og undersøkelser av båtrelaterte kulturmiljøer i fjellet kan kanskje vise at Fiskevollen i Sølensjøen ikke er så unik som vi tror.

\section{ARKIVALIER SOM OMHANDLER FJELLFISKE}

I tillegg til de fysiske sporene vi så langt har sett på, finnes det et stort antall arkivalier bestående av skriftlige kilder, eldre kart og nedtegnelser av muntlige kilder fra fjellområdene. Vi skal kort gjennomgå hvilken kunnskap disse kildene gir oss om fjellfisket.

\section{Trykte kilder om fiskeretter}

Det skriftlige kildematerialet som i størst grad omhandler fjellfiske, er lover og rettsdokumenter fra middelalder og fram til 1700 -tallet. ${ }^{43} \mathrm{I}$ historiske kilder foreligger det også skildringer av stridigheter og sosiale forhold knyttet til fiske. Disse kildene kan gi perspektiver på omfanget av og tradisjoner forbundet med fiske. Det skriftlige kildematerialet bidrar dessuten til å stedfeste historiske hendelser og viser dermed til hvor det har vært aktivitet forbundet med fiske.

Til å belyse dette kan beskrivelser av fiskestridigheter i Kaldfjorden og Sandvatn i Øystre Slidre i Nord- og Sør-Fron kommuner være egnete eksempler. Fisket $i$ Kaldfjorden må ha vært en svært viktig ressurs for de omkringliggende bygdene langt bakover $i$ tid. Det er kjent at det har vært stridigheter mellom gudbrandsdøler og valdriser om fiske siden middelalder. I 1468 skal blant annet folk fra Valdres ha skutt en ung gutt fra Sør-Fron og kastet liket opp på taket på en fiskebu ved Raggen. ${ }^{44} \mathrm{Om}$ Sandvatnet var det feid mellom bøndene i Fron og Øystre Slidre, blant annet i 1722 og 1724, da bøndene fra Fron hadde revet ned en fiskebu og tatt bort en fiskebåt for slidringene. Stridighetene mellom gudbrandsdølene og valdrisene skal ha vart til langt opp på 1800 -tallet. ${ }^{45}$

\section{Eldre kartmateriale}

Gamle kart fra fjellet kan inneholde mange opplysninger om bruken av landskapet og organiseringen av fisket i fjellvann. De kan danne et viktig utgangspunkt for arkeologiske undersøkelser og utfylle bildet der de materielle sporene ikke er bevart. Hvis man også får anledning til å sammenstille kartmateriale med skriftlige kilder, blir den kulturhistoriske kunnskapen ekstra interessant.

\section{Stedsnavn}

I sin redegjørelse for begrepet det maritime kulturlandskapet framhever Christer Westerdahl ${ }^{46}$ 
betydningen av stedsnavn for maritime arkeologiske tolkninger. I tilknytning til Vinstre i Øystre Slidre har vi registrert flere interessante lokaliteter ved sammenstilling av navn og topografi. Langs sørsiden av vannet er det en lang rekke med relativt bratte fjell, som skiller vannet fra de lavereliggende områdene rundt Beito, hvor den kjente bosetningen og aktivitetsområder for blant annet jernproduksjon har vært fra eldre tid. Flere av de farbare passasjene over fjellet har navn som kan kobles til ferdsel, og samtidig har de et maritimt preg.

En utfordring ved bruken av stedsnavn i arkeologiske analyser er at de kan være vanskelige å tidfeste. Navnene kan ha kommet til i senere tid, og det vil derfor kunne oppstå feilslutninger. I tillegg kan omskrivinger og lokale dialekter utgjøre feilkilder som må tas i betraktning. Brukt kildekritisk er det imidlertid liten tvil om at stedsnavn er gode hjelpemidler når man skal forstå den fortidige bruken av landskapet, ettersom de ofte framhever sentrale elementer i fortidens mentale landskap.

\section{AVSLUTNING}

Det er per i dag kjent kun et mindre antall båtrelaterte kulturminner i fjellet i nasjonale registre, slik som Riksantikvarens Askeladden-base (figur 14). Mangelen på arkeologiske registreringer rettet mot slike kulturminner i fjellet gir grunn til å tro at denne gruppen av kulturminner kan være underrepresentert i Sør-Norge, både i forhold til andre kulturminnetyper i fjellet og i forhold til tilsvarende lokaliteter ved kysten. Dette kan ha bidratt til at temaer som fjellfisket heller ikke har fătt den plassen de fortjener. Begrenset vektlegging av sporene etter bruken av vann og vassdrag er også symptomatisk for både forskning og den generelle historiefortellingen om de norske fjellområdene. ${ }^{47}$

Det blir gjerne hevdet at tradisjonelle landarkeologer står med ryggen vendt til sjøen, mens vi som maritime arkeologer står vendt med blikket

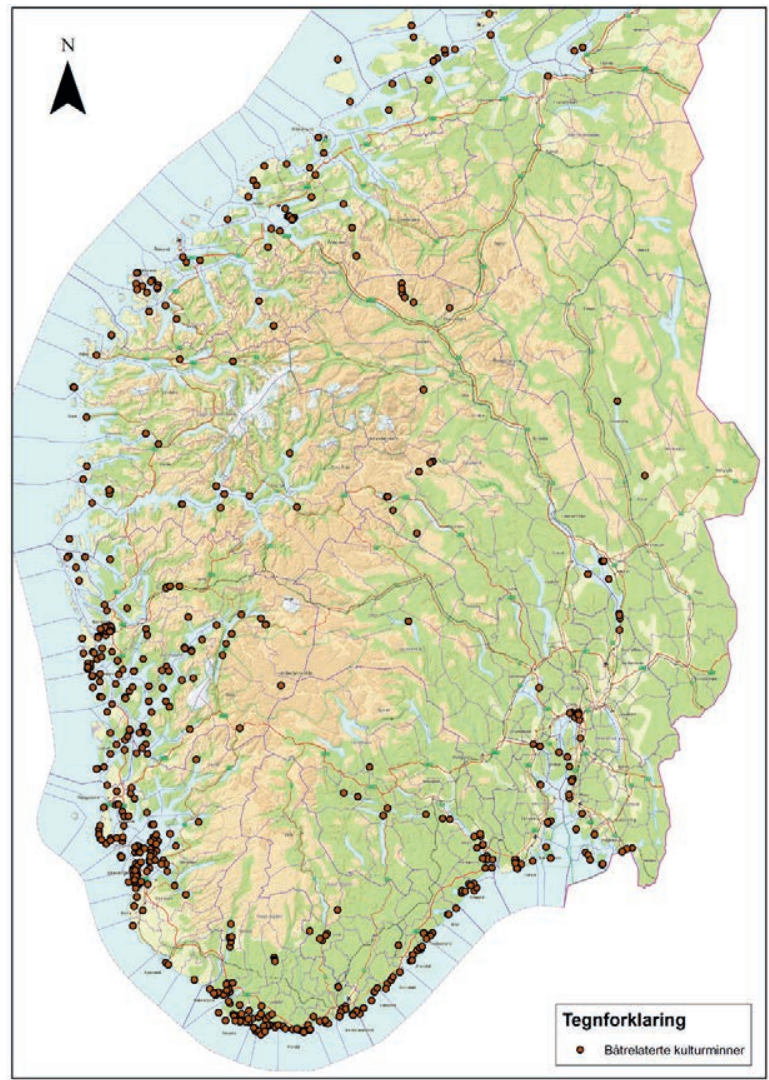

Figur 14: Kart over kjente båtrelaterte kulturminner i Sør-Norge. Posisjoner fra Riksantikvarens database over automatisk fredete kulturminner, Askeladden. Kart: Elling Utvik Wammer, Norsk Maritimt Museum.

rettet ut mot havet. Denne beskrivelsen er i høy grad riktig også i fjellet. Helt fram til de senere årene var det steinalderboplasser som ble prioritert som utgravningsobjekter i fjellet, i tillegg til hustufter, jernvinneplasser og fangstgroper. ${ }^{48}$ Samtidig var maritim arkeologi lenge en vitenskapsgren som i stor grad var konsentrert omkring skipsvrak. Sonen mellom de to perspektivene har derfor hatt en tendens til å bli glemt. I tillegg er manglende kunnskap om datering selvforsterkende i den norske 
kulturminneforvaltningen ettersom kun automatisk fredete kulturminner kan undersøkes.

På flere måter kan vi si at de båtrelaterte kulturminnene i fjellet lider samme skjebne i norsk arkeologisk forvaltning som de maritime kulturminnene og kystkulturen lenge har gjort. Fjeresteinsarkeologi er en term som Grete Lillehammer foreslo for Riksantikvaren på 1990-tallet som et ledd i arbeidet med å løfte de maritime kulturminnene. Begrepet defineres som «kystkulturen fra de eldste tidene og fram til nyere tid som et tverrfaglig forskningsfelt for å sette fokus på materielle og immaterielle kulturminner og kulturmiljøer mellom land og sjø». ${ }^{49}$

En større vektlegging av kulturminner i strandsonen langs fjellvann og vassdrag, både blant landarkeologer og blant oss maritime arkeologer, tror vi har mye for seg. De båtrelaterte kulturminnene bør som vi har sett i denne artikkelen, også settes i en kulturhistorisk sammenheng. Et styrket samarbeid mellom forskere fra ulike fagfelt, for eksempel etnologi og historie, vil trolig være svært nyttig. Fjellfisket er en tematikk som egner seg godt for slike samarbeid. Sett fra vår side er det derfor gledelig at Riksantikvaren nå setter søkelyset på innlandsfiske i sin strategiske vernestrategi. Dette gir også håp om et løft for de båtrelaterte kulturminnene i fjellet.

SUMMARY:

BOAT-RELATED CULTURALHERITAGE SITES IN THE ALPINE REGION AS SOURCES OF KNOWLEDGE OF FISHING IN THE PAST

Boats are the basis of all waterborne traffic during the summer months in the mountains. This includes fishing since common methods of line, net, and hook fishing were, for the most part, conducted while on board boats. In this article, we investigate certain cultural-heritage sites in the mountains that are relevant to travel on water. Of primary interest are two large excavations from Vinstravassdraget and Tesse in Oppland. Our goal with this article is to discuss what kind of knowledge can be gleaned from boat-related cultural-heritage sites in the mountains and how this information can be used to further our understanding of fishing practices conducted there.

There are very few boat-related culture-heritage sites from the mountains to be found in the national register. Because so few archaeological surveys have been directed toward finding these types of sites, it is possible that they are underrepresented in southern Norway in relation to other types of mountain sites. Until recently, it was Stone Age habitations sites, house foundations, iron production sites, and hunting pits that were seen as the only types of sites worthy of investigation.

After finding a number of cultural-heritage sites on the shores of mountain waterways in the recent projects, we believe there is much to say on this topic. A vigorous collaboration by researchers from various fields of expertise, e.g., ethnology and history, would be very productive. Fishing practices in the mountains is a subject that would greatly benefit from this type of interdisciplinary cooperation. 



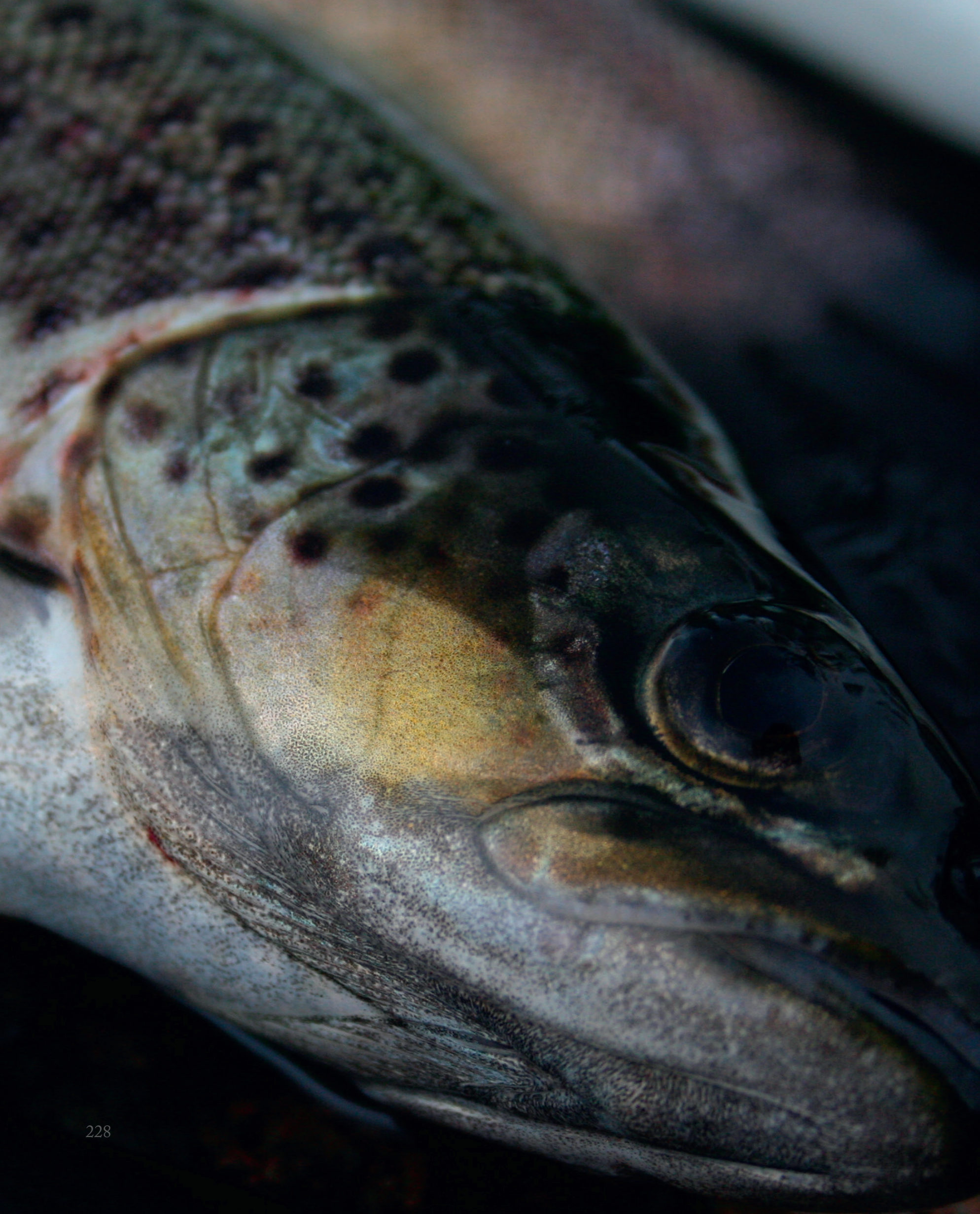




\title{
EPILOG: \\ NOEN PESSIMISTISKE TANKER OM TILSTANDEN TIL KULTURMINNENE VED VÅRE FJELLVANN
}

\author{
Axel Mjarum og Ellen Kathrine Friis, Kulturhistorisk museum, Universitetet i Oslo
}

På tross av flotte funn og ny kunnskap har undersøkelsene ved Tesse gitt grobunn for ettertanke. Hvordan er egentlig tilstanden til kulturminnene i den sørnorske fjellheimen?

I hele Norge finnes det så mye som 500000 små og store vann, hvorav halve ferskvannsarealet er regulert til vannkraftproduksjon (se figur 1 ). ${ }^{1}$ Sytti prosent av de større vassdragene er da også berørt av energiutbygging, og mange av vannkraftverkene ligger i tilknytning til fjellheimen. Den omfattende utbyggingen i fjellområdene skyldes blant annet at nedbørsrike arealer med store høydeforskjeller gir et godt grunnlag for energiproduksjon. ${ }^{2}$ Selv om 400 vassdrag og vassdragsområder er gitt et delvis vern gjennom verneplaner, ${ }^{3}$ er det ikke tvil om at fjellområdene i Sør-Norge er sterkt preget av inngrep.

Mange av fortidens aktiviteter i fjellheimen har foregått på og ved de tidligere strendene, og en spesielt stor del av virksomheten har vært knyttet til de store vassdragene og innsjøene. Dette skyldes delvis at vann og elver har vært viktige ferdselsårer, og følgelig har vannkanten vært et naturlig stoppested og et utgangspunkt for transport. ${ }^{4}$ På og ved enkelte av vannene har også forholdene for storviltjakt vært spesielt gode; ${ }^{5}$ samtidig har vassdragene skapt grunnlaget for fiske siden steinalderen. ${ }^{6}$ Det er med andre ord tett mellom fortidslevningene i vassdragene, og mange av kulturminnetypene er unike for denne delen av landskapet.

Fremsynte fagfolk så det store potensialet for ny viten, og på slutten av 1950-tallet ble det stilt krav om arkeologiske undersøkelser i vassdragene før kraftinstallasjonene ble etablert. ${ }^{7}$ Utgravninger i fjellheimen i en 30-årsperiode fra 1958 frembrakte mengder med kunnskap om bruken av fjellet i fortiden. Tross dette ble kun en mindre del av kulturminnene rundt vannene nærmere undersøkt, og et enormt kunnskapsarkiv i form av kulturminner ble etterlatt. Mange vann, som Tesse, ble også regulert i forkant av vassdragsutgravningenes tidsalder. Først de siste årene har det blitt anledning til å foreta fagmessige undersøkelser langs vannene som ble demmet før 1960, finansiert av en avgift som er pålagt vassdragssektoren.

EROSJONEN I VANNKRAFTMAGASINENEET FRISLIPP AV NATURKREFTENE

Ved kraftutbygginger må natur og spor etter fortiden ofte vike plassen for inngrep som demninger, rørgater, 


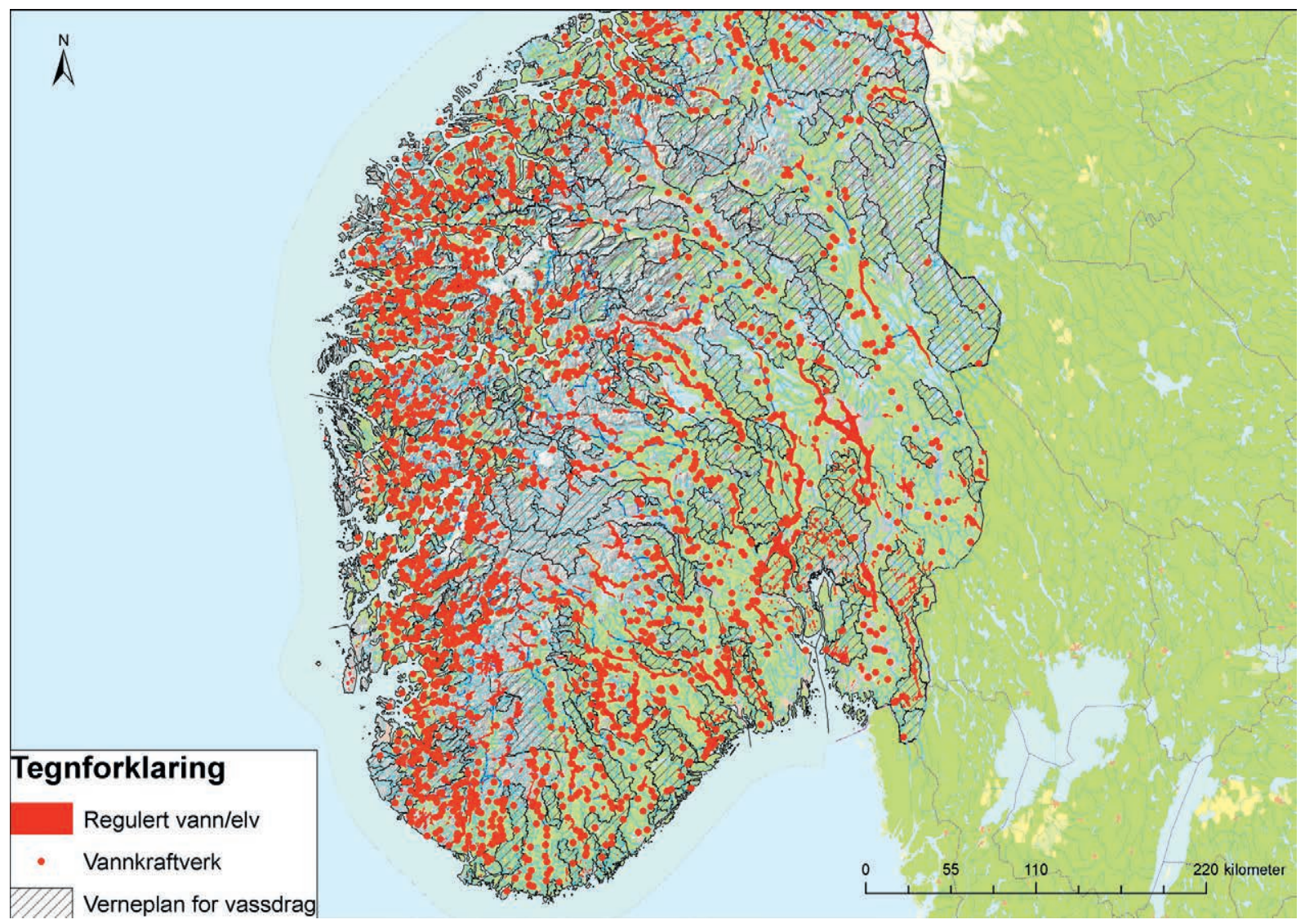

Figur 1: Oversikt over vassdragene i Sør-Norge. Kart: Axel Mjærum, KHM, basert på kartdata fra NVE.

kraftledninger, masseuttak, veier og anleggsområder. Store arealer berøres gjerne også av neddemming og soner der vannet reguleres opp og ned. Neddemmingene og reguleringene skaper erosjon, noe som innebærer at masser forflyttes, og at det fjernes større mengder masser enn det tilføres. ${ }^{8}$ Slik massetransport er blant annet forårsaket av strømmen i bekker og elver som renner inn i magasinene, bølgeerosjon langs strendene og skader som isdekket påfører på vinterstid. Hvor kraftig erosjonseffekten er, har ikke bare sammenheng med hvilke krefter som virker fra vann og vind. Typen av masser som ligger i reguleringssonen, og hellingen til terrenget spiller også en betydelig rolle for erosjonsomfanget. ${ }^{9}$ Alt dette er krefter som også virker i vann uten kraftutbygginger, men menneskers inngripen ødelegger en balanse som har etablert seg i vannene gjennom årtusener, samtidig som reguleringen gir erosjonskreftene nytt spillerom.

Arbeidet ved vannet Tesse i Jotunheimen i 2013 og 2014 ga oss en spesielt god anledning til å undersøke hvordan kulturminnene påvirkes langs vann som har vært regulert i lang tid. Dette skyldes at arkeologer har oppsøkt vannet gjentatte ganger over 


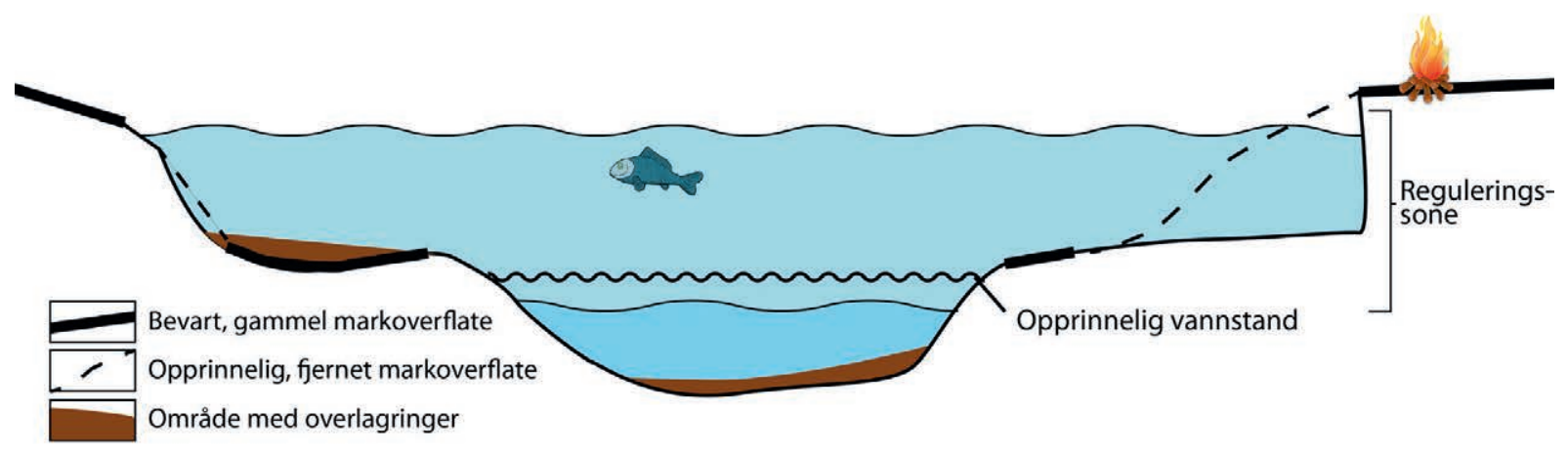

Figur 2: Eksempler på soner med ulike bevaringsforhold i et regulert vann. Muligheten for å gjøre velbevarte funn knyttet til aktivitet på land er utvilsomt størst i områder hvor markoverflaten blir bevart. Samtidig fører erosjonen til at gjenstander, ildsteder og andre spor vaskes frem, både over og under den gamle strandlinjen. Erosjonen er derfor en prosess som både tar bort og frembringer kunnskap. Illustrasjon: Axel Mjærum, KHM, med utgangspunkt i skisse av Lars Sundström. ${ }^{10}$

et lengre tidsrom, noe som har gitt en god oversikt over kulturminnene og hvordan tilstanden deres har endret seg etter kraftutbyggingen på 1940-tallet. Resultatet gir et innblikk i hvordan kulturminnene påvirkes av vannkraftproduksjon.

\section{EROSJONEN I TESSE}

Tesse ligger værutsatt til i randen av Jotunheimen. Resultatet er at erosjon skapt av vind og bølger har bidratt til betydelige skader. Vannstanden i magasinet kan heves inntil 0,8 meter over og senkes inntil 11,6 meter under den opprinnelige strandlinjen, og i denne reguleringssonen har terrenget blitt kraftig endret. Ved Tesse er det ca. 5000 meter strandlinje som er utsatt for bølgeerosjon, ${ }^{11}$ og på grunn av landskapet rundt Tesse får vinden spesielt godt tak fra nord. De største skadene er derfor på de nordvendte strendene. Vegetasjonen i reguleringssonen er borte, og sand, grus og stein er vasket ut. Nye erosjonssoner oppstår fra dag til dag, og boplasser og aktivitetsområder som har ligget i strandkanten, forsvinner.

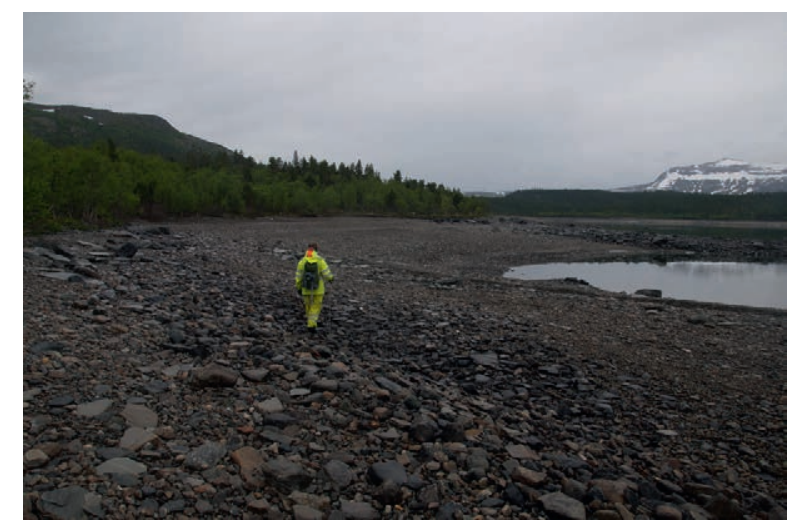

Figur 3: Reguleringssonen i enden av Tesse. Her er bevaringsforholdene dårlige, og det er få spor igjen etter tidligere aktivitet langs stranden. Foto: Ellen K. Friis, KHM.

Erosjonen i Tesse er også svært markert i områdene hvor de store elvene renner inn i vannet, men også mindre bekker og vannstrømmer fører til utvasking av silt- og sandmasser når magasinet er nedtappet. ${ }^{12}$ Særlig tydelig ble dette dokumentert i Dågåtjønnvika, innsjøens sørvestlige del. ${ }^{13}$ Erosjonen har imidlertid ikke bare gravd bort, den graver også frem. Flytting av sand og mudder på 
den gamle sjøbunnen kan ha blottlagt garnsøkker og fiskesløer, og dette kan være noe av forklaringen på at det er funnet så mange fiskeredskaper akkurat i Dågåtjønnvika.

Erosjon vil altså i mange tilfeller være ødeleggende for kulturminner. Derimot kan nedslamming eller redeponering av sekundære masser i visse tilfeller virke bevarende, men samtidig blir kulturminnene gjerne skjult under de redeponerte sedimentene (jf. figur 2). ${ }^{14}$ I Tesse ligger ingen av sporene etter fortidig aktivitet på land slik til at de blir utsatt for tilslamming, men det er derimot tilfellet for sløene og de mange garnsøkkene som har blitt funnet på bunnen av Tesse. Der kan nok de gode bevaringsforhold i stor grad tilskrives at kulturminnene har blitt overlagret av sand, både før og etter reguleringen. ${ }^{15}$

I 2011 ble det utført en vurdering av erosjonsforholdene ved Tesse. ${ }^{16}$ Forholdene ved tidligere erosjonsutsatte områder ble dokumentert og sammenlignet med skader som ble påvist i 1993. Konklusjonen er at etter 70 års regulering, med senking og heving av vannstanden, har nå erosjonen i stor grad stabilisert seg, og det har blitt dannet en ny strandlinje.

Våre undersøkelser kaster ytterligere lys over disse prosessene. Vi har oppsøkt alle de 21 steinalderboplassene som ligger langs strandlinjen ved Tesse, og fått dokumentert erosjonsforholdene og hvor mye av kulturminnene som er bevart. Større deler av åtte boplasser var bevart, men på langt nær alt. På ni var det kun igjen mindre arealer, mens tre var fullstendig vasket bort. Tallene gir en sjelden innsikt i desimeringstakten og viser at tilstanden til kulturminnene er forholdsvis dårlig. Svært mye er altså ødelagt, noe som legger klare begrensninger på mulighetene for å grave frem ny viten.

Bekymringen for erosjonsskader fikk arkeologer til å besøke Tesse i 1964 og i 1967, ca. 20 år etter reguleringen. Det ble da beskrevet hvordan erosjonen

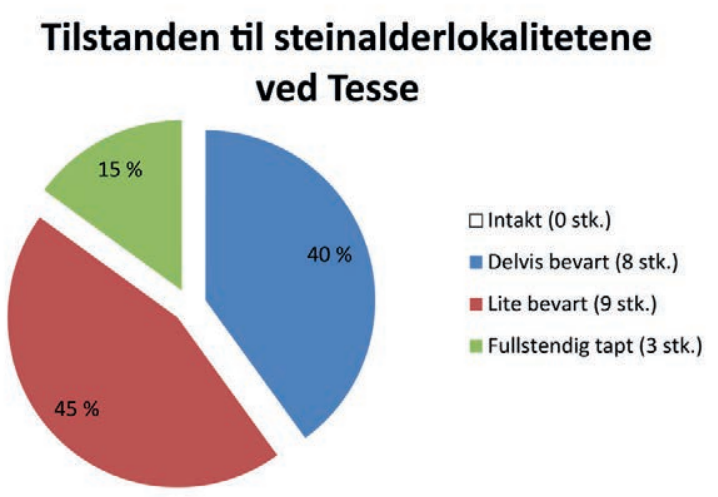

Figur 4: Tilstanden til de 20 steinalderboplassene som er kjent langs bredden av vannet Tesse.

hadde ført til utrasing og utvasking av strandsonen. ${ }^{17}$ Beskrivelsene den gangen forteller også om et værhardt vann hvor vind og bølger har flyttet masser også før reguleringen. En av boplassene som ble beskrevet i 1967, var Nåvårseter II, ${ }^{18}$ og om man sammenholder dens daværende tilstand med dens tilstand i dag, kan man få et inntrykk av erosjonsutviklingen. I 1967 ble det funnet tolv steingjenstander sammen med kull og skjørbrent stein. Funnstedet ble den gang beskrevet på følgende måte:

Boplassen ligger på et grusplatå like ved vannet, ca. 2-3 meter over høgste vannstand. Også her er torva slitt vekk av vinden, slik at det som ble funnet lå helt i dagen. Også her spor etter ildsteder.

Da funnstedet ble kontrollert i 2006, ${ }^{19}$ ble det kun funnet noe skjørbrent stein på en flate like ovenfor vannet. I 2014 foretok vi en mindre undersøkelse for å avklare tilstanden til kulturminnet. Utgravningen, som frembrakte åtte gjenstander, viste at det kun var bevart et fåtall kvadratmeter med spor fra steinalderen like over reguleringssonen. 


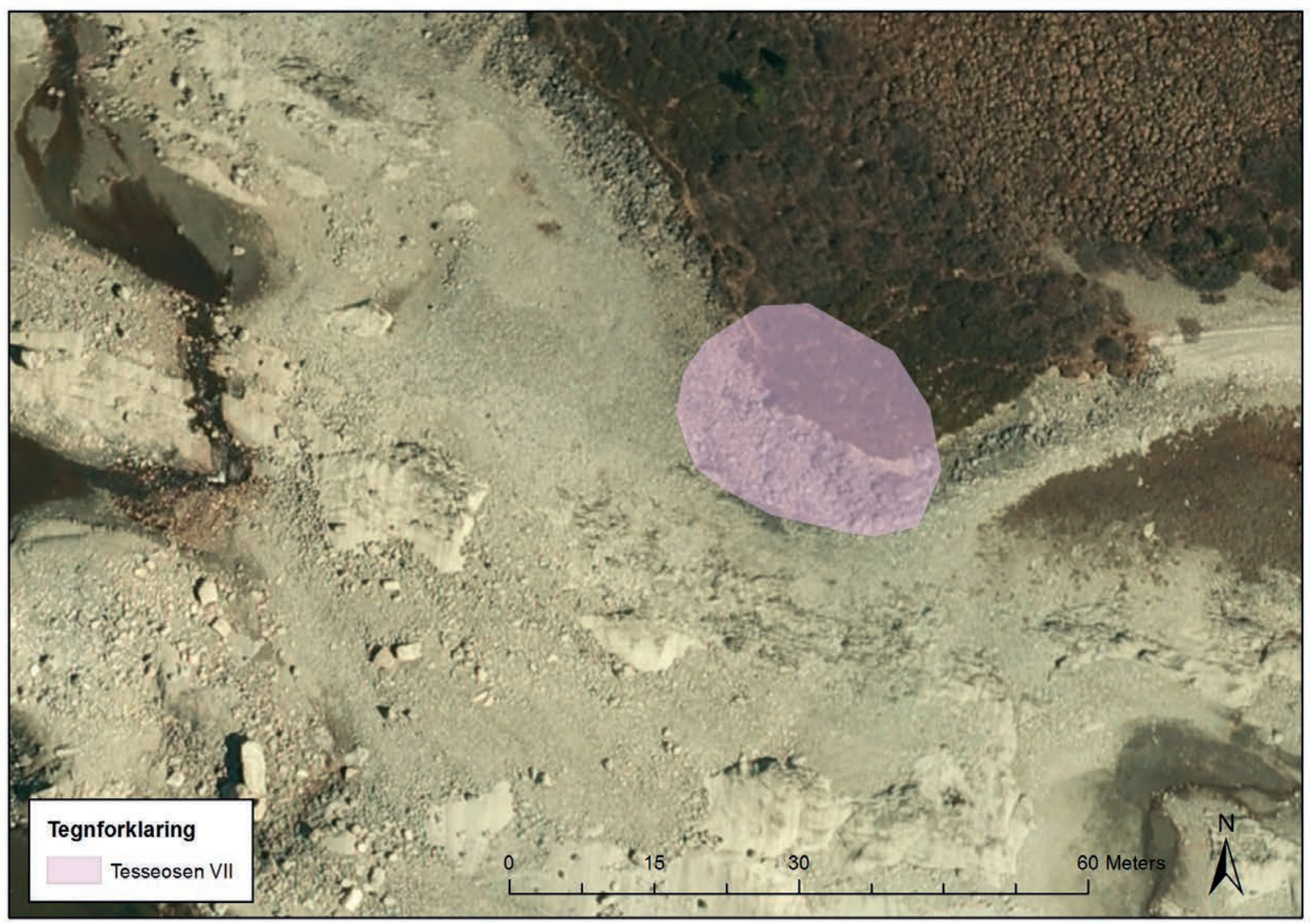

Figur 5: Steinalderboplassen Tesseosen VII, nord i Tesse. Størsteparten av området der boplassen har ligget, er totalt ødelagt av erosjon. Kart: Ellen Kathrine Friis, KHM.

Vi foretok også en innmåling på bakgrunn av de tidligere beskrivelsene for å kunne estimere hvor mye av neset og dermed også steinalderboplassen som var erodert vekk. Trolig har mellom 8 og 10 meter innenfor den gamle strandlinjen forsvunnet. Vegetasjonsdekket var altså borte alt i 1967, kanskje delvis på grunn av reguleringen. Førti år senere var en stor del av boplassen forsvunnet. De nye funnene ga imidlertid en pekepinn om boplassens alder, og det viser at det faktisk er mulig å hente ut noe informasjon fra restene som fortsatt ligger igjen.
Et annet illustrativt eksempel på en boplass som har blitt utsatt for kraftig erosjon, er Tesseosen VII (figur 5). Her bemerkes utrast torv, kull og stein som har vært oppvarmet i $1967 .{ }^{20}$ I 2014 ble det ikke funnet noen spor etter forhistorisk aktivitet. Boplassen lå svært utsatt til helt i nordenden av Tesse, der bølgeerosjonen har ødelagt mye av den opprinnelige strandsonen, og boplassen er nå å betrakte som totalt tapt.

Både det helhetlige inntrykket av Tesse og beskrivelsen av kulturminnene oppigjennom årene tyder på at reguleringen på 1940-tallet tidlig bidro til at 


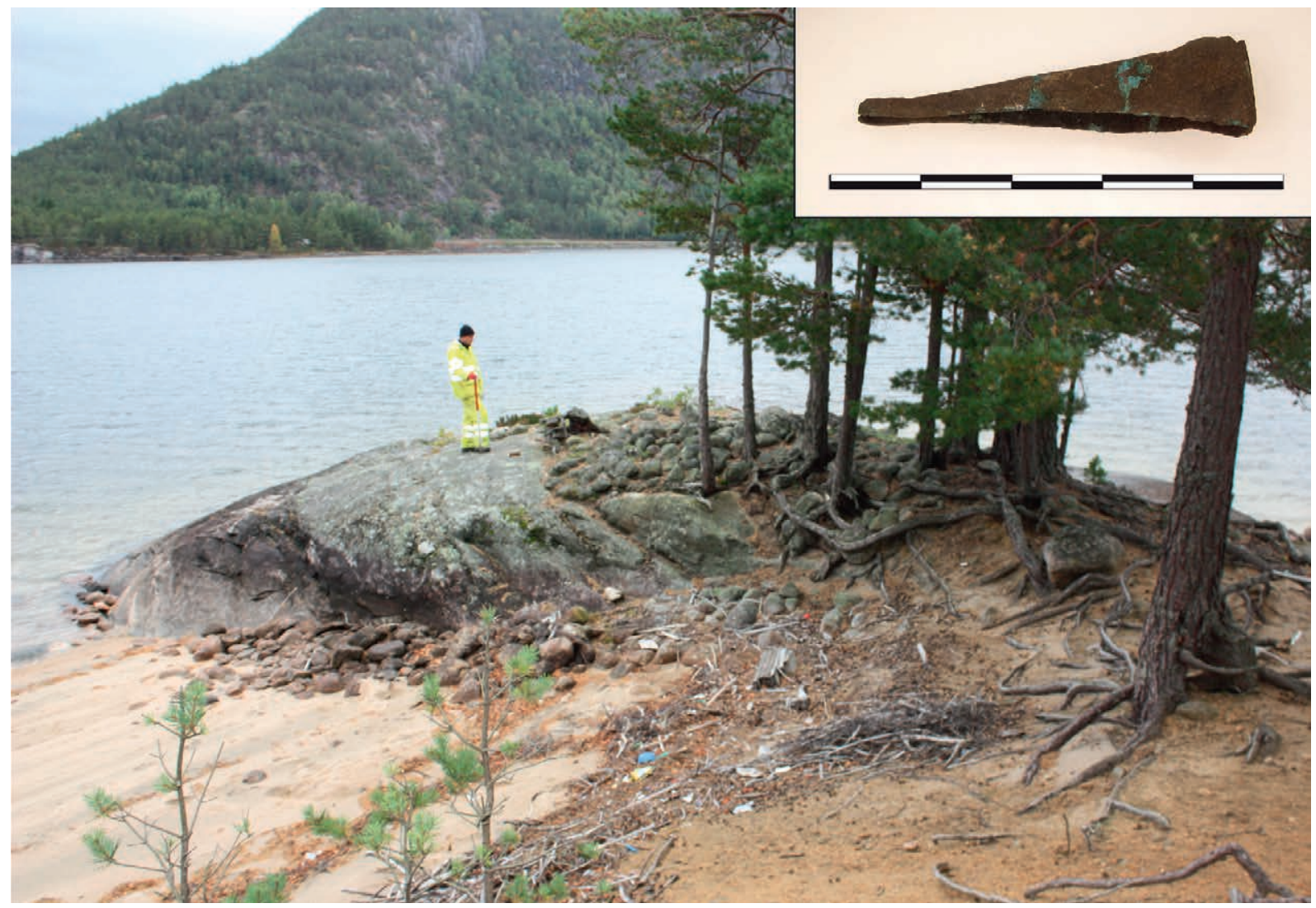

Figur 6: Gravrøys på Nånesodden ved Byglandsfjorden som er sterkt skadet av erosjon. Steinene på stranden har en gang vært en del av gravminnet. På tross av skadene ble det funnet brente bein og en bronsepinsett i gravrøysa i 2012. Funnene er datert til om lag 500 f.Kr. Røysa er nå restaurert. Foto: Helen Russ og Tom Heibreen, KHM.

torvdekket forsvant og gjenstander ble gravd frem. På 1960-tallet var fortsatt mye bevart ved Tesse, men mange funn og boplasser hadde blitt eksponert. I løpet av de neste tiårene har kulturminnene blitt påført vesentlige skader, og i 2006 var mye forsvunnet. ${ }^{21} \mathrm{Vi}$ har i løpet av våre undersøkelser observert at det på enkelte steder fortsatt raser ut fra bratte, meterhøye erosjonskanter, og at noen av steinalderboplassene sakte, men sikkert spises opp av bølgene. Likevel er det holdepunkter for å anta at erosjonsprosessene delvis har stoppet opp, en konklusjon som samsvarer godt med studiet av de pågående erosjonsprosessene $\mathrm{i}$ Tesse. ${ }^{22}$

\section{EROSJONEN I ANDRE REGULERTE VANN - DANNELSEN AV ET STØRRE BILDE}

De siste årene har man også hatt mulighet til å foreta undersøkelser av kulturminner $\mathrm{i}$ andre regulerte vassdrag. Erfaringene fra Byglandsfjorden (203 moh.) i Setesdalen i Aust-Agder er på mange måter sammenfallende med dem fra Tesse. Også her har det foregått kraftproduksjon i lang tid (konsesjon 
fra 1912), og magasinet er langstrakt og i stor grad omgitt av letterodert sand. Vannstanden er tidvis fem meter høyere enn den opprinnelige i Byglandsfjorden, og den gamle strandsonen ligger eksponert for bølger mye av året. Resultatet er, som ved Tesse, at kulturminnene i den tidligere strandsonen i stor grad er vasket vekk. ${ }^{23}$

Pålsbufjorden (736,5 moh.) er et annet vann som relativt nylig har blitt oppsøkt av arkeologer. Vannet ligger på østsiden av Hardangervidda, erosjonssonen er på om lag 25 høydemeter, og det ble regulert alt i 1914. Den gamle strandlinjen har ligget om lag midt $\mathrm{i}$ den nåværende reguleringssonen. Reguleringen innebærer at nær alle spor etter bruken av vannet er berørt av kraftproduksjonen. I et knauset morenelandskap i nordenden av dette magasinet har det forholdsvis nylig blitt undersøkt 20 boplasser fra steinalder, samtlige preget av 100 år med vannkraftproduksjon. Her skilte imidlertid bevaringsforholdene seg vesentlig fra dem i hoveddelen av Tesse og Byglandsfjorden. På enkelte boplasser var det tilført et tynt dekke av sand eller bare fjernet noen få centimeter av den opprinnelige markoverflaten. Ved Pålsbufjorden lå opptil 8500 år gamle steinredskaper, ildsteder og ikke minst en hyttetuft nær uforstyrret. ${ }^{24} \mathrm{I}$ andre områder var nær alle spor fra steinalderen skylt vekk. Det kuperte terrenget har trolig bidratt til å skjerme enkelte av boplassene. En tilleggsfaktor her er nok at manøvreringen av vannstanden i Pålsbufjordmagasinet innebærer at de gamle oppholdsstedene ligger under vann i store deler av året, noe som bidrar til å redusere kreftene fra bølger og uvær.

En tilsvarende og kanskje enda mer iøynefallende variasjon er synlig i de seks reguleringsmagasinene i Vinstravassdraget. Terrengformer, reguleringshøyder, grunnforhold, vær og vind spiller sammen og danner helt ulike forhold for kulturminnene i disse magasinene. Ved Kaldfjorden (1014 moh.) synes nærmest alle spor av fortiden å ha gått tapt, mens man kan finne tykke intakte lag med bein, kull og steinredskaper ved nabovannet Vinstervatn (1030 moh.). ${ }^{25}$

Kartleggingen av kulturminner i andre vassdrag etterlater seg tilsvarende inntrykk av store skadeomfang. ${ }^{26}$ Ødeleggelsene begrenser seg heller ikke til det som tidligere lå over vannlinjen. Også funn knyttet til båtferdsel og fiske og rester etter alt som er kastet og mistet fra boplasser og båter, står i fare for å forsvinne som en følge av reguleringene. ${ }^{27}$ Det er derfor ikke noen tvil om at svært mange kulturminner har gått tapt, og at ytterligere en stor andel er sterkt skadet i vannene som er regulert. Når vi da også vet at omtrent alle de store vannene i fjellheimen anvendes til kraftproduksjon, kan det konkluderes med at mange kulturminner og mye kunnskap alt har blitt skylt vekk. Siden mange vann er regulert for flere tiår siden, er ødeleggelsestakten i ferd med å avta, men det er ikke tvil om at desimeringen vil fortsette.

\section{SUMMARY}

\section{EPILOGUE: \\ PESSIMISTIC THOUGHTS ON THE CULTURAL HERITAGE IN THE MOUNTAINS}

Not only is the southern Norwegian inland an area with long fishing traditions; it is also an area with hydroelectric power installations in $70 \%$ of the watercourses. For more than a hundred years, power dams have caused erosion and been a threat to the cultural heritage.

Recent surveys have revealed that all the heritage sites along the shores of Lake Tesse are heavily 
FJELLFISKE I FORTIDEN | AXEL MJÆRUM - ELLEN KATHRINE FRIIS

damaged or completely lost as a result of the power production. A similar situation is seen in several lakes in the south of Norway. Many of the sites are affected, and more sites will be damaged or at worst disappear in the years to come.

Conclusively, there are still a great deal of new data to be gained by conducting archeological excavations in these areas. Nevertheless, important traces from the past have been eroded away, and valuable knowledge is lost forever. 



\section{FJELLFISKE I DAG OG I FORTIDEN}

\section{SLUTTNOTER}

1 Norges Jeger- og Fiskerforbund (2016) opplyser at $50 \%$ av den voksne befolkningen fisker én eller flere ganger per år, og at over 70 \% av barn mellom 11 og -16 år fisker årlig. Den årlige, totale fangsten av innlandsfisk er anslått til å være 10000 tonn (Søilen 2009).

2 Ifølge Fiskeridirektoratets statistikkbank har 13 personer i Oppland fylke fiske som hovedyrke i 2016, mens det i Hedmark er 15 fiskere (www.fiskeridir.no).

3 Kleiven 1928: 298-299. 


\section{TESSE - ET ARKEOLOGISK ELDORADO OG EN INNFALLSPORT TIL FJELLFISKET}

Av Birgitte Bjørkli, Ellen Kathrine Friis, Axel Mjarum, Kulturhistorisk museum, Universitet i Oslo og Elling Utvik Wammer, Norsk Maritimt Museum

\section{SLUTTNOTER}

Hesthagen 2011.

Ugulen 2016.

Hagen 1959a.

Eknæs 1975: 175.

Se Friis og Mjærum 2016.

Kgl. res. 2011.

7 Jf. Sundström 2014; Mjærum 2015; Bergstøl og Friis under arbeid.

8 Jf. Martens 1964; Hiim og Martens 1967; Amundsen 2007.

9 Se Friis og Mjærum 2016.

10 Se Hufthammer og Mjærum 2016.

11 Mjærum 2016a.

12 Se for eksempel Nordgaard 1908; Keller og Schia 1994 mfl.

13 Hufthammer og Mjærum 2016.

14 Gjenstandsbasen 2015.

15 Se Nordgaard 1908: 83; Olsen 2004: 30-31.

16 Torstein Bjørgen, Lom, pers. med.

17 Reidar Marstein, pers. med.

18 Se for eksempel Nordgaard 1908: 83; Olsen 2004: 30-31; Sørheim 2004: 119.

19 Beskrevet blant annet i Elvestad 1998.

202011.

21 Hesthagen 2011: 8.

22 Hesthagen 2011: 7.

23 Hesthagen 2011.

24 Hesthagen 2011: 108.

25 Hesthagen 2011: 108.

26 Bakken 1975: 80.

27 Se for eksempel Mjærum 2016a.

28 Mjærum og Friis 2016.

29 Se for eksempel Mjærum 2016a.

30 Hiim og Martens 1967.

31 Amundsen 2007.

32 Hufthammer 2014.

33 Mjærum 2016a.

34 Martens 1964.

35 Indrelid 1994: 179.

36 Bergsvik 2009: 112.

37 Jf. Mjærum 2016a. 
FJELLFISKE I FORTIDEN | NOTER OG APPENDIKS

\section{DE FØRSTE FISKERNE I FJELLET}

Axel Mjarum, Kulturhistorisk museum, Universitetet $i$ Oslo

\section{APPENDIKS}

\section{Numedalslågen}

RT12-15 ved Røyrtjønna i Pålsbufjorden i Hol kommune i Buskerud

Det er verdt å avsette plass til inngående presentasjon av lokaliteten RT12-15 ved Røyrtjønna nord i Pålsbufjorden. ${ }^{129}$ Dette skyldes at utgravningsresultatene synliggjør noen av dateringsutfordringene som preger en stor andel av steinalderboplassene som har blitt etablert langs elver og vann.

På RT12-15 lå det funn spredt innenfor et område på om lag $80 \mathrm{~m}^{2}$ på stedet, og $23 \mathrm{~m}^{2}$ av det sentrale boplassområdet ble gravd ut. Ved undersøkelsen fremkom 1020 gjenstander, hvorav 138 av skifer. I skifermaterialet inngår 15 spisser og fragmenter av slike. Fragmenteringen gjør nærere typebestemmelser vanskelige, men tverrsnittet på de mest intakte spissene er rombisk. I materialet inngår også spisser med og uten agnorer. Det ble videre funnet skiferavfall med parallelle slipespor. Det har følgelig blitt produsert spisser av skiferplater ved hjelp av sliping eller saging. Skiferspisser var hovedsakelig i bruk i tidlig- og mellomneolittisk tid (ca.3800-2350 f.Kr.). Det har vist seg vanskelig å foreta en nærmere typologisk datering på bakgrunn av morfologiske trekk, men tverrsnittene taler for at deler av eller alt spissmaterialet er fra etter 3300 f.Kr. ${ }^{130}$ I dette tilfelle har det vært mulig å tidfeste bevart bek eller et lignende stoff som har blitt påført ved skjeftingen av spissen. Materialet er C14-datert til 2578-2472 f.Kr. (4012 $\pm 26 \mathrm{BP}, \mathrm{AAR}-18495)$, en datering som kan ligge nokså nær spissens reelle alder. På lokaliteten var det ellers flekker i flint tilvirket med sylinderteknikk og et stykke av en slipt flintøks. Begge gjenstandstyper er velkjente fra mellomneolitikum på Østlandet og i de sørnorske fjellområdene. ${ }^{131}$ Ett flintstykke kan være flateretusjert, og følgelig er det et mulig holdepunkt for aktivitet etter ca. 2350 e.Kr. ${ }^{132}$ Andre gjenstander som peker mot en tidfesting utenfor rammene av mellomneolittisk tid, foreligger ikke.

Det ble påvist to nedgravninger på RT12-15, begge er tolket som ildstedgroper. Disse strukturene lå med en meters avstand i vestre del av utgravningsfeltet. Mellom dem lå et mørkere, brunlig, noe kullholdig kulturlag. Det østligste av ildstedene målte 0,5 meter i plan, og det var 0,2 meter dypt. Gropen var fylt med rødbrent sand og med en kullinse i bunnen. I strukturen var det $11,8 \mathrm{~g}$ brente bein. Foruten pattedyrbein ble det funnet ett kraniefragment av fisk. Det vestlige ildstedet hadde en diameter på 0,37 meter, og dybden var 0,27 meter. Formen var ujevn. I toppen lå det kull, mens det lå steiner i bunnen av gropen. Fra denne andre strukturen ble det samlet inn 22,7 $\mathrm{g}$ bein, i hovedsak av pattedyr, men også 32 fuglebein og 7 rygghvirvler av fisk.

Spredt i kulturlaget omkring ildstedene lå det ytterligere 232,7 g brente bein, deriblant 105 rygghvirvler og 1 kranieknokkel av fisk (se figur 17). Samtlige av disse beinene ble funnet $0-10 \mathrm{~cm}$ under torven, i de samme lagene som også inneholdt et omfattende littisk materiale. For å avklare alderen C14-daterte man et pattedyrbein funnet i $0-10 \mathrm{~cm}$ dybde, funnet om lag en halvmeter fra det østlige av ildstedene. Analysen underbygget det klare inntrykket av at stedet ble besøkt i mellommesolittisk tid (2911-2629 f.Kr. [4210 \pm 54 BP, Ua-45485]).

Ut fra de øvrige funnopplysningene var det derfor nærliggende å knytte fiskebeinsfunnene til den mellomneolittiske aktiviteten. Funnmengden ga imidlertid en sjelden anledning til en direkte datering 


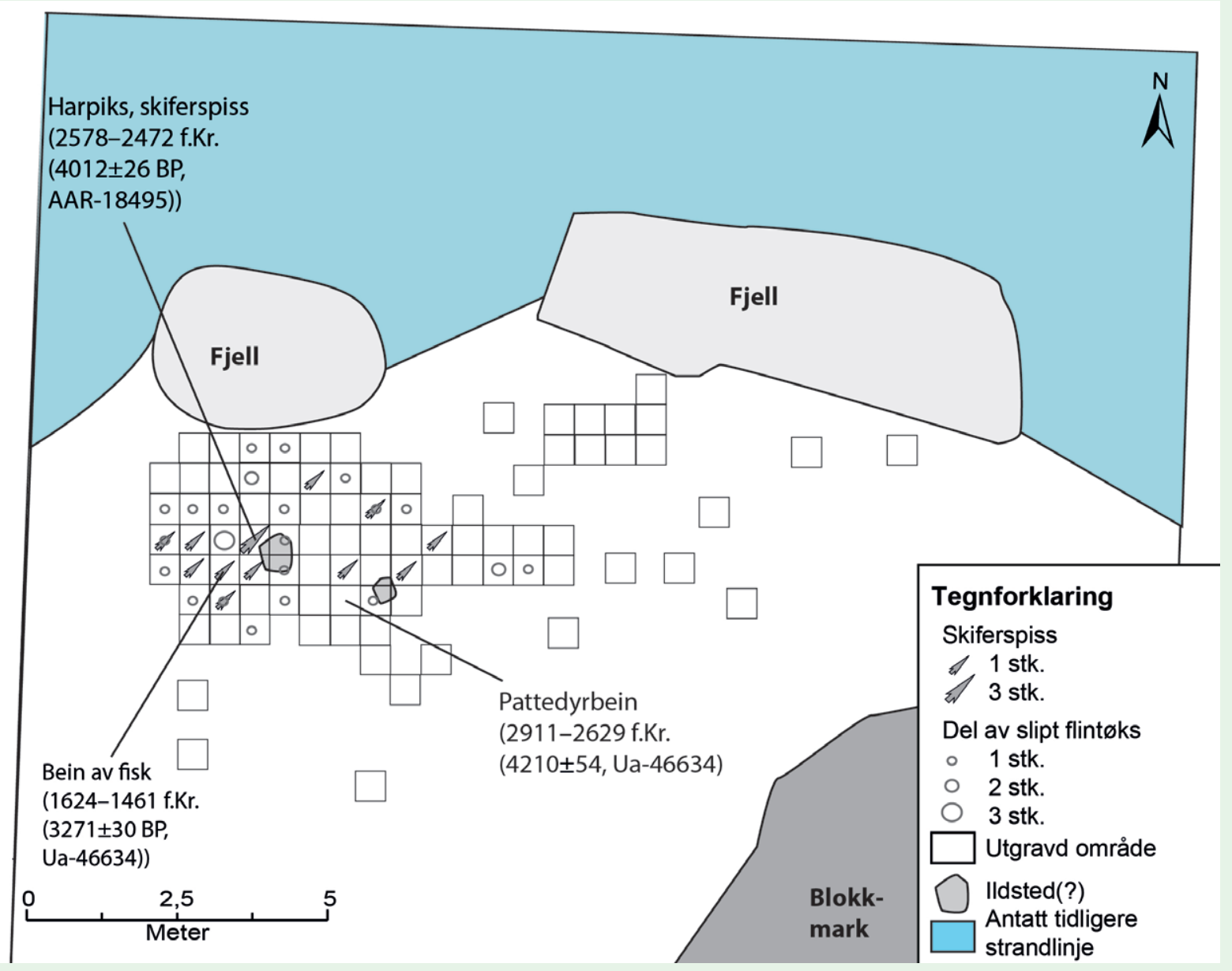

Figur 17: Lokalitet RT12-15 ved Røyrtjønna. Fiskebein er funnet i en beinkonsentrasjon i et område som har blitt besøkt i yngre steinalder (innenfor tidsrommet 3300-2350 f.Kr.). En C14-datering av beinene tidfester dem imidlertid til eldre bronsealder. Kart: Axel Mjærum, KHM.

av fiskebeinene og en radiologisk tidsangivelse som var om lag 1000 år yngre enn den øvrige aktiviteten (1624-1461 f.Kr. [3271 \pm 30 BP, Ua-46634, $\delta C^{13}$ $-18,2 \% 0])$. Slike dateringer kan bli feilaktige som følge av en reservoareffekt som gir for høy alder for dyr og planter som lever i ferskvann. ${ }^{133}$ Spesielt stor betydning har karbonforbindelser som er løst opp i vannet, og denne «hardt vann-effekten» kan gi dateringer som er mange århundrer, og i enkelte tilfeller årtusener, eldre enn beinenes reelle alder. Ut fra de opplysningene som foreligger i dette tilfellet, er det vanskelig eller umulig å vite $\mathrm{i}$ hvor stor grad hardt vann-effekten har påvirket fiskebeinsdateringen fra Røyrtjønna. ${ }^{134}$

Ved siden av at det er problemer med den radiologiske dateringen, synliggjør RT12-15 to sentrale utfordringer knyttet til boplassarkeologien i innlandet. For det første viser funnene hvordan flere bruksfaser kan resultere i et sammenblandet funnmateriale. ${ }^{135}$ Et relatert problem er at oppholdene i svært 
varierende grad er mulig å spore i det arkeologiske materialet. Frem til ca. 2350 f.Kr. foregikk tilvirkningen av steinredskaper i stor utstrekning langs bredden av elver og vann. Etter dette tidsrommet fremkommer enkeltredskaper langs vannene, men produksjonen av steinredskapene ser i større grad ut til å ha foregått $i$ hellere og andre steder i landskapet. I århundrene før Kristi fødsel opphører tilvirkningen av tilslåtte steinredskaper helt. ${ }^{136}$ Enkeltfunn fra etter Kristi fødsel, slik som jernspisser, økser, kniver og glassperler, finnes av og til på de åpne boplassene. ${ }^{137}$ I tilfeller der det mangler bygningsspor, slagg eller lignende, er det trolig ofte vanskelig å spore yngre aktivitet i gjenstandsmaterialet. I tillegg til dette må det tas høyde for at nedbrytning, dyrs graving $\mathrm{i}$ jorden, frostbevegelse, rotvelter og andre naturprosesser endrer funnbildet etter at stedet ble forlatt $i$ forhistorien. ${ }^{138}$ Samtidig skaper vannkraftreguleringer tilleggsutfordringer knyttet til bevaringsforhold og tolkninger. ${ }^{139}$ Det er følgelig ikke gitt at fiskebein eller fiskeredskaper er fra det tidsrommet som er mest iøynefallende i det arkeologiske materialet, og ofte kan det være svært krevende å tidfeste enkeltfunn innenfor snevre tidsrammer, basert på typologisk daterbare gjenstander, stratigrafi og C14-dateringer.

\section{RT12-09 ved Røyrtjønna i Pålsbufjorden i Hol kommune i Buskerud}

På RT12-09 ble det funnet ca. 3100 gjenstander i stein innenfor et område på ca. 35 x 10 meter. Størst funntetthet var det sentralt på lokaliteten, og i tre utgravningsfelt med et samlet areal på 30 $\mathrm{m}^{2}$ ble $10-20 \mathrm{~cm}$ tykke lag gravd ut. ${ }^{140}$ Det største av disse søndre feltene målte $4 \times 5 \mathrm{~m}$ og ble anlagt i et område der det opprinnelige torvlaget manglet. Massene på stedet var ellers heterogene, med en blanding av utvasket og anriket sand, kull, varmepåvirket sand og gjenstander. Det ble skilt ut fem ujevnt og uklart avgrensede lag innenfor det store utgravningsfeltet, og massene tolkes som rester etter kulturlag. Det kan ikke utelukkes at deler av laget var forstyrret av reguleringen. Funnkonsentrasjonene var velavgrensede, noe som taler for at reguleringen hadde medført begrenset skade.

Dette største feltet ble gravd ut i to lag. Først ble noen centimeter av overflaten fjernet, og så ble det gravd bort ett $10 \mathrm{~cm}$ tykt sjikt. Både ved opprensningen og ved gravingen fremkom det steingjenstander, og samlet ble det funnet $58 \mathrm{~g}$ brente bein fra sjakten. Det ble ikke observert noen entydig sammenheng mellom funndybde og gjenstandenes alder. Innenfor den fjerdedels $\mathrm{m}^{2}$ som var mest beinrik, lå det både bein av pattedyr og fugl og en rygghvirvel av fisk. Fiskebeinet ble funnet i topplaget, sammen med ytterligere 4,4 g med bein og 32 gjenstander i flint og kvartsitt. I det underliggende laget var det 18 flintfunn og 39,7 $\mathrm{g}$ bein. Ingen av gjenstandene i denne graveenheten ga gode holdepunkter for en typologisk datering.

Det sørlige funnområdet for øvrig ga et klart preg av at boplassen ble besøkt i to faser (se figur 18). Én meter fra fiskebeinsfunnet var det en samling med nærmere 100 mikroflekker. Dette er avlange små flintstykker som blant annet har blitt anvendt til å lage skarpe egger på pil- og spydspisser $\mathrm{i}$ bein. Slike jaktvåpen ble tilvirket helt tilbake til 8000tallet f.Kr. ${ }^{141}$ I den siste halvdelen av 4000-tallet f.Kr. ble de erstattet av spisser som i sin helhet ble tilvirket i stein, og frem til ca. 2350 f.Kr. var det stadig skiftende spissformer i bruk. ${ }^{142}$ Flere av disse noe senere spisstypene foreligger også fra RT1209 (figur 18), mens det var et fullstendig fravær av gienstandstyper som kan tidfestes til senere tidsrom. Ti meter fra fiskebeinfunnet lå det imidlertid en kokegrop fra jernalderen (50 f.Kr.-25 e.Kr. [2013 $\pm 31 \mathrm{BP}, \mathrm{Ua}-45480])$. I gropen var det forholdsvis mye brent bein $(74,5 \mathrm{~g})$, men ingen gjenstander.

Sammenhengen mellom beinene og flintmaterialet sannsynliggjør at fiskebeinet kan knyttes til den øvrige 


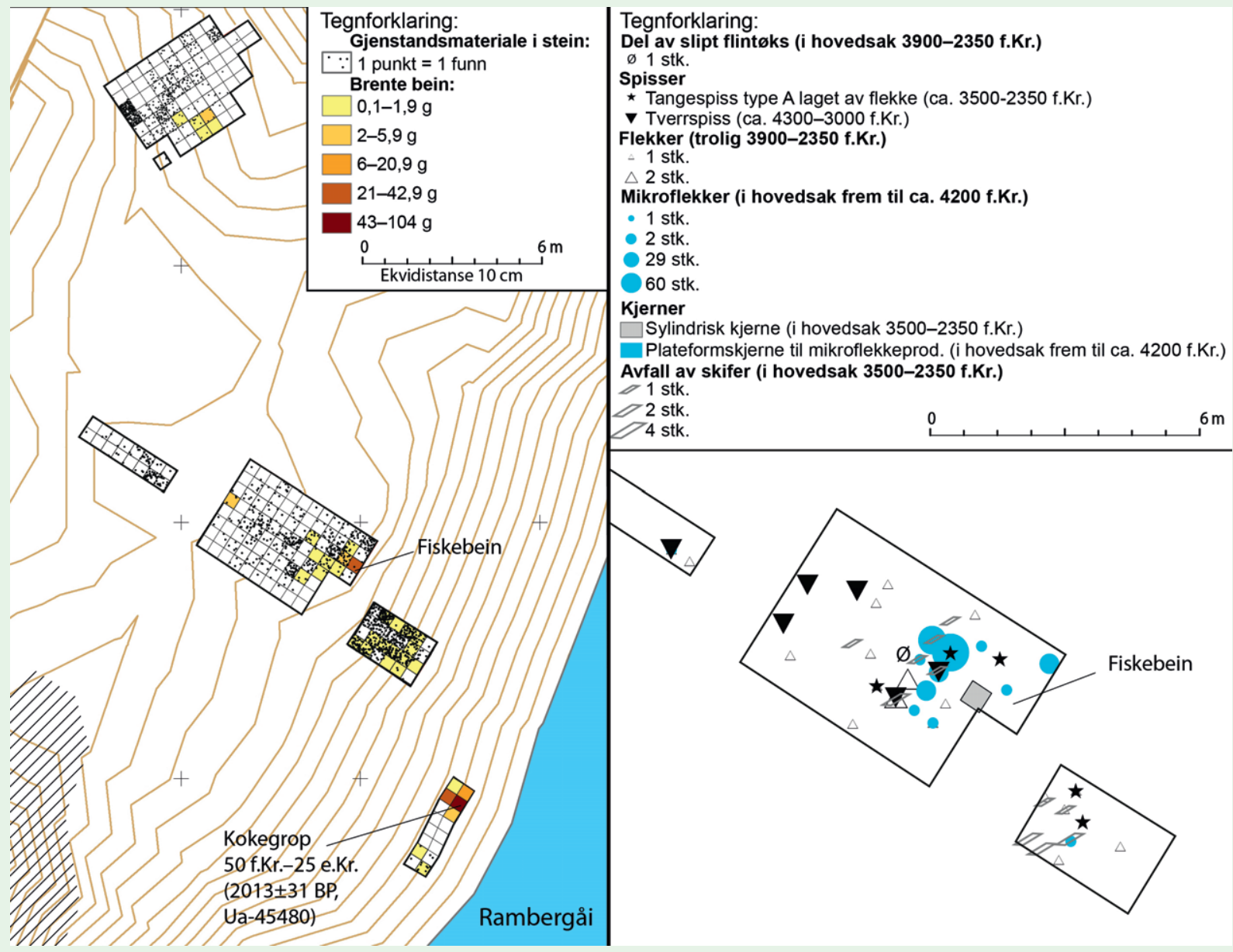

Figur 18: Lokalitet RT12-09 ved Røyrtjønna. Fiskebeinet er funnet i en beinkonsentrasjon i et område som har blitt besøkt flere ganger i eldre og yngre steinalder (innenfor tidsrommet 6500-2350 f.Kr.). T.v. sees hele RT12-09, mens et utsnitt av lokaliteten sees t.h. Kart: Axel Mjærum og Kim Darmark, KHM.

steinalderaktiviteten, og følgelig bør det tidfestes til før ca. 2350 f.Kr. Det er utvilsomt nærliggende å knytte beinene til kulturlaget og de øvrige funnene på denne delen av feltet. Erfaringene med de sprikende dateringene fra lokaliteten RT12-15 og funnet av en kokegrop gjør allikevel at man bør være varsom med å slå fast at fiskebeinet faktisk kan knyttes til steinaldergjenstandene som fremkom sammen med det.
RT12-04 ved Røyrtjønna i Pålsbufjorden i Hol kommune i Buskerud

Lokaliteten RT12-04 er det tredje stedet med fiskebein ved Røyrtjønna. ${ }^{143}$ Den sentrale delen av RT12-04 var en ca. 8 × 3 meter stor flate ryddet fri for stein, og det ble prioritert å grave denne flaten ned til $10 \mathrm{~cm}$ dybde. Det antas at man har ryddet flaten for å gi plass til telt eller andre enkle bygninger. 


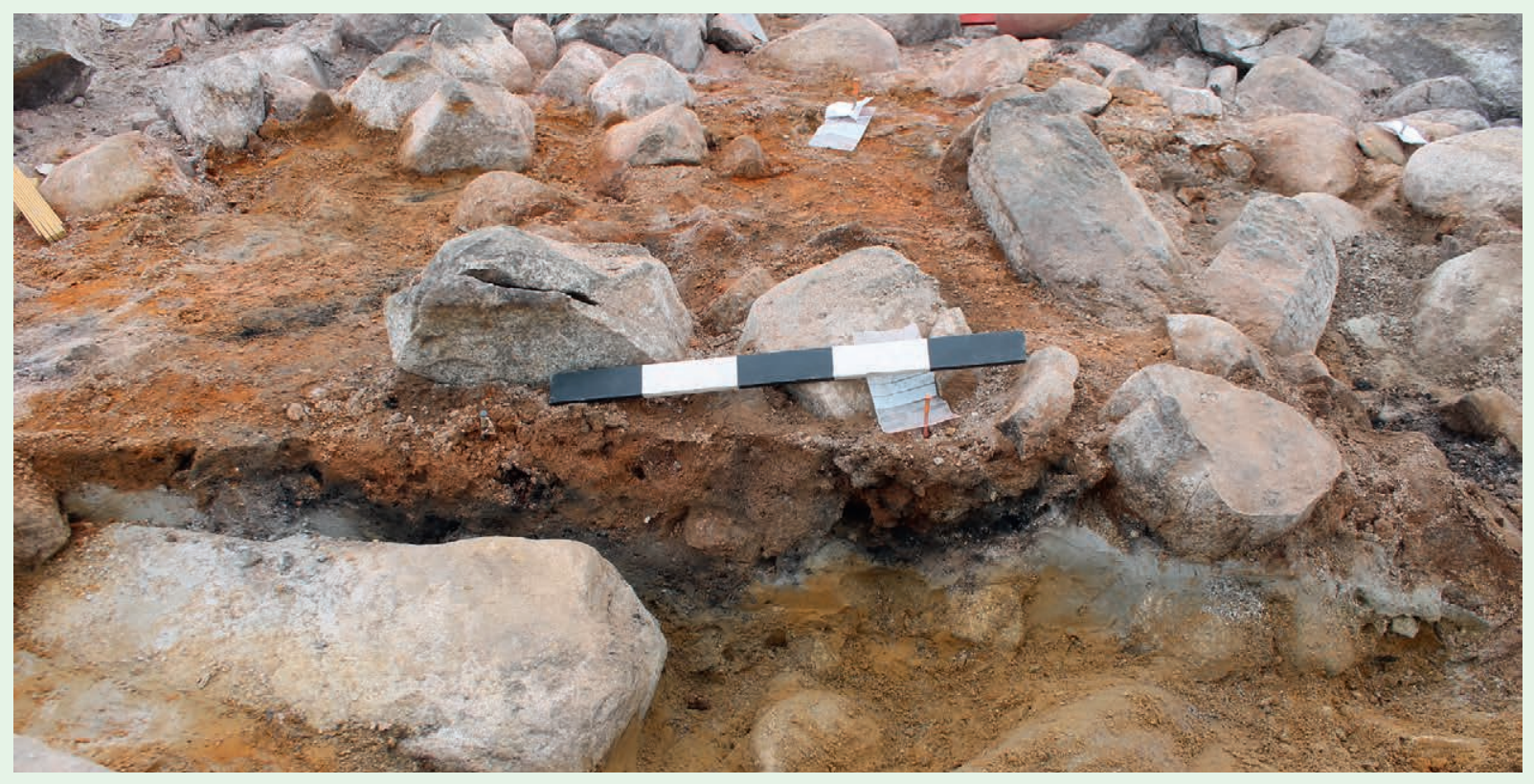

Figur 19: Tverrsnitt av ildstedet med fiskebein på lokaliteten RT12-04 ved Røyrtjønna. Ildstedet har tydelige fyllmasser og et kullag. Foto: KHM.

Ved utgravningen samlet man inn 4287 gjenstander og 2067,6 gram brente bein (figur 10).

Det er et markant innslag av mikroflekker i flint på lokaliteten (53 stk.). Produksjonen av denne gjenstandstypen fremstår som målrettet. Innslaget av mikroflekker indikerer aktivitet i mellom- eller senmesolitikum, frem til ca. 4200 f.Kr. ${ }^{144}$

I de samme kontekstene som det lå mikroflekker, var det også et variert pilspissmateriale. Blant annet ble det funnet fire tangespisser av type A, hvorav minst to er tildannet på flekker, og én tangespiss av type B. Det ble også samlet inn to eneggede spisser, to tverrspisser og tre skiferspisser. Variasjonen i spissmaterialet er mest trolig resultat av at stedet har blitt oppsøkt gjentatte ganger innenfor tidsrommet ca. 4300-2350 f.Kr. ${ }^{145}$

Ett funn skiller seg klart ut fra de øvrige: en bladformet pilspiss med hjerteform som lå 3 meter sør for ildstedet. Den flateretusjerte spissen kan klassifiseres som type $\mathrm{B}$, som dateres innenfor tidsrommet 2350-1300 f.Kr. ${ }^{146}$ Det er funnet slike spisser rundt Røyrtjønna, men produksjonen av dem mangler. Det lå en hestesko i ytterkant av lokaliteten, men det ble ellers ikke gjort funn av spor etter yngre aktivitet på RT12-04.

Etter at 10-20 cm masser var fjernet på RT1204 , fremkom et område med to eller tre ildsteder. Ildstedene overlappet delvis, og det var gjort opp ild på stedet ved flere anledninger. Den mest funnrike og best bevarte av disse bålplassene målte $1,2 \times 1$ meter og inneholdt kull og noe skjørbrent stein. Grunnen i området var tydelig farget rød av varmen fra bålet. I massene lå det ca. $490 \mathrm{~g}$ brente bein, hvorav ett var av fisk. I massene ved strukturen ble det funnet ytterligere ett fiskebein samt et større antall gjenstander som kan tidfestes til mesolittisk og neolittisk tid. 


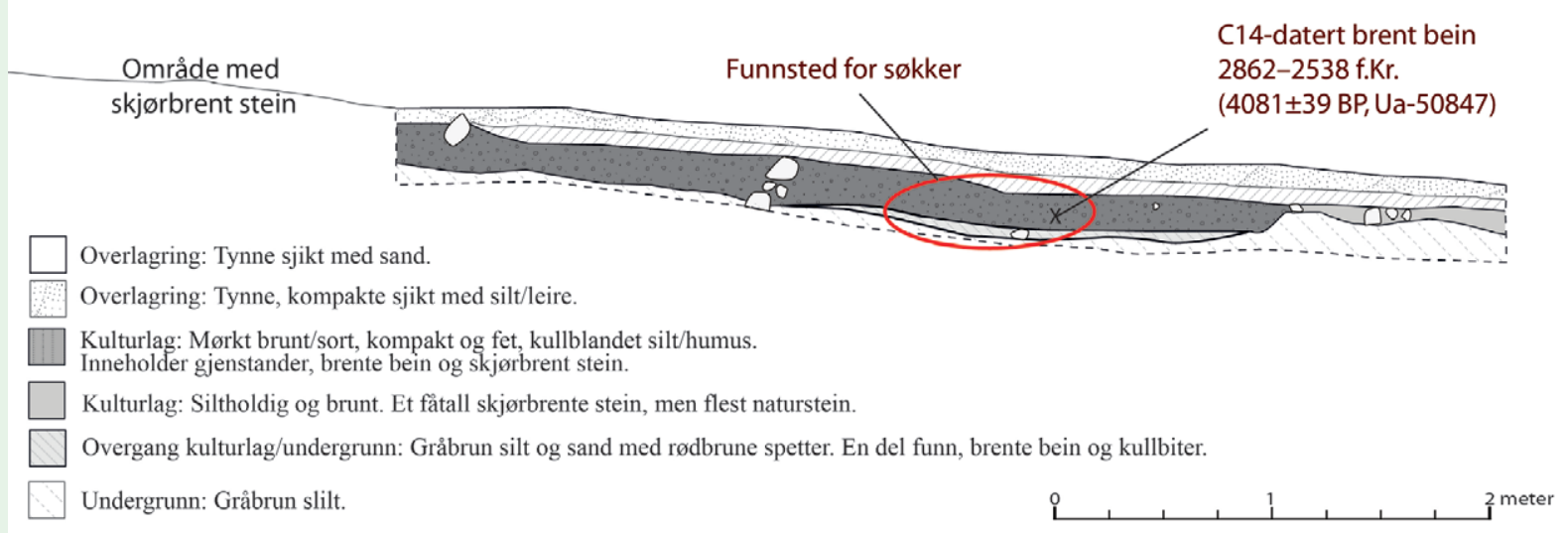

Figur 20: Profil gjennom avfallsdyngen med garnsøkkene på Olstappen. Tegnet av Kristina Steen, rentegnet av Axel Mjærum, KHM.

Både spredningen av gjenstander, andelen varmepåvirkede gjenstander, brente bein og brent stein var entydig knyttet til ildstedet, og de hadde en sammenfallende horisontal og vertikal utbredelse (figur 10).

Pattedyrbein fra kullaget i dette ildstedet er tidfestet til 4500-4340 f.Kr. (5589 \pm 43 BP, UA-45474), mens pattedyrbein fra laget over ildstedet er tidfestet til 4830-4550 f.Kr. (5844 \pm 45 BP, UA-45473). Trolig skyldes spriket i dateringer at ildstedet har blitt anvendt gjentatte ganger, men det kan ikke helt utelukkes at forskjellen er forårsaket av statistiske variasjoner knyttet til de radiologiske måleresultatene (figur 24). Man kan heller ikke se bort fra at de daterte beinene har blitt etterlatt ved ulike besøk, eller at dateringene i ulik grad er påvirket av det trevirket som har blitt brukt som brensel i ildstedet. ${ }^{147}$ Uavhengig av dette er det gode holdepunkter for at fiskerestene har samme alder som de øvrige beinene. Om dette stemmer, ble det spist fisk her innenfor tidsrommet 4830-4340 f.Kr., det vil si mot slutten av eldre steinalder.

\section{Vinstravassdraget}

I tidsrommet 2013-2016 pågår det utgravninger knyttet til vassdragsreguleringen av Vinstravassdraget. Undersøkelsene har frembrakt en rekke resultater som er av relevans for hovedproblemstillingene i denne artikkelen. Materialet er fortsatt under bearbeidelse, og nye funn og konklusjoner kan tilkomme. I det følgende presenteres informasjon som disse undersøkelsene så langt har frembrakt om det eldste fisket i vassdraget.

\section{Olstappen (ca. 662 moh.) i Nord-Fron i Oppland} Ved utløpet av den korte elvestrekningen mellom Slangen og Olstappen ligger steinalderboplassene svært tett, og de overlapper delvis hverandre. Lokalitet $\mathrm{V}$ lå nær den opprinnelige strandlinjen og er en av åtte områder som har blitt nærmere undersøkt. ${ }^{148}$ Her ble det åpnet en 0,5 meter bred og 5 meter lang sjakt i nedkant av et lag med skjørbrent stein. I sjakten var det et opptil $30 \mathrm{~cm}$ tykt kulturlagssjikt som var dekket av masser som hadde 


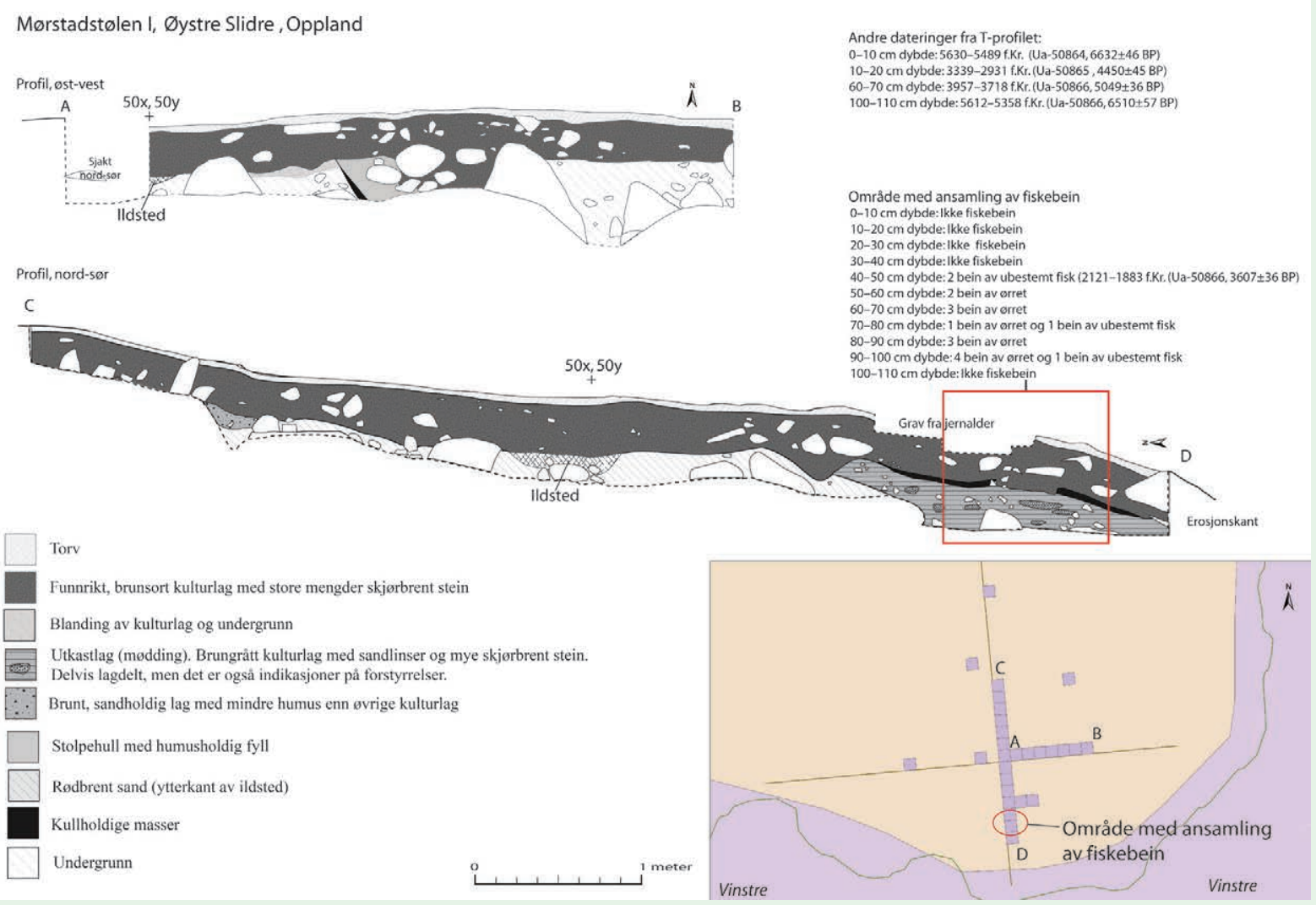

Figur 21: Tegning av profilvegger i en T-formet sjakt som ble gravd på Mørstadstølen I i 2014. Det ble gjort funn ned til om lag 1 meters dybde, og det foreligger både fiskebein og C14-dateringer av pattedyrbein fra ulike nivåer. Illustrasjon: Axel Mjærum og Ellen Friis, KHM.

lagt seg på stedet etter vassdragsreguleringen (figur 20). Fra kulturlaget foreligger to søkker og et mulig fragment av et tredje.

Søkkene lå nede i et avfallslag sammen med varmepåvirket stein, brente bein og trekull. Gjenstandsmaterialet fra sjakten var dominert av skifer i form av spisser og avfall etter spissproduksjon. Funnmaterialet har et enhetlig og enfaset preg, og det antyder en datering innenfor tidsrommet 3800-2350 f.Kr. ${ }^{149}$ Det er analysert en C14-prøve av bein fra samme kontekst som søkkene (2862-2538 f.Kr. [4081 \pm 39 BP, Ua-50847], se figur 20), og tidfestingen underbygger den typologiske dateringen. Selv om søkkene er fra et område med aktivitet $i$ et langt tidsrom, er det derfor mulig å etablere en god dateringsramme. De kan høyst sannsynlig dateres til mellomneolittisk tid.

\section{Mørstadstølen I ved Vinstre (ca. 1031 moh.) i Øystre Slidre kommune i Oppland}

Mørstadstølen I er en kompleks lokalitet som har blitt besøkt svært mange ganger i forhistorisk tid. ${ }^{150}$ Ut fra informasjonen som foreligger per i dag, er det grunn til å anta at aktiviteten starter ved innledningen 
til senmesolittisk tid ca. 6350 f.Kr., og at den strekker seg frem til den innledende delen av yngre bronsealder (ca. 1000 f.Kr.). Videre utgravninger vil kunne utfylle og nyansere dette bildet.

I 2014 ble det gravd en T-formet sjakt gjennom sentrale deler av kulturlagene på spissen av odden (figur 16 og 21). Det overordnede inntrykket var at lagfølgen stedvis var intakt, med det yngste gjenstandsmaterialet i topplagene. C14-dateringer fra sjaktene har gjennomgående gitt dateringer til steinalder, men det er ingen entydig sammenheng mellom funndybder og alder. Hoveddelen (17 stk.) av fiskebeinfunnene ble gjort i sørdelen av sjakten på nivåer fra 0,4-1 meter, mens 12 fiskebein foreligger

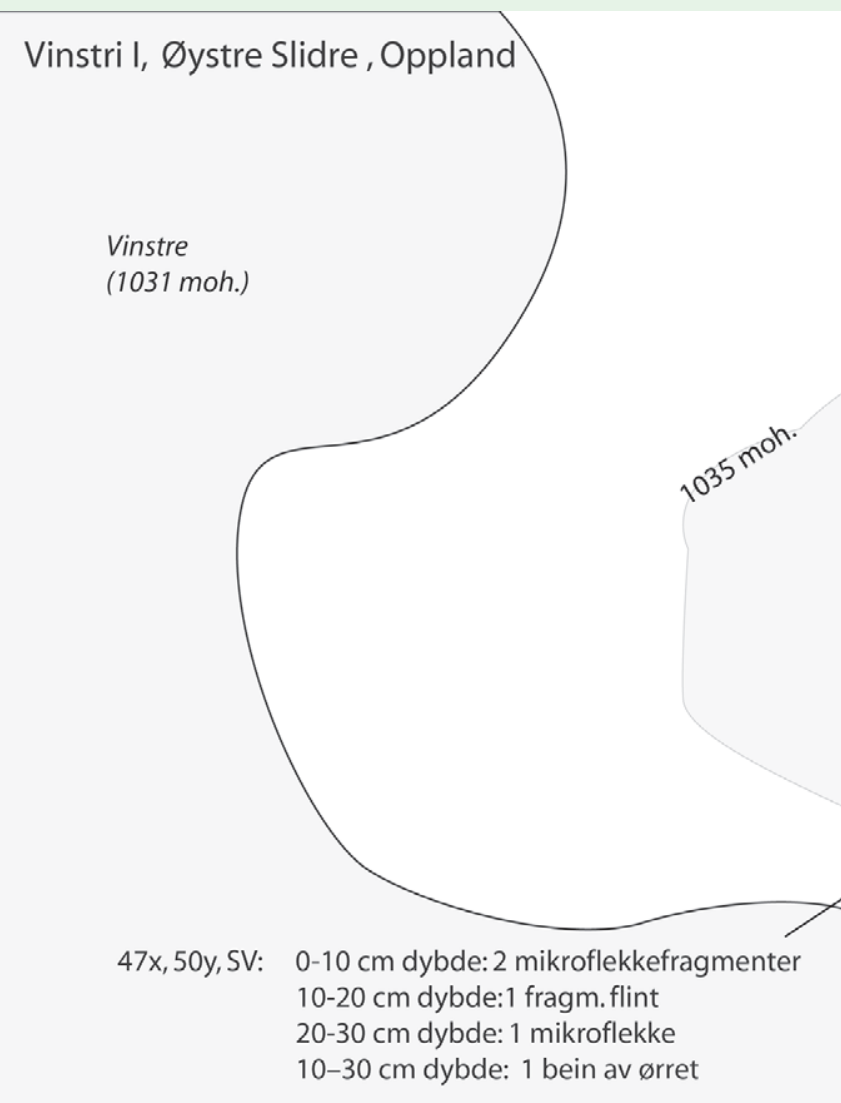

fra andre deler av lokaliteten. Funnene ble gjort i et område med klare lagdelinger, men det var indikasjoner på forstyrrelser i bunnlagene. Det er foretatt én C14-datering av pattedyr øverst i laget med fiskebein, og denne faller innenfor senneolittisk tid (2121-1883 f.Kr. [Ua-50866, $3607 \pm 36$ BP]). Lagfølgen i området kan være forstyrret, men det er mulig at C14-dateringen tidfester enkelte av fiskebeinsfunnene på Mørstadstølen I. Det kan imidlertid ikke utelukkes at det har blitt spist fisk ved denne delen av Vinstre vesentlig tidligere og/ eller noen århundrer seinere.

\section{Andre illustrasjoner}

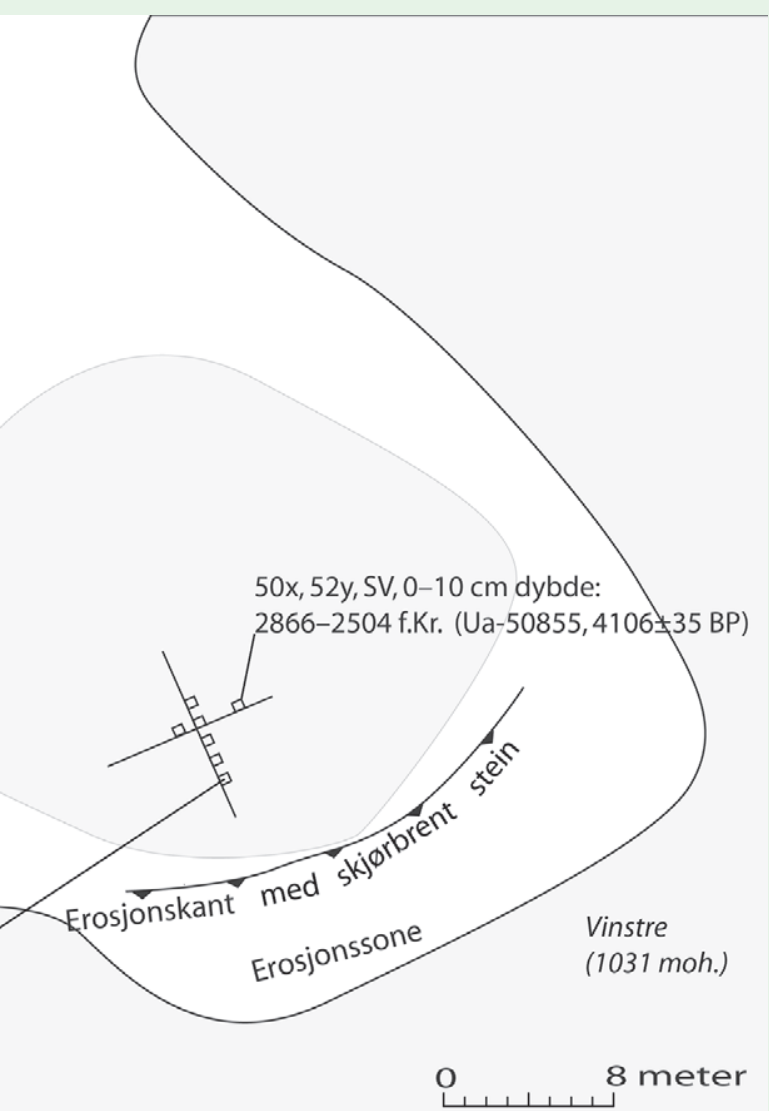

Figur 22: Plankart over den begrensede undersøkelsen på lokaliteten Vinstri I. Illustrasjon: Axel Mjærum, KHM. 

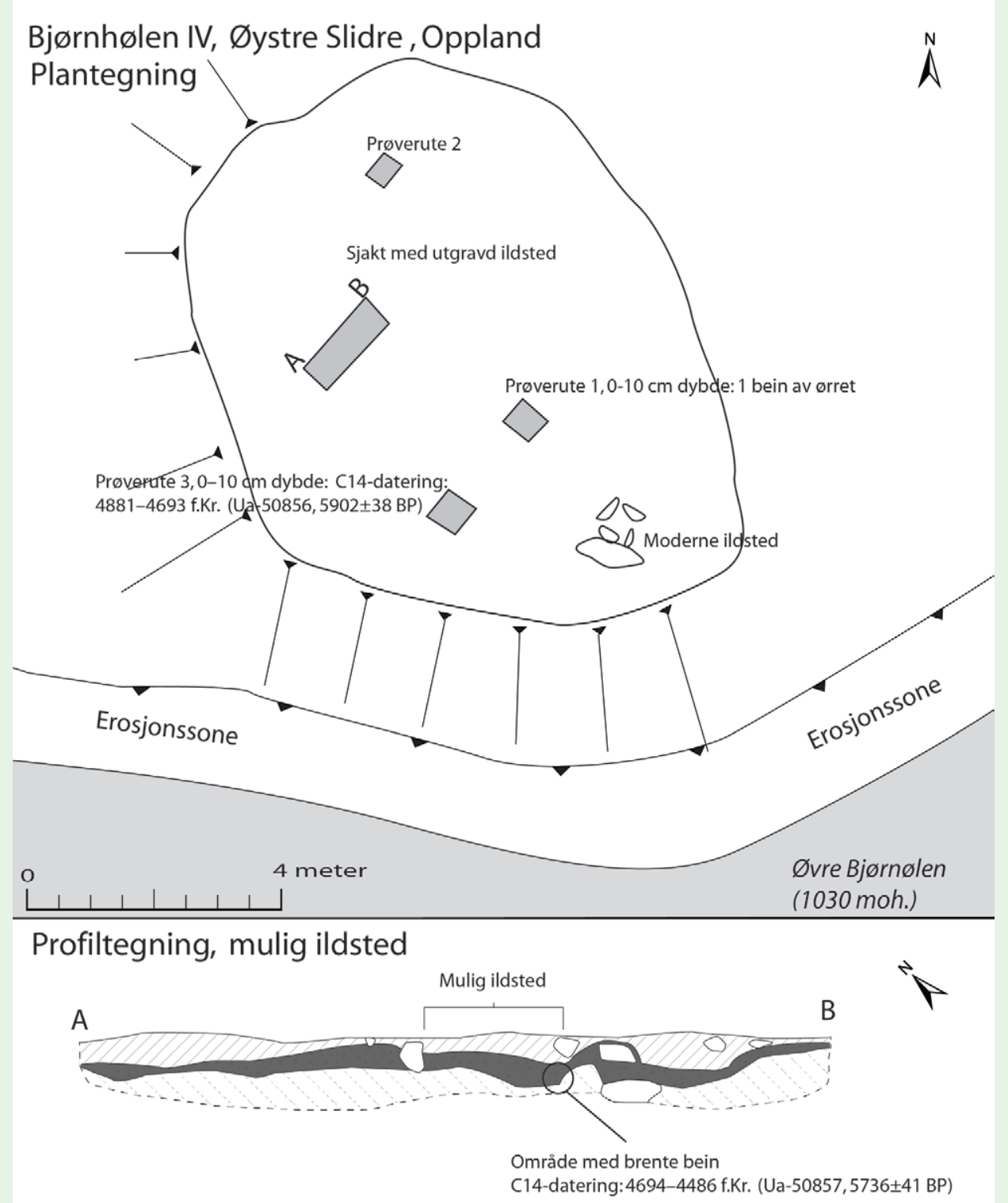

Torv. delvis med skjørbrent stein og gjenstander

Kulturlag. Brunt, humusblandet sandlag, Laget inneholder mest humus i den sentale delen av sjakten.

Undergrunn. Grusblandet sand

S Stein

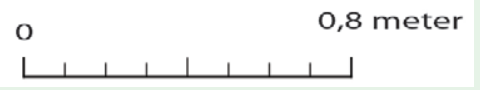

Figur 23: Plankart over og profiltegning av den begrensede undersøkelsen på lokaliteten Bjørnhølen IV. Illustrasjon: Axel Mjærum, KHM. 


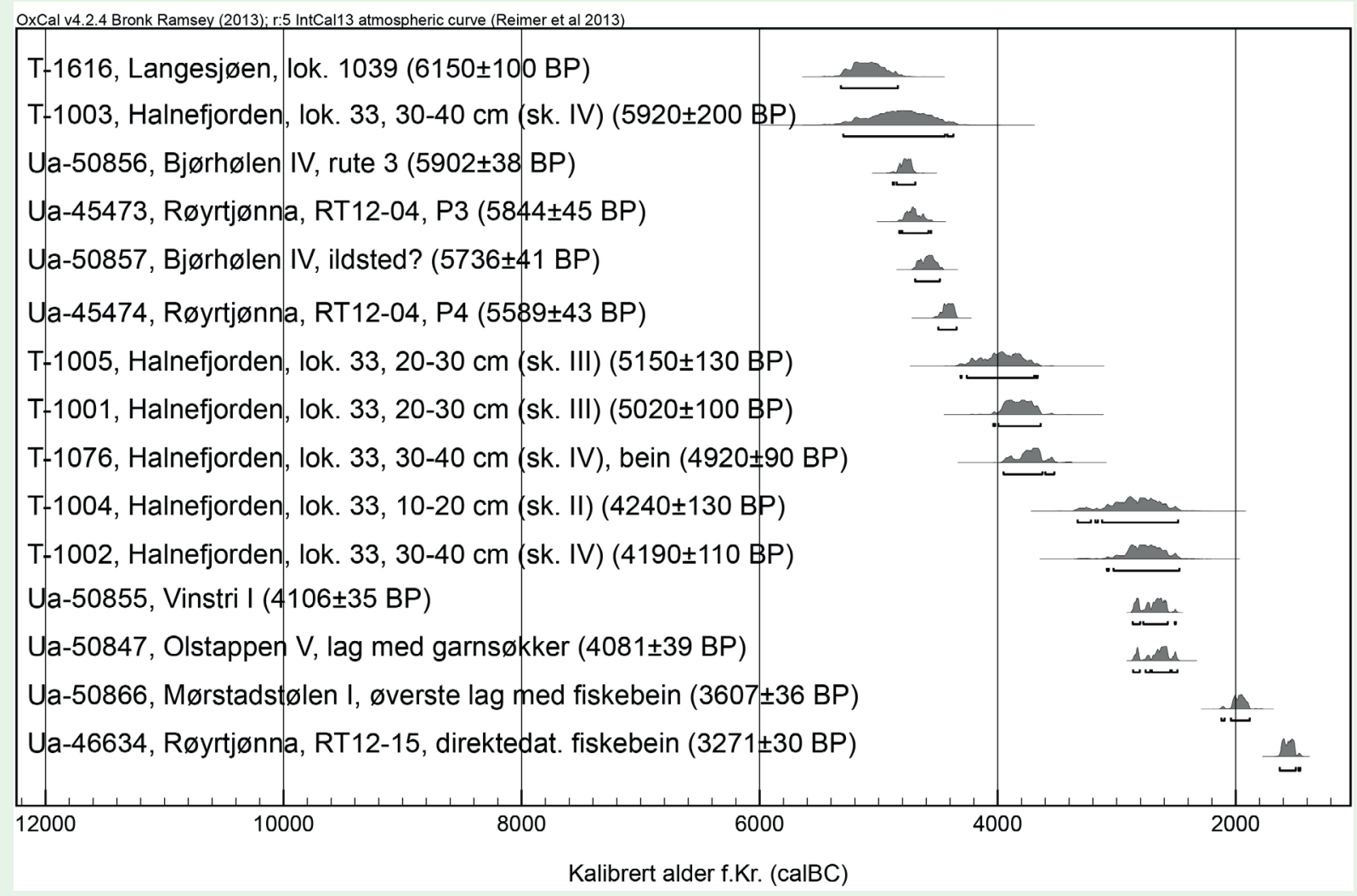

Figur 24: Sammenstilling av radiologiske dateringer som kan knyttes til fjellfiske i steinalderen i Sør-Norge.

\section{SLUTTNOTER}

Jf. Hesthagen og Kleiven 2016b.

2 Heggenes 2016; Hesthagen og Kleiven 2016b.

3 I artikkel benyttes tittelen begrepet «fjellet». I geografien anvendes termen spesifikt om høyfjellet (> 1500 moh.) og lavfjellet (snaufjellområder opp til 1500 moh.) og fjellskogsområdene (Puschmann 2005). De indre områdene i Sør-Norge er imidlertid varierte, med både fjellbygder, viddeområder og breer. I denne artikkelen vektlegges imidlertid et annet trekk ved de høyereliggende innlandsområdene, nemlig at fosser og stryk har hindret fisken fra å vandre inn på egen hånd (Hesthagen og Kleiven 2016b). Jeg konsentrerer meg derfor ikke bare om snaufjellsområdene, men om alle høyereliggende vassdrag i Sør-Norge uten naturlig innvandring av fisk.
5 Jf. Hagen 1959a; 1959b: 141-143; Mikkelsen 1989b: 65, 73, 297; Indrelid 1994: 263.

6 For eksempel Indrelid 1994: 259-262; Glørstad 2010: 265-269; Selsing 2010: 285-286.

7 Indrelid 1994: 247.

8 Se nedenfor.

9 For eksempel Carpelan 2008: 97.

10 For eksempel Mikkelsen 1989b: 24; Indrelid 1994: 240-242, 263; Selsing 2010: 290.

11 Se Hufthammer og Mjærum 2016.

12 Se nedenfor.

13 Kelly 2013: 40-45.

14 Richards og Trinkaus 2009.

15 Adán mfl. 2009: 898.

16 Glørstad 2014. 
17 Bjerck 2008: 85-86; Fuglestvedt 2009; Bang-Andersen 2012.

18 Åstveit 2014: 100.

19 Mikkelsen 1977: 149.

20 1977: figur 3, etter Engelstad 1934.

21 Linge 2014.

22 2014: figur 16.

23 Bergsvik og David 2015: 193-194, 199.

24 1951: pl. VII og IX.

25 Bergsvik 2002: 303-317; Bjerck 2008; Glørstad 2010: 82.

26 For eksempel Hufthammer 1992: 51; 1997: 53; Hjelle mfl. 2006; Glørstad 2010: 70-86; Mansrud 2014.

27 Bergsvik 2002: 290-291.

28 Lødøen og Mandt 2010.

29 Bruen Olsen 1992: 184-187; Bergsvik og David 2015; se også Matland 1990.

30 Bruen Olsen 1992: 188-189.

31 Simonsen 1961; Olsen 1994.

32 Fischer 2007.

33 Fischer 2007.

34 Ca. 2350 f.Kr.; for eksempel Hjelle mfl. 2006; Prescott 2009.

35 For eksempel Carpelan 2008; Carlsson 2007: 130-137; Nilsson mfl. under arbeid.

36 Carlsson 2007:130-137.

37 Carlsson 2007:130-137.

38 Carlsson 2007:130-131.

39 Ekman og Iregren 1984: 12, 31-32.

40 Ekman og Iregren 1984: 14; se også nedenfor.

41 Ekman og Iregren 1984: 32-36, table A.

42 Se nærmere diskusjon av temaet i Hufthammer og Mjærum 2016.

43 Jf. Carlsson 2007: 130-137.

44 Ekman og Iregren 1984: table 5.4.

45 Mikkelsen 1989a: 44; Fuglestvedt 1992; Stene mfl. 2010: 488-490. I tillegg ble det i 2016 funnet rygghvirvler av fisk ved en arkeologisk utgravning $i$ en ansamling med bein ved Osensjøen i Åmot kommune, Hedmark (pers. med. Per Persson, KHM). I 2009 ble det C14-datert bein fra det som trolig er den samme beinkonsentrasjonen. Analysen ga den gangen alderen 6694-6511 f.Kr. (TUa$83157800 \pm 35 \mathrm{BP})$, det vil si midten av eldre steinalder.

46 Carlsson 2007: 134-137; Hufthammer og Mjærum 2016.

47 Indreko 1956: type A.

48 Lannerbro 1997.

49 Helstad 2008: 67; jf. Olsen 2004: 67.

50 Broadbent 1979: 127-128; Lannerbro 1997: 25-26; Damlien 2010: 443; Stene mfl. 2010: 516.

51 Hesthagen og Kleiven 2016a.

52 Jf. Trigger 1996: 62-87.

53 For eksempel Indrelid 1994; Bergsvik 2006; Solheim 2012.

54 Jf. Loftsgarden mfl. 2013.
55 Olsen mfl. 2008; Philippsen 2013.

56 For eksempel Mikkelsen 1989b; Indrelid 1994; Bergsvik 2006.

57 Hesthagen og Kleiven 2016b.

58 Hesthagen 2007.

59 Se Ugulen 2016; Wammer 2016.

60 Bjørkli mfl. 2016.

61 Skulberg 1967: figur 3.

62 Jf. Selsing 2010: 123

63 Se Bjørkli mfl. 2016.

64 For detaljer omkring kildegrunnlaget og dateringene, se Bjørkli mfl. 2016.

65 Bjørkli mfl. 2016.

66 Jf. Hagen 1959a; 1959b: 141-143; Mikkelsen 1989b: 65, 73, 297; Indrelid 1994: 263.

67 Wammer 2016.

68 Se over.

69 Finstad mfl. 2011: 56; jf. figur 6.

70 Westerdahl 2000.

71 Melsom og Wammer 2016a.

72 Jf. Brabrand mfl. 2008: 14, 52; Rognerud og Qvenild 2013: 6, 14.

73 Indrelid 1994, 2009, 2014.

74 Mjærum 2016b.

75 Indrelid 1994: 231-231, 284.

76 Ytterligere informasjon og diskusjoner om de tre tidligere upubliserte boplassene ved Røyrtjønna finnes i vedlegget.

77 Sundström 2014; Mjærum 2015.

78 Mjærum 2016b.

79 Solhjell 1992; Selsing 2010: 50-51.

80 Se vedlegg for ytterligere informasjon.

81 Se vedlegg.

82 Qvenild 1994: 140; Hufthammer og Mjærum 2016.

83 Brabrand mfl. 2008: 71.

84 Moe 1979.

85 Indrelid 1994: 93-95.

86 Indrelid 1994: 237.

$876150 \pm 100 \mathrm{BP}, \mathrm{T}-1616$.

88 Indrelid 1973: figur 3, 58 og 84; 1994: 38.

89 Kalibreringene er utført med programmet Oxcal v4.2.4 (Bronk Ramsey 2009; Reimer mfl. 2013).

90 T-1076.

91 Indrelid 1994: 94.

92 Indrelid 1973; 1994: 36-39.

93 Indrelid 1973.

94 Indrelid 1994: 38.

95 Indrelid 1994: 247, 263.

96 Gregersen og Hegge 2009.

97 Hesthagen og Kleiven 2016b.

98 Bergstøl og Friis under arbeid. Prosjektet er knyttet til reguleringen av vassdraget, og undersøkelser blir gjennomført i fire feltsesonger fra 2013 til 2016. Det rettes en stor takk til prosjektleder Jostein Bergstøl for at han har gitt tillatelse til å benytte de foreløpige resultatene. 
99 I tillegg har det fremkommet fem ørretbein ved en undersøkelse av et ildsted ved vannet Øyangen (ca. $997 \mathrm{moh}$.) i Vinstravassdraget. Ildstedet har ikke blitt radiologisk datert, men tre tilslåtte steingjenstander i ildstedet antyder at beinene har en høy alder (Bergstøl og Friis under arbeid).

100 Bergstøl og Friis under arbeid.

101 Lannerbro 1997: 21.

102 Indreko 1956; Lannerbro 1997; Helstad 2008.

103 Lannerbro 1997: 22.

104 Bjørkli mfl. 2016.

105 Gustafson 1990; Helstad 2008: 64-72.

106 Jf. Selsing 2010: 113-140.

107 Bergstøl og Friis under arbeid.

108 Indrelid 1994: 179; Glørstad 2004: 37-38; 2010b: 261-264; Stene mfl. 2010: 509-511.

109 Indrelid 1994; Mjærum 2016b; Bergstøl og Friis under arbeid.

110 Se Hufthammer og Mjærum 2016.

111 Hesthagen og Kleiven 2016b.

112 Johansen 1978: 64-69.

113 Bjørgo mfl. 1992; Lie 1992.

114 Ekman og Iregren 1984: 32-36.

115 Jf. Heggenes 2016.

116 Woodburn 1982.

117 Woodburn 1982: 433.

118 Woodburn 1982: 432-434.

119 Lundberg 1997; Boaz 1999: 143-146; Glørstad 2010: 126-128.

120 Glørstad 2010: 265-269.

121 Bergstøl 2015.

122 Persson 2013.

123 Selsing 2010: 297-299, med videre ref.

124 Jf. Hjelle mfl. 2006; Prescott 2009.

125 Jochim 1976: 20-22.

126 Kelly 2013: 134-135.

127 For eksempel Ekman og Iregren 1984: 38; Mikkelsen 1989b; Indrelid 1994; Boaz 1998a; Glørstad 2010; BangAndersen 2012.

128 Hayden 1981.

129 Vihovde 2015.

130 Jf. Bjørkli 2005: 76; Solheim 2012: 95-101.

131 Indrelid 1994: 179; Glørstad 2004: 35-38; Solheim 2012: 94-95.

132 Jf. Mjærum 2012.

133 Philippsen 2013.

134 Jf. Philippsen 2013: 16.

135 Jf. for eksempel Indrelid 1994: 157-160; Bergsvik 2006: 116.

136 Mjærum 2012, 2016.

137 For eksempel Damlien 2010; Sundström 2014; Mjærum 2015.

138 Stene mfl. 2010.

139 Mjærum og Friis 2016.

140 Mjærum og Vihovde 2015.
141 Indrelid 1994: 179; Glørstad 2004: 37-38; 2010b: 261-264; Eigeland 2015: 374.

142 Glørstad 2004: 32-33, 36-37; Mjærum 2012; Solheim 2012: 89-92.

143 Nergaard 2015.

144 Indrelid 1994: 179; Glørstad 2004: 37-38; 2010b: 261-264; Stene mfl. 2010: 509-511.

145 Indrelid 1994: 183-195; Malmer 2002: 120-122; Solheim 2012: 92-101, med videre ref.

146 Mjærum 2012.

147 Olsen mfl. 2013.

148 Berstøl og Friis under arbeid.

149 Bjørkli 2005: 76; Solheim 2012: 95-101.

150 Berstøl og Friis under arbeid. 


\section{AUREN I JOTUNHEIMEN - NÅR VART HAN INNFØRT, OG KOR KOM HAN FRÅ?}

Trygve Hesthagen, Norsk institutt for naturforskning, Trondheim og Einar Kleiven, Norsk institutt for vannforskning, Grimstad

\section{SLUTTNOTER}

Schøning 1926.

Olsen 1941.

Jf. Ugulen 2016.

Jf. Mjærum 2016a.

Jf. Bjørkli mfl. 2016; Mjærum 2016a.

Indrelid 1994; Mjærum 2016a.

Halvorsen 1914.

Bargel og Nordgulen 2001.

Terje H. Bargel, pers. med.

10 Longva og Thoresen 1991; Longva 1994.

11 García-Marín mfl. 1999; Nesbø mfl. 1999.

12 Huitfeldt-Kaas 1918.

13 Hindar mfl. 1986.

14 Huitfeldt-Kaas 1918.

15 Refseth mfl. 1998; García-Marín mfl. 1999; Nesbø mfl. 1999; Koskinen mfl. 2000.

16 García-Marín mfl. 1999.

17 Skaala 1992.

18 Junge mfl. 2014.

19 Tande og Hegge 1993; Grøndahl 2001; Johnsen 2004; Johnsen mfl. 2015.

20 Junge mfl. 2014.

21 Pram 2004; Røgeberg 2004.

22 Hauritz 2004: 330.

23 Schøning 1926; Hiorthøy 1956 [1785-1786].

24 1926: 48.

25 Jf. Mjærum 2016a.

26 Bergstøl og Friis under arbeid.

27 Mjærum 2016a.

28 Knapstad 1967a.

29 Mjærum 2016a.

30 Knapstad 1967b.

31 Lødøen 2003.

32 Knapstad 1967c; Østmo 1975.

33 Schøning 1926.

34 DN III 1336, nr. 185: 165-166.

35 DN III, nr. 943.

36 Dahl 1870, Huitfeldt-Kaas 1927.

37 Hesthagen 2011.

38 Mjærum 2016a.

39 Ågotnes 1967a, 1967b.

40 DN III, nr. 183.

41 Høgåsen 1950.

42 Teigum 2001. mfl. 1991; Skaala 1992; Wollebæk mfl. 2011.

Heggenes og Røed 2006; Heggenes mfl. 2006; Sønstebø mfl. 2007; Heggenes 2016.

64 Finn Hellebergshaugen, pers. med.

65 Bergstøl og Friis under arbeid; Mjærum 2016a.

66 Bye 1997.

67 Jacobsen 1990.

68 Jacobsen og Larsen 1992: 139-161.

69 Jf. Lødøen 2003.

70 Bjørgo 1983.

71 Brøgger 1963.

72 Kleiven 1923.

73 Jordhøy 2005; Hesthagen 2008.

74 Amundsen mfl. 2007: 46.

75 Hesthagen og Sandlund 2004.

76 Lie 1994; Lie og Fredriksen 2007; Mørch von der Fehr 2007.

77 Weber 2007b.

78 Mikkelsen 1994; Færden 2007; Weber 2007b.

79 Solheim 2010.

80 Jf. Prescott 1995.

81 Aass mfl. 1989.

82 Ile 1960.

83 Huitfeldt-Kaas 1918: 19.

84 Hesthagen og Kleiven 2016a. 
85 Hesthagen 2013.

86 Hovdhaugen 1974.

87 Kleiven 1944.

88 Hammer 2000 [1797-1798]: 71.

89 Pram 2004 [1743]; Teigum 2004.

90 Thomle 1927.

91 Jf. Kleiven 1944.

92 Teigum 2004

93 Jf. Reinton 1957; Teigum 2004.

94 Jf. Hauritz 2004, Pram 2004.

95 Hesthagen 2001.

96 Tundrali 1965; Hiim 1967.

97 Hosar 1994.

98 Rud 1967.

99 Rud 1967.

100 Hesthagen og Kleiven 2016c.

101 Jf. Anonym 1884; Eigne data.

102 Hesthagen 2001.

103 Hesthagen 2009.

104 Bøe 1942b.

105 Gjessing 1961.

106 Hufthammer og Mjærum 2016; Mjærum 2016a.

107 Mjærum 2016a.

108 Jf. Martens og Hagen 1961.

109 Mjærum 2016a.

110 Eknæs 1977, 1979.

111 Hesthagen og Kleiven 2016a.

112 Hesthagen 2011.

113 Mjærum 2016a. 


\title{
FISKEN I FJELLET I FORTID OG NÅTID. HVA KAN DNA-ANALYSER FORTELLE?
}

\author{
Jan Heggenes, Hogskolen i Sorost-Norge
}

\section{SLUTTNOTER}

\author{
Watson og Crick 1953; Pray 2008. \\ Venter mfl. 2001; Gibbs mfl. 2003. \\ Frankham 2010; Charlesworth 2015. \\ http://humanorigins.si.edu/evidence/genetics. \\ Bryson 2006. \\ Ferguson 1989; Heggenes mfl. 2009. \\ Klemetsen mfl. 2003; Dodson mfl. 2013. \\ Ferguson 1989. \\ Hutchings 2011. \\ 10 Ferguson og Taggart 1991. \\ 11 http://www.flyfishing.co.uk/photo-galle- \\ ry/45850-trout-identification.html\#post 477540.
}

12 Bernatchez mfl. 1992; Charlier mfl. 2012; Hansen mfl. 2012.

13 Bernatchez mfl. 1992; Shubina mfl. 2015.

14 Bartlett og Stirling 2003.

15 Vignal mfl. 2002.

16 Vigilant mfl. 1991; Brauer mfl. 2004; Templeton 2007.

17 http://quest.eb.com/.

18 Putman og Carbone 2014.

19 Bernatchez mfl. 1992; Bernatchez 2001; Cortey mfl. 2009.

201992.

21 Cortey mfl. 2009.

222009.

23 Heggenes mfl. 2002; Sonstebo mfl. 2007; Thaulow mfl. 2013.

24 Heggenes og Røed 2006; Heggenes mfl. 2006.

25 Selsing 2010:194-201 med videre referanser.

26 Heggenes mfl. 2002.

27 Indrelid 1994; se også Mjærum 2016a; Indrelid og Hufthammer 2011.

28 Sonstebo mfl. 2007.

29 Heggenes mfl. 2006.

30 Heggenes mfl. 2006.

31 Thaulow mfl. 2014.

32 Sonstebo mfl. 2008a.

33 Thaulow mfl. 2013.

34 Heggenes mfl. 2006; Sonstebo mfl. 2008b; Thaulow mfl. 2014.

35 Heggenes og Røed 2006. 
FJELLFISKE I FORTIDEN | NOTER OG APPENDIKS

\section{FISKEMÅTAR I FJELLET I ELDRE TID}

Trygve Hesthagen, Norsk institutt for naturforskning, Trondheim og Einar Kleiven, Norsk institutt for vannforskning, Grimstad

\section{SLUTTNOTER}

Hjelle mfl. 2006; Prescott 2009.

Reinton 1957: 236.

Kjelland 1994.

Motzfeldt 1908; Hougen 1947.

Ugulen 2016.

Elvestad mfl. 2004: 48.

Bugge 1920; Blindheim 1979: 66.

Hougen 1947.

9 Hougen 1947; Bjøntegaard 1949; Grieg 1950: 101; 1957: 163; Reinton 1957: 236; Ile 1960: 183.

10 Bjøntegaard 1949.

11 Bull 1929: 26.

12 Rugsveen 1996: 86.

13 Johansen 1994.

14 Hermundstad 1939.

15 Jf. Hesthagen 2011.

16 Harstad 1968: 350; Bakken 1975: 24; Eknæs 1979: 32; Elvestad mfl. 2004: 48.

17 Reinton 1957: 239.

18 Landmark 1889.

19 Gjessing 1955: 49.

20 Jf. Mjærum 2016a med vidare ref.

21 Hougen 1947: 237.

22 Larsen 2009.

23 Hermundstad 1964: 149.

24 Jf. Bugge 1920.

25 Gjessing 1961: 39.

26 Hougen 1958.

27 Petersen 1922: 184.

28 Fölsch 1818: 181.

29 Liestøl 1939.

30 Brumle 1939.

31 Hermundstad 1964: 148.

32 Bergsvik og David 2015: 208.

33 Eknæs 1979.

34 Anonym 1936-1939. Opplysningane er henta frå ei landsomfattande innsamling av Ord og Sed, av Norsk Etnologisk Gransking ved «Nemdi til gransking av norsk nemningsbruk». Spørjelistene kom inn i åra 1936-1939. Nr. 27-38 i spørjelistene har med fiske å gjera.

35 Hufthammer og Mjærum 2016.

36 Martens og Hagen 1961: 81.

37 Færden 2007.

38 Sjå seinare.

39 Færden 2007.

40 Fossum 1971

41 Johansen 1981: 14
42 Nordgaard 1908; Petersen 1951.

43 Fossum 1971.

44 Anonym 1936-1939.

45 Ormstad 1968.

46 Anonym 1937.

47 Anonym 1936-1939.

48 Ågotnes 1967a.

49 Nordgaard 1908: 82.

50 Nordgaard 1908: 83.

51 Veierød 2012: 26.

52 Wammer 2015.

53 Jf. Nordgaard 1908.

54 Landmark 1889.

55 Hermundstad 1964: 188.

56 Anonym 1936-1939.

57 Anonym 1936-1939.

58 Storm 2009: 156.

59 Digitalt museum 2015.

60 Hermundstad 1964: 178.

61 Anonym 1951.

62 Eknæs 1979: 5.3.

63 Mjærum 2016a.

64 Jacobsen og Larsen 1992: 141; Mjærum 2016a.

65 Amundsen mfl. 2007: 46.

66 Hagen 1959a; Eknæs 1975.

67 Eknæs 1975.

68 Bjørkli mfl. 2016; Wammer 2016.

69 Jf. Bjørkli mfl. 2016; Wammer 2016.

70 Hagen 1959a; Hesthagen 2008.

71 Weber 2007c.

72 Nordgaard 1908: 79.

73 Bull 1916; Hougen 1947; Skjølsvold 1958.

$74925 \pm 100$ BP (T-22246). Omregnet med kalibreringsprogrammet Oxcal v4.2.4. (Bronk Ramsey 2009; Reimer 2013).

75 Eknæs 1979: 55.

76 Grimstad 1948: 158

77 Hermundstad 1964: 179.

78 Anonym 1936-1939.

79 Schøning 1926; Mælingen 1948.

80 Hattestad 1948.

81 Jf. Huitfeldt-Kaas 1916; Rugsveen 1985; 1996.

82 Hattestad 1948.

83 Rugsveen 1985.

84 Anonym 1936-1939.

85 Bakken 1975.

86 Anonym 1936-1939. 
87 Bakken 1975: 30-32.

88 Wammer 2015.

89 Anonym 1936-1939.

90 Reinton 1957: 240; Hesthagen 2001: 211.

91 Bakken 1975.

92 Jf. Eknæs 1979.

93 Eknæs 1979; Hesthagen 2008.

94 Hougen 1947: 243.

95 Hiorthøy 1990.

96 Bakken 1975.

97 Bakken 1975, 1978; Eknæs 1979.

98 Hesthagen 2011.

99 Ile 1960: 226; Hermundstad 1964: 172.

100 Eknæs 1978.

101 Wammer 2015; Bjørkli mfl. 2016.

102 Hesthagen 2011.

103 DN V, nr. 371 (datert år 1396, truleg sløefiske i Bottheimstraumen på Lesja); DN XIII, nr. 82 (datert år 1419, om sløefiske i bekken mellom Rabbalsvatnet og Vangsjøen, Øystre Slidre); DN II, nr. 890 (datert år 1474, om sløefiske i Rinda, Lillehammer); Høgåsen 1956.

104 Hesthagen 2011.

105 Hageløkken 1955.

106 Opedal 1943

107 Hermundstad 1964: 173.

108 Hesthagen 2011.

109 Hermundstad 1964: 182; Bakken 1975: 69; Eknæs 1979: 63.

110 Torp 1919.

111 Bakken 1975.

112 Hesthagen 2004.

113 Sommerfelt 1795.

1141960.

115 Bakken 1975.

116 Bakken 1975.

117 Sommerfeldt 1795.

118 Hiorthøy 1990.

119 Ile 1960: 211.

120 Hesthagen 2004.

121 Hesthagen og Kleiven 2016c.

122 Hermundstad 1964.

123 Sømme 1933.

124 Taksdal 1973: 139

125 Helland 1913.

126 Anonym 1936-1939.

127 Hermundstad 1964.

128 Anonym 1936-1939. Opplysningane frå Martinius Omundsen Fosse (fødd 1.9.1853) og Ole Olsen Megarden (fødd 18.7.1852) vart teikna ned av K. P. Åsmundstad; Hesthagen 2008.

129 Hesthagen 2008.

130 Landmark 1894.

131 Eknæs 1972a, 1974.

132 Skaraberget 1992: 67.

133 Bakken 1975.
134 Hermundstad 1964: 182.

135 Bakken 1975.

136 Hermundstad 1964.

137 Harstad 1968.

138 1964: 148

139 Hegstad 1963.

140 Liestøl og Hagland 1996.

141 Hovstad 1965.

142 Hesthagen 2007.

143 Håkon Odde (f. 1914), pers. med.

144 Eknæs 1972b.

145 Huitfeldt-Kaas 1916; Rugsveen 1985, 1996.

146 Kleiven 1949.

147 Jf. Seinare.

148 Storm 2009: 141.

149 Jf. Frisak sitert i Djupedal 1955: 98.

150 Skjølstad 1958.

151 Eknæs 1979.

152 Anonym 1936-1939.

153 Hesthagen 2008.

154 Kleiven 1949.

155 1949: 107.

156 Opedal 1943.

157 Landmark 1889.

158 Landmark 1907, 1909, 1911.

159 Aagaard 1923.

160 Hesthagen og Kleiven 2016c.

161 Vågslid 1975.

162 Hesthagen 2006, 2011.

163 Jf. Elvestad mfl. 2004: 24-25.

164 Jordhøy 2005

165 Jf. Melsom og Wammer 2016a.

166 Jordhøy 2007b; Jordhøy mfl. 2007, 2011; Jordhøy 2014.

167 Johansen 1983.

168 Shetelig og Johannessen 1929: 49.

169 Jacobsen og Larsen 1992: 141.

170 Mjærum 2016a.

171 Hougen 1947.

172 Rugsveen 1985.

173 Indrelid 1994; Nybruket 1980; Mjærum 2016a.

174 Mjærum 2016a.

175 Færden 2007.

176 Ågotnes 1967a.

177 Hans Mack Berger, pers. med.

178 Hougen 1947.

179 Hesthagen 2011. 


\section{FJELLFUNN OG FISKEBEIN \\ OM FISKE OG BRUKEN AV FJELLET I FORTIDEN}

Anne Karin Hufthammer, Universitetsmuseet, Universitetet i Bergen og Axel Mjarum, Kulturhistorisk museum, Universitetet i Oslo

\section{VEDLEGG}

\begin{tabular}{|c|c|c|c|c|c|c|c|c|c|}
\hline JSNR & $\begin{array}{c}\text { Hoyde } \\
\text { over } \\
\text { havet }\end{array}$ & Lokalitet & Kommune & Fylke & $\begin{array}{l}\text { Mulig daterings- } \\
\text { ramme for fiske- } \\
\text { beinsfunnene }\end{array}$ & $\begin{array}{c}\text { Ant } \\
\text { fragm. av } \\
\text { orret }\end{array}$ & $\begin{array}{c}\text { Antall } \\
\text { fiskebein } \\
\text { totalt }\end{array}$ & $\begin{array}{l}\text { Fiske- } \\
\text { redskaper }\end{array}$ & $\begin{array}{l}\text { Rapport/ } \\
\text { Publikasjon }\end{array}$ \\
\hline \multicolumn{10}{|c|}{ Åpne boplasser } \\
\hline 1475 & $\begin{array}{l}243 \\
\text { moh. }\end{array}$ & Melle, Rena elv & Åmot & Hedmark & 6110-5980 f.Kr. & 4 & 28 & - & Melvold 2010 \\
\hline 527 & $\begin{array}{l}1130 \\
\text { moh. }\end{array}$ & $\begin{array}{l}\text { Halnefjorden } \\
\text { Hein, lok. } 33\end{array}$ & $\begin{array}{l}\text { Nore og } \\
\text { Uvdal }\end{array}$ & Buskerud & $5300-3500$ f.Kr. & 6 & 6 & - & $\begin{array}{c}\text { Indrelid } \\
\text { 1973; } \\
\text { Indrelid } \\
\text { 1994: 36-39 }\end{array}$ \\
\hline 624 & $\begin{array}{l}1206 \\
\text { moh. }\end{array}$ & $\begin{array}{l}\text { Langesjøen, } \\
\text { lok. } 1039\end{array}$ & $\begin{array}{l}\text { Nore og } \\
\text { Uvdal }\end{array}$ & Buskerud & $4900-4250 \mathrm{f.Kr}$. & 1 & 1 & - & $\begin{array}{l}\text { Indrelid } \\
\text { 1994: 93-95 }\end{array}$ \\
\hline 1683 & $\begin{array}{l}1030 \\
\text { moh. }\end{array}$ & Øvre Bjørnhølen & $\begin{array}{l}\text { Øystre } \\
\text { Slidre }\end{array}$ & Oppland & $4880-4490$ f.Kr. & 1 & - & - & $\begin{array}{l}\text { Bergstøl } \mathrm{mfl} \text {. } \\
\text { under arbeid }\end{array}$ \\
\hline- & $\begin{array}{c}740 \\
\text { moh. }\end{array}$ & $\begin{array}{l}\text { Røyrtjønna, } \\
\text { Pålsbufjorden, } \\
\text { RT12-04 }\end{array}$ & $\begin{array}{l}\text { Nore og } \\
\text { Uvdal }\end{array}$ & Buskerud & $4830-4340$ f.Kr. & 0 & 1 & - & $\begin{array}{c}\text { Mjærum } \\
\text { 2016a }\end{array}$ \\
\hline 1474 & $\begin{array}{l}240 \\
\text { moh. }\end{array}$ & $\begin{array}{l}\text { Stene terrasse, } \\
\text { Rena elv }\end{array}$ & Åmot & Hedmark & $4220-3800$ f.Kr. & 2 & 2 & - & $\begin{array}{c}\text { Damlien } \\
2010\end{array}$ \\
\hline - & $\begin{array}{l}740 \\
\text { moh. }\end{array}$ & $\begin{array}{l}\text { Røyrtiønna, } \\
\text { Pålsbufjorden, } \\
\text { RT12-9 }\end{array}$ & $\begin{array}{l}\text { Nore og } \\
\text { Uvdal }\end{array}$ & Buskerud & Før 2350 f.Kr. & 0 & 2 & - & $\begin{array}{c}\text { Mjærum } \\
\text { 2016a }\end{array}$ \\
\hline- & $\begin{array}{l}740 \\
\text { moh. }\end{array}$ & $\begin{array}{l}\text { Røyrtiønna, } \\
\text { Pålsbufjorden, } \\
\text { RT12-15 }\end{array}$ & $\begin{array}{l}\text { Nore og } \\
\text { Uvdal }\end{array}$ & Buskerud & $1620-1460$ f.Kr. & 0 & 114 & - & $\begin{array}{c}\text { Mjærum } \\
\text { 2016a }\end{array}$ \\
\hline 1682 & $\begin{array}{l}1031 \\
\text { moh. }\end{array}$ & Vinstri I & $\begin{array}{l}\text { Øystre } \\
\text { Slidre }\end{array}$ & Oppland & Før 2350 f.Kr. & 1 & 1 & - & $\begin{array}{l}\text { Bergstøl mfl. } \\
\text { in prep. }\end{array}$ \\
\hline 1498 & $\begin{array}{l}240 \\
\text { moh. }\end{array}$ & Melvold, Rena elv & Åmot & Hedmark & Før 1700 f.Kr. & 1 & 9 & - & $\begin{array}{c}\text { Datering } \\
\text { omtalt i } \\
\text { Stene mfl. } \\
\text { 2010: } 490\end{array}$ \\
\hline 1663 & $\begin{array}{l}1000 \\
\text { moh. }\end{array}$ & Øyangen & Nord-Fron & Oppland & Før 200 f.Kr. & 5 & 5 & - & $\begin{array}{l}\text { Bergstøl mfl. } \\
\text { in prep. }\end{array}$ \\
\hline $\begin{array}{l}1661 \\
1684\end{array}$ & $\begin{array}{l}1031 \\
\text { moh. }\end{array}$ & Mørstadstølen & $\begin{array}{l}\text { Øystre } \\
\text { Slidre }\end{array}$ & Oppland & Før 1000 f.Kr. & 26 & 30 & - & $\begin{array}{l}\text { Bergstøl mfl. } \\
\text { in prep. }\end{array}$ \\
\hline \multicolumn{10}{|c|}{ Massefangstanlegg } \\
\hline $788 / 1327$ & $\begin{array}{l}1190 \\
\text { moh. }\end{array}$ & $\begin{array}{l}\text { Sumtangen, } \\
\text { Sørbu }\end{array}$ & Eidfjord & Hordaland & 200-400 e.Kr. & 107 & 114 & - & $\begin{array}{c}\text { Indrelid og } \\
\text { Hufthammer } \\
2011\end{array}$ \\
\hline
\end{tabular}


FJELLFISKE I FORTIDEN | NOTER OG APPENDIKS

\begin{tabular}{|c|c|c|c|c|c|c|c|c|c|}
\hline JSNR & $\begin{array}{c}\text { Hoyde } \\
\text { over } \\
\text { havet }\end{array}$ & Lokalitet & Kommune & Fylke & $\begin{array}{l}\text { Mulig daterings- } \\
\text { ramme for fiske- } \\
\text { beinsfunnene }\end{array}$ & $\begin{array}{c}\text { Ant } \\
\text { fragm. av } \\
\text { orret }\end{array}$ & $\begin{array}{l}\text { Antall } \\
\text { fiskebein } \\
\text { totalt }\end{array}$ & $\begin{array}{l}\text { Fiske- } \\
\text { redskaper }\end{array}$ & $\begin{array}{c}\text { Rapport/ } \\
\text { Publikasjon }\end{array}$ \\
\hline 710 & $\begin{array}{l}1120 \\
\text { moh. }\end{array}$ & Tøftom & Dovre & Oppland & $1200-1350$ e.Kr. & 530 & 1274 & 1 fiskekrok & Lie 1994 \\
\hline 1436 & $\begin{array}{l}1150 \\
\text { moh. }\end{array}$ & Krækkja & Hol & Buskerud & $1250-1300$ e.Kr. & 39 & 39 & - & $\begin{array}{c}\text { Hufthammer } \\
\text { mfl. } 2011\end{array}$ \\
\hline 552 & $\begin{array}{l}1190 \\
\text { moh. }\end{array}$ & $\begin{array}{c}\text { Sumtangen, } \\
\text { Austbu og Vestbu }\end{array}$ & Eidfjord & Hordaland & $1250-1300$ e.Kr. & 11 & 13 & & $\begin{array}{l}\text { Indrelid } \\
\text { mfl. } 2007\end{array}$ \\
\hline \multicolumn{10}{|c|}{ Overnattingssteder, sælehus og læger } \\
\hline 712 & $\begin{array}{l}930 \\
\text { moh. }\end{array}$ & Vesle Hjerkinn & Dovre & Oppland & Ca. $1000-1250$ e.Kr. & 35 & 4484 & $\begin{array}{c}2 \text { garn- } \\
\text { søkker, } \\
3 \text { mulige } \\
\text { søkker til } \\
\text { linefiske, } 2 \\
\text { fiskekroker }\end{array}$ & Weber 2007 \\
\hline 1221 & $\begin{array}{l}1130 \\
\text { moh. }\end{array}$ & $\begin{array}{c}\text { Halnelægeret, } \\
\text { Hein (lok. } \\
38 \text { og 165) } \\
\end{array}$ & Eidfjord & Hordaland & Ca. $1600-1800$ e.Kr. & 3604 & 7362 & 3 fiskekroker & - \\
\hline 1214 & $\begin{array}{l}1245 \\
\text { moh. }\end{array}$ & $\begin{array}{l}\text { Andersbu, } \\
\text { Nordmannslågen } \\
\text { (lok. 706) }\end{array}$ & Eidfjord & Hordaland & Etter 1800 e.Kr. & 3 & 9 & $\begin{array}{c}3 \\
\text { lysterspisser } \\
\text { og } 1 \\
\text { fiskekrok }\end{array}$ & $\begin{array}{l}\text { Fasteland } \\
\text { 2002: } 38\end{array}$ \\
\hline \multicolumn{10}{|c|}{ Jernvinne } \\
\hline & $\begin{array}{l}700 \\
\text { moh. }\end{array}$ & Dokkfløy, DR36 & Gausdal & Oppland & $1260-1290$ e.Kr. & 0 & 5 & - & Larsen 1991 \\
\hline \multicolumn{10}{|c|}{ Hellere } \\
\hline 771 & $\begin{array}{l}790 \\
\text { moh. }\end{array}$ & Skrivarhelleren & Årdal & $\begin{array}{l}\text { Sogn og } \\
\text { Fjordane }\end{array}$ & $\begin{array}{l}\text { Hovedsakelig ca. } \\
2350-200 \text { f.Kr. }\end{array}$ & 2 & $\begin{array}{c}214, \text { hvorav } \\
34 \text { salt- } \\
\text { vannsfisk }\end{array}$ & - & Prescott 1991 \\
\hline 647 & $\begin{array}{l}780 \\
\text { moh. }\end{array}$ & Bukkhammeren & Tynset & Hedmark & 2350 f.Kr. -700 e.Kr. & 18 & 18 & - & $\begin{array}{c}\text { Gustafson } \\
1990\end{array}$ \\
\hline 557 & $\begin{array}{l}1125 \\
\text { moh. }\end{array}$ & $\begin{array}{l}\text { Stegaros, } \\
\text { lok. } 1058\end{array}$ & Tinn & Telemark & Ca. $2500-200$ f.Kr. & 1 ? & $2 ?$ & - & $\begin{array}{l}\text { Gustafson } \\
\text { 1978: 32-33 }\end{array}$ \\
\hline 398 & $\begin{array}{l}1100 \\
\text { moh. }\end{array}$ & Langesæhelleren & Vinje & Telemark & Etter Kristi fødsel & 3 & 3 & $\begin{array}{c}1 \text { fiskekrok } \\
\text { av jern }\end{array}$ & $\begin{array}{c}\text { Martens } \\
\text { og Hagen } \\
\text { 1961: 77-85 }\end{array}$ \\
\hline 443 & $\begin{array}{l}705 \\
\text { moh. }\end{array}$ & U1lshelleren & Odda & Hordaland & Etter Kristi fødsel & 2 & 2 & - & Odner 1969 \\
\hline 444 & $\begin{array}{l}1025 \\
\text { moh. }\end{array}$ & Gauthelleren & Odda & Hordaland & Steinalder-nyere tid & 2 & 2 & - & $\begin{array}{l}\text { Odner 1964; } \\
\text { Østebø 2008: } \\
145-146\end{array}$ \\
\hline 542 & $\begin{array}{l}\text { Ca. } 950 \\
\text { moh. }\end{array}$ & $\begin{array}{l}\text { Hyttevann- } \\
\text { helleren }\end{array}$ & Bykle & Aust-Agder & $\begin{array}{c}\text { Hovedsakelig } \\
\text { 1600-1800-tallet }\end{array}$ & 2 & 2 & - & $\begin{array}{l}\text { Mikkelsen } \\
1972\end{array}$ \\
\hline \multicolumn{10}{|c|}{ Støl/fjellgård } \\
\hline 690 & 956 moh. & $\begin{array}{c}\text { Vikastø1 } \\
\text { (lok. } 34 \text { A/C) }\end{array}$ & Årdal & $\begin{array}{c}\text { Sogn og } \\
\text { Fjordane } \\
\end{array}$ & 650-890 e.Kr. & 0 & 59 & - & $\begin{array}{c}\text { Kristoffersen } \\
\text { 1992: 154; Lie } \\
\text { 1992: 324 } \\
\end{array}$ \\
\hline
\end{tabular}




\begin{tabular}{|c|c|c|c|c|c|c|c|c|c|}
\hline JSNR & $\begin{array}{l}\text { Høyde } \\
\text { over } \\
\text { havet }\end{array}$ & Lokalitet & Kommune & Fylke & $\begin{array}{l}\text { Mulig daterings- } \\
\text { ramme for fiske- } \\
\text { beinsfunnene }\end{array}$ & $\begin{array}{c}\text { Ant } \\
\text { fragm. av } \\
\text { orret }\end{array}$ & $\begin{array}{c}\text { Antall } \\
\text { fiskebein } \\
\text { totalt }\end{array}$ & $\begin{array}{l}\text { Fiske- } \\
\text { redskaper }\end{array}$ & $\begin{array}{c}\text { Rapport/ } \\
\text { Publikasjon }\end{array}$ \\
\hline 690 & 975 moh. & $\begin{array}{l}\text { Hellingbøen } \\
\text { (lok. } 82 \mathrm{~A} / \mathrm{E} \text { ) }\end{array}$ & Årdal & $\begin{array}{l}\text { Sogn og } \\
\text { Fjordane }\end{array}$ & $\begin{array}{l}\text { 640-740 e.Kr. og } \\
\text { etter } 1450 \text { e.Kr. }\end{array}$ & 0 & 4 & - & $\begin{array}{c}\text { Kristoffersen } \\
\text { 1992: } 216 ; \\
\text { Lie 1992: } 325\end{array}$ \\
\hline 690 & 950 moh. & $\begin{array}{l}\text { Urutlekråi } \\
\text { (lok. } 100 \mathrm{~A})\end{array}$ & Årdal & $\begin{array}{l}\text { Sogn og } \\
\text { Fjordane }\end{array}$ & 880-1230 e.Kr. & 0 & 267 & - & $\begin{array}{c}\text { Kristoffersen } \\
\text { 1992: } \\
\text { 189-191; } \\
\text { Lie 1992: } 326 \\
\end{array}$ \\
\hline 690 & 950 moh. & $\begin{array}{l}\text { Urutlekråi } \\
\text { (lok. } 100 \text { B) }\end{array}$ & Årdal & $\begin{array}{l}\text { Sogn og } \\
\text { Fjordane }\end{array}$ & 720-1020 e.Kr. & 0 & 31 & - & $\begin{array}{c}\text { Kristoffersen } \\
\text { 1992: 197; } \\
\text { Lie 1992: } 326\end{array}$ \\
\hline 690 & $\begin{array}{l}1020- \\
1025 \\
\text { moh. }\end{array}$ & $\begin{array}{l}\text { Berdalstølen } \\
\text { (lok. } 115 \mathrm{~A})\end{array}$ & Årdal & $\begin{array}{l}\text { Sogn og } \\
\text { Fjordane }\end{array}$ & 260-1140 e.Kr. & 0 & 9 & - & $\begin{array}{c}\text { Kristoffersen } \\
\text { 1992: } \\
\text { 268-270; } \\
\text { Lie 1992: } 326 \\
\end{array}$ \\
\hline 690 & 925 moh. & $\begin{array}{l}\text { Fossdalen } \\
\text { (lok. } 122 \mathrm{~A})\end{array}$ & Årdal & $\begin{array}{l}\text { Sogn og } \\
\text { Fjordane }\end{array}$ & $\begin{array}{l}\text { 210-430 e.Kr. og } \\
720-1170 \text { e.Kr. }\end{array}$ & $\begin{array}{l}1 \text { (laks/ } \\
\text { ørret) }\end{array}$ & 1415 & - & $\begin{array}{c}\text { Kristoffersen } \\
\text { 1992: } \\
\text { 234-241; } \\
\text { Lie 1992: } 327\end{array}$ \\
\hline 690 & 925 moh. & $\begin{array}{l}\text { Fossdalen } \\
\text { (lok. } 122 \text { B) }\end{array}$ & Årdal & $\begin{array}{l}\text { Sogn og } \\
\text { Fjordane }\end{array}$ & 880-1020 e.Kr. & 0 & 93 & - & $\begin{array}{c}\text { Kristoffersen } \\
\text { 1992: } 242 ; \\
\text { Lie 1992: } 327\end{array}$ \\
\hline \multicolumn{10}{|c|}{ Andre funnforhold } \\
\hline 779 & $\begin{array}{l}700 \\
\text { moh. }\end{array}$ & $\begin{array}{l}\text { Dokkfløy, } \\
\text { DR } 202\end{array}$ & Gausdal & Oppland & 670-1260 e.Kr. & 4 & 4 & Båtnagler & $\begin{array}{c}\text { Jakobsen og } \\
\text { Larsen 1992: } \\
\text { 164-165 }\end{array}$ \\
\hline $\begin{array}{c}555 \\
\text { (fiskebein } \\
\text { er ikke } \\
\text { tatt vare } \\
\text { på) } \\
\end{array}$ & $\begin{array}{l}1223 \\
\text { moh. }\end{array}$ & $\begin{array}{c}\text { Meinsbulægeret, } \\
\text { Bjornesfjorden } \\
\text { (lok. 1084) }\end{array}$ & $\begin{array}{l}\text { Nore og } \\
\text { Uvdal }\end{array}$ & Buskerud & 1150-1900 e.Kr. & - & 3421 & 3 fiskekroker & $\begin{array}{c}\text { Indrelid } \\
\text { 2014: 161; } \\
\text { Fasteland } \\
\text { 1973; } \\
\text { 2002: } 39\end{array}$ \\
\hline 1215 & $\begin{array}{l}1197 \\
\text { moh. }\end{array}$ & $\begin{array}{c}\text { Geitvassmuran, } \\
\text { Geitvatn } \\
\text { (lok. 1083) }\end{array}$ & $\begin{array}{l}\text { Nore og } \\
\text { Uvdal }\end{array}$ & Buskerud & 1170-1400 e.Kr. & 2608 & 3761 & 7 fiskekroker & $\begin{array}{c}\text { Fasteland } \\
\text { 2002: 39-41 }\end{array}$ \\
\hline 1218 & $\begin{array}{l}1245 \\
\text { moh. }\end{array}$ & $\begin{array}{c}\text { Nesbu, } \\
\text { Heisandtjørn } \\
\text { (lok. 705) }\end{array}$ & Eidfjord & Hordaland & Etter 1700 f.Kr. & 41 & 77 & Lysterspiss & $\begin{array}{l}\text { Fasteland } \\
\text { 2002: } 38\end{array}$ \\
\hline
\end{tabular}

\section{SLUTTNOTER}

1 Martens 1972; Rolfsen 1977; se også Ugulen 2016.

2 Martens 1973: 49; Rolfsen 1977: 96; se også Friis mfl. 2016.

3 Jf. vedlegg.

4 Innlandet er ikke entydig og klart geografisk definert. I denne sammenhengen har vi imidlertid valgt å inkludere lokaliteter som ligger mer enn 600 moh. (jf. Selsing 2010). I tillegg har vi tatt med funn fra Rena elv i Åmot kommune i Hedmark, selv om disse ligger vesentlig lavere (ca. 240 moh.). Steinalderboplassene her inngår imidlertid i et entydig innlandsmiljø (jf. Stene 2010).

5 Mjærum 2016a.

6 Fritt etter Lyman 1994.

7 Lyman 1994: 435.
$8 \quad$ Szpak 2011.

9 Nurminen 2016

10 Taksdal 1973.

11 I tallmaterialet fra Hardangervidda inngår blant annet bein fra Sørbu ( $\mathrm{n}=10$ 204) og Austbu $(\mathrm{n}=32$ 536) på Sumtangen, men også lokaliteter med en stor andel brente og sterkt fragmenterte bein.

12 Indrelid 1994: 237; jf. Mjærum 2016a.

13 Se Mjærum 2016a.

14 Indrelid 1994; Mikkelsen 1994; Indrelid mfl. 2007; Weber 2007; Hufthammer mfl. 2011.

15 Hufthammer mfl. 2011; Indrelid og Hufthammer 2011.

16 Indrelid og Hufthammer 2011: 49 med videre ref.

17 Indrelid og Hufthammer 2011: 49, tabell 2. 
18 Indrelid mfl. 2007: 134.

19 Indrelid mfl. 2007: 145-146.

20 Hufthammer mfl. 2011.

21 Indrelid og Hufthammer 2011. Det foreligger også analysert beinmateriale fra beindyngene utenfor buene ved Ørteren, men det ble ikke funnet fiskebein. Dyngene ved Ørteren ble imidlertid undersøkt med andre metoder enn de øvrige anleggene. Det er derfor usikkert om disse metodene var egnet til å avklare om avfallshaugene inneholdt fiskebein (jf. Indrelid og Hufthammer 2011: 51).

22 Mikkelsen 1994.

23 Mikkelsen 1994: 61.

24 Mikkelsen 1994: 59.

25 Lie 1994: 214; Mikkelsen 1994: 65.

26 Mikkelsen 1994: 65.

27 Fønnebø 1988: 64.

28 Fasteland 2002: 37; Indrelid 2014: 155

29 Fasteland 2002: 36.

30 Weber 2007: 183-201.

31 Lie og Fredriksen 2007: 158.

32 Weber 2007: 92.

33 Weber 2007: 126-129.

34 Larsen 2009; Rundberget 2015.

35 Martens 1988; Larsen 1991; Rolfsen 1992.

36 Larsen 1991: 272; Rolfsen 1992: 82.

37 Rolfsen 1977: 96.

38 Gregersen og Hegge 2009: kap. 3.17.

39 Jacobsen og Larsen 1992: 139-141; se også nedenfor.

40 For eksempel Lund 1951; Bergsvik og Hufthammer 2009; Bergsvik og Skeets 2012.

41 Prescott 1995; Selsing 2010: 260-261.

42 Prescott 1995.

43 Prescott 1995: 139-140.

44 For eksempel Odner 1969.

45 Hufthammer 2015.

46 Prescott 1991.

47 Prescott 1991: 16.

48 Prescott 1991.

49 Jf. Prescott 1991.

50 Gustafson 1990.

51 Se vedlegg.

52 Se Mjærum 2016a.

53 Mjærum 2016a med videre ref.

54 Martens og Hagen 1961: 83-84; Gustafson 1978.

55 Odner 1969: 31.

56 Martens 1973: 49; Rolfsen 1977: 96.

57 Martens 1972; Rolfsen 1977.

58 Lie 1992; jf. vedlegg.

59 Bjørgo mfl. 1992.

60 Lie 1992: 323.

61 Jacobsen og Larsen 1992.

62 Jacobsen og Larsen 1992: 141, 164-165.

63 Fasteland 2002; Indrelid 2014: 153-161.

64 Fasteland 2002: 36; Indrelid 2014: 154-155.

65 Fasteland 1971.
66 Fasteland 1971

67 Jf. Friis mfl. 2016.

68 Fasteland 1973.

69 Indrelid 2014: 161.

70 Melsom og Wammer 2016; Ugulen 2016.

71 Se imidlertid Bull 1916: 133-134.

72 Hougen 1947: 223.

73 Se for eksempel Melsom og Wammer 2016; Ugulen 2016.

74 For eksempel Taksdal 1973: 149.

75 Norseng 2015: 219-225.

76 Norseng 2015: 226-228; Kjelland 2016.

77 Hufthammer 2016.

78 Mikkelsen 1994: tabell XXV.

79 Hufthammer og Bratbak 2000; Barrett mfl. 2007: tabell 14.15 .

80 For eksempel Hufthammer mfl. 2011; Rundberget 2015.

81 Mikkelsen 2003: 14; Gjerpe 2010. 


\title{
TESSE-DOKUMENTET OG FJELLFISKET I MELLOMALDEREN
}

\author{
Jo Rune Ugulen, Riksarkivet
}

\section{SLUTTNOTER}

1 Jf. t.d. Ugulen 2006: 78-80.

2 Bakke 1984; Ugulen 2015.

3 Jf. Olav den helliges saga i Snorres kongesagaer [1979], kap. 111 og 112.

4 Jf. Brendalsmo 2015.

5 DN II, nr. 4 og 203. Original på pergament i Oslo, Riksarkivet, NRA dipl. perg.

6 Wammer 2014: 45, sløe 20-b.

7 Om hevd i mellomalderlovene, sjå t.d. Bøe 1962; Bjerkvik 2004.

8 DN II, nr. 205.

9 DN II, nr. 265.

10 DN XV, nr. 545.

11 Magnus Lagabøtes landslov [1915], landsleigebolken kap. 48 og 61.

12 Frostatingslova [1994] XIV 7 og 8, s. 204-206; jf. Rynning 1934: 179-180; 1968: 712-723, \$ 66.

13 Rynning 1934: 180.

14 Oslo og Hamar bispedømes jordebok 1574-1577 [1929] 170.

15 NRJ IV, s. 541-557.

16 DN VIII, nr. 81-90.

17 DN I, nr. 240.

18 DN IX, nr. 750.

19 DN III, nr. 185.

20 Wammer 2015: 58.

21 Jf. Bøe 1962, sp. 286. 


\section{OM LANDSKYLDVARA "BERGEFISK" I GUDBRANDSDALEN} Arnfinn Kjelland, Høgskulen i Volda

\section{SLUTTNOTER}

Sejersted 1978: 126ff.

Sommerfelt 1928 [1790]: 50ff.

Bjørkvik 1965.

Salvesen 1978: $109 \mathrm{f}$

Johannessen 2004.

Sandnes 1978.

Salvesen 1978: 120 .

Dyrvik 1991: 137.

Johannessen 2004.

10 Holmsen 1966a.

11 Holmsen 1980.

12 Lunden 2002: 284.

13 Holmsen 1980.

14 Fladby og Try 1969-1978.

15 Brandt 1892: $320 \mathrm{f}$.

16 Eksaminasjonsprotokoll 1723.

17 Deliberasjonsprotokoll for Gudbrandsdal fogderi 1803.

18 Brandt 1892: 321f.

19 Trykt matrikkel 1838.

20 Hunskaar 2008.

21 Bjørkvik 1965.

22 Johannessen 2004.

23 Bygningsskatt jonsok 1594.

24 Steinnes 1937: 119.

25 Steinnes 1937 og 1940.

26 Holmsen 1966b: 216.

27 Lundh og Sars 1865: 60.

28 Winge 2004.

29 Hesthagen 2001: 18.

30 Brandt 1892: 320.

31 Schøning 1980 [1778]: 32.

32 Nedkvitne 1980; Kleiven 1915: 208; Falk og Torp 1992 [1903-1906].

33 Reinton 1958: 101 f.; Bjørkvik 1965.

34 Hattestad 1948: 117.

35 Reinton 1958: 102.

36 Reinton 1958.

37 Reinton 1958.

38 Reinton 1958: 101.

39 Reinton 1958: 100.

40 Kleiven 1928: 64.

41 Hosar 1995: 189.

42 Kleiven 1915: 208.

43 Teigum 2001: 317ff.

44 Steinnes 1936: 139.

45 Mi utheving, sitat etter Eknes 1926: 51f.

46 Vigerust 2008.
47 Steinnes 1937 og 1940.

48 Johannessen 1990: 42.

49 Rugsveen 1985: 31ff.

50 Hiorthøy 1907 [1785]: 38.

51 Hiorthøy 1907 [1785]: 154.

52 Ile 1960: 194.

53 Kleiven 1928: $126 \mathrm{ff}$.

54 Huset 1992.

55 Øvrelid 1987: 184.

56 Johannessen 2004.

57 Øvrelid 1987: 118.

58 Teigum 2001: 318.

59 Hesthagen 2001: 12, $103 \mathrm{f}$.

60 Kleiven 1923: 107.

61 Kraft 1840: 42.

62 Valen-Senstad 1956: 171.

63 Frå Landkommisjonsjordeboka, C Gudbrandsdal, 1661, folio 20b, Riksarkivet: http://arkivverket.no/ URN:db_read/rk/21389/21/.

64 Frå Jordebok, Akershus len, Akershus, 15770624 15780624, Riksarkivet side 403: http://arkivverket.no/ URN:db_read/rk/206/403/.

65 Eigar: Norsk Folkemuseum. http://urn.nb.no/ URN:NBN:no-nb_foto_NF.WL_02097.

66 http://urn.nb.no/URN:NBN:no-nb_foto_NF.W_28961. 


\title{
SØRSAMENES FJELLFISKE. ØRRET, SIK OG RØYE - ET SVØMMENDE MATFORRÅD
}

\author{
Anne Severinsen
}

\section{SLUTTNOTER}

1 Mitt foredrag på Fjellfiskeseminaret i Lom bygde på artikkelen «Den sørsamiske fisker», som er publisert i Samer i sør (Severinsen 2010). Foredraget er her komplettert med nye kilder, både muntlige og skriftlige.

2 Pareli og Severinsen 1979: 35-36.

3 Drake 1979: XII-XVI.

4 Bäckman og Kjellström 1979: 21.

5 Qvigstad og Wiklund: 1909: 237.

6 Sammallahti: 1998: 5.

7 Drake 1979: XIII.

8 Sandnes 1996: 3-4.

9 Nielsen 1889-1890: 31-33.

10 Bergsland var sakkyndig på samenes side i Brekkensaken, med dom i Høyesterett i 1968 (Rettstidende 1968: 394), og det såkalte Skattefjällsmålet, som gjaldt samenes rettigheter i nordre del av Jämtland, med dom i Högsta domstolen i 1981.

11 Bergsland 1974.

12 Bergsland 1988: 275-277.

13 Bergsland 1988: 280.

14 Bergstøl og Reitan 2008: 13,18, 19, 21, 22, 26

15 Snorres kongesagaer [1968]: 66.

16 Skalleberg Gjerde 2011: 5 og 8-10.

17 Skalleberg Gjerde 2011: 17.

18 Zachrisson 1997: 170

19 Westerdahl 1986: 33.

20 Norstedt 2011: 9.

21 Kjelland 2016.

22 Qvigstad og Wiklund 1909: 233.

23 Drake 1979: 226-227.

24 Qvigstad og Wiklund 1909: 237, 239; jf. Bergsland 1988: 68.

25 Norstedt 2011: 21.

26 Norstedt 2011: 20

27 Bergsland 1974: 15-16.

28 Robsahm og Swab 1938: 69-70.

29 Koppselelandet var en del av lappskattlandet «Nuskulusoive» på Jonas Pärson Gäddas kart tilknyttet Johan Graans utkast til jordebok (Norstedt 2011: 14).

30 Winka 2014: 53-55.

31 Jebens 1999: 196.

32 Solem 1933: 86-87.

33 Kjellström 2000: 55 .

34 Wiklund 1910: 8.
35 Peterson-Berger 1904: 62.

36 Bergsland 1974: 15.

37 Opsahl og Winge 1990.

38 Bylund 1977: 110.

39 Westerdahl 1986: 38

40 Nissen og Kvamen 1962: 150, 154.

41 Qvigstad og Wiklund 1929: 16.

42 Qvigstad og Wiklund 1929: 29.

43 Nensén (1820-1825: 249-250) sin uppteckning efter Anna Thomasdotter; jf. Hermanstrand 2014: 80.

44 Hermanstrand 2009: 148.

45 Lappekommissionen 1889: 15.

46 Tomasson 1917: 192, i håndskrevet originalmanus.

47 Pareli 2007: 58.

48 Krag 1887: 59.

49 Intervju med Skjoldvor Jåma Jønsson, Hudningsdalen, Røyrvik, 18/1-2011.

50 Bremset Hansen 2004: 23.

51 Sjøen Värjaren ligger drøyt 2 mil fra riksgrensen, litt sør for Røyrvik på norsk side.

52 Andersson 2000: 60.

53 Bäckman och Kjellström 1979: 147, 151.

54 Den tida på sommeren da man melket simler med kalver.

55 Marek 1992: 168.

56 Wiklund 1910: 30.

57 Marek 1992: 170.

58 Intervjuet med Sofie Kappfjell, Majavatn, 9/5-2010

59 Intervju med Alf Willenfeldt (f.1936), Tännes, 2/8-2010.

60 Bäckman og Kjellström 1979: 22.

61 Bäckman og Kjellström 1979: 14.

62 Bäckman og Kjellström 1979: 147.

63 Bäckman og Kjellström 1979: 149-150.

64 Hesthagen og Kleiven 2016a.

65 Drake 1979: XII.

66 Drake 1979: 14.

67 Drake 1979: 15.

68 Drake 1979: 19.

69 Westerdahl 1987: 15, 36.

70 Westerdahl 1987: 74

71 Westerdahl 1986: 180-181.

72 Westerdahl 1987: 65.

73 Qvigstad og Wiklund 1929: 93.

74 Bäckman og Kjellström 1979: 150.

75 Drake 1979: 133. 
FJELLFISKE I FORTIDEN | NOTER OG APPENDIKS

76 Bäckman og Kjellström 1979: 150-151.

77 Intervju med John Kappfjell, Majavatn, 6/10-2015

78 Marek 1992: 171,172

79 Drake 1979: 135.

80 Fastboende/gårdbrukere.

81 Jåma 2001: 109.

82 Villmo 1978.

83 Namdal herredsrett 1979: 59.

84 Tomasson 1917: 250-251 i håndskrevet originalmanus.

85 Felles reindriftslov for Norge og Sverige av 2. juni 1883.

86 Brev fra A. Lifjell til Landbruksdepartementet av 28. mai 1966.

87 Brev fra A. Lifjell til Landbruksdepartementet av 16. januar 1967.

88 Brev fra Landbruksdepartementet til formannen i Ildgruben reinbeitedistrikt, A. Lifjell, datert 28. februar 1967.

89 Rettstidende 1955: 364.

90 Rettstidende 1968: 410.

91 «Oversikt over sydsamenes historie i Norge til 1751». Oslo 1968. Stensil.

92 Rettstidende 1968: 395-39. 


\section{FJELLFISKE I GRENSELANDET MELLOM FANGSTMARK OG JORDBRUKSBYGD I YNGRE JERNALDER OG MIDDELALDER}

Av Elling Utvik Wammer, Norsk Maritimt Museum

\section{APPENDIKS 1}

\section{FORSØK PÅ Å ETABLERE EN TRINSESØKKETYPOLOGI FOR TESSE}

Arbeidet med en typeinndeling av materialet at jeg valgte å ta dem ut av mitt forsøk på å gi vanskeliggjøres av at flere av søkkene er bare delvis bevart. Åtte av søkkene var så fragmentert

TYPE 1

Søkkene har surret never rundt både ring, stein og eiker. Surring på stein og eiker ser ut til å være gjort i én operasjon, etter at ringen er dekket med never. Treringens diameter og steinenes størrelse varierer en hel del innenfor gruppen.

\section{C59636-4}

\section{TYPE 2}

Søkkene i denne gruppen er konstruert på samme måte som type 1 , men har ikke never rundt steinen. Neverbåndene i krysset er kraftige, ca. 1-2 cm brede, og flere har bånd surret rundt eikene for at steinen skal holdes på plass.

TYPE 3

Disse søkkene kjennetegnes ved ikke å ha neversurring rundt ringen, bortsett fra i skjøten. Neversurring er utført rundt både stein og eiker. Steinens størrelse i forhold til ringens diameter varierer. På ett av søkkene er den spiralsurrete neveren rundt eikene brettet på langs før man har utført surringen.

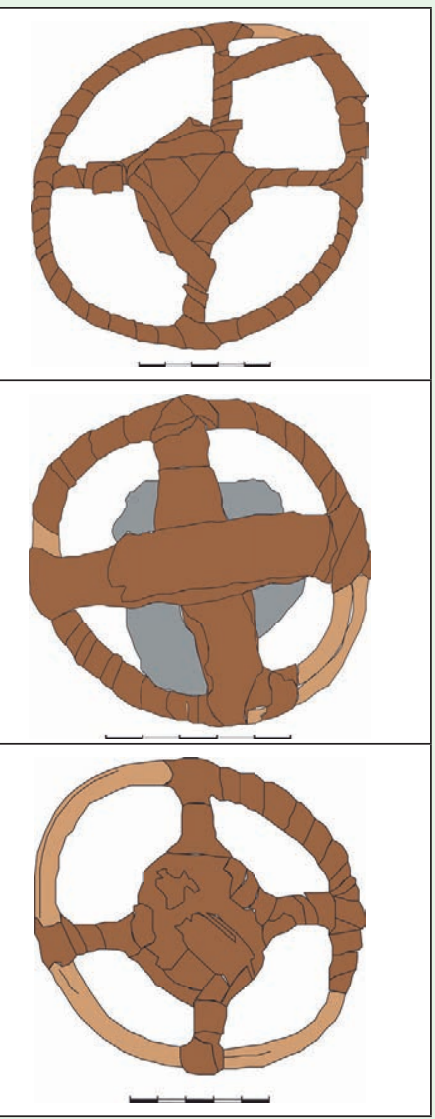


TYPE 4

Søkket i denne gruppen har dobbel vidjering. Ringen består av ett stykke tre som er kveilet dobbelt. Det er neversurring rundt stein og eiker.

C56056-12

\section{TYPE 5}

Til denne gruppen hører de søkkene som skiller seg mest fra de andre søkkene. Hovedkjennetegnet ved denne gruppen er at rundt steinen er det flettverk i stedet for surret never. Flettverket består av smale remser med never. I tillegg er neveren brettet på langs før spiralsurring rundt eikene.

\section{C59636-5}

\section{KONKLUSJON}

Dateringsmessig ser typene ut til å fordele seg noe forskjellig. Av type 1 er det tre trinsesøkker som er C14-datert. Disse stammer fra 721-946 e.Kr., 777-987 e.Kr. og 671-1014 e.Kr.; de har altså relativt lik alder, med hovedvekt i vikingtid. Av type 3 er ett søkke datert til 971-1152 e.Kr., altså noe senere enn de forrige typene. Også fra type 5 er det ett søkke som er datert, og det befinner seg i tidsrommet 1041-1221 e.Kr. Det virker dermed ut fra disse radiologiske undersøkelsene som om det skjer en endring over tid i trinsematerialet i perioden. I merovingertid og vikingtid er det mest vanlig med søkker med enkelt surret never rundt stein og ring. I middelalder slutter man å surre never rundt hele ringen og erstatter etter hvert surringen rundt steinen med flettverk, ser det ut til. En slik kronologi, basert på få dateringer

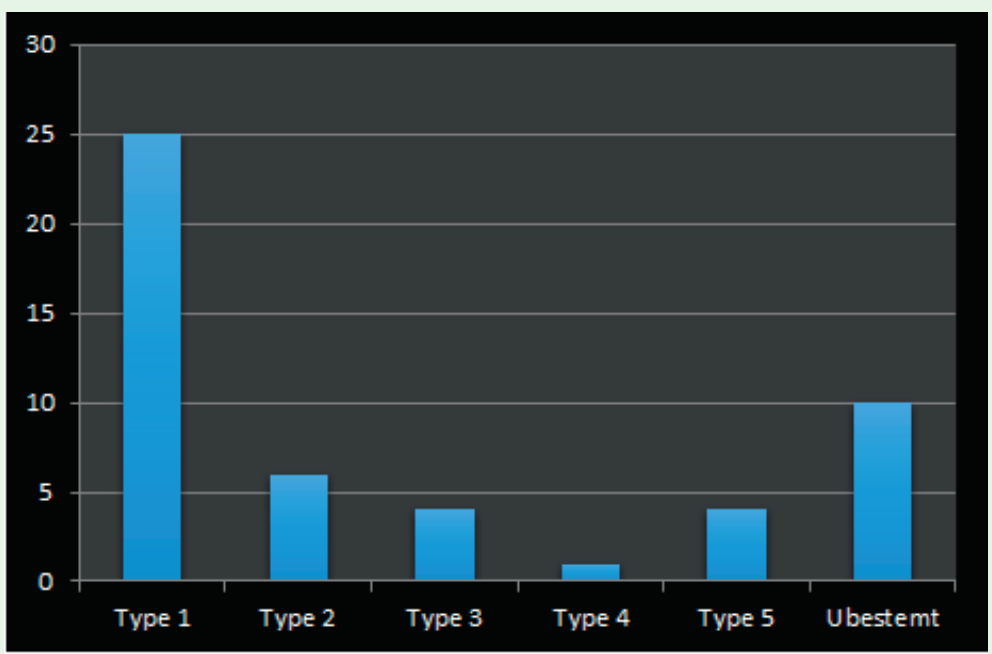

og et relativt begrenset materiale, er selvsagt usikker, men kan også være interessant ved sammenligning med andre områder.

Antallsmessig fordeler søkkene seg på følgende måte: 


\section{APPENDIKS 2}

Skriftlig gjennomgang av funnsteder for trinsesøkker utenfor Tesse i Skandinavia (grunnlag for tabeller i artikkelen)

\section{FUNNSTEDER I SøR-NORGE 77}

\section{Strandefjorden i Nord-Aurdal (C32604)}

Et trinseformet søkke er blitt funnet i Strandefjorden i Nord-Aurdal i Oppland, ved Ulnes utfor gården Steinde. Funnet skal ha blitt gjort på en grunne i vestdelen av Strandefjorden, og på den samme grunnen er det funnet diverse gjenstander fra forskjellige perioder, blant annet en pilspiss fra folkevandringstid, et enegget sverd fra ca. 800 og en armbrøstpil foruten en del jernslagg. ${ }^{78}$ Søkket har mange likhetstrekk med type 5 fra Tesse. Det har never kun rundt skjøten av ringen og har flettverk rundt steinen. Flettverket har imidlertid bredere neverremser enn type 5-søkkene i Tesse, og gjenstanden har derfor ingen direkte parallell i Tesse-materialet.

Strandefjorden ligger nede i dalføret nordvest for Fagernes, på ca. 355 moh. Området er i dag preget av barskog og jordbrukslandskap. Det er ikke registrert fangstanlegg i nærheten av funnstedet, og området kan derfor ikke regnes som en fangstmark. Det er et stort antall gravminner i hele dalen, noe som tyder på at dette har vært en jordbruksbygd i alle fall før år 1000. En samisk tilstedeværelse i Valdres i vikingtid er for kort tid siden sannsynliggjort gjennom en undersøkelse av fire runde tufter ved vannet Reinsenn i Vestre Slidre. ${ }^{79}$ Lokaliteten ligger ca. $11 \mathrm{~km}$ sørvest for funnstedet til søkket i Strandefjorden. Det er derfor ikke usannsynlig at dette området i dalen har vært brukt av eller vært $\mathrm{i}$ direkte kontakt med samer i vikingtid og middelalder.

\section{Storsjoen i Rendalen}

Ved Sana strand, i nordenden av Storsjøen, som ligger i Rendalen kommune i Hedmark fylke, fant
Harald Hoel et trinseformet søkke våren 2015. Gjenstanden er blitt C14-datert av Hedmark fylkeskommune til 1220-1280 e.Kr. ${ }^{80}$ Søkket har ikke never rundt hverken steinen eller ringen, bortsett fra i skjøten. Søkket i Storsjøen har ingen direkte typemessig parallell i Tesse-materialet. Ved en mer skjønnsmessig vurdering er det likevel fristende å påpeke den store likheten mellom dette søkket og SFJ.05299 fra Tesse. Man skulle nesten tro at disse søkkene var laget av samme håndverker! Dette viser en del av problemet med å anvende standardiserte typologiske trekk.

Storsjøen ligger 250-252 moh., nede i Rendalen, som løper parallelt med Østerdalen. Et barskogområde på ca. 10-15 km utstrekning og høyde på 600-800 m skiller de to dalførene fra hverandre. Tradisjonelt har fisket i Storsjøen vært knyttet til gårdene i bygda Ytre Rendalen. ${ }^{81}$ Dette var opprinnelig et lottfiske som ble drevet i fellesskap av de gårdene som grenset ned mot sjøen (hjemmefiske). Senere skjedde en omfordeling til faste fiskeplasser etter hvert som det ble for mange gårder. På grunn av den omfattende historikken kan det være grunn til å tro at bøndenes fiske går langt tilbake i tid i Storsjøen.

Det er registrert et relativt stort fangstanlegg av dyregraver på østsiden av vannet i den samme enden av Storsjøen hvor det trinseformete søkket ble funnet, og området kan derfor muligens regnes som en fangstmark. Selv om man i historisk tid har en omfattende jordbruksbebyggelse rundt Storsjøen, er det lenger nord i kommunen man finner den sentrale delen av bygda og hovedkonsentrasjonen av funn fra jernalder og middelalder. Jostein Bergstøl har gjort en grundig analyse av det arkeologiske materialet 
fra Rendalen. ${ }^{82}$ Han viser til en rekke funn som knyttes til samisk etnisitet, både fra jernalder og fra middelalder, blant annet en $\mathrm{z}$-formet skinnskraper, pilspisser og en runebommehammer. Bergstøls konklusjon er at «funn, fornminner og stedsnavn i Rendalen tyder på at dette er et område med stor kontakt mellom fangstfolk og norrøne bønder». ${ }^{83}$

\section{Lesjavannet $i$ Dovre}

Anders Hagen skriver i sin artikkel «Funn fra fjellvann» ${ }^{84}$ følgende:

Olaf Framheim har i brev meddelt at han har funnet tre slike treringer med stener $i$ midten innflettet med neverbaind nede ved elvekanten, på bunnen av det for lengst torrlagte Lesjavatn.

Lesjavannet i Dovre kommune i Oppland eksisterer ikke i dag, men var opprinnelig ca. $10 \mathrm{~km} 2$ stort og lå i hovedbygda fram til det i 1860 ble tappet ut for å brukes til dyrkningsjord. ${ }^{85}$ Ettersom disse tre søkkene ikke er levert inn til museet, kan vi ikke si noe sikkert om hvilken type trinsesøkke det er. Finneren bruker benevnelsen «innflettet i never», som kan indikere at vi har å gjøre med søkker like den sene type $5 \mathrm{i}$ Tesse.

Lesja er ei fjellbygd som ligger ca. 500-650 moh., og som i dag preges av store jordbruksområder. På grunn av uttappingen av innsjøen i bygda har jordbruksarealene fått et betydelig større omfang enn de hadde tidligere. Det er registrert få gravminner i området, men et betydelig antall fangstanlegg. Det er også registrert jaktutstyr på flere snøfonner i gangavstand fra bygda. Hvorvidt Lesja var en jordbruksbygd eller lå sentralt $\mathrm{i}$ en fangstmark i jernalder og middelalder, er vanskelig å avgjøre uten grundigere analyser. En del tyder imidlertid på at dette området var marginalt i jordbrukssammenheng, og at jakt og fangst ville være et mer naturlig ressursgrunnlag. Ca.
10-15 km nord for Lesja ligger vannet Aursjøen, hvor det i 2006 ble dokumentert fire ildsteder av samisk type som lå på en rekke. Denne typen anlegg regnes for å være et relativt sikkert bevis på samisk kultur/ etnisitet, og dateringene gikk tilbake til vikingtid. Ca. 40-50 km øst for Lesja finner vi gården Dovre, hvor Snorres kongesagaer forteller at samen Svåse giftet bort datteren Snøfrid til Harald Hårfagre. Det er derfor ikke usannsynlig at Lesja-området har vært brukt av eller vært i direkte kontakt med samer i vikingtid og middelalder.

\section{Samsjoen i Midtre Gauldal (T 17199)}

Fra Samsjøen i Midtre Gauldal i Sør-Trøndelag mottok NTNU Vitenskapsmuseet for en god del år siden et funn av et trinseformet søkke. Funnet ble gjort av fru Olga Lodgaard på en sandbanke ute i Samsjøen. Sjøen var den gang nedtappet til lavmål. ${ }^{86}$ Dette trinseformete søkket har bevart steinen, eikene og $1 / 4$ av vidjeringen. Rundt steinen er det flettverk av relativt brede remser. Den bevarte delen av ringen har ikke surret never rundt. Søkket har ingen direkte paralleller i Tesse-materialet, men er likt funnet fra Strandefjorden i Nord-Aurdal.

Samsjøen er regulert og ligger ca. 473-487 moh. Vannet ligger ca. $12 \mathrm{~km}$ fra Gauldalen (mot sør) og $18 \mathrm{~km}$ fra tettstedet Lundamo, nede i dalen i vest. Landskapet rundt vannet er preget av åpen barskog og myr. Ingen kulturminner knyttet til hverken fangst eller annen aktivitet er registrert ved vannet. Ved nabovannet Håen, ca. 2-3 km lenger vest, er det funnet flere jernvinneanlegg. Tre av disse er blitt arkeologisk undersøkt og er fra yngre jernalder og/eller middelalder. ${ }^{87}$ Det er også spor etter tjærebrenning i myrmiler i det samme området, som dateres til 15-1600-tallet. På nordsiden av Samsjøen ligger fjellet Rensfjellet (941 moh.). Stedsnavnet kan indikere at dette er et område hvor det har vært mye reinsdyr i eldre tid, og at området derfor 
kan ha vært en god fangstmark. Området brukes av samiske reindrivere i dag, og Midtre Gauldal regnes blant de tradisjonelle samiske bosetningsområdene.

\section{FUNNSTEDER I JÄMTLAND ${ }^{88}$}

Oversikten under oppsummerer den kjente kunnskapen om søkkene samt min vurdering av disse søkkene hva gjelder type og funnkontekst. For opplysninger om kulturminner har jeg foretatt søk i den nasjonale svenske databasen for kulturminner, Fornsök. $^{89}$

\section{Locknesjön (JLM13306)}

Funnet ved notfiske i Locknesjön i 1932. Søkket er gjengitt $i$ tegnet form $i$ «Jämten». ${ }^{90}$ Søkket er likt Tesse-type 5, men har noe bredere neverremser i flettverket rundt steinen. Locknesjön ligger ca. $20 \mathrm{~km}$ sørøst for Östersund, ca. 328 moh. Det er registrert fangstanlegg tilknyttet denne sjøen, men området har også en stor mengde jordbruksrelaterte kulturminner, slik som gravhauger. Områdene rundt Storsjøen har vært et tradisjonelt jordbrukslandskap langt tilbake i tid. ${ }^{91}$

Tjern (ukjent hvilket), Mattmars socken (JLM16867) Funnet ved tørrlegging av et tjern i Mattmars socken i 1941. Søkket ble katalogisert av Lennart Björkquist, som sammenligner det med finsk materiale. ${ }^{92}$ Dette ser ut til å være relativt likt Tesse-type 5 , men har bredere neverbånd i flettverket. Den nærmeste parallellen i Norge er søkket fra Nord-Aurdal (C 32604). Mattmars socken ligger vest for Storsjøen og Östersund og dekker områder med både fjell- og skogsområder. I soknet generelt er det registrert flere store fangstanlegg, med rekker av groper.

\section{Edeviken, Torrön (JLM22370)}

Funnet ved stubbebryting ved stranden av sjøen Torrön ved Edeviken i 1970. Dette søkket har åtte eiker og ingen surring hverken rundt ringen eller steinen. Søkket har ingen parallell i Tesse-materialet og er så langt unikt i Skandinavia. Den i dag meget avsidesliggende gården Edevik ligger helt nord $\mathrm{i}$ Torrön, 417 moh. Hvor langt tilbake i tid det har vært bosetning i Edevik, er usikkert. Området ligger i dag i et kjerneområde for sørsamisk reindrift, og det er registret flere store fangstanlegg i nærområdet. Områdets beliggenhet relativt langt til fjells gjør at det trolig må regnes som marginalt for åkerbruk. Noen større jordbruksbygd har det derfor trolig ikke vært på dette stedet.

\section{Mellansvartsjön, Frösöen (JLM29767)}

Funnet under ukjente omstendigheter i Mellansvartsjön på fastlandsdelen av Frösöen. Søkket har kun bevart steinen og eikene samt deler av flettverket rundt steinen. En typebestemmelse blir derfor usikker, men søkket har trolig vært likt JLM13306, og dermed også Tesse-type 5. Det har ikke lyktes meg å finne den nøyaktige posisjonen for dette funnstedet. På Frösöen (ved Östersund i Storsjøen) er det et stort antall kulturminner av ulike typer og antakelig aldre, herunder bygdeborger og gravfelt. Det er også registrert relativt store fangstgropsystemer på øyas nordside.

\section{Umerket fragm.}

Søkket mangler stedsangivelse og har derfor begrenset utsagnskraft, bortsett fra at det er funnet i Jämtland. Kun steinen og to av eikene er bevart, derfor blir typebestemmelse vanskelig. Ut fra det lille materialet kan det se ut til å tilsvare Tesse-type 3 . 


\section{SLUTTNOTER}

$1 \quad$ Finstad mfl. 2011.

2 For eksempel Brøgger 1925; Hougen 1947; Skjølsvold 1979; Hofset $1980 \mathrm{mfl}$.

3 Zachrisson 1997; Bergstøl $2008 \mathrm{mfl}$.

4 Ekroll 2006: 102.

5 Se for eksempel Bergstøl 2008: 206; Næss 1996. 1959a.

Eknæs 1975.

Severinsen 2016.

Fjellheim 2004.

10 Ugulen 2016.

11 Jf. Bjørkli mfl. 2016.

12 Hesthagen 2011: 104-116.

13 Hesthagen 1980: 30.

14 Tidemansen 2006.

15 Jf. Rønning Andersen 2009; Malde 2009; McLoughlin 2011.

16 Hougen 1947; Tidemansen 2006: 11.

17 1975: 176.

18 Austrheim 2015.

19 Finstad mfl. 2011: 24.

20 Ugulen 2016.

21 Askeladden, Riksantikvarens database for kulturminner.

22 Se for eksempel Sundstrøm 1989.

23 Johansen 2004.

24 Finstad mfl. 2011.

25 Lars Pilø, Oppland fylkeskommune, pers. med.

26 Friis 2015.

27 Finstad mfl. 2011: 51-52.

28 Jf. blant annet Gollwitzer 1997.

29 Finstad mfl. 2011: 34.

30 Tidemansen 2006.

31 Fossum 1996: 99.

32 Midthjell 2014.

33 Christensen 1971.

34 Eknæs 1975: 176.

35 Tidemansen 2006.

36 Fossum 1996.

37 Hagen 1959a: 37.

38 Askeladden, Riksantikvarens database for kulturminner, ID 178889.

39 Historiska museet, utstillingstekst.

40 Per Larsson pers. med.

41 Bengt Nordquist pers. med.

42 Bengt Nordquist pers. med.

43 Sundström 1981: 161.

44 Gollwitzer 1997: 33.

45 Gollwitzer 1997: 32.

46 Zachrisson 1997: 218.

47 Sirelius 1919.

48 Valonen 1952.

$$
\frac{54}{5.5}
$$

$$
38
$$

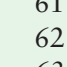

Valonen 1952: 260

Valonen 1952: 258.

Valonen 1952: 257.

Christian Størmer, Riksantikvaren, pers. med.

Hagen 1959a: 39.

Schietzel 2014: 314-315.

Schietzel 2014: 314.

Bergstøl 2008: 169.

Jf. Westerdahl 2006.

Steen 1929: 227-229.

Solberg 2000: 238.

Munch 1983.

Torstein Bjørgen, Lom, pers. med.

1980: 30 .

Se for eksempel Solheim 1940.

1952.

1957.

Eknæs 1979: 32; Hesthagen og Kleiven 2016a.

Hagen 1959a; Eknæs 1975.

For eksempel Keyland 1914: 232.

Bengt Nordquist, pers. med.

Melsom og Wammer 2016b.

Bakken 1975: 26.

https://digitaltmuseum. no/011022717259?query=fiskegarn $\% 20$

s\%C3\%B8lensj\%C3\%B8en\&pos=1.

73 Christensen 1971: 5-6.

74 Hesthagen og Gunnerød 1980: 49.

75 Melsom og Wammer 2016b.

76 https://en.wikipedia.org/wiki/File:Carta_Marina.jpeg.

77 Informasjonen er gjengitt $\mathrm{i}$ tabell $1 \mathrm{i}$ artikkelen.

78 UiO Musit Gjenstandsbasen.

79 Skalleberg Gjerde 2011.

80 Ove Holseng, Hedmark fylkeskommune, pers. med.

81 Bull 1916.

82 Bergstøl 2008: 91-104.

83 Bergstøl 2008: 104.

84 1959a: 37.

85 Svendsen 2015.

86 NTNU Gjenstandsbasen.

87 Lars Steinvik pers. med.

88 Informasjonen er gjengitt i tabell $2 \mathrm{i}$ artikkelen.

89 http://www.fmis.raa.se/cocoon/fornsok/search. html?utm_source=fornsok\&utm_medium=block\&utm_ campaign=ux-test.

90 Bjökquist 1932: 96-97.

91 Bengt Nordquist, Jämtli, pers. med.

92 Sirelius 1919: 171. 


\section{BÅTRELATERTE KULTURMINNER I FJELLET SOM KILDER TIL KUNNSKAP OM FISKE I FORTIDEN}

Charlotte Melsom og Elling Utvik Wammer, Norsk Maritimt Museum

\section{SLUTTNOTER}

Hesthagen og Kleiven 2016a.

2 Hundstad 2015.

Molaug 1985.

4 Arisholm og Nymoen 2005.

5 Bøе 1942a.

6 http://bergenmuseum.uib.no/forskning/hardangervidda/ resultater_main_sum.html.

7 Rodum 2013: 41-43.

8 1942a: 30.

9 Elvestad 2009: 13.

10 Elvestad 2009.

11 Martens 1988: 107, 160.

12 Christensen 1996: 234, 239.

13 Jf. Christensen 2000; Weibust 1959.

14 Christensen 2000: 165-166; Weibust 1959: 42-44.

15 Christensen 1992: 29.

16 For eksempel Hougen 1947: 94; Løseth $2007 \mathrm{mfl}$.

17 Jf. Engelstad 1934; Hagen 1969; Mikkelsen 1980.

18 Engelstad 1934: 114; Hagen 1969: 123; Mikkelsen 1980: 38.

19 Crumlin-Pedersen 1970: 217.

20 Martens 1973b: 91.

21 Nergaard 1911: 24, 31, 47.

22 Blehr 1972: 125.

23 Elvestad 2009.

24 Elvestad 2009: 12-13.

25 Jahnsen 1982; Kleiven 1928.

26 Melsom og Wammer 2014.

27 Kristjansson 1983.

282009.

29 Elvestad 2009: 4, 18, 22.

30 Melsom og Wammer 2013.

31 Melsom og Wammer 2014: 12.

32 Westerdahl 2006: 17.

33 Rogan 1984: 113.

34 Christensen 1971.

35 Wammer 2013.

36 Kalibrert AD 1640-1670 (310-280 BP), kalibrert AD 1780-1800 (170-150 BP) og kalibrert AD 1940-etter 1950 (10-etter $1950 \mathrm{BP})$.
37 Sommeren 2016 ble det foretatt en ytterligere utgravning av deler av naustet, som avdekket mer av konstruksjonen, et gulvlag og flere gjenstander. Det antas at disse vil gi oss sikrere dateringer, og mer informasjon om lokalitetens historikk (Wammer 2016 in prep.).

38 Se blant annet Rolfsen 1974; Nystu 1989; Storm-Munch 1983.

39 Bull 1916.

40 Hougen 1947: 222; Bergstøl 2008: 204.

41 Bull 1916: 33.

42 Skjølsvold 1958: 56.

43 Jf. Ugulen 2016.

44 Kleiven 1928.

45 Jahnsen 1982.

461992.

47 For eksempel Austrheim et al. 2015.

48 Indrelid 2009.

49 Selsing et al. 2005: 6. 


\title{
EPILOG: NOEN PESSIMISTISKE TANKER OM TILSTANDEN TIL KULTURMINNENE VED VÅRE FJELLVANN
}

Axel Mjarum og Ellen Kathrine Friis, Kulturbistorisk museum, Universitetet i Oslo.

\section{SLUTTNOTER}

\author{
Miljødirektoratet 2016. \\ Erlandsen mfl. 1997. \\ Miljødirektoratet 2016. \\ Se Melsom og Wammer 2016; se også Indrelid 2009. \\ Se Hufthammer og Mjærum 2016. \\ Se Mjærum 2016a. \\ Indrelid 2009: 22-24. \\ Sæterbø mfl. 1998: 103. \\ 9 Sæterbø mfl. 1998: 104-113. \\ 10 2014: figur 9. \\ 11 Jf. Sollibråten 2011. \\ 12 Se figur 25; Bjørkli mfl. 2016: figur 6. \\ 13 Se Bjørkli mfl. 2016: figur 3. \\ 14 Finstad 2006; Indrelid 2009: 106. \\ 15 Bjørkli mfl. 2016: figur 11 og 14. \\ 16 Sollibråten 2011. \\ 17 Martens 1964, Hiim og Martens 1967: 58. \\ 18 Hiim og Martens 1967. \\ 19 Amundsen 2007. \\ 20 Hiim og Martens 1967: 62. \\ 21 Amundsen 2007. \\ 22 Sollibråten 2011. \\ 23 Solvold 2007; Russ og Mjærum 2014. \\ 24 Mjærum 2016b. \\ 25 Bergstøl og Friis in prep. \\ 26 F.eks. Aursjømagasinet i Nesset kommune, Møre og \\ Romsdal og Lesja kommune i Oppland (Finstad 2006), \\ Møsvatn, Vinje og Tinn kommune i Telemark (Risbøl \\ 1999), Nåvatn og Skjerkevatn i Åseral kommune i Vest- \\ Agder (Amundsen 2003) og Osensjøen i Åmot kommune \\ i Hedmark (Martens 1962; Boaz 1998b). \\ 27 Nymoen og Nævestad 2006: 77-79.
}


FJELLFISKE I FORTIDEN | NOTER OG APPENDIKS 


\section{LITTERATURLISTE}

Adán, Gema E., Diego Álvarez-Lao, Pablo Turrero, Miguel Arbizu og Eva García-Vázquez 2009. Fish as diet resource in North Spain during the Upper Paleolithic. Journal of Archaeological Science 36/3: 895-899.

Amundsen, Hilde Rigmor 2007. Arkeologisk registrering 20.-21.09.2006. Nåvårsatren, Vårdal Statsallmenning Gnr 157/bnr 1, Tesse, Lom kommune, Oppland Fylke. Lillehammer: Kulturvernavd., Oppland fylkeskommune.

Amundsen, Rigmor, Anne Engesveen og Espen Finstad 2007. Arkeologisk registreringsrapport. Aursjøenprosjektet 2006. Aursjømagasinet: Aursjøen, Grynningen og Gautsjøen, Dalsida Statsalmenning gnr. 156 / bnr. 1, Lesja kommune, Oppland fylke. Lillehammer: Oppland fylkeskommune (Kulturhistorisk rapport 2007-2.)

Amundsen, Tina 2003. Rapport fra arkeologisk forundersøkelse iforbindelse med nye Skjerka. Upublisert rapport i Kulturhistorisk museums arkiv: UKM Oldsaksamlingen, Universitetet i Oslo.

Andersen, Øystein Rønning 2009. Rapport fra arkeologisk registrering med utgravning av automatisk fredete kulturminner i forbindelse med reguleringsplanarbeid for Krokum, gnr. 19/2, Vågå kommune. Lillehammer: Kulturvernavd., Oppland fylkeskommune.

Andersson, Olle 2000. Den sista rajden. Samer berättar om livet förr. Östersund: Jamtli förlag.

Anonym 1884. Statsalmenningerne i Gudbrandsdalen. Indbreretning fra den kongelige resolution af 22 de December 1874 nedsatte Kommisjon. Kristiania: Det Mallingske Bogtrykkeri.

Anonym 1936-1939. Innsamling av Ord og Sed. Nemdi til granking av norsk nemningsbruk. Institutt for kulturstudier, Norsk folkeminnesamling, Det historiskfilosofiske fakultet ved Universitetet i Oslo.

Anonym 1937. Høiffellskommisjonens kjennelse av $2^{\text {nen }}$ September 1937. I Forretningen $14^{\text {de }}$ felt øst. Oslo: Grøndahl \& Søns Boktrykkeri.
Anonym 1951. Ekspropriasjons-skjønn avbjemlet 15. februar 1951 vedr. skader m.v. innen Nord-Gudbrandsdal sorenskriveri ved reguleringer av Vinsteren og Olstappen. Lillehammer: Glommens og Laagens Brukseierforening. Agostinho Antunes, Alan R. Templeton, René Guyomard og Paulo Alexandrino 2002. nuclear genes in intraspecific evolutionary inference. Genealogy of the transferrin gene in the brown trout. Molecular Biology and Evolution 19/8: 1272-1287.

Arisholm, Torstein og Pål Nymoen 2005. Stokkebåter. Nytt om Sorumbåten og andre sørnorske stokkebåtfunn. Oslo. (Norsk Sjøfartsmuseum Skrift nr. 49.)

Austrheim, Gunnar, Kari Hjelle, Per Sjögren, Kathrine Stene og Aud Mikkelsen Trevik 2015. Fjellets kulturlandskap. Arealbruk og landskap gjennom flere tusen år. Trondheim: Museumsforlaget. (DKNVS Skrifter 2015 nr. 3.)

Bakke, Øivin 1984. Grenseoppgangen ved Nordmannslågen som vart gløymd. Hardanger: 242-267.

Bakken, Reidar 1975. Fisket i Beito: fra ei fellbygd $i$ Valdres. Magisteravhandling: Universitetet i Oslo.

Bang-Andersen, Sveinung 2012. Colonizing Contrasting Landscapes. The pioneer coast settlement and inland utilization in South Norway 10,000-9500 years before present. Oxford Journal of Archaeology 31/2: 103-120.

Bargel, Terje og Øystein Nordgulen 2001. «Geologisk utvikling gjennom milliardar av år». Bygdebok for Vågå og Sel. Band 1. Frå dei eldste tider til 1600: 18-60. Sel kommune-Vågå kommune.

Barrett, James, Allan Hall, Cluny Johnstone, Harry Kenward mfl. 2007. «Interpreting the plant and animal remains from Viking-age Kaupang». Dagfinn Skre (red.). Kaupang in Skiringssal: 283-319. Aarhus: Aarhus University Press. (Kaupang Excavation Project Publication Series, Volume 1, Norske oldfunn XXII.)

Bartlett, John M. S. og David Stirling 2003. «A Short History of the Polymerase Chain Reaction». John M. S. Bartlett og David Stirling, (red.). PCR Protocols: 3-6. Humana Press. (Methods in Molecular Biology ${ }^{\mathrm{TM}}$, 226.) 
Bergsland, Knut 1974. «Synsvinkler i samisk historie». Historisk tidskrift 1974/1: 1-36.

Bergsland, Knut 1988. Søramenes historie språklig belyst. Universitetet i Oslo. (Stensil.)

Bergstøl, Jostein 2008. Samer i Østerdalen? En studie av etnisitet $i$ jernalderen og middelalderen $i$ det nordostre Hedmark. Oslo: Unipub forlag. (Acta Humaniora 325.)

Bergstøl, Jostein 2014. Arsrapport 2013 for sektoravgiftsprosjektet knyttet til registrering og undersøkelse av automatisk fredete kulturminner langs Vinstravassdraget, Vang, Øystre Slidre, Nord-Fron, Sør-Fron og Vågå kommuner, Oppland. Prosjektnotat i Kulturhistorisk museums arkiv: Kulturhistorisk museums, Universitet i Oslo.

Bergstøl, Jostein 2015. 8000 år gamle fangstgroper for elg. Viking LXXVIII: 47-62.

Bergstø1, Jostein og Ellen Kathrine Friis under arbeid. Rapport. Arkeologisk utgravning. Storviltjakt og ferdsel langs Vinstravassdraget. Vang, Øystre Sidre, Sør-Fron og Nord-Fron, Oppland fylke. Upublisert rapport i Kulturhistorisk museums arkiv: Kulturhistorisk museums, Universitet i Oslo.

Bergstøl, Jostein og Gaute Reitan 2008. «Samer på Dovrefjell i vikingtiden». Historisk tidsskrift 2008 (1): 9-27.

Bergsvik, Knut Andreas 2002. Arkeologiske undersøkelser ved Skatestraumen, B. 1. Bergen: Universitetet i Bergen. (Arkeologiske avhandlinger og rapporter fra Universitetet i Bergen 7.)

Bergsvik, Knut Andreas 2006. Ethnic boundaries in Neolithic Norway. Oxford: Archaeopress.

Bergsvik, Knut Andreas 2009. The Importance of Landscape. Perceptions to In-group and Between-group Relations among Hunter-Fishers of Neolithic Western Norway. Glørstad, $\mathrm{H}$ and C, Prescott (red.). Neolithisation as if History Mattered. Processes of Neolithisation in NorthWestern Europe: 105-134. Lindome: Bricoleur Press.

Bergsvik, Knut Andreas og Eva David 2015. Crafting bone tools in Mesolithic Norway: A regional eastern-related Know-How. European Journal of Archaeology 18/2: 190-221.

Bergsvik, Knut Andreas og Anne Karin Hufthammer 2009. Stability and change among marine hunter-fishers in Western Norway 7000-4500 cal BC. Results from the excavations of two rockshelters in Hardanger. Philippe Crombé, Marc Van Strydonck, Joris Sergant, Mathieu Bouduin mfl. (red.). Chronology and Evolution within the Mesolithic of North-West Europe: 435-450. Cambridge Cambridge Scholars Publishing.
Bergsvik, Knut Aandreas og Robin Skeates 2012. Caves in Context. The Cultural Significance of Caves and Rockshelters in Europe. Oxford: Oxbow Books.

Bernatchez, Louis 2001. The evolutionary history of brown trout (Salmo trutta L.) inferred from phylogeographic, nested clade, and mismatch analyses of mitochondrial DNA variation. Evolution 55/2: 351-379.

Bernatchez, L., R. Guyomard og F. Bonhomme 1992. DNA sequence variation of the mitochondrial control region among geographically and morphologically remote European brown trout Salmo trutta populations. Molecular Ecology 1/3: 161-173.

Bjerck, Hein Bjartmann 2008. «Norwegian Mesolithic trends: A review». Geoff Bailey og Penny Spikins (red.). Mesolithic Europe: 61-106. Cambridge: Cambridge University Press.

Bjerkvik, Verner 2004. Hevd i Gulatingslova? Bergen: Det juridiske fakultet, Universitetet i Bergen. (Det Juridiske Fakultets Skriftserie Bd. 94.).

Bjøntegaard, Thorleif 1949. Fiske, fangst og jakt. Den Norske Turistforenings årbok 1949: 146-148.

Bjørgo, Tore 1983. Fortidsminner i Valdresdalen og Vikadalen. Den norske turistforening årbok 1983: 138-143. Bjørgo, Tore, Siv Kristoffersen og Christopher Prescott. 1992: Arkeologiske undersøkelser i Nyset-Steggjevassdragene 1981-87. Bergen: Historisk museum, Universitetet i Bergen. (Arkeologiske rapporter 16.)

Bjørkli, Birgitte 2005. Den arktiske steinalderen i sør. En studie av skiferfunn fra Sorost-Norge. Oldsaksamlingens museumsdistrikt. Hovedfagsoppgave: Universitetet i Bergen.

Bjørkli, Birgitte 2015. Rapport. Arkeologisk utgravning av steinalderboplass. Vårdalen Statsallmenning (157/1) Volnebben, Tesse. Lom kommune, Oppland fylke. Upublisert rapport i Kulturhistorisk museums arkiv: Kulturhistorisk museums, Universitet i Oslo.

Bjørkli, Birgitte, Ellen Kathrine Friis, Elling Utvik Wammer og Axel Mjærum 2016. «Prolog. Tesse - et arkeologisk eldorado og en innfallsport til fjellfisket som et tverrfaglig tema». Axel Mjærum og Elling Utvik Wammer (red.). Fjellfiske i fortiden. Artusener med svommende rikdom. Kristiansand: Portal forlag.

Bjørkvik, Halvard 1965. «Landskyld». Kulturhistorisk leksikon for nordisk middelalder fra vikingtid til reformasjonstid. Bind 10.

Bjørkquist, Lennart 1932. Ur accessionskatalogen 1932. Jämten 1932: 93-110.

Blehr, Otto 1972. Hva dyregravene på Hardangervidda forteller om villreinfangst. Viking XXXVI: 115-130. 
Blindheim, Charlotte 1979. «Et gravfunn fra fjellet mellom Valdres og Gudbrandsdalen». Sverre Marstrander og Thorleif Sjøvold (red.). Fortiden forteller. Universitetets oldsaksamling 1829-1979: 66-67. Oslo: Dreyers Forlag.

Boaz, Joel 1998a. Hunter-gatherer site variability changing patterns of site utilization in the interior of eastern Norway, between 8000 and 2500 B.P. Oslo: Universitetets Oldsaksamling. (Oldsaksamlings skrifter, ny rekke 20.)

Boaz, Joel 1998b. Steinalderregistreringer langs Osensjøen 1997. Upublisert rapport i Kulturhistorisk museums arkiv: UKM Oldsaksamlingen, Universitet i Oslo.

Boaz, Joel 1999. «Pioneers in the Mesolithic. The initial occupation of the interior of Eastern Norway». Joel Boaz (red.). The Mesolithic of Central Scandinavia: 125-153. Oslo: Universitetets Oldsaksamling. (Universitetets Oldsaksamlings skrifter, ny rekke 22.)

Borgstrøm, Reidar 2016. Utsetjing av aure i Ullensvang statsallmenning. Arbok for Hardanger historielag.

Brabrand, Åge, Trond Bremnes, Svein Jakob Saltveit og Per Aass 2008. Fiskeribiologiske undersøkelser i Pålsbufjorden. Del 1: Biologiske virkninger av terskel i Rødtjennan, Laboratorium for ferskvannsøkologi og innlandsfiske (LFI). Naturhistorisk museum, Universitetet i Oslo. (Rapport 260.)

Brandt, Fr. 1892. Tingsretten, fremstillet efter den norske lovgivning. 3. gjennemseede Opl. Kristiania: Damm.

Brauer, Günter, Mark Collard og Chris Stringer 2004. On the reliability of recent tests of the Out of Africa hypothesis for modern human origins. Anatomical Record Part a-Discoveries in Molecular Cellular and Evolutionary Biology 279A/2: 701-707.

Bremset Hansen, Runbjørg 2004. Neroyfolket 1920-1970. Kolvereid: Nærøy kommune.

Brendalsmo, Jan 2015. «Hamar bispedømmes utstrekning i middelalderen». Brita Nyquist (red.). Geistlige segl fra Hamar bispedomme: 33-50. Oslo: Riksarkivet. (Norske sigiller fra middelalderen, bd. 4).

Broadbent, Noel D. 1979. Coastal resources and settlement stability. A critical study of a mesolithic site complex in Northern Sweden. Uppsala: Uppsala universitet, Institutionen för arkeologi.

Bronk Ramsey, Christopher 2009. Bayesian analysis of radiocarbon dates. RADIOCARBON 51/1: 337-360.

Bruen Olsen, Asle 1992. Kotedalen - en boplass gjennom 5000 år. Bind 1. Fangstbosetning og tidlig jordbruk $i$ vestnorsk steinalder: nye funn og nye perspektiver. Bergen: Universitetet i Bergen, Historisk museum.

Bryson Bill 2006. En kort historie om nesten alt. Oslo: Gyldendal Norsk Forlag.
Brøgger, Anton Wilhelm 1925. Det norske folk i oldtiden. Oslo: H. Aschehoug \& Co.

Brøgger, W. 1963. Nord-Gudbrandsdalen. Brøgger, W., Myklebost, H. Røhr, A. og Strømme, S (h. red.): Norge. Bind 2. Geografisk leksikon: 628-672. Oslo: Cappelens Forlag.

Bugge, Aleksander 1920. «Om hvorledes Norge var bygget i vikingetid og middelalder. Spredte studier fra vort lands bygningssaga». Historisk tidsskrift: 337-367 og 423-467.

Bull, Edvard 1929. Sammenlignende studier over bondesamfundets kulturforbold. Et arbeidsprogram. Institutt for sammenlignende kulturforskning. Oslo: $\mathrm{H}$. Aschehoug \& Co. (Serie C II-2.)

Bull, Jacob Breda 1916. Rendalen: dens historie og bebyggelse. Kristiania: Gyldendal.

Bye, Jarle 1997. Vide vidder $i$ vest. Vestfellet $i$ Gausdal. Lillehammer: Thorsrud Lokalhistoriske Forlag.

Bygningsskatt jonsok 1594. Bygningsskatt jonsok: 3. Gudbrandsdalen, Akershus, Gudbrandsdalen fogderi, 1594-. Oppbevares i Riksarkivet. Permanent sidelenke: http:// arkivverket.no/URN:db_read/rk/263/1/.

Bylund, Erik 1977. «Kollisionen mellan svenskt och lapskt näringsfång». Knut Bergsland (red.). Samenes og sameområdenes rettslige stilling historisk belyst. 108-122. Oslo: Universitetsforlaget.

Bäckman, Louise og Rolf Kjellström (red.)1979. Kristoffer Sjulssons minnen. Nordiska Museet.

Bøe, Arne 1962. «Hævd: Noreg». Kulturbistorisk leksikon for nordisk middelalder, bd. VII: 285-287. København: Rosenkilde og Bagger.

Bøe, Johannes 1942a. Til høgfellets forhistorie. Boplassen på Sumtangen ved Finsevatn på Hardangervidda. Bergen. (Bergens museums skrifter nr. 21.)

Bøe, Johannes 1942b. De eldste fangstfolkene på hardangervidda. Naturen 66: 193-210.

Carlsson, Tom 2007. Mesolitiska möten. Strandvägen en senmesolitisk boplats vid Motala Ström. Uppsala Almqvist og Wiksell. (Acta Archaeologica Lundensia. Series in $\left.8^{\circ} 54.\right)$

Carpelan, Christian 2008. «On the history and recent studies of the 'Antrea Net Find'». Mika Lavento (red.). Karelian Isthmus. Stone Age studies in 1998-2003: 88-127. Helsinki. (Iskos, 16.)

Charlesworth, Brian 2015. What Use Is Population Genetics? Genetics 200/3: 667-669.

Charlier, J., L. Laikre og N. Ryman 2012. Genetic monitoring reveals temporal stability over 30 years in a small, lake-resident brown trout population. Heredity 109/4: 246-253. 
Christensen, Arne Emil 1992. Gamle norske trebåter. Bevaring og vedlikehold. Oslo: Grøndahl.

Christensen, Arne Emil 1996. Innlandsbåtene, spennende men lite kjent. Arbok for Norsk Skogbruksmuseum 14: 229-241.

Christensen, Arne Emil 2000: Some Archaic Details of Norwegian Fresh-Water Boats. Litwin, Jerzy (red.). Down the River to the Sea, ISBSA 8. Gdansk: Polish Maritime Museum.

Christensen, Arne Lie 1971. Etnologisk feltarbeid ved Tesse sommeren 1970. Oslo: Universitetet i Oslo.

Cortey, Martí, Manuel Vera, Carles Pla og José-Loís GarciaMarin 2009. Northern and Southern expansions of Atlantic brown trout (Salmo trutta) populations during the Pleistocene. Biological Journal of the Linnean Society 97/4: 904-917.

Crumlin-Pedersen, Ole 1970. Skind eller træ? En studie i den nordiske plankebåds konstruktive oprindelse. Hasslöf, Olof., Henningensen, Henningsen og Christensen, Arne Emil (red.). Sømand, fisker, skib og varft. Introduktion til marititm etnologi: 213-264. Koøbenhavn: Rosenkilde og Bagger.

Dahl, Jonas 1870. Jotunfjeldene. Den Norske Turistforenings årbog: 1-67.

Damlien, Hege 2010. «Rødstranda. En lokalitet med funn og strukturer fra senmesolitikum til merovingertid». Kathrine Stene (red.). Steinalderundersøkelser ved Rena elv. Gråfellprosjektet. Bind III: 405-456. Oslo: Kulturhistorisk museum, Fornminneseksjonen. (Varia 76.)

Deliberasjonsprotokoll for Gudbrandsdal fogderi 1803. Rentekammeret inntil 1814, Realistisk ordnet avdeling, Matrikler og jordebøker, Protokoller opptatt ifolge forordning av 1. oktober 1802, Jordavgift, stykke 38, 1803-1803. Oppbevares i Riksarkivet. Permanent sidelenke: http:// arkivverket.no/URN:db_read/db/39260/.

Digitalt musem 2015. Langreiv. DigitaltMuseum, Gudbrandsdalsmusea. (Lasta ned 21.10.2015).

Djupedal, Reidar 1955. Ei skildring av Lom prestegjeld frå 1743 etter sokneprest Hans Frisak. Ärbok for Gudbrandsdalen 23: 83-102.

DN = Diplomatarium Norvegicum: Oldbreve til Kundskab om Norges indre og ydre Forbold, Sprog, Slagter, Sader, Lovgivning og Rettergang i Middelalderen [1847-2011]. Chr. C. A. Lange, C. R. Unger, H. J. Huitfeldt-Kaas, Gustav Storm mfl. (red.). Christiania/Oslo: Norsk historisk Kjeldeskrift-Institutt / Riksarkivet.
Dodson, Julian J., Nadia Aubin-Horth, Veronique Theriault og David J. Paez 2013. The evolutionary ecology of alternative migratory tactics in salmonid fishes. Biological Revierws 88/3: 602-625.

Drake, Sigrid 1979. Västerbottens lapparna. Umeå: Två Förläggare Bokförlag.

Dyrvik, Ståle 1991. «1536-1814». Grunntrekk i norsk historie. Fra vikingtid til våre dager: 107-181. Oslo: Universitetsforlaget.

Eigeland, Lotte 2015. Maskinmennesket i steinalderen. Endring og kontinuitet $i$ steinteknologi fram mot neolitiseringen av Øst-Norge. Avhandling (ph.d.): Faculty of Humanities, Universitetet i Oslo.

Einstad, Birgit 1952. Østre Gausdal i heidensk tid. Årbok for Gudbrandsdalen 20: 198-202.

Ekman, Jan og Elisabeth Iregren 1984. Archaeo-zoological investigations in Northern Sweden. Stockholm: Kungl. vitterhets-, historie- och antikvitetsakademien. (Early Norrland 8.)

Eknes, Lars 1926. Utsikt over utviklingen av norsk matrikkelvesen. Oslo: Grøndahl.

Eknæs, Åsmund 1972a. Katisse - en gammel faststående fiskeinnretning. Arbok for Norsk Skogbruksmuseum 6: 119-126.

Eknæs, Åsmund 1972b. Det tradisjonelle laksefisket $i$ Drammenselva. Magisteravhandling i folkelivsgransking. Universitetet i Oslo.

Eknæs, Åsmund 1974. Avdeling for ferskvannsfiske ved Norsk Skogbruksmuseum. Fauna 27: 229-233.

Eknæs, Åsmund 1975. Trinseformede garnsøkker og deres alder. Fossum, Tore (red.). Ärbok for Norsk skogbruksmuseum 7: 172-177.

Eknæs, Åsmund 1977. Tørking av ferskvannsfisk. Årbok for Norsk skogbruksmuseum 8: 236-248.

Eknæs, Åsmund 1978. Gamle fiskeredskap fra Tesse. Opphedia 8/1: 30-32.

Eknæs, Åsmund 1979. Innlandsfiske. Oslo: Det Norske Samlaget.

Ekroll, Øystein 2006. Ei anna historie - norsk mellomalder $i$ arkeologisk lys. Trondheim:Tapir Akademisk Forlag.

Eksaminasjonsprotokoll 1723. Oppland fylke, Gudbrandsdalen, Matrikkel, 1723-1723. Oppbevares i Riksarkivet. Permanent sidelenke: http://arkivverket.no/ URN:db_read/db/39149/4/.

Elvestad, Endre 1998: Typologi som arkeologisk praksis - En analyse av klassifisertefiskeredskaper fra Trondelags historie. Hovedfagoppgave i arkeologi, NTNU.

Elvestad, Endre 2009. Båtstøene på Hardangervidda. Rapport fra registreringer 2007, 2008, 2009. Stavanger Sjøfartsmuseum. (Upublisert rapport) 
Elvestad, Endre, David Tuddenham, Morten Sylvester, Andreas Stångberg og Frode Kvalø 2004. Kulturminne iferskvann. Trondheim: Tapir Akademisk Forlag. (Acta Archaeologica Nidrosiensia, Vitark 4.)

Engelstad, Eivind S 1934. Østnorske ristninger og malinger av den arktiske gruppe. Oslo: Aschehoug. (Serie B Skrifter, 26.)

Erlandsen, Arne H., Per Einar Faugli og Carl-Erik Grimstad 1997. Vannets kraft. Samfunnsbygger og miljøpåvirker. Oslo: Norges vassdrags- og energiverk og Energiforsyningens fellesorganisasjon.

Falk, Hjalmar og Alf Torp 1992 [1903-1906]. Etymologisk ordbog over det norske og det danske sprog. Oslo: Ringstrøms antikvariat.

Fasteland, Arthur 1971. Arkeologiske undersøkingar av lokaliteten HEIN 58/132 ved Halnefforden, Nore og Uvdal kommune, Buskerud. Utfort i 1970 av Hardangerviddaprosjektet for tverrvitenskapelig kulturforskning (HTK). Upublisert rapport i Kulturhistorisk museums arkiv: Kulturhistorisk museums, Universitet i Oslo.

Fasteland, Arthur 1973. Arkeologiske undersøkingar av Meisbulageret, lokalitet 1084, ved Bjornesfjorden på Hardangervidda, Nore og Uvdal kommune, Buskerud. Utfort $i 1973$ av Hardangerviddaprosjektet for tverrvitenskapelig kulturforskning (HTK). Upublisert rapport i Kulturhistorisk museums arkiv.

Fasteland, Arthur 2002. Steinbuer på Hardangervidda. Tidfesting og bruk. Arkeo 1: 34-42.

Ferguson A. 1989. Genetic differences among brown trout, Salmo trutta, stocks and their importance for the conservation and management of the species. Freshwater Biology 21/1: 35-46.

Ferguson Andrew og John B. Taggart 1991. Genetic differentiation among the sympatric brown trout (Salmo trutta) populations of Lough Melvin, Ireland. Biological Journal of the Linnean Society 43/3: 221-237.

Finstad, Espen 2006. Miljøovervåking og FoU-utredning. Aursjøenprosjektet 2006. Aursjømagasinet; Aursjøen, Grynningen og Gautsjoen, Nesset kommune, More og Romsdal fylke og Lesja kommune, Oppland fylke. Lillehammer: Oppland fylkeskommune. (Kulturhistorisk rapport 2008:1)

Finstad, Espen, Reidar Marstein, Lars Pilø, Jan Stokstad og Arne Brimi 2011. Jotunheimen. Historien, maten, turene. Oslo: Gyldendal.
Fischer, Anders 2007. «Coastal fishing in Stone Age Denmark-evidence from below and above the presentsea level and from human bones». Nicky Milner, Oliver E. Craig og Geoff Bailey (red.). Shell middens in Atlantic Europe: 54-69. Oxford: Oxbow Books.

Fjellheim, Sverre 2004. Fra fangstbasert til nomadisk reindrift i Rørostraktene. NORs 13. nordiske forskningskonferanse om rein og reindrift, Rangifer rapport 10 2005: 21-29.

Fladby, Rolf og Hans Try 1969-1978. Skattematrikkelen 1647. 17 fylkesvise bind. Oslo: Universitetsforlaget.

Fossum, Anitra 1996. Var de alle menn? Vikingtids jakt og fangst på rein i Nord-Gudbrandsdal. Otta: Engers Boktrykkeri.

Fossum, Tore 1971. Trekk fra vår jakt - og fangsthistorie. Jakt, fiske Friluftsliv. 2: 78-91.

Frankham, Richard 2010. Challenges and opportunities of genetic approaches to biological conservation. Biological Conservation 143/9: 1919-1927.

Frostatingslova [1994]. Oversatt av Jan Ragnar Hagland og Jørn Sandnes, Norrøne bokverk. Oslo: Det Norske Samlaget.

Fuglestvedt, Ingrid 1992. Svevollen. Et senmesolittisk boplassområde i det ostnorske innland. Magistergrad: Universitetet i Oslo.

Fuglestvedt, Ingrid 2009. Phenomenology and the pioneer settlement on the Western Scandinavian Peninsula. Lindome: Bricoleur Press.

Færden, Gerd 2007. «Hesteutstyr og redskap». Birthe Weber (red.). Vesle Hjerkinn - Kongens gård og salebus: 89-100. Oslo: Universitetets kulturhistoriske museer. (Norske oldfunn XXI.)

Fölsch, Edward G. 1818. Resa i Norrige år 1817. Strengnäs: Tryckt hos C. E. Ekmarck.

Fønnebø, Reidar 1988. Langs Nordmannsslepene over Hardangervidda. Oslo: Universitetsforlaget.

García-Marin, Jose-Luis, Fred Utter og Carlos Pla 1999. Postglacial colonization of brown trout in Europe based on distribution of allozyme variants. Heredity 82: 46-56.

Geistlige segl fra Hamar bispedømme 2015. Brita Nyquist (red.). Norske sigiller fra middelalderen. Oslo: Riksarkivet. (Bind 4.)

Gibbs, R. A., J. W. Belmont, P. Hardenbol mfl. 2003. The International HapMap Project. Nature 426/6968: 789-796.

Gjenstandsbasen 2015. «Den arkeologiske gjenstandsbasen til Kulturbistorisk museum, Oslo». (27.1.2016). MUSIT. 
Gjerpe, Lars Erik 2010. «Kontinuitet og brudd i jernalderens jordbrukssamfunn». Ingar M. Gundersen og Marianne Hem Eriksen (red.). På sporet av romersk jernalder. Artikkelsamling fra Romertidsseminaret på Isegran 23.-24. januar 2010: 7-19. Oslo: Nicolay arkeologisk tidsskrift. (Nicolay skrifter 3.)

Gjessing, Gutorm 1955. Veiding og sanking i forhistorisk tid $i$ Norden. Oslo: A. H. Aschehoug \& Co.s Forlag. (Nordisk Kultur XI-XXII.)

Gjessing, Gutorm 1961. «Jakt og fiske i førhistorisk tid». Per Hohle (red.). Jakt og fiske i Norge. Jakt: 9-49. Oslo: Norsk Arkivforskning.

Glørstad, Håkon 2004. «Kronologiske resultater fra Svinesundprosjektet». Håkon Glørstad (red.). Svinesundprosjektet Bind 4. Oppsummering av Svinesundprosjektet: 21-46. Oslo: Universitetets kulturhistoriske Museer. (Varia 57.)

Glørstad, Håkon 2010. The structure and history of the late mesolithic societies in the Oslo ford area 6300-3800 BC. Lindome: Bricoleur Press.

Glørstad, Håkon 2014. Deglaciation, sea-level change and the Holocene colonization of Norway. Geological Society, London, Special Publications 411.

Gollwitzer, Martin 1997. Yngre järnalder i fälltrakterna. Inger Zachrisson (red.). Möten i gränsland. Samer och germaner $i$ Mellanskandinavien: 27-33. Stockholm: Statens historiska museum. (Statens Historiska Museum, Monographs 4)

Gregersen, Finn og Ola Hegge 2009. Bedre bruk av fiskeressursene i regulerte vassdrag $i$ Oppland. Vassdragsreguleringer og fisk i regulerte vassdrag i Oppland, Lillehammer: Miljøvernavdelingen, Fylkesmannen i Oppland. (Rapport 12/2009.)

Grøndahl, Finn Audun 2001. Driftsplan for A/L Lågen Fiskeelv 2001-2003. http://docplayer.no/5979057Driftsplan-for-a-1-lagen-fiskeelv-2001-2003.html.

Grieg, Sigurd 1950. Kulturhistoriske streiftog. Oslo: Johan Grundt Tanum Forlag.

Grieg, Sigurd 1957. Gudbrandsdalen i mellomalderen bind I. Mennsket og kulturen. Kristningsverket. Hamar: Kulturhistorisk samskipnad for Gudbrandsdalen i samarbeid med De Sandvigske Samlinger.

Grieg, Sigurd og Gustav Adolf Norman 1949. De Sandvigske samlinger. Veileder til håndverksavdelingen. Lillehammer: De Sandvigske samlinger.

Grimstad, Edvard 1948. Etter gamalt. Folkeminne frå Gudbrandsdalen II. Oslo: Norsk Folkeminnelag (Nr. 62.)

Gunnerød, T. B. og Trygve Hesthagen 1980. Fisket $i$ Tesse $i$ Lom kommune, Oppland, for og etter regulering. Trodheim: Direktoratet for vilt og ferskvannsfisk. (Rapport 12.)
Gustafson, Lil 1978. Stegaros. Et boplassområde på Hardangervidda. Ressursutnyttelse i forbistorisk tid. Bergen.

Gustafson, Lil 1990. Bukkhammeren, en beverfangstplass i Innerdalen, Kvikne. Viking LIII: 21-49.

Hageløkken, Johan 1955. Ein gammal fiskemåte. Arrbok for Gudbrandsdalen 23: 152-154.

Hagen, Anders 1959a. Funn fra fjellvann. Viking XXIII: 35-41.

Hagen, Anders 1959b. Vassdragsreguleringer og høyfjellsarkeologi. Synspunkter og resultater i forbindelse med undersøkelsene 1958 i Vest-Telemark. Universitetets Oldsaksamlings årbok 1956-1957: 98-150.

Hagen, Anders 1969. Studier i vestnorsk bergkunst. Årbok for Univeristetet i Bergen. Bergen. (Hum. Ser. 1969, No. 3.).

Halvorsen, G. K. 1914. Jotunfjeldene tidlig i tiderne. Den Norske Turistforenings aarbok: 1-12.

Hammer, Christopher 2000 [1797-1798]. Sogne-Beskrivelse over Hadeland udi Aggershuus Stift i Norge. Harald Hvattum (red.) med innledning, litteratur om Hammer og noter. Arbok for Hadeland 2000:3-225.

Hansen, Andreas M. 1929. Bre og biota. Oslo: Det Norske Videnskaps-Akademi. (Matem. Naturv. Klasse No. 5.)

Hansen, Michael M., Isabelle Olivieri, Donald M. Waller, Einar E. Nielsen og GeM Working Group 2012. Monitoring adaptive genetic responses to environmental change. Molecular Ecology 21/6: 1311-1329.

Harstad, Joakim 1968. Fiskeredskap. Kjell W. Jensen (red.). Sportsfiskerens Leksikon: 350- 359. Oslo: Gyldendal Norsk Forlag.

Hattestad, Aksel 1948. Kring skattefisken i Gudbrandsdalen. Arbok for Gudbrandsdalen 16: 117-123.

Hattestad, Aksel 1957. Statsskatten frå Gudbrandsdalen 1557-58. I Årbok for Gudbrandsdalen 25: 32-42.

Hauritz, Nils 2004. «Nordre Gudbrandsdalen sorenskriveri». Kristin M. Røgeberg (red.). Norge i 1743. Innberetninger som svar på 43 sporsmål fra Danske Kanselli. 2 Akershus Stift Hedmark Oppland: 319-332. Oslo: Solum forlag.

Hayden, Brian 1981. Research and Development in the Stone Age. Technological Transitions among HunterGatherers. Current Anthropology 22/5: 519-531.

Hegge, Ola og Trygve Hesthagen 1993. Aurebestanden i Tessemagasinet-konsekvenser av

reguleringen. Lillehammer: Miljøvernavdelingen. Fylkesmannen i Oppland.

Heggenes, Jan 2016. «Fisken i fjellet i fortid og nåtid. Hva kan DNA-analyser fortelle?». Axel Mjærum og Elling Utvik Wammer (red.). Fjellfiske i fortiden. Artusener med svommende rikdom. Kristiansand: Portal forlag. 
Heggenes, J. og K. H. Røed 2006. Do dams increase genetic diversity in brown trout (Salmo trutta)? Microgeographic differentiation in a fragmented river. Ecology of Freshwater Fish 15/4: 366-375.

Heggenes, J., K. H. Røed, B. Hoyheim og L. Rosef 2002. Microsatellite diversity assessment of brown trout (Salmo trutta) population structure indicate limited genetic impact of stocking in a Norwegian alpine lake. Ecology of Freshwater Fish 11/2: 93-100.

Heggenes, J., K. H. Røed, P. E. Jorde og A. Brabrand 2009. Dynamic micro-geographic and temporal genetic diversity in vertebrates: the case of lake-spawning populations of brown trout (Salmo trutta). Molecular Ecology 18/6: 1100-1111.

Heggenes, J., O. Skaala, R. Borgstrom og O. T. Igland 2006. Minimal gene flow from introduced brown trout (Salmo trutta L.) after 30 years of stocking. Journal of Applied Ichtbyology 22/2: 119-124.

Heggstad, Leif 1963. Gamalnorsk ordbok med nynorsk tyding. Ny umvolt og auka utgåve av "Gamalnorsk ordbok» ved Hægstad og Torp. Oslo: Det Norske Samlaget.

Helland, Amund 1913. Norges land og folk. Topografiskstatistisk beskrivelse over Kristians amt. Forste Del. Den almindelige Del. Kristiania: H. Aschehoug \& Co.

Helstad, Magnus 2008. Skaftfurekoller $i$ Hedmark: et multiredskap. Masteroppgave: Institutt for arkeologi, konservering og historie. Det humanistiske fakultet, Universitetet i Oslo.

Hermanstrand, Håkon 2009. Røyrvik. Samene i Østre Namdal. Røyrvik: Røyrvik kommune.

Hermanstrand, Håkon 2014. «Samene i Rana på 1700-tallet». Erik Norberg og Ulf Stefan Winka (red.). Sydsamer - landskap och historia. Östersund: Gaaltije sydsamiskt kulturcentrum

Hermundstad, Knut 1939. Ymse fra Valdres i gammal tid. Den Norske Turistforenings årbok: 70-80.

Hermundstad, Knut 1964. «Fisket». Knut Hermundstad (red.). Valdres Bygdebok V. Fyrste Del. Villdyr og veiding, fiske, turistferdsel, handverk og handverkarar: 147-225. Leira: Valdres Bygdeboks Forlag.

Hesthagen, Trygve 2001. Fiske og fiskekultivering i Skjåk. Skjåk: Skjåk kommune.

Hesthagen, Trygve 2004. Bruk av mæl og andre ruseliknande fiskereiskapar i Gudbrandsdalen. Arbok for Gudbrandsdalen 72: 100-114.

Hesthagen, Trygve 2006. Bruk av fiskesleo i Vågå. Årbok for Gudbrandsdalen 74: 212-235.

Hesthagen, Trygve 2007. Notfiske i Tesse. Heim og Bygd 14: 34-41.
Hesthagen, Trygve 2008. Bruk av ymse fiskereiskap i Lesjavatna. Arbok for Gudbrandsdalen 76: 137-155.

Hesthagen, Trygve 2009. Fisk og bygsling i Rondane. Arbok for Gudbrandsdalen 77: 203-213.

Hesthagen, Trygve 2011. Sløefiske i Oppland. Ein vanleg fiskemåte i gammal tid. Trondheim: Norsk institutt for naturforskning. (Temahefte 46.)

Hesthagen, Trygve og Tor B. Gunnerød 1980. Fisket $i$ Tesse i Lom kommune, Oppland, for og etter regulering. Rapport nr. 12 1980. Trondheim: Direktoratet for vilt og ferskvannsfisk.

Hesthagen, Trygve og Einar Kleiven 2016a. «Fiskemåtar i fjellet i eldre tid». Axel Mjærum og Elling Utvik Wammer (red.). Fjellfiske i fortiden. Artusener med svømmende rikdom. Kristiansand: Portal forlag.

Hesthagen, Trygve og Einar Kleiven 2016b. «Når og korleis kom fisken inn i vassdraga i Jotunheimen? Mogleg utbreiing i steinalderen og fram til nyare tid». Axel Mjærum og Elling Utvik Wammer (red.). Fjellfiske i fortiden. Artusener med svommende rikdom. Kristiansand: Portal forlag.

Hesthagen, Trygve og Einar Kleiven 2016c. Fiske i Jotunheimen - frå matauk til hobby $i$ Vagå. Norsk institutt for naturforskning Fagbok.

Hesthagen, Trygve og Odd Terje Sandlund 2004. Fish distribution in a mountain area in south-eastern Norway: human introductions overrule natural immigration. Hydrobiologia 521: 49-59.

Hiim, Marit 1967. «Innberetning om registrering ved Liavatnet, Nordberg s, Skjåk pdg., Oppland, juli 1967». Irmelin Martens (red.).Arkeologiske undersøkelser i Jotunheimen 1967: 79. Upublisert rapport i Kulturhistorisk museums arkiv: De arkeologiske museers registreringstjeneste.

Hiim, Marit og Irmelin Martens 1967. Innberetning om registrering ved Tesse, Garmo s., Lom pgd., og Vågå s. og pgd., juli 1967. Arkeologiske undersøkelser i Jotunheimen 1967. Upublisert rapport i Kulturhistorisk museums arkiv: De arkeologiske museers registreringstjeneste.

Hindar, Kjetil, Nils Ryman og Gunnar Ståhl 1986. Genetic differentiation among local populations and morphotypes of Arctic charr, Salvelinus alpinus. Biological Journal of the Linnean Society 27: 269-185.

Hiorthøy, H. F. 1907 [1785]. Physisk og Ekonomisk Beskrivelse over Gulbransdalen Provstie i Aggershuus Stift i Norge. Første Deel. Kiøbenhavn: Gudbrandsdølens Bogtrykkeri.

Hiorthøy, Hugo Fredrik 1956 [1785-1786]. Physisk og ekonomisk beskrivelse over Gulbransdalen Provstie i Aggershuus Stift i Norge. 2 bind. Faksimileutgave Oslo: Halvorsen \& Børsum. 
Hjelle, Kari Loe, Anne Karin Hufthammer og Knut Andreas Bergsvik 2006. Hesitant hunters: a review of the introduction of agriculture in western Norway. Environmental Archaeology 11/2: 147-170.

Hofseth, Ellen Høigård 1980. Fjellressursenes betydning i yngre jernalders økonomi. Sammenlignende studie av bygdene ost og vest for vannskillet i Nord-Gudbrandsdal. Stavanger: Universitetet i Tromsø, Inst. for museumsvirksomhet. (Ams-skrifter 5.)

Holmsen, Andreas 1966a. «Overgangen til selveie i Norge». Gard, Bygd, Rike. Festskrift i anledning Andreas Holmsens 60 års dag 5. juni 1966: 222-231. Oslo: Universitetsforlaget.

Holmsen, Andreas 1966b. «Gard og jordegods i gammal tid. Frå opphavstid til ø'gardstid i ei lita opplandsbygd». Gard, Bygd, Rike. Festskrift i anledning Andreas Holmsens 60 års dag 5. juni 1966: 179-221. Oslo: Universitetsforlaget.

Holmsen, Andreas 1980. Skattematrikkelen 1647. Rolf Fladby og Harald Winge (red.). Den eldste matrikkelen. En innfallsport til historien: 9-12. Oslo: Universitetsforlaget.

Hosar, Hans P. 1994. Skjåk Bygdebok. Bind 1. Historia fram til 1537. Skjåk: Skjåk kommune.

Hosar, Hans P. 1995. Skjåk bygdebok. Bind 2. Historia 1537-1800. Sjåk: Skjåk kommune.

Hougen, Bjørn 1947. Fra seter til gård. Studier i norsk bosetningshistorie. Oslo: Norsk arkeologisk selskap.

Hougen, Bjørn 1958. «Valdres i oldtiden». Knut Hermundstad (red.). Valdres Bygdebok. II. Natur, oldtid, målfore, gardsnamn og folk: 105-232. Leira: Valdres Bygdeboks Forlag.

Hovdhaugen, Einar 1974. Gardar og slekter i Fron. Bind I: Nord-Fron. Otta: Fron Historielag.

Hovstad, Bernt 1965. Laksefisket i Gaula. Ärbok for Norsk Skogbruksmuseum 4: 83-97.

Hufthammer, Anne Karin 1992. «De osteologiske undersøkelsene fra Kotedalen». Kari Loe Hjelle (red.). Kotedalen - en boplass gjennom 5000 år. Bind 2. Naturvitenskapelige undersøkelser: 10-64. Bergen: Universitetet i Bergen, Historisk museum.

Hufthammer, Anne Karin 1997. «The vertebrate faunal remains from Auve - a palaeoecological investigation». Einar Østmo (red.). Tekniske og naturvitenskapelige undersøkelser: 43-57. Oslo: Institutt for arkeologi, kunsthistorie og numismatikk, Universitetets Oldsaksamling. XVII.)

Hufthammer, Anne Karin 2014: JS 1664 Rapport. Tesse, Lom k., Oppland. Universitetsmuseet i Bergen, Universitetet $i$ Bergen. Upublisert rapport i Kulturhistorisk museums arkiv: Kulturhistorisk museums, Universitet i Oslo.
Hufthammer, Anne Karin. 2015. Osteological assemblages from rock shelters as source data for subsistence fram Bronze Age to the Middle Ages in Western Norway. Landscape exploitation and transformation. Svein Indrelid, Kari Loe Hjelle, Kathrine Stene, Birgitta Berglund mfl. Exploitation of outfield resources - Joint Research at the University Museums of Norway: 231-240. Bergen: University Museum of Bergen.

Hufthammer, Anne Karin 2016. "Fish trade in Norway AD 800-1400: Zooarchaeological Evidence». James Barrett og David C. Orthon (red.). Cod and herring. The archaeology and history of medieval sea fishing: 221-230. Oxford-Philadelphia: Oxbow Books.

Hufthammer, Anne Karin og Axel Mjærum 2016. «Fjellfunn og fiskebein -Om fiske og bruken av fjellet $\mathrm{i}$ fortiden». Axel Mjærum og Elling Utvik Wammer (red.). Fjellfiske i fortiden. Artusener med svommende rikdom. Kristiansand: Portal forlag.

Hufthammer, Anne Karin og Olaug Flatnes Bratbak 2000. Bones from the 2000 excavation at the Kaupang Tjølling site. Upublisert rapport: Zoologisk Museum, Universitetet i Bergen.

Hufthammer, A. K., O. F. Bratbak og S. Indrelid 2011. A study of bone remains and butchery patterns from medieval mass-hunting of reindeer in the South Norwegian mountain districts. Quaternary International 238/1: 55-62.

Huitfeldt-Kaas, Hartvig 1916. Mjøsens fisker og fiskerier. Trondheim: Aktietrykkeriet. (Det Kongelige Norske Videnskabers Selskabs Skrifter. (1916, nr. 2).

Huitfeldt-Kaas, Hartvig 1918. Ferskvandsfiskenes utbredelse og indvandring i Norge. Med et tillag om krebsen. Kristiania: Centraltrykkeriet.

Huitfeldt-Kaas, Hartvig 1927. Studier over aldersforholde og veksttyper hos norske ferskvannsfisker. Oslo: Nationaltrykkeriet.

Hundstad, Dag 2014. «Kystkultur. Et begrepshistorisk perspektiv». Koren, Elisabeth Solvang og Kvalø, Frode (red.). Hundre år over og under vann. Kapitler om maritim historie og arkeologi i anledning Norsk Maritimt Museums bundreåresjubileum: 43-77. Oslo: Novus Forlag.

Hunskaar, Kristian mfl. 2008. «Matrikkelgård» (15.11.2015). Lokalhistoriewiki.no. Hentet fra: http://lokalhistoriewiki. no/index.php/Matrikkelgård.

Huset, Hallvar H. 1992. Butangen, et innlandsfiskevær. Nils Viker (red.). Dal og vidde. Imsdalen, Ringebufiellet: 57-58. Oslo: Mortensen.

Hutchings J. A. 2011. Old wine in new bottles: reaction norms in salmonid fishes. Heredity 106/3: 421-437. 
Høgåsen, Martinus 1950. Nogo tå kvart frå gamal tid. II. Ei grensesak mellom Lom og Vågå i 1466. Årbok for Gudbrandsdalen 18: 215-216.

Høgåsen, Martinus 1956. Gamle diplom frå Fåberg. Utskrifter av Diplomatarium Norvegicum. Årbok for Gudbrandsdalen 24: 30-36.

Ile, Tor 1960. Bygdabok for Øyer. Natur og kultur. Innsyn og utsyn. Bind 2. Øyer: Øyer Bygdeboknemnd.

Indreko, Richard 1956. Steingeräte mit Rille. Stockholm: Almqvist og Wiksell International. (Kungl. vitterhets-, historie- och antikvitets akademiens handlingar. Antikvariska serien 4.)

Indrelid, Svein 1973. Hein 33 - en steinalderboplass på Hardangervidda. Forsøk på kronologisk og kulturell analyse. Bergen: Universitetsforlaget. (Humanistisk serie 1.)

Indrelid, Svein 1994. Fangstfolk og bonder i fellet. Bidrag til Hardangerviddas forbistorie 8500-2500 år for nåtid. Oslo: Universitetets Oldsaksamling. (Universitetets Oldsaksamlings skrifter, ny rekke 17.)

Indrelid, Svein 2009. Arkeologiske undersøkelser $i$ vassdrag. Faglig program for Sør-Norge. Oslo: Riksantikvaren.

Indrelid, Svein 2014. Oppdagelser på Hardangervidda. Kvinnherad: Nord 4.

Indrelid, S. og A. K. Hufthammer 2011. Medieval mass trapping of reindeer at the Hardangervidda mountain plateau, South Norway. Quaternary International 238/1: 44-54.

Indrelid, Svein, Anne Karin Hufthammer og Knut Røed 2007. Fangstanlegget på Sumtangen, Hardangervidda. Utforskningen gjennom 165 år. Viking LXX: 125-154.

Itkonen, Terho 1957. Suomen kielen suksisanastoa. Referat: Finnische skiterminologie. Helsinki: Suomalaisen Kirjallisuuden Seura.

Jacobsen, Harald 1990. 'Naturens tilfeldighet - Menneskets glede'. Bruken av ressursar ved Dokkfløyvatn gjennom 8000 år. Årbok for Gudbrandsdalen 58: 7-19.

Jacobsen, Harald og Jan Henning Larsen 1992. Dokkfløys historie. Dokkfloy fra istid til kraftmagasin. Øvre Gausdal: Gausdal kommune og Oppland energiverk.

Jahnsen, J. B. 1982. Striden mellom Valdres og Fron om Sandvatnet og Vinstervatnet 1454-1597. Arbok for Valdres 1982: 34-39.

Jebens, Otto 1999. Om eiendomsretten til grunnen $i$ Indre Finnmark. Oslo: Cappelen Akademisk Forlag.

Jochim, Michael A. 1976. Hunter-gatherer subsistence and settlement. A predictive model. New York: Academic Press.

Johannessen, Finn Erhard 1990. Gausdal bygdehistorie bd. 3. Folkevekst og levekair 1530-1830. Gausdal: Gausdal kommune.
Johannessen, Knut 2004. «Bygsel. Gårdklasser. Jordavgiften 1802. Jordeiendomsforhold. Landskyld». Norsk bistorisk leksikon (2. utgave, 3. opplag).

Johansen, Arne B. 1970. Høyfellsfunn ved Lardalsvassdraget. Den teoretiske bakgrunn og det forste analyseforsøk. BergenOslo-Tromsø: Universitetsforlaget.

Johansen, Arne B. 1978. Høyfellsfunn ved Lardalsvassdraget. Bind II. Naturbruk og tradisjonssammenhenger $i$ et sør-norsk villreinområde i steinalder. Bergen: Universitetsforlaget.

Johansen, Arne B. 1983. De glemte grendene på Hemsedalsfjellet. Den Norske Turistforening årbok 1983: 133-137.

Johansen, Arne B. 1994. Statsallmenningane i Gudbrandsdalen og «De kubiske Stenvarder». Ärbok for Gudbrandsdalen 62: 105-121.

Johansen, Arne B. 2004. «Da vi lærte å lage jern». Østmo, Einar (red.). For Norge ble Norge: 82-89. Oslo: Schibsted. Johnsen, Stein Ivar 2004. Kartlegging av viktige leveområder for karpefisk, abbor, hork og gjedde i Gudbrandsdalslagen fra Harpefoss til utlop i Mjøsa. Lillehammer: Fylkesmannen i Oppland, Miljøvernavdelingen. (Rapport 2/2004.)

Johnsen, Stein, Jon Museth og Jon Gunnar Dokk 2015. Kartlegging av viktige funksjonsområder for fisk $i$ Gudbrandsdalslågen. Lillehammer: Norsk institutt for naturforskning. (Rapport 1173.)

Johansen, Øystein 1981. Metallfunnene i østnorsk bronsealder. Kulturtilknytning og forutsetninger for en marginalekspansjon. Oslo: Universitetets Oldsaksamling. (Universitetets Oldsaksamlings skrifter, ny rekke 4.)

Jordebok, Akershus len 1577-1578. Jordebok, Akershus len, Akershus, 15770624-15780624, Oppbevares i Riksarkivet. Permanent sidelenke: http://arkivverket.no/ URN:db_read/rk/206/1/.

Jordebok: C Gudbrandsdal 1661. Rentekammeret inntil 1814, Reviderte regnskaper, Stiftamtstueregnskaper. Oppbevares i Riksarkivet. Permanent sidelenke: http://arkivverket.no/ URN:db_read/rk/21389/1/.

Jordhøy, Per 2005. Lesjaleira - landskap og fugleliv. Lesja: Snøhetta forlag.

Jordhøy, Per 2007a. Gamal jakt-og fangstkultur som indikatorar på trekkmonster hjå rein i Sor-Noreg. Kartlagde fangstanlegg i Rondane, Ottadalen, Jotunheimen og Forollhogna. Trondheim: Norsk institutt for naturforskning. (Rapport 246.)

Jordhøy, Per 2007b. Eit framifrå fangstanlegg for rein i Lordalsfjella. Villreinen 22: 52-57. 
Jordhøy, Per 2014. «Eit fangstområde i særklasse». Per Jordhøy (red.). Reinheimen og Breheimen. Frå pil og boge til lasso og gevar: 11-24. Villreinutvalget. Ottadalsområdet. Lesja: Snøhetta Forlag.

Jordhøy Per, Reidar Hole og Endre Hage 2007. Ein fangstgradient i særklasse. Villreinen 24: 62-67.

Jordhøy, Per, Raymond Sørensen, Stig Aaboen, Johan Berge mfl. 2011. Villreinen i Ottadalen. Kunnskapsstatus og leveområde. Trondheim: Norsk institutt for naturforskning (Rapport 643.)

Junge, Claudia, Jon Museth, Kjetil Hindar, Morten Kraabøl og Asbjørn Vøllestad 2014. Assessing the consequences of habitat fragmentation for two migratory salmonid fishes. Aquatic Conservation. Marine and Freshwater Ecosystems 24: 297-311.

Jørgensen, Jan Hoff 1987. Sølensjøfisket. Magistergradsavhandling. Oslo: Universitetet i Oslo.

Jåma, Albert 2001. Sociale og økonomiske forhold blant reindriftssamer i Vestre Namdal i 1920-1930-åra. Aarjel-saemieh, Samer i sør. Arbok nr. 7. Snåsa: Stiftelsen Saemien Sijte.

Keller, Karl-Fredrik og Schia, Erik 1994. Middelalderbyen Oslo. En rekonstruksjon. Oslo: William Dall.

Kelly, Robert L. 2013. The lifeways of hunter-gatherers. The foraging spectrum. Cambridge: Cambridge University Press.

Keyland, Nils 1914. «Afbildningar af notredskap jämte några anteckningar om vinternotfisket i senare tid». Upmark, Gustaf (red.). Fataburen. Kulturbistorisk tidsksrift: 223-241. Stockholm: Kungl. Boktryckeriet.

Kgl. res. 2011. Glommen og Laagen Brukseierforening - Ny reguleringskonsesjon for Tesse

i Lom og Vågå kommuner, Oppland fylke: 12-13. Olje og energidepartementet. (Kongelig resolusjon 08/02928.)

Kjelland, Arnfinn 1994. Felleseige, matrikkelskyld og utskifting. Arbok for Gudbrandsdalen 62: 122-131.

Kjelland, Arnfinn 2016. «Om landskyldvara «bergefisk» i Gudbrandsdalen». Axel Mjærum og Elling Utvik Wammer (red.). Fjellfiske i fortiden. Artusener med svømmende rikdom. Kristiansand: Portal forlag.

Kjellström, Rolf 2000. Samernas liv. Stockholm: Carlsson Bokförlag.

Kleiven. Ivar 1915. Gamal bondekultur i Gudbrandsdalen. Lom og Skjaak. Oslo: Aschehoug \& Co.

Kleiven, Ivar 1923. Gamal bondekultur i Gudbrandsdalen. Lesja og Dovre. Oslo: Ashehoug \& Co

Kleiven, Ivar 1930. Gamal bondekultur i Gudbrandsdalen. Fronsbygdin. Oslo: Ashehoug \& Co.

Kleiven, Ivar 1928. Gamal bondekultur i Gudbrandsdalen. Ringebu. Oslo: Ashehoug \& Co.
Kleiven, Ivar 1944. I gamle Daagaa. Forteljingo og BygdaMinne fraa Vaagaa. Treia upplage. Oslo: H. Aschehoug \& Co.

Kleiven, Ivar 1949. I Heimegrendi. Minne fraa Seksti-Aarom. 2. upplaget. Vågå Historielag. 3. upplaget. Dølaringen Boklag.

Klemetsen A., P. A. Amundsen, J. B. Dempson, B. Jonsson mfl. 2003. Atlantic salmon Salmo salar L., brown trout Salmo trutta L. and Arctic charr Salvelinus alpinus (L.): a review of aspects of their life histories. Ecology of Freshwater Fish 12/1: 1-59.

Knapstad, Torill 1967a. «Innberetning om registrering ved Vinsteren, Hegge s., Østre Slidre pgd. Oppland, juli-august 1967». Irmelin Martens (red.). Arkeologiske undersøkelser i Jotunheimen 1967: 1-20. Upublisert rapport i Kulturhistorisk museums arkiv: De arkeologiske museers registreringstjeneste.

Knapstad, Torill 1967b. «Innberetning om registrering ved Bygdin, Vang pgd., Oppland i juli 1967». Irmelin Martens (red.). Arkeologiske undersøkelser i Jotunheimen 1967: 23-32. Upublisert rapport i Kulturhistorisk museums arkiv: De arkeologiske museers registreringstjeneste.

Knapstad, Torill 1967c. «Innberetning om befaring ved NØ-enden av Nedre Heimdalsvatn, Kvikne s., NordFron pgd. Oppland august 1967». Irmelin Martens (red.). Arkeologiske undersøkelser i Jotunheimen 1967: 21-22. Upublisert rapport i Kulturhistorisk museums arkiv: De arkeologiske museers registreringstjeneste.

Kolden, Jon 2002. Bygdabok for Lom. Bind 2. Gards-og attesoge for Lii, Staurrustgrendi og Strindi til og med Geisar. Lesja: Snøhetta forlag.

Koskinen, M. T., E. Ranta, J. Piironen, A. Veselov mfl. 2000. Genetic lineages and postglacial colonization of grayling (Thymallus thymallus, Salmonidae) in Europe, as revealed by mitochondrial DNA analyses. Molecular Ecology 9: 1609-1624.

Kraft, Jens 1840. Topographisk-statistisk Beskrivelse over Kongeriget Norge. Anden del. Christiania: Chr. Grøndal.

Krag, J. 1887. Fra Namdalens ukjendte egne. Den Norske Turistforenings årbog 1887.

Kristjansson, Ludvik 1983. Islenzkir sjavarhattir III. Reykjavik: Bokautgafa Menningarjods.

Kristoffersen, Siv. 1992. «Utgravde lokaliteter frå jernalder». Tore Bjørgo, Siv Kristoffersen, og Christopher Prescott (red.). Arkeologiske undersøkelser i Nyset-Steggjevassdragene 1981-87: 147-284. Bergen: Historisk museum, Universitetet i Bergen. (Arkeologiske rapporter 16.) 
Landmark, Anthon 1889. Fiskeri-Inspektorens indberetning om ferskvandsfiskerierne for Aarene 1884-1886. Kristiania: Fiskeri-inspektørens kontor.

Landmark, Anthon 1894. Fiskeri-Inspektorens indberetning om ferskvandsfiskerierne for Aarene 1887-1890. Kristiania: Fiskeri-inspektørens kontor.

Landmark, Anthon 1907. Fiskeri-inspektorens indberetning om ferskvannsfiskerierne for aarene 1903 og 1904.

Kristiania: Fiskeri-inspektørens kontor.

Landmark, Anthon 1909. Fiskeri-inspektorens indberetning om ferskvannsfiskeriene for aarene 1905 og 1906.

Kristiania: Fiskeri-inspektørens kontor.

Landmark, Anthon 1911. Fiskeri-inspektorens indberetning om ferskvannsfiskerierne for aarene 1907 og 1908.

Kristiania: Fiskeri-inspektørens kontor.

Lannerbro, Ragnar 1997. Det sødra fångstlandet. Katalog, Del 3, Övre Österdalälven. Stockholm: Institutionen. (Stockholm Archaelogical Reports. Field studies, 5.)

Lappekommisionen af 1889. Indberetning fra den ved kongelig Resolution af 12te Juli 1889 til Undersøgelse af Lappeforholdene i Hedemarkens, Søndre- og Nordre Trondhjems Amter anordnede Kommission.

Larsen, Jan Henning 1991. Jernvinna ved Dokkfloyvatn. De arkeologiske undersøkelsene 1986-1989. Oslo: Universitetets Oldsaksamling. (Varia 23.)

Larsen, Jan Henning 2009. Jernvinneundersøkelser. Faglig program bind 2. Oslo: Kulturhistorisk museum, Fornminneseksjonen. (Varia 78.)

Lie, Rolf W. 1992. «Appendix 2. Osteologiske materiale». Tore Bjørgo, Siv Kristoffersen, og Christopher Prescott (red.). Arkeologiske undersøkelser i Nyset-Steggjevassdragene 1981-87: 320-327. Bergen: Historisk museum, Universitetet i Bergen. (Arkeologiske rapporter 16.)

Lie, Rolf W. 1994. «Appendix 2. Det osteologiske materialet fra Tøftom». Egil Mikkelsen (red.) Fangstprodukter $i$ vikingtidens og middelalderens økonomi. Organiseringen av massefangst av villrein i Dovre: 201-218. Oslo: Universitetets Oldsaksamling. (Universitetets Oldsaksamlings skrifter, ny rekke 18.)

Lie, Rolf W. og T. Fredriksen. 2007. «Osteologiske analyser. Beinmaterialet fra Vesle Hjerkinn - en middelalderlokalitet i høyfjellet». Birthe Weber (red.). Vesle Hjerkinn. Kongens gård og salehus: 141-167. Oslo: Universitetets kulturhistoriske museer. (Norske oldfunn XXI.)

Liestøl, Aslak 1957. Li-steinen. Stangfiskeren 25: 120-121.

Liestøl, Knut 1939. Fiska dei gamle nordmennene med fluge? Stangfiskeren 7: 13-15.

Liestøl Aslak og Jan Ragnar Hagland. 1996. Njålssoga. Oslo: Samlaget.
Linge, Trond Eilev 2014. Rørsle gjennom fjordlandskapet om nyfunne bergmalingar på Honnhammar i Tingvoll. Viking LXXVII: 7-36.

Loftsgarden, Kjetil, Bernt Rundberget, Jan Henning Larsen og Peter Hambro Mikkelsen 2013. Bruk og misbruk av C14-datering ved utmarksarkeologisk forsking og forvalting. Primitive tider 15: 59-70.

Longva, Oddvar og Morten K. Thoresen 1991. Iceberg scours, iceberg gravity craters and current erosion marks from a gigantic Preboreal flood in southeastern Norway. Boreas 20: 47-62.

Longva, Oddvar 1994. Flood deposits and erosional features from the catastrophic drainage of Preboreal glacial lake Nedre Glamsjø, SE Norway. Dr.scientavhandling. University of Bergen, Department of Geology.

Lund, Harald Egenæs 1951. Fangst-boplassen i Vistebulen på Viste, Randaberg, Nord-Jaren. Undersøkelsene i 1939 og 1941. Stavanger: Stavanger museum. (Stavanger museums skrifter 6.)

Lundberg, Åsa 1997. Vinterbyar: ett bandsambälles territorier $i$ Norrlands inland, 4500-2500 f.Kr. Umeå: Universitetet i Umeå. 8.)

Lunden, Kåre 2002. Norges landbrukshistorie II. 1350-1814. Frå svartedauden til 17. mai. Oslo: Det Norske Samlaget.

Lundh Otto Gr. og I. E. Sars 1865. Norske Rigs-Registranter. Tildeels $i$ Uddrag. B. 3. 1588-1602. Christiania.

Lyman, R. Lee. 1994. Vertebrate taphonomy, Cambridge: Cambridge University Press.

Lødøen, Trond 2003. Kulturminneregistrering Tyin. Arsrapport Fase $1 A-2002$. Upublisert rapport i Kulturhistorisk museums arkiv: Universitetet i Oslo/ Universitetet i Bergen.

Lødøen, Trond Klungseth og Gro Mandt 2010. The rock art of Norway. Oxford: Windgather Press.

Magnus Lagabøters landslov [1915]. Oversatt av Absalon Taranger. Kristiania: Cammermeyers Boghandel.

Malde, Ivar 2009. Arkeologisk rapport. Planlagt omlegging av fo 467 samt bygging av nytt fos, ved Andvord Sore. Maskinell søkesjakting for registrering av automatisk fredete kulturminner. Lillehammer: Kulturvernavd., Oppland fylkeskommune.

Malmer, Mats P. 2002. The Neolithic of south Sweden. TRB, GRK, and STR. Stockholm: The Royal Swedish Academy of Letters, History and Antiquities.

Mansrud, Anja 2014. Mobil eller bofast? Erverv, landskap og mobilitet i mellommesolittiske kystsamfunn i ØstNorge (8300-6300 f. Kr.). Norsk Maritimt Museums årbok 2013: 67-108.

Marek, Václav 1992. «Samene i Susendalen». Leif Elsvatn (red.). Hattfjelldal: Hattfjelldal kommune. 
Martens, Irmelin 1962. Innberetning om arkeologiske undersøkelser 1962 ved Osensjøen, Amot og Trysil PGD, Hedmark. Upublisert rapport i Kulturhistorisk museums arkiv: Universitetets Oldsaksamling, Universitet i Oslo.

Martens, Irmelin 1964. Innberetning om befaring ved Tesse, Vagå og Lom pgd., Oppland. Juni 1964. Upublisert rapport i Kulturhistorisk museums arkiv: Universitetets Oldsaksamling.

Martens, Irmelin 1972. Møsstrond i Telemark - en jernproduserende fjellbygd før svartedauen. Viking XXXVI: 83-114.

Martens, Irmelin 1973a. Gamle fjellgårder fra strøkene rundt Hardangervidda. Universitetets Oldsaksamlings årbok 1971-1972: 1-84.

Martens, Irmelin 1973b. De yngste steinbrukende kulturer i Sør-Norges fillstrøk. Noen aktuelle problemer omkring kronologi og kulturforhold. (Tromsø Museums Skrifter, vol. XIV.)

Martens, Irmelin 1988. Jernvinna på Møsstrond i Telemark. Oslo: Universitetets Oldsaksamling. (Norske oldfunn XIII.)

Martens, Irmelin og Anders Hagen 1961. Arkeologiske undersøkelser langs elv og vann. Gyrinosvatn, Hallingdal og Tokke-Vinje-vassdraget, Telemark. Meddelelser om registreringer og utgravninger i forbindelse med vassdragsreguleringer 1959. Oslo: Oldsaksamlingen. (Norske oldfunn X.)

Matland, Susan 1990. Bone implements: a re-evaluation of stone age finds from caves and rockshelters of Western Norway. Hovedfagsoppgave: Universitetet i Bergen.

McLoughlin, Anna 2011. Befaringsrapport-reguleringsplan for Lom omsorgsbustader, Kulihaugen, Lom kommune. Gnr 70 bnr 233. Lillehammer: Kulturvernavd., Oppland fylkeskommune.

Melsom, Charlotte og Elling Utvik Wammer 2013. Arkeologisk registrering i forbindelse med fornyelse og revisjon av konsesjon (sektoravgift) $i$ Vinstravassdraget 2013. Oslo: Norsk Maritimt Museum. Upublisert rapport.

Melsom, Charlotte og Elling Utvik Wammer 2014: Maritim arkeologisk registrering i forbindelse med fornyelse og revisjon av konsesjon (sektoravgift) $i$ Vinstravassdraget. Arsrapport 2014. Oslo: Norsk Maritimt Museum. Upublisert rapport.

Melsom, Charlotte og Elling Utvik Wammer 2016a. «Båtrelaterte kulturminner i fjellet som kilder til fiske i fortiden». Axel Mjærum og Elling Utvik Wammer (red.). Fjellfiske i fortiden. Artusener med svømmende rikdom. Kristiansand: Portal forlag.
Melsom, Charlotte og Elling Utvik Wammer 2016b. Arkeologisk registrering i forbindelse med fornyelse og revisjon av konsesjon (sektoravgift) $i$ Vinstravassdraget 2015. Oslo: Norsk Maritimt Museum. Upublisert rapport.

Melvold, Stine Anette 2010. «Melle. En senmesolittisk boplass.» Kathrine Stene (red.). Steinalderundersøkelser ved Rena elv. Gräfellprosjektet. Bind III: 119-131. Oslo: Kulturhistorisk museum, Fornminneseksjonen. (Varia 76.)

Midthjell, Harald Bugge 2014. Reekthehtse arkeologles vaaksjomiestie/Rapport fra arkeologisk befaring. Snåsa: Saemiedigkie/Sametinget, Byjrese- jih kultuvrevaarjelimmiegoevtese/Miljø- og kulturvernavdelingen.

Mikkelsen, Egil 1977. Østnorske veideristninger. Kronologi og økokulturelt miljø. Viking XL: 147-201.

Mikkelsen, Egil 1980. Sporaneset - En bronsealders «utpost» i Telemark. Øystein Johansen, Egil Mikkelsen, Lyder Marstrander og Perry Rolfsen (red.). Festskrift til Sverre Marstrander på 70-års dagen: 35-40. Oslo: Universitetets Oldsaksamling. (Universitetets Oldsaksamlings skrifter, ny rekke 3)

Mikkelsen, Egil 1989a. En 6000 år gammel steinalderhytte i Heradsbygd. Vinterkvarter for elg- og beverfangst. Alfarbeim, Arbok for Elverum 4: 39-54.

Mikkelsen, Egil 1989b. Fra jeger til bonde. Utviklingen av jordbrukssamfunn i Telemark $i$ steinalder og bronsealder. Oslo: Universitetets Oldsaksamling. (Universitetets Oldsaksamlings skrifter, ny rekke 11.)

Mikkelsen, Egil 1994. Fangstprodukter i vikingtidens og middelalderens økonomi. Organiseringen av massefangst av villrein i Dovre. Oslo: Universitetets Oldsaksamling. (Universitetets Oldsaksamlings skrifter, ny rekke 18.)

Mikkelsen, Peter Hambro 2003. «Agerbruget». Peter Hambro Mikkelsen og Lars Christian Nørbach (red.). Drengsted Bebyggelse, jernproduktion og agerbrug i yngre romersk og aldre germansk jernalder: 115-225. Moesgård: Jysk Arkæologisk Selskab. (Jysk Arkæologisk Selskabs skrifter 43)

Miljødirektoratet 2016. «Vassdragsutbygging». (31.1.2016). Miljøstatus.no. Hentet fra: http://www.miljostatus.no/ tema/ferskvann/Vassdragsutbygging/.

Mjærum, Axel 2012. The bifacial arrowheads in Southeast Norway. A chronological study. Acta Archaeologica 83, 105-145. 
Mjærum, Axel 2015. Arkeologiske utgravninger av lokaliteter fra steinalder og fangstgrop fra middelalder ved Royrtjønna, Pålsbufforden. Feltsesongen 2012. Hol og Nore og Uvdal kommuner, Buskerud. Upublisert rapport i Kulturhistorisk museums arkiv: Kulturhistorisk museums, Universitet i Oslo.

Mjærum, Axel 2016a. «De første fiskerne i fjellet». Axel Mjærum og Elling Utvik Wammer (red.). Fjellfiske i fortiden. Artusener med svommende rikdom. Kristiansand: Portal forlag.

Mjærum, Axel 2016b. «Hunting elk at the foot of the mountains. Remains from 8000 years of foraging at the edge of the Hardangervidda plateau in Southern Norway». Per Persson, Felix Riede, Birgitte Skar, Heidi M. Breivik og Leif Jonsson (red.). The early settlement of Northern Europe. Climate, human ecology, and subsistence. Sheffield: Equinox Publishing.

Mjærum, Axel og Trond Vihovde 2015. «RT12-09. Opphold i mesolitikum, neolitikum og eldre jernalder (C58488)». Axel Mjærum (red.). Arkeologiske utgravninger av lokaliteter fra steinalder og fangstgrop fra middelalder ved Røyrtjønna, Pålsbufjorden. Feltsesongen 2012. Hol og Nore og Uvdal kommuner, Buskerud. Upublisert rapport i Kulturhistorisk museums arkiv: Kulturhistorisk museums, Universitet i Oslo.

Moe, Dagfinn 1979. «Tregrense-fluktasjoner på Hardangervidda etter siste istid». Reidar Nydal, Sverre Westin, Ulf Hafsten og Steinar Gulliksen (red.). Fortiden i søkelyset. 14C-dateringer gjennom 25 år: 199208. Trondheim: Laboratoriet for radiologisk datering.

Molaug, Svein 1985. Var gamle kystkultur. Oslo: Dreyers Forlag.

Motzfeldt, Ulrik Anton 1908. Den norske vasdragsrets bistorie indtil aaret 1800 med domsamling. Kristiania: Avhandlinger ved det Juridiske Fakultet.

Munch, Gerd Stamsø 1983. «Hvorfor finner vi så få fiskeredskaper fra nordnorsk jernalder?». Melhus, Harald og Helskog, Erica (red.). Nordisk fiske i oldtid og middelalder: 29-32. Tromsø: Tromsø Museum. (Ottar 145.)

Mælingen, Peter 1948. Lin- og hampdyrking i gamle dagar. Arbok for Gudbrandsdalen 16: 138-139.

Mørch von der Fehr, Anne-Marie 2007. «Avfallsdyngen - endring i deponering over tid». Birthe Weber (red.). Vesle Hjerkinn. Kongens gård og salebus: 43-47. Oslo: Universitetets kulturhistoriske museer. (Norske oldfunn XXI.)

Namdal herredsrett 1979. Rettsbok, Namdal herredsrett 21.06.1979. (Sak nr. 22/1976 B).

Nedkvitne, Arnved 1980. Bergerfisk. Heimen XVIII (2): 370.
Nensén, Jonas A. 1820-1825: Uppteckning efter Anna Thomasdotter. Renskrevet av Sigrid Drake. Sigrid Drakes arkiv ved Uppsala universitetsbibliotek.

Nergaard, Hjalmar 1911. Hardangerviddas aldste befolkning. Undersøkelser og fund. Bergen: Bergen museum. (Bergen museums årbok nr. 4.)

Nergaard, Ragnhild H. 2015. «RT12-04. Flere opphold i senmesolittisk og neolittisk tid». Axel Mjærum (red.). Arkeologiske utgravninger av lokaliteter fra steinalder og fangstgrop fra middelalder ved Royrtjønna, Pålsbufjorden. Feltsesongen 2012. Hol og Nore og Uvdal kommuner, Buskerud. Upublisert rapport i Kulturhistorisk museums arkiv: Kulturhistorisk museums, Universitet i Oslo.

Nesbø, Camilla L., Leif A. Vøllestad og Kjetil S. Jakobsen 1999. Genetic divergence and phylogeographic relationships among European perch (Perca fluviatilis) populations reflect glacial refugia andpostglacial colonization. Molecular Ecology 8: 1387-1404.

Nielsen, Yngvar 1889-1890. «Lappernes fremrykning mod syd i Trondhjems stift og Hedemarkens amt». Det Norske Geografiske Selskabs Aarbog I. Kristiania: Det Norske Geografiske Selskab

Nilsson, Björn, Arne Sjöström og Per Persson. under arbeid. "The earliest evidence of stationary fishing in Northern Europe? Some archaeological characteristics of the early Holocene river-, lake- and seascapes of southern Scandinavia (9.000-6.000 years BC)». Per Persson, Felix Riede, Birgitte Skar, Heidi M. Breivik og Leif Jonsson (red.). The early settlement of Northern Europe. Climate, buman ecology, and subsistence. Sheffield: Equinox Publishing.

Nissen, Kristian og Kvamen, Ingolf 1962. Major Peter Schnitlers grenseeksaminasjonsprotokoller 1742-1745. Oslo: Kjeldeskriftfondet.

Nordgaard, Ole 1908. Trek av fiskeriets utvikling i Norge. Trondhjem: Det Kgl. Norske Videnskabers Selskabs Skrifter. (Nr. 1.)

Norges Jeger- og fiskerforbund (24.5.2016). http://www.njff. no/fiske/Sider/Sportsfiske.aspx.

Norseng, Per G. 2015: «Middelalderbyen Oslo og fiskeressursene i Indre Oslofjord». Lise Marie Bye Johansen, Egil Lindhart Bauer, Jan Brendalsmo og Knut Paasche (red.). En Aktivist for middelalderbyen Oslo. Festskrift til Petter B. Molaug i anledning hans 70-ärsdag 19. desember 2014: 189-242. Oslo: Novus.

Norstedt, Gudrun 2011. Lappskattelanden på Geddas karta. Umeå: Thalassa förlag. 
NRJ = Norske Regnskaber og Jordeboger fra det 16 de Aarbundrede (1514-1570) [1885-1983]. H. J. HuitfeldtKaas og Arne Odd Johnsen (red.). Christiania/Oslo: Norsk historisk Kjeldeskrift-Institutt.

Nurminen, Katariina 2016. Taphonomy of burned fish bones - burning experiments in the open fire. Environmental Archaeology 21/2: 157-160.

Nybruget, Per Oscar 1980. «Trekk fra steinbrukende tid i Hedmark». Øystein Johansen, Lyder Marstrander, Egil Mikkelsen og Perry Rolfsen (red.). Festskrift til Sverre Marstrander på 70-årsdagen: 155-159. Oslo: Universitets Oldsaksamling. (Universitetets Oldsaksamlings skrifter, ny rekke 3.)

Nymoen, Pål og Nævestad, Dag 2006. Hva blir borte av det vi ikke ser? Ärlig tap og skade på kulturminner under vann. En statusrapport med kartlegging av omfang, og forsla til langsiktige overvåkingsprogram. Oslo: Norsk Sjøfartsmuseum (Skrifter 50.)

Nystu, Even 1989. Undsetgrendas innlandsfiskevar. En del at storre utmarksbruk. Historie og kulturminner. Trondheim: NTH, Arkitektavdelingen.

Næss, Jenny-Rita 1996: Undersøkelser i jernalderens gravskikk på Voss. AmS-Rapport 7. Arkeologisk museum i Stavanger.

Odner, Knut 1969. Ullshelleren i Valldalen, Røldal. En studie i økologiske tilpasninger på grunnlag av et forhistorisk, arkeologisk materiale. Arbok for Universitetet i Bergen. Humanistisk serie 1969.

Olsen, Bjørnar 1994. Bosetning og samfunn i Finnmarks forhistorie. Oslo: Universitetsforlaget.

Olsen Jesper, Jan Heinemeier, Pia Bennike, Cille Krause, Karen Margrethe Hornstrup og Henrik Thrane 2008. Characterisation and blind testing of radiocarbon dating of cremated bone. Journal of Archaeological Science 35, 791-800.

Olsen, Jesper, Jan Heinemeier, Karen Margrethe Hornstrup, Pia Bennike og Henrik Thrane 2013. 'Old wood' effect in radiocarbon dating of prehistoric cremated bones? Journal of Archaeological Science 40/1, 30-34.

Olsen, Magnus 1941. Norges innskrifter med de yngre runer. Forste bind. I. Østfold fylke. II. Akershus fylke og Oslo. III. Hedmark fylke. IV Oppland. Oslo: Jacob Dybwad.

Olsen, Ole Mikal 2004. Medieval fishing tackle from Bergen and Borgund. Bergen: Fagbokforlaget. (The Bryggen Papers. Main series 5.)

Opsahl, Erik og Harald Winge 1990. Finnemanntallet 1686. Oslo: Norsk Historisk Kjeldeskrift-institutt.

Opedal, Halldor O. 1943. Makter og menneske. Folkeminne ifrå Hardanger. Oslo: Norsk Folkeminnelag (Nr. 51).
Ormstad, Olav 1968. «Støkrok». Jensen, Kjell W. (red.). Sportsfiskerens Leksikon: 1394. Oslo: Gyldendal Norsk Forlag.

Oslo og Hamar bispedomes jordebok 1574-1577 [1929]. Redigert av Sigurd Kolsrud. Oslo: Kjeldeskriftfondet. (Norske kyrkjelege jordebøker etter reformasjonen 1.)

Pareli, Leif 2007. «Om reinslakting på 1920-tallet». Reindriftsnytt 2007 (2): 57-59.

Pareli, Leif og Anne Severinsen 1997. Noen metodeproblemer i sørsamisk historieforskning. Ottar 116-117: 29-37.

Persson, Per 2013. «Changes during the Late Mesolithic in the Central Scandinavian inland». Sophie Bergerbrant og Serena Sabatini (red.). Counterpoint. Essays in archaeology and heritage in honour of Professor Kristian Kristiansen: 29-34. Oxford: Archaeopress.

Petersen, Jan 1922. Lysterfiske i forhistorisk tid. Naturen 46: 183-187.

Petersen, Jan 1951. Vikingtidens redskaper. Oslo: Dybvad (Vid.-Akad. Skr. II H.-F. Kl. 1951:4.).

Peterson-Berger, Wilhelm 1904. En tur til Oldfällen. Orwar Eriksson og Gusten Rolandsson (red.). Fjällminnen. Östersund: Jengel Förlaget för Jemtlandica.

Philippsen, Bente 2013. The freshwater reservoir effect in radiocarbon dating. Heritage Science 1/1, 1-19.

Pram, Christen 2004 [1743]. «Gudbrandsdalen fogderi». Kristin M. Røgeberg (red.). I Norge i 1743. Innberetninger som svar på 43 sporsmål fra Danske Kanselli. 2 Akershus Stift. Hedmark. Oppland: 293-318. Solum Forlag. Oslo.

Pray L. 2008. Discovery of DNA Structure and Function: Watson and Crick. Nature Education 1/1, 100.

Prescott, Christopher 1991. Kulturbistoriske undersøkelser $i$ Skrivarhelleren. Bergen: Historisk museum, Universitetet i Bergen. (Arkeologiske rapporter 14.)

Prescott, Christopher 1995. From Stone Age to Iron Age. A study from Sogn, western Norway. Oxford: Tempus reparatum: Distributed by Hadrian Books. (BAR international series 603.)

Prescott, Christopher 2009. «History in prehistory - the Late Neolithic/Early Bronze Age, Norway». Håkon Glørstad og Christopher Prescott (red.). Neolithisation as if history mattered. Processes of Neolithisation in NorthWestern Europe: 193-215. Lindome: Bricoleur Press.

Puschmann, Oscar 2005. Nasjonalt referansesystem for landskap. Beskrivelse av Norges 45 landskapsregioner NIJOSrapport. (NIJOSrapport, 10/05.) 
Putman, Alexander I. og Ignazio Carbone 2014. Challenges in analysis and interpretation of microsatellite data for population genetic studies. Ecology and Evolution 4/22, 4399-4428.

Qvenild, Tore 1994. Ørret og ørretfiske. Oslo: Aschehoug.

Qvigstad, J. og K. B.Wiklund 1909. Dokumenter angaaende fytlapperne. Kristiania: Grøndahl \& Søns bogtrykkeri.

Qvigstad, J og K. B. Wiklund 1929. Major Peter Schnitlers grenseeksaminasjonsprotokoller. Bind II. Oslo: Kjeldeskriftfondet. Grøndahl \& Søns boktrykkeri.

Refseth, U. H., C. L. Nesbø, J. E. Stacy, L. A. Vølstad mfl. 1998. Genetic evidence for different migration routes of freshwater fish into Norway revealed by analysis of current perch (Perca fluviatilis) populations in Scandinavia. Molecular Ecology 7: 1015-1027.

Reimer, Paula J, Edouard Bard, Alex Bayliss, J Warren Beck mfl. 2013. IntCal13 and Marine13 Radiocarbon Age Calibration Curves 0-50,000 Years cal BP. RADIOCARBON 55/4: 1869-1887.

Reinton, Lars 1957. Saterbruket i Noreg. II. Anna arbeid på satra. Satra i haustingsbruket og i matnoytsla elles. Oslo: H. Aschehoug \& Co.

Reinton, Lars 1958. Bergefisk (særlege problem). Heimen XI (2) 98-102.

Rettstidende 1955. Hoyesterett 23.04.1955: 361-371.

Rettstidene 1968. Høyesterett 06.04.1968: 394-410.

Richards, Michael P. og Erik Trinkaus 2009. Isotopic evidence for the diets of European Neanderthals and early modern humans. Proceedings of the National Academy of Sciences 106/38, 16034-16039.

Risbøl, Ole 1999. Fornyelse av reguleringskonsesjon for Møsvatn, Vinje og Tinn kommuner i Telemark. Konsekvenser for automatisk fredete kulturminner. Oslo: Norsk institutt for kulturminneforskning.

Robsahm, Carl Magnus og Anton Swab 1938. Resa genom Härjedalen till Norge och Röros Kopparverk 1796. Stockholm: Herman Richter. (Jernkontorets Bergshistoriska Skriftserie 6.)

Rodum, Christian 2013. Tetningsmaterialer i skandinavisk båt-og skipsbygging: En analyse av tetningsmaterialer $i$ skandinaviske klinkbygde båt-og skipsfunn fra jernalder til 1700. Upublisert masteroppgave. Universitetet i Oslo.

Rogan, Bjarne 1984. Om sundmenn og fergevesen. Et bidrag til norsk samferdsels- og reiselivshistorie. NORVEG. Folkeliusgransking 27: 97-157. Universitetsfolaget.

Rognerud, Sigurd og Tore Qvenild 2013. Ørreten på Hardangervidda. Klimaets betydning for årsklassestyrke og produksjon av fisk og naringsdyr: 6553-2013. Oslo: Norsk institutt for vannforskning.
Rolfsen, Perry 1974. Båtnaust på Jarkysten. Stavanger: Stabenfeldt Forlag. (Stavanger museums skrifter 8)

Rolfsen, Perry 1977. En fjellgård fra jernalderen i Bykle. Viking XL: 79-128.

Rolfsen, Perry 1992. «Iron production in the upper part of the valley of Setesdal, Norway». Arne Espelund (red.). Bloomery ironmaking during 2000 years. Seminar in Budalen 1991. Volume II: 79-88. Trondheim: Budalseminaret.

Rud, Ole Bleken 1967. Fiskekulturens utvikling. Arrbok for Norsk Skogbruksmuseum 5: 73-131.

Rugsveen, Magne 1985. Lågåsildfisket i Fåberg. Endring i form og bruk 1850-1980. Elverum: Norsk Skogbruksmuseum. (Særpublikasjon nr. 7.)

Rugsveen, Magne 1986. Dokumentasjonsarbeide av fiske $i$ Tesse. Brev fra Norsk Skogbuksmuseum til Universitetets Oldsaksamling datert 6. august 1986. Kulturhistorisk museums arkiv.

Rugsveen, Magne 1996. Lillehammer og Fåbergs historie. Der veger motes. Bind 1. Del 1: Steinalder til 1600-tallet. Lillehammer. Thorsrud lokalhistorisk forlag.

Rundberget, Bernt 2015. «Iron producers in Hedmark in the medieval period - who were they?». Gitte Hansen, Steven Ashby og Irene Baug (red.). Everyday products in the Middle Ages. Crafts, consumption and the individual in Northern Europe c. AD 800-1600: 270-286. Oxford: Oxbow Books.

Russ, Helene og Axel Mjærum 2014. Rapport. Arkeologisk utgravning. Gravroys og boplassfunn. Nånes, 50/1, Langrak, 54/1 og Froyrak, 55/1, 2, Bygland, Aust-Agder. Oslo: Upublisert rapport i Kulturhistorisk museums arkiv: Kulturhistorisk museums, Universitet i Oslo.

Rynning, Lorents 1934. Bidrag til norsk allmenningsrett. Bd. 1. Oslo: I kommisjon hos Jacob Dybwad.

Rynning, Lorents 1968. Bidrag til norsk allmenningsrett. Bd. 2. Oslo: Universitetsforlaget.

Røgeberg, Kristin M. 2004. Norge i 1743. Innberetninger som svar på 43 sporsmål fra Danske Kanselli. 2 Akershus stift. Hedmark. Oppland. Solum Forlag. Oslo.

Salvesen, Helge 1978. «Landskyldutviklingen». Jørn Sandnes og Helge Salvesen (red.). Ødegårdstid i Norge. Det nordiske ødegårdsprosjektets norske undersøkelser: 109-142. Oslo: Universitetsforlaget.

Sammallahti, Pekka 1998. The Saami Languages. An Introduction. Karasjok: Davvi Girji OS.

Sandnes, Jørn 1978. «Innledning». Jørn Sandnes og Helge Salvesen (red.). Ødegårdstid i Norge. Det nordiske ødegårdsprosjektets norske undersøkelser: 11-46. Oslo: Universitetsforlaget. 
Sandnes, Jørn 1996. Samer, rein og bønder. Trekk av sørsamisk bistorie til ca. 1900. Utredning for Samerettsutvalget I etter oppdrag fra Justisdepartementet. (Stensil)

Schietzel, Kurt (red.) 2014. Spurensuche Haithabu: archäologische Spurensuche in der frühmittelalterlichen Ansiedlung Haithabu : Dokumentation und Chronik 1963-2013. Neumünster: Wachholtz Verlag.

Schøning, Gerhard 1926. Reise gjennom Gudbrandsdalen 1775. Hamar: Utgitt av G. F. Gunnersen i kommisjon hos Thorbjørn Taalesen.

Schøning, Gerhard 1980 [1778]. Reise, som gjennem en Deel af Norge i de Aar 1773, 1774 og 1775 paa H. M. Kongens Bekostning er gjort og beskreven. Tredje Bind. Gudbrandsdalen og Hedemarken. Trondheim: Tapir forlag.

Sejersted, Francis 1978. Den vanskelige fribet 1814-1851. Oslo: J. W. Cappelens forlag. (Norges historie, bind 10.)

Selsing, Lotte 2010. Mennesker og natur i fellet i Sor-Norge etter siste istid med hovedvekt på mesolitikum. Stavanger: Arkeologisk museum. (AmS-varia 51.)

Selsing, Lotte, Endre Elvestad, Harald Hamre, Jens Flemming Krøger mfl. (red.) 2005. Fra Galta til Geitungen. Kystkultur og fferesteinsarkeologi i SørvestNorge. Arkeologisk museum i Stavanger.

Severinsen, Anne 2010. Den sørsamiske fisker. Aarjelsaemieh, Samer i sør. Snåsa: Stiftelsen Saemien Sijte.

Severinsen, Anne 2016. «Sørsamenes fjellfiske. Ørret, sik og røye - et svømmende matforråd». Axel Mjærum og Elling Utvik Wammer (red.). Fjellfiske i fortiden. Artusener med svommende rikdom. Kristiansand: Portal forlag.

Shetelig, Haakon og Fredrik Johannessen 1929. Kvalsundfundet og andre norske myrfund av fartøier. Bergen: Bergen museum (Bergen museums skrifter. $\mathrm{Ny}$ rekke II: 2.)

Shubina, E. A., E. V. Ponomareva, A. V. Klimov, A. V. Klimova og O. S. Kedrova 2015. Repetitive DNA sequences as an indicator of the level of genetic isolation in fish. Molecular Biology 49/3: 358-368.

Simonsen, Povl 1961. Varanger-funnene II. Fund og udgravninger på fordens sydkyst. Tromsø: Tromsø Museum. (Tromsø museums skrifter VII.)

Sirelius, Uunno Taavi 1919. Suomen kansanomaista kulttuuria : esineellisen kansatieteen tuloksia. Helsinki: Otava.

Skalleberg, Hege Gjerde 2011. Rapport. Arkeologisk utgraving. Vestre Slidre Statsallmenning, 94/1 Vestre Slidre, Oppland. Upublisert rapport i Kulturhistorisk museums arkiv: Kulturhistorisk museums, Universitet i Oslo.
Skaraberget, Kjell 1992. «.. ligesom Fiskeret i Skovens Vanddrage...' Om fiske på Grue Finnskog». Livet på Finnskogen: 63-75. Grue Finnskog: Heimbygdsforeningen Finnetunet.

Skjølsvold, Arne 1958. Det tradisjonsrike fiskeværet ved Sølensjøen. Årbok for Norsk Skogbruksmuseum 1: 51-74.

Skjølsvold, Arne 1969: En fangstmanns grav i Trysil-fjellene. Viking XXXIII: 139-199.

Skjølsvold, Arne 1979. Refleksjoner omkring jernaldersgravene i sydnorske fjellstrøk. Viking XLIII: 140-160.

Skulberg, Olav 1967. Beskrivelser og undersøkelser av vannforekomster Del 2. Gudbrandsdalslågen, Norsk institutt for vannforskning. (Vannforsyning og avløpsforhold i østlandsfylkene. Utredning for østlandskomitéen, Rapport 1.)

Skaala, Øystein, Trond Taugbøl og Jostein Skurdal 1991. Genetisk variasjon hos mjosaure. Fylkesmannen i Oppland. Lillehammer: Miljøvernavdelingen. (Rapport 1991/18.)

Skaala, Øystein 1992. Genetic population structure of Norwegian brown trout. Journal of Fish Biology 41: 631-646.

Snorres kongesagaer [1968]. Omsett av Anne Holtsmark og Didrik Arup Seip. Oslo: Gyldendal.

Snorres kongesagaer [1979]. Omsett av Anne Holtsmark og Didrik Arup Seip. Finn Hødnebø og Hallvard Magerøy (red.). Oslo: Gyldendal. Opptrykk 2003. (Bind 2.).

Solberg, Bergljot 2000. Jernalderen i Norge. Oslo: J. W. Cappelens Forlag.

Solem, Erik 1933. Lappiske rettsstudier. Oslo: H. Aschehoug $\&$ Co.

Solibråten, Tore 2011. Tessereguleringen. Kartlegging av erosjonsforhold og forslag til tiltak. Lillehammer: Glommens og Laagens Brukseierforening.

Solheim, Steinar 2012. Lokal praksis og fremmed opphav. Arbeidsdeling, sosiale relasjoner og differensiering $i$ østnorsk tidligneolitikum. Avhandling (ph.d.) Universitetet i Oslo, 2012: Faculty of Humanities, Universitetet i Oslo.

Solheim, Svale 1940. Nemningsfordomar ved fiske. Oslo: Jacob Dybwad/Det norske videnskaps-akademi i Oslo.

Solhjell, Kåre Olav 1992. Bygdehistorie for Nore og Uvdal. Bind I. Frå steinalderen til år 1800. Nore, Nore og Uvdal kommune.

Solvold, Grete Irene 2007. Rapport. Kulturbistorisk registrering. Erosjonssikring av Byglandsfforden og Araksforden. Bygland kommune, Aust-Agder. Kristiansand: Aust-Agder fylkeskommune.

Sommerfeldt, Christian 1928 [1790]. Efterretninger angaaende Christians Amt. Hamar: Særtrykk av Bygd og Bonde X. 
Sonstebo, Jørn Henrik., Reidar Borgstrom og Manfred Heun 2007. Genetic structure of brown trout (Salmo trutta L.) from the Hardangervidda mountain plateau (Norway) analyzed by microsatellite DNA: a basis for conservation guidelines. Conservation Genetics 8/1: 33-44.

Sonstebo J. H., R. Borgstrom og M. Heun 2008a. High genetic introgression in alpine brown trout (Salmo trutta L.) populations from Hardangervidda, Norway. Ecology of Freshwater Fish 17/1: 174-183.

Sonstebo J. H., R. Borgstrom og M. Heun 2008b. Genetic structure in alpine brown trout Salmo trutta L. shows that indirect stocking affects native lake populations. Journal of Fish Biology 72/8: 1990-2001.

Steen, Sverre 1929. Ferd og fest: reiseliv i norsk sagatid og middelalder. Oslo: Frydenlunds bryggeri.

Steinnes, Asgaut 1936. «Mål, vekt og verderekning i Noreg i millomalderen og ei tid etter». Johs Brøndum-Nielsen, Otto v. Friesen og Magnus Olsen (red.). Nordisk kultur. Mål og vekt: 84-154. Stockholm-Oslo-København: Bonnier-H. Aschehoug \& Co -J. H. Schultz (Nordisk kultur XXX.)

Steinnes, Asgaut 1937. Norske lensrekneskapsbøker 1548-1567 I. Rekneskap for Akershus len 1557-1558. Oslo: Jacob Dybwad.

Steinnes, Asgaut 1940. Norske lensrekneskapsbøker 1548-1567 II. Rekneskap for Akershus len 1560-1561. Oslo: Jacob Dybwad.

Stene, Kathrine 2010. Steinalderundersøkelser ved Rena elv. Gråfellprosjektet. Bind III. Oslo: Kulturhistorisk museum, Fornminneseksjonen. (Varia 76.)

Stene, Kathrine, Per Persson, Hege Damlien og Stine Melvold 2010. «Lokaliteter fra steinbrukende tid ved Rena elv». Kathrine Stene (red.). Steinalderundersøkelser ved Rena elv. Gråfellprosjektet. Bind III: 459-520. Oslo: Kulturhistorisk museum, Fornminneseksjonen. (Varia 76.)

Storm, Edvard 2009. "Ord i den Guldbrandsdalske Dialect». Ei 1700-tals ordsamling frå Vågå. Einar Kleiven, Randi Kleiven Bjørkvik og Andreas Bjørkum (red.). Lillehammer: Dølaringen Boklag.

Storm-Munch, Jens 1983. Fiskerkulturen i NordNorge: fiskerbondens gård. Foreningen til norske fortidsminnesmerkers bevaring. Ärbok 1983: 13-36.

Sundström, Jan 1989. «Järnålderens gravar i fångstlandet». Hemmendorff, Ove (red.). Arkeologi i skog, fäll och bygd. 1. Stenålder - tidig järnålder: 155-171. Jämtlands läns museum: Fornvårdaren
Sundström, Lars 2014. Arkeologiske utgravninger av boplasser fra steinalder ved Royrtjonna, Pålsbuforden og arkeologiske registeringer ved Tunhovdforden. Feltsesongen 2011. Hol og Nore og Uvdal kommuner, Buskerud. Oslo: Upublisert rapport i Kulturhistorisk museums arkiv: Kulturhistorisk museums, Universitet i Oslo.

Sveinhaug, Kristian 2014. Den eldste furua i landet, skoggrenser og klima. Ärbok for Gudbrandsdalen 82: 160-165.

Svendsen, Trond Olav 2015. «Lesja» (09.03.2015). Store norske leksikon. Hentet fra https://snl.no/Lesja.

Szpak, Paul 2011. Fish bone chemistry and ultrastructure. Implications for taphonomy and stable isotope analysis. Journal Of Archaeological Science 38/12: 3358-3372.

Sæterbø, Einar, Liza Syvertsen og Einar Tesaker 1998. Vassdragshåndboka. Håndbok i forbygningsteknikk og vassdragsmiljø. Trondheim: Tapir.

Søilen, Per 2009. «Ferskvannsfiske» (24.5.2016). Store norske leksikon. Hentet fra: https://snl.no/ferskvannsfiske.

Sømme, Jacob 1933. Ørretfiskets utvikling på Hardangervidda og de viktigste driftsmåter. Norsk Jeger og Fiskerforenings Tidsskrift 62: 169-187.

Sønstebø, Jørn Henrik, Reidar Borgstrøm og Manfred Heum 2007. Genetic structure of brown trout (Salmo trutta) from Hardangervidda mountain plateau (Norway) analyzed by microsatellite DNA: a basis for conservation guidelines. Conservation Genetics 8: 33-44.

Sørheim, Helge 2004. «Borgund and the Borgundfjord fisheries» Ingvild Øye, 2004 (red.). Medieval fishing tackle from Bergen and Borgund: 107-133. Bergen: Fagbokforlaget. (The Bryggen Papers. Main Series No. 5.)

Taksdal, Turid Fundlid 1973. Rundt Møsvatn. Busetnad og neringsliv $i$ ei fellbygd. Magistergrad i folkelivsgranskning: Universitetet i Oslo.

Tande, Ole Amund og Ola Hegge 1993. Fritidsfiske i Oppland. Oversikt over fiskemuligheter i Oppland fylke. Lillehammer: Fylkesmannen i Oppland, Miljøvernavdelingen.

Teigum, Ivar 2001. Bygdebok for Vågå og Sel. Band 1: Frå dei eldste tider til 1600. Otta: Sel kommune og Vågå kommune.

Teigum, Ivar 2004. Bygdebok for Vågå og Sel. Band 2: Frå 1600-talet til 1907. Otta: Sel kommune og Vågå kommune.

Templeton, Alan R. 2007. Genetics and recent human evolution. Evolution 61/7: 1507-1519. 
Thaulow, Jens, Reidar Borgstrom og Manfred Heun 2013. Brown trout population structure highly affected by multiple stocking and river diversion in a high mountain national park. Conservation Genetics 14/1: 145-158.

Thaulow, Jens, Reidar Borgstrom og Manfred Heun 2014. Genetic persistence of an initially introduced brown trout (Salmo trutta L.) population despite restocking of foreign conspecifics. Ecology of Freshwater Fish 23/4: 485-497.

Thomle, Erik Andreas 1927. Tolstadslægten fra Vaage. Bygd og Bonde 9: 105-131.

Tidemansen, Kjersti 2006. Maktstruktur og utmarksbruk : ei arkeologisk analyse av forholdet mellom sosial organisasjon og fangst av villrein i Lom i Oppland. Masteroppgave. Trondheim: NTNU.

Tomasson, Torkel 1917. Vittnesberättelser och Anteckningar från Ásele lappmark och Vapstens lappby i Tärna socken rörande lapparnas fyttningar till Norge på somrarna samt Utdrag ur kyrkoböcker inom Åsele- och Lycksele lappmarker öfver vissa lappsläkter samlade sommaren och hösten 1916. Uppsala: Håndskrevet manus.

Torp, Alf 1919. Nynorsk Etymologisk Ordbok. Kristiania: H. Aschehoug \& Co.

Trigger, Bruce G. 1996. Arkeologiens idéhistorie. Oslo: Pax.

Trykt matrikkel 1838. Christians amt. Skannet arkivmateriale. Riksarkivet. Permanent sidelenke: http://www. arkivverket.no/URN:db_read/db/35477/.

Tundrali, Svein 1965. Ola Lier i Åstradalen og gamle fjellfolk. Arbok for Gudbrandsdalen 33: 132-136.

Ugulen, Jo Rune 2006. "... alle the knaber ther inde och sadescwenne...»: Ei undersøking $i$ den sosiale samansetjinga av den jordeigande eliten på Vestlandet $i$ mellomalderen. Doktorgradsavhandling: Universitetet i Bergen.

Ugulen, Jo Rune 2015. «1000-1550». John Ragnar Myking, Jo Rune Ugulen og Bård Gram Økland (red.). Hardanger: Ei regionhistorie, bd. 1: 99-195. Bergen: Fagbokforlaget.

Ugulen, Jo Rune 2016. «Tesse-dokumentet og fjellfisket i mellomalderen». Axel Mjærum og Elling Utvik Wammer (red.). Fjellfiske i fortiden. Artusener med svommende rikdom. Kristiansand: Portal forlag.

Valen-Senstad, Fartein 1956. Gudbrandsdalen i middelalderen. Garden og samfunnet. Hamar: Kulturhistorisk samskipnad for Gudbrandsdalen i samarbeid med De Sandvigske Samlinger.

Valonen, Niilo 1952. Geflechte und andere arbeiten aus Birkenrindenstreifen unter Berücksichtigung finnischer Tradition. Vammala: Kansatieteellinen arkisto 9.
Veierød, Vegard 2012. Heimfellet. Surtningen-FlatningenMelingen-Bjølstadvatnet. Kulturminner, setrer og hytter $i$ et unikt kulturlandskap i Vågå og Sel. Vågå: Heimfjellet bokforlag.

Venter, J. Craig., Mark D. Adams, Eugene W. Myers mfl. 2001. The sequence of the human genome. Science 291/5507: 1304-1351.

Vigerust, Tore H. 1996. «Jordebøker for Akershus len 1577-1607». Gudbrand 2.

Vigerust, Tore 2008. Manntall over odelsbonder $i$ Gudbrandsdalens fogderi, jordebok over deres odels- og pantegods samt jordebok over det de svarer til Kronen, 17. februar 1615. (15.11.2015). http://xml.arkivverket.no/ matrikler/jb08001615odel.htm.

Vigilant L., M. Stoneking, H. Harpending, K. Hawkes og A. C. Wilson 1991. African populations and the evolution of human mitochondrial DNA. Science 253/5027: 1503-1507.

Vignal, Alain, Denis Milan, Magali SanCristobal og André Eggen 2002. A review on SNP and other types of molecular markers and their use in animal genetics. Genetics Selection Evolution 34/3: 275-305.

Vihovde, Trond 2015. «RT12-15. Skiferspissproduksjon fra mellomneolitikum og et ildsted fra bronsealder». Axel Mjærum (red.). Arkeologiske utgravninger av lokaliteter fra steinalder og fangstgrop fra middelalder ved Royrtjonna, Pålsbufjorden. Feltsesongen 2012. Hol og Nore og Uvdal kommuner, Buskerud. Upublisert rapport i Kulturhistorisk museums arkiv: Kulturhistorisk museums, Universitet i Oslo.

Villmo, Loyd 1978. Åbjorareguleringene - Kolsvik kraftverk. Opplysninger om fisket $i$ de berorte vassdrag juni 1978. Vedlegg 1.1 til sak 22/1976 B-Äbjøraskjønnet. Namdal og Brønnøy herredsretter.

Vågslid, Eivind 1974. Stadnamntydingar II. Oslo: Egen utgivelse.

Wammer, Elling Utvik 2006. Fangstfolk fra bygda? Utproving av en GIS-basert arkeologisk analyse med utgangspunkt $i$ Sonja og Edvard K. Barths registreringer av fangstanlegg $i$ Rondane. Masteroppgave: NTNU.

Wammer, Elling Utvik 2013. Arkeologisk registrering i forbindelse med fornyelse og revisjon av konsesjon (sektoravgift) i Tesse 2013. Oslo: Norsk Maritimt Museum. Upublisert rapport.

Wammer, Elling Utvik 2015. Maritimarkeologisk undersøkelse i forbindelse med fornyelse og revisjon av konsesjon (sektoravgift) i Tesse 2014. Norsk Maritimt Museum. (NMM, rapport 2015:1.) 
Wammer, Elling Utvik 2016. «Fjellfiske i grenselandet mellom fangstmark og jordbruksbygd i yngre jernalder og middelalder». Axel Mjærum og Elling Utvik Wammer (red.). Fjellfiske i fortiden. Årtusener med svommende rikdom. Kristiansand: Portal forlag.

Watson, J. D. og F. H. Crick 1953. The structure of DNA. Cold Spring Harbor symposia on quantitative biology 18 : 123-131.

Weber, Birthe 2007a. Vesle Hjerkinn. Kongens gård og salebus. Oslo: Universitetets kulturhistoriske museer. (Norske oldfunn XXI.)

Weber, Birthe 2007b. «Innledning». Birthe Weber (red.). Vesle Hjerkinn. Kongens gård og salehus: 7-10. Oslo: Universitetets kulturhistoriske museer. (Norske oldfunn XXI.)

Weber, Birthe 2007c. «Gjenstander av kleber». Birthe Weber (red.). Vesle Hjerkinn - Kongens gård og salebus: 120-129. Oslo: Universitetets kulturhistoriske museer. (Norske oldfunn XXI.)

Weibust, Knut 1959. Båter i Buskerud. Drammen og Oplands Turistforenings årbok: 40-59.

Westerdahl, Christer 1986. Samer nolaskogs. En historisk introduktion till samerna $i$ Angermanland och Åsele lappmark. Bjästad: Örnsköldsviks kommun/ Cewe-förlaget.

Westerdahl, Christer 1987. «Et sätt som liknar them uti theras öfriga lefnadsart». Om äldre samiskt båtbygge och samisk båthåndtering. Umeå. (Skrifter utgivna av Johan Nordlander-sällskapet 11).

Westerdahl, Christer 1992. The maritime cultural landscape. The International Journal of Nautical Archaeology 21: 5-14.

Westerdahl, Christer 2000. «From land to sea, from sea to land. On transport zones, borders and human space». Jerzy Litwin (red.). Down the River to the Sea. Proceedings of the 8th International Symposium on Boat and Ship Archaeology: 11-20. Gdansk: Normex. (ISBSA 8.)

Westerdahl, Christer 2006. «On the significance of portages. A survey of a new research theme». Westerdahl, Christer (red.). The significance of portages. Proceedings of the first international conference on the significance of portages, $29 \mathrm{th}$ Sept-2nd Oct. 2004, in Lyngdal, VestAgder, Norway: 15-51. Oxford: BAR International Series, 1499.

Wiklund, K. B. 1910. Lapparna i Sverige. Stockholm: Albert Bonniers Tryckeri. (Studentföreningen Verandis småskrifter.)

Winge, Harald 2004. «Bismervekt. Daler. Mark kølnsk». Norsk historisk leksikon (2. utgave, 3. opplag).
Winka, Ulf Stefan 2014. «Två lappskattelandskartor från Mala». Erik Norberg og Ulf Stefan Winka. Sydsamer landskap och historia. Östersund: Gaaltije - sydsamiskt kulturcentrum.

Wollebæk, Jens, Knut H. Røed og Jan Heggenes 2011. Genetisk struktur hos ørret i Mjøsa. Porsgrunn: Høgskolen i Telemark. (Skrift 2/2011.)

Woodburn, James 1982. Egalitarian Societies. Man 17/3: 431-451.

Zachrisson, Inger 1997 (red.). Möten i gränsland. Samer och germaner i Mellanskandinavien. Stockholm: Statens historiska museum. (Statens Historiska Museum, Monographs 4)

Økland, Jan og Karen Anna Økland 1999. Vann og vassdrag 4. Dyr og planter: Innvandring og geografisk fordeling. Stabekk: Vett \& Vitenas.

Østebø, Kjetil 2008: Hellerbruk $i$ vestnorsk eldre jernalder belyst ved lokalisering. Masteroppgave: Institutt for arkeologi, historie, kultur og religionsvitenskap. Universitetet i Bergen.

Østmo, Einar 1975. Innberetning om arkeoligisk registrering i Heimdalen, Vågå k., og Østre Slidre k., Oppland f. i tidsrommet 1078-13/8 1975. Upublisert notat i Kulturhistorisk museums arkiv. Universitetets oldsaksamling. Oslo: De arkeologiske museers registreringstjeneste.

Øvrelid, Ragnar 1987. Historia om Fron. Bd. 1. Fram til 1940. Vinstra: Fron historielag.

Ågotnes, Jakob 1967a. «Innberetning om registrering ved Gjende og nedre Leirungen, Vågå og Lom pgd., Oppland, juli 1967». Irmelin Martens (red.). Arkeologiske undersøkelser i Jotunheimen 1967: 33-42. Upublisert rapport i Kulturhistorisk museums arkiv: De arkeologiske museers registreringstjeneste.

Ågotnes, Jakob 1967b. «Innberetning om registrering av øvre og nedre Sjodalsvatn, Vågå pgd., Oppland, juli 1967». Irmelin Martens (red.). Arkeologiske undersøkelser i Jotunheimen 1967: 43-50. Upublisert rapport i Kulturhistorisk museums arkiv: De arkeologiske museers registreringstjeneste.

Aagaard, Birger 1923. Fiskeri-inspektorens innberetning om ferskvannsfiskeriene for året 1922. Kristiania: Landbruksdepartementet.

Aass, Per, Per Sondrup Nielsen og Åge Brabrand 1989. Effects of river regulation on the structure of a fastgrowing brown trout (Salmo trutta L.) population. Regulated Rivers: Research E Mangement 3: 255-266.

Åstveit, Leif Inge 2014. Noen synspunkt på den tidligmesolittiske bosetningen i Sør-Norge. Primitive tider 16: 87-104. 



\section{FORFATTERPRESENTASJONER}

Birgitte Bjørkli, fra Bodø, Nordland fylke. Utdannet arkeolog fra Universitetet i Bergen, med hovedfagsoppgaven «Den arktiske steinalderen i sør» i 2004. Birgitte har jobbet som arkeolog siden 1999, både som feltarkeolog, med formidling og med magasinforvaltning. De siste årene har hun jobbet som feltarkeolog ved Kulturhistorisk museum og da spesielt med kulturminner fra steinalderen.

Ellen Kathrine Friis, født 1981, fra Harestua, Oppland. Hun er arkeolog og fullførte mastergraden ved Universitetet i Oslo i 2007 og Friis har siden det arbeidet som feltarkeolog hos Oppland fylkeskommune og ved Kulturhistorisk museum. Friis har steinalder som spesialfelt og har de siste årene arbeidet i fjellområdene nordvest i Oppland.

Jan Heggenes, født 1956 på Rjukan, Telemark. Han er (ferskvanns)økolog, fra Norges Miljø og Biovitenskapelige Universitet og Universitetet i Oslo, og dr. philos. fra UiO (1990). Heggenes har vekselvis arbeidet i forvaltning (offentlig og privat sektor), undervisning og forskning, mye med feltorientert arbeid. Etter flere år som professor ved NMBU, flyttet han til Høgskolen i Telemark (nå Høgskolen i Sørøst Norge) og har samtidig arbeidet som professor II ved UiO. Han har jobbet med høyfjellsøkosystemer bl.a. som daglig leder ved Norsk Villreinsenter, Skinnarbu. Hovedarbeidsområdet er laksefisk, habitat, genetikk og reguleringsvirkninger.
Trygve Hesthagen er fødd 1951 i Lom. Han er fiskebiolog og tilsett som seniorforskar ved Norsk institutt for naturforskning i Trondheim (NINA). Hesthagen avla hovedfagseksamen ved Universitetet i Tromsø i 1979, og Dr. philos grad ved NTNU i Trondheim i 1997. Han arbeider med ymse felt knytta til innlandsfisk som vassdragsregulering, sur nedbør og spreiing av fiskeartar. Hesthagen har gjeve ut bok om fiske i Skjåk (2001), sløefiske i Oppland (2011) og mange artiklar om fiskehistoriske emner.

Anne Karin Hufthammer er født i 1953 i Austevoll, Hordaland. Hun avla i 1982 embetseksamen (cand. real.) i zoologi ved Universitetet i Bergen i 1982 og har siden arbeidet som paleozoolog/osteolog ved universitets naturhistoriske samlinger. Fra 1998 har hun vært ansatt som førsteamanuensis og leder for Universitetsmuseets samlinger av animalsk skjelettmateriale. Hennes forsking har hovedsakelig vært konsentrert om faunahistoriske og kulturhistoriske problemstillinger fra istid til nyere tid, basert på osteologisk materiale fra arkeologiske og naturvitenskapelige undersøkelser. I den forbindelse har hun drevet omfattende feltarbeid ved utgravninger, hovedsakelig i Norge, men også i Russland og Litauen, i samarbeid med arkeologer, zoologer og geologer.

Arnfinn Kjelland, fødd 1952 i Strand i Rogaland. Cand. philol. frå Universitetet i Trondheim 1981, 
så bygdebokforfattar og forleggar på Lesja til 1992. Engasjert som amanuensis, frå 1994 fast tilsett som førsteamanuensis i historie ved Møre og Romsdal Distriktshøgskule, Volda (Høgskulen i Volda frå 1994), dosent 2015. Har i tillegg til Lesja vore hovudredaktør og prosjektleiar for bygdebokverk, delsjangeren busetnadshistorie, for kommunane Lom, Sula og Volda, og utarbeidd forprosjektrapportar for fleire andre. Hovudinteresser: lokal- og mikrohistorisk teori og metode, emigrasjonshistorie, busetnadshistorie, allmenn tidleg nytids historie (1500- til og med 1800-talet), IKT i historiefagleg arbeid (medlem av IKT-utvalet til Norsk lokalhistorisk institutt sidan 1989).

Einar Kleiven fødd i 1947 i Vågå. Kleiven er utdanna skog- og utmarksteknikar, nå pensjonert forskar. Han har arbeidd ved Zoologisk Museum i Bergen (terkseløkologi), Miljødirektoratet og NIVA Region sør med forsuring, kalking og dessutan innsjøgytande aure. Har publisert mange artiklar om ferskvassbiologiske og fiskehistorske emner.

Charlotte Melsom, født 1974 i Bergen. Hun avla hovedfagseksamen ved Universitetet i Oslo i 2003, og har siden 2006 vært ansatt som arkeolog ved Norsk Maritimt Museum. Hennes arbeid har i hovedsak vært knyttet til saksbehandling innen kulturminneforvaltning, og ledelse av arkeologiske registrerings- og utgravningsprosjekter. De siste årene har hun hatt et særlig ansvar for NMMs arkeologiske prosjekter i vassdrag som er forbundet med sektoravgiftsordningen.

Axel Mjærum, født 1978 i Hobøl, Østfold. Han er arkeolog og avla hovedfagseksamen ved Universitetet i Oslo i 2004. I etterkant har Mjærum arbeidet som feltarkeolog, og de siste årene har Mjærum vært tilsatt som steinalderforsker ved Kulturhistorisk museum ved Universitetet i Oslo. Han har også forfattet en rekke artikler om sørøstnorsk forhistorie og vært redaktør for tidsskriftet Viking.

Anne Severinsen, født 1950 i Brasøy, Nordland. Hun avla hovedfagseksamen ved Universitetet $\mathrm{i}$ Trondheim (NTNU) i 1980. Har deretter vært ansatt i NRK og som lektor i den videregående skolen. Severinsen har publisert en rekke artikler om sørsamisk historie, og var utreder for Samerettsutvalget II, som avgav innstilling i 2007. I perioden 2008-2011 deltok hun i det norsk-svenske dokumentasjonsprosjektet «I det samiska rummet» som omfattet hele det sørsamiske området.

Jo Rune Kristiansen Ugulen, fødd 1968 i Bergen, er historikar og norrønfilolog. Cand.philol. i norrøn filologi ved Universitetet i Bergen 2002, og ph.d. i mellomalderhistorie same stad 2007. Han har sidan 2008 vert tilsett som førstearkivar i Riksarkivet i Oslo, og er mellom anna redaktør for Diplomatarium Norvegicum.

Elling Utvik Wammer, født i 1980 i Trondheim. Mastergrad i arkeologi fra NTNU (2006) og arkeolog ved Norsk Maritimt Museum siden 2012. De senere årene har han vært delaktig i flere større arkeologiske undersøkelser i vassdrag på fjellet, bl.a. som prosjektleder for NMM i Tesse. Wammer har i tillegg til maritim arkeologi en spesiell interesse for jakt og fangst i fjellet, og har deltatt ved Oppland fylkeskommunes snøfonnprosjekt siden 2007. 


\section{STEDSNAVNREGISTER}

A

Abborvikarna, Jämtlands län, Sverige 170

Abelvattnet, Västerbottens län, Sverige 168

Akershus fylke 46, 137, 145, 262

Akersvatnet, Rana kommune, Nordland 166

Alvdal k., Hedmark 40

Ancylussjøen 41

Andberg, Lom k., Oppland 152

Andersbu, Eidsfjord k., Hordaland 258

Arnkleiv, Dovre k., Oppland 154

Atna, Stor-Elvdal k. og Dovre k., Oppland 49

Atnsjøen, Stor-Elvdal k., Oppland 49

Auggedalen, Gausdal k., Oppland 149

Aulstad, Gausdal k., Oppland 149

Auravassdraget, Skjåk k., Oppland 48

Aursjoen, Lesja k., Oppland og Nesset k., Møre og Romsdal 51

Aursjømagasinet, Lesja k., Oppland og Nesset k., Møre og

Romsdal 48, 98, 272

Aust-Agder fylke 111, 234, 258

Austbu, Eidsfjord k., Hordaland 212, 258, 259

Austereng, Gausdal k., Oppland 148

Austre Gausdal, Gausdal k., Oppland 37, 46

Avsjøen, Dovre k., Oppland 48, 49

\section{B}

Bakke, Ringebu k., Oppland 150, 151

Bakkeberg, Lom k., Oppland 153

Beito, Øystre Slidre k., Oppland 105, 202, 219, 225

Belle, Lesja k., Oppland 154

Berdalstølen, Årdal k., Sogn og Fjordane 259

Berg, Øyerk., Oppland 149

Berge, Ringebu k., Oppland 150

Bergen, Hordaland $115,124,134,143,144,156$

Bergom, Øyer k., Oppland 149

Bessvatnet, Vågå k., Oppland 51

Bindal k., Nordland 165, 175-177

Bingen, Sørum k., Akershus 207

Bjornes, Nore og Uvdal k., Buskerud 85
Bjornesfjorden, Nore og Uvdal k., Buskerud 123, 259

Bjøkne, Lesja k., Oppland 154

Bjølstadvatnet, Sel k., Oppland 46

Björkvatnet, Lappland, Sverige 175

Blakar, Lom k., Oppland 45

Borgard, Gausdal k., Oppland 148

Borger, Skiptvedt k., Østfold 97

Boro, Lillehammer k., Oppland 149

Bosvatn, Bykle k., Aust-Agder 111, 122, 123

Bottenviken, Sverige og Finland 160

Bottheimstraumen, Lesja k., Oppland 256

Brandval, Kongsvinger k., Hedmark 104

Brandvål [Brandvol], Nord-Fron k., Oppland 151

Brattland, Gausdal k., Oppland 149

Breheimen, Skjåk k., Lom k., Oppl og Luster i Sogn og Fjordane 40

Breiddalsvatnet, Sjåk k., Oppland 51

Breidsjøen, Sør-Fron k., Oppland 38, 47

Brekken, Røros k., Sør-Trøndelag 179

Brekkom, Ringebu k., Oppland 150

Brekkvasselv, Namsskogan k., Nord-Trøndelag 170

Brettingen, Gausdal k., Oppland 149

Bryn, Nord-Fron k., Oppland 151

Bryn, Øyer k., Oppland 149

Bræe, Sel k., Oppland 152

Bræebygda, Sel k., Oppland 152

Bråtå, Sjåk k., Oppland 99, 100

Bråtåvatnet, Sjåk k., Oppland 51

Bu, Sel k., Oppland 151, 152

Bukkhammeren, Tynset k., Hedmark 122, 258

Bulung, Lillehammer k., Oppland 149

Burgfjäll, Västerbottens län, Sverige 176

Burvattnet, Jämtlands län, Sverige 165

Buskerud fylke $64,69,111,127,132,240,242,243,257-259$

Buvika, Engerdal k., Hedmark 224

Bygdin, Vang k., Oppland 40, 43, 44, 47, 71, 212

Byglandsfjorden, Bygland k. og Evje og Hornnes k., Aust-

Agder 234, 235

Bykle k., Aust-Agder 120, 258

Byrtnes, Lom k., Oppland 21-23, 105, 186, 219, 222 
Bærum k., Akershus 134

Bø, Gausdal k., Oppland 149

Bø, Nord-Fron k., Oppland 151

Bødalen, Gausdal k., Oppland 148, 149

Bøje, Skjåk k., Oppland 153

Børgefjell, Nord-Trøndelag og Nordland $\quad$ 166, 169, 174

Børke, Lillehammer k., Oppland 146

Bøverdalen, Lom k., Oppland 40, 152, 153

Bøvravassdraget, Lom k., Oppland 51

C

Christiania, Oslo 130

$\mathrm{D}$

Dagsgardsøygarden, Skjåk k., Oppland 153

Dagvolsjøen, Røros k., Sør-Trøndelag $\quad$ 179, 180

Dalarna län, Sverige 160, 196

Dalsvatnet, Lom k., Oppland 51

Det kaspiske hav, Kasakhstan, Russland, Aserbadjdsjan, Iran,

Turkmenistan 42

Diserud, Lillehammer k., Oppland 146

Djupe [Djupa], Nore og Uvdal k., Buskerud 104

Dokkavassdraget, Gausdal k. og Nordre Land k., Oppland 120,

123

Dokkføy, Gausdal k. og Nordre Land k., Oppland 120, 258, 259

Dokkføyvatnet, Gausdal k. og Nordre Land k., Oppland 47, 98, 108, 123

Dombås, Dovre k., Oppland 154

Dovre, k., Oppland 49, 114, 154, 161, 258, 268

Dovrebygda, Dovre k., Oppland 154

Dovrefjell, Oppland og Sør-Trøndelag 48, 49, 95, 96, 99, 118, 119

Dovreskogen, Dovre k., Oppland 154

Dragarskaret, Øystre Slidre k., Oppland 219

Drageidfjorden, Eidsfjord k., Hordaland 211

Drammen, k., Buskerud 57

Drammenselva, Drammen k., Buskerud 106

Dravtjønne, Vågå k., Oppland 51

Dunfjelltjønna, Grane k., Nordland 170

Dågåtjønn, Lom k., Oppland 32

Dågåtjønnvika, Lom k., Oppland 21, 22, 25, 26, 33, 28, 186, 188, 231,232

$\mathrm{E}$

Edevik, Jämtlands län, Sverige 269

Efteløt, Kongsberg k., Buskerud 46

Eidefoss, Vågå k., Oppland 43, 47

Eidfjord, Hordaland 86, 88, 257-259

Einsethø, Dovre k., Oppland 117

Einstad, Gausdal k., Oppland 148

Elgå, Engerdal k., Hedmark 160, 181

Elvålsvollen, Engerdal k., Hedmark 224

Engeland, Gausdal k., Oppland 148

Engelshus, Dovre k., Oppland 154

Engjom, Dovre k., Oppland 154

Espedalsvatnet, Gausdal k., Oppland 38, 47
Essand reinbeitedistrikt, Nord-Trøndelag og Sør-Trøndelag 168

Essandsjøen, Tydal k., Sør-Trøndelag 168

Esseån (Ässan), Ångermanland län, Sverige 163

$\mathrm{F}$

Fagernes, Nord-Aurdal k., Oppland 194, 267

Fatmomakke, Västerbottens län, Sverige 172

Fellese, Vågå k., Oppland 152

Femunden, Os k. og Engerdal k., Hedmark og Røros k., Sør-

Trøndelag 224

Femundsmarka, Engerdal k., Hedmark og Røros, Sør-

Trøndelag 170

Filefjell, Lærdal k., Sogn og Fjordane og Vang k., Oppland

m.fl. 104

Finland 164, 166, 186, 198, 202

Finnsbergvatnet, Eidfjord k., Hordaland 114-116, 124, 207, 208, 211, 212

Fiskevollen, Rendalen k., Hedmark 99, 192, 223, 224

Flatningen, Vågå k., Oppland 46

Flønesodden, selbu k., Sør-Trøndelag 99

Flågåstad, Lesja k., Oppland 154

Folla, Folldal k. m.fl., Hedmark 49

Follavassdraget, Folldal k. m.fl., Hedmark 48

Folldalsvatnet, Namsskogan k., Nord-Trøndelag 176

Follebu, Gausdal k., Oppland 148, 149

Forberg, Skjåk k., Oppland 153

Forbrigd, Nord-Fron k., Oppland 152

Forr, Sør-Fron k., Oppland 151

Forset, Gausdal k., Oppland 148, 149

Fortunsdalen, Luster k., Sogn og Fjordane 40

Fossbergom, Lom k., Oppland 152

Fossdalen, Årdal k., Sogn og Fjordane 259

Frengstad, Tynset k., Hedmark 95

Fron, Oppland $\quad 50,143,147,151,152,155,224$

Frosktjønna, Grane k., Nordland 170

Frösöen, Jämtlands län, Sverige 197, 269

Frøyningsfjell, Namsskogan k., Nord-Trøndelag 177

Fåberg, Lillehammer k., Oppland 107, 140, 143, 146, 147, 149

Fåvang, Ringebu k., Oppland 143, 150

G

Galde, Lom k., Oppland 153

Garmo, Lom k., Oppland 127, 130-132, 134, 135, 152, 153, 185, 186

Garmobygda, Lom k., Oppland 189

Gauldalen, Midtre Gauldal k., Sør-Trøndelag 268

Gausa, Gausdal k. og Lillehammer k., Oppland 148

Gausdal, Oppland $37,38,46,47,52,108,140,143,147,148,258$, 259

Gausdal Vestfjell, Gausdal k., Oppland 47, 108

Gauthelleren, Odda k., Hordaland 258

Gautsjøen, Lesja k., Oppland 48

Gautåsetrene, Dovre k., Oppland 49

Geitvassmuran, Nore og Uvdal k., Buskerud 123, 259

Geitvatn, Nore og Uvdal k., Buskerud 123, 259 
Gillebu, Øyer k., Oppland 149

Gillebufjorden, Øyer k., Oppland 149

Gjende, Vågå k., Oppland 40, 45, 96

Gjendeosen, V,ågå k., Oppland 97

Gjæsingvatnet, Vågå k., Oppland 46

Glitreøyni, Lærdal k., Sogn og Fjordane 108

Glomma, Sør-Trøndelag, Hedmark, Oppland og Østfold 48, 49, 53

Glommavassdraget, Sør-Trøndelag, Hedmark, Oppland og

Østfold 48, 122, 207

Godlia, Ringebu k., Oppland 150

Gokstadhaugen, Sandefjord k., Vestfold 207

Grafferdammane, Sør-Fron k., Oppland 50

Gravolsodden, Øystre Slidre k., Oppland 214, 216-218

Grimsdalen, Dovre k., Oppland 49, 117

Grjothovdtjønne, Vågå k., Oppland 51

Grotli, Sjåk k., Oppland 51

Grovi, Vågå k., Oppland 107

Grynningen, Lesja k., Oppland 48, 98

Grytendalsvatnet, Bindal k., Nordland 175

Grøtgarden, Rendalen k., Hedmark 223

Gudbrandsdalen $\quad 6,25,37,38,40,43,50,95,96,100-102,104,119$,

$127,134,135,137,138,140,141,143-145,152,154-156,262$

Gudbrandsdalslågen, Oppland 37, 41, 42, 48, 53, 71, 105, 212

$\mathrm{H}$

Hajeren, Kongsberg k., Buskerud 132

Hallingdal, Gol k. og Ål k., Buskerud 95, 119

Halnefjorden, Eidsfjord k., Hordaland og Nore og Uvdal k.,

Buskerud 56, 69, 119, 123, 211, 257

Halnelægeret, Eidsfjord k., Hordaland 119, 258

Hamar, Hamar k., Hedmark 127-132, 134, 135, 145, 146, 149, 261

Hande, Vestre Slidre k., Oppland 95

Hardanger, Hordaland 102, 107, 119

Hardangervidda, Hordaland Og Buskerud $\quad 47,56,64,85-90,104$, 111, 114, 118, 122, 123, 127, 207, 208, 210-212, 214, 217, 235, 259

Harpefoss, Sør-Fron k., Oppland 42, 43, 47, 71

Hattfjelldal, Hattfjelldal k., Nordland 166, 168, 171

Haugen, Dovre k., Oppland 154

Haugen, Ringebu k., Oppland 147, 150

Haugsetvollen, Engerdal k., Hedmark 224

Haverstad, Sør-Fron k., Oppland 151

Hedeby, Tyskland 198-201

Hedmark fylke 4, 25, 95, 99, 104, 111, 127, 159, 160, 168, 192, 197, 200, 223, 224, 238, 250, 257-259, 267, 270, 272

Hedrum, Larvik k., Vestfold 134

Heggen, Gausdal k., Oppland 148

Hegglingen, Dovre k., Oppland 48, 49

Heidalen, Sel k., Oppland 152

Heimdalsvatnet, Vågå k., Oppland 44, 134

Hein, Nore og Uvdal k., Buskerud 69, 71, 257, 258

Heisandtjørn, Eidsfjord k., Hordaland 259

Helagssjöarna, Jämtlands län, Sverige 164

Helgeland, Nordland $166,169,174-178,180,181$

Hellingbøen, Årdal k., Sogn og Fjordane 259

Hemnes k., Nordland 166, 177
Hemsedalsfjellet, Hemsedal k., Buskerud 108

Hersjøane, Nord-Fron k., Oppland 44

Hestbrepiggane, Skjåk k. og Lom k., Oppland 40

Hinøgla, Nord-Fron k., Oppland 44

Hjelle, Ringebu k., Oppland 150, 154, 250, 251, 255

Hjerkinn, Dovre k., Oppland 49, 96, 99, 119, 258

Hogsvål, Lesja k., Oppland 154

Hol, Hol k., Buskerud 64, 69, 240, 242, 243, 258

Hole, Skjåk k., Oppland 148, 153

Holen, Gausdal k., Oppland 148

Holen, Sel k., Oppland 152

Holen, Øyer k., Oppland 149

Holmen, Øyer k., Oppland 149, 219

Holmvatnet, Grane k., Nordland 176

Hong, Øyer k., Oppland 149

Honnhammaren, Tingvold k., M. og R. 57

Hordaland fylke 111, 257-259

Hov, Lillehammer k., Oppland 149

Hov Engeland, Skjåk k., Oppland 149

Hovedøya, Oslo 134

Huddingsvatnet, Røyrvik k., Nord-Trøndelag 166

Hunder, Lillehammer k. og Øyer k., Oppland 149

Hunderfossen, Lillehammer k. og Øyer k., Oppland 42, 145, 149

Hyllingen, Røros k., Sør-Trøndelag 179, 180

Hyllingsdalen, Røros k., Sør-Trøndelag 179

Hyllingsjøen, Røros k., Sør-Trøndelag 179

Hyttevannhelleren, Bykle k., Aust-Agder 258

Høvre, Øyer k., Oppland 149

Høydalsvatnet, Lom k., Oppland 51

Høylandet k., Nord-Trøndelag 176

Hån, Midtre Gauldal k., Sør-Trøndelag 268

Hågån, Lesja k., Oppland 154

I

Idre, Dalarna län, Sverige $\quad 127,160$

Ildgruben reinbeitedistrikt, Rana k., Nordland 178, 264

Ilstad, Nord-Fron k., Oppland 151

Ilva, Lom k., Oppland 21-23, 186

Imsdalen, Stor-Elvdal, Hedmark 150

Ingeridskogen, Øyer k., Oppland 149

Ingulssjøen, Vågå k., Oppland 51

Inna, Tynset k., Hedmark 122

Insta Olavsbuvatnet, Eidfjord k., Hordaland 211

Island 105, 214

Isteren, Engerdal k., Hedmark 224

$\mathrm{J}$

Jemnefjorden, Øyer k., Oppland 149

Jonasvollen, Røros k., Sør-Trøndelag 179

Joravassdraget, Dovre k. og Lesja k., Oppland 48

Jormsjön, Jämtlands län, Sverige 166

Jotunheimen, Oppland $5,9,13,15,35,37,38,40,43,44,46,47$, 50-53, 61, 62, 71, 72, 75, 100, 111, 191, 192, 202, 212, 230, 231, 252 Jotunheimen nasjonalpark, Oppland 212

Jotunheimvegen, Oppland 212 
Jutulhogget, Alvdal k. og Rendalen k., Hedmark 40

Jylland, Danmark 199

Jämtland, Sverige $\quad 164,165,169,196-198,200,202,263,269$

Jøra, Gausdal k., Oppland 148, 149

K

Kaldfjorden, Øystre Slidre k., Oppland $\quad 44,72,217,218,224,235$

Kallvatnet, Rana k., Nordland 163

Kalvfjellet, Bindal k., Nordland 176

Kalvkruvatnet, Bindal k., Nordland 176

Karelen, Finland og Russland 198

Karifjorden, Øystre Slidre k., Oppland 218

Kaupang, Larvik k., Vestfold 124

Keika, Västerbottens län, Sverige 172

Kjos, Gausdal k., Oppland 148

Kjæstad, Lom k., Oppland 105

Kjølen, Norge-Sverige $\quad 160,163,172,200$

Kjønnås, Ringebu k., Oppland 151

Kjøremsgrende, Lesja k., Oppland 154

Kjørstad, Sør-Fron k., Oppland 151

Kleive, Gausdal k., Oppland 143

Kleivrud, Sel k., Oppland 152

Kleppe, Vågå k., Oppland 50, 152

Kleva, Øyer k., Oppland 148, 149

Klimpfjäl, Västerbottens län, Sverige 176

Klomstad, Nord-Fron k., Oppland, 152

Klones, Vågå k., Oppland 152

Kojenebba, Lom k., Oppland 34

Kollstad, Lesja k., Oppland 154

Kolobekken, Sel k., Oppland 152

Koppsele, Västerbottens län, Sverige 164

Korgehølen, Vågå k., Oppland 104

Kristkyrkja, Hamar k., Hedmark 129-131

Krækkja, Hol k., Buskerud 114, 116, 117, 211, 212, 217, 258

Kubosen fiskevær, Øystre Slidre k., Oppland 218

Kvam, Nord-Fron k., Oppland 105, 149, 152

Kvarberg, Vågå k., Oppland 147, 152

Kvenna, Vinje k. m.fl., Telemark 86-88

Kvie, Vang k., Oppland 98

Kvikne, Nord-Fron k., Oppland 152

Kvikne, Rennebu k., Sør-Trøndelag og Tynset k., Hedmark 95

Kvitingen, Vågå k., Oppland 46

Kvitingskjølen, Lom k., Oppland 46, 192

Kvålen, Nord-Fron k., Oppland 152

Kyrkjebygde, Lesja k., Oppland 154

København, Danmark 130, 137, 139-141

L

Laisbyn i Pite lappmark, Norrbottens län, Sverige 163

Lalm, Vågå k., Oppland 51, 152

Lalmsvatnet, Vågå k., Oppland 45, 152

Langavatn, Eidfjord k., Hordaland 211

Langesjøen, Nore og Uvdal k., Buskerud 56, 69, 257

Langesæ, Vinje k., Telemark 96, 122

Langesæhelleren, Vinje k., Telemark 122, 258
Langfonne, Lom k., Oppland 191

Langgard, Øyer k., Oppland 149

Langsjø, Nore og Uvdal k., Buskerud 104

Larvik, Larvik k., Vestfold 64, 124

Lau, Siljan k., Telemark 207

Leksand, Dalarnas län, Sverige 196

Lemonsjøen, Vågå k., Oppland 40, 45, 46, 107

Lesja, Lesja k., Oppland 38, 40, 48, 95, 97, 98, 145, 153, 154, 161, 256, 268, 272

Lesjaskogsvatnet, Lesja k., Oppland $\quad 42,47,48$

Lesjavatna, Lesja k., Oppland 47, 48, 98, 99, 104, 106, 108

Lesjavatnet, Lesja k., Oppland 153, 194, 268

Li, Gausdal k., Oppland 37, 46

Lia, Gausdal k., Oppland 149, 151

Liavatnet, Skjåk k., Oppland 51

Lillehammer, Lillehammer k., Oppland 149, 226, 256

Limingen, Røyrvik k., og Lierne k., Nord-Trøndelag 166

Lindsetdalen, Namsskogan k., Nord-Trøndelag 176

Listad, Sør-Fron k., Oppland 143

Locknesjön, Jämtlands län, Sverige 197, 269

Lofossen, Nord-Fron k., Oppland 47

Lom, Lom k., Oppland 9, 15, 35, 40, 45, 51, 62, 94, 97, 102, 105, 106, 127, 129-132, 134, 135, 152, 154, 183, 190, 192, 194, 239, 263, 270

Lomseggen, Skjåk k. og Lom k., Oppland 40

Lortjønnin, Skjåk k., Oppland 51

Losna, Ringebu k. og Øyer k., Oppland 149

Losnavatnet, Ringebu k. og Øyer k., Oppland 42

Lougen [Lågen], Oppland 43

Lundadalen, Sjåk k., Oppland 40

Lundadalsvatnet, Sjåk k., Oppland 51

Lundamo, Melhus k., Sør-Trøndelag 268

Lunde, Lillehammer k., Oppland 147, 149

Lunde, Nord-Fron k., Oppland 151

Lunde, Ringebu k., Oppland 150

Luster k., Hordaland 40

Lycksele, Västerbottens län, Sverige 166

Lyse, Os k., Hordaland 134

Lysgard, Lillehammer k., Oppland 149

Lærdalsvassdraget, Lærdal k., Sogn og Fjordane 76

Løysnes, Fåvang k., Oppland 150

Lågen, Oppland $38,40,42,43,47-50,86-88,100,106,149-152$, 154

Lånke, Øyer k., Oppland 149

\section{M}

Majavatn, Grane k., Nordland $\quad$ 170, 172, 174, 263, 264

Malå, Västerbottens län, Sverige 164

Manstad, Gausdal k., Oppland 148

Mattmars socken, Jämtlands län, Sverige $\quad$ 199, 269

Maurstad, Skjåk k., Oppland 153

Medalen, Lom k., Oppland 40

Meinsbulægeret, Nore og Uvdal k., Buskerud 123, 259

Melbø, Gausdal k., Oppland 149

Melingen, Vågå k., Oppland 46, 97, 106 
Mellansvartsjön, Jämtlands län, Sverige 269

Melle, Rena elv, Åmot k., Hedmark 257

Melvold, Rena elv, Åmot k., Hedmark 257

Meløken, Lom k., Oppland 26

Midtre Gauldal k., Sør-Trøndelag 194, 268, 269

Mjøsa, Akershus, Oppland, og Hedmark 37, 40-42, 47, 53, 96, 100, 106, 149

Mjåvatnet, Vefsn k., Nordland 196

Mo, Lom k., Oppland 132

Moadalen, Årdal k., Sogn og Fjordane 120, 122

Mosenden i Lesja, Lesja k., Oppland 95

Moshus, Øyer k., Oppland 149

Motterud, Lesja k., Oppland 154

Musdalen, Øyer k., Oppland 149

Myre, Gausdal k., Oppland 148

Myskelsjöarna, Härjedalens län, Sverige 170

Myskelåsen, Härjedalens län, Sverige 171

Mælum, Lillehammer k., Oppland 149

Mælum, Ringebu k., Oppland 151

Mælum, Øyer k., Oppland 149

Møre og Romsdal fylke 272

Mørstadstølen, Øystre Slidre k., Oppland 43, 73, 74, 246, 247, 257

Møsvatn, Vinje k., Telemark 87, 89, 90, 104, 111, 122, 123, 208,

272

Måbødalen, Eidfjord k., Hordaland 115

Måna, Tinn k., Telemark 87,90

\section{$\mathrm{N}$}

Namdalen, Namsskogan k., Nord-Trøndelag 168

Namsvassflyene, Røyrvik k., Nord-Trøndelag 178

Namsvatnet, Røyrvik k., Nord-Trøndelag 168, 169, 176, 178

Naustviki, Lom k., Oppland 219

Nedre Fosse, Nord-Fron k., Oppland 152

Nedre Glåmsjø, Alvdal k., m.f. Hedmark 40

Nedre Heimdalsvatnet, Vågå k., Oppland 44

Nedre Leirungen, Vågå k., Oppland 45

Nedre Øy, Vågå k., Oppland 152

Ner-Øy, Vågå k., Oppland 50

Nesbu, Eidsfjord k., Hordaland 259

Nidaros, Trondheim k., Sør-Trøndelag 119, 146

Nilsinetjern, Bindal k., Nordland 176

Nord-Aurdal, Oppland 197, 267-269

Norderhus, Lesja k., Oppland 154

Nord-Fron k., Oppland 40, 72, 95, 107, 212, 245, 257

Nord-Gudbrandsdalen, Oppland 51, 95, 184, 192

Nordigard Bø, Lesja k., Oppland 154

Nordland fylke 160, 181, 196

Nordmaling, Västerbottens län, Sverige 160

Nordmannslågen, Eidsfjord k., Hordaland 127, 258

Nordmo, Lesja k., Oppland 154

Nordre Byrtnes, Lom k., Oppland 219, 222

Nordrum, Ringebu k., Oppland 143, 150, 151

Nord-Sverige 186

Nord-Trøndelag fylke $\quad 159,164,168,174,175,178,180$
Nore og Uvdal k., Buskerud 64, 69, 257, 259

Norefjorden, Nore og Uvdal k., Buskerud 64

Normannsslepa, Buskerud og Hordaland m.fl. 119

Norrbotten, Norrbottens län, Sverige 159

Norrland, Sverige 172

Novgorod, Russland 198

Numedalslågen, Kongsberg k. m.fl., Buskerud 64, 71, 240

Numedalsvassdraget, Kongsberg k. m.fl., Buskerud 64, 69, 75

Nygard Saksum, Lillehammer k., Oppland 149

Nyset-Steggjevassdragene, Lærdal k. og Årdal k., Sogn og

Fjordane 76

Nørdre Elve, Lom k., Oppland 26

Nørdre Lia, Sør-Fron k., Oppland 151

Nørdre Rolstad, Lesja k., Oppland 154

Nørstedalsseter, Luster k., Sogn og Fjordane 40

Nørstegard, Lesja k., Oppland 154

Nånesodden, Bygland k., Aust-Agder 234

Nåvårseter, Lom k., Oppland 31-33, 45, 232

$\mathrm{O}$

Odda k., Hordaland 258

Oden, Sør-Fron k., Oppland 151

Odenrud, Sør-Fron k., Oppland 151

Offigstad, Øyer k., Oppland 149

Okstindan, Hemnes k., Nordland 163

Oldfällen, Jämtlands län, Sverige 165

Oleskarbuene, Øystre Slidre k., Oppland 218

Olevann, Øystre Slidre k., Oppland 219

Olstappen, Nord-Fron k., og Sør-Fron k., Oppland 38, 40, 43, 44, 47, 71, 72, 98, 245

Ommondgard, Lesja k., Oppland 154

Oppland fylke $4,15,25,35,37,51,53,72,73,96,98,101-103,107$, $111,120,123,127,135,162,192,207,226,238,245,246,257-259$,

267, 268, 272

Oppsal, Fåvang k., Oppland 150

Oppsalåsen, Fåvang k., Oppland 142

Orvatnet, Røyrvik k., Nordland 168, 169

Os k., Hordaland 134

Oseberghaugen, Tønsberg k., V.fold. 207

Oselva, Os k., Hordaland 134

Oslo fylke $17,18,21,124,130-134$

Otta, Sel k., Oppland 49, 152

Ottadalen, Oppland $\quad 15,38,40,99,189,190,193,194,219$

Ottadals-bygdene, Oppland 155

Ottaelva, Oppland 49, 152

Ottavassdraget, Oppland $\quad 40,47,48,52$

Ottavatnet, Oppland 45

Ovre, Gausdal k., Oppland 148

Ovren, Fåvang k., Oppland 149

$\mathrm{P}$

Piteå, Norrbottens län, Sverige 198

Pålsbufjorden, Hol og Nore og Uvdal, Buskerud 64-66, 69, 235, 240, 242, 243, 257

Pålsbufjordmagasinet, Hol og Nore og Uvdal, Buskerud 235 
$\mathrm{R}$

Rabbalsvatnet, Øystre Slidre k., Oppland 256

Raggen, Øystre Slidre k. og Nord-Fron k., Oppland 12, 224

Ramberg, Lillehammer k., Oppland 149

Rambergåi, Hol k., Buskerud 66

Rana k., Nordland 160, 163-166, 172, 178, 181

Randaberg k., Rogaland 58

Randsfjorden, Oppland 47

Randsverk, Vågå k., Oppland 152

Rasletindane, Vang k. og Vågå k., Oppland 40

Raudsjøen, Gausdal k., Oppland 37, 46

Rauland, Vinje k., Telemark 210

Rauma k., Møre og Romsdal 47

Raumavassdraget, Oppland og Møre og Romsdal 47, 48

Rauvatnet, Hattfjelldal k., Nordland 163

Reinheimen, Oppland og Møre og Romsdal 108

Reinsenn, Vestre Slidre, Oppland 267

Reistad, Gausdal k., Oppland 148

Reistad, Lillehammer k., Oppland 149

Rendalen k., Hedmark 40, 99, 194, 202, 267, 268

Rensennvatnet, Vestre Slidre, Oppland $\quad 162,180$

Rensfjellet, Sør-Trøndelag 268

Riast-Hyllingen reinbeitedistrikt, Sør-Trøndelag

Rinda, Lillehammer k., Oppland 256

Rindal, Dovre k., Oppland 154

Ringebu k., Oppland 107, 147, 149-151

Ringebufjellet, Ringebu k., Oppland 155

Ringvatnan, Bindal k., Nordland 176

Rjukanfossen, Tinn k., Telemark 87,88

Rogaland fylke 58,128

Rogen, Engerdal k., Hedmark og Jämtlands län, Sverige $\quad 170,171$

Romsdalen, Lesja k., Oppland Rauma k., Møre og Romsdal 40

Romundgard, Sel k., Oppland 152

Rondane, Hedmark og Oppland $\quad 117,122$

Rondvatnet, Sel k., Oppland 51

Rostenfalla, Sel k., Oppland 42

Rotås, Ringebu k., Oppland 150

Rudi, Sør-Fron k., Oppland 151

Russland 198

Russvatnet, Vågå k., Oppland 50, 51

Ruste, Nord-Fron k., Oppland 151

Ryddøla, Dovre k., Oppland 154

Røldal, Odda k., Oppland 122

Røros k., Oppland 155, 181

Rørvik, Ringebu k., Oppland 150

Røssvatnet, Hattfjelldal k. og Hemnes k., Nordland 163, 166

Røyne, Fåvang k., Oppland 149

Røyrtjønna, Hol og Nore og Uvdal, Buskerud 64, 67, 240-244, 250, 257

Røyrvik k., Nord-Trøndelag $\quad$ 167, 263

S

Saksum, Lillehammer k., Oppland 149

Saksumdalen, Lillehammer k., Oppland 149

Samsjøen, Midtre Gauldal, Sør-Trøndelag $\quad$ 194, 268
Sana strand, Rendalen k., Hedmark 267

Sandbu, Sel k., Oppland 151

Sandbu, Vågå k., Oppland 134

Sande k., Vestfold 134

Sandsvær, Kongsberg k., Buskerud 46

Sandvatn, Nord-Fron k., og Øystre Slidre k., Oppland 44, 217, 224

Sandvikselva, Bærum k., Akershus 134

Sarjelsjaur, Koppsele, Västerbottens län, Sverige 164

Segalstad bru, Gausdal k., Oppland 148

Sel k., Oppland 38, 40, 51, 107

Selbusjøen, Klæbu k., og Selbu k., Oppland 99

Seljord k., Telemark 194

Selsvatnet, Sel k., Oppland 107

Setesdalen, Aust-Agder 111, 120, 122, 234

Sigstadvollen, Nord-Fron k., Oppland 152

Siljan k., Telemark 207

Siljehaugen, Dovre k., Oppland 154

Silli, Nord-Fron k., Oppland 152

Simenrud, Lillehammer k., Oppland 149

Sjoa, Sel k. og Vågå k. Oppland 104

Sjoavassdraget, Sel k. og Vågå k. Oppland 40, 45, 47, 52

Sjodalsvatnet, Vågå k., Oppland 40, 45, 104

Sjugurdsjøen, Vågå k., Oppland 51

Sjårdalen, Vågå k., Oppland 152

Skagerakkysten 57

Skarphol, Lesja k., Oppland 154

Skarstad, Sør-Fron k., Oppland 151

Skim, Skjåk k., Oppland 45, 51, 152, 153

Skjøli, Sjåk k., Oppland 40

Skjønsberg, Øyer k., Oppland 149

Skjåk k., Oppland 40, 51, 99, 145, 148, 152, 153

Skogerveien, Drammen k., Buskerud 57

Skrivarhelleren, Årdal k., Sogn og Fjordane 120, 121, 123, 258

Skåbu, Nord-Fron k., Oppland 95, 97, 98, 100, 104, 106, 152

Skåne län, Sverige 132

Skårset, Lillehammer k., Oppland 149

Skårsroe, Vågå k., Oppland 148

Skårvangen, Vågå k., Oppland 152

Skårå, Sel k., Oppland 152

Slangen, Nord-Fron k., Oppland 44, 245

Slette, Dovre k., Oppland 154

Slidre, Oppland $73,88,95,162,202,212,224,225,246,256,257$, 267

Slåa, Nord-Fron k., Oppland 152

Smestad, Lillehammer k., Oppland 146

Smådalen, Lom k., Oppland 45, 46, 192

Smådalsvatna, Lom k., Oppland 45, 51

Smådøla, Lom k., Oppland 27, 34, 45, 52, 101, 102, 186, 192

Snertingdalen, Gausdal k., Oppland 149

Sogn, Sogn og Fjordane $\quad 38,76,111,120,258,259$

Sogn og Fjordane fylke 111, 120, 258, 259

Sognefjellet, Oppland og Sogn og Fjordane 51, 145

Sognefjorden, Sogn og Fjordane 122

Sollefteå, Västernorrlands län, Sverige 163

Spjeltfjelldalen, Hemnes k., Nordland 177 
Sporaneset, Vinje k., Telemark 210

Stavanger, Rogaland 124, 212

Stegaros, Tinn k., Telemark 122, 258

Steinde, Nord-Aurdal k., Oppland 267

Steinumgard, Ringebu k., Oppland 150

Steinvatnet, Grane k., Nordland 170

Stene terrasse, Rena elv, Åmot k., Hedmark 257

Store Krækkja, Hol k., Buskerud 114, 116, 117, 212, 217

Store Straumen, Øystre Slidre k., Oppland 218

Storevatn, Vestre Slidre, Oppland 95

Stormorke, Nord-Fron k., Oppland 152

Storsjøen, Rendalen k., Hedmark 194, 267, 269

Storvik-gardane, Vågå k., Oppland 46

Strande, Ringebu k., Oppland 151

Strandefjorden, Nord-Aurdal k., Oppland 194, 267, 268

Struksrud, Lillehammer k., Oppland 149

Strynefjellet, Stryn k., Sogn og Fjordane 145

Strypbekken, Dovre k., Oppland 49

Størkestad, Ål k., Buskerud 95

Sumtangen, Eidsfjord k., Hordaland 114-116, 207, 257-259

Surtningen, Vågå k., Oppland 46

Susendalen, Hattfjelldal k., Nordland 169

Svartehavet, Russland, Tyrkia 42

Svatsum, Gausdal k., Oppland 148, 149

Sverige $59,62,159,160,163,164,166,168,171,180,196,197,202$, 264

Sylte, Nord-Fron k., Oppland 147, 152

Synstgard, Gausdal k., Oppland 149

Särna, Dalarnas län, Sverige 127

Sæter, Lillehammer k., Oppland 149

Sødorp, Nord-Fron k., Oppland 152

Södra Storfället, Västerbottens län, Sverige 168,171

Sølensjøen, Rendalen k., Hedmark 4, 99, 106, 192, 202, 223, 224

Sønstebø, Nord-Fron k., Oppland 152, 252

Sør-Aurdal k., Oppland 102, 104

Sørbu, Eidsfjord k., Hordaland 257, 259

Sørdalen, Øyer k., Fåberg k. og Gausdal k., Oppland 147

Søre Båtskaret, Øystre Slidre k., Oppland 213

Søre Kallstad, Gausdal k., Oppland 149

Sør-Fron k., Oppland 12, 107, 212, 224

Sør-Helgeland, Nordland 174

Sør-Trøndelag fylke 99, 168, 179, 197, 268

\section{$\mathrm{T}$}

Tande, Øyer k., Oppland 149, 252

Tandsjön, Jämtlands län, Sverige 170

Telemark fylke 96, 111, 127, 194, 208, 210, 258, 272

Tessa, Lom k. og Vågå k., Buskerud 47

Tessand, Vågå k., Oppland 46

Tesse, Lom k., Oppland 4, 5, 9, 13, 15-18, 21, 23, 26, 28, 30-32, 34, 35, 45-47, 51, 52, 61, 62, 64, 72, 98-102, 105, 111, 127, 130-132, 134, 135, 153, 183-186, 188-194, 196-202, 204, 207, 219, 222, 224, 226, 229-235, 239, 265, 267, 268

Tessekalven, Lom k., Oppland 25

Tessemagasinet, Lom k., Oppland 33, 97, 98, 219
Tesseosen, Lom k., Oppland 33, 34, 233

Tingvollfjorden, Tingvold k., M. og R. 57

Tinn k., Telemark 258, 272

Tinnelva, Tinn k., Telemark 87

Tinnsjø, Tinn k., Telemark 87, 88

Tjølling, Larvik k., Vestfold 134

Tjønnosen, Vågå k., Oppland 51

Toft, Gausdal k., Oppland 148

Tofte, Dovre k., Oppland 162

Tolstad, Vågå k., Oppland 51

Tordhol, Lesja k., Oppland 154

Torolmen, Årdal k., Sogn og Fjordane 120, 121

Torrön, Jämtlands län, Sverige 269

Torsgard, Ringebu k., Oppland 150

Torstad, Øyer k., Oppland 149

Totak, Vinje k., Telemark 210

Tretten, Øyer k., Oppland 149

Tromsåe, Ringebu k., Oppland 150

Trondheim, Trondheim k., Sør-Trøndelag 99, 124

Trælen, Lesja k., Oppland 48

Trøndelag fylke 25, 134, 166, 174

Tullia, Ringebu k., Oppland 150

Tune, Nord-Fron k., Oppland 152

Tunhovd, Nore og Uvdal k., Buskerud 88

Tunhovdfjorden, Nore og Uvdal k., Buskerud 64

Tunsberg, Tønsberg k., V.fold. 132

Tverrlandet, Lom k., Oppland 186

Tya, Årdal k., Sogn og Fjordane 47, 121

Tydal k., Sør-Trøndelag 161, 168

Tyin, Vang k. Oppland og Årdal i Sogn og Fjordane $40,44,47,104$, 120, 121

Tynset k., Hedmark 258

Tyskland 198

Tänndalen, Härjedalens län, Sverige 170

Tännes, Härjedalens län, Sverige $\quad$ 170, 263

Tärna, Västerbottens län, Sverige 164-166, 168

Tärnaby, Västerbottens län, Sverige 159

Tärnafjellet, Västerbottens län, Sverige 172

Tärnamo, Väterbottens län, Sverige 175

Tøftom, Dovre k., Oppland 117, 118, 258

Tåkåstad, Sør-Fron k., Oppland 151

$\mathrm{U}$

Ullensvang statsallmenning, Ullensvang k., Hordaland 46

Ullshelleren, Odda, Hordaland 122, 258

Ulnes, Nord-Aurdal k., Oppland 267

Ume lappmark, Västerbottens län, Sverige 159,163

Ume älv, Västerbottens län, Sverige 163

Umeå, Västerbottens län, Sverige 163,164

Umeå sogn, Västerbottens län, Sverige 163

Ural, Russland 198

Urutlekråi, Årdal k., Sogn og Fjordane 259

Utnesvandet, Røyrvik k., Nordland 166 
V

Vaage [Vågå], Oppland 43

Valdres Oppland $25,27,38,93,95,96,98,100-102,104,105,108$,

$162,202,224,267$

Valdresdalen Oppland 47

Valdresflya, Vang k. og Øystre Slidre k., Oppland 40

Valle, Vågå k., Oppland 152

Vang k., Oppland 40, 93, 108, 212

Vangsjøen, Øystre Slidre k., Oppland 256

Vardal, Lom k., Oppland 130

Vedem, Øyer k., Oppland 149

Vefsn k., Nordland 165, 166, 196, 198, 200

Vefsna, Vefsn k., Nordland 166

Vefsnfjorden, Vefsn k., Nordland 196

Vektaren, Røyrvik k., Nordland 166

Velfjord, Brønnøy k., Nordland 175

Venabygda, Ringebu k., Oppland 151

Venåsen, Ringebu k., Oppland 151

Veodalen, Lom k., Oppland 100

Vesle Hjerkinn, Dovre k., Oppland 49, 96, 99, 258

Vesleberget, Lillehammer k., Oppland 149

Veslefjorden, Øystre Slidre k., Oppland 212, 213, 218

Veslehamar, Lillehammer k., Oppland 149

Vesl-Kollstad, Lesja k., Oppland 154

Veslvatnet, Vågå k., Oppland 46

Vest-Agder fylke 272

Vestbu, Eidfjord k., Hordaland 258

Vestfold fylke $64,124,132$

Vestlandet 25, 47, 140, 145, 201, 208

Vestre Namdal reinbeitedistrikt, Fosnes k., Høylandet k.,

Namsskogan k., dal k., Nærøy k., Nord-Trøndelag 176

Vestre Rækarvatn, Røyrvik k., Nordland 178

Vestre Slidre k., Oppland 95, 162, 267

Vestvidda, Hordaland 46

Vigerust, Dovre k., Oppland 154, 252, 262

Vikadalen, Årdal k., Sogn og Fjordane 47

Vikastøl, Årdal k., Sogn og Fjordane 258

Vingnes, Lillehammer k., Oppland 149

Vingromstranda, Lillehammer k., Oppland 149

Vinje k., Telemark 122, 208, 258, 272

Vinje-vassdraget, Vinje k. og Tinn k., Telemark 96

Vinstra, Nord-Fron k., Oppland 38, 40, 47, 71, 212

Vinstradalen, Nord-Fron k., Oppland 152

Vinstravassdraget, Vang k., Øystre Slidre k., Nord-Fron k., Sør-Fron k., Oppland 38, 40, 43, 45, 47, 64, 71-73, 75, 96, 207, 212, 217, 219, 224, 226, 235, 245, 251

Vinstre, Øystre Slidre k., Oppland $\quad 43,44,71-73,202,212,214$, 216-219, 225, 246, 247

Virvatnet, Rana k., Nordland 163

Vistad, Nord-Fron k., Oppland 152

Vistehola, Randaberg k., Rogaland 58

Volnebben, Lom k., Oppland 31, 32, 186, 219

Västannortjärn, Dalarnas län, Sverige 196

Västerbotten, län, Sverige $159,163,165,166,172,180,181$

Västra Värjaren, Jämtlands län, Sverige 169
Vøringsfossen, Eidfjord k., Hordaland 115

Vågå k., Oppland $15,35,38,40,43-45,50,51,62,96,97,106,107$, $145,147,152,154,189,190,208,212,216$

Vågåfjellet, Vågå k., Oppland 51, 104

Vågåmo, Vågå k., Oppland 152

Vågåvatnet, Lom k. og Vågå k., Oppland 45, 47, 152, 185

Vålåsjøen, Dovre k., Oppland 48, 49

Y

Ytre Rendalen, Rendalen k., Hedmark 267

Е

Ässan, Ångermanland, Sverige 163

$\varnothing$

Øfstgard, Ringebu k., Oppland 150

Ørteren, Hol k., Buskerud 114, 117, 260

Østerdalen, Hedmark 106, 267

Østersjøen 198, 199

Östersund, Jämtlands län, Sverige 196, 269

Østfold fylke 97

Østlandet 102, 104, 134, 166, 223, 240

Øvre Bjørnhølen, Øystre Slidre k., Oppland 43, 72, 73, 257

Øvre Heimdalsvatnet, Øystre Slidre k., Oppland 44

Øvre Hyllingen, Røros k., Sør-Trøndelag 180

Øvre Jørstad, Lillehammer k., Oppland 149

Øvre Ottavassdraget, Oppland 52

Øvre Sjodalsvatnet, Vågå k., Oppland 45, 104

Øvre Skår, Vågå k., Oppland 152

Øvstdal, Lillehammer k., Oppland 149

Øvsthågå, Gausdal k., Oppland 149

Øyangen, Nord Fron k., Oppland 44, 72, 251, 257

Øyer k., Oppland 103, 145, 147, 149

Øyerfjellet, Øyer k., Oppland 104

Øygarden, Vågå k., Oppland 152

Øyre, Lillehammer k., Oppland 149

Øystre Slidre k., Oppland 40, 73, 202, 212, 224, 225, 246, 256, 257

Øyvatnet, Nord-Fron k., Oppland 44

$\AA$

Åbjøra, Bindal k., Nordland 176

Åbjøravassdraget, Bindal k., Nordland 176,177

Åmot k., Hedmark 250, 257, 259, 272

Ångermanland, Sverige 159, 163, 172

Ånstad, nørdre, Skjåk k., Oppland 153

Årdal k., Sogn og Fjordane 40, 258, 259

Årdalsfjorden, Årdal k., Sogn og Fjordane 47

Årdalsvassdraget, Årdal k., Sogn og Fjordane 40

Årdalsvatnet, Årdal k., Sogn og Fjordane $\quad 120,121$

Åsagrende, Dovre k., Oppland 154

Åsele Lappmark, Västerbottens län, Sverige 159

Åseng, Sel k., Oppland 152

Åsmundstad, Nord-Fron k., Oppland 152, 256 
FJELLFISKE I FORTIDEN 